+ 


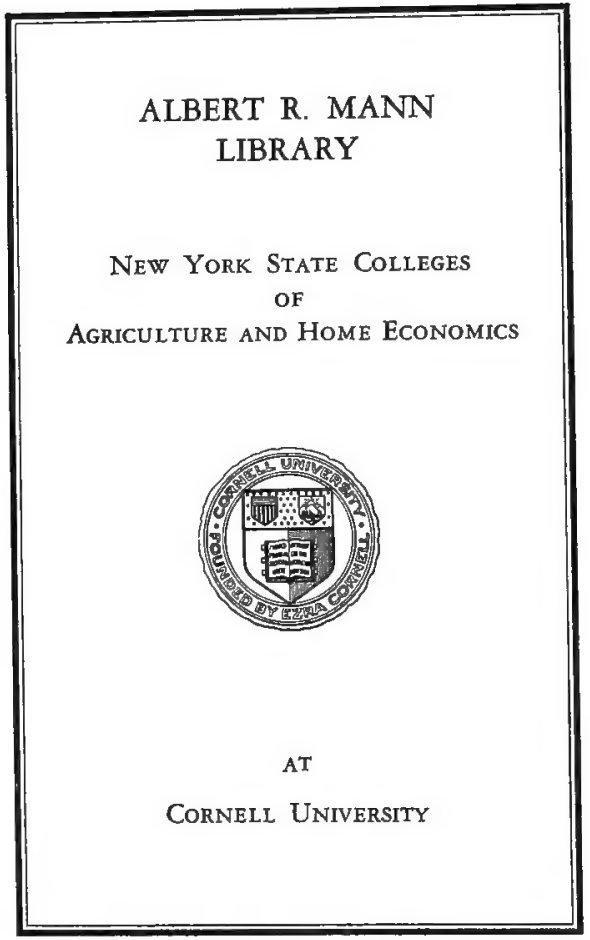




\section{Cornell University Library \\ OL 684.C6S51}

A history of the birds of Colorado.

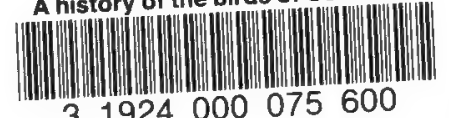

31924000075600

mann 


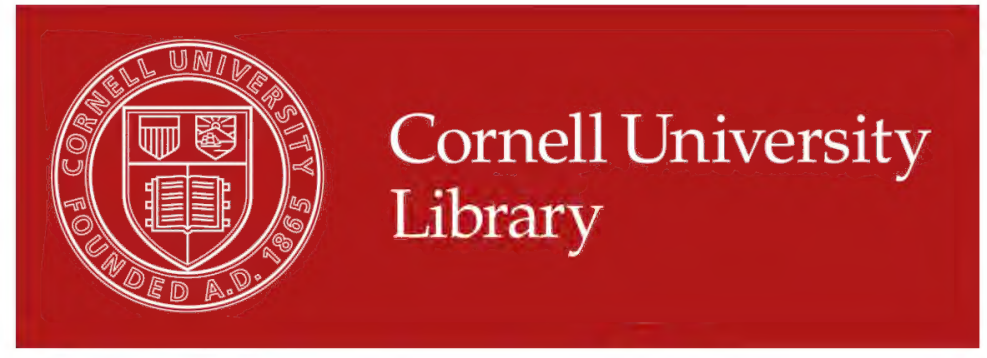

The original of this book is in the Cornell University Library.

There are no known copyright restrictions in the United States on the use of the text. 


\section{A HISTORY OF}

\section{THE BIRDS OF COLORADO}





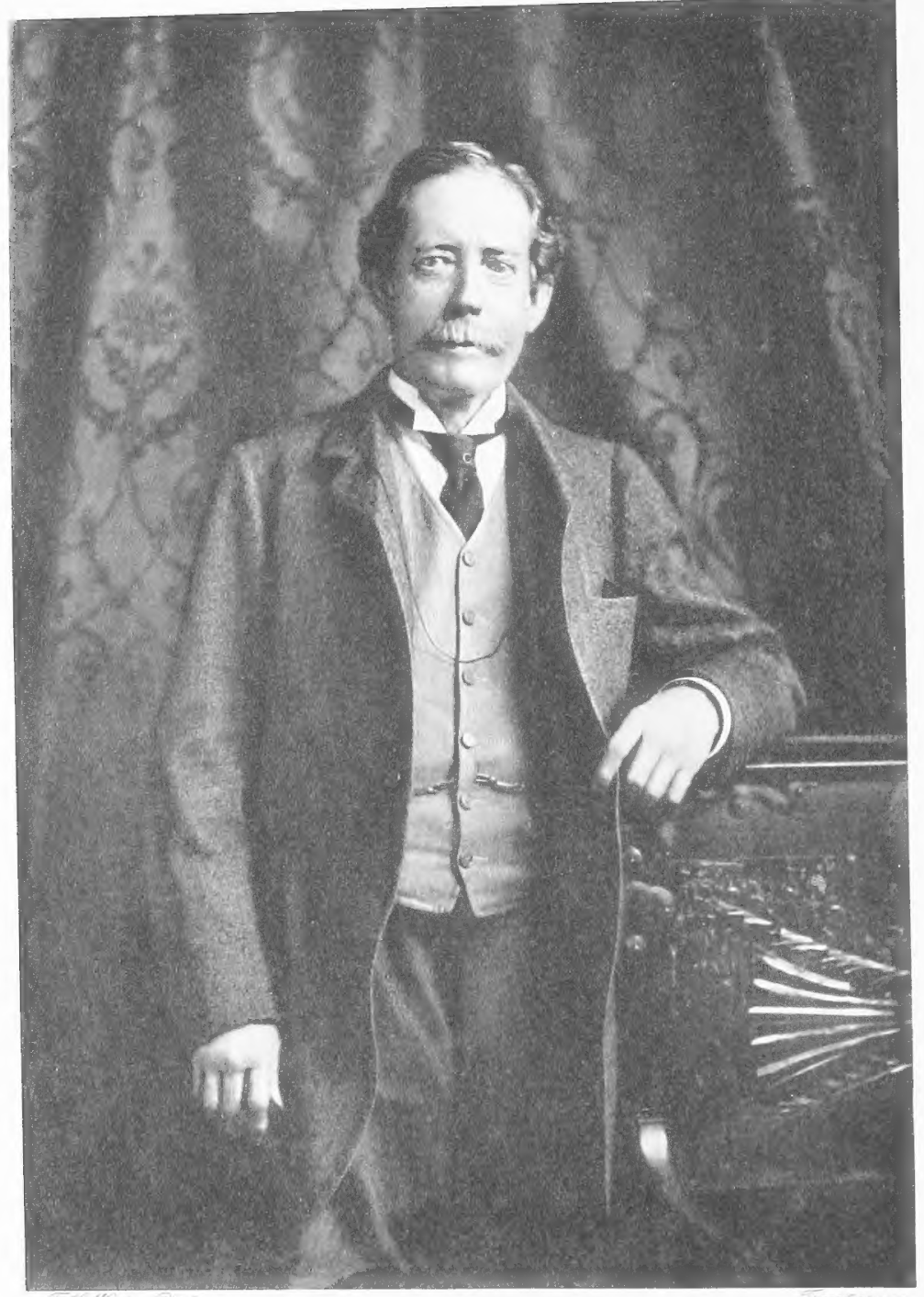

$$
\text { pre traemer }
$$






\title{
A HISTORY OF
}

\section{THE BIRDS OF COLORADO}

B Y

\author{
WILLIAM LUTLEY SOCLATER \\ M.A.(Oxon.), M.B.O.U., Hon, M.A.O.U. \\ (Lately Director of the Colorado College Museum)
}

WITH SEVENTEEN PLATES AND A MAP

WITHERBY \& CO.

326 HIGH HOLBORN LONDON

1912 
PRINTED BY WITHERBY \& CO., AT THEIR PRINTING PRESS IN MIDDLE ROW PLACE, LONDON. 
TO THE MEMORY OF

GENERAL WILLIAM JACKSON PALMER, OF GLEN EYRIE, NEAR COLORADO SPRINGS, TO WHOSE MANY KINDNESSES I OWE THE POSSIBILITY OF PREPARING THIS WORK. 



\section{CONTENTS.}

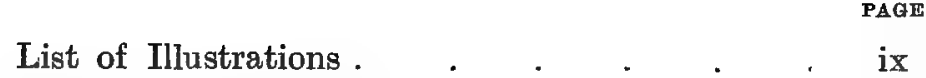

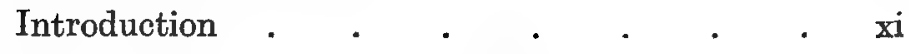

A History of the Birds of Colorado . . . 1

Bibliography . . . . . . . . $\quad$. 533

Gazetteer . . . . . . . 553

Index $. \quad . \quad . \quad . \quad . \quad . \quad . \quad .563$ 



\section{LIST OF ILLUSTRATIONS.}

Portrait of General William Jackson Palmer Frontispiece PLATE.

PAGE

1. Nesting Colony of Great Blue Heron . $\quad 82$

2. $\left\{\begin{array}{l}\text { Young Great Blue Heron } \\ \text { Young Night-Herons }\end{array}\right.$

3. Ptarmigan in September and March . . 148

4. Nesting Site of Westorn Redtail . . 174

5. Adult and Young of Rocky-Mountain Screech Owl . . . . . . . 204

6. Nest of Western Horned Owl • . . 210

7. Young Red-shafted Flickers . . . 240

8. Nest of Broad-tailed Humming-bird . . 254

9. Arkansas Kinghird and Nest . . . 262

10. Horned Lark in the Snow . . . 280

11. Magpies from the Nest . . . . 284

12. White-headed Jay . . . . . . 290

13. Nest of Yellow-headed Blackbird . . 304

14. Nest of House-Finch and Arkansas Goldfinch 332

15. Black-headed Grosbeak on the Nest . . 400

16. Nest of American Dipper . . . . 476

Contour Map of Colorado . . . . . $\quad 552$ 



\section{INTRODUCTION.}

PERHAPs some apology is necessary for the appearance of a new American Bird-book.

Mine must be that the only complete work on Colorado Birds is that of Cooke, which, though brought up-to-date by successive supplements, is now out of print and very difficult to obtain. Moreover, Cooke gives no descriptions or keys, so that it is not of much use to the tyro who wishes to identify the birds which he has observed or obtained:

The present volume is founded on the very complete collection of Colorado birds formed during the last thirty-five years by Mr. Charles E. Aiken, of Colorado Springs. This collection was recently acquired by General William J. Palmer, and presented by him to the Museum of Colorado College. As was well known to all General Palmer's intimate friends, he was a great lover of Nature, and specially of the wild birds of his adopted State, and it was in accordance with his often expressed desire that I undertook the preparation of this work, and made use of the Aiken collection for the purpose.

Before arrangements could be made for its publication his death occurred.

The complete volume has, therefore, been dedicated to him; and, as a personal memorial, the necessary expenses involved in publication have been defrayed by his sisterin-law, Mrs. William Lutley Sclater and his brother-in-law, Mr. Chase Mellen, of New York. 


\section{Physical Fiatures of Colorado.}

The State of Colorado lies near the centre of the United States, about two-thirds of the distance from the Atlantic to the Pacific coasts. It is quadrilateral in shape, measuring about 276 miles from north to south, and about 375 from east to west. It has an area of about 103,900 square miles.

In general terms, the eastern third of the State consists of open, bare, dry plains, where the country is flat or rolling, and where there is hardly any timber except along the river bottoms. The elevation of these plains (the prairies) rises from about 3,500 feet at the Kansas border to 6,000 feet at the foothills of the Rocky Mountains.

West of the 105th meridian, and rising with extraordinary abruptness from the plains to the east, the Rocky Mountains occupy roughly the middle third of the State. In a very general way the system forms two parallel ranges running north and south, joined by subsidiary east and west connections; between these are the great mountain parks, open wide valleys rather bare of trees, and situated at elevations of 7,000 to 8,000 feet.

The chief of these are North and South Parks, drained by the North and South Platte rivers, which meet out in the plains of Nebraska and join the Missouri near Omaha ; Middle Park, drained by the Grand River, the principal affluent of the Colorado River of the west, draining into the Gulf of California ; and the San Luis Valley, draining into the Rio Grande on the south.

The western third of the State consists, to a large extent, of a series of descending plateaus through which the rivers, all tributaries of the Colorado, have cut cañons 
of varying depth, while there are several ranges, such as the Elk and the Gunnison mountains, rising above the plateaus.

Colorado has the highest average elevation of all the States of the Union-6,800 feet-while there are a number of peaks of between 14,000 and 14,500 feet.

Colorado lies within the arid region; the rainfall east of the mountains seldom amounts to 20 inches, and is often less; in the mountains it often exceeds 30 . The bulk of the rainfall is in the summer months, and the winter is generally dry.

\section{Analysis of the Bird Fauna.}

The number of Colorado birds included in the present work is 392. Of these 225 may be considered regular breeders within the State. I have divided these into three catagories, viz.: (A) Those resident throughout the year, 67 in number; (B) The strict migrants which, so far as we know, never winter within the limits of the State, 118 in number; (c) Those birds which breed within the State and in winter are undoubtedly less numerous, so that they may be considered partly migrant and partly resident, 40 in number.

The non-breeding birds number 167. Of these the largest category by far are the Casual or rare species, which have only been recorded on very few occasions; these number 106. The other two groups, which are not always easy to separate satisfactorily, are the winter residents, numbering 28 , and the birds which pass through the State on the Spring and Fall migration; these are 33 in number.

The following lists show the birds in these various categories.

(A) Resident through the year-67, or about 17 per cent. :- 
Histrionicus histrionicus, Colinus virginianus, Callipepla squamata, Lophortyx californicus (introduced), Dendragapus obscurus, Bonasa u. umbelloides, Lagopus leucurus, Tympanuchus americanus, Pediocates p. campestris, Centrocercus urophasianus, Meleagris g. merriami, Archibuteo ferrugineus, Aquila chrysaētos, Haliaètus leucocephalus, Aluco pratincola?, Asio uilsonianus, Cryptoglaux acadicus, Otus a. maxwellia, Otus a. aikeni Otus flammeola, Bubo v. pallescens, Speotyto c. hypogoea, Glaucidium gnoma, Geococcyx californianus, Dryobates v. monticola, Dryobates p. homorus, Dryobates s. bairdi, Picoides a. dorsalis, Colaptes c. collaris, Otocoris a. leucoloma, Pica p. hudsonia, Cyanocitta cristata, Cyanocitta s. diademata, Aphelocoma woodhousei, Cractes c. capitalis, Corvus c. sinuatus, Corvus cryptoleucus, Corvus b. hesperis, Nucifraga columbiana, Cyanocephalus cyanocephalus, Hesperiphona $v$. montana, Pinicola e. montana, Carpodacus cassini, Carpodacus $m$. frontalis, Loxia c. minor, L. c. stricklandi?, Leucosticte australis, Spinus pinus, Passer domesticus (introduced), Junco aikeni?, Junco caniceps, Pipilo $f$. mesoleucus , Bombycilla cedrorum, Cinclus $m$. unicolor, Catherpes $m$. conspersus, Thryomanes $b$. bairdi, Telmatodytes $p$. plesius, Certhia f. montana, Sitta c. nelsoni, Silta canadensis, Sitta pygmae, Baolophus griseus, Penthestes a. septentrionalis, Penthestes gambeli, Psaltriparus plumbeus, Regulus s. olivaceus, Myiadestes townsendi.

(B) Summer residents migrating south in winter118 , or about 30 per cent. :-

Colymbus n. californicus, Podilymbus podiceps, Larus delawarensis, Sterna forsteri, Hydrochelidon n. surinamensis, Querquedula discors, $Q$. cyanoptera, Spatula clypeata, Aix sponsa, Erismatura jamaicensis, Plegadis guarauna, Ixobrychus exilis, Ardea herodias, Egretta 
candidissima?, Grus americana, Porzana carolina, Steganopus tricolor, Recurvirostra americana, Himantopus mexicanus, Philohela minor, Cataptrophorus s. inornatus, Bartramia longicauda, Actitis macularia, Numenius americanus, Oxyechus vociferus, Podasocys montana, Columba fasciata, Cathartes a. septentrionalis, Pandion h. carolinensis, Coccyzus americanus, Coccyzus a. occidentalis, Sphyrapicus v. nuchalis, Sphyrapicus thyroideus, Melanerpes erythrocephalus, Phalonoptilus nuttalli, Chordeiles $v$. henryi, Cypseloides $n$. borealis, Aèronautes melanoleucus, Architrochilus alexandri, Selasphorus platycercus, Selasphorus rufus, Tyrannus tyrannus, Tyrannus verticalis, Tyrannus cassini, Myiarchus cinerascens, Sayornis saya, Nuttallornis borealis, Myiochanes richardsoni, Empidonax difficilis, $E$. trailli, $E$. hammondi, E. wrighti, Dolichonyx oryzivorus, Molothrus ater, Xanthocephalus xanthocephalus, Icterus spurius, $I$. galbula, I. bullocki, Quiscalus q. oneus, Astragalinus psaltria, A. p.. arizono, Poceetes g. confinis, Passericulus s. alaudinus, Coturniculus s. bimaculatus, Chondestes g. strigatus, Zonotrichia leucophrys, Spizella p. arizono, S. pallida?, S. breweri, Amphispiza b. deserticola, A. nevadensis?, Peuccea cassini?, Melospiza lincolni, Pipito montanus, Oreospiza chlorura, Zamelodia ludoviciana, Z. melanocephala, Guiraca c. lazula, Passerina amona, Spiza americana, Calamospiza melanocorys, Pyranga ludoviciana, Progne subis, Petrochelidon lunifrons, Hirundo erythrogastra, Iridoprocne bicolor, Tachycineta t. lepida, Riparia riparia, Stelgidopteryx serripennis, Vireosylva olivacea, Vireosylva g. swainsoni, Lanivireo s. plumbeus, Vireo belli, Vermivora virgineo, Vermivora celata?, Dendroica astiva, $D$. auduboni, D. gracia, D. nigrescens?, Oporornis tolmiei, Geothlypis t. occidentalis, Icteria $v$. longicauda, Wilsonia p. pileolata, 
Setophaga ruticilla, Anthus rubescens, Oreoscoptes montanus, Mimus p. leucopterus, Dumetella carolinensis, Toxostoma rufum, T. benderei, Troglodytes a. parkmani, Regulus calendula Polioptila c. obscura, Hylocichla f. salicicola, H. u. swainsoni?, H. g. auduboni, Sialia sialis, Sialia m. bairdi.

(c) Birds which breed within the State and occasionally winter, though usually going further south-40, or about 10 per cent. :-

Mergus americanus, Anas platyrhynchos, Chaulelasmus streperus, Mareca americana, Nettion carolinensis, Dafila acuta, Marila americana, M. vallisneria, Clangula islandica, Branta canadensis, Botaurus lentiginosus, Nycticorax n. novius, Rallus virginianus, Fulica americana, Gallinago delicata, Zenaidura carolinensis, Circus hudsonius, Accipiter velox, A. cooperi, Buteo b. calurus, $B$. b. Icrideri, B. swainsoni, Falco mexicanus, $F$. $p$. anatum, $F$. columbarius, $F$. c. richardsoni, $F$. sparverius, F. s. phalona, Ceryle alcyon, Asyndesmus lewisi, Sturnella neglecta, Euphagus cyanocephalus, Astragalinus tristis, A. t. pallidus, Calcarius ornatus, Melospiza $m$. montana, Lanius l. excubitorides, Salpinctes obsoletus, Planesticus $m$. propinquus, Siatia currucoides.

(D) Birds not known to breed within the State, but found more or less commonly in winter-2s, or about 7 per cent. :-

Gavia arctica, Mergus serrator, Lophodytes cucullatus, Marila affinis, Clangula c. americana, Chareonetta albeola, Harelda hyemalis, Astur atricapillus?, Archibuteo l. sancti-johannis, Asio flammea, Nyctea nyctea, Agelaius p. fortis, Euphagus carolinus, Leucosticte tephrocotis, L. t. littoralis, L. atrata, Acanthis linaria, Plectrophanes nivalis, Calcarius l. alascensis, Rhyncophanes mccowni, Zonotrichia l. gambeli, Spizella $m$. ochracea, Junco 
hyemalis, Junco o. shufeldti, J. mearnsi, Pipilo $m$. arcticus, Bombycilla garrula, Lanius borealis.

(E) Birds not known to breed in the State, but more or less regular transients through in spring and autumn33 , or about 8 per cent. :-

ALchmophorus occidentalis, Gavia immer, Larus argentatus, L. philadelphia, Xema sabini, Pelecanus erythrorhynchus, Marila marila, Oidemia deglandi, Chen hypoboreus, Olor columbianus, Grus canadensis, Lobipes, lobatus, Macrorhamphus g. scolopaceus, Micropalama himantopus, Pisobia maculata, P. fuscicollis, P. bairdi, $P$. minutilla, Ereneutes pusillus, Calidris leucophoa, Limosa fedoa, Totanus melanoleucus, T. flavipes, Numenius hudsonicus, Squatarola squatarola, Charadrius dominicus, Empidonax minimus, Centronyx bairdi, Vermivora peregrina, Dendroica coronata?, D. townsendi (?), Seiurus $n$. notabilis, Hylocichla guttata.

(F) Birds not known to breed in the State which have only been taken on from one to half-a-dozen occasionscasuals and wanderers-106, or about 27 per cent. :-

Colymbus holbcelli, C. auritus, Gavia adamsi, Stercorarius parasiticus, Rissa tridactyla, Larus occidentalis, L. californicus, $L$. atricilla, $L$. franklini, Sterna naradis a, S. hirundo, Phalacrocorax auritus, $P . v$. mexicanus, Pelecanus occidentalis, Anas fulvigula maculosa, Marila collaris, Somateria dresseri, Oidemia americana, 0 . perspicillata, Chen $h$. nivalis, Chen rossi, Anser m. gambeli, Branta c. hutchinsi, Branta c. minima, Branta b. glaucogastra, Olor buccinator, Ajaja ajaja, Guara alba, G. rubra, Plegadis autumnalis, Mycteria americana, Herodias egretta, Dichromanassa rufescens, Butorides rufescens, Nyctinassa violacea, Grus americana, Creciscus jamaicensis, Gallinula galeata, Pelidna $a$. sakhalina, Ereunetes mauri, Algialitis semipalmata, 
Arenaria i. morinella, Lophortyx gambeli, Pedioccetes p. columbianus, Melopelia asiatica, Elanoides forficatus, Ictinia mississippiensis, Astur a. striatulus, Buteo $b$. harlani, Strix varia (breeding ?), S. occidentalis, Cryptoglaux $f$. richardsoni, Conuropsis carolinensis (extinct), Coccyzus erythropthalmus, Dryobates villosus, Phlootomus p. abieticola, Centurus carolinus, Colaptes a. luteus Antrostomus vociferans, Phalcenoptilus $n$. nitidus, Chordeiles a. texensis, Stellula calliope, Myiarchus $l$. olivascens, Sayornis phobe, Myiochanes virens, Empidonax t. alnorum, E. griseus, Otocoris a. euthymia, Agelaius tricolor, Carpodacus purpureus, Loxia leucoptera, Acanthis $l$. rostrata, Astragalinus p. mexicanus, Ammodramus lecontei, Zonotrichia querula, $Z$. coronata, $Z$. albicollis, Spizella pusilla arenacea, Junco dorsalis, Aimophila v. scottii, Melospiza melodia, M.georgiana, Passerella i. schistacea, Pipilo aberti, Cardinalis cardinalis, Passerina cyanea, Pyranga erythromelas, Pyranga r. cooperi, Lanivireo s. cassini, Fireo vicinior, Mniotilta varia, Protonotaria citrea, Vermivora chrysoptera, Compsothlypis a. usnex, Dendroica carulescens, D. magnolia, $D$. cerulea, D. striata, D. virens, D. palmarum, Seiurus aurocapillus, Oporornis agilis, Wilsonia pusilla, W. canadensis, Nannus hiemalis, Cistothorus stellaris, Hylocichla mustelina, Saxicola cenanthe.

The vertical distribution of the Colorado birds has occupied the attention of many observers; Mr. F. M. Drew published in the Auk in 1885 a complete list of Colorado birds, as then known, with their vertical distribution both in the breeding season and at other times. I have confined myself to an analysis of the vertical distribution during the breeding season, as the data for more detailed study are still very imperfect. In addition to this, storms and accidents of various kinds may often 


\section{Introduction}

drive birds down below or up above their normal vertical habitat, so that it appears to me to be rash to base any generalisations except on the position of birds during the breeding season, when they are more or less necessarily confined to the neighbourhood of the nesting site.

In the following analysis the birds, 225 in number, have been divided into those breeding at three different levels :-

(1) The plains, up to, but not including, the foothills. This corresponds more or less to the Upper Sonoran zone.

(2) The foothills and mountain parks from about 6,000 to 8,000 feet, corresponding to the Transition zone of Piñons and Cedars.

(3) The mountains from about 8,000 feet to timber-line at 11,500 feet, corresponding to the Hudsonian and Canadian zones. There are only three birds which breed regularly above timber-line. These are Leucosticte australis, Anthus rubescens and Lagopus leucurus.

(A) Birds breeding on the plains and up to about 6,000 feet-35 in number, or about 15 per cent. :-

Podilymbus podiceps, Sterna forsteri, Hydrochelidon n. surinamensis, Dafila acuta, Marila americana, M. vallisneria, Ixobrychus exilis, Philohela minor, Bartramia longicauda, Colinus virginianus (Lophortyx californianus), Tympanuchus americanus, Buteo b. krideri?, Aluco pratincola?, Dryobates bairdi, Cyanocitta cristata, Corvus cryptoleucus, Icterus spurius, I. galbula, Quiscalus q. ceneus, Coturniculus s. bimaculatus, Spizella pallida, Amphispiza b. deserticola, Peuccea cassini, Zamelodia ludoviciana, Guiraca a. lazula, Spiza americana, Riparia riparia?, Stelgidopteryx serripennis, Vireo olivacea, Vireo belli, Icteria $v$. longicauda, Toxostoma bendirei, Thryomanes b. bairdi, Sialia sialis. 
(B) Birds breeding on the plains, and in the foothills and parks as well, up to about 8,000 feet-80 in number, or about 36 per cent. :-

Colymbus $n$. californicus, Larus delawarensis, Anas platyrynchos, Chaulelasmus streperus, Mareca americana, Nettion carolinensis, Querquedula discors, Q. cyanoptera, Spatula clypeata, Aix sponsa?, Erismatura jamaicensis, Branta canadensis, Plegadis guarauna, Botaurus lentiginosus, Ardea herodias, Egretta candidissima, Nycticorax n. ncevius, Rallus virginianus, Porzana carolina, Steganopus tricolor, Recurvirostra americana, Himantopus americanus, Helodromas s. cinnamomeus, Podasocys montana, Numenius americanus, Bonasa u. umbelloides?, Pedioccetes $p$. campestris, Centrocercus urophasianus, Meleagris g. merriami, Circus hudsonius, Accipiter velox, A. cooperi, Falco p. anatum?, F. columbarius, Asio flammea?, Otus a. maxwellic, O. a. aikeni, Speotyto c. hypogcea, Coccyzus americanus, C. a. occidentalis, Melanerpes erythrocephalus, Phalcenoptilus nuttalli, Tyrannus tyrannus, $T$. verticalis, $T$. cassini, Myiarchus cinerascens, Sayornis saya, Empidonax trailli, Corvus b. hesperis, Dolichonyx oryzivorus, Molothrus ater, Xanthocephalus xanthocephalus, Agelaius phoniceus, Sternella neglecta, Icterus bullocki, Astragalinus tristis, A. t. pallidus, A. psaltria, A. p. arizona, Poocetes g. strigatus, Spizella breweri, Amphispiza nevadensis?, Melospiza m. montana, Pipilo montanus, P. f. mesoleucus ?, Zamelodia melanocephala, Passerina amona, Calamospiza melanocorys, Progne subis, Petrochelidon lunifrons, Bombycilla cedrorum?, Lanius excubitoroides, Oroscoptes montanus, Mimus p. leucopterus, Dumetella carolinensis, Toxostoma rufum, Catherpes $m$. conspersus, Telmatodytes p. plesius, Polioptila c. obscura, Hylocichla $\%$ salicicola. 
(c) . The following birds appear to breed throughout the plains and up into the mountains from 3,000 to 11,500 feet and upwards. They are 33 in number, or about 14 per cent. :-

Fulica americana, Cataptrophorus s. inornatus, Actitis macularia, Oxyechus vociferus, Callipepla squamata, Zenaidura carolinensis, Cathartes a. septentrionalis, Buteo b. calurus, Buteo swainsoni, Archibuteo ferrugineus, Haliceètus leucocephalus, Falco mexicanus?, Falco sparverius, F. s. phalcena, Asio wilsonianus, Bubo v. pallescens, Ceryle alcyon, Colaptes c. collaris, Chordeiles $v$. henryi, Selasphorus platycercus, Myiochanes richardsoni, Otocoris a. leucolocma, Pica p. hudsonia, Euphagus cyanocephalus, Spinus pinus, Passer domesticus, Hirundo erythrogastra, Iridoprocne bicolor, Dendroica astiva, Salpinctes obsoletus, Troglodytes a. parkmani, Planesticus m. propinquus, Sialia currucoides.

(D) 'The following 14 birds are practically confined to the foothills and "parks" region, between 6,000 and 8,000 feet, during the breeding season. They represent about 6 per cent. of the total number of breeding birds :-

Pandion h. carolinensis?, Geococcyx californianus, Architrochilus alexandri, Aphelocoma woodhousei, Carpodacus m. frontalis, Loxia c. minor, Junco aikeni?, Vermivora virginice, V. celata?, Geothlypis t. occidentalis, Setophaga ruticilla, Bcoolophus i. griseus, Psaltriparus plumbeus, Sialia m. bairdi.

(刃) List of birds breeding through the mountains, between 6,000 and 11,500 feet, but not in the plains-24 in number, about 10 per cent. :-

Grus mexicana, Columba fasciata, Aquila chrysaétos, Otus flammeola, Glaucidium gnoma, Dryobates v. monticola, D. p. homorus, Asyndesmus lewisi, Selasphorus 
rufus, Corvus c. sinuatus, Cyanocephalus cyanocephalus, Passericulus s. alaudinus, Spizella p. arizona, Piranga Iudoviciana, Vireo g. swainsoni, Lanivireo s. plumbeus, Dendroica auduboni, D. nigrescens?, Oporornis tolmiei, Wilsonia $p$. pileolata, Cinclus $m$. unicolor, sitta c. nelsoni, Penthestes a. septentrionalis, Myadestes townsendi.

(F) Birds chiefly confined during the breeding season to the mountains, between 8,000 and 11,500 feet-39 in number, or 17 per cent. :-

Mergus americanus?, Clangula islandica, Histrionicus histrionicus, Gallinago delicata, Dendragapus obscurus, Lagopus leucurus (up to 13,500 feet), Falco c. richardsoni, Cryptoglaux acadicus, Picoides a. dorsalis, Sphyrapicus v. nuchalis, S. thyroideus, Cypseloides borealis, Aëronautes melanoleucus, Nuttallornis borealis, Empidonax difficilis, $E$. hammondi, $E$. wrighti, Cyanocitta $s$. :diademata, Cractes c. capitalis, Nucifraga columbiana, Hesperiphona v. montana, Pinicola e. montana, Carpodacus cassini, Leucosticte australis, Zonotrichia .leucophys, Junco caniceps, Melospiza lincolni, Oreospiza chlorura, Tachycineta t. lepida, Dendroica gracio, Anthus rubescens (to 13,000 feet), Certhia $f$. montana, Sitta canadensis, S. pygmcea, Penthestes gambeli, Regulus s. olivaceus, $R$. calendula, Hylocichla u. swainsoni, $H . g$. auduboni.

\section{ACKNOWLEDGMents.}

I am deeply indebted to Mr. Charles E. Aiken of Colorado Springs, for constant help and advice during the preparation of this work. As has already been stated, the descriptions are all based on the large collection of Colorado birds made by him, and now the property of Colorado College; but apart from this, I have been able through his kindness 
to embody much information derived both from his notes and from what he has told me from his own experiences. Mr. Edward R. Warren has also helped me in many cases with specimens and information, and has kindly allowed me to make use of several MSS. lists of birds drawn up by him, especially those made in various places in Gunnison county.

To Judge Junius Henderson and to the authorities of the State University of Colorado, I am indebted for the use of the invaluable notes kept during many years of collecting by the late Mr. Dennis Gale, of Gold Hill, Boulder co.

All the information we have in regard to the breeding of a large number of species of Colorado birds is to be found in these note-books, which have been most carefully arranged, indexed and typewritten by $\mathrm{Mr}$. Henderson, and which are now the property of the State University.

Messrs. R. B. Rockwell, L. J. Hersey, F. M. Dille and H. G. Smith, all of Denver ; Mr. C. S. Thompson, of Glenwood Springs; and Messrs. W. W. Cooke, H. C. Oberholser and C. W. Richmond, of Washington, have all helped me in various ways with information or advice, and to all these gentlemen my heartiest thanks are hereby tendered.

For the photographs illustrating principally the nests and eggs of Colorado birds I have to thank again Messrs. E. R. Warren, R. B. Rockwell and L. J. Hersey, as well as Mr. H. W. Nash, of Pueblo. In each case an acknowledgment of the source of the photograph reproduced is given. 


\section{ExplaNations.}

The nomenclature and classification used are almost without exception that of the recently published third edition of the A.O.U. Checklist. It was not, therefore, thought necessary to give original references to descriptions of species and genera. Measurements are all stated in inches and decimals of an inch. A list of the local references to Colorado ornithological writings is given with every species, under the author's name and date of his publication. For the complete reference the Bibliography on pages $533-51$ should be consulted. 


\section{A History of \\ The Birds of Colorado}

\section{KEY OF THE ORDERS.}

This Key is adapted from that in Ridgway's "Manual of North American Birds," and must be used with caution as it is impossible to construct a perfect key to the orders of birds on external characters alone ; in cases of doubt, reference should always be made to the diagnoses of the orders themselves.

A. Hind and front toes connected by a web. Steganopodes, p. 26.

B. Find toe, if present, never so connected.

a. Cutting-edges of the bill more or less fringed or dentate; toes completely webbed.

Anseres, p. 30.

b. Cutting-edges of the bill not fringed or dentate.

$a^{1}$ Legs inserted far behind the middle of the body, so that when standing the position is more or less erect; toes webbed or lobed.

Pygopodes, p. 3 .

$b^{1}$ Lega inserted near the middle of the body, so that when standing the position is more or less horizontal.

$a^{2}$ Anterior toes very fully webbed and tarsus shorter than tail.

Longipennes, p. 12.

$b^{2}$ Anterior toes not, or not fully, webbed.

$a^{3}$ Lower portion of the thighs naked.

$a^{4}$ Hind toe long and inserted nearly at a level with the others; claws never excessively lengthened; loreal or orbital regions, or both, naked.

Heriodiones, p. 73. 
$b^{4}$ Hind toe, when present, generally inserted above the level of the others; loreal and orbital regions fully feathered.

$a^{5}$ If wing is over fifteen inches, hind toe elevated above the others, if under ten inches, hind toe on a level with the others. Paludicolæ p. 89.

$\mathrm{b}^{5}$ Wing never over fifteen inches; hind toe when present short and elevated. Limicolæ, p. 99.

$b^{3}$ Lower thighs feathered.

$a^{4}$ A soft fleshy cere at the base of the upper mandible. $a^{5}$ Bill strongly hooked and pointed. $a^{6}$ Three toes in front, one behind.

$a^{7}$ Feathers of the face forming a facial disk; eyes large and forwardly directed.

Striges, p. 194.

$b^{7}$ Feathers of the face not forming a facial disk ; eyes moderate and laterally directed.

Accipitres, p. 161.

$b^{6}$ Two toes in front, two behind; cere sometimes feathered.

Psittaci, p. 215.

$b^{5} \quad$ Bill more or less straight, not strongly hooked.

Columbæ, p. 156.

b4 No cere at base of upper mandible.

$a^{5}$ Hind to small and elevated. Gallinæ, p. 137.

$b^{5}$ Hind toe well developed and on a level with the others.

$a^{6} \quad$ Wing long of ten primaries; tail of ten rectrices; bill very short with a very wide gape, or very long and slender, far exceeding the head.

Machrochires, p. 241.

$b^{6} \quad$ Wing not very long; tail usually of twelve rectrices ; gape and bill moderate and normal.

$a^{7}$ Toes two in front and two behind; tailfeathers stiff and pointed: Pici, p. 222.

$b^{7}$ Toes two in front and two behind, or three in front and one behind, if the latter, the middle and outer ones connected for half their length; tail-feathers not stiff and pointed. Coccyges, p. 216.

$c^{2}$ Toes three in front and one behind; middle and outer toes not united. Passeres, p. 257. 


\section{ORDER PYGOPODES.}

This order contains diving birds, and includes the Grebes, Loons and Auks. The chief feature which they have in common is the completely posterior position of the legs, so that when resting on the ground the axis of the body is more or less vertical and the whole of the tarsus is often applied to the ground, while the tail lends additional support.

Other external features are-nostrils never tubular or aborted; wings short and rounded, never reaching the end of the tail, which is always short and sometimes absent ; tarsus compressed; toes either webbed or lobate.

Kex of the Families and Genera.

A. No obvious tail-feathers (Colymbida).

a. Bill more or less slender and acute.

$a^{1}$ Bill longer than the head; tarsus, culmen and middle toe about equal.

Exchmophorus, p. 4.

$b^{1}$ Bill equal to or shorter than the head; tarsus shorter than the middle toe and claw.

Colymbus, p. 5 .

b. Bill short, deep and strongly compressed, crossed by a black band.

Podilymbus, p. 8.

B. A tail of 18 to 20 short, stiff feathers (Gaviida). Gavia, p. 10.

\section{Family COLYMBID E.}

Bill rather variable ; wing with twelve primaries, outer ones rather narrow and falcate; tail practically absent, no obvious rectrices; tarsus extremely compressed, toes flattened and expanded into continuous lobes connected with each other at the base by an interdigital web; hind toe slightly elevated, lobe free from the other toes; claws flat and nail-like; head usually with crests or ruffs in the breeding season; plumage thick and compact. 


\section{Genus ECHMOPHORUS.}

Bill long, slender and pointed, clearly exceeding the head; culmen straight; neck long; tarsus, culmen and middle too with claw all approximately equal, no very conspicuous crest or ruff.

One species only in western United States.

\section{Western Grebe. BAchmophorus occidentalis.}

A.O.U. Checklist no I-Colorado Records-Morrison 89, p. 146 ; Kellogg 90, p. 90 ; H. G. Smith 96, p. 48 ; Cooke 97, pp. 49, 155, 191 ; Felger 09, p. 86.

Description.-Adult-Top of the head, which is slightly crested, and line down the back of the neck bleck, becoming dusky brown on the back, with concealed white bases to the primaries and some white on the secondaries; below from the bill, pure white, with a satiny gloss; iris orange-red to pink with a white ring, bill olivaceous, feet dusky, yellowish about the toes and inside of tarsus. Length 26; wing 8.25 ; tail 2.0 ; tarsus 2.9 ; bill 2.8 .

The female is smaller-wing $7 \cdot 5$. In winter the head and neck are dusky brown like the back.

Distribution.-Breeding from Manitoba and Saskatchewan south to central Mexico, wintering in the southern part of the range.

In Colorado the Western Grebe is of rare occurrence during the fall migration. It was first reported by Breninger from near Fort Collins (Morrison) and subsequently from Estes Park by Pierce (Kellogg), but the first undoubted record is that of H. G. Smith who saw three examples in a Denver taxidermist's shop, which had boen shot in October, 1888, on lakes in the immediate neighbourhood. Two were subsequently obtained on Sheldon's Lake near Fort Collins on October $29 \mathrm{th}, 1898$, and one of these individuals is now mounted in the MIuseum at that place. Felger recently reports another example teken November 9th, 1902, at Citizen's Lake, a fow miles south-west of Denver; the skin is preserved in his collection.

Habits.-The Western Grebe haunts rush-covered lakes where it rides the water lightly and easily. It is an expert diver, either sinking quietly out of sight or rising up and taking a header. Though difficult to flush from the water, it flies well and strongly. The nest is a raftlike structure of tall stems, grass and water-plants, 
sometimes floating, sometimes built up from the shallow bottom; the eggs, four to five, are dull bluish-white and measure $2.31 \times 1.52$.

\section{Genus COLYMBUS.}

Bill moderate, rather stout, hardly compressed, about equal to or less than the head, culmen usually slightly decurved at tip; middle toe and claw exceeding the culmen and the tarsus; neck moderately long; head with a crest, or ruff or both.

A large cosmopolitan genus with four specias in the United States.

\section{KEY OF THE SPECIES.}

a. Larger, with a longer bill, culmen over 2.0 ; throat white, part of neck rufous.

C. holbœlli, p. 5.

b. Smaller with shorter bill, culmen under 1.5.

$\mathrm{a}^{1}$ Throat and neck black or dusky. $\quad$ C. n. californicus, p. 6 .

$b^{1} \quad$ Throat dusky; neck rufous.

C. auritus, p. 6.

$\mathbf{c}^{1}$ Throat and neck dirty white. C. auritus, heims et juv, p. 6.

\section{Holboell's Grebe. Colymbus holboelli.}

A.O.U. Checklist no 2-Colorado Records-Drew 85, p. 18 ; Morrison 88 , p. $140 ; 89$, p. 146 ; Cooke 97 , pp. 49,155 .

Description.-Adult-Crown (which bears a very short crest and inconspicuous ruffs) and nape greenish-black, a line down the neck and upper-parts bleck, with brown on the wings; sides of the head and throat silvery ash; neck, except along the dorsal line, rufous; lower-parts silvery white, somewhat dappled; iris carmine, bill black, yellowish on the lower mandible. Length 19.0 ; wing 7.60 ; culmen $2 \cdot 10$; tarsus $2 \cdot 50$.

Young birds, and adults in winter, have the rufous of the neck replaced by ashy-brown or grey, the sides of the head and throat pure white, and the bill chiefly yellow.

Distribution-Breeding from eastern Asia and Greenland, south to the northern row of states from. Washington to Minnesota; in winter south to South Carolina and Monterey Bay in California.

The status of this bird in Colorado is rather indefinite. It is noted by Drew and Morrison as occurring in the south-western part of the State, but without any definite statement. On the other hand it has been obtained by Bond on lakes near Cheyenne in autumn. This is actually in Wyoming but only a few miles from the State border. It will probably be found to be a rare fall-migrant in the north-eastern part of the State. 


\section{Horned Grebe. Colymbus auritus.}

A.O.U. Checklist no 3-Colorado Records-Cooke 97, pp. 49, 155; Hersey \& Rockwell 09, p. 101.

Description-Adult-Crown, sides of the face and chin, together with ruff, glossy black; a yellowish stripe deepening to chestnut at the end, runs from the base of the bill through the eye and ends in a crest at the side of the nape; rest of the upper-surface, including the back of the neck, dusky black; the secondaries white; neck and sides rich rufous; rest of under-parts silky white; iris carmine with a white ring, bill dusky, tipped with yellow, feet dusky and yellow. Length $15 \cdot 0$; wing $5 \cdot 5$; culmen $\cdot 90$; tarsus $1 \cdot 65$.

Adults in winter, and young birds, have very slight indications of the crests and ruff; the crown, back of the neck and back are dusky black; the lower-parts white, tinged with grey on the neck and pale dusky on the sides.

Distribution.-Throughout the northern hemisphere. In America, breeding chiefly north of the United States boundary, from Alaska to New Brunswick; south in winter throughout the greater part of the States.

This is another Grebe whose status as a Colorado bird is rather doubtful. Captain Thorne states that according to his journal he killed a specimen near Fort Lyon, on the Arkansas River, October 8th, 1887, but he does not appear to have preserved it. Mr. E. L. Berthoud informed Cooke that he had seen two Horned Grebes which had been killed on some lakes north-erst of Golden; and Hersey (09) saw two near Barr May 5th, 1906. It will probably be found to be a rare autumn migrant, like the two previous species.

\section{American Eared Grebe.}

\section{Colymbus nigricollis californicus.}

A.O.ঠ. Checklist no 4-Colorado Records-Henshaw 74, p. 243 ; 75 , p. 489 ; Scott 79, p. 96 ; Allen \& Brewster 83, p.198; Goss 84, p. 18 ; Morrison 89, p.146; W. G. Smith 89, p. 138 ; 90, p. 141 ; Osburn 90, p. 68; Cooke 97, pp. 19, 49, 191 ; Dille 03, p. 74 ; Warren 08, p. 20; 09, p. 13; Rockwell 08, p. 156 ; 10, p. 188; Henderson 09, p. 224.

Description.-Adult-Crown, which is crested, neck all round, back, chin and throat, black ; auricular tufts golden to tawny, well developed and conspicuous; primaries brown; secondaries mostly white; below from the breast silky white, the sides tawny-rufous and a little mottled with black; iris carmine, bill black, feet dark olivaceous to blackish. Length 12 ; wing $5 \cdot 0$; culmen $1 \cdot 0$; tarsus $1 \cdot 70$. 
The adults in winter lack the crest and auricular tufts; the chin, throat and sides of the nape are white and the flanks slaty, without rufous. Young birds are very similar, but the upper-parts are rather lighter and duller.

Distribution.-Western North America, from Great Slave Lake south to Guatemala, and from the Mississippi Valley to the Pacific.

A common summer-resident in Colorado, where suitable conditions exist, arriving from the south at the end of April or beginning of May, and breeding from the plains to about $\mathbf{8 , 0 0 0}$ feet, chiefly in alkali lakes. The following are breeding records : Loveland (W. G. Smith), Barr, May to early July (Rockwell), Grand Lake 8,300 feet (Warren), Middle Park (Carter apud Cooke), Twin Lakes ? 9,300 feot (Scott), San Luis Lakes 7,500 feet (Henshaw), Plateau Valley, Mesa Co., 6,500 feet (Rockwell).

It passes through the mountains on migration, and has been seen as high as 9,000 feet near, Crested Butte in spring, by Warren, and at Breckenridge by Carter. It is also met with along the foothillsEl Paso co. (Aiken coll.), and Denver (Henshaw), on the plains as far east as Limon (Aiken), and on the western slope near Coventry on migration (Warren 09).

Habits.-All Grebes resemble one another to a great extent in their habits; they are found almost exclusively on shallow lakes and ponds, the margins of which are thickly grown with reeds and rushes. They swim very low in the water and dive with great facility, having the power of sinking quietly down into the depths when alarmed, and moving under water with great rapidity by means of their lobed flipper-like feet. They feed chiefly on small aquatic insects and crustacea and perhaps small fish, and are accused of devouring trout ova and fry. On land they are very awkward, generally shuffling along on their bellies with the help of their wings, like a seal. They fly well, as is shewn by their very considerable migrating powers.

Henshaw, who first noticed this bird in Colorado, found them nesting in considerable numbers at the San Luis Lakes near Fort Garland. The nests are generally 
floating in about eighteen inches of water, and placed in a thick reed-bed; they are built up of broken reeds and other debris and fastened round the growing reeds, but the whole structure is hardly high enough to keep the eggs dry. These, according to Henshaw, were three in number, though Smith (90) found four to be more usual. They are white in colour and sometimes roughened with a chalky deposit, but generally stained and soiled; they measure $1.75 \times 1.25$.

When the bird leaves the nest it invariably, if time allows, covers up the eggs with grass or other vegetable matter, in order to conceal them; and as they both leave and return to their nests by diving quietly, Henshaw believed that the eggs were partially, at any rate, hatched by the heat of the decaying vegetable matter with which he found them covered, but it is now generally agreed that this is done only for concealment.

Henshaw was at San Luis Lakes on June 23rd, and Aiken found fresh eggs at the same place in July, while Dille gives June 19th as an average date for fresh eggs. Rockwell has recently published an illustrated account of its nesting habits at Barr, near Denver.

\section{Genus PODILYMBUS.}

Bill very short, deep and strongly compressed; no crest or ruff, but the frontal feathers rather stiff and bristle-like; tarsus about threefourths the length of the middle toe and claw, and nearly twice the culmen.

Only one species found throughout most of America.

\section{Pied-billed Grebe. Podilymbus podiceps.}

A.O.U. Checklist no 6-Colorado Records-Ridgway 79, p. 234; Morrison 89, p. 147 ; W. G. Smith 89, p. 138 ; Osburn 90, p. 68 ; Cooke 97, pp. 18, 50, 191 ; Henderson 03, p. 107 ; 09, p. 224 ; Rockwell 10, p. 188 
Description.-Adult-Crown and back of the neck greyish-black, becoming a paler grey on the sides of the head and front of the neck; a black oval patch on the chin and throat; rest of the upper-parts and wings dark fuscous-brown; little white on the inner webs of the secondaries; below silvery white, but obscured on the sides and across the breast by dusky and buffy mottlings; iris brown and white, bill yellowish, bluish-white in life, encircled by a broad black band, legs blackish. Length 13.0 ; wing 5.5 ; culmen .90 ; tarsus $1 \cdot 75$.

In winter the bill is dull yellowish and has no black band; the throatpatch is absent and there are more or less distinct pale edges to the feathers of the upper-parts. Young birds are like the adults in winter, but the throat and sides of the head have indistinct brownish streaks.

Distribution.-Nearly the whole of America, from Saskatchewan to Patagonia, breeding throughout most of its range; wintering from about New Jersey and the southern United States southwards.

This Grebe does not appear to be a common bird in Colorado; generally it is a summer resident but is more abundant on migration. The first breeding record is that of W. G. Smith who found several nests at Loveland, but it probably also breeds at San Luis Lakes as there is a specimen in the Aiken collection from that place, taken on July lst. It reaches Loveland in spring in the latter half of April, and was seen by Carter on migration at Breckenridge (Cooke). Warren informs me he has noticed it on a small lake near Crested Butte at 9,000 feet in October. It is included by Henderson in the Boulder co. list, and is a common breeder at Barr in May and June (Hersey \& Rockwell), the letter of whom has recently published some notes and photographs of its nesting habits. I have not heard of it in the southwest or western part of the State, though it probably occurs there.

Habits.-This, the most familiar of the Grebes in the East, is often known as the Water-witch, Hell-diver or Divedapper; it does not materially differ from the other Grebes in its habits, nor has anything special been noticed about its occurrence in Colorado. Nests found by Smith in a lake close to Loveland contained six eggs as a rule and were, when first laid, a pale pea-green colour, but soon became stained by the wet weeds with which they were covered. A clutch of six eggs taken by I. C. Hall at Storm's Lake near Greeley on May 25th, 1902, and presented by him to the Colorado College 
Museum, were slightly incubated and show the characteristic staining over the pale green. They are oval in shape, rather pointed at one end, and average about $1.75 \times 1 \cdot 20$.

\section{Family GAVIIDE.}

The characters of the family are the same as those of the only genus.

\section{Genus GAVIA.}

Bill stout, strong and compressed, about as long as the head; no crests or ruff; tail short, of 18 to 20 stiff feathers; legs feathered to the upper tarsal joint; tarsus strongly compressed; four toes, the three anterior completely webbed; the hallux very short with a small semicircular lateral lobe, and connected with the others by basal web, plumage dusky above, white below.

Five species from the northern portions of both hemispheres.

\section{KEY OF THE SPECIES.}

A. Back spotted with white.

a. Head and neck black.

a Bill mostly black, white spots on the scapulars about square.

G. immer, p. 10 .

$b^{2}$ Bill mostly yellow, white spots on the scapulars longer than broad.

G. adamsi, p. 11 .

b. Head and back of the neck grey.

G. arctica, p. 11 .

B. Back without spots.

a. Back with paler grey margins, no spots on wing-coverts. $a^{1}$ Bill mostly yellow. G. adamsi, hiems, p. 11.

$b^{1}$ Bill mostly black.

G. immer, hiems, p. 10.

b. A few spots on the wing-coverts.

G. arctica, hiems, p. 11 .

\section{Loon. Gavia immer.}

A.O.U. Checklist no 7-Colorado Records-Morrison 89, p. 147 ; Cooke 97, pp. 50, 191; Henderson 03, p. 234 ; 09, p. 224.

Description.-Adult-Head and neck glossy greenish-black; throat in front with two patches of white, and black streaks; entire upperparte black, spotted with white, except the upper tail-coverts and the primaries; under-parts white, the sides of the breast striped with black ; iris red, bill and feet black. Length 34 ; wing 14.05 ; culmen $3 \cdot 0$; tarsus $3 \cdot 5$. 
Adults in winter and young birds are brownish-black above and white below; the iris is brown and the bill is bluish-white, dusky along the culmen. The female is rather smaller than the male and the young bird has a markedly shorter bill.

Distribution. - Widely spread over the northern portion of both hemispheres, the Loon in America breeds from along the northern border of the United States northwards to Alaska, and Greenland, and winters throughout the States to the Gulfs of Mexico and California. In Colorado it is a rare migrant and is not yet known to winter or to breed, though it has been taken at Sweetwater Lake, Garfield co. in July (Cooke). There is an example from Barr Lake near Denver, killed in April by S. Wood, in the Denver Museum of Natural History, and another from near Boulder, collected by L. Bragg, now in the Museum of the University of Colorado, while Aiken tells me a good many specimens have reached him from time to time in spring.

\section{Yellow-billed Loon. Gavia adamsi.}

A.O.U. Checklist no 8-Colorado Record-Cooke 97, p. 155.

Description.-Resembling $G$. immer, but slightly larger, and head a longer yellowish-horn bill, which is dusky only at the base; the with and neck are steel blue rather than green, and the white spots on the upper-parts are rather larger, those on the scapulars being longer than broad instead of square. Length about 36.0 ; wing 15.0 ; culmen. 3.50 $-3 \cdot 75$; tarsus $3 \cdot 50$.

Distribution.-North-east Asia, Arctic America, from Behring Straits to Hudson Bay and north-west Europe, but hardly known in the United States.

A young male Loon obtained by W. G. Smith near Ioveland, May 25th, 1885, and now in the collection of Mr. M. Hardy, Brewer, Me., has been identified with this rare Arctic form. This constitutes the only Colorado record.

\section{Black-throated Loon. Gavia arctica.}

A.O.U. Checklist no 9-Colorado Records-Cooke 97, p. 192 ; Aiken 00, p. 298 ; Henderson 03, p. 234 ; 09, p. 225.

Description.-Adult-Crown and nape grey; rest of the upper-parts, including the throat and fore-neck glossy black, the sides of the neck, back and wings streaked, barred and spotted with white; a band of white streaks on the throat; rest of the under-parts white, with a band of blackish at the base of the under tail-coverts; iris red, bill and feet blackish. Length 27.0 ; wing 12.5 ; culmen 2.50 ; tarsus $2 \cdot 90$. 
Adults in winter and young birds are dusky black above, the feathers of the back margined with greyish, giving a scaly appearance; below white; the neck slightly speckled with dusky; iris brown, bill bluishgrey, feet dusky greenish.

Distribution.-Breeding in the northern parts of both hemispheres, in America only far north from Hudson Bay to Alaska; in winter south, casually but rarely to the northern borders of the United States.

The Black-throated Loon is a rare winter visitor to Colorado. Three examples were killed on Prospect Lake, close to Colorado Springs, in November, 1898, and another near the same place in the fall of 1882 (Aiken); an example in winter-dress obtained on Monument Creek, also close to Colorado Springs, November 5th, 1091, in the Aiken collection, is now preserved in the Colorado College Museum. Henderson considers his former record of this species too doubtful to be retained.

\section{ORDER LONGIPENNES.}

The members of this order, which includes the Gulls, Terns, Skimmers and Skuas, are chiefly marine forms, and are therefore not well represented in Colorado.

They are all birds of medium size, with moderatesized bills and simple, not tubular, nostrils; the wings are long and consist of eleven primaries, the outer (twelfth) minute and hardly noticeable; rectrices twelve in number, feet with the three front toes webbed, generally completely; a small hind toe, not connected with the others, and jointed at a higher level, generally present.

\section{KFy OF THE FaMtLIES AND Genera.}

A. Bill with a horny cere overhanging and partially concealing the nostrils (Stercorariidce).

B. Bill without cere (Larida).

Stercorarius, p. 13.

a. Bill stout, hardly as long as the head ; upper mandible longer than the lower, with the tip hooked down over it. $a^{1}$ Tail square.

$a^{2}$ Hind toe very small or absent, without claw.

$b^{2}$ Hind toe present and clawed, though small.

Rissa, p. 14.

Larus, p. 15. 
$b^{\text {I }}$ Tail distinctly forked.

Xema, p. 21.

b. Bill long, straight and rather slender; both mandibles equal. a 1 Tail short and nearly square; webs between the toes emarginate. Hydrochelidon, p. 24.

$b^{1}$ Tail very distinctly forked; outer feathers elongated and pointed; toes fully webbed.

Sterna, p. 22.

\section{Family STERCORARIIDÆ.}

\section{Characters of the only genus.}

\section{Genus STERCORARIUS.}

Bill stout and gull-like with a terminal hook covering the tip of the lower mandible, the basal two-thirds covered by a horny cere which overlaps the nostrils, so that the opening is much reduced; wings long and strong, outer primary the longest; tail with the two centre feathers much produced; anterior toes fully webbed, hallux small and stumpy.

Three species on the coasts of the United States.

\section{Parasitic Jaeger. Stercorarius parasiticus.}

A.O.U. Checklist no 37-Colorado Recorde-Ridgway 79, p. 232 ; Drew 85, p. 18 ; Morrison 89, p. 147 ; H. G. Smith 96, p. 48 ; Cooke 97, p. 50 ; Henderson 03, pp. 234, 109 ; 09, p. 225.

Description.-Adult-In the sooty form or dark phase the plumage is dark brown throughout, darkest on the mantle, wings and tail; neck with acuminate rigid feathers streaked with golden straw; outer primaries with white shafts. The light phase has the upper-parta slaty, becoming blackish on the crown, wings and tail, the throat and under-parts white; bill brownish-horn, darkest in front of the cere; legs black. Length about 18.0 ; wing 12.0 ; tail 4.5 ; to end of central feathers 8.0 ; culmen 1.3 ; tarsus 1.85 .

Distribution.-The Parasitic Jaeger has a circumpolar range in both hemispheres, breeding in America in Alaska, the Barren Grounds and Greenland, and wandering in the winter to South Africa, New Zealand and portions of South America, chiefly along the coast. It is only occasionally found inland.

This bird is a rare fall and winter straggler in Colorado. There was an example in Mrs. Maxwell's Museum, taken near Boulder, in December, sometime before 1874 ; H. G. Smith examined a young male in the dark phase, shot on Sloans Lake near Denver in the fall of 1889, and Lowe obtained third example, now in his collection, on the Arkansas River below Pueblo in the fall of 1894. 
Habits.-The Parasitic Jaeger, or as it is often called, Richardson's Skua, is remarkable for presenting, irrespective of age or sex, two very distinct phases of plumage -a light and a dark. Birds of both phases pair with one another indiscriminately, where they meet, and the young are sometimes intermediate. This bird is parasitic in its mode of life; it seldom catches fishes for itself, but is constantly chasing smaller Gulls and Terns, and compelling them to disgorge their prey. So active is the Skua that it usually manages to catch the fish as it drops from the bill of the Gull, before it reaches the surface of the water.

It is a purely marine form, but seldom seen inland, though it nests in the far north, on moorlands and swamps, using a slight depression in the ground scantily lined with grasses. The eggs, usually two in number, are olive-brown, marked heavily with chocolate.

\section{Family LARID压.}

Bill without cere, middle tail-feathers never elongated.

\section{Genus RISSA.}

In most respects resembling Larus, but the hind toe rudimentary or absent, very rarely with a claw; tail square; tarsus short, less than the middle toe without claw; toes fully webbed.

Two species only of circumpolar range.

\section{Kittiwake. Rissa tridactyla.}

A.O.U. Checklist no 40-Colorado Records-Ridgway 79, p. 232 ; Cooke 97, p. 50 ; Henderson 09, p. 225.

Description.-Adult-Head, neck, tail and under-parts pure white, back and wings pearl-grey; outer web of the first primary and the last three inches of the tip of both first and second primaries black; the third to fifth black subterminally with an increasing white tip; hind toe very small - a minute knob without claw ; bill yellowish, feet black. Length 17 ; wing 12 ; tail 4.5 ; culmen 1.40 ; tarsus 1.3 . 
In winter the top of the head and back of the neck are washed with pearl-grey, and there is a dark spot above the eye. Young birds have a dusky spot in front and behind the eye; a broad bar across the neck behind; the lesser and median coverts, bastard quills, inner secondaries and $a$ terminal bar on the tail black; the four outer primaries black, except for the inner half of the inner webs, the 5th and 6th black only at their ends, with a white speck at the tip; bill black and feet yellowish.

Distribution.-The northern parts of the northern hemisphere. In America breeding on the Atlantic coasts from the Magdalen Islands northwards to Hudson Bay and Greenland; in winter south along the Atlantic coast and to the Great Lakes.

An example of this species, said to have been taken in Boulder co. in December, and preserved in Mrs. Maxwell's collection, is the only ione recorded from Colorado.

\section{Genus LARUS.}

Bill stout and hooked, the upper mandible slightly longer than the lower and bent down over its tip; bill shorter than the head and without cere; wings moderately long; tail square or nearly so ; front toes fully webbed, hind toe quite small but usually perfect, and provided with a claw.

A large genus spread all over the world, except the central Pacific; about eighteen species in the United States.

\section{Key of THE SPECIES.}

A. Larger, wing over 16 ; bill yellow with a red spot near the tip of the lower mandible.

a. Mantle dark slate; two or three outer primaries tipped with white.

L. occidentalis, p. I6.

b. Mantle pale pearly-grey; outer primaries with a subapical white spot as well as a white tip. $\quad$ L. argentatus, p. 16.

B. Medium, wing $14-16$; bill yellow with a transverse black band.

a. Tarsus about equal to the middle toe and claw; a red spot on the lower mandible.

L. californicus, p. 17.

b. Tarsus obviously longer than the middle toe and claw; no red spot on the lower mandible. L. delawarensis, p. 17.

C. Smaller, wing under 13.5 ; hooded, i.e. head and neck black, in summer.

a. Bill and feet reddish (in summer).

$a^{1}$ Larger, wing over 12; tarsus longer than the middle toe and claw.

L. atricilla, p. 18.

$b^{1}$ Smaller, wing under 12, tarsus about equal to the middle toe and claw.

L. franklini, p. 19.

b. Bill black, feet reddish.

L. philadelphia, p. 20 . 


\section{Western Gull. Larus occidentalis.}

A.O.U. Checklist no 49-Colorado Record-Cooke 97, p. 50.

Description.-Adult-Mantle dark slaty; primaries, including the inner webs of the first, second and usually the third, black tipped with white; rest of the plumage white; eyelid vermilion; bill chrome-yellow with a vermilion spot at the angle; feet flesh-coloured. Iength 24 ; wing 16.5 ; culmen $2 \cdot 30$; tarsus $2 \cdot 75$.

In winter adults have the top of the head and back of the neck streaked with dusky. Young birds are brownish-slaty above, varied with buff and whitish; quills and tail-feathers dull black, usually tipped with white; under-parts brownish-grey, speckled with whitish; bill black.

Distribution.-The Pacific coast, breeding from British Columbia to Lower California, occasionally wandering inland. Its inclusion in the Colorada avifauna resta on the statement of Professor Wm. Osburn, who informed Cooke he took an example at Loveland, September 30th, 1889.

\section{Herring-Gull. Larus argentatus.}

A.O.U. Checklist no 5l-Colorado Records-H. G. Smith 86, p. 285 ; Morrison 89, p. 147 ; Cooke 97, p. 50 ; Felger 09, p. 277.

Description.-Closely resembling the Western Gull, but with a less robust bill and lighter, paler blue mantle; the outer primary is black, becoming slaty towards the base, and has a white tip and subapical white spot on both inner and outer webs, as a rule; the other quills are usually without the subapical spot, but have the white tip; iris silvery to pale yellow, bill bright yellow with a vermilion spot on the mandible, legs flesh-colour. Length 24 ; wing $17 \cdot 18$; culmen 2.40; tarsus $2 \cdot 75$.

In winter the head and neck are streaked with dusky and the bill is duller. Young birds are mottled with dusky above and below; the wing and tail-feathers are dusky blackish, narrowly edged at the tips with white; iris brown, bill dusky blackish, flesh-coloured towards the base.

Disribution.-The Northern Hemisphere generally; in America breeding from Minnesota, the Great Lakes and Maine, north to Labrador, Hudson Bay and perhaps Alaska; in winter south to Cuba and on the Pacific coast to Lower California.

The Herring-Gull is only a straggler in Colorado; a young bird shot on a lake near Denver, November 17th, 1883, is said by H. G. Smith to be preserved in the collection of A. W. Anthony; Breninger informed Cooke that he had observed it near Fort Collins. There is a young 
mounted male in the Colorado Museum of Natural History at Denver, taken at Valagoe Lake near Greeley, while Felger states that it is not uncommon at Barr, where it is found associating with the Ringbills.

\section{California Gull. Larus californicus.}

A.O.U. Checklist no 53-Colorado Records-Morrison 89, p. 147 ; Cooke 97, pp. 50, 192 ; Warren 09, p. 13.

Description.-Adult-Mantle slaty-grey, rather pale and delicate; rest of the plumage white; primaries black, tipped with white, and white and slaty-grey at the bases; the outer on $\theta$ with a large subapical white spot across both webs and the shaft; the second with a much smaller subapical spot divided into two by the black shaft; tips of the secondaries white; iris brown, eyelids yellow or red, bill chromeyellow with a bright vermilion patch at the angle of the lower mandible, followed by a transverse bar of black across both, feet bluishgreen, yellow on the webs. Length 20 ; wing 15.5 ; teil 5.75 ; culmen $1 \cdot 80$; tarsus $2 \cdot 25$.

In winter the head and neck are streaked with dusky and the bill is dull. Young birds are mottled with dusky, buffy and grey; the wings and tail are blackish and the bill dusky with a black tip.

Distribution.-Western North America from Alaska to Mexico, breeding chiefly in the interior, especially on Great Salt Lake in Utah ; wintering chiefly on the coast.

The California Gull is an occasional or transient visitor to Colorado; but has seldom been observed or obtained.

Professor Wm. Osburn procured one specimen at Loveland, May 7th, 1890, and there are two examples in the Carter collection now in the Denver Museum of Natural History-one taken in Middle Park, April 28th, 1884, the other at Denver, October 26th, 1878. According to Warren, C. H. Smith saw one at Coventry in 1905. This completes the list of definite records.

\section{Ring-billed Gull. Larus delawarensis.}

A.O.U. Checklist no 54-Colorado Records-Allen \& Brewster 83, p. 198 ; Drew 85 , p. 18 ; Woodbury 87, p. 116 ; Morrison 89, p. 147 ; Cooke 97, pp. 18, 51, 192 ; Henderson 03, p. 234 ; 09, p. 225 ; Rockwell 08, p. 157 ; Warren 09, p. 13.

Description.-Adult-Mantle pearly to pale slaty-grey, gradually whitening on the secondaries; head all round, under-parts and tail white; first primary black, with a white subapical spot divided by the dark shaft, and with the basal half of the inner web white; second to sixth primaries black with increasing pale basal portions and white 
tips, a small subapical white spot generally on the inner web of the second; iris straw-yellow with red on the eyelid, bill greenish-yellow with a yellow tip and a subspical black band, feet greenish-yellow. Length 18.0 ; wing $14 \cdot 25$; tail $5 \cdot 25$; culmen 1.5 ; tarsus $2 \cdot 0$.

In winter the head and neck are spotted with dusky. Young birds are mottled with dusky above and below, especially on the wing-coverts ; the primaries are black and there is no subapical spot on the first; the tail has a broad subterminal black band; bill yellow on basal, black on terminal half.

Distribution-Breeding chiefly in the interior of America, from Colorado and Newfoundland northwards to Hudson Bay and the Barren Grounds. In winter, on the Atlantic and Pacific coasts south to Cuba and Mexico.

This is the only Gull which can be called at all common in Colorado. It is fairly abundant on migration in spring and autumn, and has been found breeding on the San Luis Lakes by Couke. Migration records are-Fort Lyon, March 23rd (Cooke), near Colorado Springs, March 3Ist to May Ist (Aiken coll.), Barr Lake in summer and winter, but not known to breed (Hersey \& Rockwell), near Orchard may be seen in March (Warren), Loveland, March 9-20th (Cooke), all in the plains and foothills; Twin Lake (Aiken coll.), South and Middle Parks in spring (Carter), in the mountains; and on the western slopes-Grand River, near Grand Junction, June (Rockwell), Norwood near Coventry, April, 1906 (Warren).

Habits.-This Gull is found about lakes and rivers, and has a singular habit of catching grasshoppers and other insects in the air, noticed by both Allen and Goss. Cooke found it breeding quite commonly at San Luis Lakes (7,500 feet) June 18th, 1898, but gives no further details. The nest, as with other Gulls, is placed on the ground, usually on islands in lakes and ponds, and is made chiefly of grasses; the eggs, 2 to 3 in number, are whitish to clay-coloured, rather evenly spotted with chocolate; they measure $2.30 \times 1 \cdot 65$.

\section{Laughing Gull. Larus atricilla.}

A.O.U. Checklist no 58-Colorado Records-Morrison 89, p. 147 ; H. G. Smith 96, p 48 ; Cooke 97, p. 51.

Description.-Adult in summer-Head all round slaty-black, mantle bluish-grey, rest of the plumage, except the primary quills, white, a 
faint rosy tinge on the breast fading after death; three outer primaries black, the fourth and fifth black toward tho end, all but the first usually with a small apical spot; iris blackish, eyelids and bill carmine, feet dusky red. Length 16.50 ; wing 13.0 ; tail $5 \cdot 0$; tarsus $2 \cdot 0$; culmen $1 \cdot 75$.

In winter there is no hood, and the head is white with a little blackish, and the breast has no rosy tinge; bill and feet dusky. Young birds are mottled with greyish and brown above, the tail has a broad subterminal band of blackish-brown, and the quills are the same colour; upper tail-coverts white.

Distribution.-Breeding chiefly on the Atlantic and Gulf coasts from Maine to Texas, and on the Pacific coast of Mexico; in winter to the West Indies and northern South America as far as the Amazons and Peru; rare inland.

This Gull has been reported from Fort Lyon by Captain Thorne (Morrison), while H. G. Smith identified an example killed at Sloans Lake, in the western suburbs of Denver, in December, 1889. These are the only recorded occurrences in Colorado.

\section{Franklin's Gull. Larus franklini.}

A.O.U. Checklist no 59-Colorado Records-Cooke 97, pp. 19, 51; Felger 09, p. 278 ; Hersey \& Rockwell 09, p. 110.

Description.-Adult-Head all round slaty-black with u white ring round and chiefly behind the eye; mantle slaty-grey, nearly greyishblue; rest of the plumage, except the quills, white tinged with rosypink on the breast; first primary chiefly white on the inner and tip of the outer web, dusky slate on the outer web, and with a rounded black spot on the inner web about 1.25 inches from the tip; the next four slaty, paling to white at the tip and crossed by a subterminal band of black; eyelids orange, bill red with a darker subterminal bend; legs dusky red. Length 13.5 ; wing 11.25 ; tail 4.0 ; culmen $1 \cdot 25$; tarsus $1 \cdot 70$.

In winter the hood is absent, the head is white with a few dusky feathers and the breast has no rosy tinge. Young birds have the top and sides of the head and back greyish-brown, the quills dusky tipped with white, and the tail with subterminal band of dusky; forehead, eye-spot and under-parts white.

Distribution.-Breeding in the interior of North America from Iowa northwards to Manitoba and the interior of the Dominion; south on migxation from the Mississippi Valley to Utah, wintering in Mexico and Central America and as far south as Peru.

Though quite a common bird on migration, both in Kansas and Utah, Franklin's Gull is hardly known from Colorado. In fact the 
only record is that of W. G. Smith who took it at Loveland, on May $6 \mathrm{th}$, while Anthony examined one in Denver, stated to have been killed near by. Felger reports that Miss Patten noticed this Gull, May 8th,1905, near Yuma, and Hersey (09) saw one at Barr, October $17 \mathrm{th}, 1907$.

Habits.-This beautiful Gull, called by the farmers on the plains of eastern Kansas the "Prairie Pigeon" or "Prairie Dove," is frequently found far from water on arable lands in the spring, following the plough and picking up worms and insects, while in the autumn it destroys immense numbers of grasshoppers. In Utah, Mr. Bailey tells us that Brigham Young used to offer up prayers that they should be sent to destroy the locusts and destructive insects. It seems strange that it should have been so seldom noticed in Colorado.

The nest is placed on the ground, on islands among lakes and rivers or often in marshes and sloughs, and is made chiefly of rushes and grasses. They breed in large communities. The eggs, usually three, vary a good deal, but are generally olive-green to drab, splashed with bold markings of sepia. They measure about $2.1 \times 1.44$.

\section{Bonaparte's Gull. Larus philadelphia.}

A.O.U. Checklist no 60-Colorado Records-Ridgway 79, p. 232 ; Morrison 89, p. 147 ; Cooke 94, p.182 ; 97, pp. 51, 155, 193 ; H. G. Smith 96 , p. 48.

Description.-Adult in summer-Head all round slaty-black; a white ring round the eye broken in front; mantle pearl-grey, rest of plumage white, washed with rosy below; outer primary white with the outer web and tip black, the next five white, tipped with black; iris dark brown; eyelids red, bill black, logs red. Length 13 ; wing 10.0 ; tail $3 \cdot 6$; culmen $1 \cdot 0$; tarsus $1 \cdot 25$.

In winter the head is white tinged with grey behind, and there is a dusky spot on the ear-coverts and in front of the eye; the bill is lighter coloured at the base of the lower mandible and the feet flesh. Young birds in the first winter are like the winter birds but have a patch of dusky on the wing-coverts and black on the outer 
and inner web along the shaft of the three or four outer primaries, and a black aubterminal bar across the tail with a narrow terminal band of white.

Distribution.-Breeding from Manitoba northwards to Hudson Bay and Alaska; on migration both along the coasts and in the interior of the United States and the coasts of western Mexico.

In Colorado Bonaparte's Gull is an occesional visitor on migration, chietly in the fall. It has been taken about half a dozen times on the plains at the eastern bases of the mountains from Pueblo to Fort Collins in October and November, and by Carter on the spring migration, in Middle Park. The records are: Pueblo, November 15th, H. W. Nash (Cooke), near Colorado Springs (Aiken coll), near Denver on three occasions in October and November (H. G. Smith), Barr Lake, one killed but not preserved, fall of 1907 (Hersey), and Fort Collins (Cooke).

\section{Genus XEMA.}

Resembling the smaller forms of Larus, with hooded head in summer and with a slender bill, but the tail distinctly forked though not for more than the length of the tarsus.

One species only.

\section{Sabine's Gull. Xema sabini.}

A.O.U. Checklist no 62-Colorado Records-Ridgway 79, p. 232 ; W. G. Smith 89, p. 176 ; Morrison 89 , p. 147 ; H. G. Smith 96, p. 48 ; Cooke 97, pp. 51, 155, 193 ; Henderson 03, p. 234; 07 p. 198 ; 09, p. 225.

Description.-Adult-Fead all round deep slaty, bordered by a narrow ring of velvety black; lower part of neck, tail, under-parts, inner primaries, most of secondaries and greater coverts white; mantlo and the inner secondaries slaty-blue; outer primaries black, with the half of the inner web away from the shaft and tips white; eyelids orange, bill black on the basal, yellow on the apical half, feet black. Length 13 ; wing $10 \cdot 75$; tail to fork $3 \cdot 75$, to longest feather $5 \cdot 0$; culmen $1 \cdot 0$; trisus $1 \cdot 25$.

In winter the head and neck are white with little dusky on the ear-coverts and back of the head. Young birds are like the winter birds, but the back of the head and neck as well as the mantle is slaty, most of the feathers edged and tipped with whitish; the outer primaries are more black and the white tips are small or wanting; the tail has a subterminal bar of black, becoming narrower towards the outer feathers, and is less forked; the bill and legs are flesh-coloured and. dusky, and the dimensions are smaller-wing $10 \cdot 25$. 
Distribution.-Breeding far north in north-east Asia, and Arctic America from Alaska to Greenland, irregularly south in winter through the United States to the Bermudas.

Sabine's Gull occasionally strays to Colorado during the fall migration. There are about half a dozen well authenticated records both from the plains and the mountains. W. G. Smith obtained a male at Loveland, October 12th, 1889, and H. G. Smith about the same time saw one in the flesh in Denver, killed October lst; Carter obtained a specimen from an Alpine lake above 10,000 feet near Breckenridge, September 26th, 1886, and Aiken another at Manitou Park, Teller co., about 8,000 feet, October 12th, 1897 (Cooke). James Cowie shot one out of a flock of six on w lake near Boulder, September 15th, 1907, which is now in the Museum of the University of Colorado (Henderson). There is a young female in the Colorado College Museum, collected by J.G. Frey at Salida, September 26th, 1908 ; and another in the Museum at Denver, taken by Hersey, October 3lst, 1896, at Barr, where it is also not infrequent on migration in March.

\section{Genus STERNA.}

Bill long, pointed and compressed, both mandibles of equal length ; wings very long and pointed, the outer primary the longest; tail strongly forked, always for more than the length of the tarsus, the outer feathers elongated, attenueted and pointed, sometimes to a considerable extent; tarsus short, less than the middle toe and claw; toes fully webbed.

A large genus of world-wide distribution on the seas and inland waters; about ten species in the United States.

\section{Key OF THE SPECIES.}

A. Outer web of the outer tail-feather white, inner grey.

S. forsteri, p. 22.

B. Outer web of the outer tail-feather grey, inner white.

a. Dark band on the inner web along the shaft of the primaries broader, occupying about half the web. S. hirundo, p. 24.

b. Dark band on the inner web narrower, about a quarter the width of the web. $\quad$ S. paradisea, p. 24.

\section{Forster's Tern. Sterna forsteri.}

A.0.U. Checklist no 69-Colorado Records-Ridgway 73, p. 188; Allen \& Brewster 83, p. 198 ; Morrison 89, p. 147 ; Cooke 97, pp. 19, 51, 193 ; Felger 02, p. 294 ; 09, p. 278 ; Dille 03, p. 74.

Description.-Adult in summer-Top of the head bleck ; upper-parts pearl-grey; below white; rump white, tail becoming a little dusky 
on the outer feathers, very long and narrow, white on the outer, dusky grey on the inner, web ; bill orange-red, dusky at the tip, legs orangered. Length 15.0 (to end of tail) ; wing 9.5 ; tail to fork $2 \cdot 5$, to longest feather 6.0 to $8 \cdot 0$; culmen 1.5 ; tarsus 85 .

In winter the black cap is lost, but the nape is always slightly variegated with dusky and there is a black band on either side through the eye- and ear-coverts; bill and feet duller coloured. Young birds are mottled on the head and back with brownish, the primaries are less silvery and the tail brownish and deeply emarginate, but less so than in the adult. Bill smaller and weaker and brownish-black.

Distribution.--Breeding locally from Texas north through the middle states and Utah to Manitoba and the Fur countries and along the coast to Cobb's Island, Virginia, and in California; south in winter as far as Guatemala and Brazil.

Forster's Tern was reported as a breeding bird in Colorado as long ago as $1873 \mathrm{by}$ Ridgway, though no definite evidence of the fact was given. In more recent years it has been observed to arrive at Loveland about May 5th from the south, and Felger has found it breeding at Barr Lake near Denver on May 19th, where Hersey informs me there is a colony of about fifty birds in summer. It may be considered a regular resident in summer in parts of north-east Colorado.

Habits.-All the Terns have much the same habits. They are all birds of swift and easy flight, coursing through the air like Swallows, generally in the neighbourhood of, or over, water. They can often be seen with their heads and bills pointed downwards toward the water, watching for a fish or insect. Suddenly they plunge down but seldom become quite submerged; turning sharply on the surface, they rise again with the morsel in their beaks.

They nest in large communities, generally on a slight elevation in grassy swamps or marshes. The nest is made up of weeds or grasses and the eggs, usually three, are very variable-from whitish or buffy to olive-brown, heavily marked with chocolate. They measure $1.80 \times$ 1.30. They are roving birds having a harsh, grating cry, to which they give vent especially when they are disturbed on their nests. 


\section{Common Tern. Sternahirundo.}

A.O.U. Checklist no 70-Colorado Record-Cooke 09, p. 314.

Description.-Resembling the Arctic Tern in the arrangement of the coloration of the tail-feathers, but with a longer tarsus averaging longer than the middle toe without claw, and with the dark bands on the inner web of the outer primary much more distinct and wide, averaging $\cdot 25$ to $\cdot 30$ instead of $\cdot 12$ to $\cdot 15$; bill red, usually with dusky tip, feet vermilion. Dimensions about the same.

Distribution.-A common species found over the greater part of the world north and south; breeding chiefly in arctic circumpolar regions.

One example, taken May 14th, 1908, at New Windsor by Geo. Osterhout, was sent to Cooke for identification. This is the only Colorado record.

\section{Arctic Tern. Sterna paradiscza.}

A.O.U. Cheoklist no 71-Colorado Records-H. G. Smith 96, p. 48 ; Cooke 97, p. 51.

Description.-Closely resembling Forster's Tern but smaller, though with a longer wing and with the outer web of the outer tail-feather grey or dark and the inner web white, instead of the reverse; underparts slightly paler than the mantle but hardly white; bill red without dusky tip, feet vermilion. Length 14-17, varying with length of tail ; wing 10.0 ; tail $2 \cdot 5$, to longest feather 6.5 to 8.5 ; culmen 1.20 ; tarsus $\cdot 65$.

Distribution.-Breeding in the circumpolar regions of the old and New Worlds; in America from Alaska and Labrador south to Massachusetts. In winter ranging widely throughout the world's coasts to South Africa and South America, as well as in many parts of the United States.

The Arctic Tern, is a rare straggler in Colorado. An example killed at Marston's Lake near Denver in the spring of 1887 was identified as this species by Ridgway (H. G. Smith); while a second, an adult male, was taken by W. G. Smith at Loveland, July 9th, 1889 (Cooke).

\section{Genus HYDROCHELIDON.}

Closely allied to Sterna but with a very short tail, less than half the wing and very slightly forked; with feeble legs, the webs much indented so that the toes appear to be only half webbed; lower-parts of the body always black, or very' dark grey in the breeding season.

Four species, only one in North America. 


\section{Black Tern. Hydrochelidon nigra surinamensis.}

A.O.U. Checklist no 77-Colorado Records-Aiken 72, p. 210 Coues 74, p. 708 ; Drew 83, p. 18 ; Morrison 89, p. 147 ; Cooke 97, p. 52 ; Henderson 03, p. 234 ; 09, p. 225 ; Warren 08, p. 20.

Description.-Adult in summer-Head and nape all round and underparts to the vent jet black; under tail-coverts white; above from the nape silvery grey, a little duskier on the primaries; iris brown, bill black, feet reddish-brown. Length 8.5 ; wing 8.30 ; tail 3.40 ; culmen $1 \cdot 0$; tarsus 65 .

In winter the black of the head and under-parts is replaced by white, but the hind helf of the crown is dusky grey and there is a dusky bar from the ear-coverts to the eye; above as in the summer, but many of the feathers edged with whitish. Young birds resemble the winter adults but have a good deal of brown about the scapulars and a marked bleck crescent in front of the eye.

Distribution.-Breeding from the middle states from Kansas and Illinois north to Hudson Bay and Alaska; south in winter as far as Chili and Brazil. Along the Atlantic coast on migration only.

The Black Tern is a not very unenmmon summer resident in Colorado, breeding in communities where suitable conditions occur, chiefly in, the eastern plains portion of the State. It is probably still more common on migration. Coues saw a large colony on the Arkansas River near Fort Lyon on, June 10th, 1864, which were probably breeding, and there are egga in the Colorado College Museum presented by I. C. Hall, and taken by him on Storms Lake near Greeley, May 26th, 1902. There are a few birds on Barr Lake and several single nests have been taken by Hersey and Rockwell. Other references are El Paso co. (Aiken), Boulder co. plains (Henderson), and Bear Lake near Steamboat Springs in Routt co., where Warren saw a dozen or fifteen flying about, June 1st; this is the only definite record from the western slope.

Habits.-The Black Tern is usually seen in flocks of larger or smaller size, flying over or near water, either a river, lake or marsh. "The flight is buoyant in the extreme," says Coues, "and wayward, desultory and uncertain; perhaps no bird of this country has so great an expanse of wing for its weight, certainly none fly more lightly. In hovering along on the look-out for insects, they hold the bill pointing straight down like other Terns. In the spring I have observed them plunging 
into the water for food, probably small fry, but in the fall they seem to feed chiefly on winged insects," and specially on dragon-flies.

They breed, as already remarked, in large companies; their nests consist merely of a heap of decaying rushes and other vegetable matter, piled up in the shallow water of a lake or marsh. The eggs, 2 to 4 , are pale brownish or greenish-olive, thickly blotched and spotted with very dark chocolate; they are rather pointed at one end and measure $1.30 \times 1 \cdot 0$. Hall's eggs were fresh and taken somewhat early-on May 26th-the more more usual nesting-time is June.

\section{ORDER STEGANOPODES.}

This order contains a number of swimming and diving birds, such as the Cormorants, Darters, Gannets and Pelicans; they can be recognized at a glance by a very obvious external character; the feet are totipalmate, that is, all the toes, including the first or hallux, which is turned forwards more or less parallel to the other toes, are fully webbed.

\section{Key of the Famtifes and Genera.}

a. Bill shorter than the middle toe, compressed; gular sac small, hardly distensible (Phalacrocoracida).

Phalacrocorax, p. 26.

b. Bill much longer than the middle toe, flattened and depressed; gular sac large and greatly distensible (Pelecanidcce).

Pelecanus, p. 28.

\section{Family PHALACROCORACIDÆ.}

Characters of the Genus.

\section{Genus PHALACROCORAX.}

Bill subcylindrical and slightly compressed, the upper mandible strongly hooked at the tip; nostril rudimentary; wings short and rounded; tail of twelve or fourteen feathers rather short and stiff; tarsus short and compressed; all the toes well webbed. 
A large and cosmopolitan genus of about forty species, five in the United States.

\section{KEY OF THE SPECIES.}

a. Larger, wing over 110 ; no white gorget. P. auritus, p. 27.

b. Smaller, wing under 11.0. a white gorget along the edge of the gular sae in the breeding plumage.

P. v. mexicanus, p. 28.

\section{Double-crested Cormorant. Phatacrocorax auritus.}

A.O.U. Checklist no 120-Colorado Records-Ridgway 79, p. 234 (P. dilophus) ; H. G. Smith 86, p. 285 ; 96, p. 48 ; Morrison 89, p. 148 ; Cooke 97, pp. 62, 156 ; Felger 09, p. 279.

Description.-Adult-Plumage glossy greenish-black, the feathers of the scapulars and wings slaty with black borders; a few long curly feathers above and behind the eye form a double crest; tail of twelve feathers ; iris green, eyelids blue, bill yellow, darker along the culmen; gular sae orange and convex in shape posteriorly, feet dull black. Length about 32 ; wing $12 \cdot 0$; tail 6.0 ; culmen $2 \cdot 10$; tarsus $2 \cdot 20$.

The crests are lost in the winter and the eyelids are not so blue; young birds are dark brown, paling on the throat and breast to almost white.

Distribution.-The greater part of North America on the coast and in the interior; breeding from the Bay of Fundy and North Dakota northwards; south in winter to the Gulf coast.

In Colorado this Cormorant can only be regarded as a straggler in the fall migration; there are about four definite records, all from the neighbourhood of Denver in the fall between 1885 and 1891, given by H. G. Smith, and others by Felger. Aiken informs me that he has examined a few examples killed near Colorado Springs.

Habits.-Cormorants are generally found about the sea coast, and this species is the only one which is widely distributed in the interior parts of North America. They are expert fishers and swim and dive with great ease; they seize their prey in their powerful bills under water, and on returning to the surface they toss the fish in the air and swallow it head first. When not fishing, much of their time is spent sitting and sunning themselves on rocks or posts on the beach. They nest in communities on the rocks or in the cliffs beside the sea, and 
on trees in the interior, laying pale bluish eggs of oval shape, often covered with a chalky investment. They have been reported to breed in Utah and Wyoming, but not hitherto in Colorado.

\section{Mexican Cormorant. Phalacrocorax vigua mexicanus.}

A.O.U. Checklist no 121-Colorado Record-Felger 01, p. 189.

Description.-Resembling $P$. auritus but smaller-wing 10.0 to 10.5 -and with a white gorget bordering the gular sac behind and almost reaching the eye; the white nuptial plumes form a packet on either side of the head, and others are scattered on the neck and belly. Length about 28 ; wing $10^{\circ} 0$; tail 6.0 ; tarsus and culmen about $2 \cdot 0$.

In winter the gorget and nuptial plumes are absent. Young birda are greyish-brown, paler and whiter below.

Distribution.-The coasts of the Gulf of Mexico and the West Indies, north along the Mississippi Valley to Kansas and Illinois.

A. H. Felger reports that an adult male of this species was taken at Smith's Iake, fourteen miles north of Denver, October 15th, 1899 ; it was identified by himself and by H. G. Smith. This is the only Colorado record.

\section{Family PELECANID王.}

Characters of the only genus.

\section{Genus PELECANUS.}

Bill long and flattened, the culmen forming a rounded ridge and ending at the tip in downward curved hook; nostrils small and rudimentary; a very large gular pouch of naked skin depending from between the two somewhat flexible rami of the lower jaw and reaching posteriorly some way down the neck; wing long, tail short, slightly wedge-shaped, of twenty-two to twenty-four feathers.

Eleven species are generally recognized; three of these occur in the United States.

\section{American White Pelican. Pelecanus erythrorhynchos.}

A.O.U. Checklist no 125-Colorado Records-Ridgway 73, p. 188 ; Drew 85, p. 18 ; Beckham 85, p. 144 ; Morrison 89, p. 148 ; Cooke 97, pp. 18, 52, 193 ; Rockwell 08, p. 157; Henderson 09, p. 225 ; Felger 09 , p. 279. 
Description.-Adult-Plumage white throughout, except for the primaries, their coverts, and some of the secondaries, which are black; some elongated feathers on the oceiput, breast and lesser wing-coverts straw-yollow; tail with twenty-four feathers; iris pearl-white, bill, which bears a horny excrescence on the culmen, orange-red with the ridge of the culmen whitish; bare skin about the eye, gular pouch and feet orange. Length 60.0 ; wing 24.0 ; tail $6{ }^{\circ} 0$; culmen $12 \cdot 0$; tarsus $4 \cdot 5$.

After the breeding season the excrescence is lost, and the crest is replaced by a dusky spot. In winter the occiput is white and the bill, pouch and feet are yellow not orange. Young birds are like the winter adults, but have a little grey on the top of the head and on the lesser coverts.

Distribution.-Breeding chiefly in the western interior of North America, from Oregon and Utah north to Hudson Bay; in winter south to the Gulf of California and Mexican coasts as far as Guatemala.

The Pelican was formerly not uncommon on migration, while a few are said to have bred in Colorado. Of late years, no doubt owing to increase of population, it has been less often seen, nor have I met with any undoubted account of its nesting within the State.

It arrives from the south at the end of April, and has been noticed by W. G. Smith at Loveland on the 23rd of that month. On May 22nd, 1898, nine out of a flock of eighteen were killed on Prospect Lake on the confines of Colorado Springs, and a flock of forty was seen near Denver in the spring of the same year. It is an irregular summer resident at Barr but not known to breed (Hersey \& Rockwell). In the fall migration it appears to pass through the mountains, and has been observed by Carter at an elevation of 13,000 feet, and there is an example in his collection killed near Breckenridge, August 10th, 1892. It is also recorded from San Luis Valley in October, and from Grand Junction on the western slope, where Mr. Sullivan saw a flock of eight, September 4th, 1904.

Habits.-White Pelicans are found on the sea coasts and in the interior, chiefly along the larger rivers and in marshes where there is a plentiful supply of fish, on which they feed almost exclusively; they fly well with the neck bent and the head close to the shoulders, and often ascend to a great height in the air and there perform wonderful aerial evolutions; they also swim well and strongly, but are said not to be able to dive. They pursue their prey in considerable numbers in a 
long line, driving the fishes before them into the shallow water and catching them when floundering. They fill the elastic pouches beneath their long bills with great quantities of fishes, which they devour at leisure or carry off and disgorge to feed their young.

They breed in great communities, generally on islands in lakes. The nest is on the ground, sometimes a simple depression in the sand, sometimes put together with a few sticks and weeds. The eggs, usually two, are oval, white and chalky, and measure 3.50 $\times 2.30$.

\section{Brown Pelican. Pelecanus occidentalis.}

A.O.U. Checklist no 126-Colorado Record-Smith 10, p. 133.

Description.-Adult-Top of the head and a spot on the upper-breast straw-yellow, white line on eitner side of the breast; hind-head and neek brown, rest of the body silvery grey except the primaries, which are black; under-parts brown streaked with white. Length 50.0 ; wing 19.5 ; tarsus 2.65 ; bill 11.0 . After the breeding season the bird's head and neck are white tinged with straw-yellow; young birds are similar but duller.

Distribution.-The Atlantic coasts of tropical and subtropical America breeding north to South Carolina, accidental in other parts of the United States.

According to H. G. Smith a single example of this species, now preserved in the State Museum at Denver, was killed on Wood's Lake, Thomasville, Colorado, by Mr. P. J. Engelbrecht in June, 1908. This is the only record for the State.

\section{ORDER ANSERES.}

This order includes the Ducks, Geese and Swans, and forms a well-marked and clearly circumscribed group of birds. Externally they can be distinguished by their characteristically shaped bill, which is generally broad, flattened and depressed, and is covered by a soft membrane except at the tip of the upper mandible, where there is a hard nail ; furthermore both mandibles have, just inside their cutting-edges, a series of horny 
lamellæ of varying development; the number of tailfeathers varies from fourteen to twenty-four; the legs are short and the anterior toes fully webbed; the hind toe is small and jointed above the level of the others; the eggs are numerous, white, pale greenish or creamy, and unspotted; the young are covered with down when hatched, and able to run or swim at once.

All the North American genera are included in a single family-Anatidce. This, for convenience, can be divided into five subfamilies, as follows:-

KaX OF THE SUBFAMULES.

A. Tarsus as long as the middle toe without claw; with reticulate scales all round.

a. Neck very long, as long as the body ; lores naked in the adults.

b. Neck moderate, no naked patch on the lores.

Cygninæ, p. 71.

Anserinæ, p. 65 .

B. Tarsus shorter than the middle toe without claw, scutellate in front.

a. Hind toe not lobed.

Anatinæ, p. 35.

b. Hind toe lobed.

$a^{1}$ Bill flattened and depressed.

$b^{1}$ Bill cylindrical and compressed.

Fuligulina, p. 49.

Merginæ, p. 31 .

\section{Subfamily MERGINÆ.}

The Mergansers have a narrow, almost cylindrical, bill, with the lamellæ only present in the upper mandible and developed into prominent tooth-like serrations ; tarsi compressed, scutellate anteriorly; hind toe lobate; head usually crested; sexes unlike.

Kry of The Gentera aNd Spectes.

A. Bill chiefly red, about as long as the head; crest low and only in the occipital region (Mergus).

a. Nostrils near the middle of the bill, breast all white in, $\delta$

M. americanus, p. 32.

b. Nostrils nearer the base of the bill; breast with w patch of reddish-brown in $\delta^{\prime} \quad$ M. serrator, p. 33.

B. Bill chiefly black, shorter than the head ; crest highly developed, orect and semicircular (Lophodytes). $\quad$ L. cucullatus, p. 34 . 


\section{Genus MERGUS.}

Bill about as long as the head, chiefly red, serrations acute, recurved, clew-like; tarsus about two-thirds as long as middle toe; crest low and flimsy; head green or brown.

Two species in the United States.

\section{American Merganser. Mergus americanus.}

A.O.U. Checklist no 129-Colorado Records-Allen 72, p. 164; Drew 85, p. 18 ; Beckham 85, p. 144 ; Morrison 89, p. 148 ; Cooke 97, pp. 52, 194; 06, p. 19.

Description.-Malo-Head with its slight short crest, and upperneck glossy dark green; upper-parts black, fading into ashy on the rump and tail; wings white except the primaries, outer secondaries and bases of the greater coverts, which are black; below, including the lower part of the neck all round, white marbled with dusky on the flanks ; iris carmine, bill red, culmen and hook darker, legs deep red. Irength 26 ; wing $10 \cdot 80$; tail $4 \cdot 75$; culmen $2 \cdot 10$; tarsus $1 \cdot 75$.

The female is smaller-wing about 10.0 ; head (with a crest slightly longer than in the male) and neck rufous-brown, throat white, upperparts ashy; white on the wings restricted to a few of the inner secondaries and coverts; below white; iris yellowish, legs orange with dusky webs.

Distribution.-Breeding from south Alaska and Labrador south to the northern tier of the United States and further south along the mountain ranges to New Mexico and Pennsylvania; south to winter as far as the Gulf coasts and southern California.

This bird in most common on migration in Colorado, chiefly in April, but at the same time a good many winter especially along the South Platte near Fort Morgan, and in the lakes near Denver; and certain number breed in summer in the mountains, though of this we have only two definite statements-Allen saw a pair near Montgomery at the head waters of the Platte, at about 11,500 feet in July, and Carter states that it nests at Breckenridge. The only other definite record is that of Beckham, who observes that it is common in April on the Arkansas at Pueblo. Warren informs me he has seen examples killed on Deckers Lake near Crested Butte, about 9,000 feet, in the fall

Habits.-These Ducks are usually found in pairs or small family parties along rivers or on open lakes where there is plenty of fish. These they pursue and catch by diving, in which they are very expert. They are hardly edible in consequence of their fish diet. The 
nest is generally placed in a hollow tree, sometimes on the ground; it is constructed of moss and leaves and lined with down, plucked from the parents' breast; the eggs, usually ten, though as many as fourteen have been found, are oval and pale buffy to white in colour; they measure $2.65 \times 1.78$.

\section{Red-breasted Merganser. Mergus serrator.}

A.O.U. Checklist no 129-Colorado Records-Ridgway 79, p. 234 ; Thorne 87, p. 264 ; Morrison 89, p. 148 ; Cooke 94, p. 183 ; 97, pp. 53, 194 ; Henderson 03, p. 234 ; 09, p. 225 ; Cary 09, p. 180.

Description.-Malo-Head (with a long thin occipital crest) and upperneck all round, black glossed with green; back black, becoming greyish on the rump and tail ; wings chiefly white on the surface but the primaries black; below including the lower-neck all round, except for a dorsal dark line, white; a patch of reddish-brown streaked with dusky on the breast; iris, bill and feet red. Length $24^{\circ} 0$; wing $9^{\circ} 0$; tail $4^{\circ} 0$; culmen $2 \cdot 20$; tarsus $1 \cdot 6$.

The female and young have the crown greyish-brown, becoming more rufous on the sides and neck; rest of the upper-parts slaty, the white wing-patch much restricted; below white; wing about 8.5 .

Both sexes can be easily distinguished from $M$. americanus by the position of the nostril, which is nearer the base of the bill instead of about the middle of its length.

Distribution.--The northern parts of both hemispheres; in America breeding from Alaska and Greenland south to Minnesota and Now Brunswick; in winter south of these limits to California, the Gulf and Cubs.

The Red-breasted Merganser is a somewhat rare bird in Colorado, but it occasionally winters at Barr, near Denver, and along the Platte River; it is more common on migration and has been recorded from Fort Collins and Middle Park (Cooke), Boulder co. (Henderson) and Fort Lyon by Thorne, probably all on migration. Cary reports he saw a mounted specimen at La Veta which had been shot on a reservoir near by. Hersey informs me he has seen this species with "flapperg' in July, on the Fraser Creek in Middle Park at about 7,500 feet, and he believes that it breeds there.

Habits.-The Red-breasted does not differ very much from the American Merganser, except that the nest appears to be generally placed on the ground though sheltered 
and concealed by a log or in a rocky crevice. The eggs are drab with a tinge of olive.

\section{Genus LOPHODYTES.}

Bill shorter than the head, chiefly black; bill-serrations low, oblique, not hooked; tarsus about half as long as the middle toe; crest very highly developed, erect, compressed, and semicireular.

One species only.

\section{Hooded Merganser. Lophodytes cucullatus.}

A.O.U. Checkligt no 131-Colorado Records-Beckham 85, p. 144 ; Morrison 89, p. 148 ; Cooke 97, pp. 53, 194; 06 p. 21; Henderson 03, p. $234 ; 09$, p. 225 .

Description.-Male-Head, neck and upper-parts black, becoming browner on the lower back; a large compressed, semicircular, erectile crest with the central portion white; below, from the fore-neck white; sides finely waved with dusky and cinnamon; wing with a white speculum and two black bars; iris yellow, bill black, feet dusky. Length 18 ; wing $7 \cdot 75$; tail 4.0 ; oulmen $1 \cdot 60$; tarsus $1 \cdot 20$.

The female is smaller-wing $7 \cdot 25$-and has a smaller crest; it is grejish-brown above, browner on the crown; the under-parts whitish with the sides dusky brown, not undulated; wing with less white, the speculum crossed by only one bar. Young birds are like the female, but the erest is absent or much smaller.

Distribution.-Throughout the greater part of North America from British Columbia and Hudson Bay to Mexico and Cuba; breeding locally throughout most of its range, in the United States and northwards.

In Colorado the Hooded Merganser is said to be not uncommon though it has received but little notice. Cooke states that a few birds winter, a few breed in the mountaing, and rather more pass through on migration. There is no definite statement of its nesting in the State, though Thorne found it at Fort Lyon on June 20th and July 2nd, and Carter near Canon City on June 1st. The only other definite records are-Barr Lake, not uncommon in winter (Hersey \& Rockwell), Pueblo (Beckharn) and Boulder co. (Henderson).

Habits.-This Merganser is seldom seen on sea-water, and prefers swamps and quiet lakes to running water; it feeds on roots and weeds as well as on fishes and aquatic insects. 
It nests in holes in trees and stumps near the banks of lakes, and lines its nest with grasses, feathers and down. When the young birds are hatched they are carefully transported to a secluded pool by the mother, who carries them in her bill by the neck or wing. The eggs, 6 to 10 or even more, are white or buffy and measure $2.05 \times 1 \cdot 70$.

\section{Subfamily ANATIN巫.}

The river Ducks have a broad flattened bill with fine comb-like lamellæ in both mandibles; the tarsi are scutellate, and shorter than the middle toe without claw; the hallux is without a lobe, and the sexes are generally unlike.

\section{Key of the Genera and Specters.}

A. Bill distinctly spatulate, broad at the end, narrow at the base (Spatula).

S. clypeata, p. 46 .

B. Bill more or less parallel-sided, not spoon-shaped.

a. Tail graduated for more than one-third of its total length, tail-feathers sharp-pointed.

$a^{1}$ Fourteen tail-feathers; speculum green and black (Mareca).

M. americana, p. 40 .

$b^{1}$ Sixteen tail-feathers.

$\mathrm{a}^{2}$ Bill longer than the middle toe without claw; tail very long and produced in adult male (Dafila).

D. acuta, p. 47.

$b^{2}$ Bill shorter than the middle toe without claw; speculum white (Chaulelasmus).

C. streperus, p. 38.

b. Tail graduated less than one-third of its total length; tail feathers sharp-pointed.

a Larger, wing over 8 (Anas).

$\mathrm{a}^{2}$ Head and neck glossy green. A. platyrhynchos, p. 36.

$b^{2}$ Head streaked with fuscous and buffy. $\delta$ in winter.

$a^{3}$ Below mottled, dusky and grey. A. platyrhynchos, p. 36.

$b^{3}$ Below mottled, dusky and brown. A. f. maculosa, p. 38 .

$b^{1}$ Smaller, wing under 8.

$a^{2}$ No blue on wing; speculum green (Nettion).

N. carolinensis, p. 41 .

$\mathbf{D} 2$ 
$\mathrm{b}^{2}$ Wing-coverts sky blue (Querquedula).

$a^{*}$ A white patch on the sides of the face.

$b^{4}$ No white on head.

$\mathrm{a}^{5}$ Below clear cinnamon. Q. cyanoptera, $\delta$ p. 44.

$\mathrm{b}^{5}$ Below dusky and dark buff. Q. cyanoptera, 9 p. 44 .

$r^{5}$ Below dusky and grey. $\quad$ Q. discors, + p. 43.

c. Tail-feathers wide and rounded; head distinctly crested ( $A$ ix $x$ ).

A. sponsa, p. 48

\section{Genus ANAS.}

Bill about as long as the head or longer, exceeding the tarsus, broad and with the sides more or less parallel, nail narrow, less than one-third as wide as the end of the bill; nostrils high up in the basal half of the bill; tail rounded, less than half the wing, of 16 to 18 pointed feathers; speculum violet, framed in black and white.

Three species in the United States.

\section{Mallard. Anas platyrhynchos.}

A.O.U. Checklist no 132-Colorado Records-Henshaw 75, p. 472 (Anas boschas); Drew 81, p. 142; 85, p. 18; Allen \& Brewster 83, p. 198 ; Beckham 85, p. 144 ; Morrison 88 , p. 140 ; 89 , p. 148 ; Kellogg 90, p. 90 ; McGregor 97, p. 38 ; Cooke 97, pp. 53, 194; 06 p. 22 ; Dille 03 , p. 74 ; Henderson 03, p. 234 ; 09, p. 225 ; Rockwell 08, p. 157 ; Warren 09, p. $13 ; 10$, p. 29.

Description.-Male in breeding dress-Whole head and upper-neck glossy green, followed by a white ring; back dark greyish-brown becoming black on the rump; the longer upper tail-coverts recurved; tail-feathers mostly whitish; breast rich chestnut, belly greyish-white finely mottled with dusky; under tail-coverts black; speculum rich purple bordered in front and behind by narrow bands of black and white; iris brown, bill greenish-yellow, feet orange-red. Length 230 ; wing 11.0 ; tail 4 ; culmen 2.25 ; tarsus $1 \cdot 75$.

After the breeding season, in early summer, the male moults into a plumage closely resembling the female, and after the body-moult is complete, loses its quills and is unable to fly. The second or breeding plumage is again assumed in the fall.

The female has the top of the head streaked with fuscous and buffy, the rest of the plumage mottled, scolloped and streaked with dusky and grey, more greyish below; the chin is plain buffy, and the undersurface of the wing white; speculum as in the breeding male; bill dusky, blotched with orange; dimensions smaller than the malo-wing about $10 \cdot 50$. 
Distribution.-The greater part of the northern hemisphere of the Old and New Worlds; in America breeding north and west of a line drawn from Lower California to about western Pennsylvania and thence north to Hudson Bay, and wintering over the greater part of the United States, especially in the lower Mississippi Valley and Mexico as far as Mexico City.

The Mallard is the most abundant Duck in Colorado; it is not uncommon in winter; it breeds throughout most of the State from the plains to about 9,000 feet, and it is still more abundant on migration, especially in the fall.

It is a common summer resident as well as a winter bird at Barr near Denver, it breeds in South and Middle Parks (Carter) and in Estes Park (Kellogg) and in Mesa co., along the Grand River, in Plateau Valley from about 6,000 feet to 9,000 feet. on Beaver Creek at its head (Rcckwell).

It is an early migrant; the spring flight takes place from about March 5th to 25th, and the return from October 15th to the end of the month; it has been observed on migration throughout the whole State.

Habits.-This, the Wild Duck par excellence, is far the commonest of all the Ducks, not only in most of North America, but also in the Old World. It is undoubtedly the original progenitor of our domestic Ducks, and will often cross with them; though monogamous in a wild state, it soon becomes polygamous when domesticated. It is essentially a fresh-water Duck, seeking its food in swamps and marshes rather than in large bodies of open water, and feeding on snails, frogs and aquatic insects, but chiefly on grain and vegetable matter. It is therefore, as a rule, well flavoured and sought after for the table. The nest is placed on the ground in the grass near the edges of ponds or marshes, and is made of grass, leaves and weeds, loosely put together and lined with feathers or down. The eggs, 6 to 10 in number, are buffy or whitish, usually with a green tinge. They measure $2 \cdot 30 \times 1 \cdot 60$. Dille gives the second week in May as the average time for fresh eggs near Denver. 


\section{Mottled Duck. Anas fulvigula maculosa.}

A.O.U. Checklist no 134a-Colorado Records-Ridgway 73, pp. 177, 188 (Anas obscura) ; Morrison 89, p. 148; Cooke 97, pF. 53, 156, 194 ; Felger 09, p. $280 ; 10$, p. 451.

Description.-Resembling a dark-coloured femalo Mallard; head and neck buffy, finely streaked with dusky; chin and throat isabellacolour unmarked; under-parts mottled about equally with dusky and light brown; feathers of the breast and back with brown centres and margins; speculum greenish purple framed in black, the feathers narrowly tipped with white; iris dark brown, bill greenish with a black spot at the base of the lower edge of the upper mandible; legs reddishorange. Wing $10 \cdot 0$; tarsus $1 \cdot 75$; culmen 2.25 .

The sexes are alike, except that the female has no black spot on the mandible.

Distribution.-Breeding in Texas and probably north to Kansas and Colorado.

A Duck identified formerly as the Dusky or Black Duck of the Atlantic coast, has been recorded on several occasions from Colorado. It was first noticed by Ridgway on the authority of Aiken. Thorne took it at Fort Lyon (Morrison) and Osburn on the Big Thompson near Lovelend, March 15th, 1889. Cooke in his second supplement (p.194) considered that these Ducks should be referred to the present subspecies.

In the Natural History Museum at Denver there is a Duck taken November 6th, 1907, near Lovoland, by Mr. Blaney; it is mounted, and the bill has been coloured so that it is impossible to make out the spot on the mandible, but the throat is clearly plain and unstreaked, and I have little doubt that it should be referred to this subspecies, which may therefore be considered a straggler to Colorado. Felger (09) gives several additional records from the neighbourhood of Denver, and in a recently published note (10) considers that Cooke is in error, and that these Colorado Ducks should be referred to $A$. rubripes. I have myself carefully examined the example mounted in Denver, and am inclined to support Cooke in his determination.

\section{Genus CHAULELASMUS.}

Closely resembling Anas, with a tail of sixteen feathers, but wing speculum white, and in the male the greater coverts black, the middle coverts chestnut.

One nearly cosmopolitan species.

\section{Gadwall. Chaulelasmus streperus.}

A.O.U. Checklist no 135-Colorado Records-Allen 72, p. 159 ; Aiken 72, p. 210 ; Henshaw 75, p. 474 ; Drew 81, p. 142 ; 85, p. 18 ; 
Tresz 82, p. 245; Beckham 85, p. 144; W. G. Smith 87, p. 169; Morrison 88, p. 140 ; 89, p. 148 ; Kellogg 90, p. 86 ; Cooke 97, pp. 18, 53, 156, 194; 06, p. 27 ; Henderson 03, p. 234; 09, p. 225 ; Rockwell 08, p. 157 ; Warren 09, p. 13.

Description.-Male-General colour including the head, which bears B low orest, neck, upper-back, scapulars and sides brown, speckled and undulated with greyish-white; lower back plain brown, becoming black on the rump and upper tail-coverts; belly white with sharply defined velvety black on the abdomen and lower tail-coverts; wing with a patch of chestnut, velvety black, and white; iris reddish-brown, bill black, legs dull orange. Inength 20.0 ; wing 11.0 ; tail 3.5 ; culmen $1 \cdot 75$; tarsus $1 \cdot 7$.

The female is smaller-wing 10.0 , and brown throughout except on the lower breast and abdomen, which are white and everywhere speckled or variegated with buffy-brown; the patches of chestnut, black and white on the wing are rather smaller. The young male is like the female.

Distribution.- - One of the most widely spread of Ducks, found throughout Europe, Asia and North America, and wintering south in Africa and southern Asia. In America its breeding range extends from Hudson Bay and southern. British Columbia, south to southern Colorado and most of California. In winter it resorts chiefly to the southern states and the lower Mississippi Valley, and to Mexico as far as Mexico City.

In Colorado the Gadwall is a fairly common summer resident and quite common on migration, but has been noticed only, so far as I can ascertain, at Barr in winter. It arrives from the south early and has been noted at Fort Lyon on March 1st and at Loveland from March lst to 12th ; it is not so common apparently on the western slope and was only once seen by Sullivan-on the Gunnison. River, March $28 \mathrm{th}$ (Rockwell), while at Coventry it has been seen in April (Warren). Breeding records are-Barr Lake (Hersey \& Roclkwell), Estes Park (Kellogg), Middle Park, Carter (Cooke), South Park (Tresz), San Luis Lakes (Aiken \& Henshaw), La Plata co. (Morrison), and Calhan El Paso co. June (Aiken).

Habits.-The Gadwall resembles the Mallard in habits ; it is essentially a fresh-water Duck, preferring secluded marshy ponds and reedy streams to large open pieces of water. It feeds largely on vegetable matter, waterweeds, grass, roots and often grain, as well as on insects, tadpoles, etc., and it is as well-flavoured as the Mallard. 
The nesting-habits are similar to those of the Mallard, though they have been known to breed in trees. The eggs, 8 to 12 in number, are creamy-white and average $2.20 \times 1.50$.

Natural hybrids among Ducks are not uncommon; W. G. Smith (87) shot, near Loveland, a fine male, the characters of which were equally divided between a Gadwall and a Baldpate.

\section{Genus MARECA.}

Resembling Anas but with a shorter bill, not as long as the head; tail pointed, of fourteen feathers, not as long as the wing; speculum green, top of the head white or whitish.

Two species in the United States.

\section{Baldpate. Mareca americana.}

A.O.U. Checklist no 137-Colorado Records-Aiken 72, p. 210 ; Coues 77, p. 51; Morrison 89, p. 148 ; Cooke 97, pp. 18, 54, 194; 06, p. 28 ; Henderson 03, p. 234; 09, p. 225 ; Rockwell 08, p. 157 ; 10 , p. 29 ; Felger 09, p. 280.

Discription.-Male-Crown pure white, sides of the face, cheeks and neck also white or buffy, spotted with dusky; chin brown; a patch from the eye to the nape glossy green; fore-neck, chest and sides of the body cinnamon, some of the feathers finely barred with dusky; lower-breast and abdomen white, abruptly black on the lower tailcoverts; rest of the upper-parts various shades of brown, some of the feathers, especially the scapulars, finely barred with buffy; speculum green, bordered by black with a white patch above it; iris brown, bill greyish-blue with a black tip, feet very similar. Length 20.0 ; wing 10.5 ; tail $4 \cdot 75$; culmen 1.50 ; tarsus 1.40 .

Younger males have the whole head and neck white or buffy and speckled with dusky. Females have the head like the young male; the colour generally is brown mottled with dusky and the belly white; on the wing the pattern is the same as in the male, but the white is much restricted and the green of the speculum often faint.

Distribution.-Breeding in north-central North America, within a line drawn from Hudson Bay to Lake Michigan, thence west to Nevada and north-west to the Pacific; south in winter over the southern states and Mexico as far as Costa Rica and the West Indies.

In Colorado the Baldpate like the Gadwall is most common on migration, while a certain number remain to breed, and others appear to winter. 
The only definite account of its nesting is that of Coues, who found it with young birds and several other species of Duck on a small lake on the southern edge of North Park, probably about 8,000 feet, shortly after the nesting-season; there is an adult male in the Aiken collection taken at Falcon on May 3rd, and Hersey and Rockwell include it as a summer resident at Barr. It was seen on the San Luis Lakes in June by Warren.

On migration it was noticed by W. G. Smith at Loveland, March 10th to 13th, and seen by Carter in Middle Park (Cooke), while Sullivan reports it as plentiful in the fall but scarce in the spring at Grand Junction (Rockwell). Felger states that it is not uncommon in winter at Barr.

Habits.-Like the Mallard and Gadwall this is a shoalwater Duck, preferring the edges of lagoons and grassy lakes to large pieces of water, and feeding chiefly on vegetable matter, so that it is generally good eating. Goss states that they rob Canvas-back and other deep-water Ducks of the vallesneria grass which grows in deep water, and which they cannot procure for themselves as they do not dive. The eggs, 6 to 12 in number, are pale buff to nearly white, and measure $2.05 \times 1.45$.

\section{Genus NETTION.}

Very small ducks-wing under 8-with a slightly crested head and a narrow parallel-sided blackish bill, a green speculum and grey, buffy-tipped wing-coverts without blue.

Two species in the United States.

\section{Green-winged Teal. Nettion carolinensis.}

A.O.U. Checklist no 139-Colorado Records-Aiken 72, p. 210 ; Henshaw 75, p. 475 ; Beckhan 85, p. 144 ; Drew 85, p. 18 ; Morrison 89, p. 148; Kellogg 90, p. 90 ; Cooke 97, pp. 18, 54, 194; 06 p. 30 ; Henderson 03 , p. 234 ; 09, p. 225 ; Rockwell 08, p. 157 ; Warren 09, p. 13.

Description.-Adult Male-Head and neck all round chestnut, blackening on the chin; a patch from round the eye to the nape glossy" green, ending in a nape crest of chestnut and black; general colour above and along the rides, grey brown and white in narrow undulations; breast pale cinnamon, with rounded black spots, paling to nearly pure unspotted white on the abdomen; under tail-coverts 
black centrally, pale buffy laterally ; speculum bright green, bordered in front by buffy, below by black and behind with a little white; a white patch on the sides of the breast; iris brown, bill black, feet dusky. Length 14.0 ; wing 7.5 ; tail 2.75 ; culmen 1.5 ; tarsus $1 \cdot 20$.

The female has no crest and the speculum is less perfect; the head and neck are streaked with dark and tawny-brown, the throat and lower-parts are white and the back, sides and breast dusky, scolloped and mottled with buff.

Distribution.-Breoding from New Brunswick along the northern tier of atates to Oregon, northwards to the Barren Grounds of Alaska, and south along the mountains to New Mexico; in winter south to the south-western United States, Mexico to Mexico City and the West Indies.

The Green-winged Teal is one of the commonest of the migrating Ducks in Colorado, and is also a resident. It is one of the earliest to arrive, reaching Fort Lyon February 20th to March 3rd, Loveland February 2lst, and Salida March 27th (Frey). It is common on the Arkansas near Pueblo in April and September (Beckham), and has been observed as high as Breckenridge on migration by Carter, and at Crested Butte by Warren.

On the western slope it is the commonest Duck at Coventry on migration only (Warren) and also in Mesa co. (Rockwell). It has been found nesting at San Luis Lakes by Henshaw and is stated to be a common summer resident in Estes Park by Kellogg, and at Barr by Hersey and Rockwell, where it is also not uncommon in winter.

Habits._-"This handsome little duck," writes Goss, "is usually found in small flocks along the edges of shallow, grassy waters, feeding largely on seeds, aquatic plants and insects ; they fatten very fast in the ricefields, and are very fond of acorns. In exposed situations they feed largely at night, resting by day on bare spots surrounded and hidden by reeds. They are perhaps the best-tasting of our ducks."

Henshaw found this species nesting at San Luis Lakes, on June 24th; the nest was placed under a sage bush thirty feet from the water; it consisted of a hollow in the sand, lined with grasses, and down plucked from the parent-birds' breast. The eggs were pale yellow and measured $1.80 \times 1 \cdot 30$. The usual complement is 9 to 12 , but as many as eighteen have been found. 


\section{Genus QUERQUEDULA.}

Size very small-wing less than 8 ; no sign of a crest; bill broader then in Nettion; speculum glossy green, wing-coverts sky blue.

Two species in the United States.

\section{Blue-winged Teal. Querquedula discors.}

A.O.U. Checklist no 140-Colorado Records-Baird 58, p. 780; Henshaw 75, p. 477 ; Drew 81, p. 142 ; 85, p. 18 ; Beckham 85, p. 144 ; W. G. Smith 87, p. 169 ; Morrison 88 , p. 140 ; 89, p. 149 ; Cooke 97, pp. 18, 54, 194; 06, p. 32 ; Henderson 03, p. 234; 09, p. 225; Warren 06, p. 19 ; 09, p. 13 ; Rockwell 08, p. 157 ; Felger 09, p. 280.

Description.-Male-Crown, base of the bill and chin, dark brown; a crescent-shaped white mark across the face in front of the eye; rest of the head and neck ashy-grey with a mauve gloss; upper-parts dusky brown, scalloped and streaked with buffy-brown; below vinaceous, heavily spotted throughout with black; under tail-coverts black; a white spot on either side at the base of the tail; wing with a green metallic speculum, bordered in front by white; the whole basal portion of the wing light blue; iris brown, bill black, legs dingy yellow. Length 16 ; wing $7 \cdot 0$; tail 3.0 ; culmen 1.5 ; tarsus $1 \cdot 20$.

The female is mainly speckled above, and grey, mottled with dusky, below, but has the characteristic blue, white and green on the wings. The young bird has the abdomen white, and green on the wing absent.

Distribution.-The breeding range of this duck is mainly north of a line drawn from Nova Scotia to New Mexico and thence to Oregon and northwards to Saskatchewan, while on migration and in winter it covers a vast extent of country from Virginia and California to Brazil and Chili.

In Colorado the Blue-wing is quite common on migration throughout the state in spring and autumn. Hersey and Rockwell state that it is far the most common breeding Duck at Barr, arriving late and leaving early. Henshaw writes that he found it equally abundant with the Green-wing at San Luis Lakes and believed that it bred there; Aiken who visited San Luis Lakes the following year, confirms this. It was taken by Lieut. Bryan on the South Platte in July many years ago (Baird), and Cowie informed Henderson that it breeds on the plains of Boulder co. Mr. Aiken tells me he found a nest, but without eggs, on June 4th, on the Big Sandy Creek neax Ramah, about forty miles east of Colorado Springs on the plains, and there is a specimen in the Aiken collection taken on May 3rd at Falcon in El Paso co. which might have been breeding or preparing to breed. All other observers only seem to have noticed this duck on migration. It arrives from the south rather late. Smith notes it at Loveland from March 25th 
to April 13th, and Frey at Salida, March 27th. It returns early in the fall. Goss states that it is very susceptible to cold. It has been noticed on the Arkansas near Pueblo in May and September (Beckham), near MLnon, JIay 6th (Warren 06), and in Boulder co. (Henderson); in the mountains at Crested Butte (Warren), and at Breckenridge (Carter) on migration; on the western slopes in La Plata co. in spring (Morrison), in San Juan in the fall (Drew), at Coventry on migration (Warren 09), and in Mesa co., spring and fall (Rockwell).

Habits.-The Blue-wing inhabits sloughs, shallow pools and reedy margins of ponds. It feeds chiefly on vegetable matter, roots, weeds and seeds; it is specially fond of rice, and its flesh is greatly esteemed. It is generally silent and flies in small, rather densely massed flocks, it also crowds together when it alights to feed, so forming an easy mark for the pot-hunter.

The nest is placed on the ground among rushes bordering a pool or marsh, and is made up of grasses and lined with down. The eggs, 6 to 12 in number, are buffy to creamy-white, and measure $1.85 \times 1.30$. Felger has taken fresh eggs at Barr on June 26th.

\section{Cinnamon Teal. Querquedula cyanoptera.}

A.O.U. Checklist no 141-Colorado Records-Aiken 72, p. 210 ; Henshaw 75, p. 477 ; Coues 77, p. 51 ; Allen \& Brewster 81, p. 198; Tresz 82, p. 245 ; Beckham 85, p. 144 ; Drew 85, p. 18 ; T. G. Smith 89, p. 77 ; Morrison 89, p. 148 ; Cooke 97, pp. 18, 54, 194; 06 p. 34; Hendurson 03, p. 234 ; 09, p. 225 ; Rockwell 08, p. 158; Tarren 09 , p. 13.

Description.-Male--Head, neck, breast and sides, rufous-brown, darkening on the crown and chin and middle of the abdomen; under tail-coverts dark brown; back brown, varied with rufous bars and edges; wings like the Blue-wing, blue at base, then white, then a green speculurn; iris orange, bill black, feet orange, dusky on the joints and webs. Length $16 \cdot 50$; wing $7 \cdot 75$; tail 3.50 ; culmen $1 \cdot 70$; tarsus $1 \cdot 25$.

The female is like the female Blue-wing, but is darker and more spotted on the breast and neck, only the upper-throat and chin being unspotted. A young male is like the female, but the markings below are more longitudinal and streak-like.

Distribution.-The Cinnamon is remarkable in having two distinct breeding ranges, north and south of the equator in America. The 
northern area extends from British Columbia to western Kansas and south to northern Mexico, the southern area from central Peru to the Straits of Magellan and the Falkland Islands. The winter range of the northern birds extends but little further south to southern Mexico, that of the southern birds north, perhaps to Columbia.

In Colorado the Cinnamon Teal is a fairly common summer resident from the plains to quite high in the mountains. A considerable number also pass through the State to their breeding-grounds further north. They arrive rather late for Ducks, about the middle of April-Colorado Springs April 9th, Loveland April 13th, Lay April 20th (Cooke), and return late in September. They have been noticed breeding on the southern divide of North Park (Coues), at San Luis Lakes (Henshaw), in the mountains of La Plata co. (Morrison), on the mountain lakes near Coventry (Warren), and in the plains near Loveland (W. G. Smith), and at Barr, where it is common but less so than the Blue-wing (Hersey \& Rockwell).

Habits.-The haunts and habits of the Cinnamon are very similar to those of the Blue-wing. W. G. Smith gives a good account of the nesting-habits; according to him a dry spot is usually chosen about a hundred yards from the water, shaded by a bunch of grass; here a deep hole is made, lined with grass, and down from the breast. The eggs, nine or ten in number, are creamy-white and measure $2.0 \times \mathbf{1 . 3 5}$. The female, while laying, covers over the eggs with down, on leaving the nest, so that it is very difficult to locate them.

A clutch of eleven eggs of this species was taken by I. C. Hall on June 1st, near Greeley, and presented to the Colorado College Museum. In this case the nest is stated to have been placed in a slough in over six inches of water and to have been made of rushes.

\section{Genus SPATULA.}

Resembling Anas in most respects but with a large spoon-shaped bill exceeding the head or tarsus in length, and much wider towards the tip than at the base; bill laminæ numerous and projecting; tail short and pointed of fourteen feathers.

One species only in the United States. 


\section{Shoveller. Spatula clypeata.}

A.O.U. Checklist no 142-Colorado Records-Aiken 72, p. 210 ; Henshaw 75, p. 478; Coues 77, p. 51 ; Allen \& Brewster 83, p. 198 ; Morrison 89, p. 148 ; Cooke 97, pp. 18, 54, 194 ; 06, p. 36 ; Henderson 03, p. 234; 09, p. 225; Warren 06, p. 19; 09, p. 13 ; Rockwell 08, p. 158.

Description.-Malo-Head and neck black, slightly glossed with green on the sides of the face and bearing a slight nape crest ; lowerneck, breast, some of the scapulars and the outer tail-feathers white; lower breast and abdomen rufous; under tail-coverts black; wing with the lesser coverts light blue and the speculum green with a white bar above; the scapulars white, light blue and black; iris orange, bill black, legs orange. Length 20 ; wing 10 ; tail 3.5 ; culmen 2.7 ; tarsus $1 \cdot 7$.

The female is spotted and streaked with dusky, but has the wing as in the male though duller. Young birds are like the female.

The shape of the bill will always distinguish this species in any plumage.

Distribution.-The northern hemisphere, south to north Africa, southern Asiz and Australia. In America breeding from Alaska and Hudson Bay south to California and Texas, but not in eastern Canada or the eastern United States; south in winter from the Carolinas and the Gulf states to Columbia and through the West Indies.

In Colorado the Shoveller is mainly a migrant though a certain number stay to breed, chiefly in the mountains. Cooke states it is a common resident especially on the western slope, but I have found only a few notices of its breeding-near the south divide of the North Park (Coues), and at San Luis Lakes where Aiken and Henshaw both observed it. At Barr it nests, but less commonly than some of the other Ducks (Rockwell \& Hersey). It reaches Loveland from the south March 10th to 20th, and has also boen observed on migration in Baca co. (Warren), El Paso co. (Aiken), at Breckenridge (Carter), in Boulder co. (Henderson), and at Orchard (Warren). On the western slope it is rare at Coventry in April (Warren), and not often seen in the Plateau Valley of Mesa co. on migration (Rockwell).

Habits.-The favourite resort of the Shoveller is a weedy, shallow pool or marsh where it dabbles on the muddy bottom, with its broad bill and head immersed, in search of weeds, insects, snails and crustacea, which form its food. It is generally in pairs or quite small parties; it is strong on the wing but has a feeble voice. Its nest is placed on the ground near water or some- 
times on a hummock in a marsh; it is made of grass and down. The eggs, eight to ten or more, are greenish or buffy and measure $2 \cdot 14 \times 1 \cdot 50$.

\section{Genus DAFILA.}

Bill shorter than the head, exceeding the tarsus and also the middle toe and claw, nearly parallel-sided and with a small nail ; neck rather long; tail of sixteen feathers, graduated for at least one-third of its total length; in the adult male when fully developed, nearly as long as the wing, the two central feathers produced and pointed.

One species only in North America.

\section{Pintail. Dafila acuta.}

A.O.U. Checklist no 143-Colorado Records-Aiken 72, p. 210; Morrison 89, p. 164; Cooke 97, pp. 18, 55, 194 ; 06, p. 37 ; Henderson, 02, p. 234; 09, p. 25 ; Rockwell 08, p. 155; Warren 09, p. 13 ; 10, p. 29.

Description.-Male-Head and upper part of the neck and a line along the nape forming a crest, brown; back and a patch on the flanks brown, finely undulated with white; central tail-feathers elongated, pointed and black; below, including the fore-neck and a narrow line on either side of the nape crest, white; belly a little speckled with dusky ; under tail-coverts black; wing chiefly grey brown with a green speculum narrowly bordered above by chestnut and below by white, and on the sides by black; iris brown, bill black, a little greyish on the edge, legs greyish-blue. Length about 26 ; wing 11.0 ; tail 8.0 ; culmen $2 \cdot 2$; tarsus $1 \cdot 60$.

The female is brown above, speckled on the head, mottled on the back with buffy and white; below paler, almost white on the breast; sides like the back; wing with a faint speculum of greenish between two narrow bars of white; tail about 4.5 , shorter than that of the male; wing 9.75. Young birds resemble the females.

Distribution.-The Pintail is another widely-spread Duck with a circumpolar range; it breeds in the northern parts of the Old and New Worlds. In Ameriea the breeding range is north of a line running roughly from Lake Michigan to the Pacific, and west from Lake Michigan to Hudson Bay. They winter to the south as far as Panama and the West Indies.

In Colorado the Pintail is a common migrant. It is one of the earliest birds in spring, and has been noticed at Loveland the first week in February and at Grand Junction on February 27th (Rockwell). Except for the Blue-winged Teal, Hersey and Rockwell found it the most abundant nesting Duck at Barr, while a few birds stay there all the winter. Warren saw a female with four one-third grown young near 
Medano Ranch on July 2nd, so that it probably breeds in the San Luis Valley. On migration it has been noticed by Carter in Middle Park and by Smith at Coventry (Warren), while there are examples in the Colorado College Museum from El Paso co. and from Barr Lake, near Denver, both obtained in March.

Habits.-This is a typical fresh-water Duck, haunting wet prairies, mud flats and small pools in preference to large sheets of open water, and obtaining a good deal of its food by dibbling on the bottom with its head down and its tail and legs sticking up in the air; it seldom, if ever, dives.

The eggs, of $a_{b}$ buffy or greenish colour, are 7 to 10 in number as a rule, and are laid in a nest made of grasses and lined with down, placed on the ground, usually under the shelter of a bush. They nest early-early May in south Dakota. I have no dates for Colorado.

\section{Genus AIX.}

Head crested; bill shorter than the head, hardly equal to the tarsus, narrow and more or less parallel-sided, with a large terminal and downwardly curved nail, lamelie fow, small and not conspicuous, tail of sixteen feathers broad and rounded at the tips.

One North American species.

\section{Wood-Duck. Aix sponsa.}

A.O.U. Checklist no 144 -Colorado Records-Aiken 72, p. 210 ; Morrison 89, p. 165 ; H. G. Smith 95, p. 48 ; Cooke 97, pp. 55, 156, 194 ; 06, p. 40 ; Henderson 03, p. 234 ; 07, p. 198 ; 09, p. 226.

Description.-Male-Head and crest brilliant purple and green with white stripes; throat white; chest rich chestnut with rows of white triangles ; sides grey with black and white bars and crescents ; shoulders crossed by black and white bars; rest of the upper-parts black, with rich irridescent colours; iris red, bill pinkish-white, darker at the base, culmen, tip and lower mandible black, feet orange. Length 19.5 wing $9 \cdot 25$; tail $4 \cdot 75$; culmen $1 \cdot 35$; tarsus 1.45 .

The female has the head dull grey glossed with green; the crest, crown, sides of the head and the throat white; the chest brown and the belly white; the back richly glossed with greyish-brown; wing $8 \cdot 60$; iris brown, bill plumbeous, black on the culmen, legs yellowish. 
Distribution.-Breeding throughout temperate North America from Nova Scotia and southern British Columbia, to Cuba, Florida, south Texas and southern California; wintering in the southern portion of its breeding range.

In Colorado the Wood-Duck is distinctly a rare bird, though probably a summer resident when it does occur; but the nest has not yet been taken in the State.

It is occasionally found on the lakes round Denver, and one taken. at Littleton on the South Platte May Ist, 1892, is stated by Cooke to be in the collection of Mr. E. J. Oslar; Hersey reports he took a pair two miles west of Barr Lake in the fall of 1889. It hes also been noticed by Aiken in El Paso co.; by Rowland, Cowie and Werley in Boulder co. (Henderson) and by W. G. Smith at Loveland (Cooke). Morrison states that it is common near Fort Lewis on the La Plata River, and occurs up to an elevation of 9,500 feet; and though he believed it bred, he did not find the nest.

Habits.-The Wood- or Summer-Duck-the most brilliantly coloured of all the American species-is found about small lakes, weedy ponds and shady streams, in close proximity to scattered woods, and is only seen on large bodies of water during migration. It is not shy, and often comes to farms and associates with the barn-yard Ducks. Its flight is swift and graceful, and its food consists of insects, seeds and leaves; it is specially fond of acorns.

The nest is placed in a hollow tree, sometimes in the hole of a Woodpecker, sometimes in a natural cavity. It is often quite high up and far from water. The eggs, 6 to 14 in number, are ivory-white and measure $2 \cdot 0 \times$ 1.50. If the nest is very high up, the parents carry the young birds down to the water in their beaks.

\section{Subfamily FULIGULIN ÆE.}

The Sea-Ducks have the flattened bill of the RiverDucks, but are distinguished by the hind toe being lobate, i.e. bearing a large membranous lobe; the legs are rather shorter and placed far back, so that though 
more awkward on land, they swim and dive with greater facility. The sexes are, as a rule, unlike.

\section{Key of THE Genera.}

a. Tail more than half the wing, the feathers stiff and their bases hardly hidden by the short coverts.

Erismatura, p. 64.

b. Tail normal.

a $^{1}$ Feathering on the lores or forehead not reaching beyond the posterior border of the nostrils.

$\mathrm{a}^{2}$ Graduation of the tail less than the length of the bill from the nostril. Marilla, p. 50.

$b^{2}$ Graduation of the tail more than the length of the bill from the nostril.

$a^{3}$ Anterior edge of the nostril in front of the middle of the culmen.

Clangula, p. 56.

$b^{3}$ Anterior edge of the nostril behind the middle of the culmen.

a Upper mandible widest behind the nostril, and not elevated or swollen at the base.

$a^{5}$ Feathers ending in a straight line across the forehead.

Harelda, p. 59.

$b^{5}$ Feathers ending in an acute-pointed triangle on the forehead.

$a^{6}$ Upper mandible constricted to a small nail-like tip. Charitonetta, p. 58.

$b^{6}$ Upper mandible rounded at the tip.

Histrionicus, p. 60.

$b^{4}$ Upper mandible widest at anterior edge of nostril, and elevated or swollen at the base.

Oidemia, p. 62.

$b^{1}$ Feathering on the lores or forebead extending forward well beyond the posterior border of the nostril.

Somateria, p. 61 .

\section{Genus Marila}

Bill of ordinary shape without any special swellings or gibbosities, about as long as the head, rising high at the forehead; nail distinct, about one-third the width of the end of the bill and decurved; tril short and rounded, graduated less than the length of the bill from the nostrils, of 14 to 16 feathers; tarsus less than two-fifths length of the middle toe and claw; head not crested; speculum white or grey.

A large cosmopolitan genus with five North American species. 


\section{KEY OF THE SPECTES.}

A. Head and neck brown.

a. Bill not longer than the head with a concave culmen.
M. americana, p. 51 .

b. Bill longer than the head ; culmen ad

b. Bill longer than the head; culmen almost straight, not concave.

M. vallisneria, p. $\mathbf{5 2}$.

B. Head and neck black with a greenish or purplish gloss.

a. Speculum white.

a ${ }^{1}$ Larger, wing about $9 \cdot 0$; head with a greenish gloss.

b $^{1}$ Smaller, wing about 8.0 ; head with a purplish gloss.

M. marila, p. 54.

M. affinis, p. 54 .

b. Speculum grey or silvery; male with a chestnut collar.

M. collaris, p. 55 .

\section{Redhead. Marila americana.}

A.O.U. Checklist no 146-Colorado Records-Aiken 72, p. 210 ; Morrison 89, p. 165 ; Cooke 97, pp. 18, 55, 195 ; 06, p. 41 ; Henderson 03, p. 234, 09, p. 226 ; Rockwell 08, p. 158 ; Felger 09, p. 281 ; Hersey \& Rockwell 09, p. 112.

Description.-Male-Head and neck all round rufous-chestnut, on the nape and neck with a coppery-red gloss; fore-neck, breast, forepart of the back, rump, upper and under tail-coverts and tail black, becoming white on the middle of the abdomen; rest of the back, wings and sides of the body silvery, finely undulated with dusky; longer wing-feathers and speculum silvery, not undulated, iris orange, bill dull blue with the terminal fifth black, feet dull greyish-blue. Length 20.0 ; wing $9 \cdot 25$; tail $2 \cdot 75$; culmen 1.85 ; tarsus 1.50 .

The female is smaller-wing $8 \cdot 70$-and has the head and neck dull reddish-brown becoming paler on the cheoks and chin, the upper-parts are brownish with the feathers paler-edged; breast and sides greyish brown, margined with ochraceous, becoming white on the centre of the abdomen.

The Redhead closely resembles the Canvas-back; it can be distinguished in any plumage by its short bill, less than the middle toe without claw, its concave culmen and high forehead, and its nostril well in the basal half of the bill.

Distribution.-Breeding along the northern United States and southern border of the Dominion, from Michigan to the Pacific, and in Utah, Nevada and California; wintering chiefly along the south Atlantic and Gulf Coasts and Mississippi Valley south to Mexico City.

In Colorado the Redhead is a common migrant throughout the State, and one of the earliest to arrive in spring. Felger states that a few 
also winter at Barr. It has been seen at Loveland from February 2nd to March 6th; on the western slope it reaches Grand Junction from February 27th to March 6th, and returns between September 28th and October 22nd, according to Sullivan (Rockwell). It has also been noted from Fort Lyon (Cooke), El Paso co. (Aiken collection) and Boulder (Henderson), while Warren informs me he saw two in the fall of 1902, on Decker's Lake, near Crested Butte, at about 9,000 feet. This is the only mountain record I have met with.

Hersey and Rockwell report that this Duck nests in some numbers at Barr, though it is far more common on migration. A clutch of seven eggs, believed to be this species, was taken by I. C. Hall at Greeley on June 14th, 1903, and were presented by the collector to the Colorado College Museum.

Habits.-The Redhead is usually found in considerable flocks on open water, often associating with Canvasbacks and other species; it is a diving duck and obtains most of its food - aquatic grasses, mollusca, small crustacea and insects-in this way, though sometimes it dibbles as well in the shallows.

It is, as a rule, very good-eating, rivalling to the taste of some the Canvas-back, for which it is often substituted. Its nest is placed on the ground near the water, or sometimes among reeds over water like a Coot's. Hall describes the nest he took at Greeley as being placed in a clump of rushes over open water, eight inches deep, and as being made of dry flags and lined with down. The eggs, in this case seven, but often ten in number, are dull white with a greenish tinge and average $2.40 \times 1.70$.

\section{Canvas-back. Marila vallisneria.}

A.O.U. Checklist no 147-Colorado Records-Aiken 72, p. 210 ; Morrison 89, p. 165 ; Cooke 97, pp. 18, 55, 195 ; 06, p. 43 ; Felger 02, p. 294 ; 05, p. 421; Henderson 03, p. 234 ; 09, p. 226 ; Rockwell 08, p. 158.

Description.-Malo-Resembling generally the Redhead but distinguished by the colour of the head and neck which is darker and browner and by the blackish chin and crown; the markings of the back are more silvery ; this colour prevails over the wavy, dusky lines which are much narrower and more broken up; finally the bill is longer 
at least equal to the midale toe without claw; it is straighter, and the forehead does not rise up high behind it, while the nostrils reach the middle of the bill ; iris red, bill blackish throughout, feet greyish-blue. Length 22.0 ; wing 92.5 ; tail 27.5 ; culmen 2.4 ; tarsus 1.7 .

The female resembles the female Redhead, but can be distinguished by the back being barred with fine wavy white lines and by the Ionger and blackish bill.

Distribution.-Breeding from Oregon and Minnesota northwards to Great Slave Lake and Alaska ; in winter eastwards to the Atlantic Coast from Delaware south through the southern and western states and Mexico to the City of Mexico.

In Colorado the Canvas-back is somewhat less abundant than the Redhead, but it has been met with on migration over the greater part of the State, especially on the eastern side of the mountains. It arrives from the south early, only a little later than the Redhead. Loveland, February 10th to March 12th, are dates given by Cooke, and it has been noticed in El Paso co. (Aiken), at Orchard, March 26th (Warren), at Fort Lyon (Cooke), and in Boulder co. (Henderson) on the eastern plains; at Breckenridge (Carter), in the mountains and at Grand Junction, February 20th, by Sullivan (Rockwell).

Felger reports that he found it nesting at Barr Lake on June 6th and July 4th, 1900, and this is confirmed by Hersey and Rockwell. Aiken saw a small flock of five on a lake near Limon, May 19th, 1899, which may have contemplated nesting, or were possible late migrants. Cooke believed that a few birds wintered on the plains of northern Colorado, and Felger confirms this.

Habits.-The great reputation of the Canvas-back is due to the fact that in its winter home on Chesapeake Bay it feeds almost entirely on the roots and bulbs of the so-called wild celery (Vallisneria) which grows very abundantly in that estuary; elsewhere it is no better than any other Duck; in fact the flavour of all Ducks is entirely dependent on what they have been feeding on.

The Canvas-back is generally found in large flocks on considerable sheets of water, and is a strong flyer and a wonderful diver; when wounded it often escapes in this manner. Owing doubtless to constant persecution, it is exceedingly shy and wary.

It resembles the Redhead in its nesting-habits, building very often in shallow water among thick rushes and 
lining its often bulky nest with down. The eggs are said to be rather more greenish in shade than those of the Redhead, and to measure $2.50 \times 1.75$.

\section{Scaup Duck. Marila marila.}

A.O.U Checklist no 148-Colorado Records-Drew 81, p. 142 ; 85 , p. 18 ; Morrison 88, p. 140 ; 89, p. 165 ; Cooke 97, pp. 55, 195; 06, p. 44 ; Henderson 03 , pp. 107, 110 ; 09, p. 226 ; Warren 09, p. 13 ; Felger 09, p. 281.

Description.-Closely resembling $M$. affiris-the next species-but larger, the head glossed with green instead of purple, and the flanks nearly white with but faint traces of the wavy bars. The female can be distinguished from that of $M$. affinis by its larger size. Length 19.75; wing 9.0 ; tail 2.80 ; culmen 2.0 ; tarsus 1.55 . Wing of female 8.50.

Distribution.- The northern parts of the Old and New Worlds, south in winter ; in America breeding from Minnesota and south-east British Columbia north to Alaska; in winter chiefly on the Atlantic cosst from Massachusetts to Delaware, in the Mississippi Valley, and westwards to southern Californik.

The Scaup is rather a rare duck in Coloredo. It has been reported from Boulder oo. (Henderson) Barr (Hersey), Longmont (Felger), Breckenridge (Carter), Coventry in April (Warren), and La Plata in fall (Morrison) on migration, while Drew came across it in December in San Juan co, at 9,000 feet, so that perhaps it spends the winter in the southern part of the State.

\section{Lesser Scaup Duck. Marila affinis.}

A.O.U. Checklist no 149-Colorado Records-Aiken 72, p. 210 ; Drew 81 , p. 142 ; 85 , p. 18 ; Morrison 88 p. 140 ; 89, p. 165 ; Cooke 97, pp. 18, 56, 195 ; 06, p. 46 ; Henderson 03 , p. 107 ; 09, p. 225.

Description.-Male-Head, neck, front half of the breast, and back black ; the sides of the head glossed with purple; lower-back, rump, upper and under tail-coverts, tail and primaries, dusky brown or blackish; middle of the back, scapulars, and some of the upper coverts white with narrow wavy bars of dusky; below white, slightly mottled. with dusky on the lower abdomen and sides; wing with a white pateh on the secondaries forming a speculum; iris jellow, bill dull bluish with nail black, legs slaty. Length 16.5 ; wing 8.0 ; tail 2.25 ; culmen 1.7 ; tersus 1.2 .

The female is chiefly dark brown with a conspicuous white patch at the base of the bill, a white chin, speculum and abdomen. The male after the breeding season moults to a plumage like the female but darker. 
Distribution.-Breeding from Michigan and central British Columbia northwarda to Alaska; wintering south of this to Panama and the West Indies, and specially on the Atlantic from Delaware to Florida.

In Colorado the Lesser Scaup seems to be more abundant than the larger form; it winters at Barr Lake and perhaps elsewhere on the north-eastern plains, while Drew met with it occasionally in winter in San Juan co. It is, however, most abundant and widespread as a transient on migration, arriving fairly early in spring-Loveland March 8-19th; it is also reported from La Plata co. (Morrison), Fort Lyon (Thorne), Salida April 17th (Frey), El Paso co. (Aiken), Longmont October (Henderson), and Breckenridge (Carter). A mounted female in the Aiken collection, taken as late as May 3rd at Falcon, not far from Colorado Springs, was probably a late migrant.

Habits.-This Duck, also frequently known as the Black-head or Blue-bill, takes its most usual name from the sand-banks called scaups or scalps, on which it feeds when on the sea coast in winter. In Colorado it is chiefly known as a transient, when it alights on lakes or reservoirs to rest during its northward and southward journeys. It is a great diver and feeds chiefly on mollusca which it procures in this way, though it is also fond of grain and wild rice.

\section{Ring-necked Duck. Marila collaris.}

A.O.U. Checklist no 150-Colorado Recorda-Aiken 72, p. 210 ; Morrison 89, p. 165 ; Cooke 97, pp. 56 ; 06, p. 48 ; Henderson 03, p. 234 ; 09, p. 226 ; Warren 09, p. 13 ; 10, p. 79 ; Felger 09, p. 281.

Description.-Male-Head and neck all round, except the white chin, black glossed with purple; a ring of dark chestnut round the lower-neck; fore-breast and upper-parts black, glossed with greenish and purplish; below white, finely mottled on the sides and lower abdomen with dusky; under tail-coverts black; wings with a silvery speculum; iris yellow, bill black, with the base and a subterminal band bluish-grey, legs slaty. Length 17.75 ; wing 8.0 ; tail 2.5 ; culmen 1.9 ; tarsus 1.25.

The female has the head and neck umber-brown with whitish cheeks and chin, a white eye-ring and no collar; rest of the plumage dusky brown, becoming white on the lower-breast and abdomen; speculum grey as in the male.

Distribution.-Breeding from Wisconsin and Manitoba to Athabasca Lake and west of the Rockies from Oregon to British Columbis; in 
winter south over most of the United States and Mexico to Cubs and Guatemala.

This is one of the rarer ducks in Colorado and has only been reported a few times. It is probably only a migrant. There is an example in the Colorado Museum of Natural History at Denver, taken on a lake near Denver, November 10th, 1898, by B. Flayward.

\section{Genus CLANGULA.}

Bill shorter than the head, about as long as the tarsus, very high at the base, narrowed towards the tip; nostrils well in front of the middle of the bill; head puffy-looking and crested; tail about half the length of the wing, pointed and 16-feathered; males with a green head with a white patch; females plain brown.

Two species only.

\section{KEY OF THE SPECHES.}

A. Head glossed with greenish; cheok spot oval or rounded.

C. c. americana, $\delta$ p. 56.

B. Head glossed with purplish; cheek-spot triangular.

C. Head brown.
a. White wing-patch undivided.
C. c. americana, + p. 56 .
b. White wing-patch divided.
C. islandica, $q$ p. 57.

\section{American Golden-eye. Clangula clangula americana.}

A.O.U. Checklist no 151-Colorado Records-Aiken 72, p. 210 ; Henshaw 75, p. 480 ; Scott 79, p. 96 ; Morrison 89, p. 165 ; Cooke 97, p. 56 ; 06, p. 49 ; Henderson 03 , p. $107 ; 09$, p. 226.

Description.-Malo-- Head and crest rich dark green with a round white patch near the base of, but not touching, the bill ; neck all round and under-parts white; back black, shoulders white, wing with a white central patch and white stripes on the scapulars; iris golden yellow, bill dusky, feet orange. Length 20 ; wing 9.10 ; tail 4.0 ; culmen 14 ; tarsus $1 \cdot 6$.

The female has the head and upper-neck light snuffy-brown, a wide white or grey collar round the neck; chest, sides and shoulders grey; belly white; wing (8.25) dusky with white on the coverts and secondaries.

A young male is like the female, but generally shows traces of the white face patch; bill generally dusky brown, not yellow.

Distribution.-Breeding from northern New England along the northern border of the United States to British Columbia, northwards 


\section{Barrow's Golden-eye}

to the tree limit. In winter hardly south of the United States and rare to the south. In Colorado the Golden-eye must be considered a migrant, sometimes spending the winter; but few observations are recorded. Henshaw reports a young female from Conejos cañon at about 9,000 feet, taken by Aiken on August 30th, 1874, and Scott obtained a male in worn summer plumage on June 21st, 1878, at Twin Lakes. It does not seem unlikely, however, that these two birds were Barrow's Golden-eye, which is known to breed in the mountains.

Henderson states that there in an example from Boulder co. taken on Bearley Lake, February 17th, 1908, in the Museum of the University, and that a few examples are killed every year in that neighbourhood. Hersey and Rockwell find it common on migration, and not rare in winter at Barr Lake.

\section{Barrow's Golden-eye. Clangula islandica.}

A.O.U. Checklist no 152-Colorado Records-Brewer 79 p. 148 ; Drew 85, p. 18 ; Morrison 89, p. 165 ; Cooke 97, pp. 56, 195 ; 06 p. 51 ; Henderson 09, p. 226.

Description.-Closely resembling $C$. c. americana, but the head glossed with purplish instead of greenish, and the white patch on the crescentic or triangular, not round, and applied to the whole base of the upper mandible; the white patch of the wing more or less divided by a dark bar. Length about 22 ; wing 9.20 ; culmen 1.75 ; tarsus 1.60 .

The female cannot always be distinguished with certainty from that of $C$. s. americana; but the head is darker brown, the collar is narrower, and the white area on the wing is more or less completely divided. Mrs. Bailey states that the nail of the bill is always wider-over .23, against .20 or under in the other species; bill generally yellow.

Distribution.-Breeding from eastern Canada north to Labrador, and Iceland, and from the mountains of Colorado and Oregon north to Alaska; in summer only a little south of the breeding range to Virginia, the Great Lakes, Utah and San Francisco.

In Colorado Barrow's Golden-ëye is a summer resident, breeding in the mountains up to 10,000 feet, while it appears probable that some birds winter in the State, and others, especially on the northeastern plains, pass to and fro only on migration.

Edwin Carter was the first to find the nest and egge of this Duck in the Rocky Mountains, or even in the United States, in 1876, as reported by Brewer. He took several nests in Middle Park and even as high as 10,000 feet on Georgia Pass. Morrison reports it as nesting freely in Dolores co. and wintering on the La Plata River, between Fort Lewis and Farmington. Gale observed a female with three young on July 19th, on the north St. Vrain Creek in Boulder co. 
Habits.-The Golden-eyes are birds of strong flight, and this is accompanied by a loud whistling noise, caused by the rapid vibration of their wings. They are therefore frequently known among gunners as "whistlers." They prefer large open lakes, where they dive for their food; this consists chiefly of mollusca, crustacea and small fishes, though water-weeds are doubtless eaten as well. The nest is always placed in a hollow tree, often in a comparatively small cavity. The eggs, 6 to 10 in number, are bluish-green or sea-green, and average $2.50 \times 1.70$.

\section{Genus CHARITONETTA.}

Closely resembling Clangula, but with the nostrils nearer the base of the bill than the tip.

One species only.

\section{Buffle-head. Charitonetta albeola.}

A.O.U. Checklist no 153-Colorado Records-Aiken 72, p. 210 ; Morrison 89, p. 165 ; Cooke 97, pp. 18, 56, 195 ; 06, p. 51 ; Henderson 03, p. 234 ; 09, p. 226.

Description.-Malo-Head rather puffy in appearance, glossed with green and purple; a conspicuous white patch from just below the eye to the nape; lower neck all round, under-parts, some of the scapulars and a patch on, the wing, white; rest of the upper-parts dusky black, becoming greyish posteriorly; iris brown, bill dull blue, dusky on the nail and base, feet fleshy. Length 15.0 ; wing 6.75 ; tail 3.0 ; culmen 1.10 ; tarsus 1.20 .

The female is dusky grey above, with a white spot below the earcoverts, a white speculum and belly; wing 6.50.

Distribution.-Breeding from Wisconsin and Quebec, north to Hudson Bay and Alasks; south in winter, chiefly in the Cnited States from Massachusetts, Utah and British Columbia southwards to the Valley of Mexico.

The Buffle-head is common Duck in winter and on migration in Colorado. Mr. Hersey informs me there is always a flock all through the winter on Barr Lake, near Denver; it is better known perhaps as a migrant arriving towards the latter half of March. It is reported from Fort Lyon, March 27th (Cooke), El Paso co. (Aiken), Boulder co. (Henderson), and Loveland, March 20th (Cooke). Carter obtained 
it in Middle Park, April 14th, 1877, and later a pair in July-which looks as if it might occasionally breed in the mountains, but I have no further confirmation of this.

Habits.-In no important respect differing from the Golden-eye in its habits, the Buffle-head is often known as the "Butter-ball " or " Hell-diver." It is noted for its quick diving to escape a shot, rivalling even the Grebes in this respect. Its flesh is fishy and poor-eating.

The nest is placed in holes or in hollow trees, and lined with feathers and down; the eggs, 9 to 10 or even 14, are buffy-drab, and measure about $2.0 \times 1 \cdot 5$.

\section{Genus HARELDA.}

Bill short, high at the base, the rounded end occupied by a broad nail; head not crested, nostrils in the basal half of the bill; feathers ending in a straight line across the forehead; tail of fourteen feathers, much elongated in the male by the prolongation of the central pair of feathers; scapulars also elongated.

One species only.

\section{Old Squaw. Harelda hyemalis.}

A.O.U. Checklist no 154-Colorado Records-Deane 95, p. 292 ; Cooke 97, pp. 56, 195 ; 06, p. 52 ; Henderson 03, p. 234 ; 09, p. 226 ; H. G. Smith 08, p. 184 ; Felger 09, p. 282.

Description.-Male in winter-Head, neck, front part of the back, abdomen, sides, under tail-coverts and lateral tail-feathers white; scapulars which are elongated and pointed, and a square patch on the side of the face from the eye to the ear-coverts, grey; another behind this and the whole of the breast, dark brown; rest of the upperparts and wings black or brownish-black; central tail-feathers much elongated; iris yellow, bill black with a transverse band of pink (in dried skins orange), legs yellow (in dried skins). Length about 21 ; wing 8.5 ; tail 6.0 ; culmen 1.1 ; tarsus 1.3 .

In summer the male is chiefly sooty with ashy-grey face, white eyelids and belly, and streaks of chestnut on the back and scapulars.

The female in winter is dark brown above with the scapulars, which are not elongated, more or less margined with white; head and neck white, with a dark patch on the crown and side of the neck; a little mottling also on the fore-breast; below pure white; tail pointed, but feathers not elongated; wing 8.5. 
In summer plumage, there is more black about the head and the feathers of the back are margined with rufous and are without white.

Distribution.-A circumpolar species, breeding far north and wintering south in both hemispheres. In America breeding from Labrador to Alaska northwards, south in winter to North Carolina, the Great Lakes and northern California and casually elsewhere.

The Old Squaw is an occasional winter visitor to north-east Colorado, and has been reported on some half-dozen occesions. A prir shot on MeKay Lake north of Denver, November 13th, 1892, by J. B. Sibley, were noticed by Deane. Breninger found one dead near Fort Collins (Cooke). One was shot at Loveland, October 16th, 1898, another at Calkins Lake, Longmont, October 23rd, 1898, by Bryan Haywood, and a third, a male, secured also at Longmont by Judge Park, about November 20th, 1903 . These are reported by H. G. Smith, and are now in the State Collection at Denver. Others from the same neighbourhood are noticed by Felger.

Habits.-The Old Squaw is one of the swiftest flying as well as most noisy of our Ducks; it is very common in winter on the New England coasts, where it feeds chiefly on various mollusca and small fishes; its meat is not good.

\section{Genus HISTRIONICUS.}

Bill very small and short, rounded at the tip, which bears a large nail ; nostrils in the basal half of the bill ; feather line across the forehead pointed in the middle line in front; wings and tail short; plumage variegated with white patches.

One species only.

\section{Harlequin Duck. Histrionicus histrionicus.}

A.O.U. Checklist no 155-Colorado Records--Drew 81, p. 142; 85 , p. 18 ; Morrison 88, p. 140 ; 89, p. 165 ; Cooke 97, pp. 57, 195 ; 06 p. 54.

Description.-Male-Head and neck bluish-black with three white patches, one crescent-shaped, in front of the eye, becoming chestnut over the eye, a small rounded one, and a crescentic one on the neck, behind the eye; middle of the crown black, collar white, a white shoulder-patch edged with black; chest and shoulders leaden-blue; belly sooty, sides bright rufous ; rump black with a white spot on either side; wing with a steely-blue speculum and four white patches; iris reddish-brown, bill olivaceous, feet greyish-blue. Length 17.0; wing 8.0 ; tail 4.0 ; culmen $1 \cdot 10$; tarsus 1.30 . 
The female is sooty-brown above, paler and mottled with white below and has a white patch on the ear-coverts and sides of the face at the brse of the bill; wing 7-5. The young male at first resembles the female and gradually acquires the male characteristic, taking from two to three years to do so.

Distribution.-Breeding from Newfoundland north to Greenland and Iceland, and to Alaska and Siberia, also in Rocky Mountains south to Colorado and central California ; in winter south of its breeding range to Long Island, the Great Lakes and on the Pacific coast from Monterey to Japan.

The Harlequin is a rare resident in Colorado, apparently breeding in the mountains from 7,000 to about 10,000 feet, and wintering at lower elevations, but very few observations have been made and we know very little about its movements or its habits.

Drew first reported it from San Juan co. where he believed it nested at high elevations; Morrison followed Drew, but gave no definite evidence about its breeding; he stated, however, that it was common on the river in winter below Fort Lewis, with Barrow's Golden-eye. The only other notice of this duck in Colorado is that of Carter, who found it breeding on the Blue River, below Breokenridge, at an altitude of 9,200 feet.

\section{Genus SOMATERIA.}

Ducks of large size, with the bill varying in shape but swollen at the base; feathers of the head running forwards on to the bill, and forming various frontal and lateral prolongations as far as the nostrils; plumage chiefly black and white with green about the head.

Four species of Arctic or Subarctic range are found in North America but only one hitherto is known to wander to Colorado.

\section{American Eider. Somateria dresseri,}

A.O.U. Checklist no 160-Colorado Records-Cooke 97, pp. 156, 224 ; 06, p. 57.

Description.-Male-Top of the head, rump, tail-coverts and underparts from the breast black; occiput washed with sea-green; rest of the plumage, including the curly inner secondaries and most of the wing-coverts white; bare frontal spaces on either side at the base of the bill, long, broad, club-shaped and divergent; bill yellowish. Length 2.40 ; wing 11.0 ; tail 4.0 ; culmen 2.0 ; tarsus 1.75 .

The female is everywhere varied chiefly in bars with black, chestnut and yellowish-brown, becoming greyish with dusky mottling below.

Distribution.-Breeding from the coast of Maine north to Hudson Bay; wintering from Newfoundland to New Jersey and occasionally 
on the Great Lakes. In Colorado this bird is only an accidental atraggler. One was taken by W. G. Smith at Loveland, and was recognised by Prof. Wm. Osburn (Cooke).

\section{Genus OIDEMIA.}

Bill variously swollen at the base (except in $O O$. americana) and brightly coloured; nostrils about the middle of the bill or beyond; plumage black or dusky brown with white patches.

Confined to the.Northern Hemisphere; three species in the United States.

Kry OF THE SPECIES.

A. Feathering of the head not reaching near the nostrils; no white patches. $\quad 0$. americana, p. 62.

B. Feathering of head reaching forward to a level with the nostrils. a. A white patch on the wing. $\quad 0$. deglandi, p. 62 .

b. No patch on the wing, but two on the forehead and nape respectively.

O. perspicillata, p. 63.

\section{American Scoter. Oidemia americana.}

A.O.U. Cheoklist no 163 -Colorado Records-Ridgway 79, p. 234 ; Morrison 89, p. 165 ; Cooke 97, p. 57 ; Felger 09, p. 283.

Description.-Male-Black throughout, a little less glossy below, and greyish on the inner web of the primaries; iris brown, line of the base of the bill forming a straight line with the frontal feathers, nostrils "in the middle of the bill, bill itself black, basal knob yellow; feet blackish. Length about 20 ; wing 9.0 ; tail 3.5 ; culmen 1.6 ; tarsus 1.7 .

The female is smaller-wing 8.0-and sooty brown above, paler below; the bill is black throughout and has no basal knob.

Distribution.-Breeding in northern Labrador and on the Alaskan and north-east Siberian coasts; wintering on the coasts south to New Jersey and southern California, and on the Great Lakes.

An accidental straggler to Colorado, seldom recorded. There was an adult male in Mrs. Maxwell's collection, presumably taken in Colorado (Ridgway); Breninger found a dead bird of this species at Fort Collins (Cooke). Hersey informs me it has been taken at Barr, and Felger notes one from Aurora Lake, in the neighbourhood of Denver, October 2nd, 1901.

\section{White-winged Scoter. Oidemia deglandi.}

A.O.U. Checklist no 165-Colorado Records-Cooke 94, p. 183 ; 97, pp. 57, 195 ; 06, p. 61 ; H. G. Smith 96, p. 48 ; 08, p. 184 ; Henderson 03, p. 107 ; 07, p. 198 ; 09, p. 226 ; Bergtold 04, p. 78. 
Description.-Male-Plumage black throughout, less glossy below; a white patch on the wing and a small white spot below and behind the eye; iris white; frontal feathers encroaching on the bill along the culmen to a level with the nostrils, which are in the anterior half of the bill; on the sides to a less extent, so that the line of the base of the bill is much curved; bill black at the base and sides, front part of knob and tip orange; legs orange with black webs and joints. Length 22.0 ; wing 11.5 ; tail 3.25 ; culmen 1.8 ; tarsus 2.0 .

The female is sooty brown above, paler below and retains the white speculum and has indistinct whitish patches on the face; iris dark brown, bill less swollen and black throughout, feet fleshy but with black webs.

Distribution.-Breeding from the Gulf of St. Lawrence and North Dakota to the Arctic coasts, and on the Pacifio coasts of British Columbia and Alaska; south in winter to Lower California and South Carolina on the coasts, and to the Great Lakes and prairie States in the interior.

A rare winter visitor, chiefly in October and November to north-east Colorado. Some nine instances are recorded from lakes near Denver, Loveland, and Fort Collins, all in October or November. There is a specimen shot at Lasalle, near Greeley, October 24th, 1904, and presented to the State Museum at Denver by H. G. Clark, and Aiken tells me he has examined an example shot on a reaervoir near Skinners, south of Colorado Springs, in October, 1907, by Johnson of Denver. This last is the most southern record for the State.

\section{Surf Scoter. Oidemia perspicillata.}

A.O.U. Checklist no 166-Colorado Records-H. G. Smith 96, p. 48 ; 08, p. 184 ; Cooke 97, pp. 57, 196 ; 06, p. 62.

Description.-Male-General colour glossy black, duller below, no white on the wings, but a triangular patch pointing forward on the forehead, and another on the nape pointing back. Iris pearly white; frontal feathers extending forward along the culmen nearly or quite to the nostrils, but not at all on the sides; bill swollen on the sides, coloured white, orange, red and black, the latter forming a rounded spot at the base of the upper mandible; feet orange-red with dusky webs and joints. Length 21.0 ; wing 9.25 ; tail 3.40 ; culmen 1.5 ; tarsus $1 \cdot 63$.

The female is sooty brown, paler silvery-grey below, with a whitish loreal and auricular patch. Iris yellowish-white; bill hardly swollen, blackish throughout; feet dusky orange with dusky webs; wing 8.50.

Distribution.-Breeding from Quebee Province and from Sitka north to the Arctic coast; in winter along the coasts to Lower 
California and Florida, and in the interior to the Great Lakes and the prairie states to the west.

In Colorado the status of this Scoter is very similar to that of the White-winged, but it has not been noticed quite so often. H. G. Smith first reported it-a young male or femalo-from Marston Lake, near Denver, in October, 1887. There are two examples in the State collection at Denver-a male from Barr Lake, obtained by L. B. Meek, Octobar 22nd, 1899, and another from Loveland, shot by H. A. Flynn, October 3lst of the same year.

Habits.-All the Scoters are very similar in habits; they are essentially marine Ducks, feeding principally on mussels and other shell-fish. Consequently their flesh is coarse and rank. They live almost entirely on the water, sleeping there at night and swimming and diving during the day.

\section{Genus ERISMATURA.}

Bill about equal to the head; the nail at the tip hardly visible from above but expanded below, and decurved and bent back underneath the tip of the bill; tail-feathers 16 to 20 in number, elongated, more than half the length of the wing, stiffened and exposed almost to their bases owing to the shortness of the coverts; tarsus short, about half the middle toe with claw.

An almost cosmopolitan genus with only one North American species.

\section{Ruddy Duck. Erismatura jamaicensis.}

A.O.U. Checklist no 167-Colorado Records-Aiken 72, p. 210; Drew 85, p. 18 ; Beckham 85, p. 144 ; W. G. Smith 88, p. 132 ; Morrison 89 , p. 165 ; Cooke 97, pp. 18, 57, 196 ; 06, p. 63 ; Keyser 02, p. 143 ; Dille 03, p. 74 ; Henderson 03, p. 234, 09, p. 226 ; Warren 09, p. 13.

Description.-Male-Crown and back of the neck black; sides of the face from the bill to the ear-coverts, including the chin, white; Jower neck all round, sides and upper-parts, rufous chestnut; dusky brown on the wings, rump and tail; below silvery white, slightly mottled with brown, especially about the lower flanks; iris reddish-brown, bill, eyelids and feet bluish. Length 17 ; wing 6.0 ; tail 3.5 ; culmen $1 \cdot 6$; tarsus $1 \cdot 2$.

The young male and adult female are mottled rufous and dusky, speckled brown, above and below, rather darker on the crown and whiter on the cheeks; below, the rufous forms a tawny wash.

The shape of the bill and the long stiff tail at once distinguishes this Duck from all others. 
Distribution.-Ranging from Labrador and British Columbia to Guatemala and the West Indies, breeding chiefly towards the north but also south, as far as Guatemala, Cuba and Porto Rico, and wintering as far north as Maine and southern British Columbia.

In Colorado the Ruddy Duck is a summer resident breeding in the plains and also in the mountains, probably up to about 8,000 feet, though Drew says 10,000 feet. It arrives rather late for a duckat the end of March or beginning of April. It breeds at Loveland (Smith) and Barr (Hersey \& Rockwell), and near Greeley, whence there are eggs in the Colorado College Museum, and probably at San Luis Lakes, where it was taken by Aiken, July 11th.

Other localities are Boulder co. (Henderson), El Paso co. (Aiken), Pueblo (Beckham), Fort Lyon (Thorne), Breckenridge on migration (Carter), Buens Vista (Keyser), Crested Butte and Coventry (Warren).

Habits.-The Ruddy Duck in some ways resembles the Grebes in its habits. It swims high in the water with its tail erect and spread out like a fan; it prefers to escape by diving rather than by flight, and it can sink silently into the water, where it uses its long tail like a rudder. It feeds chiefly on roots and the slender stems of water-plants growing on the bottom, which it obtains by diving, and also on small mollusca.

Smith states that their nests are difficult to find, and that eggs are dropped about rather promiscuously. Rockwell tells me that he has often found them in the nests of other ducks; the nests are built chiefly of flags in water six to twelve inches deep, while a run-way of roots is built up on one side. The eggs, 7 to 9 in number, are remarkably large for the size of the bird ; they measure about $2.45 \times 1.85$, and are rough, thick-shelled and dirty white. Dille gives June 19th as an arverage date for fresh eggs. Those presented to the Colorado College by I. C. Hall were taken June 28th, but they were slightly incubated.

\section{Subfamily ANSERINA.}

The Wild Geese are distinguished from the Swans by having the lores and face completely feathered, and 
by their shorter necks, and from the Ducks by their reticulate tarsi; the sexes are alike and the hallux or hind toe is simple and not lobed.

KEY OF THE GENERA.

A. Bill and feet always black.

Branta, p. 68.

B. Bill and feet not black, usually pink or yellow.

a. Depth of bill at base more than the length of the culmen; plumage mainly white.

Chen, p. 66 .

b. Depth of bill at base less than half the culmen; plumage never mainly white.

Anser, p. 68.

\section{Genus CHEN.}

Bill about equal to the head, high at the base, its depth there more than half the length of the culmen; serrations on the cutting-edge of the upper mandible prominent, large and fully exposed; plumage chiefly white, or white and grey; bill and feet red.

Four species, chiefly in the Arctic regions of the Northern Hemisphere.

KEx OF THE SPECIES.

A. Outline of the frontal feathering forming convex line at the base of the bill.

a. Larger; wing over 17 . C. h. nivalis, p. 67 .

b. Smaller; wing under 17 . C. hyperboreus, p. 66 .

B. Outline of the frontal feathering nearly straight; size still smaller, wing about 14.5. $\quad$ C. rossi, p. 67

\section{Snow-Goose. Chen hyperboreus.}

A.O.U. Checklist no 169-Colorado Records-Henshaw 75, p. 470 ; Thorne 87, p. 264 ; Morrison 89, p. 165 ; Cooke 97, pp. 18, 58, 196 ; 06, p. 65 ; Henderson 03 , p. 234 ; 09, p. 226 ; Rockwell 08, p. 158.

Description.-Adult-Pure white except the wing, the tips of which are black and the bases grey; head often stained with rusty-brown; iris dark brown, bill dull red with $\mathrm{a}$ white tip and black along the cutting-edge; legs dull pink. Length $25 \cdot 0$; wing 17.0 or less; tail $5 \cdot 5$; culmen $2 \cdot 3$; tarsus $3 \cdot 1$.

Young birds have the top of the head and upper-parts light grey, and the bill and feet dark.

Distribution.-Breeding on the Arctic coasts of the Mackenzio Province and probably in north-east Asia; wintering from the Mississippi Valley to California and south to central Mexico; in Asia to Japan. 
In Colorado the Snow-Goose is a bird of passage in spring and autumn, chiefly on the eastern plains; it is also reported by Sullivan at Grand Junction about March 4th and October 20th (Rockwell). It was noted at Fort Lyon and Loveland in the plains by Carter, and in Middle Park (Cooke), while there is an example in the Colorado Museum of Natural History at Denver, killed at Barr Lake by J. T. Mason. Henshaw, many years ago, was informed that it wintered in San Luis Valley, but this has never been confirmed.

Habits.-Goss states that he has seen thousands of these Geese in the fall and early spring in the Arkansas Valley, feeding on the winter wheat, pulling up the young and tender blades with a sudden jerk and doing a great deal of damage. The flight is noisy and usually in the form of a $\mathrm{V}$, headed by a recognized leader.

\section{Greater Snow-Goose. Chen hypoboreus nivalis.}

A.O.U. Checklist no 169a-Colorado Rreords-Cooke 97, pp. 58, 196 ; Henderson 03 , p. 234 ; 09, p. 226.

Description.-Only differing from Chen hypoboreus in its larger dimensions-i.e. length 27 ; wing 17.0 or more ; tail 6.5 ; culmen 2.5 ; tarsus $3 \cdot 25$.

Distribution.-Breeding north of Hudson Bay-exact locality uncertein; in winter chiefly east of the Mississippi Valley, and on the Atlantic coast to the Greater Antilles.

In Colorado this eastern bird is only a straggler. A Goose shot by Z. X. Snyder east of Greeley, March 20th, 1895, and another on Boyd's Lake near Loveland, April 9th, 1899, by J. F. Campion, the latter now in the State collection at Denver, both seem referable to this subspecies.

\section{Ross's Goose. Chen rossi.}

A.O.U. Checklist no 170-Colorado Record-Felger 07, p. 211. Description.-In plumage resembling the Snow Goose but much amaller; outline of frontal feathers on the base of the bill nearly straight, not convex; base of the bill studded with numerous fleshy papillæ, and the cutting-edges of the bill not black and not showing the horny teeth so plainly. Length 21 ; wing 14.5 ; tail 5.0 ; culmen 1.5 ; tarsus $2 \cdot 5$.

Distribution.--Exact breeding grounda unknown, probably the Arctic islands between $120^{\circ}$ and $110^{\circ} \mathrm{W}$. long. ; south in winter, chiefly on the coast of California. 
Ross's Snow-Goose is a rare straggler in Colorado, and has only once been recorded. A male specimen was shot on December 23rd, 1906, at the Kennicott Club Lake, near Longmont, by Capt. Eli, U.S.A., and is now in the Colorado Museum of Natural History at Denver. It was associating with a flock of Mallards at the time.

\section{Genus ANSER.}

Resembling Chen but with a somewhat weaker bill, the depth of which is less than half the culmen, and with the lamellre somewhat less exposed; plumage never extensively white.

Confined to the Northern Hemisphere with only one North American species.

\section{American White-fronted Goose. Anser albifrons gambeli.}

A.O.U. Checklist no 171a-Colorado Records-Ridgway 79, p. 233 ; Morrison 89, p. 165 ; Cooke 97, pp. 58, 196 ; Felger 09, p. 283.

Description.-Male-Anterior part of the face and forehead white, bordered by dusky; rest of the head and neck, shoulders and chest dark grey; back dusky grey; upper tail-coverts white; below black or spotted with black, becoming white on the under tail-coverts; iris dark brown, bill pink and yellow with the nail white, feet yellow. Length 28.0 ; wing $17 \cdot 0$; tail 5.5 culmen $2 \cdot 0$; tarsus $3 \cdot 0$.

The female is rather smaller. A young bird is rather darker and has no white on the face or black on the under-parts; bill, including the nail, dusky.

Distribution.-Breeding on the coast of Alaska and Yukon, and wintering in the southern half of the United States, and further south to Cubs and northern Mexico.

The White-fronted Goose is hardly known in Colorado. There was an example in Mrs. Maxwell's collection probably from Colorado, and there is a specimen in the Carter collection from Middle Park, where Carter reports he has seen it on occasions in considerable numbers. Hersey has observed it once or twice at Barr, and Felger reports one killed near Masters on the South Platte, March 25th, 1903.

\section{Genus BRANTA.}

Bill rather short; lamellæ of upper mandible quite hidden; bill and feet entirely black; head partly or wholly black.

The Northern Hemisphere with three species in North America.

KEY OF THE SPECIES.

A. A white cheek-patch on the black head.

a. Larger; wing over $17 ; 18-20$ tail-feathers.

B. canadensis, p. 69 . 
b. Smaller; wing $15-17 ; 16$ tail-feathers. B. c. hutchinsi, p. 70
c. Smallest; wing under $15 ; 14-16$ tail-feathers.

B. No. minima, p. 70 .

B. No white cheek-patch; head wholly black.

B. b. glaucogastra, p. 71 .

\section{Canada Goose. Branta canadensis.}

A.O.U. Checklist no 172-Colorado Records-Ridgway 73, p. 188 Coues 77, p. 51 ; Drew 85, p. 18 ; Morrison 89, p. 166 ; Cooke 97, pp. 58, 156,196 ; 06, p. 72 ; Henderson 03, p. 234 ; 09, p. 226 ; Rockwell 08, p. 158 ; Warren 09, p. 13.

Description.-Adult-Head, neck, rump and tail black; a white patch on the face behind the $\theta y \theta$, meeting its fellow below; upperparts greyish-brown, with paler tips to many of the feathers, and dusky to blackish on the flight-feathers; upper tail-coverts white; below ashy grey, becoming white on the abdomen and under tail-coverts; tail with eighteen or twenty feathers; iris brown, bill and legs black. Length about 36.0 ; wing 18.20 ; tail $7 \cdot 0$; culmen 2.0 ; tarsus 3.5 .

Young birds have the white of the cheeks speckled with dusky.

Distribution.-Breeding from Newfoundland to Iowa and the interior of British Columbia northwards; wintering in the southern United States from Maryland to California.

In Colorado this is probably the most common of the Wild Geese; it is known as a summer resident, chiefly in the north, as a winter resident in the south and north, and perhaps most commonly as a migrant. It was found breeding by Coues in a small lake on the southern slopes of North Park many years ago. Carter reports it as breeding in Middle Park, while Cooke discovered that it nested near Niwot in Boulder co. at the low elevation of 5,500 feet. At Barr it is a fairly common winter resident, and still more common on migration. It has been noted by Gale in the Boulder foothills, March 17th, by Sullivan at Grand Junction, a large flock, March 18th (Rockwell), and by Smith at Coventry in spring (Warren). It is possible some of these notices refer to the smaller Hutchins's Goose.

Habits.-The familiar "Honk, honk, honk," of the migrating Canada Goose is well known over the greater part of North America, and notwithstanding the many wiles and devices of the gunner they still hold their own. Their flight is strong and steady, and very high up when migrating, the flock forming a $V$ or long line; when in winter quarters they spend the night on the 
water, sleeping on the surface in considerable numbers; at daybreak they move off their feeding-grounds, and this is the time when the sportsman, lying hidden on the edge of the lake, gets his chance. They feed. in the stubble-field in the autumn and among the young wheat in spring, when they do a good deal of damage. They nest naturally on the ground near water; if it is dry, merely lining a depression in the ground with down, but otherwise putting together a bulky structure of grass or weeds. Where robbed or persecuted they often make use of trees, sometimes adopting the nests of Herons or Hawks for the purpose. The eggs, 6 to 7 in number, are dull white with often a faint greenish tinge, and measure $3.75 \times 2.45$.

\section{Hutchins's Goose. Branta canadensis hutchinsi.}

A.O.U. Checklist no $172 \mathrm{a}$-Colorado Records-Aiken 73, p. 210; Morrison 89, p. 166 ; Cooke 97, p. 59.

Description.-In every other respect resembling the Canada Goose, but smaller and with normally eixteen instead of eighteen tail-feathers. Length about 25.0 ; wing 16.0 ; tail 5.5 ; culmen 1.4 ; tarsus 2.7 .

Distribution.-Breeding far north, along the coast of the Arctic Ocean from Melville Peninsula to Alaska; south in winter to the southern United States west of the Mississippi and especially to California.

In Colorado Hutchins's Goose is either of rare occurrence or has not been distinguished from the Canada Goose. There is an example in the State Historical Society's collection at Denver, shot near Loveland, April 10th, 1898, by J. F. Campion; and Aiken many Jears ago killed one in December, near Fountain, El Paso co. Hersey informs me it is not so plentiful as formerly, but that bunch of seven birds wintered at Barr in 1908-09, in company of a flock of the Canada. It is a rare migrant, occasionally spending the winter.

\section{Cackling Goose. Branta canadensis minima.}

A.O.U. Checklist no $172 \mathrm{a}$-Colorado Record-Cooke 97, p. 196 ; 99, p. 187.

Description.-Closely resembling $B$. canadenois but rather darker especially below, the cheek patches usually separated on the throat 
by a black patch, and a more or less distinct white half collar on the lower-neck; tail with fourteen or sixteen feathers; size smaller even than $B$. c. hutchinsi. Length $23 \cdot 25$; wing $14 \cdot 0$; culmen $1 \cdot 0$; tarsus $2 \cdot 6$.

Distribution-Breeding in Alaska and the Aleutian Islands; in winter from southern British Columbia to southern California; elsewhere a wanderer.

The Cackling Goose is a rare straggler to Colorado. One specimen, only has been identified (Cooke); this was shot near Loveland, April 10th, 1898, by Mr. J. F. Campion, and is now in the State collection in the Capitol at Denver.

This example appears to me to be more properly referable to Hutchins's Goose than to this species. It is the only definite record.

\section{Brant. Branta bernicla glaucogastra.}

A.O.U. Checklist no 173-Colorado Records-Thorne 87, p 264 ; Cooke 97, p. 59.

Description.-Adult-Head, throat, neck and upper-breast black; a little white mottling on the sides of the neck; back brownish-grey margined with lighter; longer lateral upper tail-coverts white; lowerbreast ashy-grey, fading to white on the abdomen, darker on the sides; iris brown, bill and feet black Length 24.0 ; wing 13.0 ; tail 4.5 ; culmen 1.35 ; tarsus 2.25 .

Young birds are very similar, but have less white on the sides of the neck and the wing-coverts and secondaries are white tipped.

Distribution.-Breeding on the west coast of Greenland, and as far north as land extends; south in winter to the Atlantic coast from New Jersey to Florida; a straggler only elsewhere.

There is only one recorded notice of the occurrence of the Brant in Colorado. Captain Thorne shot a specimen at Fort Lyon, April 11th, 1883. Though not preserved, there can be little doubt about its identification.

\section{Subfamily CYGNIN压.}

The Swans resemble the Geese, having reticulate tarsi, a simple unlobed hallux and sexes alike; they are distinguished from them by their long necks, and by having the lores between the eye and the bill naked and without feathers-at least in the adults.

\section{Genus OLOR.}

In addition to the above-mentioned characters, the prevailing colour of the plumage is white, and normally the trachea is prolonged and coiled in a cavity in the sternum.

Several species in the northern hemisphere and South America. 


\section{KEY OF THE SPECIES.}

A. A yellow spot on the bill in front of the eye.

B. No yellow on the bill $\quad$ O. buccinator, p. 72 .

\section{Whistling Swan. Olor columbianus.}

A.O.U. Checklist no 180-Colorado Records-Ridgway 73, p. 188 ; 79 , p. 233 ; H. G. Smith 95, p. 48 ; Cooke 97, pp. 59, 196 ; 09, p. 84 ; Henderson 03, p. 107 ; 09, p. 226.

Description.-Adult-Plumage white throughout; tail normally of twenty feathers; iris brown, bill black with usually a yellow spot at its base in front of the eye, nostrils at about the middle of the bill, feet black. Length about 54 ; wing 22 ; tail 8 ; culmen 4 ; tarsus $4 \cdot 35$.

The female is slightly smaller and the young birds are grey.

Distribution.-Breeding chiefly north of the Arctic circle from Hudson Bay to Alaska; wintering on the Atlantic and Pacific coasts of the United States, and occrsionally in the interior and on the Gulf.

The Whistling Swan is perhaps rather more often met with than the Trumpeter, but both can only be classed as occasional stragglers on migration in Colorado. There was a pair in the Maxwell collection, and H. G. Smith gave a list of half a dozen instances of their occurrence, mentioning Berthoud, Rush Creek and Julesberg as localities, Cooke states that one was obtained near Fort Collins, March 16th, 1895, and that Carter procured one in Middle Park. Finally, according to Henderson, there is an example in the Museum of the University of Colorado at Boulder, and three more were brought in for identification by local hunters in the spring of 1907 .

\section{Trumpeter Swan. Olor buccinator.}

A.O.U. Checklist no 181-Colorado Records-Morrison 89, p. 166 ; H. G. Smith 95, p. 48 ; Cooke 97, p. 59 ; 06, p. 86.

Description.-Adult-Plumage white throughout; tail normally of twenty-four feathers; iris brown, bill entirely black, the nostrils situated in its basal half; feet black. Length about 60 ; wing 24 ; tail 9 ; culmen 4.5 ; tarsus 5.0 .

Young birds are smaller and have the plumage grey, with the head and upper-neck inclining to rusty brown.

Distribution,-Breeding now north of $60^{\circ} \mathrm{N}$. lat., between the Rocky Mountains and Hudson Bry, formerly as far south as Iowa and Idaho. In winter south to Texas and southern California.

The Trumpeter is now only very occasionally met with in Colorado; it was probably more abundant formerly, though there is no evidence of its breeding in the State. 
Smith notices two examples-one shot thirty miles south of Denver, probably at Palmer Lake, and one in the south of the State; Cooke adds another shot at Fort Collins in the fall of 1896, while there is an example in the Colorado Museum of Natural History at Denver, obtained at Eaton, near Greeley.

\section{ORDER HERODIONES.}

This order contains the Storks, Herons, Ibises and Spoonbills, but not the Cranes. They are all marshloving birds, mostly of large size, and have long bills and necks and legs. The lower part of the tibial portion of the leg is nearly always bare; the toes are long with only a basal web as a rule, while the hind toe is jointed on a level with the others in nearly every case; the young are hatched helpless, and dependent on their parents for a considerable time.

The order comprises six families; representatives of three of these are found in Colorado.

\section{Key of the Families and Genera.}

A. Bill flattened and spoon-shaped (Plataleida). Ajaja, p. 74.

B. Bill long and down-curved and grooved throughout. (Ibidida). a. Face and chin naked in adults. Plegadis, p. 76.

b. Only the front of the face naked.

Guara, p. 75.

C. Bill long and straight, with the tip only decurved; not grooved on the sides; claw of middle toe not pectinated (Ciconiido).

Mycteria, p. 78.

D. Bill long and straight, grooved along the sides; claw of the middle toe pectinated on the inner side (Ardeida).

a. Ten tail-feathers.

a. Larger tarsus shorter than the middle toe and claw.

Botaurus, p. 79.

$b^{2}$ Smaller tarsus about equal to the middle toe and claw.

Ixobrychus, p. 81.

b. Twelve tail-feathers.

al Naked portion of the tibio-tarsus equal to or exceeding the inner toe and clew.

a. Plumage white.

$a^{8}$ Long plumes on the back only. Herodias, p. 84. 
$b^{3}$ Long plumes on the crown and neck as well as the back.

Egretta, p. 84.

$b^{2}$ Plumage not white.

$a^{3} \quad$ Larger-wing over 17 ; w white line on the throat.

Ardea, p. 82.

$b^{3} \quad$ Smaller-wing under 15 ; no white on throat, but plumage sometimes entirely white. Dichromanassa, p. 86 .

$\mathrm{c}^{3}$ Smallest-wing under 8; prevailing colour green.

Butorides, p. 86.

$b^{1}$ Naked portion of the tibio-tarsus much shorter than the inner toe and elaw.

$a^{2}$ Tarsus short, about equal to middle toe and claw.

Nycticorax, p. 87.

$\mathrm{b}^{2}$ Tarsus longer, exceeding the middle toe and claw.

Nyctanassa, p. 88.

\section{Family PLATALEDE.}

The Spoonbills are so closely allied to the Ibises in all essential anatomical characters, that they have often been all placed together in one family; the curious spoon-shaped bill, however, at once distinguishes these birds from all others, and constitutes their claims to family distinction.

\section{Genus AJAJA.}

In addition to the spoon-shaped bill, these birds have the head bald in the adult, and the throat somewhat pouched; the nostrils are basal and linear-oblong; tail of twelve feathers; tarsi reticulate with hexagonal plates; toes semipalmate; plumage white and pink; sexes alike.

Only one species is recognized.

\section{Roseate Spoonbill. Ajaja ajaja.}

A.O.U. Checklist no 183 -Colorado Records-Morrison 89, p. 166 ; H. G. Smith 96, p. 65; Cooke 97, p. 59.

Description.-Adult-Head and throat bare of feathers, varied green, yellow, orange and black; neck and upper-back white, sometimes tinged with pink; sides of the breast and end of the tail ochraceousbuff; rest of the plumage pink to carmine; iris pink, bill like the head, legs carmine. Length 32 ; wing 14.5 ; tail 5.0 ; culmen 6.25; tarsus 4.0 . 


\section{White Ibis}

The female is slightly smaller; the young bird has brown on the wings, and does not attain its full plumage till the third year.

Distribution.-From Florida and the Gulf states south to the Straits of Magellan. A rare wanderer to Illinois and Colorado.

The Spoonbill has been twice noticed in Colorado. Trippe reported to Morrison that wemale was caught, and died shortly after, near Silverton, in June, 1888, and H. G. Smith saw one in Denver, which was said to have been killed near Pueblo in August, 1890.

\section{Family IBIDID压.}

Bill long and down-curved throughout, the sides somewhat compressed, a longitudinal groove on each side, at the base of which are the nostrils; tail of twelve rectrices; tarsi reticulate or scutellate.

\section{Genus GUARA.}

Face, including the chin, naked in the aduIts; head not crested; claws stout and strongly curved; plumage not metallic, either white or acarlet.

KEY OF THE SPECLES.
a. Plumage white.
G. alba, p. 75 .
b. Plumage scarlet.
G. rubra, p. 76 .

\section{White Ibis. Guara alba.}

A.O.U. Checklist no 184-Colorado Records-H. G. Smith 96, p. 65 ; Cooke 97, p. 59.

Description.-Adult-Plumage white except the tips of the wings, which are black; iris pearly-blue, bare face, bill and legs orange to carmine. Length 26 ; wing 11.75 ; tail 5.0 ; culmen 5 to 7 ; tarsus $3 \cdot 5$.

The female is slightly smaller; young birds are dull brown above, and have less bare skin about the face.

Distribution.-The southern United States north to North Carolina, Illinois and Utah; south to the West Indies and northern South America.

A single instance of the occurrence of the White Ibis is reported from Colorado: H. G. Smith identified a specimen shot at Barr Lake near Denver in 1890. 


\section{Scarlet Ibis. Guara rubra.}

A.O.U. Checklist no [185]-Colorado Records-Lowe 94, p. 324 ; Cooke 97, pp. 60, I56;97a, p. 316; 98, p. 183.

Description.-Adult-Clumage scarlet, except the tips of the wing, which are black; bare parts of head, bill and legs, red. Dimensions as in the White Ibis.

Distribution.-Eastern parts of tropical South America, north casuelly on about half-a-dozen occasions to the United States. Lowe reports an example shot on Grape Creek in Wet Mountain Valley, Custer co., May, 1876, by a friend of Mr. Livesey, in whose collection the specimen was preserved. A subsequent record published by Cooke (97a) was based on a misapprehension on the part of the taxidermist, and afterwards corrected.

The occurrence of the Scarlet Ibis in the mountains of Colorado at an elevation of at least 8,000 feet is most remarkable, as this bird is essentially an inhabitant of the damp tropical forests and rivers of South America.

\section{Genus PLEGADIS,}

Only a space between the eye and the base of the bill without feathers; c'aws long and slightly curved; plumage metallic glossy green and chestnut.

\section{KEY OF THE SPECIES.}

a. Feathers surrounding the bare face black. P. autumnalis, p. 76.

b. Feathers surrounding the bare face white. P. guarauna, p. 77.

\section{Glossy Ibis. Plegadis autumnalis.}

A.O.U. Checklist no 186-Colorado Record-Cooke 97, p. 196.

Description.-Resembling the White-faced Glossy Mbis, but the feathers round the bare face black, not white, and the bare skin of the face slaty-blue or greenish, not red; dimensions rather larger. Irength 25 ; wing 11.85 .

Distribution.-The warmer parts of the Old World; in the New, the south-eastern United States and the West Indies, straggling further north and west. Cooke notes two occurrences only in Colorado. Mr. A. T. Allen, of Denver, shot a fine specimen in full plumage some years ago near that place, which was examined by Cooke, and Mr. Voight killed an adult male April 12th, 1898, on the Arkansas, three miles above Salida, which was identified by Aiken. Hersey informs me he has one in his collection teken June, 1905, at Barr. 


\section{White-faced Glossy Ibis. Plegadis guarauna.}

A.O.U. Checklist no 187-Colorado Records-Ridgway 73, p. 187; 79, p. 233 ; Drew 85, p. 18 ; Morrison 89 , p. 166 ; Smith 96, p. 65 ; Cooke 97, pp. 60, 156, 197; 98, p. 183 ; Warren 09, p. 13 ; Felger 09, p. 284; Hersey \& Rockwell 09, p. 114.

Description.-Male-A margin of white feathers round the bare spaces on the sides of the face; rest of the head, neck, shoulders and under-parts rich dark chestnut; crown, back and wings glossed with metallic purple and green; iris red, bill blackish, reddening towards the tip s bare skin of face reddish, dusky in dried skins, legs dusky red. Length 24 ; wing 10.5 ; tail 4.5 ; culmen 5.5 ; tarsus 4.0 .

The femele is smaller-wing 9.5. Young birds in first plumage are a lustrous plain green with the legs and bill black.

Distribution.-South and western North America from Florida and Texas to Oregon, and thence south to the Argentine and Chili, through the West Indies and Mexico.

The White-faced Glossy Ibis is a rather uncommon summer resident in Colorado, breeding up to about 7,500 feet. It was first noticed by Aiken, who observed it on the South Platte in South Park in September, 1872, and subsequently found it nesting at San Luis Lakes, July 1st, 1875. H. G. Smith reports it from Marston Lake, near Denver, and Beymer secured one out of a flock of six, April 23rd, 1897, on the Arkansas near Rocky Ford (Cooke). Other occurrences are Barr Lake, October 3rd, 1898, Twin Lakes, South and Middle Parks and Glenwood Springs (Cooke); Norwood, San Miguel co., September 21st, 1907 (Warren). Hersey and Rockwell saw two individuals, probably the same birds, on five occasions in May and June, 1907, at Barr, but could find no evidence of their nesting.

Habits.-Goss states that at a distance the metallic colours of the Glossy Ibis are invisible, so that it appears to be a plain blackish bird, and is therefore generally known as the Black Curlew. It is a gregarious species, frequenting moist ground at the edges of lakes. The food consists of cray fish, frogs, snails, and aquatic insects. In flight the head and neck are stretched out to their fullest extent. They rise in confusion, but when going any distance quickly form into line abreast and $\mathrm{fly}$ forward in a wavy formation.

They breed in colonies, often with Herons and other marsh-birds, in swamps or shallow lakes. The nest 
is strongly and compactly woven of dead reeds, about a foot in diameter and well cupped. The eggs, usually three sometimes five, are deep bluish-green and average about $2.0 \times 1 \% 42$.

\section{Family CICONIIDE.}

The Storks are large birds with stout bills, longer than the head, straight to the tip or sometimes slightly decurved but without distinct grooves on either side; tibiæ half bare; front toes webbed at the base, outer one specially so, and the claw of the middle toe not pectinated.

\section{Genus MYCTERIA.}

Bill decurved at tip; nostrils basal; whole head and neck of adult naked and scaly, and crowned with a horny plate; tibiz bare for half their length; anterior toes webbed at the base.

This genus, known until quite recently as Tantalus, has had its name changed to Mycteria (see Allen, "Auk" xxv., p. 37).

Only one species is recognized.

\section{Wood Ibis. Mycteria americana.}

A.O.U. Checklist no 188-Colorado Records-Ridgway 79, p. 233 (Tantalus loculator); Morrison 89, p. 166 ; Cooke 97, pp. 60, 197 ; Felger 03, p. 65.

Description.-Adult-Plumage white throughout, except for the wing-quills and tail-feathers, which are glossy black; the under wingcoverts pink in the breeding season; iris brown, bill dingy yellow, naked head and neck scaly, legs bluish. Length about 48 ; wing 19 ; tail $7 \cdot 10$; culmen $9 \cdot 0$; tarsus $8 \cdot 0$.

The female is smaller-wing 17. A young bird has the head and neck covered with greenish-brown feathers, and the rest of the plumage dull white.

Distribution.-The southern United States, from the Carolinas and California south to the West Indies and the Argentine; casually to middle and northern United States.

An occaional wanderer to Colorado; Mrs. Maxwell'g collection contained a young bird; Carter reported its occurrence on the Blue River, twenty-five miles below Breckenridge, on the evidence of a wing 
and bill; Felger states that two were taken by Mr. L. I. Llewellyn at Fort Logan, close to Denver, August 30th, 1902, one of which is now in the State collection at Denver.

\section{Family ARDEID压.}

This family is a large one, containing the Herons, Egrets, Bitterns, and their allies. The bill is generally slender and straight with the usual longitudinal groove, and notched at the tip; there are eleven primaries and the number of the rectrices varies from eight to twelve; hind toe on a level with the others; a basal web between the middle and inner, nearly obsolete between the middle and outer toes; claw of the middle toe pectinated. For key of the genera, see p. 73.

\section{Genus BOTAURUS.}

Birds of medium gize-wing about 12, with the bill rather short; culmen slightly shorter than the tarsus; mandibles serrated near the tips; tail short, of ten feathers only; tibio-tarsus feathered down to about three-quarters of an inch from the joint; tarsus distinctly shorter than the middlề toe and claw; plumage long, lax, mottled yellow and black; no ornamental plumes.

A widespread genus found over the greater part of the world, with only one American species.

\section{American Bittern. Botaurus lentiginosus.}

A.O.U. Cheoklist no 190-Colorado Records-Aiken 72, p. 209 ; Drew 85, p. 18 ; Morrison 89, p. 166 ; Cooke 97, pp. 19, 60, 197 ; Dille 03, p. 74 ; Rockwell 08, p. 158 ; Henderson 09, p. 227 ; Felger 09, p. 285.

Description.-Adult-Upper-surface ochraceous-yellow and dark rufous freckled with dusky, becoming plain dusky brown on the primaries and on the crown; below paler yellow, with a number of brown darker-edged stripes chiefly on the lower-neck and breast; white on the throat; a black lateral streak on the neck; iris yellow, bill yellowish, dusky on the culmen, legs dull yellowish-green. Length 28.0 ; wing 11.25 ; tail 4.0 ; culmen 3.0 ; tarsus 3.60 .

The female is smaller-wing about 10.0 , but the variation in aize is very great, irrespective of locality or sex. Coues gives the length as varying from 32 to 45 , and the wing from 9.50 to 13 . 
Distribution.-Temperate North America from Newfoundland and British Columbia south to the West Indies and Guatemala; breeding throughout the greater part of its range, but in the northern half only a summer resident. Occasionally in Europe.

In Colorado the Bittern is a fairly common summer bird, arriving early in May and breeding in the plains and foothills up to about 8,000 feet. Felger saw one as late as December 28th, near Fort Morgan, so a few may perhaps spend the winter in the State. Carter found it nesting in Middle Park at about 7,000 feet, and A. D. Baker in the Wet Mountain Valley at about 8,000 feet (Cooke). On the western slope it has been noticed by Sullivan near Grand Junction in summer, but he did not succeed in finding the nest. Other records are Fort Lyon, April 26th, and Loveland, May 13th (Cooke), Boulder co., plains (Henderson), Barr, common summer resident, breeding (Hersey \& Rockwell), near Colorado Springs, May 15th and October 5th (Aitien), Crested Butte, in the fall (Warren), Salida, April (Frey).

Habits.-The Bittern is a singular bird, found solitary or in pairs in swamps and marshes. It is very deliberate in its movements, and has marvellous powers of concealment. It simply stands still with bill and neck vertically upraised, when the striped plumage so completely harmonizes with the surroundings that it is practically invisible. It is also noted for its astonishing vocal performance. This resembles the working of an oldfashioned pump, or even in the same bird the driving of a stake into a bog. From this it is sometimes known as the "Thunder-pumper" or "Stake-driver." The noise can be heard a long way off, and is caused by inflating the throat and emitting the air with a gulping motion.

The food of the Bittern consists of frogs, small fishes, and aquatic insects, which are usually obtained by spearing with the sharp-pointed bill.

The nest is generally placed on the ground in or near marshes; it is built up chiefly of rushes. The eggs, 3 to 4 in number, are brownish drab, oval in shape, and measure $2.0 \times 1.48$. Dille gives June 20th as the average time for fresh eggs in northern Colorado. 


\section{Genus IXOBRYCHUS.}

Very small Bitterns-wing 4 to 5-with the head and nape slightly crested; the culmen about equal to or slightly exceeding the tarsus and the middle toe with claw, which are themselves about equal; ten tail-feathers; sexes unlike.

A large, world-wide genus, with two American species only.

\section{Least Bittern. Ixobrychus exilis.}

A.O.U. Checklist no 191-Colorado Records-Cooke 94, p. $183 ; 97$ pp. $61,157,197$.

Description.-Male-Crown, which is slightly crested, back and tail glossy black; neck behind, greater wing-coverts and some of the inner quills rich chestnut, outer primaries slaty, tipped with rufous; other wing-coverts brownish-yellow; under-parts, including the front and sides of the neck buffy-yellow and white, with narrow streaks of darker ; a dark maroon patch on either side of the breast; iris yellow, bill yellow, darker on the culmen, legs greenish-yellow. Length 14; wing 4.8 ; tail 1.85 ; culmen 1.80 ; tarsus 1.75 .

The female has the black of the crown and back replaced by a rich, dark glossy-chestnut, more dusky on the former; a pale buffy stripe along the outer borders of the scapulars is very conspicuous.

Distribution.-From New Brunswick and northern California southwards to the West Indies and Brazil ; a resident in the southern United States and southwards; a summer bird only north of this.

The Least Bittern is a rare summer resident in Colorado; about eight instances of its occurrence are recorded, but it is probably less rare than is generally supposed, as it is seldom seen owing to its skulking and nocturnal habits. It was first reported by Cooke on the strength of an example taken near Colorado Springe, now in the Aiken collection. This, and a second one found alive, but injured, in a yard in Colorado Springs, June 18th, 1907, are now in the Museum of Colorado College. Other records given by Cooke are : near Denver, reported by $\mathbf{H}$. G. Smith; Berkeley Lake near Denver, June 8th, 1898, shot by R. Borcherdt; Middle Park, August 5th, 1897, W. A. Sprague; South Park, May 14th, 1875, Carter ; and Wet Mountain Valley, A. D. Baker.

Habits.-Even more retiring and secretive than the American Bittern, this little species inhabits the most inaccessible and densely grown-up swamps and marshes. It has a habit of climbing up and clinging motionless to stout rushes, with its neck stretched out and its bill pointed up, when it is almost entirely invisible. 
There is a clutch of five eggs of this bird in the Colorado College Museum, presented by I. C. Hall. They were taken by the donor near Greeley on June 1st, 1903. The nest is described as a platform of rushes among cat-tails, about ten inches above the level of the shallow water. The eggs, oval and white with a pale blue tinge, measure $1^{\cdot 20} \times{ }^{\cdot 90}$. This, so far as I know, is the only instance of a nest being found in Colorado, and I have every confidence in the correctness of the identification.

\section{Genus ARDEA.}

Large birds-wings 18 to 21-with a long, straight, pointed beak, about two-thirds the length of the tarsus; tail short of twelve feathers; legs long, the lower third, at least, of the tibio-tarsus bare; tarsus longer than the middle toe and claw; head with two long plumes in the breeding season; feathers of the fore-neck and scapulars elongated, but not decomposed.

A universally spread genus of about a dozen species, with only one commonly known in North America.

\section{Great Blue Heron. Ardea herodias.}

A.O.U. Checklist no 194-Colorado Records-Aiken 72, p. 209; Nash 83, p. 225 ; Drew 85, p. 18 ; Morrison 89, p. 166 ; Cooke 97, pp. 18, 61, 157, 197 ; Dille 03, p. 74 ; Henderson 03, p. 234 ; 07, p. 162 ; 09, p. 227 ; Markman 07, p. 155 ; Rockwell 08, p. 158 ; Warren 09, p. 13.

Description.-Adult-Top of the head white bordered by black, and with a black occipital crest, which bears two or more long slender plumes in the breeding season; neck purplish-grey, with a mixed white, black and rusty throst line, becoming white on the chin and cheeks; shoulders and under-parts chiefly black, striped with white; upper-parts bluishgrey, becoming black on the primaries; tibial feathering and edge of the wing chestnut; iris yellow, bill yellow, darker along the culmen, feet blackish. Length about 45 ; wing 19.25 ; tail 7.5 ; culmen 6.0 ; tarsus $7 \cdot 25$.

The female is smaller-wing about 18.25. In the non-breeding plumage the long occipital plumes are absent and the scapulars are not lengthened and lanceolate. The young birds have no lengthened feathers, the whole crown is black, and the colours generally paler and less distinct. 


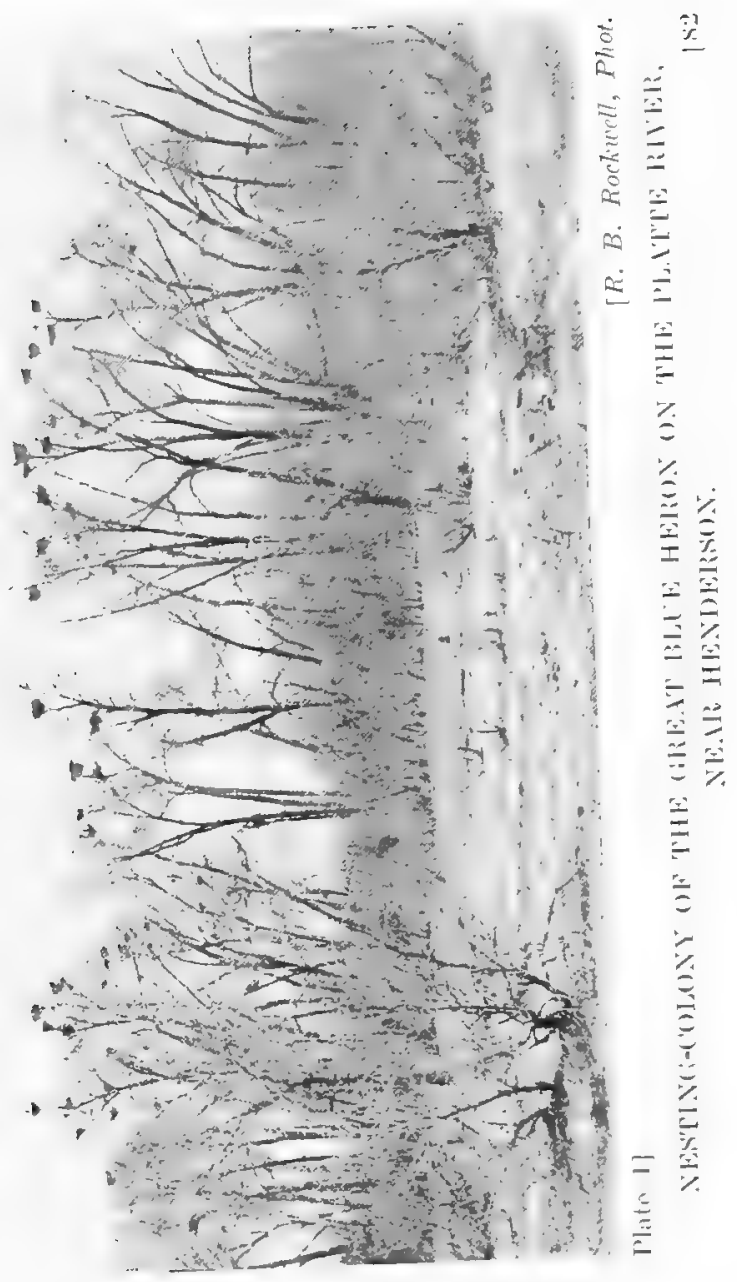



Distribution.-From Alaska and Labrador south through the West Indies and Central America to Venezuela; a summer resident only, north of the middle states; south of this, a resident.

The Great Blue Heron is found throughout Colorado on migration and breeds in suitable localities, chiefly in the north-eastern part of the State, but also in the mountain parks up to about 8,000 feet. It arrives from the south about the second week of April. Frey saw one at Salida as early as March 30th.

It has been observed nesting on the Cache la Poudre Creek near Fort Collins (Cooke), at Windsor (Hall), on Crow Creek, north-west of Greeley (Markman), on the St. Vrain near Lyons, in Boulder co. (Henderson), near Barr (Rockwell \& Hersey), in Middle Park by Carter, and in Wet Mountain Valley at about 8,000 feet, by Baker (Cooke). In Mesa co. on the western slope it appears to be common up to 9,000 feet, but has not been found breeding; while Aiken observed it on one occasion as late as November 27th near Divide in Teller co., at about 9,000 feet.

Habits.-This large Heron, often mis-called the "Blue Crane," is chiefly met with along the larger rivers and lakes; here it can often be seen standing motionless in the shallows, in a somewhat stilted attitude, watching intently for small fishes or frogs, which it quickly snaps up. The flight though powerful is rather heavy and leisurely, the neck crooked and the head drawn back between the shoulders and the legs stretched out behind. They are solitary birds, except during the breeding season, when they generally nest in communities, called heronries. The nest is usually placed in high trees, but sometimes in bushes or on the ground or among the rocks. In Colorado the higher cotton-woods along the rivers and creeks are usually chosen.

A set of four eggs of this Heron was presented to the Colorado College Museum by I. C. Hall. They were taken from a heronry of about 200 nests in high cottonwood trees near Windsor on the Cache la Poudre River. The nests were thirty feet up, and were made of small twigs put solidly together. The eggs were taken May 
Ilth, and incubation was somewhat advanced. They are oval in shape, pale greenish-blue in colour and measure $260 \times 1.80$

Heronries are occasionally entirely broken up by a severe hailstorm. Such a disaster occurred to a colony near Lyons in Boulder co., in July 1907; the ground under the trees was covered with dead birds.

\section{Genus HERODIAS.}

Closely resembling Ardea, but smaller, wing 16-17; plumage white throughout, with a train of decomposed scapulars developed in the breeding season; no occipital crest.

One species only in North Americe.

\section{American Egret. Herodias egretta.}

A.O.U. Checklist no 196-Colorado Records-Aiken 00, p. 298; Cooke 97, p. 197.

Description.-Adult-Plumage entirely white; a train of long, decomposed plumes from the scapulars extending ten to twelve inches beyond the tail when fully developed; no lengthened feathers on the head and neck; iris and bill yellow, legs black. Length 39.5 ; wing 14.75 ; tail 6.25 ; culmen 4.5 ; tarsus $6-5$.

The female is slightly smaller-wing 14. After the breeding season the long plumes are lost. Young birds have a black bill and no long plumes.

Distribution.-The southern United States and the Pacific slope from Oregon south to Patagonia and the West Indies; a straggler north as far as Nova Scotia and Manitoba.

The only notice of this species in Colorado is that of Aiken, who states: "On May 12th, 1900, Mr. A. Gruber and Mr. F. Cikanck, taxidermists in my employ, reported seeing a single bird in a tall cotton. wood tree five miles south of Colorado Springs. As they are familiar with this species as well as with the more common Snowy Heron, there appears no reason to doubt their identification." Hersey informs me he has one in his collection, taken at Barr in June, 1905.

\section{Genus EGRETTA.}

Resembling Herodias, but smaller, wing 9.5-11.5; plumage white with an occipital crest, and the dorsal train of decomposed feathers slightly recurved at the tips.

Only one North American species. 


\section{Snowy Egret. Egretta candidissima.}

A.O.U. Checklist no 197 -Colorado Records-Hersey 76, p. 430 ; Morrison 89, p. 166 ; H. G. Smith 96, p. 65 ; Cooke 94, p. 183; 97, pp. 61, 157, 198 ; Henderson 03, p. 234 ; 09, p. 227 ; Warren 06, p. 19 ; 08, p. 20 ; 09, p. 13 ; Cary 09, p. 180 ; Hersey \& Rockwell 09, p. 114.

Description.-Plumage white throughout, with decomposed plumes on the occiput, lower-neck and scapulars, the latter recurved when perfect; iris bare, space on face and toes yellow, bill, legs and claws black. Length 24.0 ; wing 11.0 ; tail 4.0 ; culmen 3.5 ; tarsus 4.0 .

The adults after the breeding season lack the decomposed plumes.

Distribution.-From Long Island and Oregon south through the West Indies and Central America to the Argentine; breeding throughout its range, but only a summer resident in the middle states.

In Colorado the Snowy Egret is a somewhat scarce summer bird. It was first noticed by J. C. Hersey, who reported the capture of a solitary specimen in a small lake thirty miles north-west of Denver, May 4th, 1876. It is less uncommon than usually supposed, but has not yet been found breeding. L. T. Hersey and Rockwell noticed it at Barr or several occasions in April, May and June, but failed to find the nest. It is chiefly met with along the eastern base of the mountains, but has been taken as high as Twin Lakes and Leadville, and was also on the western slopes at Glenwood (Carter).

Other recorded localities are, near Denver (H. G. Smith), Loveland, Fort Collins and Pueblo (Cooke), Colorado Springs (Aiken), Salida, spring and fall (Frey), Kremmling and Coventry (Warren), while there is an example in the Aiken collection taken at Howbert in South Park, May 1st, 1904, at about 8,600 feet. Cary notes it from White River P.O. and La Veta.

Habits.-In the south, where they were formerly found in great numbers, the Snowy Egrets were social birds, roosting and breeding in large assemblies, generally in bushes over the water, and scattering during the day to obtain their food-small fishes, frogs or aquatic insects. In Colorado, however, they are never very abundant, and only an occasional wanderer is to be found in the neighbourhood of lakes and rivers.

This and the Snowy Egret are the birds which have suffered chiefly at the hands of the plume-hunters, owing to the demand for "aigrettes," which are made 
up from the decomposed plumes developed only in the breeding season. Both birds were formerly to be found in millions in Florida and along the Gulf coast; now, except in a few specially protected United States birdreservations, the care of which has been assumed by the National Audubon Society, they are practically exterminated.

\section{Genus DICHROMANASSA.}

Egrets of medium size, wing 12-14, with very short toes, the middle one barely half the length of the tarsus; feathers of the heed and neck slightly elongated and a dorsal train in breeding season : plumage dichromatic with two distinct colour phases independent of age, sex or season.

One North American species.

\section{Reddish Egret. Dichromanassa rufescens.}

A.O.U. Checklist no 198-Colorado Records-Cooke 97, pp. 61, 157.

Description.-Adult, dark phase-Head and neck rufous-chestnut glossed with vinaceous; rest of the plumage dark slaty; decomposed plumes from the interscapular region reaching beyond the tail; iris white, bill flesh-coloured, terminal two-thirds black; legs blue-black. Length 31 ; wing 13.5 ; tail 4.5 ; culmen 4.0 ; tarsus 6.0 .

In the white phase the plumage is white throughout with a slight speckling of grey on the primaries. Young birds of either phase are similar, but without the decomposed plumes.

Distribution.-Florida, the Gulf states, and Lower Californis south to Guatemala and the West Indies; a casual wanderer north to Illinois and Colorado.

There is a single example - a young bird of the dark phase-in the Aiken collection, taken in 1875 near Colorado Springs. Another is said by Cooke to have been shot by E. L. Berthoud near Golden in about 1890. These are the only known occurrences in the State.

\section{Genus BUTORIDES.}

Small Herons with wings under 8.0 ; bill moderate, longer than the tartus; tail with twelve feathers; an occipital crest of lengthened, lanceolate, but not decomposed, feathers; upper-parts glosey green.

A wide-spread genus, found all over the New World, and most of the Old except Europe and Northern Asia. Only one species in North America. 


\section{Green Heron. Butorides virescens.}

A.O.U. Checklist no 201-Colorado record-Cooke 09, p. 314.

Description.-Crown with a long, soft crest, and lengthened, narrow feathers of the back lustrous green; wing-quills and tail dusky greenish with a narrow white edge to the wing; coverts green with tawny edgings; neck rich purplish-chestnut with the throat-line variegated dusky and white; below mostly brownish-ash with white on the belly; iris and eyelids bright yellow, bill greenish-black, feet dull yellowish-green. Length 12 ; wing 7.0 ; tail 2.5 ; culmen 2.45 ; tarsus 2.05.

Distribution. Temperate North America, from Oregon and Ontario south thorough the West Indies and Central America as far as Brazil.

Though not uncommon in Kansas, this little Heron has only recently been met with in Colorado. Edward A. Preble of the Biological Survey took one at Loveland, July 23rd, 1895. It has probably been overlooked and should not be really rare.

\section{Genus NYCTICORAX.}

Birds of medium size, wing 12-13, with a short neck, stout and somewhat compressed bill; the culmen, tarsus and middle toe with claw, all being approximately equal; tail short, of twelve feathers; tibio-tarsus feathered except for about half an inch; no elongated or decomposed plumes except those on the occiput.

A cosmopolitan genus with eight or nine species; only one in North America.

\section{Black-crowned Night Heron. Nycticorax nycticorax novius.}

A.O.U. Checklist no 202-Colorado Records-H. G. Smith 87, p. 285 ; 96, p. 65 ; 08, p. 185 ; Morrison 89, p. 166 ; Cooke 94, p. 183; 97, pp. 19, 61, 198 ; Dille 03, p. 74 ; Henderson 03, p. 234 ; 09, p. 227 ; Markman, 07, p. 155 ; Rockwell 08, p. 159, 10, p. 113.

Description.-Adult-Crown and nape, centre of back and scapulars glossy greenish-black; rest of the upper-parts pale lavender-grey; below, including the forehead, sides of the face and neck, white; two or three long filimentous plumes, generally white, from the occiput; iris red, bill black, legs yellow. Length 26.0 ; wing 12.5 ; tail 4.75 ; culmen $3 \cdot 15$; tarsus $3 \cdot 20$.

The female is smaller-wing 11.5 ; after the breeding season the occipital plumes are lost. The young birds are greyish-brown with paler edges to some of the feathers, and spotted conspicuously with white; the crown darker, the under-parts paler, streaked with dusky and buffy. 
Distribution.-From Now Brunswick and Manitoba south through the West Indies and Central America, to Brazil and Peru; breeding throughout its range; a resident from the southern states southwards.

In Colorado the Night Heron is a migrant and a summer resident, and is not uncommon; it is chiefly met with in the north-east part of the State, along the Platte and its affluents, but also goes up into the mountain parks. It was found breeding at San Luis Lakes by Aiken many years ago, and has been taken in Middle and South Parks by Carter. It is rarer on the western slope where it was eeen near Grand Junction, August 22nd, 1904, by Sullivan (Rockwell), while Gilmore met with it at Sweetwater Lake. It reaches Colorado towards the end of April. Smith reports an example taken at Fort Lupton between December 20th and 24th, 1902. It is possible, therefore, that some birds may winter.

Additional records are : Fort Collins, breeding (Cooke), Boulder co. (Henderson), Barr Lake (Smith 08, and Hersey \& Rockwell) Colorado Springs and Limon (Aiken).

Habits.-The Night Heron is a somewhat social bird especially in the breeding season, when they nest together in large heronries in marshes-sometimes in trees, sometimes in bushes, or even on the ground. They are rather silent birds except for a guttural "Qua," whence they get the common name of "Qua-bird."

Their food consists of small fishes, frogs and other aquatic animals, and is obtained by wading slowly and with considerable dignity through the shallows, and except when the young require constant attention, is chiefly sought at dusk.

The eggs, generally four, are of the usual greenishblue colour and average $2 \cdot 0 \times 1 \cdot 50$. Rockwell (10) has recently published an interesting series of photographs and notes on the breeding of this bird in the Barr swamps.

\section{Genus NYCTANASSA.}

Resembling Nycticorax in shape, but with much longer tarsus, easily exceeding the culmen and the middle toe and claw, which are approximately equal; a dorsal train of partly decomposea feathers.

Only one species is assigned to this genus. 


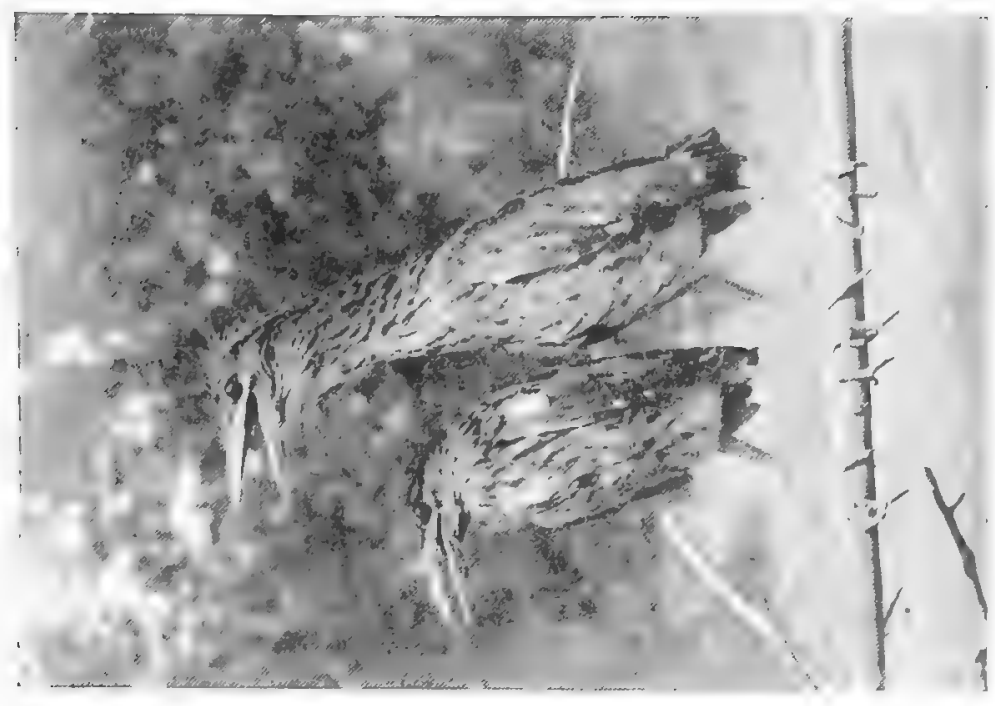

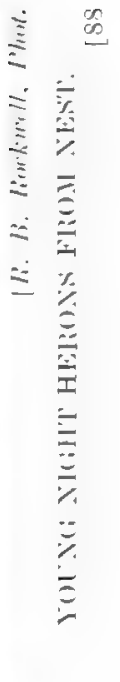

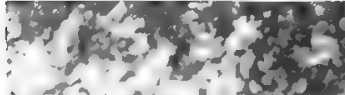

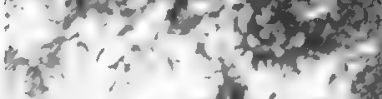

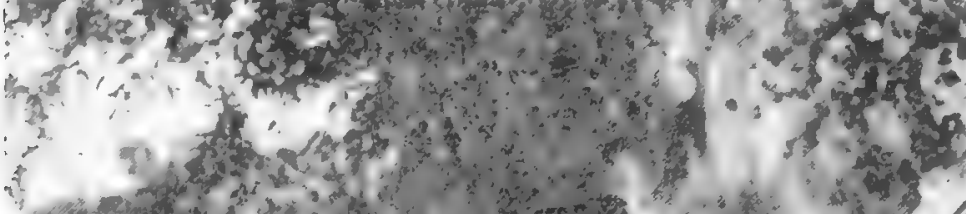

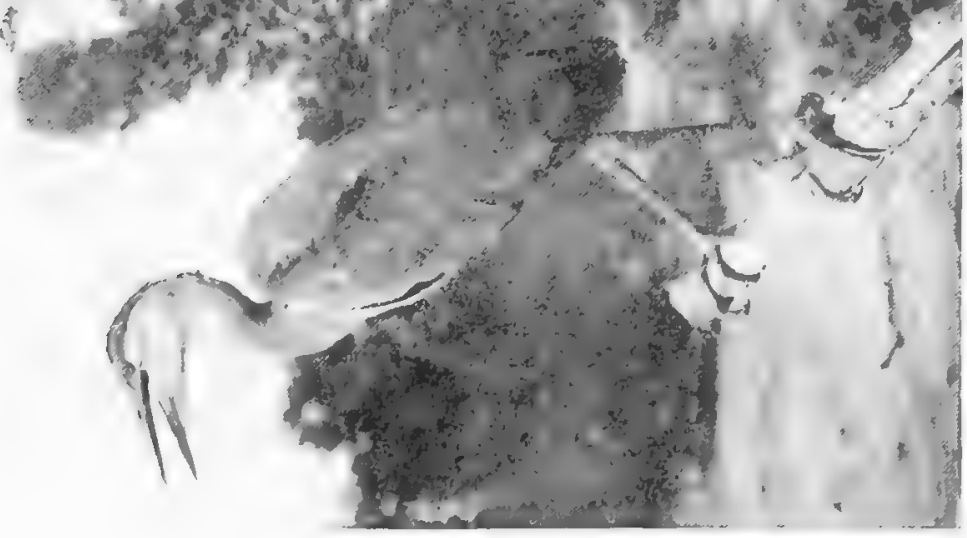

告 



\section{Yellow-crowned Night Heron}

\section{Yellow-crowned Night Heron. Nyctanassa violacea.}

A.O.U. Checklist no 203-Colorado Records-Ridgway 79, p. 233 ; Cooke 97, p. 62 ; Warren 09, p. 33.

Description.-Adult-Crown and a stripe behind the eye white, tinged with tawny; rest of the head all round black; general colour above and below greyish-blue, the feathers of the wings and scepulars with darker centres and paler edges; an occipital crest of 2 to 3 narrow filamentous plumes, and the scapulars elongated, lanceolate and partly decomposed; iris yellow, bill and legs black. Length 24; wing 12.25 ; tail 4.75 ; culmen 2.9 ; tarsus 3.8 .

The female is slightly smaller, wing 11.0 ; a young bird is greyishbrown streaked and spotted with buffy, below streaked brown and white, crown black, streaked with white or buffy.

Distribution.-From South Carolina, southern Illinois and Lower California south through the West Indies and Central America to Brazil ; casually further north.

In Colorado the Night Heron is a very rare straggler; there was an adult male in Mrs. Maxwell's collection known to have been killed in Colorado, and this constituted the only record until recently, when J. W. Frey obtained a single female out of a bunch of five on the Arkansas River just above Salida, May 1st, 1908. This specimen, reported by Warren, was presented by him to the Colorado College Museum.

\section{ORDER PALUDICOL $A$.}

This order contains the Cranes and Rails of our fauna, together with several other families which do not here concern us. It is such a varied assortment that it is quite incapable of definition by anatomical charactersstill less so by external characters, and a reference must be made to the diagnoses of the two families.

\section{KFy OF the Fammits and Genera.}

A. Larger birds; wing over 15; toes short and webbed at the base; hind toe set well above the others (Gruidce). Grus, p. 90.

B. Smaller birds; wing under 10 ; toes long, slender, not webbed, but sometimes lobed (Rallides).

a. Toes simple, no lateral marginal lobes.

$a^{1}$ Bill longer; culmen exceeding middle toe and claw.

Rallus, p. 93 . 
b Bill shorter; culmen less than the middle toe and claw. $a^{2}$ No frontal shield.

$a^{3}$ Larger; wing over 4; nostrils about the middle of the bill.

Porzana, p. 95.

$b^{3}$ Smaller; wing under 3 ; nostrils nearer the base of the bill.

Creciscus, p. 96.

$b^{2}$ A frontal shield on the front part of the head.

Gallinula, p. 97.

b. Toes with a series of lateral marginal lobes; a frontal shield present.

Fulica, p. 97.

\section{Family GRUID在.}

The Cranes are large birds with long legs and necks; the bill is long and generally exceeds the length of the head; part of the face is generally naked and often wattled or papillose; there are twelve tail-feathers and eleven primaries, and the trachea or windpipe is generally convoluted and packed away in a hollow space formed between the walls of the keel of the sternum; the legs are long, the tarsi seutellate in front, the toes short and webbed at the base; the hallux very short and elevated above the other toes.

The Cranes are externally not unlike the Storlss, with which they were formerly often associated, but they differ very essentially in internal structure. Externally they may be distinguished by the grooving of the bill, in which are situated the nostrils, and by the elevation of the hallux above the toes.

\section{Genus GRUS.}

The characters of the family, to which may be added-plumage white or grey in the adult, rusty in the young; head more or less bare of feathers and not crested.

All the three North American species have been taken in Colorado.

KEY OF THE SPECIFS.
A. Plumage white, primaries black.
G. americana, p. 91 .

B. Plumage slaty-grey.
a. Larger; wing $21-22$.
G. mexicana, p. 92 .
b. Smaller; wing 18-19.
G. canadensis, p. 91 . 


\section{Whooping Crane}

\section{Whooping Crane. Grus americana.}

A.O.U. Checklist no 204-Colorado Records-Aiken 72, p. 209 ; Morrison 89, p. 166 ; Cooke 97, pp. 18, 62 ; Felger 09, p. 286.

Description.-Adult-Plumage pure white, except the primaries, their coverts, and the alula, which are black; iris yellow ; bill duskygreenish; bare skin of head which runs back to a point on the occiput, and also on to the cheeks below the eyes, carmine; legs black. Length about 50 ; wing 24 ; tail $9 \cdot 0$ culmen 6 ; tarsus 12 .

A young bird has the head feathered and the plumage varied with rusty-brown.

Distribution.-Breeding chiefly from Iowa to Saskatchewan; migrating south along the Mississippi Valley to Central Mexico.

In Colorado the Whooping Crane was formerly, perhaps, more common. Aiken, thirty-five years ago, noted it as "occasional on migration," but it now seems to be very rare, and I only find two definite records of its occurrence. W. G. Smith observed it at Loveland, April 8th to 16th. There is a moulted specimen in the Museum at Fort Collins, but it is not definitely stated by Cooke where it was obtained.

\section{Little Brown Crane. Grus canadensis.}

A.O.U. Checklist no 205-Colorado Records-Thorne 87, p. 264; Cooke 94, p. 183 ; 97, pp. 62, 198.

Description.-Resembling in every respect the Sandhill Crane (G. mexicana) but considerably smaller. Length 36 ; wing 19.5 ; tail 7.75 ; culmen 4.40 ; tarsus 8.5 .

Distribution.-Breeding far north, from Alaska to Hudson Bay, migrating south through Colorado to Texas and Mexico.

Most of the Colorado references to this species really belong to the Sandhill, as the two birds have often been confused. The Little Brown Crane, however, passes through Colorado on migration. It was taken by Captain Thorne at Fort Lyon; there is a mounted example in the Museum at Fort Collins and also one in the collection of Mr. A. T. Allen, taken near Denver (Cooke), while Aiken tells me he had two brought to him, March 27th and 28th, 1900, which had been killed close to Colorado Springa. In the State Historical Society's collection at Denver there is male, killed at Hooper, Costilla co., March 27th, 1906, by J. L. Wolfe, and a female from Magnolia, Arapahoe co., about fifteen miles east of Denver, taken by H. Todenwarth. The stomach of the former example contained "about half-a-pint of wheat."

C. S. Thompson informs me of the capture of an example at Edwards, Eagle co., April 1st, 1903. This is apparently the first record for the western slope. 


\section{Sandhill Crane. Grus mexicana.}

A.O.U. Checklist no 206-Coloredo Records-Baird 54, p. 14 (G. canadensis); Aiken 72, p. 109 ; Henshaw 75, p. 467 ; Drew 81, p. 142 ; 85, p. 18 ; Nash 83, p. 225 ; Beckham 85, p. 144 ; Morrison 88 , p. 140 ; 89 , p. 167 ; Cooke 97 , pp. 62,198 ; Warren, 04, p. 39 ; 09, p. 13 ; Rockwell 08, p. 159.

Description.-Adult-Genersl colour above and below slaty-grey, more or less washed with rusty; chin, cheeks and throat rather paler, primaries more dusky ; iris crimson, bill blackish, the bare skin of the head, which runs back to form a more or less straight line transversely on the occiput, and hardly extends on to both cheeks, reddish; legs blacki.h. Length about 48 ; wing 21 ; tail 10.0 ; culmen 5.25 ; tarsus $9 \cdot 0$.

Young birds have the head feathered and much stronger rusty wash, which however is not lost till after maturity.

Distribution.-Southern Canada south to Florida and Central Mexico, not in the eastern states north of Georgia; wintering along the Gulf and in Mexico; breeding locally elsewhere.

The Sandhill Crane is not a very rare bird in Colorado; it breeds chiefly in the mountain parks from 7,000 to 9,500 feet, and migrates south in winter. It is stated by Cooke to winter in the Rio Grande Valley, whence it was first taken in the State by Capt. Gunnison in 1853 (Baird); but the bulk at any rate of these birds spend a month or so there only, in autumn and spring, on their way further south and north.

It has been observed breeding in the Animas Parks at 7,000 feet by Drew, in Middle Park by Carter, in Routt co. by Cooke, and in Mesa co. by Rockwell, while Warren found it nesting in the north-west corner of Gunnison co., at about 8,000 feet.

This is a bird which is soon driven away by closer settlement, and it was no doubt formerly much more abundant. Other records are, Bart Lake (Hersey \& Rockwell), Pueblo (Nash), La Plata co. (Morrison), and Wet Mountain Valley (Baker apud Cooke).

Habits.-The Sandhill, like other Cranes, prefers an open, treeless country where it can see the approach of enemies from afar. If alarmed it springs up into the air and flies heavily away, giving out its powerful and sonorous cry, which is also often heard when the birds are migrating, far overhead.

Cranes are also very remarkable for their dances and antics during the breeding season; they bow low and 
leap, droop their wings, and skip and work themselves into a great state at this time.

Warren (04) found a nest on an island in a small lake in north-western Gunnison co., at an elevation of 8,000 feet, on June 5th, 1903 ; the nest was placed on a tussock of grass, and was merely a flat platform about two feet across, chiefly composed of swamp-grass; on this platform lay two large eggs. These are light greenishbrown in colour, blotched all over with reddish-brown, rather more thickly towards the larger end of the egg, though in shape they are almost elliptical. They average $398 \times 244$.

\section{Family RALLIDE.}

The Rails and Coots, which constitute this family, are marsh or water birds of retiring habits, running through and skulking in grass and reeds. The face is always feathered, the tail is generally very short, and contains ten to fourteen rectrices; the legs are rather short and the lower portion of the tibia is always bare of feathers; all the toes are long and slender, and the hind toe is jointed at a higher level than the others.

\section{Genus RALLUS.}

Bill long and slender, the culmen longer than the middle toe and claw; no frontal shield; nostrils in a long groove near the base of the bill; tail short, less than half the length of the wing; tarsus shorter than the middle too and claw.

A cosmopolitan genus, containing the Water Rails; some eight species and subspecies are recognized in North America.

\section{Virginia Rail. Rallus virginianus.}

A.O.U. Checklist no 212-Colorado Records-Aiken 72, p. 210 ; Henshaw 75, p. 468 ; Beckham 85, p. 144 ; 87, p. 124 ; Morrison 89, p. 166 ; Cooke 97, pp. 18, 63, 158, 198 ; Henderson 03, p. 234 ; 09, p. 227.

Description.-Above dusky brown, the feathers of the back edged with olive-brown; sides of the face ashy-grey, darker round the eje; 
chin white, becoming pale rufous on the breast; thighs, abdomen and under tail-coverts ashy-black, barred with white; wing-coverts chestnut, forming a patch; iris red, bill dusky, paler on the lower mandible, feet yellowish-brown. Length $9 \cdot 0$; wing $4 \cdot 25$; tail 1.6 ; culmen 1.55; tarsus 1.5 .

The female is slightly smaller-wing 3.90 ; young birds have the plumage much mottled with black, but the chestnut wing-patch is always present.

Distribution-Breeding throughout temperate North America from Labrador and Vancouver Island, south throughout the United States; wintering in the southern United States and south to Guatemala and Cuba.

In Colorado the Virginia Rail, though seldom seen, appears to be a fairly common summer resident in the eastern plains, extending up into the parks to about 8,000 feet. I have not heard of it on the western slopes, though, as it is found in Utah, it probably occurs. It arrives from the south about the second week in April-Loveland, April 9th (H. G. Smith) - and breeds where suitable conditions exist. Apparently a few birds occasionally winter in the State, as an example was brought to Aiken, February 16th, 1899, which was taken at a spring a few miles from Colorado Springs, and this was at the end of one of the coldest spells known for many years. Mr. J. C. Hersey informs me that a fow spend the winter at Barr Lake every sear, where it also nests quite, commonly. Breeding records are : Loveland and Fort Collins (Cooke) Boplder co., plains (Gale), Fountain and San Luis Lakes (Aiken); other records are-Pueblo, May 20th and November 3rd (Beckham), Wet Mountain Valley (Cooke).

Habits.-Like all Rails this species is a timid, skulking bird, hiding in the thick reed-beds of swamps and marshes both fresh and salt, and more often heard than seen. It has a kind of grunting note, heard most frequently in the evening or at night when it is more actire than in the middle of the day. The Virginia Rail walks with a very deliberate step, with its short tail cocked up, and presents rather a ludicrous appearance.

The nest is placed on the ground, usually in wet, boggy places, and is composed of rushes and swamp-grasses woven together; it is sometimes fixed on a dry tussock, and is generally carefully concealed. A clutch of twelve eggs, taken by I. C. Hall near Greeley, June 1st, 1903, 
and presented by him to the Colorado College Museum, were slightly incubated. They are pale creamy-white with scattered spots and specks of reddish-brown and a very pale lilac, and average $1 \cdot 25 \times \cdot 90$. Gale's nest only contained seven eggs-it was taken May 27th, and the eggs were badly incubated.

\section{Genus PORZANA.}

Bill short and compressed, the culmen less than the middle toe and claw, nostrils linear oval, about the middle of the bill; tail very short as in Rallus; tarsus shorter than the middle toe and claw; toes not webbed.

An almost cosmopolitan genus, but as now restricted, with only one North American species.

\section{Sora. Porzana carolina.}

A.O.U. Checklist no 214-Colorado Records-Ridgway 73, p. 187 ; Morrison 89, p. 167 ; Cooke 97, pp. 63, 199 ; Henderson 03, p. 107 ; 09 , p. 227 ; Warren 08, p. 20 ; Felger 09, p. 86 ; Hersey \& Rockwell 09, p. 114.

Description.-Malo-General colour above olive-brown, most of the feathers with black centres and very characteristic, dead-white edges to others; crown, face in front of eye, chin, and a narrow throat-patch black; rest of the head and breast ashy-grey; lower-breast white, tinged with rufous towards the under tail-coverts; sides and under wing-coverts barred black and white; iris brown, bill greenish, rather orange at the base in the breeding season, legs greenish. Length 6.75; wing 4.25 ; tail 1.5 ; culmen .85 ; tarsus 1.25 .

The female is slightly smaller-wing 4.0; a young bird has no black or ashy on the face or neck; the chin is white and the throat and breast washed with rufous.

Distribution.-Breeding from Newfoundland and British Columbia south over most of the United States; wintering from South Carolina and the Gulf States to the West Indies and northern South America.

The Sora is quite a common summer resident in Colorado in suitsble localities, breeding from the plains up to about 9,000 feet in the valley of the Blue River (Carter), but chiefly in north-east Colorado. It has been reported from Boulder co. (Henderson), Barr, where is nests plentifully (Hersey \& Rockwell), Lay, in Rout co., probably breeding (Warren), Colorado Springs (Aiken) and Salida (Colo. Coll. Mus.), and is probably common elsewhere. Felger found, on September 2nd, 1903, 
a dead bird of this species near the terminal moraine of the Arapahoe glacier in Boulder co., at an elevation of about 12,500 feet. This was probably an accidental occurrence.

Habits. - This little Rail is very abundant in the swamps of the Atlantic states, where large numbers are killed by gunners for the restaurants, and it is known as the "Ortolan." In their habits they are not very different from the Virginia Rail, though more often found in meadow-lands and on cultivated ground.

A set of seven eggs taken at Greeley on June 1st, 1903, by I. C. Hall and presented by him to the Colorado College Museum, are quite distinct from those of the Virginia Rail. They are drab with a few large blotches and round spots of purplish and reddish-brown; in shape they are rather more pointed and they average 1*25 $\times \cdot 91$. Gale notes that fresh eggs are found about May 15th, at 5,500 feet, and about July 5th, at 10,000 feet. A nest with fourteen eggs, collected by Bragg north-east of Boulder, June 7th, 1904, is in the University of Colorado Museum.

\section{Genus CRECISCUS.}

Hardly differing from Porzana, except that the bill is more slender and acute, and that the nostrils are nearer the base of the bill than the tip.

Two closely allied species are recognized in the last supplement of the A.O.U. Checklist, from eastern and western North America respectively.

Black Rail. Creciscus jamaicensis.

A.O.U. Checklist no 216-Colorado Record-Cooke 97, p. 158.

Description.-Adult-Above blackish, nape and shoulderg dark reddish-brown, back and wings spotted with white; below slaty-grey, darker and cross-barred with white on the abdomen and under wingcoverts ; iris red, bill black, feet greenish. Length 5 ; wing 2.95 ; tail 1.35 ; culmen .53 ; tarsus 89 .

Young birds are paler below, especially on the throat, and the crown is brownish rather than blackish. 
Distribution.-The eastern United States from Massachusetts and Kansas southwards to Jamaica and Cuba, but always a rare bird.

The claim of the Black Rail to be included in the Colorado list rests on the statement of Mr. David Bruce of Brockport, N.Y., that he once shot a specimen in May at a pond near Denver. Like all Rails, it is a skulking bird, and is probably not nearly so rare as is generally aupposed. It is known to breed in Kansas.

\section{Genus GALIINULA.}

Bill short, stout and rather compressed, running directly back into a frontal shield on the fore-part of the head; nostrils elongated ovals near the middle of the bill; tarsus shorter than the middle toe and claw; toes with a narrow lateral membrane, but not webbed or lobed.

A widely distributed genus in the Old and New Worlds, with one North Amorican species; occurring but seldom in Colorado.

\section{Florida Gallinule. Gallinula galeata.}

A.O.U. Checklist no 219-Colorado Records-Allen \& Brewster 83, p. 198 ; Morrison 89, p. 167 ; Cooke 97, pp. 63, 158.

Description.-Head, neck and under-parts greyish-black; darkest on the head, whitening on the abdomen; back brownish-olive; wings and tail dusky; outer web of outer primary, a few stripes on the flanks and under tail-coverts, white; iris red or brown, bill and frontal shield red, the former tipped with yellow; legs greenish with a red ring round the tibia. Length 14.0 ; wing 6.8 ; tail 3.0 ; tarsus 2.2 ; culmen 1.10, with frontal shield $1 \cdot 75$.

The young have no red on the bill or legs, the frontal shield is undeveloped, and the under-parts are more extensively white.

Distribution.-From Ontario, Minnesota and California south through the West Indies and Central America to the Argentine.

The Florida Gallinule is hardly known in Colorado; it can only be considered a rare straggler. Allen and Brewster saw one in the flesh in Colorado Springs on May 9th, and E. I. Berthoud informed Cooke he had seen one on Lathrop Lake, near Golden, in 1883.

\section{Genus FULICA.}

Resembling Gallinula generally as regards bill, frontal shield and wing, but the toes long and provided with a scalloped lateral membranous lobe on either side, corresponding to the individual phalanges.

A cosmopolitan genus with one North American species. 


\section{American Coot. Fulica americana.}

A.O.U Checklist no 221-Colorado Records-Ridgway 73, p. 187 ; Henshaw 75, p. 469 ; Drew 85, p. 18 ; Morrison 89, p. 167 ; Cooke 97 , pp. 18, 63, 199 ; Keyser 02, p. 145 ; Dille 03, p. 74 ; Henderson 03, p. 234, 09, p. 227 ; Warren 06, p. 19; 08, p. 20; 09, p. 13 ; Markman 07, p. 155 ; Richards 08 , p. 38 ; Rockwell 08, p. 158 ; Hersey \& Rockwell 09, p. 114.

Description.-Adult-Dark ashy-grey above, paler below, darkening on the head and neck to blackish; edge of the alula, outer edge of the outer web of the outer primary, tips of the secondaries and outer undertail-coverts white; central under tail-coverts black; iris carmine, bill white or fleshy with a spot of reddish-black near the tip and at the base of the frontal shield, legs yellowish-green. Length $14 \cdot 0$; wing $7 \cdot 6$; tail 1.75; culmen with frontal shield 1.70; tarsus 2.0.

In winter the abdomen is whitish owing to white tips to the feathers ; young birds are duller and paler; they have the bill dingy and no frontal shield.

Distribution.-From Now Brunswick and British Columbia southwards through the West Indies and Central America to northern South America.

The American Coot or Mud-hen, as it is more familiarly termed, is a common summer resident in Colorado, breeding plentifully chiefly in the north-eastern plains region and in the mountain parks, but also at very considerable elevations, up to 10,000 feet at least. There is a nestling in the Aiken collection obtained by Aiken at California Gulch near Leadville, between 10,000 and 11,000 feet. It does not seem to be so abundant on the western slopes, where it is noted as not common both near Coventry (Tharren) and in Mesa co. (Rockwell). It arrives from the south about the second half of March. I am told by Hersey that a certain number spend the winter at Barr Lake, while this is confirmed by Richards, who saw a Mud-hen at Littleton on Christmas Day, 1907.

Other breeding records are Loveland (Gale), Greeley (Hall), Middle and South Parks (Carter), Buena Vista (Keyser), and San Luis Lake (Henshaw).

Habits.-Coots somewhat resemble Gallinules in their habits, but they are more social in their ways, and fonder of open water. They like to swim about in small companies, nodding their heads in a characteristic fashion as they go, and are easily identified by their shiny-whity beaks. They rise from the water with considerable 
difficulty, but when fairly in the air fly quite steadily and strongly, though they always prefer to avoid danger by hiding in the reeds. They are not very good divers.

The American Coot nests in colonies among growing reeds in shallow or sometimes in deeper water. The nests which are only a few feet apart, are massive structures of interlaced weeds and rushes, generally floating and anchored among the growing reeds, and high enough out of the water to keep the eggs dry. The eggs, from eight to twelve in number, are pale drab fairly uniformly spotted and dotted with dark brown.

A clutch of eight taken by I. C. Hall, May 26th, 1902, near Greeley, and presented to the Colorado College Museum, are rather rough and pointed, and measure $1.95 \times 1 \cdot 3$. Gale found fresh eggs between June 5th and 20th about Loveland, while Henshaw states that by June 22nd they had hardly finished laying at San Luis Lakes.

\section{ORDER LTMICOL}

The birds included in this order are chiefly shore and marsh haunting forms, such as Snipes, Sandpipers, Plovers and their allies.

The members of the order are characterized by a bill which is usually slender, and has a groove on each side with the nostril-opening near its base; the wings are generally long and there are always eleven primaries; the legs, too, are generally long and have the lower part of the tibio-tarsus naked; the toes are usually short and are three or four in number; the hind toe, if present, is jointed well up above the others; the anterior toes are fully webbed or not webbed, but most frequently partially webbed. The young birds when hatched, are clothed with down, and able to run about almost at once. 


\section{Key of the Famthites and Genera.}

A. Toes with a marginal web like a Coot (Phaleropodidae).

a. Marginal web sealloped at each joint. Lobipes, p. 101.

b. Marginal web even and continuous, not scalloped.

B. Toes without a marginal web.

Steganopus, p. 102.

w. Tarsus with reticulate scales before and behind.

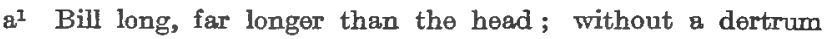
(Recurvirostrida).

$a^{2}$ Bill flattened and up-curved. Recurvirostra, p. 104.

$b^{2}$ Bill acute, slender and straight. Himantopus, p. 106. b1 Bill as long as, or less than, the head, ending in a hard convex swelling the dertrum (Charadriida).

$a^{2}$ A small hind-toe present. Squatarola, p. 130.

$b^{2}$ No hind toe.

$\mathrm{a}^{8}$ Upper-parts spotted, below black in summer.

$b^{3} \quad$ Above plain coloured, below white.

Charadrius, p. 131.

$a^{2}$ With black bands or patches on the fore-neck.

$\mathbf{8}^{5}$ Tail less than half the wing, nearly even.

Egialitis, p. 134.

$b^{5}$ Tail at least half the wing, strongly graduated.

Oxyechus, p. 132.

b4 Without black bands or patches. Podosacys, p. 135.

b. Tarsus with transverse scutes in front and behind (Scolopacida).

$a^{1}$ Hind toe present.

$a^{2}$ Ear-opening below the eye.

$\mathbf{a}^{3} \quad$ Three outer primaries attenuated. Philohela, p. 107.

$\mathrm{b}^{3}$ Three outer primaries normal.

$a^{4}$ Sixteen tail-feathers, plumage streaky.

b4 Twelve tail-feathers, plumage mottled.

Gallinago, p. 109.

Macrorhamphus, p. 111.

$b^{2} \quad$ Ear-opening behind the eye in the normal position.

$\mathrm{a}^{3}$ Toes cleft to the base, without webs.

$a^{4}$ Bill about equal to the tarsus. Pisobia, p. 113.

b Bill distinctly longer than the tarsus. Pelidna, p. 116.

$b^{3} \quad$ Toes always webbed to a greater or less extent.

a4 Culmen distinctly shorter than the tarsus.

$a^{5}$ Tail long, about half the wing, graduated.

Bartramia, p. 125.

$b^{5}$ Tail short, less than half the wing, even.

Totanus, p. 120. 
b Culmen approximately equal to the tarsus.

$a^{5}$ Tail unbarred.

$a^{6}$ Larger ; wing over 5.0, bill longer than the head.

Micropalama, p. 112.

$b^{6}$ Smaller; wing under $4 \cdot 0$, bill hardly as long as the head.

Ereunetes, p. 117.

$b^{5}$ Tail barred with dusky and white-on the outer feathers, at any rate.

a. Larger ; wing over 7.

$a^{7}$ A white patch on the wing and at the base of the tail. Catoptrophorus, p. 123.

$b^{7}$ No white patches on wing and tail.

$b^{6} \quad$ Smaller ; wing under 6.

Limosa, p. 119.

$a^{7}$ Axillaries and under wing-coverts banded. white and dusky; lower breast plain white.

Helodromas, p. 122.

$b^{7}$ Axillaries and under wing-coverts plain white, abdomen spotted.

Actitis, p. 126.

b1 Three toes only, without webs.

Calidris, p. 118.

c. Tarsus with transverse scutes in front and reticulated at the sides and behind.

a. Bill long and slender and down-curved. Numenius, p. 128.

b1. Bill short, conical and straight (Aphrizida). Arenaria, p. 136.

\section{Family PHALEROPODID压.}

The Phalaropes are a small family of birds, resembling the Sandpipers in general form and structure, except that their anterior toes are bordered by $a_{t}$ well-developed marginal web, sometimes cut into lobes, as in the Coots and Grebes. The females are larger and more brightly coloured than the males and, as is generally the case under these circumstances, the latter perform the duties of incubation.

\section{Genus LOBIPES.}

Bill long and slender, though shorter than in Steganopus, tapering, acute and pointed, the culmen slightly exceeding or equal to the tareus and middle toe and claw; tail short and rounded; lega comparatively short, and only a short portion of the tibio-tarsus bare; toes margined with a membrane scdlloped at each joint; the middle and inner toe united basally to the second joint, the middle and outer to the first joint. 


\section{Northern Phalarope. Lobipes lobatus.}

A.O.U. Checklist no 223-Colorado Records-Drew 81, p. 249 ; Morrison 88, p. 140 ; 89, p. 167 ; Cooke 97, pp. 19, 63, 199 ; Warren 08 , p. 20 ; 09, p. 13 ; Henderson 09, p. 227 ; Felger 09, p. 287.

Description.-Female in summer-Above dark slaty, becoming dusky on the wings and tail; back and scapulars with a few streaks of tawny; a. white wing-bar; a large rusty patch on either side of the neck nearly meeting below; under-parts chiefly white; the sides of the breast and flanks marked with dusky; iris dark brown, bill and feet black. Length 7.5 ; wing 4.25 ; tail 2.0 ; culmen, -85 ; tarsus $\cdot 75$.

The male is smaller and duller. In winter there is no rusty or tawny; the upper-parts are grey or ashy, variegated with white edges; below thronghout, including the forehead and a stripe above the eye, white; a dusky stripe below the eye to the ear-coverts. Young birds are dusky above and often show buffy edges to the scapulars.

Distribution.-Circumpolar, breeding far north in both hemispheres, wintering in north Africa and south Asia in the Old World. In America breeding from Alaska to Hudson Bay and Greonland, south in winter es far as Guatemala.

In Colorado this species is only known as a migrant, passing through the State in May and returning in October. It crosses the mountains as well as the plains, and has been reported from Howardsville, 9,500 feet, May 22nd (Drew), Middle Park, May 26th, and Breckenridge (Carter), Coventry and near Steamboat Springs, June lst (Warren), in the mountainous half of the State; in the plains from Colorado Springs, May 14th and 29th (Aiken coll.), Loveland, May 1st to 9th (Cooke), Barr Lake, May, September (Felger) and Boulder co. (Hendersod).

Habits.-The Phalaropes are all more abundant along the coast than inland. They swim lightly and easily, picking among the floating debris for their food. The male undertakes the chief duties of incubation, and as is generally the case, this habit is correlated with smaller size and duller markings.

\section{Genus STEGANOPUS.}

Bill long and slender, slightly flattened and depressed, the culmen about equal to the tarsus, both clearly exceeding the middle toe and claw; tail short and doubly emarginate; toes with an even, unscalloped marginal web, united basally only, not beyond the first joint in the case of the middle and inner ones. 


\section{Wilson's Phalarope. Steganopus tricolor.}

A.O.U. Checklist no 224-Colorado Records-Ridgway 73, p. 187 ; Morrison 89, p. 167 ; Cooke 97, pp. 19, 63, 199 ; Henderson 08, p. 107 ; 09, p. 227 ; Markman 07, p. 156; Warren 09, p. 14 ; 10, p. 29 ; Hersey \& Rockwell 09, p. 114.

Description.-Female in summer-Crown ashy-grey, becoming white on a narrow stripe along the neck; a black band from the eye along the sides of the neck, becoming chestnut posteriorly and continued ae scattered patches on to the scapulars; rest of the upper-parts slatygrey, dusky brown on the wings; upper tail-coverts white; below white, the lower part of the neck and sides of the chest washed with rufous ; iris dark brown, bill and legs black. Length 9.5 ; wing $5 \cdot 1$; tail 2.0 ; culmen 1.3 ; tarsus $1 \cdot 2$.

The male is rather smaller-wing 4.8-and less brightly marked. In winter there is no black or rusty ; the upper-parts are pure ashy-grey edged with whitish; below, the upper tail-coverts, line over the eye and forehead, white; breast and sides washed with dusky. Young birds are dusky brown above, the feathers edged with buffy-rufous; below white, the breast and lower-neck washed with rufous.

Distribution.-Breeding from the eastern slopes of the Rocky Mountains in Alberta, south to Utah and Illinois; south in winter as far as Patagonia.

Wilson's Phalarope is a fairly common migrant in Colorado, while a certain proportion of the birds stop through the summer and breed in the north-east of the State along the lower Platte Valley, and perhaps at San Luis Lakes, whence there is a young bird of the year, taken July 10th, in the Aiken collection. Warren recently found it common at Medano Ranch in June. In other parts of the State it is chiefly known as a migrant. It reaches Loveland about the last week of April. Breeding records are Fort Collins (Cooke), Loveland (Gale); Barr Lake (Hersey \& Rockwell); on migration, Middlo and South Parks (Carter), Salida, May 4th (Frey), Glenwood Spring (Cooke), and Coventry (Warren).

Habits.-This Phalarope is almost always found near water, where they either swim about in a very buoyant manner or run in shallows and moist grass, picking up small mollusca and insects which form their food. Galo found three nests on June 19th, near Loveland; they consisted merely of a little depression in the ground near a lake, lined with a few grasses and contained four 
eggs. He believed that a second brood was usual, and that the first eggs were laid about May 20th. On another occasion he watched a large number of these birds on a lake near Boulder. Some of the birds had paired and kept near the shore where they were busy feeding, but the larger number were swimming about in the centre of the lake. These he subsequently watched performing a series of aerial evolutions under the leadership of one bird-up, around and zigzagging to and fro across the lake. He believed that these birds were preparing to go further north.

The eggs, usually four in number, are rather pyriform in shape; they are greenish or olive-brown, rather thickly spotted and blotched with sepia or blackish-brown, and measure $1 \cdot 10 \times 80$.

\section{Family RECURVIROSTRIDF.}

This small family comprises the Avocets and Stilts, characterized by their long legs and bills, which latter are either straight or up-turned; tarsus without scutes, covered with reticulate scales; toes three or four, semipalmate or nearly fully webbed.

\section{Genus RECURVIROSTRA.}

Bill long and pointed, much longer than the head, both mandibles flattened and up-curved towards the tips; legs long, the tarsus about twice the length of the middle toe and covered with reticulated scales all round; hind toe small but clawed, front toes about half-webbed.

A cosmopolitan genus of four species, only one of which is North American.

\section{American Avocet. Recurvirostra americana.}

A.O.U. Checklist no 225-Colorado Pecords-Aiken 72, p. 209 ; Coues 74, p. 460 ; Henshaw 75, p. 448; Drew 81, p. 18 ; Morrison 89, p. 167 ; Gross 91, p. 152; Cooke 97, pp. 18, 64, 199; Dille 03, p. 74; Henderson 03, p. 234; 09, p. 227 ; Markman 07, p. 156 ; Warren 09, p. 14. 
Description.-In summer-Head and neck all round pale cinnamon; paling to white on the front of the face and below behind the breast; lower-back and upper tail-coverts white; tail pearly-white; wings chiefly black with two longitudinal bands of white formed by the edges of some of the coverts, secondaries and outer scapulars; iris pink or brown, bill black, legs dull blue. Length 17.0; wing 9.0.; tail 3.0 ; culmen 3.7 ; tarsus 3.7 ; but dimensions varying considerably.

In winter the head and neck are pearly-grey. Young birds are like the summer adults, but have tawny edgings to the black feathers and a more or less straight bill.

Distribution.-Breeding chiefly from, Alberta and Manitoba to southwestern Texas ; in winter south as far as Guaternala, Cuba and Jamaica.

In Colorado the Avocet is common on migration, and is also an abundant summer resident in suitable localities, breeding along the shores of the alkali lakes, in the South Platte valley of the north-east plains, and in the mountain parks up to about 8,000 feet. It nests abundantly at San Luis Lakes, where it was noticed by Aiken, Goss and Cooke, and also along the Arkansas near Fort Lyon (Coues) and in South Park (Carter), while Gale and W. G. Smith took nests near Loveland, and Rockwell and Hersey at Barr. Other records are : Arkansas River (Aiken) and Coventry (Warren), where, as seems always the case on the western slope, it is not at all common. It is noted from Fort Lyon as early as March 28th, and from Loveland, April 9th, and in the fall at Salida by Frey, September 26th.

Habits.-The favourite resort of this Avocet are the alkaline lakes which are so abundant throughout the dry western districts of North America. Here it wades along in the shallow water, probing with its curiously shaped bill in the soft mud. It also swims with perfect ease and considerable grace, often alighting on the water from above. Where they have not been much molested they are not shy, and fill the air with their harsh cries when their breeding-places are being invaded.

The nests are placed near the shores of the lakes, and consist of a slight depression lined with a few grasses or weeds. The eggs, generally four in number, are somewhat pyriform in shape, and olive-drab heavily blotched with purplish-brown in colour. They measure about $1.90 \times 1 \cdot 30$, but vary considerably not only in 
dimensions but in colour and shape. Dille gives June 12th as an average date for fresh eggs; Henshaw at San Luis Lakes found by June 21st most of the eggs already hatched, but Goss took a clutch of four at the same place as late as July 5th.

\section{Genus HIMANTOPUS.}

Bill very long, slender and pointed, about twice as long as the middle toe and claw; tail short; legs very long, stretching far beyond the wings and tail; tarsus about three times the length of the middle toe and claw, covered with a fine network of hexagonal scales; hind toe absent, front toes moderate, basally webbed.

An almost cosmopolitan genus with about seven species; only one is found in North America.

\section{Black-necked Stilt. Himantopus mexicanus.}

A.O.U. Checklist no 226-Colorado Records-Henshaw 75, p. 450 ; Drew 81, p. 18 ; Morrison 89, p. 167 ; Cooke 97, p. 64 ; Henderson 03, p. 234 ; 09, p. 227 ; Rockwell 08, p. 159 ; Felger 09, p. 287 ; Hersey \& Rockwell 09, p. 115.

Description.-Adult female-Above, including the crown, sides of the face round the eye, back of the neck, centre of the back and wings, glossy black; below, including the front of the face, a spot above and behind the $ө y \theta$, rump and upper tail-coverts white; tail pearly-grey; iris red, bill black, legs red drying yellow. Length 14.0; wing 8.5; tail 2.4 ; culmen 2.3 ; tarsus 3.9 .

The male is rather larger--wing 9.25 ; culmen 2.70 . Young birds have the upper-parts ashy-brown, the feathers margined with buffy or whitish, and the tail with dusky markings.

Distribution.-Breeding chiefly from Mlinnesota and Oregon to Florida and Texas, south in winter as far as Peru and the West Indies.

The Stilt is apparently a rare bird in Colorado, except in the south. It was first found nesting in the State by Henshaw at the San Luis Lakes many years ago, and the only other definite notices of its occurrence are those of Rockwell, who quotes Miss Eggleston to the effect that it is an irregular and rather rare migrant at Grand Junction, and of Hersey and Rockwell who once saw it at Barr. Neither Gale, Carter nor G. W. Smith mentions it, nor does it appear to reach Wyoraing. Henderson's Boulder record seems a doubtful one, but ther $\theta$ is an example in the State Historical Society's Collection at Denver, shot near Fort Logan in April, 1899 (Felger). 
Habits.-Henshaw found the Stilt associating with the Avocet and closely resembling it in nearly every respect, except that it does not swim readily, though other observers state that it occasionally does take to deep water; as its toes are not webbed and its legs very long, this is as one would expect. Notwithstanding its long legs it is a graceful bird, and flies well and strongly, with head partially drawn back and its legs extended behind.

As already stated Henshaw found a single nest at the San Luis Lakes, June 21st; it resembled in every way that of the Avocet, and was merely a depression in the ground lined with grasses; it contained four eggs resembling those of the Avocet but smaller; they measured $1.74 \times 1.30$.

\section{Family SCOLOPACIDE.}

This is the most extensive family of the order and contains the Snipes and Sandpipers. The bill is long, nearly always exceeding the head, and is generally covered with soft, sensitive skin throughout, and never ends in the hard swelling or dertrum so characteristic of the Charadriidoe; it is straight or slightly up- or down-curved; nostrils exposed, generally near the base of the nasal groove, which extends for half or three-quarters the length of the bill; tail of twelve feathers (except Gallinago); tarsus always scutellate in front and, with the exception of Numenius, behind as well; four toes present except in Calidris; webbing variable.

\section{Genus PHILOHELA.}

Bill long, straight and slender, covered with a soft and sensitive skin and slightly swollen at the tip; culmen about twice the length of the tarsus; wings short and rounded, the three outer primaries attenuate and falcate and abruptly shorter than the fourth; tail short 
and rounded of twelve feathers; legs short; tibio-tarsus feathered almost to the joint, the tarsus scutellated in front and behind; hind toe present, front toes without web ; eye very large and placed far back, the ear-opening below and slightly in front of it.

This genus contains only one species, and is distinguished from that containing the Old World Woodcocks by the attenuation of the three outer primaries.

\section{American Woodcock. Philohela minor.}

A.O.U. Checklist no 228-Colorado Records-H. G. Smith 86, p. 283 ; 96, p. 65 ; Morrison 89, p. 167 ; Cooke 97, pp. 64, 158 ; Fisher 01, p. 447 ; Henderson 03, p. $234 ; 09$, p. 227.

Description.-Adult-Above mottled black, dusky brown and buffy; hinder-part of crown black with narrow transverse bars of buff; primaries plain dusky; below pale-rufous ; iris dark brown, bill light brown, paler at the base, legs reddish-brown. Length 10.5 ; wing 5.25 ; tail 2.25 ; culmen 2.5 ; tarsus 1.25 .

The female is larger-wing $5 \cdot 50$, culmen $2 \cdot 75$.

Distribution.--Southern Canada and the eastern United States from the Atlantic to Manitoba and eastern Texas, breoding throughout its range; wintering chiefly on the Atlantia and Gulf coasts.

In Colorado the Woodcock is only known from the Platte Valley and from Denver along the foothills northwards, where it may be regarded as a scarce summer resident. It was first reported by $\mathbf{H}$. G. Smith who saw an example in a gun-store in Denver, which was killed near the town about August 12th, 1885. Four or five additional specimens have been noticed from Denver or Boulder co., while Cooke reports that H. Horner observed a pair with three young ones, only about a week old, one of which was taken July 3rd, 1897, neer Timmath; so there can be litle doubt that, occasionally at any rate, it nests in Colorado.

Habits. - The Woodeock is a crepuscular bird, feeding chiefly at dusk and in the night, and keeping concealed during the day in thickets and rank grass. It inhabits marshy or moist country, and lives almost exclusively on worms which it draws out of the mud with its long and sensitive bill.

It has an enormous appetite-a Woodeock weighing six ounces is said to consume at least its own weight in earth-worms in twenty-four hours. Owing to its 
excellent flavour, it commands a high price as a gamebird, and has in consequence been nearly exterminated through the greater part of its range.

The nest, a loose structure of grass and old leaves, is placed on the ground in a higher part of the swamp, out of reach of the rising water. The eggs, usually four in number, are buffy, mottled and spotted with reddishbrown, and measure about $1^{\cdot} 60 \times 1^{\cdot} 16$. They lay very early in the south, but judging from our only record, June 10th would be about the date in Colorado.

\section{Genus GALLINAGO.}

Resembling Philohela in most respects, but the ear-opening little further back below the middle of the eje and without attenuated primaries; tail short, rounded, of sixteen feathers in the American species; markings on the head longitudinal rather than transverse.

A nearly cosmopolitan genus with some twenty species; only one in North America.

\section{Wilson's Snipe. Gallinago delicata.}

A.O.U Checklist no 230-Colorado Records-Aiken 72, p. 209 (G. wilsoni); Scott 79, p. 96 ; Drew 81 , p. 142 ; 85, p. 18 ; Thorne 83 , p. 46 ; R.V.R.S. 86, p. 5 ; Beckham 87, p. 121 ; Morrison 86, p. 107 ; 88 ,p. 139 ; 89, p. 167 ; Cooke 97 , pp. 64, 158, 199 ; Henderson 03, p. 234 ; 09, p. 227 ; Rockwell 08, p. 159 ; Warren 09, p. 14 ; Dille 09, p. 86.

Description.-Male-Above chiefly black, mottled and variegated with buffy and white; crown black with a median buffy stripe; primaries and their coverts dusky, the outer one white-edged; below, the breast speckled dusky and white, the abdomen pure white, the flanks and under wing-coverts barred black and white; tail-feathere sixteen in number, the outer ones barred with black; iris brown, bill brown, paler at the base, greenish-grey in the flesh; legs like the bill. Length 9.25 ; wing 4.80 ; tail 2.10 ; culmen 2.25 ; tarsus 1.25 .

The female is alightly larger-wing $5 \cdot 25$; culmen $2 \cdot 5$.

Distribution.-Breeding from Alaska and Newfoundland to the most south in winter as far as the West Indies and northern South America, northerly row of the States and a little further south in the mountains; though often wintering further north, even in Colorado and Wyoming.

The Snipe is far from uncommon in Colorado; it is perhaps most common on migration when it is found all over the State; it is also 
frequently to be met with during the winter where there are springs which remain unfrozen, both in the plains and the mountains up to 9,500 feet, at which elevation "R.V.R.S." saw two on the edge of the ice along the Animas River near Silverton, January 2nd, 1886.

It is perhaps less common in summer, but has been found breeding in the mountain parks up to about 9,500 feet. Dille has recently stated that it nests in the plains about ten miles north-east of Boulder, and Hersey and Rockwell found one nest, June 20th, 1908, at Barr. The following are other breeding records : Middle Park at 9,000 feet, Sprague (Cooke), Twin Lakes (Scott), San Luis Lakes (Aiken), and San. Juan co. (Drew). In winter it has been reported from Boulder, just outside the city limits, by Henderson; near Colorado Springs, where fairly common, by Aiken; Salida in January (Frey), Fort Lyon (Thorne), Sweetwater Lake by Gilmore and Routt co. by Bennet (Cooke), and Plateau Valley (Rockwell).

Habits.-The Snipe is an unsocial bird, and is nearly always found solitary or perhaps with only one companion. It prefers open, moist ground where it can probe in the mud with its long and soft, sensitive bill for worms, which form the greater part of its food.

When flushed it rises very suddenly, with a startled cry of "Scaipe," and flashes off with zigzag turns and twists. It is therefore a difficult bird to kill on the wing, and for the young gunner it is a moment of great satisfaction when he brings down his first Snipe.

Snipe are somewhat nocturnal in their habits, though not to such an extent as the Woodcock; still they feed and migrate chiefly at night or during thick weather. During the breeding season and occasionally in the fall as well, the Snipe rises high in the air and then darts down again with great velocity, at the same time making a curious vibrating rushing sound. The noise is usually known as "drumming" or "bleating." The explanation is rather doubtful, but it appears to be caused by the rapid vibration of the webs of the outer tail-feathers as they are drawn through the air. 
The nest is a mere depression in the grass, generally on or under a sheltering tuft; it is lined with a few leaves. The eggs, 3 to 4 in number, are somewhat pyriform in shape, and are olive to brownish with bold markings of dark umber and sharp, scratchy lines of black. They measure $1.55 \times 1 \cdot 15$. Scott's nest was found in June near Twin Lakes. There is no more definite information on the nesting-date for Colorado.

\section{Genus MACRORHAMPHUS.}

Bill and position of ear-opening Snipe-like, otherwise resembling a Sandpiper; wings rather long and pointed; tail of twelve feathers doubly emarginate; legs long, tarsus exceeding middle toe and claw ; tibia naked for about an inch above the joint; toes webbed basally, most fully between the middle and outer toe; tail-feathers barred.

The genus contains only one species, forming two subspecies. The western race, which is found in Colorado, is rather larger, has a longer bill, and is rather more highly coloured.

\section{Long-billed Dowitcher.}

\section{Macrorhamphus griseus scolopaceus.}

A.O.U. Checklist no 232-Colorado Records-Henshaw 75, p. 453 ; Allen \& Brewster 83, p. 197 ; Drew 85, p. 18 ; Morrison 89, p. 167 ; Cooke 97, pp. 19, 65; Hersey \& Rockwell 09, p. 115.

Description.-Female in summer-Above, except the rump and lowerback, speckled and mottled with black, brown and buff; a dusky stripe from the eye to the bill ; rump white, upper tail-coverts barred with black; tail barred black and white; below bright cinnamon, speckled on the throat, barred along the sides and on the under tailcoverts with dusky; iris hazel, bill and foet greenish-dusky. Length 11.0 ; wing 5.8 ; tail 2.5 ; culmen 2.8 ; tarsus 1.55 .

In winter there is no cinnamon and the bird is grey-brown above, the feathers edged paler, below grey on the neck and breast, paling to white on the abdomen, a white superciliery line to the bill and spot below the eye. The male is similar but smaller; wing 5.70; culmen $2 \cdot 45$.

Distribution.-Breoding from Alaska to British Columbia, south and south-east in winter to Floride and Central Mexico.

In Colorado the Dowitcher is only known as a migrant, and has been reported only from the plains portion of the State east of the Rocky 
Mountaine. It arrives from the south about the beginning of May, and has been noticed at Fort Lyon, May 2nd, by Thorne, near Colorado Springs (Allen \& Brewster), near Denver, where common in May (Henshaw), at Barr, where it is common on migration (Hersey \& Prockwell), and at Loveland, where it was seen by Smith, April 29th. A female in winter plumage, taken October 4th at Barr Lake by Warren, is preserved in the Colorado College Museum.

Henshaw's record of an example taken by himself at Denver, July $24 \mathrm{th}, 1873$, is obviously a mistake, as on that date, by his own account, he was far away in New Mexico, near Fort Wingate.

Habits. - The Dowitcher (i.e. Deutscher or German Snipe) is found about marshes and lagoons. It is usually met with in small flocks, but in other respects is not unlike the Snipe, except that it has slightly webbed toes and swims well.

\section{Genus MICROPALAMA.}

Bill long and slender, slightly widened at the tip; ear-opening normal, behind the eye; wings long and pointed; tail doubly emarginate; toes distinctly wobbed basally; resembling Macrorhamphas generally, but distinguished by its plain, unbarred tail, and the position of the ear-opening.

Only one species is known.

\section{Stilt Sandpiper. Micropalama himantopus.}

A.O.t. Chocklist no 233-Colorado Rocords-Thorne 87, p. 264 ; Morrison 89, p. 167 ; Osburn 93, p. 212 ; H. G. Smith 96, p. 65; Cooke, 97, pp. 19, 65, 199 ; Henderson 03, p. 234 ; 09, p. 227 ; Hersey \& Rockwell 09, p. 115.

Description.-Female in summer-Above mottled black, dusky, tawny and white; the primaries and most of the coverts plain dusky; the upper tail-coverts white, spotted with dusky; tail ashy-grey, edged and centred with white; ear-coverts chestnut; below white, streaked anteriorly, barred posteriorly, with dusky and tawny; iris brown, bill and feet dusky greenish. Length 8.5 ; wing 5.4 ; tail 2.0 ; culmen 1.65 ; tarsus 1.70 .

In winter the adults are ashy-grey above without black or tawny, but with white edges to the feathers; under-parts and a line orer the eye white, slightly suffused with dusky and finely stresked with darker on the throat and breast. The male is slightly smaller-wing $5 \cdot 0$; bill $1 \cdot 5$. 
Distribution.-A rare bird, breeding far north and only known to do so along the shores of the Arctic Ocean and in the Mackenzie Province; south in winter through the United States chiefly east of the Rocky Mountains, to the West Indies and South America as far as Peru and Brazil.

The Stilt-Sandpiper is a rare migrant in Colorado, and has been chiefly met with on the plains east of the range. It appears to arrive late from the south; the earliest date is May 14th, when Aiken took a female near Colorado Springs. The other records are: Fort Lyon, May 22nd, Loveland, May 20th, Middle and South Parks and Breckenridge (Carter), near Denver in the fall (Smith), Boulder co., record rather doubtful (Henderson), Barr, common on migration (Hersey \& Rockwell).

\section{Genus PISOBIA.}

Bill moderately long and slender, about equal to the tarsus ; wings long and pointed; outer primary usually the longest; tertials also lengthened and pointed; tail rather long and doubly emarginate; the two central tail-feathers usually projecting; tibia bare towards the joint; tarsus with transverse scutes before and behind; hind toe present, front toes long, slender and cleft to the base.

A large genus of highly migratory birds, breeding chiefly far north in both hemispheres, and wintering in the temperate and tropical zones. All the four regular North American species pass through Colorado.

\section{KEY OF THE SPECIES.}

A. Rump and upper tail-coverts black, at any rate centrally.

a. Larger; wing 5.4; breast dark ashy, and heavily streaked with dusky.

P. maculata, p. 113 .

b. Medium; wing 4.8 ; breast lightly suffused with ashy, streaking faint. P. bairdi, p. 115.

c. Smaller ; wing $3 \cdot 3$; chest spote heavier. P. minutilla, p. 115.

B. Rump dusky, upper tail-coverts white. P. fuscicollis, p. 114.

\section{Pectoral Sandpiper. Pisobia maculata.}

A.O.U. Cheoklist no 239-Colorado Records-Ridgway 73, p. 187 ; Drew 85, p. 18 ; Morrison 88, p. 139 ; 89, p. 167 ; Cooke 97, p. 65 ; Rockwell 08, p. 159 ; Hersey \& Rockwell 09, p. 115.

Description.-Adult in summer-Above black, the feathers edged with pale ochraceous-buff; rump and upper tail-coverta black, lightly tipped with buffy; middle tail-feathers lougest, pointed and margined 
rather larger and perhaps a little darker; more richly coloured on the back. Length $5 \cdot 10$; wing 3.3 ; tail 1.5 ; culmen .65 ; tarsus $\cdot 70$.

Distribution.-Breeding from Quebec to south Yukon northwards, south on migration through the greater part of the United States, to winter along the Gulf coast and in South America to Peru.

In Colorado a fairly common transient visitor in spring and autumn, arriving from the south in the second half of April, passing ehiefly through the plains and the mountain parks up to about 7,000 feet.

The following are records: Monon, May 2nd (Warren), Fort Lyon and Loveland, April 19th (Cooke), Colorado Springs and Lincoln co. (Aiken coll.), Barr (Hersey \& Rockwell) in the plains; Salida, April 28th (Colo. Coll. Mus.), South and Middle Parks (Carter) in the parks; Grand Junction, common in spring and fall (Rockwell) on the western slopes. Felger notes it as not uncommon through the summer at Barr, but has no evidence of its breeding.

Habits.-All the Sandpipers have very similar habits; they are mostly seen in small flocks running along patches of sand or mud by the sides of rivers or lakes; they are nervous and active, and when flushed fly off quickly with a little shrill "Peep, peep" of alarm.

\section{Genus PEIIDNA.}

Bill rather long and slender, slightly decurved, much longer than the tarsus, which slightly exceeds the middle toe and claw; in other respects like Pisobia; plumage with a white wing-bar and a black patch on the abdomen in the breeding season.

Only one circumpolar species; European and American birds are sufficiently distinct to form two subspecies.

\section{Red-backed Sandpiper. Pelidna alpina sakhalina.}

A.O.U. Checklist no 2438 -Colorado Records-Ridgway 73, p. 187 ; 79, p. 233; Morrison 89, p. 168 ; Cooke 97, pp. 19, 66.

Description.-Adult in summer-Above rufous with dusky centres and white tips to most of the feathers; wings and tail dusky ashy, the former with a white wing-bar and white edges to some of the secondaries; below white, a black patch covering most of the abdomen; fore-neck and chest streaked with dusky ; iris dark brown, bill and feet black. Length 8.25 ; wing 4.75 ; tail 2.0 ; culmen 1.6 ; tarsus 1.05 .

In winter the birds are plain ashy-grey above, generally with darker shaft-streaks; below white with the fore-neck and chest suffused with 
ashy and streaked. Young birds are very similar to the summer adults, but have the belly spotted with black, not with a continuous black patch.

Distribution.-Breeding chiefly on the Barren Grounds from Hudson Bay to northern Alaska and Siberia, migrating chiefly along the coaste to winter in south California, the Gulf and South Atlantic States.

A very rare migrant in Colorado, only twice recorded. There was an adult in winter dress in the Maxwell collection supposedly from Colorado, and W. G. Smith obtained two examples at Loveland, April 28th and May 9th.

\section{Genus EREUNETES.}

Bill about as long as the tarsus, rather stout for the family; toes baeally webbed and broadly margined; in other respects like Pisobia.

Two North American species closely allied to one another, comprise this genus. Both are recorded from Colorado.

a. Bill longer.

b. Bill shorter.
E. mauri, p. 118.

E. pusillus, p. 117 .

\section{Semipalmated Sandpiper. Ereunetes pusillus.}

A.O.U. Checklist no 246-Colorado Records-Henshaw 75, p. 454 ; Allen \& Brewster 83, p. 198 ; Beckham 85, p. 143; Morrison 89, p. 168 ; Cooke 97 , pp. 19, 66.

Description.-Adult in summer-Above, including the upper tailcoverts ashy-brown with dusky centres and some tawny edges; central tail-feathers and primaries plain dusky; below white with a few small dusky streaks on the lower-neck and chest; iris dark brown, bill and legs greenish-black. Length 5.5 ; wing 3.65 ; tail 1.5 ; culmen 80 ; tarsus $\cdot 75$.

In winter the upper-parts are nearly plain ashy-grey, and the spots on the breast faint or obsolete; young birds have a slight wash of buffy but no spots on the breast, and a good deal of white edging on the scapulars. It can be distinguished at once from $P$. minutilla, which it closely resembles in plumage by its basally-webbed toes.

Distribution.-Brөeding from Labrador and Hudson, Bay to northern Alaska, south through the United States east of the Rocky Mountains, to winter in the Gulf States, West Indies and eastern South America.

This little Sandpiper is not uncommon on migration in eastern Colorado, chiofly on the plaing but ranging up as high as the mountain parks; it has been noticed by Carter in South and Middle Parks. It reaches Colorado about the end of April or beginning of May, and has 
been seen at Fort Lyon, May lat (Thorne), near Pueblo, May 17th (Beckham), in El Paso co., May Ist (Allen \& Brewster), at Horse Creek, May 17th (Aiken coll.), and at Loveland, May 6th (W. G. Smith).

I have not heard of any fall records though it doubtless returns south through the State.

\section{Western Sandpiper. Ereunetes mauri.}

A.O.U. Checklist no 247.-Colorado Record-Cooke 97, p. 66 (E. occidentalis).

Description.-Closely resembling $E$. pusillus but with a much longer bill, averaging .88 in the male and 1.05 in the female, againat .72 and .84 respectively.

Distribution.-Breeding chiefly in western Arctic America; south on migtation mostly in the west but also on the Atlantic coast, in winter to Central and South America.

In Colorado this Sandpiper is of rare occurrence on migration. Cooke gives only three records: Loveland, May 12th and July 4th (Osburn), and near Pueblo in the fall (Lowe).

\section{Genus CALIDRIS.}

Bill moderate, about equal to the tarsus; resembling Pisobia in other respects, but with no hind toe; anterior toes cleft to the bese, without webs.

The genus contains only the Sanderling, cosmopolitan species.

\section{Sanderling. Calidris leucophcea.}

A.O.U. Checklist no 248-Colorado Records-Cooke 94, p. 183 ; (Calidris arenaria); ㅌ. G. Smith 96, p. 65 ; Cooke 97, pp. 66, 158 ; Hersej \& Rockwell 09, p. 115.

Description.-Adult in summer-Above mottled black, white and tawny-rufous; wings with the primsries dusky, paler on the inner web, and with white shafts, secondaries also with a good deal of white; rump and upper tail-coverts dusky centrally, white on the sides ; below white, the throat and breast sometimes slightly spotted with dusky and tawny; iris, bill and legs black. Length 7.5; wing 4.8 ; tail 2.0 ; culmen $\cdot 95$; tarsus $\cdot 95$.

Adults in winter have no tawny; upper-parts ashy-grey, generally with dusky shaft-stripes and lighter edges; under-parts pure white. In any plumage the absence of the hind toe at once distinguishes this from other Sandpipers.

Distribution.-Breeding far north; eggs have been taken on the Arctic Coast near Franklin Bay, in Mackenzie and in Greenland; on migration 
south along the coasts or across the continents to winter in South America, South Africa, South Asia and Australia, besides occurring as a wanderer in most of the islands of the three great ocerns. In America it chiefly winters along the cosst from Virginia and California to Chili and Patagonia.

In Colorado the Sanderling is a rare transient visitor in spring and autumn. It was first noticed from Colorado by Cooke, who reported an example in the Museum at Fort Collins, killed in the neighbourhood. Other instances are Horse Creek, May (Aiken coll.), Sloan's Lake, Denver, May (H. G. Smith), Barr, May 31st and in the fall (Hersey \& Rockwell), Loveland, September 24th and 30th and May 12th, Pueblo, October 1st (Cooke).

\section{Genus LIMOSA.}

Rather large birds-wing 7 to 9 ; with a long bill slightly upcurved, the culmen slightly exceeding the tarsus; wing long and pointed; tail short and even; legs long, tarsus far exceeding the middle toe, scutellete in front and behind; toes short, rather flattened, basally webbed, eөpecially between the inner and outer ones.

An almost cosmopolitan genus with two common North American species. The Black-tailed Hudsonian Godwit has not been met with in Colorado, though known from Kansas.

\section{Marbled Godwit. Limosa fedoa.}

A.O.U. Checklist no 249-Colorado Records-Henshaw 75, p. 457 ; Morrison 89, p. 168 ; Cooke 97, pp. 19, 66, 200; Hersey \& Rockwell 09 , p. 116.

Description.-Adult Male-General colour cinnamon, heavily barred and mottled with dusky above, the rump, tail-coverts and tail plainly barred rufous and dusky; below finely barred with dusky on the chest and sides, streaked on the throat, and white on the chin; primaries chiefly dusky, shaft of the outer one white; lining of the wings and axillaries chestnut ; iris dark brown, bill black on its terminal, reddishbrcwn on its basal, half; legs ashy-black. Length 17.5; wing 9.0; tail 3.3 ; culmen 2.9 ; tarsus 2.8 .

The female is rather larger-wing 9.5, culmen 4.5. There is no seasonal change, and the young birds are slightly paler and have the breast and sides unmarked.

Distribution.-Breeding chiefly in the upper Missouri Valley from Iowa to southern British Columbia, and migrating south in winter to Guatemala.

The Marbled Godwit is a rare bird in Colorado, and has not yet been found breeding; it is probably only a migrant. 
It passes through Colorado at the end of April, and has been noticed at Loveland, April 20th and May 1st, by W. G. Smith. It also ranges in to the mountains, since Carter observed it at Breckenridge. The only other definite records are: San Luis Lakes, where a single example was taken by Aiken, October 1st, 1874 (Henshaw), and Barr, where it has been noticed at various dates in May and July by Hersey and Rockwell.

\section{Genus TOTANUS.}

Bill long and slender and straight or nearly so, longer than the head, but the culmen shorter than the tarsus; the lateral grooves on the bill only extending for half its length; tail short, nearly even and barred; legs long, tibia nearly half their length; tarsus, which far exceeds the middle toe and claw, scutellated before and behind; hind toe present; web between the middle and outer toe fairly well developed, between middle and inner toe almost obsolete.

This genus, as restricted, contains four or five species breeding in the northern parts of the Old and New Worlds. The two North American species commonly met with both occur in Colorado.

\section{KEY OF THE SPECIES.}

A. Larger; wing 7 to 8 .

B. Smaller; wing 6 to 7 .
T. melanoleucus, p. 120 .

T. flavipes, p. 121 .

\section{Greater Yellow-legs. Totanus melanoleucus.}

A.O.U. Checklist no 254-Colorado Records-Allen 72, pp. 152, 159 ; Tresz 81, p. 244 ; Drew 85, p. 18 ; Morrison 89, p. 168; Cooke 97, pp. 18, 66, 200 ; Eenderson 03, p. 234 ; 09, p. 228 ; Rockwell 08, p. 159 ; Felger 09, p. 289.

Description.-Adult in summer-Above ashy-grey and dusky black, mottled with white, rather more atreakily marked on the head; upper tail-coverts white, sometimes with a few narrow bars of dusky, tail ashy to white barred with dusky; primaries plain dusky black, the shaft of the outer one white; below white streaked about the fore-neck and breast, barred on the sides and flanks with dusky; iris and bill brown, legs chrome-yellow. Length 13; wing 7.75; tail 2.75; culmen 2.20 ; tarsus $2 \cdot 60$.

The sexes are alike. In winter the birds are dark ashy-grey without black above and more white below, with fine ashy-grey streaks on the throat and upper-breast only.

Distribution.-Breeding apparently from Anticosti to British Columbia and south in the Missouri Valley to Iowa, but breeding records are very 
scarce; south on migration throughout the United States to winter along the Gulf Coast and south California, and thence to the Argentine and Chili.

The Greater Yellow-legs is a fairly common migrant throughout the State both in spring and autumn, in the plains and mountain parks; it has been noticed by Rockwell as high as 10,000 feet on the Grand Mesa. It reaches Loveland the first week in April from the south, and Rockwell saw one as early as March 28th, at Orchard. It has not yet been found nesting in the State, but there is no reason why it should not do so, and Felger has noticed it at Barr every month from March to October. Additional records are Boulder co. (Henderson), Palmer Lake, August 5th, and South Park (Allen), Middle Park (Carter), Wet Mountain Valley (Baker) and Fort Lyon, Thorne (Cooke).

Habits.-The Yellow-legs is in no way different from other Sandpipers in its habits ; it is found in small flocks or pairs, as a rule, along the shores of lakes or in marshy ground where it wades along the shallows in search of snails, worms, minnows and other aquatic animals which form its food. When disturbed it rises with a loud whistling cry, often wheeling round and circling back again to the same spot.

The nest is usually placed on the ground near a marsh and constructed chiefly of grasses. The eggs, four in number, are greyish-white, spotted or blotched with dark brown, and measure about $1.75 \times 1.31$.

\section{Yellow-legs. Totanus flavipes.}

A.0.U. Checklist no 255-Colorado Records-Allen 72, p. 152 ; Drew 85, p. 18 ; Beckham 85, p. 143 ; Morrison 89, p. 168 ; Cooke 97, pp. 18, 66, 200 ; Henderson 03, p. 234 ; 09, p. 228 ; Rockwell 08, p. 159 ; Hersey \& Rockwell 09, p. 116.

Description.-Closely resembling $T$. melanoleucus in plumage but very decidedly smeller in all dimensions. Length 9.25 ; wing 6.50 ; tail 2.4 ; culmen 1.4 ; tarsus 2.1 .

Distribution.-Breeding far north on Hudson Bay and the Barren Grounds; south on migration, most abundantly through the eastern United States, and wintering from the Gulf States to Patagonia. Occasionally in Europe.

The Yellow-legs is only known as a migrant in Colorado; in its movements and dates it follows closely the Greater Yellow-legs, in the 
company of which it is frequently found. It comes back early from the north-in fact it was taken on July 23 rd by Thorne at Fort Lyon, and may possibly have been breeding there. Other records are: Pueblo, May 8th (Beckham), El Paso co., May 7th (Aiken coll)., Barr Lake where very common, and observed through May, June and July, but not known to breeed (Hersey \& Rockwell); Loveland, April 15th (W. G. Smith), while Carter noticed it in Middle and South Parks, and Rockwell on the Grand Mess, at 10,000 feet, in the mountaine.

\section{Genus HELODROMAS.}

Bill moderate, slightly exceeding the head; tarsus short, slightly exceeding the middle toe and claw, approximately equal to the culmen; resembling Totanus in most respects, but the sternum with only one notch instead of two posteriorly, and laying its eggs in trees in the deserted nests of other birds.

This genus contains one Old World and one Now World species, the latter separated into an eastern and western race. The western one is characterized by its larger size and greyer wings.

\section{Western Solitary Sandpiper.}

\section{Helodromas solitarius cinnamomeus.}

A.O.U. Checklist no 256a-Colorado Records-Allen 72, pp. 152, 159 ; Henshaw 75, p. 459; Tresz 81, p. 244 ; Allen \& Brewster 83, p. 198 ; Drew 85, p. 18 ; Morrison 89,p. 168 ; Cooke 97,pp. 18, 67, 200 ; Henderson, 03, p. 107 ; 09, p. 228; Rockwell 08, p. 160 ; Cary 09, p. 180 ; Hersey \& Rockwell 09, p. 116.

Description.-Adult-Above dark olive-brown, streaked on the head, speckled elsewhere with white; primaries and edge of the wing rather darker, almost black; central tail-feathers and their coverts like the back with a few white spots at the edges; laterel tail-feathers and their coverts white, barred with black; below white, the throst and breast streaked, the sides and under wing-coverts closely barred with dusky ; iris brown, bill and legs dusky-greenish. Length 8.5 ; wing $5 \cdot 15$; tail 2.0 ; culmen 1.3 ; tarsus 1.25 .

The sexes are alike; there is but little seasonal chenge, but the tone is more ashy and there is less white speckling above in winter. Young birds have distinct cinnamon spots above instead of white.

Distribution.-Western North America, breeding in northern Alberta and probably south to Colorado and Utah, wintering in California and probable south to Peru. 


\section{Western Solitary Sandpiper}

In Colorado this Sandpiper is a fairly common transient visitor, while some birds stay through the summer and probably breed, though egge have not been taken in the State.

It reaches Coloredo about the last week in April, and is most common in the plains though noticed as high as Breckenridge by Carter, and at Pennsylvania Lake at 8,500 feet, August 27th, by Felger (Henderson). Summer and possibly breeding records are : Grand Junction, June 22nd, (Rockwell), near Kremmling, July 13th (Cary), Pueblo, July 27th (Henshaw), South Park, July, and Palmer Lake, Augus (Allen) ; while on migration it has been taken at Salida, April 25th (Colo. Coll. Mus.), El Paso co., May lst (Allen \& Brewster), Barr Lake in the fall (Hersey \& Rockwell), and Loveland, April 20th (W. G. Smith).

Habits.-The solitary Sandpiper is fond of quiet ponds among the mountains surrounded by forest, and is then rather solitary in its habits, but during migration it is often seen in flocks. It wades with graceful movements along the shallows in search of mollusca, insects and worms, for which it probes with its bill. It is somewhat silent, differing in this respect from the Yellow-legs or Tatlers.

It has only quite recently been discovered ("Tbis," 05 , p. 158) that they make use of the nests of other birds in which to lay their eggs. Evan Tompson, a collector employed by Walter Raine, took three clutches in June, 1903 and 1904, in northern Alberta; they were found in the nest of an American Robin, a Bronzed Grackle, and a Cedar Bird respectively. In each case the elutch was four, and the eggs, which averaged $1.36 \times \cdot 98$, were pale greenish-white, spotted and blotched with shades of brown and purple. In this matter the Solitary Sandpiper follows the Green Sandpiper of Europe. Further search will probably result in the discovery of eggs in Colorado.

\section{Genus CATOPTROPHORUS.}

Large birds - wing 8 to 9 - with the general characteristics of Totanus; bill longer than the head, culmen about equal to the tarsus; 
legs moderate, but tarsus clearly exceeding middle toe and claw; webbing between the toes more extensive; base of the tail and a patch on the wing white.

One species confined to America with an eastern and western race, the latter averaging larger and paler.

\section{Western Willet.}

\section{Catoptrophorus semipalmatus inornatus.}

A.O.U. Checklist no 258a-Colorado Records-Ridgway 73, p. 187; Henshaw 75, p. 457; Allen \& Brewster 83, p. 198 ; Drew 85, p. 18 ; Morrison 88 , p. 139 ; 89, p. 168 ; Cooke 97, pp. 19, 67, 200; Warren 06, p. 19 ; Hersey \& Rockwell 09, p. 116.

Description.-In summer-Above ashy-grey, streaked with dusky to a varying degree, chiefly along the centres of the feathers; upper tail-coverts white, some of the longer ones barred with dusky ; primaries dusky, white on the basal half, making a conspicuous white wing-patch ; most of the secondaries white; below white, fore-neck spotted, breast and sides marked with transverse bars of dusky, often a little pale rufous as well; iris brown, bill dusky, legs bluish. Length 14.5; wing 8.75 ; tail 3.2 ; culmen 2.5 ; tarsus 2.6 .

In winter the birds are nearly uniform ashy above, and white below, shaded on the fore-neck with greyish. Young birds are darker and more brown above, the feathers edged with ochraceous.

Distribution.-Breeding from Manitoba and Alberta south to Texas, west of the Mississippi ; in winter further south into Mexico.

The Willet is fairly common in Colorado on migration, while a certain number of birds are said to remain to breed, both in the plains and mountains up to 12,000 feet (Morrison), though I have not been able to find any definite account of the nest and eggs being taken in the State.

It arrives from the south about the first week in May and has been noticed at Monon, April 28th (Warren), Fort Lyon, May 2nd (Thorne), near Colorado Springs, May 1-7th (Aiken coll), Denver, May 10th (Henshaw), Barr, common in spring (Hersey \& Rockwell), and Loveland, April 27th, May 5th (W. G. Smith)-in the plains-and at Crested Butte, May (Warren), and Breckenridge (Carter)-in the mountains. Morrison found it common near Fort Lewis in September, and Aiken procured a bird of the year, August 29th, close to Leadville.

Habits.-This large and conspicuous bird is found about marshes and lakes, where it obtains its food among the stones and weeds. It is very restless and noisy, especially when its breeding-places are invaded. 
Nests, according to Goss who found this bird breeding at Lake Como, Wyo, are placed in tussocks of grass, near the water's edge, and are bulky structures; the eggs are usually four, somewhat pyriform in shape, buffy to greyish-white in colour, spotted and blotched with brown and purplish; they average $2.10 \times 1.55$. They doubtless nest in Colorado, though nothing is known of their doing so.

\section{Genus BARTRAMIA.}

Of moderate size-wing 6 to 7 ; bill short and slender, about equal to the head, but distinctly shorter than the tarsus; tail long, about half the wing, strongly graduated; tarsus scutellated, exceeding the middle toe and claw; outer toe webbed, inner one cleft; plumage highly variegated, tail barred.

One species only ; accidental in Europe.

\section{Upland Plover, or Bartramian Sandpiper. Bartramia longicauda.}

A.O.U. Checklist no 261-Colorado Records-Allen 72, p. 152 ; Allen \& Brewster 83, p. 198 ; Drew 85, p. 18 ; Morrison 89, p. 168 ; Cooke 97, p. 67 ; Rockwell 08, p. 160 ; Cary 09, p. 180 ; Hersey \& Rockwell 09, p. 116.

Description.-Above dusky black, variegated with tawny edges to the feathers, especially on the middle of the back and wings; rump and upper tail-coverts plain dusky, central tail-feathers brown banded with darker, lateral ones tawny-brown with irregular bars of dusky and white tips, primaries plain dusky barred with white on the inner web; below soiled white, the fore-neck, breast and sides marked with streaks of dusky, becoming bars posteriorly; axillaries and under wing-coverts transversely barred with dusky; iris dark brown, bill yellowish with dusky tips, legs dull yellow. Length 11.0 ; wing 6.4; tail 3.0 ; culmen 1.15 ; tarsus 1.85 .

There is no seasonal change of plumage, and the young are very similar to the adults.

Distribution.-Breeding from Yukon and Ontario south to Utah, Kansas and Virginia; wintering far south, chiefly in South America on the Argentine plains. Accidental in Europe.

In Colorado this Sandpiper does not appear to be well known, though it is probably a common summer resident on the eastern plains of the State. It does not occur in the mountains or foothills. On the western 
slope Rockwell observed a single bird on a sage-brush flat in the Plateau Valley at about 6,800 fe日t, in Mesa co., while Cary heard and saw a good many individuals on migration near Lay and Meeker in August. Messra. Allen and Brewster noted a good many specimens brought into market in Colorado Springs, April 28th. This is the only dated record for its arrival in the spring. Hersey and Rockwell found a nest with fresh eggs, June 28th, 1907, near Barr, where it is not uncommon.

Habits.-The Bartramian Sandpiper, or Upland Plover as it is more frequently known, although a wader by structure, prefers the dry upland prairies and cultivated fields. It lives chiefly on grasshoppers and also eats berries, and is consequently very fat and delicate and a much esteemed bird for the table.

The nest, according to Goss, is placed on the open prairies in a depression or sheltered by a tuft of grass, and is lightly constructed and difficult to find. The eggs, four in number, are greyish-white to pale buff, spotted all over, chiefly at the larger end, with various shades of brown. They are somewhat pyriform in shape and measure $1.75 \times 1.27$.

\section{Genus ACTITIS.}

Small Sandpipers, wing under 4.5 ; bill, head, tarsus and middle toe with claw, all about equal; tail rather long, about half the length of the wing; outer toe basally webbed, inner one cleft; no white on the rump or central tail-feathers; spotted below.

One Old World and one New World species only.

\section{Spotted Sandpiper. Actitis macularia.}

A.O.U. Checklist no 263-Colorado Records-Allen 72, pp. 152, 159, 164 ; Aiken 72, p. 210 ; Coues \& Trippe 74, p. 501 ; Drew 81, p. 142 ; 85 p. 18 ; Tresz 81, p. 245 ; Allen \& Brewster 83, p. 198 ; Beckham 85 , p. 18 ; Morrison 88, p. 140 ; 89, p. 168 ; Kellogg 90, p. 86 ; Low $\theta$ 92, p. 101 ; McGregor 97, p. 38 ; Cooke 97, pp. 18, 67, 200 ; Henderson 03, p. 234 ; Warren 06, p. 19 ; 08, p. 20; 09, p. 14 ; Markman 07, p. 156 ; Rockwell 08,p. I60; Hersey \& Rockwell 09, p. 116.

Description.-Female in summer-Above bronzy-brown, lightly streaked on the head, cross-barred on the back and wings with dusky; 
primaries dusky; secondaries and their coverts white tipped, both the former with white bars; lateral tail-feathers with white; stripe over the eye and under-parts white, the latter with large rounded dusky spots; axillaries and under wing-coverts white with a brown bar across the latter; iris dark brown, bill waxy-yellow, black at the tip and along the culmen, legs olive-grey. Length 6.75 ; wing 4.1 ; tail 2.0 ; culmen .95 ; tarsus .90 .

The male is alightly smaller, and the black spots not so numerous; in winter the spots are absent and the breast is washed with grey, and the back is less glossy.

Distribution.-Breeding from Alaska and Labrador south over the greater portion of the United States; wintering in the southern United States and south to Brazil.

In Colorado the Spotted Sandpiper, with the exception of the Killdeer Plover, is the commonest wader; it ranges from the plains quite to the timber line, wherever there is a small pool or stream suitable to its wants, and nests everywhere though perhaps most abundantly at the higher elevations. It arrives from the south at the end of April or the first week in May and leaves again in September, though some remain a good deal later into the cold weather. Breeding records are : Boulder co. 10,000 to 11,000 feet (Gale), Barr (Hersey \& Rockwell), Breckenridge (Carter), Montgomery (Allen), Selida, arriving May 5th and breeding (Frey), Lily (Warren 08), Mesa co. (Rockwell), San Juan co. (Drew), La Plate co., up to 13,000 feet (Morrison).

Habits.-This Sandpiper is often known as the "Peetweet" from its note, or the "Teeter" or "Titups" from its way of balancing itself on its legs and elevating and depressing its tail with clockwork regularity; it is rather solitary in its habits, and more than two are seldom found in one spot. Its flight is also rather striking, the wings appearing to be turned downwards all the time as it skims along the mud flat.

The nest is placed on the ground in a slight depression near a lake or stream; it consists only of a few blades of dry grass, slightly put together. The eggs, nearly always four in number, are rather pointed in shape and creamy or olive-drab in colour, spotted and blotched with brown and purplish; they average $1.30 \times 1.0$. Gale found fresh eggs between June 10th and 20th, 
at elevations of 10,000 to 11,000 feet near Gold Hill; Warren's nest and eggs were taken June 30th, while Allen's nest at 12,000 feet was found as late as July 24 th.

\section{Genus NUMENIUS.}

Bill long, sometimes abnormally so, slender, down-curved and arched, the tip of the upper mandible slightly knobbed and projecting beyond the lower; legs stout, tarsus covered in front with transverse scutes, elsewhere with reticulate scales; hind toe well developed, a basal web between the anterior toes best developed between the middle and outer.

A cosmopolitan genus of about nine species, three of which are common in North America. The smallest of these, the Eskimo Curlew (Numenius boredilis), is not yet known from Colorado, but should be looked for as it is quite common on spring migration in Kansas. It is included in the key.

\section{Key of the Spectes.}

A. Large - wing 10 to 12 , bill 4 to 8 ; primaries varied with rufous. N. americanus, p. 128 .

B. Yedium-wing 9 to 10 , bill 3 to 4 ; primaries varied with rufous or whitish.

N. hudsonicus, p. 129.

C. Small_wing under 9 , bill 2 to 2.5 ; primaries without rufous.

N. borealis.

\section{Long-billed Curlew. Numenius americanus.}

A.O.U. Checklist no 264-Coloredo Records-Say 23, vol. ii., p. 4 ; Aiken 72, p. 210 (N. longirostris); Henshaw 75, p. 461 ; Morrison 89, p. 168 ; Lowe 92, p. 101 ; Cooke 97, pp. 18, 67, 200 ; Henderson 03, p. 235 ; 09, p. 228 ; Warren 06, p. 19 ; 09, p. 14 ; Rockwell 08, p. 160 ; Felger 09, p. 290.

Description.-Adult-General colour above pale tawny rufous, mingled with dusky black; streaky on the head and neck, more barred on the back; primaries plain dusky on the outside web, barred with rufous on the inside; below pale tawny with narrow dusky streaks on the fore-neck and chest, becoming nearly white on the throat; bill black, paler on the Iower mandible; legs dark bluish-grey. Length of a male 20 ; wing 11.0 ; tail 3.9 ; culmen 5.6 ; tarsus 3.0 . The bill of a female taken the same day measures 7.5. There is little seasonal or sexual variation in the plumage, but the intensity of the rufous and the length of the bill varies a good deal with individuals. Coues states the bill varies from four to eight inches in extreme cases. 
Distribution.-Breeding from British Columbia and Alberta south to Arizona and Oklahoma, but chiefly in the prairie states; wintering in the Gulf States and south to Guatemala. It is rare and only a migrant in the North Atlantic States.

In Colorado this Curlew is a fairly common summer resident chiefly on the prairie portion of the State though mounting up into the parks to about 7,500 feet. It arrives from the south about the middle of April ; Salida, April 29th (Frey), Loveland, April 10th to 15th (W. H. Smith). It has been noticed in Baca co. (Warren), near Pueblo (Lowe), Fremont co. (Aiken coll.), Boulder co., breeding (Gale), Middle and South Parks, breeding (Carter), and is stated to be abundant near Fort Lewis by Morrison, while Rockwell believes that it is rare in Mesa co., whence he has only one record : Plateau $\nabla$ alley, 6,500 feet, in the spring of 1905 ; Felger states that it is common summer resident about Barr Lake.

Habits.-The Curlew is as of ten found on the dry upland prairies as in marshy places near water; its food consists chiefly of worms, small mollusca, and insect larvæ, and it probes for these with its long bill where the ground is soft enough. It has a loud whistling note, and if disturbed on its breeding-grounds, its harsh cries of alarm resound.

Gale found nests on several occasions near Gold Hill. He gives May lst to 15 th as the date for fresh eggs. The nest is only a slight depression in a dry meadow bottom, and is lined scantily with a few blades of grass. The eggs, usually four in number, are rather ovate and not so pyriform as those of other waders. They are buffy to olive-drab, blotched and spotted with several shades of brown, and average $2.85 \times 1.85$.

\section{Hudsonian Curlew. Numenius hudsonicus.}

A.O.U. Checklist no 265-Colorado Records-Beckham 85, p. 143; Thorne 87, p. 264 ; Morrison 89, p. 181 ; Cooke 97, p. 67 ; Hersey \& Rockwell 09, p. 116.

Description.-Resembling $N$. americanus, but decidedly smaller and with a shorter bill ; top of the head more or less uniform blackishbrown with a median and two lateral stripes of whitish; general colour 
paler rufous than in $N$. americanus, but with the inner webs of the primaries marbled with paler. Length 18 ; wing 10.0 ; tail 3.75 ; culmen 3.6 ; tarsus 2.7 .

A mounted example in the Aiken collection taken in the fall does not show the median pale stripe on the crown very clearly; it is probably a bird of the year.

Distribution.--Breeding chiefly far north in the Barren Grounds from Hudson Bay to northern Alaska, south on migration to winter in the Gulf states and Lower California and through the West Indies and Mexico as far as Brazil and Chili.

The Hudsonian Curlew is a rare migrant in Colorado, hitherto only recorded on one or two occasions from the plains east of the mountains. Beckham first reported an example which he examined, and which was said to have been shot near Pueblo. Thorne, and subsequently Morrison, noticed it near Fort Lyon on April 30th, 1885, and in early May, 1888, respectively. Hersey and Rockwell report it as rare in the fall migration at Barr. There is a single example in the Aiken collection, taken September 23rd, 1900, near Colorado Springs.

\section{Family CHARADRIID压.}

A large family containing the Plovers and their allies, in which the bill never exceeds the length of the head and is generally shorter; it ends in a characteristic convex, horny terminal portion-the dertrum; tarsus reticulate without scutes; toes, except in Squatarola, always three in number; webbing between the toes variable. (For key of genera, see p. 100.)

\section{Genus SQUATAROLA.}

Resembling in every respect Charadrius, but with a small and distinct hind toe, contrary to the general rule in the family.

This genus contains only the Grey or Black-bellied Plover, a bird of wide distribution in both hemispheres.

\section{Black-bellied Plover. Squatarola squatarola.}

A.O.U. Checklist no 270-Colorado Records-Ridgway 79, p. 232 ; H. G. Smith 86, p. 285 ; 96, p. 65 ; Morrison 89, p. 181 ; Cooke 94, p. $183 ; 97$, pp. $68,201$.

Description.-In summer-Above mottled blackish and ashy-white; upper tail-coverts chiefly white; tail barred black and white ; primaries dusky with white on the inner webs; forehead, line over the eye and 
down the sides of the neck, wing linings and under tail-coverts, white; rest of the lower parts from the chin to the abdomen, including the axillaries, black; iris brown, bill and legs black. Length 9.75 ; wing 7.25 ; tail 2.5 ; culmen 1.1 ; tarsus 1.75 . A minute hind toe present measuring $\cdot 1$.

In winter, and as generally seen in Colorado, the upper-parts are speckled dark brown and white, with a few spots of tawny; and below white, washed with grey and slightly striped with dusky on the foreneck and breast; the axillaries, however, always black; iris brown, bill black, legs dark bluish.

Distribution.-Breeding far north beyond the Arctic circle in both hemispheres, south in winter chiefly along the sea coasts in America as far as Peru and Brazil.

This Plover is rather a rare migrant through Colorado, and has generally been noticed in the fall on its way south. H. G. Smith reported two from near Denver, one a young male killed October 22nd, 1888. Cooke shot one near Fort Collins, October 28th, and W. G. Smith noticed it at Loveland. There is an example from Barr in the Museum at Denver, and one from near Colorado Springs in the Aiken collection. All the records hitherto are from the plains east of the mountains.

\section{Genus CHARADRIUS.}

Bill moderate, about as long as the middle toe and claw, tip swollen forming a "dertrum"; wings long and pointed, the outer primary clearly the longest; tail short, slightly rounded, less than half the length of the wing; tarsus and bare part of the tibis with reticulate scaling throughout; basal web between the middle and outer toes; hind toe absent.

There are several species of Golden Plovers, but only one commonly occurs in North America.

\section{American Golden Plover. Charadrius dominicus.}

A.O.U. Checklist no 272--Colorado Records-Ridgway 73, p. 187 (C.pluvialis virginicus); Morrison 89, p. 181 ; Cooke 97, p. 68; Hersey \& Rockwell 09, p. 116.

Description. - Summer-Above blackish, spangled with golden-yellow and white; below, including the base of the bill and sides of the face to the eyes, black, bordered above by white; tail barred brown and grey; wings dusky, paler at base; lining of wings and axillaries ashygrey ; iris dark brown, bill black, legs dusky. Longth 10 ; wing 7.0; tail 2.5 ; culmen $\cdot 85$; tarsus $1 \cdot 7$. 
In winter and juvenal plumage very similar to the ebove, but with less yellow; below whitish, streaked and mottled on the sides of the neck and body and on the breast with dusky, but the axillaries always ashy-grey.

Distribution.-Breeding chiefly on the Barren Grounds from Hudson Bay to northern Alaska, south in winter to the Argentine Pampas, passing mostly down the Atlantic coast and Mississippi Valley.

There is very little information about the occurrence of the American Golden Plover in Colorado. Ridgway included it in his list of Colorado birds, and Cooke states that a few pass in the spring and fall over the plains of Colorado below 5,000 feet. Hersey and Rockwell find that it is not uncommon at Barr during migration. There is no Colorado example in the Aiken collection.

\section{Genus OXYECHUS.}

Bill rather slender; tail long, at least half the length of the wing graduated an inch or more; plumage with two black bands across the chest.

One American species.

\section{Killdeer. Oxyechus vociferus.}

A.O.U. Checklist no 273-Colorado Records-Allen 72, pp 152, 159 ; Aiken 72, p. 209 ; Scott 79, p. 96 ; Tresz 81, p. 243 ; Drew 81, p. 142 ; 85, p. 15 ; Nash 83, p. 225 ; Allen \& Brewster 83, p. 197 ; Beckham 85 , p. 143 ; 87 , p. 124 ; Morrison 88, p. 139 ; 89, p. 181 ; Lowe 92 , p. 101 ; McGregor 97, p. 38 ; Cooke 97, pp. 18, 68, 201 ; Dille 03, p. 74 ; Henderson 03, p. 234; 09, p. 228 ; Warren 06, p. $19 ; 08$, p. 20 ; 09 , p. 14 ; Markman 07, p. 156 ; Rockwell 08, p. 160 ; Hersey \& Rockwoll $09, \mathrm{p}, 116$.

Description.-Adult-Above brown, with an olive tinge, a white frontal band running back through the eye, bordered above by black; a white collar also bordored by black; rump and upper tail-coverts rufous; wings dusky with a good deal of white on the secondaries and coverts; tail dusky, rufous and white; below white, with two black bands across the chest; iris brown, eyelids orange-red or scarlet, bill black, legs pale flesh. Length 9.5 ; wing 6.4 ; tail 3.75 ; culmen 8 ; targus $1 \cdot 3$.

The sexes are alike; young birds are rather duller above, and the feather's margined with rusty and the black bands are greyish.

Distribution.-Breeding throughout temperate North America from British Columbia and Ontario southwards; wintering in the Gulf States and southern California south to northern South America. 
The Killdeer is perhaps the commonest of all the waders in Colorado ; it is a summer resident, arriving from the south early in March and breeding throughout the State, from the plains to about 10,000 feet, between April and June. It leaves again for the south late in October.

Breoding records are: Barr (Hersey \& Rockwell), El. Paso co. (Aiken) and Bece co. (Warren), in the plains; Breckenridge (Carter) and Twin Lakes (Scott), in the mountains; Mesa co. (Rockwell) and La Plata co. (Morrison), on the western slope. H. G. Smith informed Henderson that he saw three just east of Boulder, December 3lst, 1904; possibly a fow individuals winter in the State.

Habits.-This little Plover, which gets its common name from its shrill two-syllabled whistle, is commonly found in Colorado, not only near water but in high, dry prairies and mesas. It is not specially gregarious, and is generally met with in pairs, except at migration time. As a rule it is not very shy and is easily approached, while it is bold and most demonstrative in defence of its young.

It makes its nest on the ground, very generally near water on the sand, but at other times in meadows or cultivated fields and even in quite dry, high places. The nest, a poor affair of a few twigs is arranged in a depression. The eggs, almost always four in number, are buffy or drab, with spots and heavy blotches of dark purplish or blackish-brown, most numerous at the larger end. In shape they are very pyriform and pointed, and they average $1.5 \times 1.05$. The nesting time appears to extend over a long period in Colorado. Gale found eggs exceptionally early in April, and gives as an average date, April 20th to May 20th; an egg in the Colorado College Museum, presented by I. C. Hall, was taken so late as June 24th, near Greeley, and is stated to have been fresh and unincubated. Possibly two broods are raised. Both parents share in the labours of incubation. 


\section{Genus 瓜GIALITIS.}

Bill of varying size; tail never reaching half the length of the wing, hardly graduated; webbing of toes rather variable; with only one, or an incomplete, black bar across the chest.

A considerable genus of wide distribution; three species and one subspecies are common in the United States, and two of these, Aw. meloda circumcincta (the Belted Piping Plover), and AE. nivosa (the Snowy Plover), should occur in Colorado. The former is a common bird of the Mississippi Valley and has been taken at Cheyenne, and is recorded by Dawson (99) from Julesburg; it is well known in Nebraska. The latter is common in Utah, and was found nesting by Goss in south-west Kansas. Both are included in the key.

\section{Key to the Speches.}

A. Inner and outer toes webbed to the second joint; bill short, black and orange in colour.

E. semipalmata.

B. Web only between the middle and inner toe to the first joint. a. Bill short and stubby, black and orange; a narrow black collar across the fore-neck. $\quad$ E. circumcincta.

b. Bill slender and black, no collar, merely a patch of dusky on either side of chest.

E. nivosa.

\section{Semipalmated Plover. Asgialitis semipalmata.}

A.O.U. Checklist no 274-Colorado Record-Cooke 97, pp. 68, 201.

Description.-Adult-Above brownish-grey, below pure white; a black ring round the fore-neck, bordered above by a white half-collar on the back of the neck continuous with the white throat below; front of the face black, with a white patch across the forehead; wing chiefly dusky, with white on the secondaries and coverts; tail mostly whitetipped, outer-feathers nearly all white; iris hazel, eyelids bright orange, bill black, orange at base ; legs pale flesh. Length 7.10 ; wing 4.75 ; tail 2.3 ; culmen .52 ; tarsus .95 ; toes webbed to the second joint.

In winter the black on the head and neck is replaced by the brown of the back; young birds have the feathers of the upper-parts edged with buffy.

Distribution.-Breeding chiefly from Labrador to Alaska; south in winter to the Gulf coast and southern California, and thence to the West Indies, Chile and Patagonia.

The Semipalmated Plover is a rare straggler on migration in Colorado. It was obtained at Loveland by H. G. Smith, May 6th, 1890, and at Grand Lake, Middle Park, in the fall by Carter. There is an example 
at the Colorado Museum of Natural History at Denver, taken by Hersey at Barr in the spring, where it is rare.

\section{Genus PODASOCYS.}

Resembling Algialitis, but without black bands or patches on the breast; tail short, less than half the wing, square; tarsus long, about half as long again as the middle toe and claw; toes very short, the outer one basally webbed.

This genus contains only one species.

\section{Mountain Plover. Podasocys montana.}

A.O.U. Checklist no 281-Colorado Records-Allen 72, pp. 152, 159 ; Aiken 72, p. 209 ; Coues 74, p. 456; Henshaw 75, p. 447; Tresz 81, p. 244 ; Allen \& Brewster 83, p. 197 ; Drew 85, p. 18 ; Beckham 85, p. 143 ; Dille 86, p. 29 ; 03, p. 74 ; W. G. Smith 88, p. 187 ; Morrison 89, p. 181 ; Cooke 97, pp. 18, 68, 201 ; Warren 06, p. 19 ; 10, p. 30 ; Markman 07, p. 156 ; Henderson 09, p. 228 ; Hersey \& Rockwell 09, p. 116.

Description.-Male-Above pale brown, feathers edged to a varying extent with rusty or yellowish; a bleck band across the front of the crown of varying width and purity; wings dusky, white on the shafts and on the bases of some of the inner quills; tail dusky, paler on the outer feathers, edged with white; frontal band and lower-parts white, a black stripe from the eye to the base of the bill and a rather faint grey or tawny band across the chest, but no black; iris brown, bill black, legs pale brown. Length 8.0 ; wing 5.9 ; tail 2.4 ; culmen .9 ; tarsus 1.6. The sexes are alike; in winter there is no black crown or loreal bands, and the rusty or buff is more evident.

Distribution.-Western North America, from Dakota and Texas westwards, hardly north of the United States boundary; wintering from Texas and northern California to central Mexico.

The Mountain Plover, in contradistinction to its name, is a common summer resident on the eastern plains of Colorado, though extending up into the parks to about 8,000 feet. It is fairly abundant in the San Luis Valley (Henshaw), where Warren also saw a female with two half-grown young on July 19th ; South Park (Tresz) and Middle Park (Coues). It arrives from the south about the middle of April, though noticed as early as March 26th at Fort Lyons and March 18th at Loveland, and returns south late in October. It has been reported in addition from Greeley (Dille), from Barr, where it is very common on dry prairie (Hersey \& Rockwell), from El Paso, Lincoln and Huerfano cos. (Aiken coll.), from Fort Lyon, eggs June 9 (Thorne), and from Baca co. (Warren). I have not heard of it anywhere on the western slope. 
Habits.-This Plover is chiefly found about the dry, grassy prairies and mesas and also in sage-brush country, and is quite independent of the presence of water. It is a rather solitary bird, though after the breeding season may be met with in small parties of ten or twelve; it subsists chiefly on insects and especially locusts and grasshoppers, of which it must destroy enormous numbers. It has a whistle-like note, reminding one of a Curlew according to Dille, and when disturbed or molested in the breeding season, has the power of shamming being crippled or wounded, and at the same time shrieks as if in great agony. The nest is a depression in the ground, sometimes lined with a few stray grasses, sometimes without lining; it is situated on the dry prairie as a rule. The eggs, nearly always rour, are not so pointed as those of most Plovers; they are olive-drab, spotted and dotted especially at the larger end with shades of brown, but not blotched. They measure $1.45 \times 1 \cdot 10$. Dille gives May 29th as the average date for fresh eggs in the plains; it is perhaps a little later in the mountain parks, as Allen noticed newly-hatched young on July 28th in South Park.

\section{Family APHRIZIDE.}

This family was first formed by Coues to contain the Surf-birds and Turnstones. They have a stout, rather short, bill, a scutellated tarsus and four toes; the anterior ones without webs.

\section{Genus ARENARIA.}

Bill moderate, conical and tapering, culmen about equal to tarsus; no dertrum or swelling towards the tips of the mandibles; tail of twelve feathers slightly rounded; tarsus short, about equal to the middle toe and claw, with a few trensverse scutes in front, otherwise reticulated; hind toe present; no webs. 
Two species are known, one nearly cosmopolitan, the other confined to the coasts of North America.

\section{Ruddy Turnstone. Arenaria interpres morinella.}

A.O.U. Checklist no 283a-Colorado Records-H. G. Smith 96, p. 65 ; Cooke 97, pp. 69, 201.

Description.-Male in summer-Above, including the wings, variegated with chestnut, black and a little white; upper tail-coverts white; tail chiefly black, but white at the base and tips of the feathers; below white with a black patch on either side of the fore-neck, surrounding white patches on the throat and either side of the head and neck; iris and bill black, feet orange-red. Length 9.0 ; wing 6.0 ; tail 2.25; culmen 9.; tarsus 1.0 .

The female has less chestnut and the black is duller. In winter the upper-parts are brown, the feathers edged with fulvous or grey; below white with the breast dusky, mottled with whitish.

Distribution.-Breeding far north from the Mackenzie River to perhaps Melville Island; south on migration chiefly along the coasts as far as Patagonia and Chile; rare inland.

The Turnstone is a rare straggler to Colorado; H. G. Smith reported one from Sloans Lake near Denver, killed April 26th, 1890, and R. Borcherdt obtained eight out of a flock on Berkeley Lake, also close to Denver, May 18th, 1900. One of these latter specimens is exhibited in the Colorado Museum of Natural History in Denver. Hersey' took one out of a bunch of three at Barr, September 9th, 1907.

\section{ORDER GALLINAE.}

This order contains the game-birds, such as Pheasants, Grouse, Turkeys, Brush-Turkeys and Curassows; they can easily be recognized by their short, arched bills, their strong legs, well adapted to walking, and their rounded, rather feeble wings; the tarsus is often armed, especially among the males, with a strong, sharp spur; the hallux is alway's present, and in all the Colorado species is jointed above the level of the other toes; the wing has ten primaries, but the number and arrangement of the tail-feathers is subject to considerable variation. The nest is usually placed on the ground, and the young, 
when hatched, are covered with down and able to run and fly almost at once.

\section{Key of the Fameles and Genera.}

A. Head completely feathered.

a. Tarsus bare and not feathered (Odontophorida).

a1 Head without a true crest, tail shorter, about $\frac{3}{5}$ of wing. Colinus, p. 138

$b^{1}$ Head with a full, soft crest ; tail longer, about $\frac{4}{5}$ of wing.

Callipepla, p. I4I.

c1 Head with an upstanding club-shaped crest, distinct from crown-feathers.

Lophortyx, p. 142.

b. Tarsus always more or less feathered ( $T$ 'etraonida).

a1 Tarsus feathered for half its length; with shoulder rufis.

Bonasa, p. 147.

$b^{1}$ Tarsus feathered to the bases of the toes at least, but toes not completely feathered.

$a^{2}$ Tail long, about equal to the wing, highly graduated and attenuated.

Centrocercus, p. 153.

$b^{2}$ Tail long, about $\frac{3}{4}$ of wing; not attenuated, slightly rounded.

Dendragapus, p. 145.

$c^{2}$ Tail short, lese than $\frac{1}{2}$ of wing.

$a^{3} \quad$ Tail strongly graduated, middle tail-feathers projecting ; no tufts.

Pediocæes, p. 15I:

$b^{3}$ Tail moderately graduated, middle-tail-feathers not projecting ; neck tufts present. Tympanuchus, p. 150.

$c^{1}$ Tarsus and toes densely feathered throughout.

Lagopus, p. 148.

B. Head and neck naked; tarsus not feathered (Meleagridce).

Meleagris, p. $\mathbf{I 5 5 .}$

\section{Family ODONTOPHORID压.}

Head fully feathered; tarsus bare and without a spur; hind toe jointed above the level of the others; plumage never metallic.

\section{Genus COLINUS.}

Feathers of the crown lengthened and erectile, but hardly forming a true crest; tail of twelve feathers about $\frac{3}{5}$ the length of wing.

The genus is confined to North America, and goes as far south as Yucatan. There are two species only in the United States; the 
typical form of one of these only is found in Colorado. It is possible that the Texan subspecies (C. v. texanus) may reach south-east Colorado. It is distinguished by its slightly smaller size-wing $4 \cdot 4$, by its heavier brown barring below, and its less reddish tone above.

\section{Bob-white Colinus virginianus.}

A.O.U. Checklist no 289-Colorado Records-Drew 85, p. 14 ; Morrison 89, p. 181 ; Kellogg 90, p. 87 ; Bendire 92, p. 1 ; Cooke 97, pp. 69,201 ; Dille 03, p. 74 ; Henderson 03 , p. 235 ; 09, p. 228 ; Judd 05, pp. 9-46; Warren 06, p. 19 ; Rockwell 08, p. 160.

Description.-Male-Above and the fore-neck chiefly rufous-chestnut, variegated and mottled with grey, black and tawny-yellow; the rump and tail chiefly grey; the edges of the tertials chiefly tawny; a strong superciliary line and the throat white, bordered by black; rest of the under-parts whitish with transverse double crescentic bars of black, and a few stripes of chestnut on the sides; iris brown, bill dark brown, paler at the base of the lower mandible, legs brownish-grey. Length 9.0 ; wing 4.5 ; tail 2.6 ; culmen .55 ; tarsus 1.15 .

The female has the supercilium and throat buffy-yellow with less black around, and is less distinctly marked generally; it is atrifle smaller-wing 4.35 .

Distribution.-Eastern North America from Maine and southern Ontario to northern Florida, westwards to south Dakota and oastern Colorado.

The Bob-white did not extend much beyond central Kanses in the middle of last century, but with the spread of settlement it has extended its range westwards over the prairies to the eastern portion of Colorado; while at the same time it has been introduced by human agency all along the foothills-country from Pueblo to Fort Collins. It is alse to be found in Estes Park and Wet Mountain Valley, at La Junta and near Grand Junction, where it has doubtless been introduced as well.

Bob-whites are not uncommon in the south-east.corner of the State (Warren), but whether these are the eastern or Texan form is uncertain. It is probably a resident throughout ite range.

Habits.-The Bob-whites prefer fairly open, cultivated lands, meadows and pastures, with patches of bush and briars where they can take shelter. They are generally to be found in small coveys or parties, which do not range very far from where they were raised. In the spring the coveys break up into pairs. The Bob-white, which is often called the Quail or Partridge in the east, 
derives its name from its call-note. This is usually uttered by the male when perched on a rail-fence or a low limb of a tree.

The coveys very often roost in the open on the ground in a solid circle with heads out and tails in, and like all Gallinaceous birds dust themselves in little pits to get rid of vermin. The food consists of about 80 per cent. of vegetable matter, 15 per cent. of animal matter; the latter, chiefly eaten in the summer and fed to the young birds, consists mostly of beetles and grasshoppers; the former of seeds and weeds. They are therefore most valuable birds to the farmer, and should be encouraged and protected in every way. They are also a very valuable sporting bird, lying well to a dog and rising when flushed with dash and vigour, besides being exceedingly well-flavoured and wholesome for eating purposes.

The nest is placed on the ground ; it is a simple affair consisting of a saucer-shaped excavation, sheltered by a patch of weeds or grass, and lined with a little grass or small twigs. The number of eggs is large, usually 12 to 15 , and as many as forty-two eggs have been found in one nest, though these are probably the production of several hens. They are pyriform and pointed in shape, and white in colour, and average $1.25 \times 1.0$.

Dille gives June 5th as the average date for a clutch of fresh eggs, while Gale states May 20th to June 10 is the usual time. A clutch of fifteen eggs taken by I. C. Hall near Greeley, and presented to the Colorado Museum, were obtained as late as July 24th, and are described as being unincubated. But the Bob-white varies very much in this respect, and eggs have been taken in every month in the year, except December, in various parts of the United States. 


\section{Genus CALLIPEPLA.}

Crown with a full, soft and depressed crest; tail of fourteen feathers; about $\frac{s}{5}$ the length of the wing; plumage of the under-parts scaly in appearance.

Only one species of this genus is recognized, confined to south-west United States and Mexico.

\section{Scaled Quail. Callipepla squamata.}

A.O.U. Checklist no 293-Colorado Records-Lowe 95, p. 298 ; Anthony 95, p. 388 ; Cooke 97, pp. 69, 202 ; Bailey 03, p. 112 ; Judd 05, p. 61 ; Warren 06, p. 19 ; 10, p. 30 ; Dille 09, p. 87.

Description.-Adult-Above slaty-blue, washed with tawny on the wings and middle-back ; feathers of the upper-back and breast edged with black, producing a scaly appearance; crown with a full, soft crest, tipped with white; inner tertiaries edged with white; below the throat is pale yellowish-white, the sides are slaty, streaked with white and the abdomen is mottled with brown and white; iris hazel, bill black, legs brownish. Length 10 ; wing 4.5 ; tail 3.25 ; culmen .5 ; tarsus 1.2.

A young bird has the upper-parts marked with black bars and white mesial streaks, while the breast is brownish with white triangular streaks.

Distribution.-A resident from southern Colorado, south through western Texas, New Mexico and Arizona to the valley of Mexico.

The Scaled Quail was first found in Colorado by Lowe, who on June 10th, 1895, killed one in the eastern foothills of the Wet Mountains. Apparently they have always been abundant in the cedar country to the south of the Arkansas River, in Las Arimas and western Baca co,, but during the last ten years they have been spreading north and east. In 1899-1900 they were very common near Rocky Ford (Cooke), and lest summer (1908) there were quite a number round about Colorado Springs, while on June 2nd and 8th of that year a pair were killed near the summit of Pikes Peak-a most remarkable instance of their wandering propensities. They are also spreading eastward into south-western Kanses, and are well known at Monon and Springfield (Warren).

Habits.-This bird, also known as the Cotton-top and Blue Quail, and sometimes rather erroneously as the Scaled Partridge, is chiefly found in open and arid country where the yucca, cactus and sage-brush flourish. It is 
often far from water. In the autumn it forms small coveys, probably several families joining together, and thus remains till pairing time.

Along the Arkansas Valley they are rather domestic and keep near the farms all the winter, and often nest in the gardens or close by. The food consists of about 30 per cent. insects, chiefly grasshoppers and beetles, and 70 per cent. vegetable matter, principally weed-seeds, but they undoubtedly eat a certain quantity of plant tips and buds as well.

The nest is placed on the ground and consists merely of a slight depression lined with a little grass, but generally somewhat concealed by a bush or tuft of grass. The eggs, usually eleven or twelve, are thick-shelled, somewhat lustreless and sub-pyriform or ovate; they are white to pale buff, very finely marked, as a rule, with pin-points of reddish brown. I have no nesting dates for Colorado, but further south eggs have been taken as early as April, and as late as September.

\section{Genus LOPHORTYX.}

Crown with a crest of several upstanding club-shaped, imbricated black feathers at least an inch long, rather smaller in the female; tail normally of twelve, sometimes of ten or fourteen, feathers, about the length of the wing.

Three species and subspecies of this genus are found in the United States and Mexico.

\section{KEY OF THE SPECIES.}

A. Lower-breast scale-like; the edges of the feathers black.

a. Occiput brown, separated from the whitish forehead by a black band.

L. californicus, of p. 143 .

b. Occiput and forehead dull brown. L. californicus, ㅇ p. 143 .

B. Lower-breast buffy-white, with a black patch on the belly.

L. gambeli, of p. 144 .

C. Lower-breast and belly buffy-white, faintly streaked; no black patch.

L. gambeli, o p. 144 . 


\section{California Quail. Lophortyx californicus.}

A.O.U. Cheeklist no 294 -Colorado Records-Drew 85, p. 14 ; Cooke 97, pp. 69, 202 ; Judd 05, p. 47 ; Rockwell 08, p. 47 ; Cary 09, p. 180.

Description-Male-Above slaty-blue with an olive wash on the wings and pale tawny edges to the secondaries and tertiaries; head. with a characteristic club-shaped crest of several glossy-black feathers; forehead.whitish, continued as a line over the eye, bounded posteriorly by black ; occiput brown; , ides of the face and throat black, bordered by white; sides and back of the neck mottled with black edges and white spots; breast slaty-blue; rest of the under-parts tawny-olive, rufous, white and black, the latter chiefly in narrow cross-bands. Length 10.0 ; wing 4.5 ; tail 3.75 ; culmen .5 ; tarsus 1.15 .

The female has the head dull brown above and the throat rather paler and streaked, but no definite markings; it is also without the rufous on the abdomen; young in first plumage have white, blackbordered shaft-lines above, angular white spots on the breast and obscure grey bars on the belly.

Distribution.-The lower transition and upper sonoran zones of the Pacific coastlands from Oregon to Monterey co. in California. Introduced into Washington and British Columbia and many other parts of the world.

The California Quail has been introduced and has increased and thoroughly established itself in many parts of Colorado, especially in the neighbourhood of Denver, Colorado Springs and Grand Junction. About the last-mentioned place they have become so abundant that the farmers are beginning to complain. They have spread up the Gunnison Valley as far as Hotchkiss, and have also been introduced and have spread in Montezuma co.

Habits.-Miss Eggleston, quoted by Rockwell, says : "A few years ago these birds were introduced near Grand Junction, and have multiplied rapidly. They make their nests under the piles of pruned branches from the orchards and bring out large broods. One hen has been seen with twenty-three chicks, of two distinct broods. They are very tame, sitting on the fence-posts or trees by the roadside, and calling noisily to one another. They feed early in the morning, and large numbers of them can be driven from the gardens." The California Quail undoubtedly does eat and damage grapes, though in other respects it does useful 
work in devouring grass-seeds: It roosts in bushes, not on the ground, and is not so good a sporting-bird as the Bob-white.

The nest is a depression, lightly lined with grass, and generally sheltered by brushwood or a rock. The eggs, 12 to 16 in number, are white or buffy, irregularly spotted all over with brown and drab. They average $1.25 \times 1.0$.

\section{Gambel's Quail. Lophortyx gambeli.}

A.O.U. Checklist no 294-Colorado Records-Morrison 89, p. 181 Cooke 97, pp. 70, 202.

Description.-Male-Front half of crown and crest black, with a few white lines on the forehead; 'posterior half chestnut-brown, w white transverse line across the crown, another running back from the eye, and a third surrounding the black throat; general colour above ashyblue, with dark shaft-lines to the feathers round the neck; breast like the back; other under-parts buffy, rich chestnut stresked with white on the flanks, and a black patch in the middle of the belly; iris brown, bill black. Length 6.5 ; wing 4.75 ; tail 3.75 ; culmen 45 ; tarsus $1 \cdot 15$.

The female has the head plain greyish-brown, little whiter on the chin; the crest is dark brown and not recurved, and the black bellypatch is absent, but the lower-breast and belly are faintly streaked with brown.

Distribution.-From Western Texas to southern California north to southern Utah and Colorado, south to Sonora in Mexico.

The claim of Gambel's Quail to admission to the Colorado list seems rather doubtful; Morrison gives it as rare in the south-west part of the State, and Cooke in more detail says that Morrison shot three, forty miles south-west of Fort Lewis. This would certainly take one well over into New Mexico, so that although it most probably occurs within the State boundary, it does not appear to have been actually taken.

\section{Family TETRAONID王.}

Head fully feathered; tarsus partially or completely feathered and without a spur; hind toe jointed above the level of the others; plumage never metallic. 


\section{Dusky Grouse}

\section{Genus DENDRAGAPUS.}

Large birds without crests or any specially lengthened feathers, but with a bare space on the neck, ordinarily concealed by feathers but capable of inflation into drum or tympanum; tail long, even or slightly rounded, about $\frac{5}{4}$ of the wing, of eighteen to twenty feathers normally; tarsus feathered to the toes.

This genus contains one western species with three local races confined to the pine forests of the Rocky Mountains.

\section{Dusky Grouse. Dendragapus obscurus.}

A.O.U. Checklist no 297-Colorado Records-Pike 10, ii., p. 458 (Coues' ed.); Say 23, ii., p. 14 ; Allen 72, pp. 159, 164 ; Trippe 74, p. 399 ; Henshaw 75, p. 435 ; Scott 79, p. 96 ; Tresz 81, p. 189 ; Drew 81 , p. 142 ; 85 , p. 17 ; Morrison 88 , p. 139 ; 89, p. 181 ; Kellogg 90 , p. 87 ; Bendire 92, p. 41 ; Lowe 94, p. 267 ; Burnett 96, p. 64 ; McGregor 97, p. 38 ; Cooke 97, pp. 70, 202 ; Henderson 03, p. 235 ; 09, p. 228 ; Judd 05, p. 41 ; Gilman 07, p. 153 ; Warren 08, p. 20 ; Rockwell 08, p. 161.

Description.-Male-Above mottled, dusky and slaty-blue, most blue on the hind-neck, the wings with a little tawny as well; tail slatyblack with w terminal band of pale slaty; below slaty-grey, varied with white on the sides and abdomen; chin and throat white, spotted with slaty ; iris orange-brown, bill black, feet blue-grey, comb over the eye and neck-drum yellow. Length 20 ; wing 9.5 ; tail 7.5 ; culmen .8 ; tarsus 1.8 ; weight about three to five pounds.

The female is a good deal smaller-length about $17 \cdot 5$, wing 8.5 ; and has more dark-brown and buffy mottling on the back and chest. Young birds are like the female, but have in addition white shaft-marks and tips to many of the feathers, and the two central tail-feathers mottled and barred with dusky and tawny.

Distribution.-The Rocky Mountains region from Montana and Idaho and the Black Hills of Dakota, south to the White Mountains of Arizona and to New Mexico. A regident throughout its range.

In Colorado the Dusky Grouse is a resident, found throughout the year in the mountainous portion of the State, chiefly in the pine forests from about 7,000 feet to timber line. It has been noted from Estes Park (Kellogg) to the Wet Mountains (Lowe), and from Mesa co. (Rockwell) to La Plata (Morrison). It was undoubtedly killed by Pike on the slopes of Cheyenne Mountain near Colorado Springs, who alludes to it as the "Pheasant,"

Habits.-The Dusky Grouse, also known as the Blue or Grey Grouse, and more familiarly as the Fool-hen, 
keeps to the heary spruce timber most of the year. It is a solitary bird, never forming large flocks, though after the breeding season often seen in coveys or family parties along the mountain meadows. During the winter it remains in the thickest spruces, where it feeds on the pine needles and buds, and where its presence can often be detected by the debris collected underneath.

The iood consists chiefly of vegetable matter, about 93 per cent. according to Judd; this is mostly made up of berries, especially those of the Kinnick-kinnick (Arctostaphylos), and of pine needles, buds and flowers; the animal matter, about 7 per cent., is chiefly grasshoppers, taken at high elevations in the fall or late summer, when they are to be met with even above timber line. - In the spring especially the male makes a curious booming or rumbling sound. It is said to most nearly resemble the sound caused by whirling a rattan cane round and round through the air. The production of this sound is connected with the two nalred patches on each side of the neck. These are hollow vesicles in connexion with the air sacs, and are inflated to the size of half an orange at this time and are most conspicuous, while at ordinary times they are concealed by the overlaying feathers.

The nest, which has been described by Henshaw and Burnett, is placed on the ground, generally in an open glade, but sheltered or somewhat concealed; that found by Burnett was placed in a hollow under two old logs, It is a simple structure of dried grass or pine needles; the eggs, eight or nine in number, are whitish to buffy, with fine spots or dots of chocolate fairly evenly distributed. They average $2.0 \times 1 \cdot 40$. Fresh eggs may be looked for about the middle of June at the higher elevations, earlier at lower elevations, according to 
Gale. Henshaw's nest, which contained seven eggs about to hatch, was found on the Upper Rio Grande on June 18th.

\section{Genus BONASA.}

Head with a full, soft crest; base of the neck with a ruff of black, fan-shaped feathers, concealing a rudimentary drum; less developed in the fermale; tail of normally eighteen feathers, long, nearly equalling the wing, truncate and slightly rounded; tarsus half bare of feathers, covered in front by two or three rows of scutes.

One species only, confined to North Americe, but forming three local races, makes up this genus.

\section{Grey Ruffled Grouse. Bonasa umbellus umbelloides.}

A.O.U. Checklist no $300 \mathrm{~b}$-Colorado Records-Allen 72, p. 181 ; Morrison 88, p. 139 ; 89, p. 181 ; Cooke 97, pp. 70, 159, 202.

Description.-Above variegated brown, black, white and grey, chiefly the latter, spotted with paler dark-edged cordate or arrow-headed markings on the back and rump; tail-feathers grey, vermiculated with black and with a subterminal black band; below whitish, tinged with tawny, with brown cross-bars on most of the feathers ; fore-neck and throat mingled brown, grey and white; on each side of the neck covering the shoulders a tuft of broad, soft, spreading, glossy, greenishblack feathers-the ruff or ruffe. Length about 17.0; wing 7.25; tail 6.50 ; culmen $\cdot 70$; tarsus 1.65 .

The female is smaller-wing 6.75 -and has the ruffe less developed or even obsolete. Young birds are somewhat similar, but with more brown and without ruffles.

Distribution.-The Rocky Mountains region of North America from Alaska and Yukon to Utah and Colorado.

The Ruffled Grouse is a very rare bird in Colorado, but appears to be a resident at lower elevations in the mountains. An example was shot and others seen about eighteen miles south of Denver in December, 1894 (Cooke); Mr. L. D. Gilmore saw five near Sweetwater Lake in Garfield co., January 3rd, 1898, and several more subsequently, while Cooke was fortunate enough to see w family of old and young birds, August 12th, 1899, on the South Fork in Estes Park, which seems to point to their having bred in Colorado. There is no other definite record.

Habits.-The Ruffled Grouse is celebrated for its "drumming," a performance carried out by the male 
on a specially selected spot-a log or flat rock generally. The sound is caused by the rapid vibration of the wings, and is sometimes kept up for hours and resembles the sound of a kettle-drum. It is only indulged in by the male, and is a love-call to attract the female.

\section{Genus LAGOPUS.}

No crest, ruff or tufts; only a naked comb over the eye; tail short, about $\frac{2}{3}$ of wing, of fourteen rectrices nearly covered up by the coverts ; tarsi and toes densely feathered to the claws; plumage white in winter.

A considerable genus containing three well-marked North American and three well-marked European species, as well as a good many less well-defined species and subspecies, all restricted to the boreal zone.

\section{White-tailed Ptarmigan. Lagopus leucurus.}

A.O.U Checklist no 304-Colorado Records-Baird 58, p. 636; Allen 72,p. 164 ; Aiken 72, p. 209 ; Batty 74, p. 390 ; Coues \& Trippe 74, p. 426 ; Brewer 74, p. 348 ; Henshaw 75, p. 438 ; Coues 76, p. 263 ; Scott 79, p. 96 ; Drew, 81, p. 141 ; 84, p. 392 ; 85, p. 17 ; Morrison 89, p.181 ; Kellogg 90, p. 87 ; Bendire 92, p. 83 ; McGregor 97, p. 38 ; Cooke 97, pp. 70, 202 ; Warren 00, p. 169 ; 08, p. 20 ; Osgood 01, p. 180 ; Henderson 03, p. 235 ; 09, p. 228 ; Henshaw 05, p. 315 ; Judd 05, p. 47.

Description.-In summer-Above, including the head, fore-neck and breast, mottled, barred and spotted with black, white and tawny; tail, wings, belly and legs white, sometimes yellowish and discoloured, the white of the tail partially hidden by the long coverts; iris hazel, comb over the eje red, bill black. Length 12.0 ; wing 6.75 ; tail 4.5 ; bill -37 ; tarsus 1.20 .

In late summer after the post-nuptial moult, the dark parts are more uniformly grey with finer markings; in winter pure white throughout. The moults take some little time to complete, so that specimens in every intermediate stage are frequently met with (see Plate 3).

Distribution.-The Rocky Mountains at high elevations, chiefly above timber line, from British Columbia south to the Cascade range in Oregon and the Tros range in New Mexico.

This Ptarmigan is fairly abundant throughout the higher mountain ranges of Colorado, and is a resident there all through the year. It breeds above timber line from about 11,500 feet to the summits of the mountains, while in winter it stays about timber line though sometimes driven down to lower levels, perhaps 9,000 feet, by heavy storms. It 


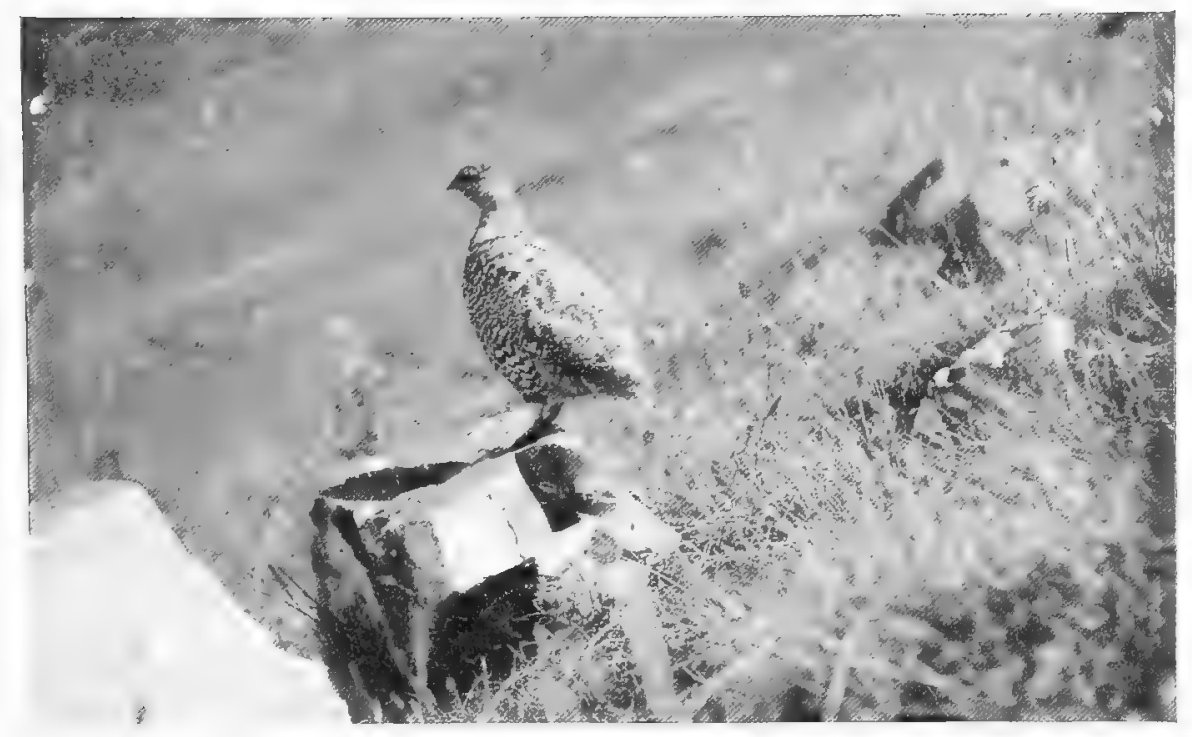

Plate 3]

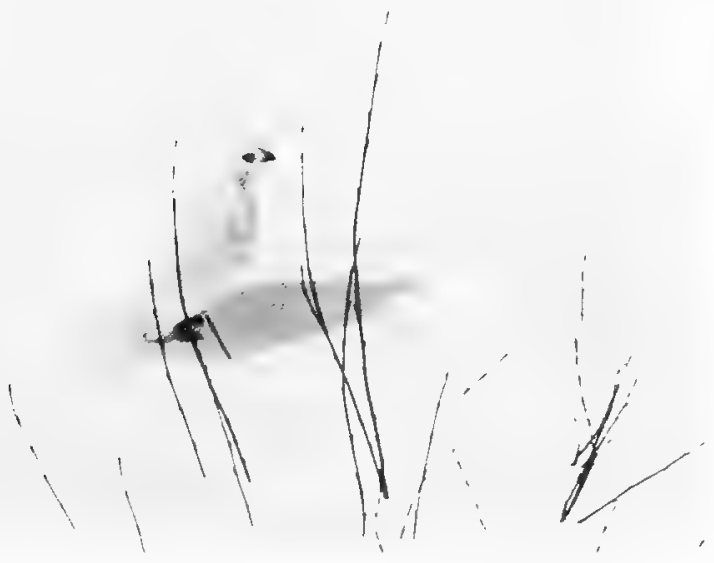

[E. R. Warren, Phot.

THE PTARMIGAN AT CRESTED BUTTE.

(1) IN SEPTEMBER (2) IN MARCH. 

was first taken in Colorgdo by Dr. Anderson, attached to Captain Marcy's party when marching from Fort Bridger in Utah to Santa Fé, probably on the Cochetopa Pass, in January, 1858. It has been found nesting near the Chicago Lakes by Trippe and Evan Lewis (Brewer, Trippe and Bendire), near Breckenridge by Carter, near Crested Butte by Warren, in Saguache co. by Anthony (Bendire), and in the San Juan Mountains, San Juan co., by A. D. Wilson (Cotres), and appears to be generally distributed.

Habits.-This bird, generally known in Colorado as the "Mountain Quail," is with the Leucostictes the highest-ranging and most alpine of all the birds in the State. It is, where not molested, very tame and easily approached, and is chiefly met with among the rockslides and bare, almost vegetation-free country lying above timber line. It is with difficulty flushed, and even where this is accomplished it flies but a short distance, and generally tries to escape by running and squatting among the rocks which it so closely resembles. Its food consists chiefly of leaves, stalks and flowers of alpine plants, and grasses, especially of Caltha leptocephala, the Rocky Mountain marsh-marigold. During the winter it feeds on the buds and needles of pines and willows. Its note is a loud cackle; and it is somewhat gregarious, keeping in flocks of twenty up to one hundred individuals throughout most of the year, except in the breeding season.

The white plumage begins to change in March, but the summer-dress is seldom complete until the end of May or beginning of June. After the breeding is over the complete post-nuptial moult, common to nearly all birds, takes place, and the white wing- and tail-feathers are replaced; later on, in October, a special moult of the dusky and grey feathers of the back commences, and the birds gradually assume the pure white winter-dress.

The nest is generally near the summit of a ridge, and is merely a depression among the rocks, lined with a 
little dried grass, a few white feathers from the breast of the female and sometimes a few leaves; the eggs, usually eight in number, are oval and buff, of a light creamy or darker reddish shade; the markings are few and well defined as a rule, and are of a darker reddishbrown; in size they average $1.70 \times 1 \cdot 20$. Trippe's nest containing eight eggs was taken on June 28th. Evan Lewis's at the same place, of only four eggs in which incubation had commenced, on June 19th; while Wilson's nest from the San Juan mountains, containing five or six nearly fresh eggs, was not taken till July 15 th. The male does not apparently take part in incubation, nor is a second brood raised.

\section{Genus TYMPANUCHUS.}

Head slightly crested; neck with two long tufts of feathers covering a bare yellow tympanum or wattle capable of distention, like a amall half-orange; tail short, graduated, less than half the wing, of eighteen feathers, rather stiff and truncated; tarsus feathered in front and at the sides; toes bare and webbed at the base.

This genus contains three species and one additional subspecies, and is practically confined to the United States. The Lesser Prairie Chicken ( $T$. pallidicinctus) should be looked for in south-oast Coloredo. It occurs in south-west Kansas and Oklahoma. It is smallerwing less than 8.5-and paler and more bleached than the common form.

\section{Prairie Chicken. Tympanuchus americanus.}

A.O.U. Checklist no 305-Colorado Records-Drew 85, p. 17 ; Morrison 89, p. 181 ; Cooke 97, pp. 159, 202 ; Hersey \& Rockwell 09, p. 116.

Description.-Male-Above variegated with black, brown, tawny and white; the latter chiefly on the wing, the markings mostly in irregular bands; below paler, more regularly banded, chiefly white and brown, throat pale yellowish, sometimes speckled with darker; primaries and tail-feathers nearly plain brown; tail narrowly tipped with white; a pair of neck-tufts of several long, stiff feathers, dusky and tawny, about 3.5 in. long; iris brown, bill dark brown, feet yellowish. Length 18.5 ; wing 9.0 ; tail 3.5 ; culmen .7 ; tarsus 1.85 . 
The female resembles the male, but is smaller-wing 8.5 -and has quite inconspicuous neck-tufts. Young birds have the feathers of the upper-parts with rather conspicuous white mesial streaks.

Distribution.-The Mississippi Valley from Louisiana and Texas north to Manitoba and west to the borders of Colorado, east to Indiana and Kentucky; migratory over the northern part of its range.

Like the Baltimore Oriole, the Cardinal and the Blue Jay, the Prairio Chicken is gradually extending its range westwards with the opening up and settlement of the western prairies and the cultivation of the ground. Though included by Drew and Morrison in their Colorado lists, the first definite recorded instance of its occurrence seems to be that of J. S. Robertson of Barton, just two miles within the Colorado border line in the extreme north-east of the State, who had seen them twice on his farm in 1897 ; later on, in 1900, Otto Derr wrote to Cooke that at Wray the Prairie Hen is a not uncommon breeder. Hersey and Rockwell state that in 1907 a pair nested fourteen miles northeast of Denver, near Barr, and in the following year two pairs raised eighteen young.

It may be considered an uncommon resident in the north-eastern part of the State.

\section{Genus PEDIOC ETES.}

Head slightly crested; a naked patch over the eye bearing numerous yellow papillæ; no tufts or ruffs; but semi-concealed bare patch on the neck forming a rudimentary tympanum; tail short, less than half the wing, of eighteen feathers strongly graduated, the central pair narrow, square-tipped and projecting about an inch beyond the others; feathering on the tarsus extending about half way down the toes, confined to the front and sides; toes with a lateral fringe of horny processes.

One species only, with two additional local races confined to North America.

KEY OF THE SPECIES.

A. More rusty and tawny in tone.

P. p. campestris, p. 152 .

B. More buffy and greyish in tone.

P. p. columbianus, p. I5l.

\section{Columbian Sharp-tailed Grouse.}

\section{Pedioccetes phasianellus columbianus.}

A.O.U. Checklist no 308a-Colorado Record-Cary 09, p. 181.

Description.-Hardly differing from $P . p$. campestris, but with the ground-colour buffy-greyish or pale greyish with little if any rusty tinge. 
Distribution.-Western America, from British Columbia to northern California, and east to western Colorado.

Cary identifies a Grouse taken by him in August, 1906, near Hahn's Peak in northern Routt co., with this subspecies, and concludes that all the Sharp-tailed Grouse of western and southern Colorado should be referred to this form. He noticed the Sharp-tailed Grouse also in San Miguel, Dolores, Montezuma and Archuelta countios up to an elevation of 9,500 feet, and concluded that they were this subspecies.

\section{Prairie Sharp-tailed Grouse. Pediocotes phasianellus campestris.}

A.O.U. Checklist no 308b-Colorado Records-Allen 72, p. 152 ; Aiken 72, p. 208 ; Morrison 87, p. 58 ; 88, p. 139; 89, p. 182 ; Ridgway 87, p. 192 ; Osburn 93, p. 212 ; Cooke 97, pp. 71, 159, 203 ; Gilman 07, p. 153 ; Rockwell 08, p. 161 ; Warren 09, p. 14 ; Henderson 09, p. 228. (Some of these may refer to the other subspecies.)

Description.-Above tawny, mottled with black, white and reddish markings, rather fine except on the scapulars, the white chiefly on the wing-coverts ; primaries and their coverts plain brown with white spots, chiefly on the outer web ; throat buffy, rest of the under-parts white; fore-neck and breast with numerous brown U-shaped spots, extending over the flanks to the lesser extent; four middle tail-feathers like the back, mottled tawny and rufous, others chiefly white; iris brown, bill and feot horny-brown. Iength 18 ; wing 8.75 ; tail 3.0 , to end of longest tail-feather 4.0 ; culmen .6 ; tarsus 1.75 .

The female is smaller-wing about 8.0. A young bird is rather lighter and has white shaft-raarkings above.

Distribution.-The prairie region of middle America from Manitoba to Texas and New Mexico, east to Winconsin, west to Colorado; probably a resident throughout.

In Coloredo this bird is by no means common. It was apparently more so in former days, but it is a species which prefers wild country and retreats before settlement, and it is now but seldom met with. It was chiefly an inhabitant of the prairie country east of the mountains, and was abundant formerly about Loveland (Osburn). It is ocoasionally met with in the wilder parts of Routt co. There is an example in the collection at the Capitol in Denver from Wray, presented October 19th, 1903, by B. E. Sisson; Aiken observed one near Limon in May, 1899, and Carter found it breeding in Middle Park at 7,500 foet.

In south-west Colorado near Fort Lewis both Gilman and Morrison state that it is fairly common among the scrub-oaks on the mesas at about 7,500 feet, but whether it is the present subspecies or $P . p$. columbianu, the characteristic form of the Great Basin region, is at 
present uncertain. Cary believes the Routt co. bird is referable to the other subspecies.

Habits.-The Sharp-tailed Grouse is very generally mis-called the "Prairie Chicken" in the north-west. It is a bird of the prairie in summer, retiring in winter to ravines and wooded lands, and often roosting beneath the snow when the weather is severe.

The food consists chiefly of vegetable matter-about 90 per cent. ; it is a great browser, devouring leaves, buds and flowers of various bushes and trees, while in La Plata co. it chiefly feeds on the acorns of the scrub-oak.

In the breeding season the males give a dancing display before the females. A nest, described by Gilman, was found on May 11th : it was a slight depression in the ground lined with grass and feathers, and hidden and sheltered by a small scrub-oak. The eggs were eleven in number; these were creamy-buff to pale olive-brown, plain or very finely spotted with reddish-brown. They average $1.7 \times 1 \cdot 24$, and are small for the size of the bird.

\section{Genus CENTROCERCUS.}

Head hardly crested; neck with a large protuberance in front capable of great distention, covered above by long hair-like filamentary plumes and below with scaly, stiff feathers; tail as long as, or even exceeding the wing, very strongly graduated, composed of 16 to 20 stiff, narrow, acuminate feathers.

Only one species; confined to the dryer parts of western North America.

\section{Sage-Hen. Centrocercus urophasianus.}

A.O.U. Checklist no 309-Colorado Records-Fremont 45, p. 284 ; Baird 58, p. 624 ; Aiken 72, p. 209 ; Henshaw 75, p. 437 ; Scott 79, p. 96 ; Morrison 88,p. 139 ; 89, p. 182 ; Cooke 97, pp. 71, 203 ; Warren 08, p. 20 ; 09, p. 14 ; Rockwell 08, p. 161.

Description.-Male-Above mottled tawny, black and a little white, markings finest on the head, primaries and their coverts plain brown; below, chin and the lower-breast black; under tail-coverts black with 
white tips; breast covered with scaly, stiff, worn feather-bases from which project black, hair-like filaments; a patch of downy white feathers on either side of the neck cover the naked tympanum or air sac, which is enormously inflated under sexual excitement; flanks and leg feathers mottled like the back. Bill black; air-Eacs yellow. Length 30.0 ; wing 13.0 ; tail 12.0 ; culmen 1.5 ; tarsus 2.25 ; weight up to 911 lbs. (Morrison).

Before the breeding season the breast of the male is black. The female is much smaller than the male-length about 20 , wing 11.0 ; the throat and breast are mottled like the back, but with more white, the air-sac is present but quite small, and there are no specially modified feathers.

Distribution.-The sage-brush plains of western North America from south British Columbia and North Dakota, south to south-oast California and Now Mexico. A resident with a slight vertical migration in some parts.

In Colorado the Sage-Hen is a resident chiefly in the drier sage-brush plains of the north and west of the State, but goes up to a certain extent into the mountains and breeds as high as 9,000 fe日t at Dillon (Carter)* and near Twin Lakes (Henshaw \& Scott); but it does not seem to occur at all in the eastern plains. The following are localities : Grand, Routt and Gunnison cos. (Warren), Mesa co. (Rockwell), near Cortez (Morrison), the lower Trinchera Valley in Costilla co. (Brunner in litt.).

Habits. - The Sage-Grouse or Sage-Hen is the largest American game-bird except the Turkey, and is remarkable in many respects. It is almost entirely confined to the sage-brush (Artemesia) areas, and its diet is largely confined to the shoots and leaves of these desert plants, and as a result—unless drawn immediately after it is killed-its flesh is far from palatable.

The mating season begins early, and the courting habits are very remarkable. The males strut round with the yellow air-sacs enormously distended, so that the whole head and neck are balloon-like in appearance. With tail standing erect they scrape their breasts along the bare ground and finish the performance by expelling the air from the sacs with a chuckling, rumbling

\footnotetext{
- It was probably in this neighbourhood that it was seen by Fremont, June 20th, 1844 .
} 
sound. This courting act, according to Bond, is continued daily during the pairing and nesting season.

The nest is a depression with a little grass lining or sometimes nearly bare, and is usually sheltered by a sage bush or clump of grass. The eggs, about eight in number, are olive-buff to greenish-brown, spotted with chocolate-brown; the colour is superficial and easily removed from a freshly laid egg. The size averages $2.20 \times 1.50$.

They roost on the ground often in the same place, as can be told by their droppings, and in winter they pack into parties of fifty to one hundred birds.

\section{Family MELEAGRIDIDÆ.}

Characters of the single genus.

Genus MELEAGRIS.

Head and upper-neck naked and carunculate, with an erectile process on the crown; tarsi naked with scutes in front and behind, that of the male spurred ; tail broad and rounded of 14-18 feathers ; plumage lustrous and iridescent.

This genus contains two species only, and is confined to North America. The domestic bird is without doubt derived from the Mexican race (M. gallapavo Linn.) and the Colorado bird is more closely allied to it than to the wild Turkey of eastern North America (M. g. Bilvestris).

\section{Merriam's Turkey. Meleagris gallopavo merriami.}

A.O.U. Cheoklist no 310d-Colorado Records-Pike 10, Vol. ii., pp. 442, 462 (Coues' ed.); Ridgway 73, pp. 186, 195 ; Morrison 88, p. 139 ; 89, p. 182 ; Cooke 97, pp. 71, 203 ; Gilman 07, p. 153 ; Warren 09, p. 14 ; Felger 09, p. 191.

Description.-Malo-Head and neck bare, dull bluish, with an erectile process hanging from above the bill ; chest with a bristly tuft; feathers of the under-parts metallic bronzy-green and reddish, tipped with velvet-black; feathers of the lower-back and rump metallic tipped with black; tail, tail-coverts and feathers of the lower-rump tipped with buffy-whitish; iris brown, bill dusky, legs dusky red. Length 48 to 50 ; wing 20.5 ; tail 16.0 ; culmen 1.6 ; tarsus 5.26 . The female is similar but duller and smaller. 
Distribution.-The Rocky Mountains region of the United States from Colorado through New Mexico and Arizona to northern Mexico.

Turkeys were formerly abundant throughout the greater part of Colorado. Pike, in 1806, on his merch up the Arkansas Valley to what is now Cañon City, several times alludes to them, and fed his soldiers on those he was able to shoot; they are still to be met with occasionally in the less-accessible parts of the State. Morrison, in 1888, found them abundant along the Pine River in La Plata co. One was taken on the Buckhorn in Larimer co. in 1861; R. Borcherdt killed three out of a flock of twenty-five in the fall of 1868 on Plum Creek, south of Denver (Felger) ; they doubtless still exist in the south-eastern corner of the State south of the Arkansas River, while Warren states that C. H. Smith, of Coventry, saw one in the San Miguel cañon in January, 1898. There is a mounted male example of a Colorado Turkey in the Colorado Museum of Natural History at Denver. It was killed by Carter near Cañon City in January, 1878 ; another specimen, a mounted female in the State Historical Society's collection, was obtained near Durango in the winter of 1895 by A. J. Allen, and both these seem undoubtedly referable to this subspecies; but it is possible that the Turkeys of the lower Arkansas Valley may be the eastern race (M. g. silvestris), distinguished by their deep rusty tail-tips and the rich-dark chestnut of the lower-rump and tail-coverts.

Habits.-Merriam's Turkey seems to be more of a mountain bird than the Turkey of the eastern states. It feeds on insects, berries and plant tops, and is specially fond of acorns. The nest is placed on the ground, generally sheltered somewhat, and is lined with leaves, weeds and grass. The eggs, eight to fourteen, are white, dotted with reddish-brown evenly distributed, and measure $2.75 \times 1.90$.

\section{ORDER COLUMBA.}

The Pigeons form a well-marked group, having no close well-defined relationships, except with the Old World Sand-Grouse.

They are birds of moderate size with short legs, and toes without a trace of a web. The bill is very characteristic, the distal portion being slightly swollen and hard, and the proximal portion, in which the nostrils open, 
covered by a soft skin, forming what is called a cere. There are eleven primaries; the number of tail-feathers varies from twelve to twenty; the hind toe, which is always present, is jointed on a level with the other toes. The young, when hatched, are naked and helpless, and are entirely dependent on their parents for some considerable time.

There are only three Pigeons found in Colorado; they can be distinguished as follows:-

KEY OF THE SPECIES.

A. Large-wing 8 to 9 ; a rounded tail and a white collar.

B. Smaller-wing 6 to 7 .

Columba fasciata, p. 157.

a. Tail wedge-shaped; black spots on the scapulars.

Zenaidura m. carolinensis, p. 159.

b. Tail rounded; a white patch on the wing.

Melopelia asiatica, p. 161.

\section{Genus COLUMBA.}

Bill somewhat short and stout; the soft basal portion rounded; no black spots on the scapulars; tail of twelve feathers about $\frac{2}{3}$ the length of wing, nearly even, the feathers broad and rounded; tarsus about half feathered and scutellate.

A cosmopolitan genus with a very large number of species; only two are at all common in the United States.

\section{Band-tailed Pigeon. Columba fasciata.}

A.O.U. Checklist no 312-Colorado Records-Say 23, ii. p. 10 ; Henshaw 75, p. 429 ; Drew 85, p. 17 ; Morrison 89, p. 6 ; Kellogg 90, p. 87 ; Iowe 94, p. 267 ; H. G. Smith 96, p. 65 ; Cooke 97, pp. 72, 160, 203 ; Dille 09, p. 87 ; Henderson 09, p. 228.

Description.-Male-Head all round and under-parts lavender-grey, paling to white on the abdomen and under tail-coverts; a narrow white half-collar on the nape; back slaty-blue becoming dusky on the wings, and with a patch of iridescent green behind the collar; tail with a dusky black transverse band, the terminal portion paler than the back; eye with a red ring, bill yellow, black at the tip; legs yellow. Length 14.0 ; wing 8.25 ; tail 4.75 ; culmen .7 ; tarsus 1.0 .

The female is like the male but rather duller; the lavender of the head and under-parts is obscured by brown, and the white collar and 
metallic patch are less well developed or even absent; the young bird is like the female, but has lighter edges to the feathers and no collar or metallic patch.

Distribution.-The Rocky Mountain region east to the Pacifie, from British Columbia southwards to Guatemala; a summer resident orly north of Arizona and New Mexico.

In Colorado the Band-tailed Pigeon is not uncommon summer resident of rather irregular distribution, chiefly in the mountains from 6,000 to 10,000 feet from Estes Park (Kellogg \& Cooke), and the mountains about Glenwood (Cooke) southward. Other recorded localities are : A gulch near Gold Hill, Boulder co. (Gale), Mountains above the Platte Valley (Say), Platte Cañon (Smith), South Park, breeding (Carter), Wet Mountain up to 10,000 feet (Lowe), Del Norte (Henshaw), Durango, breeding (Cooke).

Habits.-This Pigeon is particularly fond of the acorns of the various kinds of oaks growing in Colorado, and its distribution probably largely depends on the presence of these; but it also eats berries in the summer before the acorns are ripe, and possibly other seeds as well. It generally goes about in smaller or larger flocks, and has an Owl-like hooting note.

Morrison is the only Colorado observer who describes the breeding habits; he found nests both on the ground as well as in scrub-oak bushes; they all contained only one glossy white egg, measuring $1^{1} 63 \times 1.09$. The nest is a slight platform of twigs on a flat tree limb, while sometimes the nest of another bird is utilized. In some cases two eggs are laid. The egg is described by Bendire as a pointed elliptic alovate, and averages $1.55 \times 1 \cdot 10$. I have not found any nesting date for Colorado, but in Arizona eggs have been met with every month in the year, and several broods are probably raised.

\section{Gernus ZENAIDURA.}

Bill shorter than the head, slender and weak; a bare space round the eye; tail long, about equal to the wing, of fourteen very strongly graduated feathers, which are tapered and somewhat obtusely pointed; tarsus not feathered, scutellate; black spots on the scapulars. 


\section{Mourning Dove}

This genus contains two slightly differing subspecies, spread over North Americe and the West Indies respectively.

\section{Mourning Dove. Zenaidura macrura carolinensis.}

A.O.U. Checklist no 316-Colorado Records-Baird 58, p. 604; Allen 72, pp. 152, 159, 181 ; Aiken 72, p. 208 ; Henshaw 75, p. 431; Scott 79, p. 96 ; Tresz 81, p. 188 ; Stone 81, p. 45 ; Drew 81, p. 141 ; 85, p. 17 ; Allen \& Brewster 83, p. 197 ; Beckham 85, p. 143 ; Morrison .88 , p. 139 ; 89, p. 6 ; Kellogg 90, p. 87 ; Low 92 , p. 101 ; 94, p. 267 ; 01, p. 276 ; Cooke 97, pp. 18, 73, 203 ; Keyser, 02, p. 43 ; Dille 03, p. 74 ; Henderson 03, p. 234 ; 09, p. 229 ; Warren 06, p. 20 ; 08, p. 20 ; 09,p. 14; Gilman 07, p. 153 ; Markman 07, p. 156 ; Rockwell 08, p. 161.

Description.-Male-Above, including the middle tail-feathers, olivebrown, the wing-feathers dusky with a slaty-blue wash and the inner secondaries and scapulare with black spots; outer tail-feathers slaty with a median black bar, and tips of the four outer ones white; head cinnamon-bluish on the occiput and nape, and a black spot below the ear-coverts; sides of the neck irridescent pink; below lavender-pink, becoming cinnamon posteriorly; iris dark brown, skin round the eye bluish, bill black, legs red, drying yellowish. Length 12.25 ; wing $6 \cdot 1$; tail 6.0 ; culmen $\cdot 6$; tarsus $\cdot 75$.

The female is a little smaller-wing 5.75, and the colour less bright; a young bird lacks the iridescence and black spots, and has pale edgings to many of the feathers.

Distribution.-North America from southern Ontario and British Columbia to Panama ; a summer resident north; a resident throughout the year south of about $36^{\circ}$.

The Mourning Dove is a very abundant summer resident throughout Colorado, in the plains and up to about 7,000 feet. At higher altitudes it beoomes much more scarce. It was found breeding at Breckenridge at about 9,500 feet by Carter, while Drew states that it occasionally wanders as high as 12,000 foet.

It arrives from the south about the middle of April though often seen earlier, and leaves in September. A few birds doubtless winter in the State; Lowe saw a flock of forty on January 7 th, near Beulah, and Gale states that a certain number winter in Boulder co., while at Grand Junction it has been seen as early as February 26th, and as late as November 2nd (Rockwell).

Habits.-This Dove, also frequently known as the Carolina Dove and Turtle-Dove, is of "very wide distribution and seems readily to adapt itself to its surroundings. It is found everywhere, but is perhaps most abundant 
in the cotton-woods along the river valleys in the plains and foothills. It is a bird of strong flight, and the rapid strokes of its wings make a whizzing sound. It has a very mournful, cooing note, which soon becomes annoying and tiresome to man, but which appears to gratify its mate.

The food consists chiefly of seeds and berries and it doubtless takes a toll of the grain fields.

The nesting season begins early, and eggs can be found from the end of May till the beginning of September, and doubtless two or three broods are raised in a season.

In the plains the nest is most frequently placed on the ground; in the mountains, according to Gale, more often in bushes and trees, but the nesting-sites chosen vary very considerably. Two fresh eggs taken by I. C. Hall, and presented to the Colorado College Museum, were found on June Ist near Greeley, in a flat nest of small twigs, placed on a heap of old, dead rushes in a marsh. Gale found nests at the angle where a branch joins a tree-trunk, upon the longitudinal branch of a bunch of undergrowth, upon the crown of an old stump, and upon the ground.

The nest is a slight affair of a few twigs and sometimes a little dry grass. The eggs, generally two in number, though often only one, are pure glossy-white, generally nearly oval, and measure about $1 \cdot 1 \times \cdot 9$

\section{Genus MELOPELIA.}

Bill slender and lengthened, about equal to the tarsus; a bare space round the $\theta y \theta$; tail shorter than the wing, of twelve broad, rounded feathers ; tarsus naked and scutellate; no black spots on the scapulars, but a white patch on the wing.

Only one North American species found along the southern border of the United States. 


\section{White-winged Dove. Melopelia asiatica.}

A.O.U. Checklist no 319-Colorado Records-Berthoud 77, p. 83 (M. leucoptera) ; Cooke 97, pp. 73, 160, 203.

Description.-Male-General colour above, including the middle tailfeathers, olive-brown; top of the head and neck dull pinkish, an irridescent patch on the sides of the neck and a steely-blue spot below the ear-coverts; primaries dusky with a narrow white edging; wing with a broad white bar from the carpal joint to the longest coverts; rump and under-parts bluish; outer tail-feathers slaty-blue, then slaty-black; then squarely tipped with ashy-white; iris purple, bill black, legs pinkish-purple. Length 12.0 ; wing 6.5 ; tril 4.5 ; culmen and tarsus $\cdot 87$.

The female is similar, but smaller and duller coloured.

Distribution.-The southern United States from Florida, Texas, New Mexico and Arizona, south to Costa Rica and the West Indies.

The White-winged Dove is only of accidental occurrence in Colorado. It is essentially a bird of the hot and dry lower sonoran and tropical zones. Berthoud reported that he saw a flock of a dozen and killed one or two in July, 1869, in Cub Creek in Jefferson co., at timber line-a very remarkable record. Cooke states that one was shot by $\mathrm{Mr}$. A. D. Baker in the Wet Mountain Valley in September, 1889. These are the only known instances of its occurrence.

\section{ORDER ACCIPITRES.}

This order contains the Eagles, Hawks, Vultures, American Vultures or Condors, and other diurnal birds of prey. They are characterized as follows : Bill stout, strong and hooked, with a soft-skinned cere at the base within which open the nostrils; lores generally naked and bristly, never forming a regular ruff or facial disk as in the Owls; eyes not forwardly directed as in the Owls, but looking out laterally as in other birds; with a few exceptions, wing with ten primaries, tail with twelve rectrices; legs generally rather short and stout, with three toes in front and one behind, cleft or only basally webbed, provided with strong curved and sharp pointed claws, adapted for grasping their prey. 


\section{Key of the Famities and Genera.}

A. Head and neck naked (Cathartido). Cathartes, p. 163.

B. Head and neck feathered.

a. Outer toe not reversible, claws never all the same length (Falconidce).

$a^{1}$ Large; wing over 17.0.

$a^{2}$ Tarsus feathered to the bases of the toes. Aquila, p. 181.

$b^{2}$ Tarsus feathered about half way down. Halizetus, p. I83.

$b^{I} \quad$ Smaller ; wing less than 17.

$\mathbf{a}^{2}$ Nostrils rounded, with a bony tubercle, edge of bill distinctly toothed.

Falco, p. 184 .

b $^{2}$ Nostrils without a bony tubercle; edge of bill never toothed, though often festooned.

$a^{2}$ Legs with the tibia always exceeding the tarsus.

a Only the outer two primaries emarginate on the inner web.

$a^{5}$ Tail forked to half its extent; tarsus reticulate throughout.

Elanoides, p. 165.

$b^{5}$ Tail about even; tarsus with transverse scutes in front.

Ictinia, p. 165 .

$b^{4}$ Three to five of the outer primaries emarginate.

$a^{5}$ Face with an Owl-like ruff; tarsus with scutes anteriorly and posteriorly. Circus, p. I66.

$b^{5} \quad$ Face without ruff.

$a^{B}$ Tarsus half feathered, with scutes in front only.

Buteo, p. 173.

$b^{6}$ Tarsus feathered to the toes. Archibuteo, p. 178.

$b^{3}$ Legs with the tibia and tarsus about equal.

a Tarsus feathered about $\frac{1}{3}$; middle toe very long, without claw exceeding the outer toe with claw.

Accipiter, p. I68.

b4 Tersus feathered about $\frac{1}{2}$; middle toe shorter, without claw not exceeding the outer toe with claw.

- Astur, p. 17l.

b. Outer toe reversible, claws all approximately the same length

(Pandionida).

Pandion, p. 192.

\section{Family CATHARTIDÆ.}

Head and neck naked; bill hooked, comparatively weak; nostrils large, oval and completely pervious owing to the absence of the inter-nasal septum; toes long, basally webbed; claws rather weak, slightly curved and 


\section{Turkey-Vulture}

obtuse; hind toe slightly elevated above the level of the others.

\section{Genus CATHARTES.}

Characters of the family: tarsus long, naked and covered with reticulated scales.

Several species of Turkey-Vultures are recognized, but only one occurs in the United States.

\section{Turkey-Vulture. Cathartes aura septentrionalis.}

A.O.U. Checklist no 325-Colorado Records-Allen 72, pp. 152, 159, 181 ; Tresz 81, p. 188 ; Drew 81, p. 141 ; 85, p. 17 ; Allen \& Brewster 83 , p. 197 ; Beckham 85, p. 143 ; Morrison 88, p. 139 ; 89, p. 7 ; Lowe 92, p. 101 ; 94 ; p. 267 ; Cooke 97, pp. 18, 73 ; Henderson 05, p. 235 ; 09 , p. 229 ; Warren 06, p. 20 ; 08, p. 20 ; 09, p. 14 ; Gilman 07, p. 154 ; Markman 07, p. 156; Rockwell 08, p. 161 ; Hersey \& Rockwell 09, p. 116.

Description.-Adult-Plumage black throughout, glossy in parts, and some of the feathers edged with dark brown; wing and tail-feathers ashy below; iris brown, bill white, head and neck naked but for a few bristles, crimson to pale carmine; fe日t flesh-coloured. Length 27 ; wing 20.0 ; tail 10.5 ; culmen with cere 2.0 ; tarsus 2.25 .

The female resembles the male, but is slightly smaller; young birds are darker than adults and have the bill and skin of head dark; nestlings are covered with white down.

Distribution.-From southern New England, Manitoba and British Columbia southwards to the Mexican border, where it merges with a smaller subspecies found throughout Central Amerioa and the West Indies.

In Coloredo the Turkey-Vulture is a fairly common summer resident, both in the plains and mountains up to 12,000 feet, at which elevation it was noted by Morrison in La Plata co., and by Lowe in the Wet Mountains. It is specially abundent, according to Rockwell, in the Plateau Valley of Mesa co., where it arrives normally about April 15th, though at a lower elevation at Grand Junction it has been seen as early as March 18th and as late as September 27th. To the east of the mountains it arrives about the same time. Other localities are : Weld co. (Markman), Boulder co. (Henderson), Barr, not uncommon (Hersey \& Rockwell), El Paso and Fremont cos. (Aiken coll.), Baca, Las Animas and Routt cos. (Warren) ; it appears to be generally distributed.

Habits.-The Turkey-Vulture, more commonly known as the "Buzzard ". or "Turkey-Buzzard," is a carrion 
feeder and a scavenger, and in the south is a most valuable aid to sanitation. When a carcass is found, the Buzzards assemble and gorge themselves to repletion; they retire to a perch close by to roost and digest, and return again and again until the bones are picked quite clean. When in the air they sail and circle high with outspread wings, on the look-out for a meal. They have no note or cry beyond a hissing, wheezy sound.

Buzzards, though not usually gregarious, often use a common roosting-place-Rockwell describes such a roost in a grove of trees on Plateau Creek, where he has seen as many as fifty of these birds assembled at night time. Morrison found them breeding in the La Plata mountains at an elevation of about 12,000 feet. The nest was merely a ledge in the cleft of a broken boulder on the mountain side; there were two eggs of a dirty-white colour, blotched with reddish-brown, these measured $2.73 \times 1.95$ and $2.70 \times 1.91$ respectively. The eggs were much soiled and the whole surroundings of the spot loathsome and evil-smelling. Dennis Gale is the other observer who has found the Buzzard breeding in Colorado. He reports that he saw several nesting in cotton-wood trees on the Little Thompson, with Blue Herons. They were probably making use of the nests of the Herons, though Gale, in his notes, does not distinctly say so. This was on April 16th.

\section{Family FALCONID}

Head and neck never naked (in the New World forms) ; bill generally stout, strong and hooked, with a cere or soft cushion at the base within which the nostrils open; nostrils never pervious; wings with ten primaries, tail of twelve rectrices with rare exceptions; feet strong, toes cleft or only webbed at the extreme base, the 
outer one never shorter than the inner one, and never reversible; hind toe not elevated above the others. For key of the genera, see p. 162.

\section{Genus ELANOIDES.}

Bill rather weak ; nostrils oval and oblique; wings long, acute and pointed, tenth (outer) primary about equal to sixth, ninth and tenth longest; two outer primaries emarginate on the outer web; tail very long, often nearly equal to wing; very strongly forked; the outer feathers about twice the length of the central pair; tarsus short, half feathered, elsewhere with reticulate scales.

This genus contrins only one species.

\section{Swallow-tailed Kite. Elanoides forficatus.}

A.O.U. Checklist no 327-Colorado Record-Cooke 97, pp. 73, 160. Description.-Male-Head and neck all round, a band across the rump and the whole of the under-parts, including the under wing-and under tail-coverts, white'; back, wings and tail glossy black with greenish lustre ; iris black, bill bluish-black, cere and legs bluish. Length 20.5; wing 15.75 ; tail 10.5 up to 14.0 ; culmen .9 ; tarsus 1.3 .

The female is larger-wing 17.0. Young birds have white tips to some of the wing-and tail-feathers, and the head with narrow brown shaft-lines.

Distribution.-Chiefly met with in the middle and southern United States, from Minnesota and Virginia south through Texas and Mexico to South America.

The Swallow-tailed Kite is a very rare straggler in Colorado, and has been met with only by Aiken. He saw one at Leadville in August, 1871 ; and the same month in 1877 , two were brought to him in the flesh; one of these was killed close to Colorado Springs, and is now in the Colorado College Museum; the other at Manitou Park in Teller co., at about 7,700 feet.

\section{Genus ICTINIA.}

Bill moderate, edge of upper mandible slightly lobed; nostrils circular ; wing long; eighth primary longest; the tenth (outer) about equal to the fourth; two outer primaries emarginate on the inner web; tail nearly even; tarsus half feathered with a row of transverse scutes in front.

A genus containing, two species, confined to temperate and tropical America. 


\section{Mississippi Kite. Ictinia mississippiensis.}

A.O.U. Checklist no 329-Colorado Record-Cooke 97, pp. 73, 160.

Description.-Male--Head, neck, secondaries and under-parts greyishwhite, rest of the upper-parts bluish-slate, becoming black on the primaries and tail; wing-quills with a narrow indistinct stripe of chestnut-rufous on the outer webs and larger spots of the same on the inner; bases of the feathers of the head, neck and under-parts white, and often showing through; concealed white spets on the scapulars; iris lake-red; bill, cere and claws black; feet red. Length 14.15; wing 11.50 ; tril 6.60 ; culmen .90 ; tarsus 1.35 .

The female is larger-wing 11.75 ; it has the head and secondaries derker, and less chestnut-rufous on the primaries. An immature bird has the head streaked black and white, whiter on the throat ; the back, wings and tail with tawny or white edges and the lower-parts whitish, heavily streaked with rusty-rufous; iris and feet brownish.

Distribution.--The south-eastern United States from southern Mlinois and South Carolina to Texas, Mexico and Guatemala; not uncommon in southern Kansas.

This Kite is a straggler in Colorado. Breninger informed Cooke that an example taken near Trinidad was preserved in Denver, and Aiken reports that he once observed an example near Colorado Springs.

\section{Genus CIRCUS.}

Face rather Owl-like, surrounded by an incomplete ruff; bill strong, beset by bristles; the edge of the upper mandible lobed, but hardly toothed; nostrils oval; wings long, the outer primary shorter than the fourth, the seventh and eighth the longest; the outer three to five primaries emarginate on the inner web; tail long about $\frac{2}{3}$ of wing, almost even; legs long, tarsus clearly exceeding the middle toe and claw, but shorter than the tibia, with scutes before and behind.

A widely spread genus found all over the world, with one species only in the United States.

\section{Marsh-Hawk. Circus hudsonius.}

A.O.U. Checklist no 331-Colorado Records-Allen 72, pp. 152, 159 ; Tresz 81, p. 188; Drew 81, p. 141; 85, p. 17; Allen \& Brewster 83, p. 197; Beckhem 97, p. 121; Morrison 89, p. 7 ; Lowe 94, p. 267; Cooke 97, pp. 73, 204 ; Henderson 03, p. 235; 09, p. 229 ; Warren 06, p. 20 ; 08, p. 20 ; 09, p. 14 ; Gilman 07, p. 153 ; Rockwell 08, p. 161.

Description-Male-Above silvery or bluish-ash, seldom pure, nearly always obscured by dusky and traces here and there of the juvenal tawny; upper tail-coverts white, wing-quills chiefly dusky with white bases; tail banded more or less distinctly with dusky, the terminal one most distinct; below, the throat and breast slightly ashy 
posteriorly white with a few pale rufous spots ; iris brown, bill horny, cere greenish-yellow, legs yellow. Length 18 ; wing 13.5 ; tail 8.5 ; culmen 2.9 ; tarsus 1.0 .

An adult female is larger-wing 15 ; and is dark umber-brown above, varied with reddish and yellowish-brown; but the tail-coverts are white, and form a conspicuous mark; underneath p paler tawny streaked with darker. Young birds resemble the female, and are often darker, but the tail-coverts are always white.

Distribution.-Breeding from Alaska and Hudson Bay to about the southern border of the United States; wintering in the southern United States and further south to Panama and Cuba. The MarshHawk is a very common bird in Colorado, especially on the plains, where it breeds. It is not quite so numerous in the mountains, though it nests up to about 8,000 feet, and wanders as high as 14,000 feet. It may be considered a summer visitor, though undoubtedly a few birds winter in the plains.

The following are chief records: Boulder co., wintering in the valley, nesting in hills and plains (Gale \& Henderson); Breckrenridge, breeding at 8,000 feet (Carter); Orchard, March (Warren); El Paso co., February and August (Aiken, coll.); Wet Mountains, up to 10,000 feet (Lоне); Baca co., very common; Routt co., occasionally (Warren); Mesa co., fairly common, April to November (Rockwell); San Juan co., up to 14,000 feet in September (Drew).

Habits.-The Marsh-Hawk frequents meadows and marshy districts, beating to and fro near the surface of the ground with an easy and graceful flight and searching for its prey. This consists largely of small rodents, ground-squirrels and meadow mice, and to a lesser extent of frogs, insects and small birds. Occasionally when hard pressed it will take carrion or dead and wounded birds shot by gunners.

The nest is always placed on the ground, usually in or near a marsh, and is sheltered by a tuft of grass or a bush; it is a simple structure of dry grass and a few sticks, roughly thrown together, though when used for several successive years, a considerable amount of

The eggs are usually 4 to 6 in number; they are greenishmaterial is accumulated.

blue to bluish-white and generally unmarked, though 
sometimes blotched and spotted with buffy or brown. They average $1.80 \times 1 * 40$. The male assists the female in the construction of the nest, the incubation of the eggs and the rearing of the young. According to Gale, fresh eggs should be looked for near Gold Hill from May 25th to June 10th, but the notices of the breeding of the Marsh-Hawk in Colorado are very scanty.

\section{Genus ACCIPITER.}

Bill moderate or rather small, edge of the upper mandible slightly festooned; nostrils rounded; wing rather short, the five outer primaries emarginate on the inner web, the sixth and seventh the longest; tail long, about $\frac{2}{3}$ of wing, slightly rounded; legs long, tarsus feathered about $\frac{1}{3}$, rather slender, with scutes in front and behind, often fusing to one long " boot" ; middle toe very long, without claw, clearly exceeding the outer toe with claw.

A large, almost cosmopolitan genus of some thirty species; only two occur in the United States.

KEY OF THE SPECIES.

A. Smaller; wing 6 to 8.5 ; tail eren.

A. velox, p. 168 .

B. Larger; wing 9 to 11 ; tail rounded.

A. cooperi, p. $1 ; 0$.

\section{Sharp-shinned Hawk. Accipiter velox.}

A.O.U. Checklist no 332-Colorado Records-Ridgway 73, p. 186 (Nisus fuscus); Drew 81, p. 141; 85, p. 17; Allen \& Brewster 83, p. 197 ; Morrison 87 , p. 27 ; 88, p. 115 ; 89, p. 7 ; Iowe 94, p. 267; Cooke 97, pp. 74, 204 ; Henderson 03, p. 235 ; 09, p. 229 ; Warren 06, p. 10 ; 09, p. 14; Gilman 07, p. 154 ; Rockwell 08, p. 161 ; Hersey \& Rockwell 09, p. 116.

Description.-Male-Above dark slaty-blue, dusky on the quills, the tail with four cross-bands of dusky and a narrow terminal edging of whitish; nape-feathers and scapulars with concealed white bases; below white, the middle parts mottled in irregular cross-bars with palo tawny; quills strongly banded below with black and white; tail square; iris yellow, bill bluish-horn, cere greonish, legs yellow. Irength 12.0; wing 7.3 ; tail 5.75 ; culmen $\cdot 6$; tarsus 1.8 .

The female resembles the male but is larger; length 13.5 ; wing 8.5. A young bird is dusky brown above with tawny odges to most of the feathers, and the white of the head and scapulars often showing through; below white, with longitudinal stripes of brown and darker brown shaft-marks. 
Distribution. - The whole of North America, breeding from Alaska and Hudson Bay and Newfoundland south to the southern border of the United States; wintering from about $40^{\circ} \mathrm{N}$. to Guatemala.

The Sharp-shinned Hawk is a common bird throughout Colorado from the plains to about 10,000 feet in the mountains, though chiefly breeding in the latter. A few birds are resident throughout the jear, but the greater number are migrants from the south.

The following are the principal notices of its occurrence : Boulder co., resident in the valley, breeding in the mountains (Gale); Breckenridge, breeding (Carter); Barr Lake, common on migration (Hersey \& Rockwell); El Paso co., March and April (Aiken coll.); Manitou Park, October (Colorado Coll. Mus.); Baca co., May (Warren) ; Wet Mountains, common to 10,000 feet (Lowe) ; Mesa co., bre日ding, not known to winter (Rockwell); La Plata co., breøding (Morrison).

Habits.-This is one of the most abundant of Hawks throughout the United States, and nothwithstanding its small size is well known for its dash and boldness. It preys almost entirely on other birds, often tackling species as large or larger than itself, such as Mourning Doves, Robins and Grackles; it has a special predilection for young chickens, and unless checked will clear a poultry-yard in a very short time. It is impossible to regard it as useiul or beneficial, except that it destroys large numbers of young sparrows. Its flight is very swift, and it will dash on its prey in the air, on the ground or even when sheltered in a bush.

Morrison found a clutch of three eggs on June 22nd, 1886, near Fort Lewis ; an old Magpie's nest, the roof of which had collapsed, was made use of, a few Jeaves and feathers having been added to form a lining. It was twelve feet above the ground. The eggs are described as white with a purplish tinge, heavily blotcbed with brown. in one case so as to form a complete cap to the end of the egg.

Bendire states that the usual nest is a bulky one, placed in a fir tree or occaisionally on cliffs. The eggs, four or five in number, vary considerably; they are 
sometimes almost unmarked, and sometimes so heavily blotched as to conceal the ground-colour. They average $1.4 \times 1.2$. Gale gives the usual date for eggs June 10th to July 10th; the latter at 11,000 feet elevation in Boulder co.

\section{Cooper's Hawk. Accipiter cooperi.}

A.O.U. Checklist no 333-Colorado Records-Drew, 81, p. 141; 85, p. 17 ; Allen \& Brewster, 83, p. 197 ; Morrison 88, p. 115 ; 89, p. 7 ; Bendire 92, p. 192 ; Lowe 94, p. 267 ; Cooke 97, pp. 74, 204 ; Henderson 03, p. 235; 09, p. 229 ; Gilman 07, p. 154 ; Rockwell 08, p. 162 ; Warren 09, p. 14.

Description.-Closely resembling A. velox in plumage, but much larger with the crown a distinctly darker slate than the back, the tail more strongly white-tipped and rounded, not square. Length 16.5; wing 9.1 ; tail 7.2 ; culmen .8 ; tarsus 2.4 . The female is larger-wing 10.0 , tail 8.25. The young bird bears a rather close resemblance to the young Goshawk (Astur atricapillus), but it is smaller and can be at once distinguished by the generic character of the long middle toe.

Distribution.-Breeding from the St. Lawrence Valley and British Columbia south to southern Mexico; a migrant north, a resident south of gbout $40^{\circ}$.

Cooper's Hawk is a fairly common bird in Colorado, and generally distributed, breeding from the plains to about 9,000 feet. It is stated to be a resident and probably is so to a certain extent in the south, though I have found no winter records, nor is it included in Gale's list of birds wintering in Boulder co. It is undoubtedly more abundant in the summer.

The following are localities : Boulder co., breeding in the mountaing (Gale) ; Middle Park, breeding (Carter); El Paso co., April to September (Aiken coll.) ; Salida, May (Frey) ; Wet Mountains, to 8,000 fe日t (Lowe) ; Mesa cG., once in March (Rockwell) ; Naturita Cañon, April (Warren); La Plata co., breeding (Morrison).

Habits.-Cooper's Hawk is generally met with about moderately open country and cultivated districts. It is in every respect a larger edition of the Sharp-shinned: equally audacious and rapacious, but in Colorado far less common. Its flight is ordinarily not swift, but when in pursuit of its prey it has a wonderful power of twisting and doubling. It is very destructive to 
poultry and pigeons, and according to Morrison, preys largely on grouse, hares and various reptiles. Out of 133 stomachs examined by Fisher, 34 contained poultry and game and 52, other birds, while only 11 contained mammals.

Cooper's Hawk sometimes makes use of the old nests of other birds or even squirrels, and sometimes builds for itself. Gale found a nest forty feet up in a thick spruce, on May 29th, near Gold Hill. It was a bulky structure of sticks and twigs, with green sprays of balsam-fir intertwined, and contained four fresh eggs; another nest, found June 28th, consisted merely of a few flakes of spruce bark lying on a natural bunch of matted scrub. The eggs, generally four, are pale bluish-white, sometimes immaculate, sometimes faintly marked with scrawls and spots of brown and fawn. They average $1.90 \times 1 \cdot 50$. Gale gives May 30 th as an average date for fresh eggs, and states that the female is often very bold and pertinacious in defence of her nest.

\section{Genus ASTUR.}

Resembling Accipiter, but with stouter and shorter legs and toes; tarsus feathered at least half way down; middle toe without claw not exceeding outer toe with claw.

A large and very wide ranging genus, with only one species in the United States separated into two races.

KWY OF THE SPECIES.

A. Above slaty-blue, marked with slaty-grey below.

A. atricapillus, p. 171.

B. Above darker, almost sooty; below markings darker and heavier.

A. a. striatulus, p. 173 .

American Goshawk. Astur atricapillus.

A.O.U. Cheoklist no 334-Colorado Records-Ridgway 73, p. 186 ; Drew 81, p. 141 ; 85, p. 17 ; Morrison 89, p. 7 ; Osburn 93, p. 212 ; Lowe 94, p. 267; Cooke 97, pp. 74, 204 ; Henderson 03, p. 107; 09, 
p. 229 ; Warren 09, p. 14 ; 10, p. 30. (Some of these records may more properly apply to $A$. a. striatulus.)

Description.-Male-Above dark slaty-blue, most of the feathers with darker shaft-lines; crown and ear-coverts almost black; the eyebrow and nape with white bases showing more or less plainly; quills dusky; tail tipped with white and with traces, sometimes more, sometimes less distinct, of the four dusky cross-bars of the young bird; below, except on the tail-coverts, mottled very finely with white and slaty-grey, most of the feathers with dusky-black lines; iris reddish-orange, bill dark slate, feet yellow. Length 21.0 ; wing 13.25 ; tail 9.3 ; culmen 1.1.; tarsus 3.1.

The female is larger; wing 14.0. The young bird in the plumage most frequently met with in Colorado, is very different. Above dark brown, the feathers of the head, back and wing-coverts largely edged with tawny and with white across the back of the neck forming an indistinct collar; tail with fine, distinct, darker cross-bands; below white with a faint tinge of tawny marked with Iong brown, drop-like spots; iris yellow.

Distribution.--Breeding in the northern part of North America from the Yukon valley and Labrador, south perhaps to Idaho and northern new England; south in winter, casually as far as Virginia, Kansas and Now Mexico.

The Goshawk is a rather uncommon winter bird in Colorado, ranging from the plains up to about 9,000 feet. It is stated to breed in the mountains between 9,000 and 10,000 feet by Cooke and other authors, but I can find no evidence for this statement except that Carter found it in summer at Breckenridge, and Drew states that it is a rare resident in San Juan co. All other records are winter ones, viz., Sugar Loaf Bill, Boulder co., February (Henderson); Arkins, Larimer co., February and March (Osburn); El Paso co., October and December (Aiken coll.); Wet Mountains, up to 9,000 feet (Lowe); Mosca, January (Tarren); Montrose co., winter (Warren).

Habits. - The Goshawk is very similar to the Cooper and Sharp-shinned Hawks in its habits. It is bloodthirsty and ferocious, and kills more than it needs, for the sake of killing. It rather prefers a well-wooded country, and nests chiefly in the forests north of the prairie country. It preys on poultry, the large gamebirds, rabbits and squirrels, and is said by Lowe to attack the Dusky Grouse in Colorado. It breeds early in the southern part of its range, laying from two to 
five eggs. These are pale bluish in colour, nearly always unspotted, and average $2.3 \times 1.75$.

Western Goshawk. Astur atricapillus striatulus. A.O.U. Checklist no 334a-Colorado Records-Cooke 97, pp. 74, 204 ; Gilman 98, p. 28.

Description.-Resembling A. atricapillus, but darker, almost sooty above, while below the markings are also much darker and heavier. A young bird is brownish-black above, this colour predominating over the tawny markings; stripes on the lower parts broader and deeper black, and the thighs with large, often cordate spots.

Distribution.-Replacing $A$. atricapillus in the west; breeding from Sitka south along the coast ranges to about latitude $38^{\circ}$ in California, merging to the eastwards in Colorado with the typical form.

Most of the Colorado Goshawks are intermediate, though on the whole referable to the eastern form; a specimen, taken at Sweetwater Lake in Garfield co., February 12th, 1898, by J. T. Meiner, was identified at the United States National Museum as this subspecies; and it is quite possible that others may be found nearer the western than the eastern bird.

\section{Genus BUTEO.}

Bill moderate, the cutting-edge of the upper mandible slightly festooned; nostril oval, without a central bony tubercle; wing rather long and pointed, the outer three or four primaries emarginated on the inner web, the sixth to the eighth the longest; tail rather short from $\frac{1}{2}$ to $\frac{2}{3}$ of the wing, even or slightly rounded; tarsi half feathered, scutellated in front, reticulate on the sides and posteriorly; melanism very common.

The genus contains the Buzzards, as they are generally called in Europe, and embraces numerous species found all over the world, excepting Australia. There are four common species in the United States, two of which commonly occur in Colorado. I have included $B$. lineatus elegans in the key, as it is reported by Cooke to have been seen in Colorado by Breninger though it has never been taken.

\section{KEY OF THE SPECIES.}

A. Four outer primaries emarginated on the inner web.

a. Outer webs of primeries not spotted with white. a. Above dark brown and tawny, without white.

$a^{2}$ Tail in adult rich rufous, with a subterminal band of black.

B. b. calurus, p. 174 .

$b^{2}$ Tail mottled with greyish, rusty, white and dusky.

B. b. harlani, p. 176. 
b1 Above lighter, with a good deal of white, especially on the head and tail-coverts; tail pale rufous.

B. b. krideri, p. 175 .

b. Outer webs of primaries spotted with white. B. 1. elegans.

B. Only the three outer primaries emarginate on the inner web.

B. swainsoni, p. 176.

\section{Western Red-tail. Buteo borealis calurus.}

A.O.U. Checklist no $337 \mathrm{~b}$-Coloredo Records-Baird 54 p. 12 (B. montanus); Allen 72, p. 152 ; Drew 81, p. 141; 85, p. 17 ; Dille 87, p. 97 ; Morrison 88 , p. 115 ; 89, p. 7 ; Kellogg 90, p. 87 ; Lowe 94, p. 267 ; McGregor 97,p. 38 ; Cooke 97, pp. 75, 204 ; Dille 03, p. 74 ; Heдderson 03, p. 235 ; 09, p. 229 ; Gilman 07, p. 154; Warren 08, p. 20 ; 09, p. 14 ; Rockwell 08, p. 162.

Description.-Adult female-Above dark smoky-brown throughout, with a few inconspicuous traces of tawny to the edges of some of the feathers, but hardly a trace of white; tail rich rufous, with a subterminal band of black and traces of other bands more or less complete, and a narrow whitish tip; below mingled smoky-brown and tawny, the former chiefly on the throat and belly, the latter chiefly on the breast and thighs; iris brown, bill bluish-horn, cere yellowish, legs jellow. Length 22.5 ; wing 16 ; tail 8.5 ; culmen 1.4 ; tarsus 3.6 .

The male is smaller-wing 15.25. Other individuals in the light phase are rather paler above, and are more marked with tawny, whilo below they are chiefly white with a little tawny on the throat and a fow dark shaft-marks across the belly. In this plumage they are hardly separable from the true $B$. borealis. Intergrades between the dark and light phases are quite common.

Young birds are like the adults, but have a little more white and tawny ; the tail like the back with 10-12, narrow, dusky black, transverse bars and a terminal white tip; below white with a few spots of smoky brown, and the thigh transversely banded or showing traces of transverse bands of dusky tawny.

Distribution.-Western North America from Mackenzie and British Columbia south along the eastern bases of the Rocky Mountains to north-west Texas and west to the Pacific.

The Western Red-tail is the commonest of the larger Hawks in Colorado; it is a resident, though much more common in the summer. The migrants arrive in March and breed in May and early June from the plains up to at least 12,000 feet, according to Drew, though I know of no definite record higher than Breckenridge (9,500 feet).

The following are recorded localities : Willow Creek, Weld co., breed ing (Dille 87); Estes Park (Kellogg); Boulder co., wintering in valley, 


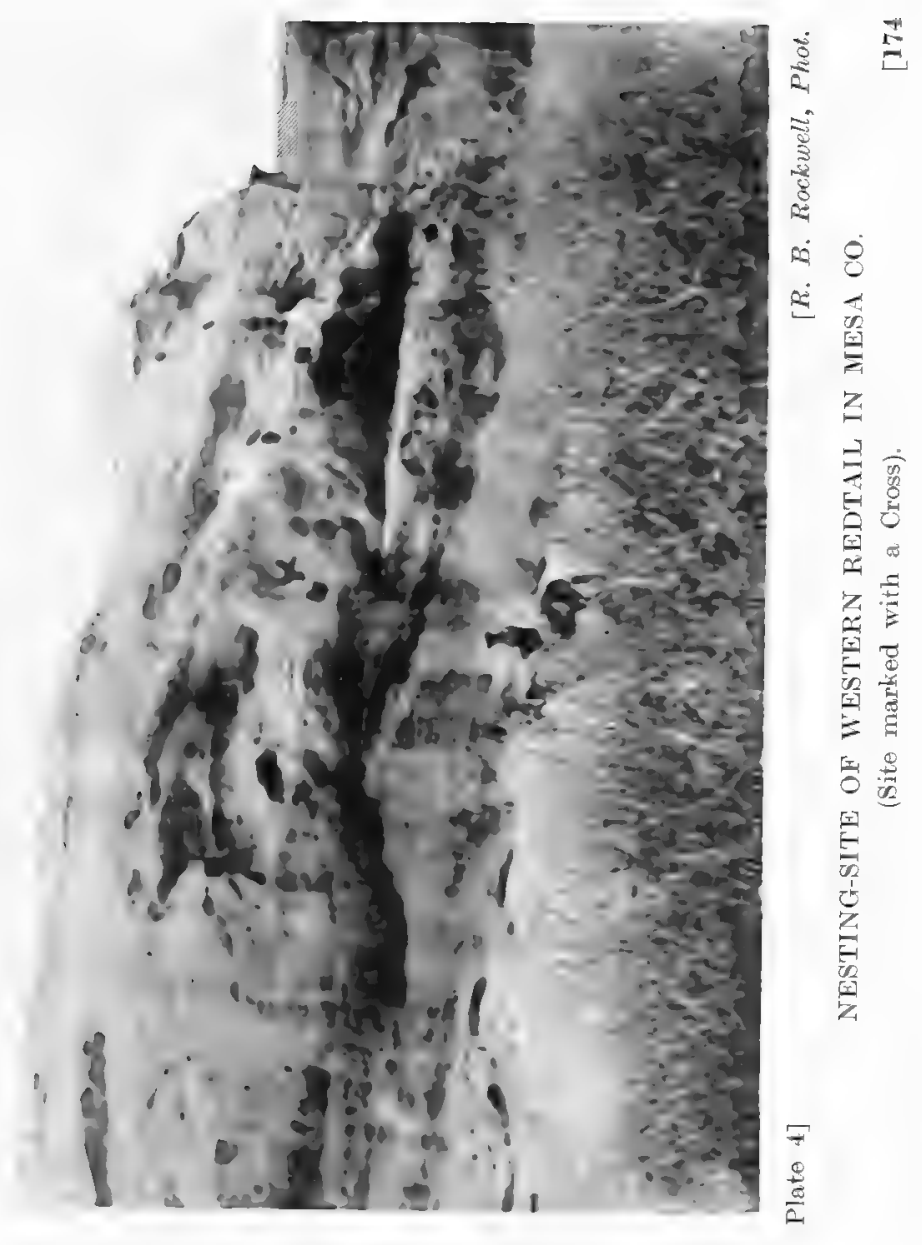



nesting in hills (Gale); El Paso co., March, May, October (Aiken coll.) ; Wet Mountains to 10,000 feet (Lowe); Mesa co., breeding to 9,000 feet (Rockwell) ; San Juan co., breeding (Drew) ; Fort Lewis, breeding (Morrison).

Habits.-The Red-tail, often called the Hen-Hawk, suffers a good deal of unjust persecution, on account perhaps of its name, for it is undoubtedly of considerable service to the farmer. Though it may occasionally take a chicken, the great bulk of its prey consists of mice and other small mammals : out of 562 stomachs examined by Fisher, 409 contained traces of these. It also destroy's a good many snakes as well as large numbers of grasshoppers, especially in the fall, and the good it does undoubtedly far exceeds the harm.

In the plains and lower valleys the Red-tail builds in tall cotton-woods; at higher elevations, in spruces, on sandstone ridges in the cliffs (see Plate 4), or in scruboak eight to ten feet up. Morrison, Dille, Rockwell and Gale all give accounts of the nesting habits.

Gale found a nest near Gold Hill, May 27th, 1884 ; it was placed in the crotch of an upper limb of a cottonwood, about thirty-five feet above the ground, and was a bulky structure, built of twigs and lined with a little dry grass and a few green sprays of the cottonwood. It contained three nearly fresh eggs-the usual number. These were greenish chalky-white, varyingly but scantily marked with brown; they average $1.3 \times 1.8$. The parents made no effort to defend their nest, but quietly withdrew.

Krider's Hawk. Buteo borealis krideri.

A.O.U. Cheoklist no 337a-Colorado Records-Dille 87, p. 99 ; Cooke 97, p. 74 .

Description.-Closely resembling $B . b$. calurus but lighter-coloured, with a great deal of white on the upper side, especially on the upper tail-coverts and head; tail pale rufous, usually without the black 
subterminal bar; below almost entirely white with sometimes u fow brown spots across the belly. In a young bird the tail has a whitish wash, and is crossed by the usual 10 to 12 narrow transverse bars.

Distribution.-The Great Plains of middle America from Minnesota and Iowa south to Texas.

This, a very pale form of the Red-tail, seems to occur on the eastern plains and foothills of Colorado. Cooke gives it as a resident since Dille found a nest and three eggs, May 24th, in Weld co., west of Greeley. There are two young Red-tails in the Colorado College Museum, which seem to be referable to this subspecies, one traken by Aiken nerr Colorado Springs, September 27th, 1902, the other shot by J. F. Baker at Manitou Park, August 29th, 1906.

\section{Harlan's Hawk. Buteo borealis harlani.}

A.O.U. Checklist no 337d-Colorado Records-Ridgway 84, p. 253, 85, p. 165 ; Cooke 97, p. 75.

Description.-Resembling $B$. b. calurus, but with the tail confusedly and irregularly mottled with greyish, rusty, white and dusky, crossed near the end with a subterminal band of black, and tipped with white; upper-parts sooty to black; lower-parts varying from sooty to white, but rarely if ever with tawny or ochraceous.

Distribution.-The Gulf States and lower Mississippi Talley, casually north to Kansas, Iowa and Pennsylvania.

A Hawk obtained by Aiken in El Paso co. some time before 1875, was referred by Ridgway to this subspecies. I have not been able to trace this specimen in the Aiken collection.

\section{Swainson's Hawk. Buteo swainsoni.}

A.O.U. Checklist no 342 -Colorado Records-Baird 54, p. 11 ; 58, p. 19 ; Henshaw 75, p. 421 ; Allen \& Brewster 83, p. 197 ; Drew 85, p. 17 ; Dille 87, p. 97 ; 03, p. 74 ; Morrison 88, p. 116 ; 89, p. 7 ; Fisher 93, p. 72 ; Lowe 94, p. 267 ; Cooke 97, pp. 75, 204; Henderson 03, p. 107 ; 09,p. 229 ; Markman 07,p. 156 ; Gilman 07,p. 154 ; Rockwell $08, p, 162$.

Description.-Male in normal phase-Above dusky-brown with often paler but never tawny edges to the feathers; upper tail-coverts banded with white; tail slaty or brown, with a narrow bar of black; wings with the three outer primaries only, narrowed or cut out on the inner web; below throat and belly white, contrasted with a reddish-brown chest-band; the under-parts sometimes washed and mottled with chestnut to varying extent ; iris brown, bill black, cere and legs greenishyellow. Length 18 ; wing 14.5 ; tail 7.5 ; culmen 1.2 ; tarsus 2.6 . 
The female is larger-wing 16 , and has the pectoral-patch dark sootybrown instead of rufous-brown. In the complete dark or melanistic phase the under-parts are dusky brown throughout with the under teil-coverts spotted or barred with rufous and white; between this and the normal phase every gradation exists.

Young birds are dark, almost black above, varied with tawny or yellowish-white edgings to the feathers, especially on the head; below pale tawny, spotted with dusky to a varying extent, sometimes only a fow spots on the breast, sometimes almost completely covered with spots.

A species with very puzzling changes of plumage, but easily recognized in any stage by the cutting out of the three outer primaries only.

Distribution.-Western North America from Alaska and Manitoba south to Arkansas, and west to the Pacific; further south through central and South America as far as the Argentine; north of about $40^{\circ}$ a summer migrant, south of $40^{\circ}$ a resident.

In Colorado, Swainson's Hawk is an abundant resident, perhaps more abundant in summer than in winter, and more frequently met with on the eastern plains than in the mountains, though it is reported to breed up to 10,000 feet in the Wet Mountains by Lowe, at Breckenridge (Carter) and at Crested Butte (Warren).

Other localities are: Weld co., breeding (Dille); near-Limon, breeding (Aiken); El Paso co., March, June (Aiken coll.); Fort Lyon (Thorne apud Fisher); Mesa co., common in summer, resident, but not known in winter (Rockwell); La Plata co., breeding (Morrison).

Habits.-Swainson's Hawk is chiefly a bird of the open prairie or sage-brush country, and is seldom found in heavy timber or in the mountains strictly speaking. It is reputed to be a gentle and unsuspicious bird, and most inoffensive for a Hawk, frequently sharing a nesting tree with a King-Bird or Oriole. Its food consists almost entirely of small rodents, mice and gophers, while in the autumn it preys largely on grasshoppers and locusts, hopping after them across the fields in a rather ludicrous manner. It is occasionally found in large flocks. Aiken saw about a dozen birds, March 11th, 1901, in a tree in one of the chief streets of Colorado Springs. Those he secured were all in the melanistic phase, and he was told that there was a large flock of at least five hundred in the Fountain Valley, just below the town. A similar 
instance was noticed by A. S. Bennett at Lay in Routt co., July 10th, 1889 (Fisher). In this case they were engaged in feeding on locusts.

The nest, according to Gale, is generally placed in a cotton-wood tree, about twenty-five to fifty feet above the ground. It is made of twigs and lined with a little grass or strips of pine bark. The eggs, usually three according to Gale, two according to Bendire, are faintly greenish, and are as a rule very lightly spotted and marked with reddish-brown. They average $2.25 \times 1 \cdot 7$. The old nest is generally occupied year after year. Gale found fresh eggs from May 15th to 30th. Dille gives June 5th.

\section{Genus ARCHIBUTEO.}

Very similar to Buteo, but with the tarsus feathered to the base of the toes ; usually four outer primaries emarginate on the inner web; melanism very common.

A sinall section of the Buzzards, with representatives in the northern parts of the Old and New Worlds; two species in the United States.

\section{KEY OF THE SPEOIES.}

A. Bill smaller and weaker, chord of the culmen and cere about 1.2 ; belly with a patch of black in the normal phase.

A. 1. sancti-johannis, p. 178.

B. Bill stouter and stronger, chord of the culmen and cere about 1.6. thighs rufous with black cross-bands in normal phase.

A. ferrugineus, p. 179 .

\section{American Rough-legged Hawk. Archibuteo lagopus sancti-johannis.}

A.O.U. Checklist no 347a-Colorado Records-Ridgway 73, p. 186 ; Henshaw 75, p.425; Drew 85, p. 17 ; Morrison 89, p. 8 ; Nash 96, p. 15 ; Cooke 97, p. 75 .

Description.-Plumage very variable-in the normal light phase, mingled white, dusky brown and black above, white prevailing on the head, the upper tail-coverts and the inner webs of the primaries above the notch; tail chiefly white, with two or three transverse black bands and a white tip; below mottled white and dusky, sometimes with a 


\section{Ferruginous Rough-leg}

tawny wash, often the black massed across the abdomen. Young birds are very similar, but have the basal half of the tail white, the terminal portion dusky brown with a white tip, while below the brown is chiefly massed across the belly. In the melanistic phase both young and old are entirely deep black, except for the white forehead, the white on the inner webs of the quills above the notch, and some broken. bands on the tail. The two phases are connected by every gradation of intermediate states. Iris brown or yellow, bill bluish-horn, cere and legs yellow, claws black. Length (of a male) 21 ; wing 17.5 ; culmen 1.2 ; tarsus 27. The female is larger-wing 18.0 .

Distribution.-Breeding in the northern North America, from Alaska and Yukon to the lower St. Lawrence Valley; south in winter over the greater part of the United States as far south as Virginia and southern California.

In Colorado the Rough-legged Hawk is not uncomon on the eastern plains, and perhaps in the foothills from November to March, but it has been but little noticed, and definite records are wanting. I have not heard of it on the western slopes. There are several examples in the Aiken collection from El Paso co., one an adult male taken January 15th; and Henshaw also states that he saw several near Colorado Springs in November. Warren informs me that Mr. Hersey shot one near Orchard as late as March 26th.

Habits.-The Rough-legged Hawk is a peaceful and unoffending bird, which preys chiefly on meadow mice or voles of the Arvicoline group in its winter range, and on lemmings in the far north. As the voles are highly destructive to crops and to fruit trees, especially in winter, this Hawk is undoubtedly a most valuable aid to the farmer, and should be most rigidly protected. It is somwehat crepuscular in its habits, and obtains its prey either by watching from a fixed point or beating to and fro, like the Harrier or Marsh-Hawk, over the meadows with slow and noiseless flight.

\section{Ferruginous Rough-leg. Archibuteo ferrugineus.}

A.O.U. Checklist no 348-Colorado Records-Ridgway 73, p. 186; Henshaw 75, p. 425 ; Allen \& Brewster 83, p. 197 ; Drew 85, p. 17 ; Dille 85, p. 44; 87, p. 97 ; 03, p. 74 ; Morrison 89, p. 8 ; Kellogg 90, p. 90 ; Bendire 92, p. 259; Lowe 97, p. 69 ; Cooke 97, pp. 75, 204 ; 
Markman 07, p. 156 ; Richards 08, p. 38 ; Henderson 09, p. 229 ; Warren 10 , p. 30 .

Description.-Normal phase-Above dusky-brown, the feathers edged with tawny-rufous and a little white, more pronounced toward the neck and head; tail white at the base and tip, rest ashy tinged at the edge with tawny; below white, legs and thighs rich chestnut barred with dusky, a few cross-lines of dusky on the belly and shaftlines on the breast; iris yellow to brown, bill bluish-horn, greenishyellow at the base, below and on the cere; legs yellow. Length (of a female), 24.5; wing 18.5; tail 9.75 ; culmen 1.6; tarsus 3.6 . A male is much smaller-wing 16.5. A young bird has less tawny and more white above, and traces of dusky bands on the tail; below pure white including the legs, with few brown spots and streaks here and there.

Dark or melanistic phase sooty-black above and below, except for the under side of the tail-feathers and the bases of the wingquills above the notch on the inner web, where it is white; intermediate forms varied with tawny to a greater or less extent are frequently met with.

Distribution.-Western North America from Saskatchewan to Mexico, and from the Dakotas and Texas to the Pacific; chiefly on the plains and prairies. A resident at least as far north as Colorado.

The Ferruginous Rough-leg, perhaps more commonly known as the Squirrel-Hawk, is is fairly common resident-bird in eastern Colorado on the plains and up into the parks, breeding 'joth in the plains and as high as Breckenridge (Carter), but wintering chiefly in the plains. It does not seem to be common on the western slope, though Warren tells me he saw it in the fall near Crested Butte. Rockwe!l gives no definite information of its occurrence in Mesa co. The following are recorded localities: Estes Park, common (Kellogg), near Boulder (Henderson), Weld co., breeding (Dille), Littleton, near Denver, on Christmas Day (Richards), El Paso co., January and June (Aiken coll.), Limon, breeding (Aiken), near Medano Ranch, July (Warren).

Habits.-This large and powerful Hawk is chiefly a bird of the open plains and prairies, where it gets its living by preying on ground-squirrels or gophers, other small mammals and reptiles; it never seems to kill birds or poultry-perhaps its flight is too sluggish. It builds a very large nest in the branches of a cotton-wood or willow in Colorado, but in localities where trees are scarce it nests on the ground, usually on rocky hillsides 
or on a ledge in the precipitous banks of streams. Dille has taken several nests near Greeley. They are built up of stout sticks, and lined with tufts of grass with the roots still on. The eggs are usually three or four in number and very handsome, being dull-creamy to pale greenish-white, spotted and blotched to a varying extent with lilacs and browns. They average about $2.40 \times 1.95$.

\section{Genus AQUILA.}

Birds of a large size and robust form-wing 24 to 26 ; bill and claws very powerful, the claw of the hind toe the largest, exceeding the outer toe (without claw). In most structural characters resembling Archibuteo, with a fully feathered tarsus. Occiput and nape with lanceolate and acute feathers.

There is onlyone species of the genus in the Americas-the Golden Eagle-while in the Old World there are several others.

\section{Golden Eagle. Aquila chrysaëtos.}

A.O.U. Checklist no 349-Coloracio Records-Allen 72, p. 159 ; Drew 81, p. 141 ; 85, p. 17 ; Allen \& Brewster 83, p. 197 ; Morrison 88, p. 139 ; 89, p. 8 ; Kellogg 90, p. 87 ; Bendire 92, p. 263 ; Lowe 94, p. 267 ; Cooke 97, pp. 75, 204 ; Henderson 03, p. 235 ; 09, p. 229 ; Dille 03, p. 74; Oberholser 06, p. 20; Gilman 07, p. 154; Warren 08, p. 10 ; Rockwell 08, p. 162 ; Warren 09, p. 14.

Description.-Male-Above and below dark sepia-brown, often a litte lighter about the wing-coverts; the feathers at the base of the neck elongated and pointed, and a tawny-fulvous shade; iris brown, bill and claws bluish-horn, cere and feet greenish-yellow. Length 32 ; wing 24.5 ; tail 13 ; culmen 1.9 ; tarsus 3.7 .

The female is larger-wing 25.5 , tail 14. A young bird somewhat resembles the adult, but has the basal half of the tail white, the long neck-feathere hardly differentiated, and a good deal of concealed white on the scapulars, breast and primaries.

Distribution.-The northern portions of the old and New Worlds, in the latter from Alaska to Labrador south of the Barren Grounds, extending southward in western America nearly to Mexico City, and in the east along the Alleghanies to South Carolina, chietly in the mountains.

In Colorado the Golden Eagle is a far from uncommon resident-chielly in the mountains, where it breeds from the foothills up to about 
12,000 feet. It is also found in the mountains in the winter up to about 11,000 feet, and sometimes wanders out on to the plains during this season. Warren informs me that he has seen it near Orchard, where it was said to breed, and also on Irwins Ranch in Las Animas co., where he noticed an old eyrie. Breeding records are: Specimen Mount above Estes Park (Kellogg), Boulder co. (Gale), Wet Mountain, up to 11,000 feet (Lrowe), near Grand Junction (Rockwell), La Plata co. (Morrison). It is not at all uncommon near Colorado Springs in winter, and there are several old eyries still close by, though now deserted.

Habits.-Essentially a bird of the mountains, the Golden Eagle is perhaps more abundant in Colorado than in any other state in the Union. It quickly disappears before civilization, however, and has been destroyed in many parts of the country by poison. It is somewhat wary and shy, and is usually met with in pairs, which are believed to mate for life. It has a harsh and rather shrill scream, and is fierce and untamable though easily kept in captivity.

The Golden Eagle preys chiefly on hares, groundsquirrels and the various grouse. In Colorado it is said to kill a great many lambs of the mountain sheep, and to descend to the plains in winter to pursue the young antelope. It occasionally carries off a lamb or a young calf, while it will freely eat carrion if pressed by hunger.

In California the Golden Eagle generally builds its nest in trees, but in Colorado it always fixes its eyrie in a crevice or on a ledge in a vertical cliff. The nest is built up of sticks and added to year after year, so that it often becomes very bulky; Gale measured one six feet in diameter and nine feet high ; the lining is scanty, of a few smaller twigs or tufts of grass, but a fresh spray of evergreen, either spruce or balsam-fir, is almost invariably found in the nest. The eggs, two or three in number, are ovate and dirty white in ground-colour. The markings vary greatly: sometimes they are wholly 
absent, sometimes the egg is thickly blotched with various shades of brown; in size they average $2.95 \times 2: 3$.

The Golden Eagle is a very early breeder. Gale states that they begin to repair their nests towards the end of February, and fresh eggs are found from March 10th to April 10th. Dille gives March 1st as an average date. Incubation lasts about thirty days, and the male takes no part. Even if robbed, no second brood is raised. In Gale's notes there is a curious notice of finding two fresh eggs on September 3rd, 1893. If the entry is correct, it must have been a quite abnormal occurrence.

\section{Genus HALIFETUS.}

Large birds, wings 22-24, resembling Aquila, but the tarsus only feathered about half way down; a few scutes on the lower half in front, and no web between the middle and outer toes.

About eight species of these Fishing Eagles are known, but there is only one species in the United States.

\section{Bald Eagle. Haliceetus leucocephalus.}

A.O.U. Checklist no 352-Colorado Records-Allen 72, p. 181 ; Drew 85, p. 17 ; Beckham 85, p. 143 ; Morrison 89, p. 65 ; Kellogg 90, p. 87 ; Cooke, 97, pp. 76, 204 ; Henderson 03, p. 235 ; 09, p. 229 ; Rockwell 08, p. 162 ; Warren 09, p. 14.

Description.-Male-Head and neck all round, tail-coverts and tail white; rest of the plumage dark brown of varying intensity; iris, bill and feet yellow. Length 32 ; wing 22 ; tail 11.5 ; culmen 3 ; tarsus 3.4 .

The fernale is lerger-wing 24, tail 12.75. Young birds in the first year are nearly uniform black, but the feathers of the under-parts have white bases which often show. In the second year they are brownish, and there is a good deal of white both above and below; the tail is blackish, blotched with white; iris brown, bill black, feet yellow. The pure, white head and tail are only acquired in the third year.

Distribution.-The whole of North America north of the Mexican border including Lower California, the Aleutidn and Commander Isles and Kamchatka.

The Bald Eagle is not generally so common in Colorado as the Golden, though Sullivan found the former more abundant about Grand Junction in the summer (Rockwell). It breeds more commonly in the mountains 
up to about 10,000 feet, but also in the plains as well, while in winter: it is chiefly met with on the plains. The following are the chief localities noticed : Estes Paxk, rare (Kellogg), Breckenridge, breeding to 10,000 feet (Carter), Manitou, September (Beckham), near Fort Lyon, breeding (Thorne apud Cooke), near Coventry in winter (Warren). It is not represented in the Aiken collection, but there is a mounted specimen in the State Historical collection at Denver, taken by L. Morse, at Orchard, in Morgan co., on December 24th, 1904, and a fine pair in immature dress, killed near Denver by T. Dines and R. Borcherdt, are mounted in the Colorado Museum of Natural History.

Habits.-The Bald or White-headed Eagle is the National Bird of the United States, to which dignity it was elevated June 20th, 1782. In its young dress it is sometimes called the Bird of Washington. It is essentially a fish-eater, and is therefore more at home on the sea-coast and along the banks of the larger rivers than in a dry country like Colorado. It also preys on water-fowl and mammals, and has been known to carry off in its talons a lamb of the same weight as itself, a distance of five miles. Its voice is a loud, harsh scream, and its flight is powerful.

Little has been noticed about its nesting habits in Colorado. Captain Thorne found a nest near Fort Lyon, June 12th, containing two young birds, while Carter found it breeding near Breckenridge. As a rule it builds in trees, though sometimes on ledges in cañon walls. The nest is added to year after year and is a massive struoture of sticks, like that of the Golden Eagle. The eggs, usually two in number, are white, though often nest-stained; they are ovate in shape and average $2.8 \times 2 \cdot 1$.

\section{Genus FALCO.}

Bill rather strong, with a prominent, tooth-like projection on the cutting-edge of the upper mandible; nostrils circular, with a central bony tubercle; wing long and pointed, the ninth and eighth primaries 


\section{Prairie-Falcon}

the longest; the outer only, or the outer two, emarginate on the inner web ; feet rather short, tarsus feathered or bare, without regular scutes.

This genus contains the Falcons and Kestrels, and is found all over the world.

\section{KEY OF THE SPECIES.}

A. Larger ; wing over 11 ; only the outer primary emarginate. a. Clay-brown above; below with dusky, linear spots.

F. mexicanus, p. 185.

b. Slaty-blue above; below transversely banded with dusky.

F. p. anatum, ad., p. 187.

ت. Blackish, edged with tawny above; below streaked with dusky. F. p. anatum, juv., p. 187.

B. Smaller, wing under 10 ; the two outer primaries emarginate.

a. Tarsus scarcely as long as the middle toe without claw; without vertical black stripes on the face.

a Tail with traces at least of four black transverse bands, including the broader subterminal one; no white spots on the outer webs of the primaries. F. columbarius, p. 188.

$b^{1}$ Tail with traces of five black transverse bands; outer web of primaries spotted with white. F. c. richardsoni, p. 189.

b. Tarsus very clearly exceeding the middle toe without claw; face with two vertical black stripes.

$a^{1}$ Smaller and more highly coloured. F. sparverius, p. 190.

b1 Larger and peler coloured. F. s. phalœna, p. 192.

\section{Prairie-Falcon. Falco mexicanus.}

A.O.U. Checklist no 355-Colorado Records-Henshaw 75, p. 410 (F. lanarius polyagrus); Coues 77, p. 26 ; Scott 79, p. 96 ; Allen \& Brewster 83, p. 197 ; Drew 85, p. 17 ; Dille 87, p. 97 ; Morrison 89, p. 65 ; Kellogg 90, p. 87 ; Lowe 94, p. 267 ; Cooke 97, p. 76 ; Henderson 03, p. 235, 09, p. 229 ; Gilman 07, p. 154 ; Richards 09, p. 164.

Description.-Male-Above pale clay-brown, tinged with rusty and indistinctly barred with pale buffy anteriorly, and pale bluish-grey posteriorly; a white nuchal collar and dark patches on the side of the face; primaries ashy-brown, with paler tips and whitish bars on the inner webs only, the outer one only with the inner web cut out; below white, marked most hervily on the flanks, less so on the belly, with dusky, linear spots; throat unmarked; iris brown, bill bluish-horn, yellow at the base; cere and feet yellow. Length 17.0; wing 12 ; tail 7.25 ; culmen .8 ; tarsus 2.1 .

The female is larger-wing $13 \cdot 5$, tail $8 \cdot 2$-and has a more uniform appearance above without the lighter bars. Young birds have more 
fulvous above, and are more heavily spotted below, while the white of the under-parts is distinctly tinged with ochraceous.

Distribution.-Western North America from southern British Columbia and western Manitoba, south to central Texas, and thence west to the Pacific.

The Prairie-Falcon is a moderately common bird in Colorado, chiefly perhaps on the eastern plains, but found also in the mountains, oocasionally even up to timber line where Kellogg observed one above Estes Park. Cooke classes it as a resident, but the greater number of the birds doubtless go south in winter, and I have not been able to find any winter dates for Colorado. The following are the chief records : Pawnee Buttes in Weld co., breeding (Dille), Boulder co., breeding (Gale), Deer Creek, near Littleton, nesting (Richards), El Paso co. (Aiken coll.), Twin Lakes, rare (Scott), Wet Mountains up to 10,000 feet (Lowe), near Fort Lewis, rare (Gilman).

Habits.-The Prairie-Falcon or American Lanner is a noble bird, chiefly met with on the open plains, where it may be seen perched on a high cotton-wood or a telegrapb pole, on the look-out for its prey. This consists of jack-rabbits, prairie-dogs and other mammals, as well as birds of moderate size, such as the Mourning Dove and Blackbird. It is strong, bold and tenacious of life, and its flight is easy and very rapid. Dille found a nest on the top of a ohimney of sandstone in some buttes in the north of Weld county, on May 25th; it was an immense pile of rubbish, with skeletons and dead animals scattered round, and contained only one egg. Gale took four eggs of this species from an old eagle's nest on April 24th, in a cliff on the Little Thompson River, the situation was about fifty feet from the bottom, and thirty feet from the top of the cliff; he also found another nest in a similar position on the St. Vrain. The eggs are oval and rather light-coloured for Faloon's eggs. The ground-colouring is creamy-white, rather heavily blotched with various reds and browns. In size they average $2.2 \times 1 \cdot 6$, and the clutch numbers three to five. 


\section{Duck-Hawk. Falco peregrinus anatum.}

A.O.U. Checklist no 356a-Colorado Records-Allen 72, pp. 152, 158 ; Drew 85, p. 17 ; Morrison 89, p. 65 ; Kellogg 90, p. 90 ; Cooke 97, pp. 18, 76, 160 ; Henderson 03, p. 235 ; 09, p. 229.

Description.-Female-Above slaty-blue, varying from dark to light; most of the feathers with paler edges; the dark slate extends below the eye, forming a moustache patch; primaries marked on the inner web with pale reddish or tawny bands; tail barred dusky and silvery grey, and tipped with whitish; below pale tawny-rufous, posteriorly from the breast closely and regularly barred with dusky; iris brown, bill bluish-horn, base and cere yellowish, feet yellow. Length 18 ; wing 13.7 ; tail 7 ; culmen 1.1 .; tarsus 2.2 .

The male is amaller-wing $12 \cdot 5$, tail $6 \cdot 5$. A young bird is blackish above and has most of the feathers edged with tawny*rufous, darker than the adult, and streaked, not barred, with dusky.

Distribution.-The greater part of the New World, from Alaska and Labrador south to Chili and the Argentine.

In Colorado the Duck-Hawk can hardly be called common, though it is not infrequently met with in suitable localities. It is placed by Cooke among the residents, but I have not found any definite winter record for it, and it is certainly chiefly met with during the summer months. It is not recorded from the western or southern districts of the State, though there is no reason why it should not be found there. The following are localities: Loveland, arriving March 29th (W. G. Smith), Estes Park, rare (Kellogg), Boulder co. (Gale \& Henderson), Fairplay (Allen), Garden of the Gods, near Manitou breeding (Aiken), St. Charles Cañon, near Pueblo, breeding (Lowe apud Cooke).

Habits.-The Duck-Hawk is hardly to be distinguished from the Peregrine Falcon of the Old World, which was formerly esteemed the noblest of its kind. Its flight is marvellously rapid, and it can overtake swiftflying ducks with the greatest ease. It prefers timbered lands along streams and cliffs and rocky places, where it builds its nest. It preys almost exclusively on other birds, especially water-fowl, but Blackbirds and Doves are sometimes taken, while destructive inroads are often made on poultry and domestic ducks. In fact, it is one of the few birds of prey in whose favour little can be said. 
But few details have been noted about its nesting-habits in Colorado, except that it makes use of crevices and ledges in high cliffs and cañon walls. Some notes by Gale, quoted by Bendire and Cooke for this species, refer, according to Gale's notebook, to the Mexican Falcon, and not to this species. The eggs are deposited about the middle or end of April on a bare ledge, with little or no nest. They are three or four in number, and are generally short, rounded and ovate. They vary considerably in colour and markings, the ground-colour, when visible, being creamy-white, sometimes blotched and streaked, sometimes entirely overlaid, with reddish and sepia browns. In size they average $2 \cdot 1 \times 1 \cdot 6$.

\section{Pigeon-Hawk. Falco columbarius.}

A.O.U. Checklist no. 357-Colorado Records-Ridgway 73, p. 186 ; Drew, 85, p. 17 ; Morríon 88, p. 115 ; 89, p. 65 ; Kellogg 90, p. 87 ; Fisher 93, p. 109 ; Lowe 94, p. 267 ; McGregor 97, p. 38 ; Cooke 97, p. 76 ; Rockwell 08, p. 163.

Description.-Adult Male-Above bluish-slate, most of the feathers with a black shaft-line; quills dusky, with white spots along the inner webs only; tail like the back, with four transverse black bands more or less completely developed, the terminal one much broader than the others and tipped with white; below white, washed with tawny posteriorly, the throat plain, the rest longitudinally streaked with sepia-brown; sides of the face bluish and streaked; iris brown, bill bluish-black, base and cere yellowish, legs yellow. Length 11.5; wing 7.7 ; tail 4.5 ; culmen .55 ; tarsus 1.4 .

The female is dusky brown above, and the tail is like the back, but crossed by four narrow, sometimes nearly obsolete, whitish bands the uppermost often concealed by the coverts; below as in the male, but often more fulvous and the streaking heavier; wing 8.5. Young birds resemble the female, and this is the plumage most generally met with, as adult males are not often seen.

Distribution.-The whole of North America, breeding chiefly north of the United States, but south of the boundary along the higher elevations of the Cascades, Rockies and Alleghanies; south in winter to the West Indies and northern South America.

In Colorado the Pigeon-Hawk is by no means a common bird, and is chiefly met with on migration, though a few birds remain to breed in the 
mountains and a few perhaps stay out the winter. Rockwell saw an example on Plateau creek in Mesa co. at about 6,000 feet, December 23rd, 1901. Other notices are : Estes Park, not uncommon (Kellogg), Denver (McGregor), El Paso co., May (Aiken coll.), Wet Mountains to 8,500 feet (Lowe); Fort Lewis, breeding (Morrison).

Habits.-The Pigeon-Hawk is a bold little bird, and represents the Merlin of Europe. It preys chiefly on other birds, often successfully attacking those larger than itself, such as Mourning Doves, Flickers and Grackles. In the summer it catches large numbers of insects, especially dragon-flies and grasshoppers. Cooke stated that it breeds from the plains to about 9,000 feet, but the only account of its nesting in Colorado, which I have met with, is that of Morrison, who took a set of five eggs, June 3rd, 1887, near Fort Lewis. The nest was in a clump of alders about eight feet up, and was composed of small twigs loosely put together, and lined with dry grass and a few feathers.

Bendire states that the nest is sometimes an open one in a spruce or other tree, sometimes placed in a hollow limb, and at other times on ledges of cliffs or bluffs. The eggs, generally four in number, are creamywhite, blotched or sometimes wholly suffused with reddish-brown, and measure $1^{1} 6 \times 1^{1.25}$.

\section{Richardson's Pigeon-Hawk. \\ Falco columbarius richardsoni.}

A.O.U. Checklist no 357b-Colorado Records-Ridgway 73, p. 186 ; Coues 74, p. 347; Allen \& Brewster 83, p. 197 ; Drew 85, p. 17 ; Morrison 89, p. 65 ; Goss 91, p. 286 ; Lowe 94, p. 267 ; Cooke 97, p. 76 ; Henderson 09, p. 229 ; Hersey \& Rockwell 09, p. 117.

Description.-Resembling $F$. columbarius, but lighter in colour, and the tail with five almost white bands alternating with five black bands, the broader terminal black one tipped with white; the primaries distinctly spotted on the outer webs. Dimensions the same.

The female and young male are quite different from the corresponding stages in the type species. Above earthy-brown, each feather with a 
dark shaft-line and a tawny to whitish edging; tail with five dark and five narrower white bands, the terminal band of black tipped with white; below white, faintly washed with ochraceous and streaked with brown, except on the throat.

Distribution.-Western North America from southern British Columbia and the Saskatchewan south to the Mexican border, east to the Mississippi, west to the Pacific.

In Colorado this subspecies appears to be a resident, having been met with in both winter and summer, though no authenticated instance of its nesting is known. It probably nests in the mounteins and winters in the plains, but it is quite a rare bird and doubtless has been frequently confused with the Pigeon-Hawk.

The only definite local records are : Silver Lake, Boulder co, 10,000 feet, September (Henderson), Berthoud's Pass (Ridgway), Barr Lake (Hersey \& Rockwell), El Paso co., January, November (Aiken coll.), Wet Mountains at 8,000 feet (Lowe).

Habits.-So far as is known, this little Falcon in no way differs from the Pigeon-Hawk in its habits.

\section{American Sparrow-Hawk. Falco sparverius.}

A.O.U. Checklist no 360-Colorado Records-Baird 54, p. 12 ; 58, p. 13 ; Allen 72, pp. 152, 159 ; Henshaw 75, p. 413; Scott 79, p. 96 ; Tresz 81, p. 187 ; Drew 81, p. 141 ; 85, p. 17 ; Allen \& Brewster 83, p. 197 ; Beckham 85, p. 143 ; 87, p. 124 ; Morrison 88, p. 115 ; 89, p. 65 ; Kellogg 90, p. 87 ; Bendire 92, p. 309 ; Lowe 92, p. 101 ; 94, p. 268 ; 04,p. 276 ; Cooke 97, pp. 18, 76, 204 ; Henderson 03, p. 235 ; 09, p. 230 ; Dille 03, p. 74 ; Warren 06, p. 20 ; 08, p. 21 ; Gilman 07, p. 154 ; Markman 07, p. 156 ; Hersey \& Rockwell 09, p. 117.

Description.-Male-Centre of the crown, back, scapulars and tailfeathers, except the outermost, rich rufous, the back with a few transverse bars of black; a ring round the crown and the wing, except the primaries, slaty-blue, the latter with black spots; nape pale rufous, with a black central patch and three others paired on either side of the face ; primaries black, with white indentations on the inner web; tail with a broad, black terminal band tipped with white, outer pair of tailfeathers chiefly white, barred with black; below white, washed with tawny on the chest and with a few small dusky spots chiefly on the flanks; iris brown, bill bluish-horn, cere and legs yellow. Length 10.5 ; wing 7.4 ; tail 5.0 ; culmen .6 ; tarsus 1.45 .

The female has the whole back, tail and wings transversely barred with rufous and dusky; the indentations on the primaries are tinged with tawny, and the lower parts white, streaked with pale sepia-brown 
on the fore-neck and breast only; wing 7.75. A young male is like the adult male, but is rather darker rufous, has hardly any black spots on the wings, and has a tawny tip to the tail instead of white; below the spots are larger and more conspicuous, though hardly more numerous, A young female is slightly darker rufous above, and has the bars blacker and the crown-patch with black shaft-marks.

Distribution.-From Alaska, Hudson Bay, and Newfoundland southwards, east of the Rocky Mountains to northern South America; repleced west of the Rockies by $F^{\prime}$. 8. phalcena, if really distinguishable.

In Colorado the Sparrow-Hawk is perhaps the commonest of all the raptorial birds, breeding in the plains and mountains up to about 10,000 feet. It is chiefly a summer migrant, arriving towards the end of March; near Colorado Springs, Maroh 26th (Aiken), Loveland, March 21st (W. G. Smith), and leaving again late in October. A few winter in the south of the State and even as far north as Boulder (Henderson) and Barr (Hersey) ; Lowe (01) saw two on Januery 14th, near Beulah.

The following are breeding records : Boulder co. (Gale), Twin Lakes (Scott), Garden of the Gods, near Manitou (Allen), Wet Mountains to 10,000 feet (Lowe), Salida (Frey).

Habits.-The Sparrow-Hawk spends most of his time on a fence-post or telegraph pole, watching for his prey, which consists almost exclusively of grasshoppers and beetles; occasionally small birds and mice are taken, but 215 out of 320 stomachs examined by Fisher contained only insects. Sometimes he hovers over a field or meadow; then darts suddenly down and seizing the victim, retires to a convenient perch to devour it.

Like so many other insect-eating birds, the SparrowHawk goes high up above timber line in late summer, to feast on the grasshoppers there.

In most cases the Sparrow-Hawk utilizes the old holes of Flickers and other Woodpeckers for its eggs. Sometimes it uses a natural hole in a stub or tree; sometimes the crevices and cracks in rocks, as in the Garden of the Gods. Gale found it breeding on the bottom of an old Flicker-hole-it was flat and hard, and there was no nest 
beyond a few weed stems; he found the eggs, four to six in number, arranged in two rows with a space between, and believed the bird rests on the solid floor and covered the two rows underneath her wings. The same site is frequently used, year after year. One brood seems usual, though if robbed, a second or third set of eggs may be deposited. Both birds incubate. Gale found fresh eggs from May 12th to June 10th, while Dille gives May 1st as an average date. A set of five eggs, taken by I. C. Hall, May 20th, 1902, at Greeley, and presented by him to the Colorado College Museum, are whitish ovals, suffused and thickly dotted and blotohed with dark rufous. They average $1.38 \times 1 \cdot 15$, but there is much variation in shape and markings.

Desert Sparrow-Hawk. Falco sparverius phalcena.

A.O.U. Checklist no 360a-Colorado Records-Cooke 97, p. 205 (F. s. deserticolus); Rockwell 08, p. 163 ; Warren 09, p. 14. Some of the records under $F$. sparverius may refer to this subspecies.

Description.-Very close to F. sparverius but larger, and with a relatively longer tail and paler rufous coloration. In the female the streaks are more numerous and more yellow below; the bars on the upper-surface are narrower, and those of the tail often incomplete.

Distribution.-This subspecies, which seems to be hardly distinguishable from the typical form, is found throughout western North America, from British Columbia to Guatemala and east to the Rocky Mountains.

Cooke found that some of the Sparrow-Hawks in the Carter collection obtained in the Middle and South Parks, were more nearly allied to this subspecies, and probably all the birds taken on the westerr slope should be so referred, if the distinction between the two forms can be maintained. I have examined a male taken near Yampa in Routt co., and a female from Sulphur Springs, both in the Warren collection, and cannot certainly distinguish them from those taken in El Paso cs.

\section{Family PANDIONID}

Feathers without after-shafts ; outer toe reversible.

\section{Genus PANDION.}

Bill strongly hooked, but without any tooth or notch on the edge of the upper mandible; nostrils oval and oblique; wings very long and 
pointed, the eighth and ninth primaries the longest; tail short, less than half the wing; feet large and strong; tarsus very little feathered; toes free to the base, covered with rough, granular, reticulate scales.

The genus contains only one almost cosmopolitan species, which has recently been divided into a number of local races, or $\theta$ of which is found throughout North America.

\section{American Osprey. Pandion haliaëtus carolinensis.}

A.O.U. Checklist no 364-Colorado Records-Ridgway 73, p. 186 ; Scott 79, p. 96 ; Drew 85, p. 17 ; Morrison 89, p. 66 ; Cooke 97, pp. 18, 77, 160, 205; Rockwell 08, p. 163 ; Hersey \& Rockwell 09, p. 117.

Description.-Male-Above dark brown, blackish on the quills; tail with darker cross-bars and tipped with white; the inner webs of all but the central feathers barred with white and dark, but these disappearing with age; head, neck, and under-parts white; the centre of the crown and a postocular patch dark-brown; breast slightly spotted with brown ; iris yellow, cere, bill and claws bluish-black, legs greyish-blue. Length 22.0 ; wing 19.0 ; tail 7.5 ; culmen 1.5 ; tarsus 2.3 .

The female is larger-wing about $20 \cdot 5$, and the chest is more heavily spotted with brown. Young birds are darker than the adults, and are mottled with white or buffy edges to the feathers above, and the tail is more regularly barred.

Distribution.-The whole of the United States north to Labrador, Hudson Bay and Alaska, south to northern South America; a summer visitor only, north of the middle states.

The Osprey is a not uncommon bird in suitable localities in Colorado, but naturally in a dry and somewhat arid country it is not numerous. It is a summer visitor, arriving from the south early in April-Loveland, April 8th (W. G. Smith)-and nesting in the mountains up to about 9,000 feet. The following localities have been noticed-Barr, not uncommon during migration (Hersey \& Rockwell), Twin Lakes, nesting (Scott), Blue River, nesting up to 8,500 feet (Carter), Salida, April (Frey), Sweetwater Lake, common in spring and summer (Gilman apud Cooke), Grand River, near Grand Junction, occasionel (Rockwell), La Plata co. (Morrison).

Habits.-The Osprey, generally known as the FishHawk, is a gentle bird and never molests other species. It even allows Grackles and other birds to build in the interstices of its nest. Its food consists entirely of fishes, which it captures for itself, hovering above the water and descending at an angle with great velocity on its 
victim, and often plunging under the surface. The structure of its feet, the reversible inner toe, the gianular, rough soles, the claws of equal length, all strongly curved, are all adapted to the capture of fishes. It is frequently robbed by the larger and stronger Bald Eagle of its hardly-earned prey.

The nest is generally placed in a tree and is used year after year, so that it becomes a very bulky structure. It is built up of sticks with various kinds of rubbish added to it. The eggs, usually three in number, are very handsome, varying very much in shape and markings. The ground-colour is creamy-white and this is marked with various shades of brown, sometimes so heevily as to conceal the ground-colour. They average $2.45 \times 2.0$. Morrison found fresh eggs at the end of April, while Scott thought eggs were laid about June 13th, as the female was constantly on the nest after this. These are the only two dates I have found for Colorado.

\section{ORDER STRIGES.}

This order, containing the nocturnal birds of prey or Owls, is easily distinguished by the following external characters.

Head very broad from side to side, and the feathers arranged to form a ruff or facial disk, radiating outwards from the eyes on either side; bill with a basal, soft-skinned cere, at the edge of which open the nostrils; the base of the bill concealed to a great extent by the feathers of the facial disk; edge of the bill never lobed or hooked; eyes forwardly directed, and very large; ear-opening often very large. and provided with an operculum or movable flap, those of either side often quite asymmetrica and sometimes causing asymmetry in the skull 
itself; tarsus and toes feathered, or at any rate covered with bristles; hind toe jointed on the same level as the others.

\section{Key of the Famitifs and Genera.**}

A. Claw of the middle toe serrate on the inside edge, middle and inner toes approximately equal (Aluconides). Aluco, p. 196.

B. Claw of the middle toe not serrate ; middle toe always exceeding inner toe (Strigidoe).

a. Ear-tufts present and generally conspicuous.

$a^{3}$ Large; wing over 14; tail nearly concealed below by the lengthened under tail-coverts.

Bubo, p. 208:

$b^{1}$ Medium; wing 10 to 12 ; tail-coverts not abnormally long; toes feathered to the claws.

Asio, p. 197:

$\mathrm{e}^{1}$ Small ; wing under 8 ; toes bristly or naked. Otus, p. 204.

b. Ear-tufts absent.

$a^{1}$ Larger; wing over 12.

$a^{2}$ Bill concealed by frontal feathers; plumage chiefly white .

$b^{2}$ Bill yellow, not concealed; plumage not white.

Nyctea, p. 210.

$b^{\text {I }} \quad$ Medium; wing 6 to 8 .

Strix, p. 200.

$a^{2}$ Tarsus hardly exceeding the middle toe without claw; toes densely feathered. Cryptoglaux, p. 202.

$b^{2}$ Tarsus about twice the length of the middle toe without claw ; toes bristly, not feathered.

Speotyto, p. 211.

$c^{1}$ Small; wing under 4; nostrils well within the swollen cere ; toes bristly.

Glaucidium, p. 213.

\section{Family ALUCONID王.}

This family, containing the Barn-Owls, is distinguished externally from the other Owls by having the claw of the middle toe pectinate or serrated along its inner side, and the middle and inner toes about equal in length. Anatomically the sternum is entire - not notched posteriorly and the clavicles or furculum are anchylosed to the sternum.

\footnotetext{
- The names of the families of most of the genera have been changed in accordance
} with the new A.O.U. Checkliat. 


\section{Genus ALUCO.}

Bill lengthened, rather compressed; facial disk well developed and rather triangular in shape; no ear-tufts or plumicorns; wings long and pointed, reaching beyond the tail when folded; tail short and nearly even; tarsus long, about twice the middle toe without claw, closely fenthered above, but becoming rather bristly below.

A cosmopolitan genus with one North American species, closely related to the European stock form.

\section{American Barn-Owl. Aluco pratincola.}

A.O.U. Checklist no 365-Colorado Records-H. G. Smith 96, p. 76 ; 09, p. 185; Cooke 97, pp. 77, 160, 205 ; Henderson 03, p. 235 ; 09, p. 230 ; Gilman 07, p. 154; Betts 10, p. 218 ; Bergtold 10, p. 207.

Description.-Female-Above tawny-yellow, very finely mottled and marbled with ashy and white, with traces of dark bars on the tail; facial ruff whitish, stained with claret-brown, bordered with rustybrown, especially in front of the eye; below white to tawny-white, dotted with brown spots; plumage very variable; iris brown, bill pearly-white, feet dirty yellow. Length 17 ; wing 13.5; tail 5.5; culmen $1 \cdot 1$; tarsus $3 \cdot 4$.

The male is smaller-wing 12.75. Young birds after losing their nestling-down are like the adults.

Distribution.-The middle and southern United States, from about New England, Colorado and Oregon south to Mexico. Very closely allied species or geographical races are found throughout the rest of America and all over the Old World.

In Colorado the Barn-Owl is a rare bird. It has chiefly been met with in the south of the State, and is probably a resident, though not known to breod. It was first recorded by H. G. Smith from an example taken in the Town Hell of South Denver. Subsequent notices are: Denver, a second time (H. G. Smith), Boulder co. (Betts), Kit Carson co. (Bergtold), Pueblo, three occasions, Wet Mountain Valley and Rocky Ford (Cooke), Holly (H. G. Smith), Fort Lewis and Mancos (Gilman).

Habits.-The Barn-Owl is one of the most beneficial of the rapacious birds; it feeds almost entirely on the smaller rodents, such as field-mice and gophers, which from their great numbers and destructive habits are a curse to the agriculturist. Like other Owls, this species swallows its prey whole, and afterwards rejects the skin and bones and indigestible parts in the form of pellets. An examination of these reveals its utility. 


\section{American Long-eared $0 \mathrm{wl}$}

The Barn-Owl is the most distinctively nocturnal of its tribe, and spends the day in a hollow tree, a dark nook or crevice, or often in barns or outhouses. It never hoots, but sometimes utters a harsh scream or makes a loud snoring noise. The nest is placed in cavities of trees, holes in banks and among rocks, or often, when these are available, in towers, buildings or barns. The eggs are often laid on an accumulation of debris, and little or no regular nest is made. They are usually four to seven in number, ovate, dead white, and measure $1.65 \times 1.25$.

\section{Family STRIGID压.}

This family, containing all the other Owls, has no serration on the claw of the middle toe, which is always longer than the inner one; the sternum is always notched once or twice on each side behind, and is never joined to the furculum, which is often defective or rudimentary.

\section{Genus ASIO.}

Bill rather weak; cere somewhat inflated with the nostrils at the edge; facial disk circular and well developed; ear-tufts present; wings long; tail about half the length of the wing; legs festhered to the claws; ear-openings very large, asymmetrical and provided with a movable operculum for their whole length.

An almost cosmopolitan genus with about twelve species; only two in the United States.

A. Ear-tufts long, over an inch. A. wilsonianus, p. 197.

B. Ear-tufts small and inconspicuous, under an inch.

A. flammeus, p. 199 .

American Long-eared Owl. Asio wilsonianus.

A.O.U. Checklist no 366 -Colorado Rocords-Baird 54, p. 12 ; 58, p. 53 ; Drew 81, p. 141 ; 85, p. 17 ; Allen \& Brewster 83, p. 197 ; Dille 86, p. 15 ; 03, p. 74 ; Morrison 87, p. 107 ; 88, p. 115 ; 89, p. 66 ; Cooke 97, pp. 77, 205; Henderson 03, p. 235; 09, p. 230; Warren 06, p. 20 ; 10, p. 31 ; Gilman 07, p. 154 ; Rockwell 08, p. 163.

Description.-Adult-Above finely mottled dusky-brown and white with a little tawny, especially about the centre of the back; facial disk yellowish-black around the eye, framed by a black line mottled with 
white; ear-tufts long, over an inch, and conspicuous; quills barred brown and mottled grey, which becomes tawny basally; tail also barred; below confusedly marked with brown, white and tawny with irregular streaks and bars; almost plain tawny on the feet and under tail-coverts; iris yellow, bill and claws blackish. Length 13.5 ; wing 11.5 ; tail 6.0 ; culmen 1.0 ; tarsus 1.5 . Variable in size, but the female averages a little larger.

Distribution.-North America from Hudson Bay and Mackenzio south over the whole of the United States to the Mexican tableland. The Long-eared Owl is one of the commonest resident Owls in Colorado, breeding from the plains up to about 10,000 or 11,000 feet, and wintering also in the plains and mountains. It has been reported from Weld co. (Dille) to Baca co. (Warren) in the eastern plains; from the mountains of Boulder co. (Gale) to the San Luis Valley (Baird \& Warren) in the mountains and parks, and from Mesa co. (Rockwell) to La Plata co. (Morrison) on the western slope, and probably breeds throughout.

Habits.-The Long-eared $\mathrm{O} w \mathrm{l}$ is a thoroughly nocturnal species, hunting only at night and keeping quiet in retired nooks by day, so that it is seldom noticed. Its food consists almost entirely of small rodents, chiefly field-mice, and it is a most beneficial species and should never be destroyed. It is rather silent for an Owl, but has a gentle hoot in the spring time; if disturbed when nesting it generally makes a chattering, snapping noise with its mandibles, and it also gives a mournful cry. Its favourite resort in Colorado is in the thickets of willows along the creek bottoms.

Morrison, Dille (86) and Gale give good accounts of the nesting-habits. It seldom builds a nest for itself, generally using in Colorado an old Magpie's nest, tearing off the dome and adding a little grass and feathers for a lining. It also makes use of Crows' or Hawks' nests, and occasionally builds one for itself. The eggs are laid from about April 15th to May 15th. Fresh eggs found later than this are a second laying, due to the loss of the first. Morrison noticed that four to six eggs were the rule at low elevations, three at about 8,500 feet, 
while two nests found at 10,500 feet only contained two eggs. These are oval in shape, white in colour and measure $1.55 \times 1.25$.

Warren found a pair with a young one at Sand Creek, near Medano Ranch, June 24th, at an old Magpie's nest.

\section{Short-eared Owl. Asio flammeus.}

A.O.U. Checklist no 367-Colorado Records-Ridgway 79, p. 231 (Otus brachyotus); Beckham 85, p. 143 (A. accipitrinus); Thorne 87, p. 264 ; Morrison 88, p. 115 ; 89, p. 66 ; H. G. Smith 96, p. 76 ; Cooke 97, pp. 77, 205 ; Henderson 03, p. 235 ; 09, p. 230 ; Rockwell 08, p. 163.

Description.-Female-Above variegated with dusky brown, pale tawny and white, the markings chiefly streaks, with barring on the wings and tail; below the breast streaked like the back; posteriorly white, finely streaked with brown on the lower-breast and flanks; immaculate on the legs, abdomen and under tail-coverts; facial disk whitish, becoming black round the eye; ear-tufts small and inconspicuous, under an inch; iris bright yellow, bill and claws dusky bluish-horn. Length 14.5 ; wing 12 ; tail 6.0 ; oulmen .9 ; tarsus 1.6 .

The males average a jittle smaller. Young birds are rather darker and have a black face.

Distribution.-The whole of America from Alaska and Mackenzie to Patagonia, except the West Indies; and in the Old World throughout Europe, Asia and northern Africa. In North America it breeds chiefly north of the United States boundary, and is a rare resident south of this, though fairly abundant in winter, when its numbers are reinforced. from the north.

In Colorado the Short-eared or Marsh-Owl is chiefly a winter visitor, found most abundantly in the plains, but extending up into the parks, even as high as Breckenridge, where it was found by Carter in winter. The only writer who alludes to its nesting in the State is Morrison. He reports that it breeds in the south-western and south-eastern portions. It is known to nest in Nebraska and Kansas. All other records are winter ones, viz. Niwot, March, and Longmont, December (Rockwell apud Henderson), Denver, winter (H. G. Smith), Orchard, March 28th (Warren), Pueblo, April (Beckham), Fort Lyon (Thorne), Mosca, January 22nd (Warren), Mesa co., winter (Rockwell), Fort Lewis, February (Morrison).

Habits.-The Short-eared Owl is often seen abroad in day time, especially on cloudy days, and is much less nocturnal than the Long-eared Owl. It prefers the 
open country where there is water with high grass and bushes, among which it lurks. It is a silent bird, but if disturbed utters a few mournful cries, and chatters with its mandibles. It preys chiefly on mice and other small rodents, occasionally on small birds and insects.

The nest is a rough affair of coarse grass and sticks, sparsely lined with finer material and feathers. It is placed on the ground, usually sheltered and hidden by a tuft of grass or by a bush. The eggs, four to seven in number, are white in colour and ovate in shape, and average $\mathbf{1 . 5 5} \times \mathbf{1} \cdot \mathbf{2 5}$. Morrison states: "Begins laying in April. Eggs four or five. Nest on the ground on open prairie, or more commonly upon mesas under a clump of scrub-oak, or bunch of high grass or sage-brush." He does not implicitly say that he himself found a nest.

\section{Genus STRIX.}

Of moderate size; wing 12-14; bill yellow, nostrils at the edge of the small cere; facial disk complete and large; no ear-tufts ; earopenings large, somewhat asymmetrical with a moderate operculum, scarcely extending the length of the opening; wing rounded, not twice the length of the tail; tarsus always completely feathered; toes wholly or partly so.

A large genus, chietly in the northern hemisphere, with two distinct United States species and several local races.

A. Larger ; wing generally over 13 ; abdomen streaked with dark brown.

S. varia, p. 200 .

B. Smaller; wing generally under 13; abdomen transversely barred with brown.

S. occidentalis, p. 201 .

\section{Barred Owl. Strix varia.}

A.O.U. Checklist no 368-Colorado Records-Aiken 00, p. 298 (Syrnium rebulosum): Cooke 97, p. 205; Henderson 07, p. 19S; 09 , p. 230.

Description.-Above dark brown irregularly barred and spotted with buffy, whitish and yellowish-brown; wings and tail banded; head, neck and breast widely barred with dark brown and white or buffy; belly streaked with dark brown on a whitish or buffy ground; facial 
disk in a frame of black and white; blackish round the eye, obscurely ringed with black and white ; iris blackish, bill dull yellow, claws hornyyellow. Length 19.2 ; wing 13.25 ; tail 9.0 ; tarsus 2.2 .

Young birds are barred throughout except the wing and tail quills, which are as in the adult.

Distribution.-From Newfoundland and Manitoba south to Georgia and Texas, west to Nebraska and Kansas; a resident except towards its northern limits.

The Barred Owl is a rare straggler in Colorado. The only record is that of B. G. Voight, who, reports Aiken, found a pair breeding at Holyoke, in the north-east of the State near the Nebraska line, in March, 1897. One of the birds and two eggs were secured. Gale believed that he saw a pair in the Boulder Valley in 1886, but gives no particulars.

Habits.-The Barred Owl or Hoot-Owl frequents heavy timber in swampy tracts or near water-courses. It is nocturnal as a rule, though occasionally seen abroad in cloudy weather, and has a very loud, weird and unearthly hoot. Its nest is usually placed in a hollow tree, though sometimes the old nest of a Hawk or Crow is made use of. The eggs, two to four in number, are oval in shape, white in colour, and average $2.00 \times 1 \cdot 70$.

\section{Spotted Ow1. Strix occidentalis.}

A.O.U. Checklist no 369-Colorado Records-H. G. Smith 86, p. 284 ; Morrison 89, p. 66 ; Cooke 97, p. 77 ; Gilman 07, p. 154.

Description.--Resembling $S$. varia but smaller, and the head and neck coarsely spotted, not barred, with white; wing-quills spotted with pale brown and whitish, and broadly tipped with whitish; below, whitish, barred throughout with brown, with streak-marks on the belly. Length 19 ; wing 12 to 13 ; tail 8.5 to 9.0 ; culmen .9 .

Distribution.-From Southern California, Arizona and Colorado south to Lower California and Guanajuato on the Mexican tableland.

The occurrence of the Spotted Owl in Colorado rests on rather indefinite $\theta$ vidence. Mr. Aiken informs me he examined and identified. a specimen brought to him some years ago, killed near Colorado Springs. Gilman states that he observed two examples near Fort Lewis in spring, and Brunner writes me that he saw in the summer of 1907 an Owl of this species on the south fork of the Trinchera Creek in Costilla co. 


\section{Genus CRYPTOGLAUX.}

Resembling Strix but much smaller-wings 7 to 8 -and with both skull and ear-openings highly asymmetricel; the ear-openings very large and operculate; legs densely feathered to the bases of the claws.

Two species are recognized; one of circumpolar distribution with an American subspecies, the other confined to North America.

A. Larger-wing 7; bill yellow'; head spotted with white.

C. f. richardsoni, p. 202.

B. Smaller-wing under 6 ; bill black; crown with white shaftlines.

C. acadicus, p. 202 .

\section{Richardson's Ow1. Cryptoglaux funerea richardsoni.}

A.O.U. Checklist no 371-Colorado Record-Cooke 97, pp. 160, 205.

Description.-Above chocolate-brown spotted with white; spots small and profuse on top of the head, on the nape larger and almost forming a nuchal collar, on the back and wing-coverts large and sparse; below whitish, hesvily and somewhat confusedly streaked with dark brown; flanks and feet buffy, more or less spotted with brown; facial disk whitish, black round the $\theta y \theta$; iris and bill yellow. Length 11 ; wing 7 ; tail 4.5 ; tarsus 1.0 .

A young bird is plain brown without spots except on the wings and tail; below brown, paling to yellowish-brown posteriorly; flanks slightly spotted; facial disk dark, with a white superciliary and malar streak.

Distribution.-Breeding north of the United States border up to the limit of trees; south in winter to Oregon, Colorado and New Englend. Only two instances of its occurrence are known in Colorado. Mr. H. C. Lee Meyer took a male at Crested Butte in October, 1896, which was identified by Cooke, and there is an example in the Carter collection obtained at Breckenridge, December 28th, 1882. It may be considered a rare winter visitor in the mountainous part of the State.

\section{Saw-whet Ow1. Cryptoglaux acadica.}

A.O.U. Checklist no 372-Colorado Records-Ridgway 79, p. 232 ; Morrison 89, p. 66 ; Bendire 92, p. 350; Cooke 94, p. 183 ; 97, pp. 77, 205 ; H. G. Smith 96, p. 76 ; Henderson 03, p. 235 ; 09, p. 230.

Description.-Above sepia-brown, the crown with white shaft-lines, the nape and back with white bases to the feathers; the wings and tail regularly spotted, those on the tail forming two incomplete cross-bands of white; below white, streaked a lighter tawny-brown; facial disk whitish, black round the eye ; iris yellow, bill and claws black. Length $7 \cdot 5$; wing 5.25 ; tail 2.9 ; culmen .6 ; tarsus $1 \cdot 1$. 
The young bird is very different; above ruddy chocolate-brown, without any white; wings and tail darker, and marked as in the adult; below, throat and breast like the back; posteriorly brownish-yellow; no streaks.

Distribution.-Breeding from Hudson Bay and British Columbia south, to New York and Indiana in the east, in the west through the mountains as far as Mexico, wandering often into the lower country and further south in winter.

In Colorado the Saw-whet is a rather uncommon resident, wintering in the eastern plains, and breeding in summer in the mountains from about 7,000 to 9,000 feet. It has not hitherto been met with on the western slope, though noticed by Morrison in La Plata co.

The following are winter records: Fort Collins, January (Cooke), Fort Lupton, February, and Clear Creek, neвr Denver, April (H. G. Smith), Beloit, near the Kansas border, April (Cooke), Buttes, January (Aiken coll.), Salida, December (Frey).

Summer records are: Estes Park, breeding at 7,000 feet (W. G. Smith), Boulder co., breөding at 8,500 feet (Gale), Breckenridge, August (Carter), Dome Rock, June (H. G. Smith).

Habits.-This little $\mathrm{Owl}$ gets its name from its shrill note, which is said to resemble the sound of sharpening a saw with a file. It is a thoroughly nocturnal species, and is only very exceptionally seen abroad in the day time. It preys almost exclusively on mice of various species, and is doubtless very beneficial from the farmers' point of view. Both Gale and W. G. Smith have found this bird breeding in Colorado (Bendire). In most cases an old Flicker-hole in an aspen tree had been made use of, but in one instance what appeared to be an old squirrel's drey was taken possession of. The clutch varies from three to five, and incubation appears to commence after the first egg is laid, since the young birds are generally found to be of obviously different ages. Gale's nests were found on May 24th and June 3rd, and the earlier one contained three young and one egg, and the later, three nearly fresh eggs, so that the egg-laying seems to extend over a couple of months at least. The eggs are white, nearly spherical, and average $1.20 \times 1.0$. 


\section{Genus OTUS.}

Small Owls with wings under 7.5 ; facial disk not well doveloped, hardly noticeable; ear-tufts well developed; skull and ear-openings symmetrical, the latter small and normal; wing rounded, but long and about twice the short, rounded tail; tarsus feathered, toes bristly or naked; plumage with marked dichromatic phases.

A large cosmopolitan genus with only two North American species, but separated into a great many subspecies difficult to discriminate.

A. Larger ; wing over 6 ; toes bristly or partly feathered.
a. Paler and less heavily streaked.
O. a. maxwelliæ, p. 204.
b. Darker and more heavily atreaked. .
O. a. aikeni, p. 205 :

B. Smaller; wing under 6 ; toes naked.

O. flammeola, p. 207 :

\section{Rocky Mountain Screech Owl. Otus asio maxwellia.}

A.O.U. Checklist no 3730-Colorado Records-Ridgway 77, pp. 210, 213 ; 79, pp. 232, 235 ; Morrison 89, p. 66 ; Kellogg 90, p. 90 ; Bendire 90, p. 298 ; 91, p. 91 ; 92, p. 263 ; Hasbrouck 93, p. 256 ; Cooke 97, pp. 78, 160 ; Burnett 03, p. 156 ; Dille 03, p. 74 ; Henderson 03, p. 235 ; 09, p. 230 ; Rockwell 07, p. 140 ; 08, p. 207 ; H. G. Smith 08, p. 185.

Description.-Very closely resembling $O$. a. aikeni, but very distinctly paler, the ground-colour much lighter, and the black streaking much less heavy, both above and below; white on the wings and scapulars more conspicuous, and a tawny wash across the back, showing rather plainly. Measurements average a little larger; wing $7 \cdot 0$, tail 3.5 (see Plate 5).

Distribution.--North-east Colorado, chiefly north of the Arkansas Platte Divide, but occasionally in winter south to Colorado Springs; extending northwards along the foothills as far as Fort Custer in south Montana.

This Owl is a resident in north-east Colorado, and is found chiefly along the foothills and river valleys from Denver northwards. Kellogg reports it as rare in Estes Park, and it has been taken out on the plains as far as Dry Willow Creek in Yuma co., in June by H. G. Smith.

Habits. - This $\mathrm{Owl}$ is an inhabitant of the cotton-wood groves along the Platte and its tributaries in north-east Colorado. It is chiefly abroad at night, spending the day in a hollow tree, or sitting quietly on a horizontal branch close to the trunk, which it closely resembles. Its home is generally betrayed by disgorged pellets lying below.

The nest and eggs were first taken by Anthony on the Platte River, six miles from Denver, May 4th, 1884 ; 

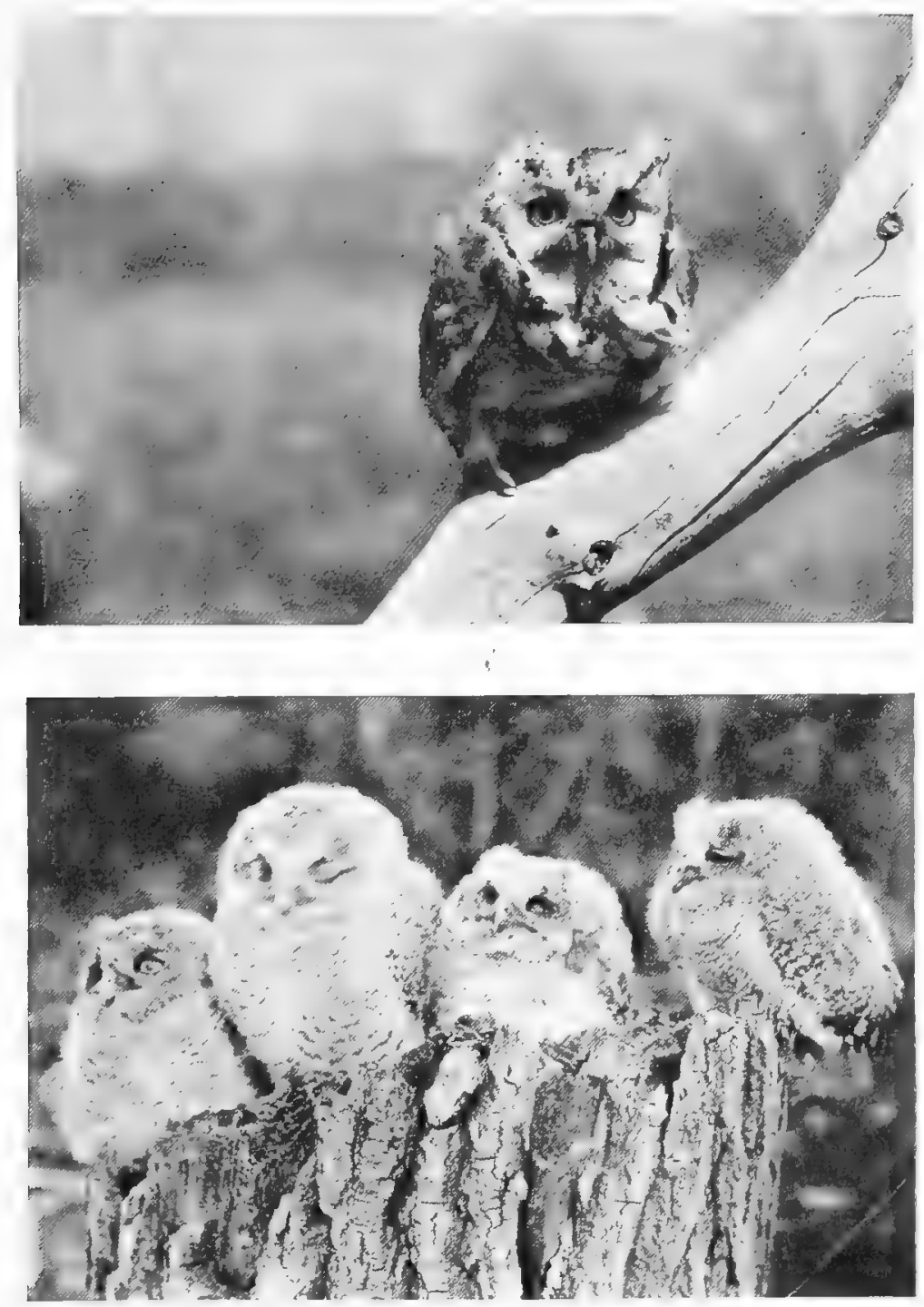

Plate 5]

[R. B. Rockwell, Phot.

ADLIT AND YOCNO OF THE ROCKY-MOLNTAIN SCREECH OWL, CLEAR CREEK, JEFFERSON CO. 

but Gale, Burnett and Rockwell have all written on thic subject. The most usual situation is an old Flickerhole in a cotton-wood tree, but natural cavities in willows or box-elders are also made use of, while W. G. Smith informed Bendire that he once found a deserted Magpie's nest adopted. Often the Owl has a "scrap" with the Flicker for the possession of the hole, and if the Flicker is once able to effect an entrance it is generally able to hold possession with the menace of its sharp bill.

No nest is made, but the bottom of the nest-hole is often found littered with wood-dust, feathers and the other remnants of former feasts. The site selected is generally near a stagnant pool or a stream, possibly for the convenience of procuring crawfish and small fishes, which form no small part of their diet.

Incubation is carried on entirely by the female, and begins after the first egg is laid ; and as there is an interval of from twenty-four to seventy-two hours between the laying of each egg, the young birds, when hatched, are of various ages. The male is generally found near the nest-site in another cavity, which often forms a larder. Gale found remains of Blue Birds, Juncos, mice, frogs and crawfish in these caches.

Gale found fresh eggs chiefly from April 15th to 30th ; those of later date, taken in May, he believed to be a second laying, due to loss or destruction of the first.

The usual number of eggs is four; these are rounded. ovals and moderately glossy, and measure $1 \cdot 44 \times 1 \cdot 18$.

\section{Aiken's Screech Owl. Otus asio aikeni.}

A.O.U. Checklist no 373g-Colorado Records-? Morrison 88, p. 115 (Scops asio maccalli); Brewster 91, p. 139 ; Bendire 92, p. 370; Hasbrouck 93, p: 258; Lowe 94, p. 268 (Megascops asio maxwellice); Cooke 97, p. 78 . 
Description.-Adult-Above finely mottled grey and dusky and streaked with black, rather heavily on the crown; a good deal of white on the scapulars and wing-coverts and the fulvous tinge very faint or absent; below mottled like the back, but rather paler, heavily blotched and streaked with black, the streaks usually taking branched, tree-like shapes; iris yollow?, bill and claws bluish-horn. Length 6.25 ; wing 6.5 ; tail 3.0 ; culmen $\cdot 75$; tarsus $I .5$.

A young bird of the year is hardly to be distinguished from the adult. A male Screech Owl in the Aiken collection, taken in Colorado Springs, January, 1904, in the "red phase" was referred by Brewster, who examined it, to the typical Otus asio, but there seems to me to be no reason for regarding it as anything but the red phase of $O$. aikeni. In this specimen the whole of the grey mottling above is replaced by rich rufous, with a little black streaking; the white on the scapulars and coverts is as in the grey phase; below there is a little rufous on the foro-neck and sides, and a few dark streaks, but the central portion of the under-parts is chiefly white.

Distribution.-Aiken's Screech Owl is a fairly common resident in Colorado, and is found along the foothills of the Rocky Mountains from El Paso co. south, probably to Fort Wingate in New Mexico. There is a good series, all from the immediate neighbourhood of Colorado Springs, mostly taken in winter, in the Aiken collection. Lowe met with this Owl commonly in the foothills of the Wet Mountains, and once found a family party in thick piñons at 7,800 feet, while the Scre日ch Owls of La Plata co. noticed by Morrison, should probably be referred here.

Warren has recently (March 28th, 1909) obtained a Screech OwI from. Orchard on the Platte in the north of the State which I cannot distinguish from this form, though presumably it should be 0 . $a$. maxwellice, and I very much doubt if it will be possible to maintain the distinction between the two subspecies unless their ranges can be separated.

Habits.-This little Owl is usually found lurking in the hollows of old willows or cotton-woods, and is so tame or perhaps frightened that it can often be caught in the hand. Aiken found the remains of a Pink-sided Junco in the stomach of one examined by him, and it probably preys on small birds as well as mice.

A nestling in downy plumage was brought alive to Aiken on June 25th, 1905. He kept it for about six months. It became very tame and a great pet. It 
moulted all its feathers except those of the wings and tail, between July 15th and September 15th. The note or cry most often heard was a "Wow, wow," resembling the bark of a puppy.

Morrison found a Screech Owl breeding in La Plata co., in the hollows of old piñons. He took three young ones and an addled egg in June. It was probably this subspecies.

\section{Flammulated Screech Ow1. Otus flammeolus.}

A.O.U. Checklist no 374-Colorado Records-Ridgway 79, p. 232 ; 80 , p. 185 ; Deane 79, p. 188 ; Ingersoll 80, p. 121 ; Brewster 83, p. 123 ; Drew 85, p. 17 ; Morrison 89,p. 66 ; W. G. Smith 91, p. 27 ; Bendire 92, p. 374 ; Hasbrouck 93, p. 260 ; H. G. Smith 93, p. 364 ; Ingrahmm 97, p. 403 ; Cooke 97, pp. 78, 161, 206 ; Jones 98, p. 46 ; Henderson 03, p. 235 ; 09, p. 230 ; Dille 04, p. 50 ; 09, p. 87 ; Gilman 07, p. 154 ; Cary 09, p. 181 .

Description.-Smaller than 0 . asio aikeni, and essily distinguished by its shorter ear-tufts and bare, unfeathered toes. Above finely mottled dusky and white, with black streaking; the white scapulars tinged with tawny and often a faint wash of tawny all over the head and facial disk; below paler with dark streaks, much as in $O$. a. aikeni; iris brown, bill and toes yellowish. Length 6.0 ; wing 5.4 ; tail 2.1 ; culmen .5 ; tarsus $1 \cdot 0$.

A red phase is known, but not hitherto noticed in Colorado. Young birds are more or less cross-barred, especially below.

Distribution.-From southern California and Colorado, chiefly in the mountains or foothills, south through Mexico to Guatemala.

In Colorado as elsewhere this little Owl has always been reckoned a very rare species, and every occurrence seems to have been carefully recorded. It is a resident along the eastern foothills and breeds there, and from about 7,000 to 10,000 feet in the mountains.

It was first recorded from Colorado by Ridgway, who mentioned an example in Mrs. Maxwell's collection, taken near Boulder, and it must now be considered a not uncommon resident.

The following are breeding records: Estes Park at 10,000 feet (W. G. Smith \& Dille), Idaho Springs, E. Lewis (Bendire), Fremont co., Ailken (Deane), near Beulah 7,000 to 8,000 fe日t (Ingraham \& Jones) and La Plata co. (Morrison). There are two examples in the Aiken collection taken near Colorado Springs, but it is not known from the western or north-western portions of the State. 
Habits.-The Flammulated Screech Owl resembles the other larger Screech Owl in its habits. It is nocturnal, and preys on small mammals and large insects. The eggs are laid in a natural cavity or in a Flicker-hole, generally in a coniferous tree-a piñon at lower levels, a spruce at higher-at the end of May or beginning of June.

Aiken was the first to find the nest and eggs of this Owl. He took a female from the nest, which was in a dead pine tree and contained one egg. This was in the Wet Mountain Valley, at about 7,500 feet, on June 15th, 1875. W. G. Smith subsequently obtained several sets of eggs in Estes Park, between 8,000 and 10,000 feet. The clutch usually numbers four, and the eggs are white with a faint creamy tinge, and oval in shape; they average $1.12 \times 1.0$.

\section{Genus BUBO.}

Large Owls with wing (in the American species) over 14; bill robust and black; facial disk well marked, the eyes placed nearer the upper than the lower margin; skull and ear-openings symmetrical, the latter small, normal and non-operculate ; ear-tufts conspicuous; wing rather short and rounded, falling short of the tail when folded; tail slight, rounded, almost concealed below by the lengthened under tailcoverts; legs densely feathered to the bases of the claws, but the latter not concealed.

A considerable genus, spread over most of the world; but with only one United States species, divided into a number of subspecies; some of these however are far from satisfactorily defined.

\section{Western Horned Owl. Bubo virginianus pallescens.}

A.O.U. Checklist no 375a-Colorado Records-Ridgway 73, p. 185 ; Henshaw 75, p. 407 ; Scott 79, p. 95 ; Beckham 85, p. 143 ; Drew 85, p. 17 ; Morrison 88, p. 115 ; 89, p. 67 ; Kellogg 90, p. 87 ; Bendire 92, p. 383 ; Osburn 93, p. 212; Lowe 94, p. 268 ; 95, p. 169 ; Dille 03, p. 74 ; Henderson 03, p. 235 ; 09, p. 230 ; Oberholser 04, p. 192 (Aвio magellanicus occidentalis); Warren 06, p. $20 ; 08$, p. $21 ; 09$, p. 14 ; Gilman 07, p. 154 ; Rockwell 08, p. 14; 08, p. 163 ; Smith 10, p. 133. 
Description.-Adult-General colour above mottled with black, dusky and white, with a varying amount of tawny intermixed; eartufts large and conspicuous; tail and wing markings in more or less well-developed bands; below, a white patch on the throat, upperbreast irregularly blotched with black and tawny on white; posteriorly white with narrow transverse bands of dusky, often washed and tinged with tawny; legs white to pale tawny, hardly marked; facial disk yellowish bordered by black. The variation in the amount of tawny and black is very considerable, but the bird is always less tawny than the eastern type; iris yellow, bill and claws black. Length 21 ; wing 14 ; tail 8.5 ; culmen 8 ; tarsus 2.80 .

Some observers believe that two subspecies can be distinguished in Colorado. There is certainly a great deal of variation in the plumage of individuals, but whether it is possible to discriminate two distinet forms seems very doubtful. Recently Aiken has received from the Fountain Valley a pair of Owls killed with one shot, so that they certainly appeared to be mated. These two individuals seem to represent the two extreme types of the tawny and dusky phases, as I prefer to regard them.

Distribution.-Western North America, from British Columbia and Manitoba south to the Mexican tableland.

In Colorado the Horned $\mathrm{Owl}$ is a fairly common resident, breeding over nearly the whole of the State from the plains up to timber line, according to Drew, and wandering up to 13,000 feet in the fall; the highest definite record. I have met with is 10,000 feet, in the Wet Mountaing (Lowe).

Other localities are: Near Denver, breeding (Rockwell, see Plate 6), El Paso co. (Aiken coll.) and Baca co., breeding (Warren), in the lains; Estes Park (Kellogg), Boulder co., breeding (Gale), Crested Butte (Warren) and Wagon Wheel Gap (Aiken coll.), in the mountains ; Mesa co. (Rockwell) and La Plata co. (Morrison), on the western slope.

Habits.-This is the largest Owl found commonly in Colorado. It prefers wooded distriets in the plainschiefly the cotton-wood groves along the rivers; in the mountains, the thickets along the bottoms of the valleys. Each pair appears to have its own particular range, beyond which it seldom strays. It has a loud, guttural note, "Whaugh-hoo-hoo." It is destructive to gamebirds and water-fowl, and also preys largely on rabbits and prairie-dogs, as well as the smaller rodants. In settled districts it often catches an unwary fowl. 
The Horned Owl in Colorado makes use, as a rule, of an old Magpie's or Red-tailed Hawk's nest, in which to lay its eggs. Warren noticed it however nesting in a hole in a sandstone bluff at Gaume's ranche in Baca co. Gale found it a most persistent layer; he took three sets of eggs from the same pair of birds; the sets numbered four, three and two respectively, and the nest-site was changed each time. Incubation, which is undertaken entirely by the female, lasts about four weeks. The eggs, usually four in number, are rounded ovals, white in colour and not very glossy; they measure $2.2 \times 1.90$.

This Owl is one of our earliest breeders; Gale found fresh eggs between March 10th and 25th; any found later, he believed to be second or third layings, due to failure or robbery of the first set.

\section{Genus NYCTEA.}

Owls of large size-wing 15 to 18 - with plumage mostly white; resembling $B$ Bubo in other respects, but with the ear-tufts rudimentary or wanting, and the bill and claws almost entirely concealed by the dense growth of the frontal and toe feathers.

Only one circumpolar species is comprised in this genus.

\section{Snowy Ow1. Nyctea nyctea.}

A.O.U. Checklist no 376-Colorado Records-Morrison 89, p. 67; Cooke 94, p. 183 ; 97, pp. 80, 161, 206 ; H. G. Smith 96, p. 76 ; Henderson 03 , p. $235 ; 09$, p. 230.

Description.-Male-Pure white above and below, sometimes immaculate, more generally marked with transverse spots or bars above and below ; the face, throat and feet usually the least marked. Iris yellow ; bill and claws black. Iength 22.0 ; wing 15.5 ; tail 9.25 ; culmen 1.50 ; trisus 1.8 .

The female is larger - wing 17.3, tail 10.0-and much darker, only the face, throat and middle of the breast and feet immaculate; top of the head and hind-neck spotted, rest of the body barred with dark brown.

Distribution.-Breeding in the Arotic regions of both hemispheres, in America north of $53^{\circ}$, from Alaska to Labrador; south in winter, more or less regularly, to the northern and middle states; more common in the east. 


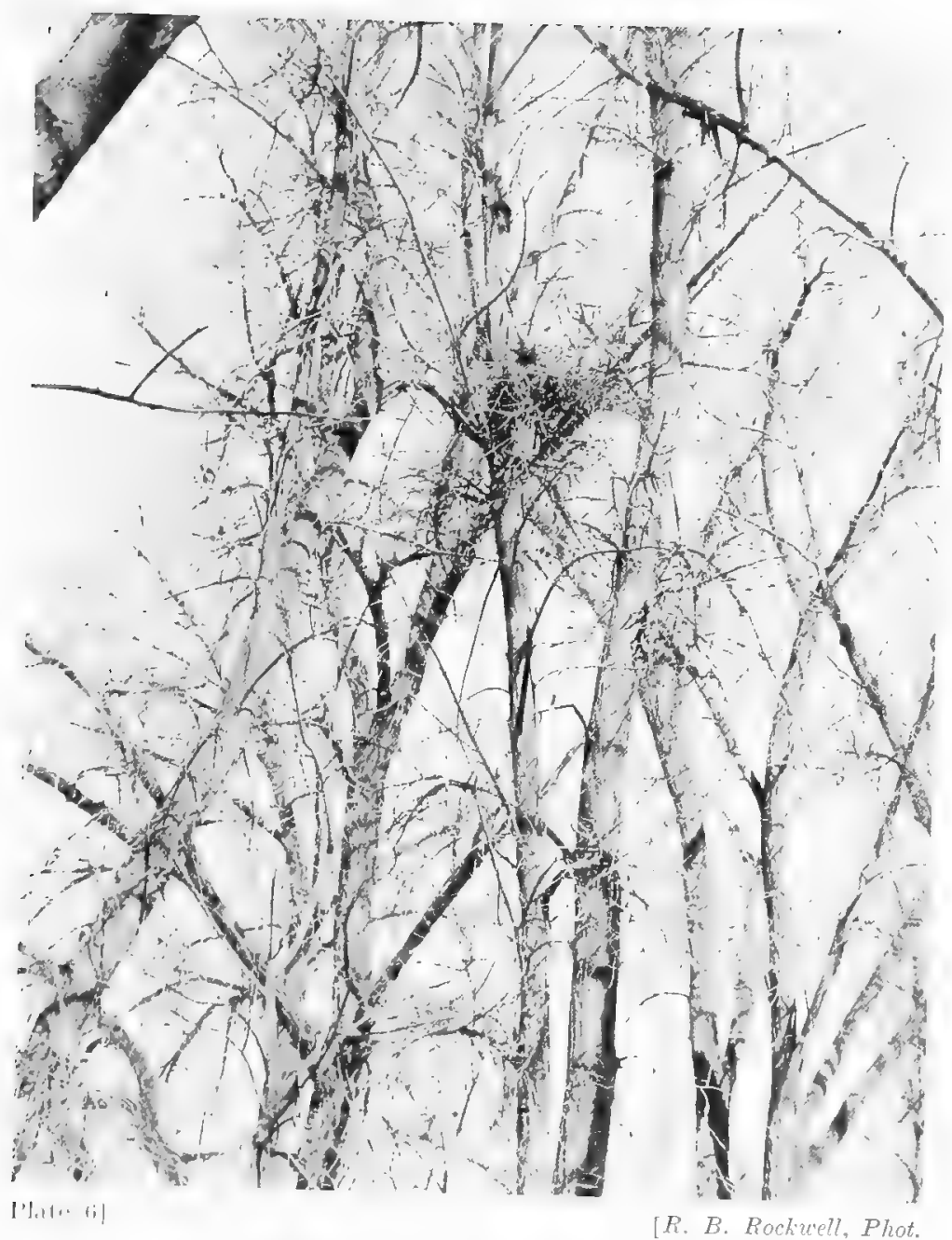

NEST OF THE WESTERN HORNED OWL AT COAL CPEEK, NEAR DENIER. 



\section{Burrowing Owl}

In Colorado the Snowy Owl is a rare winter visitor, more abundent in severe winters. It has been chiefly taken in the north-east of the State near Fort Collins, Greeley, Loveland, Barr and Denver, whence it has been reported by Cooke and Smith. Further south and in the mountains it is only a straggler; but it has been recorded from Colorado Springs by Aiken, from Wet Mountain Valley by Baker, and from Breckrenridge by Carter.

\section{Genus SPEOTYTO.}

Medium-sized Owls-wing 6 to 8 -with a quite incomplete facial disk and no ear-tufts; ear-openings small and normal ; cere somewhat swollen; wing moderate, slightly rounded; tail short, less than half the wing; legs long and slim, tarsus twice the length of the middle toe without claw, scantily feathered in front, bare behind; lower portion and toes with a few bristles.

This genus is confined to America; there is only one species found in the United States.

\section{Burrowing Owl. Speotyto cunicularia hypogaea.}

A.O.U. Checklist no 378-Colorado Records-Say 23, vol. ii., pp. 36, 200 ; Allen 72, p. 151 ; Coues 74, p. 322 ; Allen \& Brewster 83, p. 197 ; Drew 85, p. 17 ; Beckham 85, p. 143 ; Morrison 89, p. 67 ; Bendire 92, p. 395 ; Cooke 97, pp. 18, 81, 206 ; Dille 03, p. 74; Henderson 03, p. 235 ; 09, p. 230 ; Warren 06, p. 20 ; 08, p. 21 ; 09, p. 14 ; Gilman 07,p. 154 ; Markman 07, p. 156 ; Hersey \& Rockwell 09, p. 118.

Description.-Adult-Dull brown above, spotted finely on the head, more largely on the back, with white or tawny-whitish; on the wingquills and tail the spots tend to form cross-bars, generally broken in the centre on the shafts; below white, the throat and fore-breast immaculate, separated by a brown band, posteriorly with a series of brown, transverse spots, almost forming bars; thighs and under tailcoverts plain ; iris jellow, bill greenish-yellow, cere and claws blackish. Length 9.5 ; wing 7.25 ; tail 3.5 ; culmen $\cdot 6$; tarsus 1.85 .

The sexes are alike. Young birds are plain brown above, but with much white on the wings; below with white chin, brown collar, and isabelline white and immaculate posterior parte.

Distribution.-Western North America, breeding from southern British Columbia, Assinaboia and Minnesota south to northern Texas, Mexico and Guatemala.

In Colorado the Burrowing Owl is most common on the eastern plains, wherever there are prairie-dog towns. It is also found in the mountains up to about 8,000 feet, while Cooke states it occasionally reaches 10,000 feet; but I have not found any reference to it higher than Middle Park, where Carter obtained it. There is also some doubt as to whether 
it is a resident or only a summer bird; it is generally considered to belong to the former category, but there seems to be no winter record for the State except that of Hersey and Rockwell, who noticed a few during that season at Barr.

The following localities are reported : Fort Collins, breeding (Bendire), Greeley, breeding (Colo. Coll. Mus.), Boulder co., breeding on plains (Gale), nеar Colorado Springs and Limon, not common (Aiken), Baca co., very common (Warren), Routt co., rare (Warren), Grand Junction common resident (Rockwell), Cortez (Gilman) and La Plata co., common (Morrison).

Habits.-This little Owl presents a very remarkable departure from the habits of all other Owls. It inhabits the treeless plains, it is more or less gregarious, and it nests in burrows underground. As is well known, it is often found associated with prairie-dogs and rattlesnakes, but the old idea of the three living together in perfect amity has been long since dispelled. As a rule certainly, perhaps invariably, the $\mathrm{Owl}$ only takes up its abode in deserted burrows, and these partioular ones can nearly always be detected by the litter and filth strewed near the entrance.

This Owl is quite diurnal in habits, and often stands on the little mound by the side of its hole. Here it can be noticed bowing and dipping, by the passer-by. In other parts of its range it inhabits badger, skunk or spermophiles' holes, and it is said that occasionally it burrows for itself. Bendire, at any rate, watched it enlarging one. It hunts chiefly in the evening and at night, preying on young prairie-dogs and small mammals, but more often, judging by Fisher's researches, on grasshoppers and beetles. It seldom catches birds, though Gale found the remains of a Horned Lark in a burrow examined by him.

The nest is a rounded chamber, about two to three feet below the surface, and is approached by a curved or straight passage of from four to five feet long. Gale 
noticed an extra chamber off the passage, which he supposed was for the male bird. The eggs are laid on a bed of horse or cow droppings, broken up fine, and there is usually an accumulation of food-remains, and other filth as well, while the whole spot swarms with fleas and is very ill-smelling. The eggs number from seven to nine; they are rounded ovates in shape, and pure white in colour when clean, though usually very nest-soiled. They measure about $1 \cdot 3 \times 1 \cdot 1$. Gale found fresh eggs from May 10th to 20th; Dille gives May 22nd, while Bendire states that fresh eggs have been found at Fort Collins as late as July lst.

A set of five eggs in the Colorado College Museum, presented by I. C. Hall, were taken by him near Greeley, May 10th, 1903. They were found at the end of a prairiedog's hole, seven feet long and a foot deep, and were placed on a bed of horse manure. A large toad was also found in the hole.

\section{Genus GLAUCIDIUM.}

Small Owls, wing under 4.0 ; facial disk hardly developed ; no eartufts ; ear-openinge normal ; nostrils circular, opening well within the cere; wing short and rounded; tail long, slightly rounded, about $\frac{3}{4}$ of wing; tarsus densely feathered; toes bristly.

A large genus of small Owls chiefly met with in the Tropics, with three species and one subspecies in the United States.

\section{Pygmy Owl. Glaucidium gnoma.}

A.O.U. Checklist no 379-Colorado Records-Ridgway 73, pp. 185, 195 ; Henshaw 85, p. 79 ; H. G. Smith 87, p. 284 ; 96, p. 76 ; Morrison 88 , p. 115 ; 89 , p. 67 ; Kellogg 90, p. 90 ; Bendire 92, p. 403 ; Lowe 94, p. 268 ; Cooke 97, pp. 81, 161, 206 ; Henderson 03, p. 235 ; 09 , p. 230 ; Gilman 07, p. 154.

Description.-Above slaty-brown, with small round spots of white on the head and larger ones on the wing-coverts; $a$ collar of mixed white and black round the back of the neck; wing-and tail-quills a duskier brown, marked with white spots on both webs ; ohin and forebreast white, separated by a brown band; rest of the under-parte white, 
heavily streaked with dusky; sides of the breast like the back, spotted; iris yellow, bill and toes duller yellow. Length 6.75; wing 3.9; tail 2.9 ; culmen .55 ; tarsus $1 \cdot 1$.

The young bird has the top of the head plain grey. No red or tawny phase has yet been met with.

Distribution.-Western America from the interior of British Columbia south to the Mexican tableland, east to Colorado and New Mexico, but not reaching the coast lands of the Pacific in the west.

The Pygmy Owl was first taken by Aiken in November, 1871, near, Fountain in the foothills. Since then it has been met with a good many times, and may be considered a rare resident, breeding in summer at elevations up to about 10,000 feet, and wintering in the foothills and the neighbouring plains. The following are breeding records: Estes Park, nesting at 10,000 feet (W. G. Smith apud Bendire), Breckenridge (Carter), Ute Pass (Aiken apud Cooke), Wet Mountains, common, 7,800 to 8,000 feet (Lowe), La Plata co., breeding (Morrison); winter records are: Loveland (W. G. Smith apud Bendire), Boulder, January (Henderson), Denver (H. G. Smith), El Paso co., (Aiken coll.), Salida (Frey), Pueblo (Cooke), Durango (H. G. Smith), and Routt co., below 6,000 feet (Cooke).

Habits.-The Pygmy Owl is chiefly met with in or near pine woods ; it is often seen about in bright sunshine, though perhaps more common in late afternoon or early morning. It hides in pines or other thick timber, perching upright on a branch close to the trunk, where it is practically invisible. Its note is rather musical for an Owl, somewhat resembling the "Coo" of the Mourning Dove.

It is very bold and fearless, and will attack birds much larger than itself. One was brought to Aiken from a ranche near Colorado Springs, which was shot while attacking a Quail, and on other occasions it has been known to pounce on a Long-crested Jay and on chickens. It also preys on small rodents and insects.

A nest containing three young ones and an egg on the point of hatching, was taken by W. G. Smith, in Estes Park, May 31st, at about 10,000 feet. It was placed in an old Woodpecker's hole in a dead aspen, and was 
composed of a few feathers and rubbish. Morrison took several nests in La Plata co. at about 9,000 feet in June ; they were all in pines in old Woodpeckers' holes, but no eggs appear to have been available for Bendire to examine.

\section{ORDER PSITTACI.}

This order contains the Parrots, easily distinguished externally by their stout, strongly hooked bill, furnished with a cere, which however is frequently feathered, and by their feet, which are zygodactylous, i.e. the first and fourth toes are posteriorly, the second and third anteriorly directed.

\section{Family PSITTACID瓜.}

\section{Genus CONUROPSIS.}

Bill stout; cere, within which opens the nostrils, completely feathered; tail long, equal to the wing; wedge-shaped and strongly graduated; tarsus very short, covered with granular scales.

One species only in the United States.

\section{Corolina Paroquet. Conuropsis carolinensis.}

A.O.U. Checklist no 382-Colorado Records-Pike 10, p. 78 (Coues's ed., II., p. 474) ; Coues 77, p. 50 ; Morrison 89, p. 67 ; Hasbrouck 91, p. 369 ; Cooke 97, pp. 81, 162.

Description.-Above and below, green of various shades; head all round and edge of wing yellow; forehead and cheeks orange-red; iris brown, bill whitish, feet flesh-coloured. Length $12 \cdot 0$; wing $7 \cdot 10$; tail 5.75 ; culmen $\cdot 9$; tarsus $\cdot 7$.

The sexes are alike. Young birds are green without yellow.

Distribution.-Formerly ranging over all of the middle and southeastern United States, from Colorado, Nebraska, and New York south to the Gulf; now confined to Florida and to a less extent to Arkansas and Olzlahoms.

Pike captured a live bird new to him on Christmas Day, 1806, in the upper Arkansas Valley, not far from where Salida now is. He described it as green with a tufted head, and he fed it on meat. Coues identified it with the Carolina Paroquet, but I am more inclined to think it was 
the Long-crested Jay. E. L. Barthoud, however, informed Coues that he had seen the Parrot on several occasions in the early sixties, at Golden, close to Denver, on the Little Thompson, and also near Fort Lyon. These are the only notices of its occurrence in Colorado, and it is now doubtless extinct in the State.

\section{ORDER COCCYGES.}

This order, containing the Cuckoos, Trogons and Kingfishers, is very difficult to diagnose by external characters, but the bill is without cere, and is never hooked or chisel-shaped; the tail-feathers are never stiff or sharp-pointed, and the toes are either arranged two in front and two behind; or if three in front, the third and fourth are bound together for half their length, i.e. syndactylous.

\section{Key of the Families and Genera.}

A. Toes, two in front and two behind (Cuculida).

a. Wing short, $\frac{2}{3}$ the length of tail; head orested.

Geococcyx, p. 216.

b. Wing longer, about equal to tail; head not crested.

Coccyzus, p. 218.

B. Toes three in front, one behind; the third and fourth bound together for half their length (Alcedinida). Ceryle, p. 221.

\section{Family CUCULID在.}

Toes arranged with two-the second and third-in front and two-the first and fourth-behind; tail with ten rectrices in all North American forms.

\section{Genus GEOCOCCYX.}

Terrestrial Cuckoos with crested head and a small bare, space round the eye; bill long, rather slender and downeurved towards the tip; wings very short, rounded and conosve, less than $\frac{2}{3}$ length of tail, which consists of ten long, tapering feathers, and is very much graduated; legs stout and adapted to walking; the tarsus scutellate before and behind.

The genus contains two species only, one from the United States and one from Mexico. 


\section{Road-runner. Geococcyx californianus.}

A.O.U. Checklist no 385-Colorado Records-Aiken 72, p. 206 ; Coues 73,p. 751 ; Henshaw 75, p. 383 ; Goss 78,p. 114 ; Drew 85, p. 17 ; Beckham 85, p. 143 ; Morrison 88, p. 17 ; 89, p. 67 ; Lowe 94, p. 268 ; Cooke 97, pp. 81, 207 ; Warren 06, p. 20 ; Cary 09, p. 181 ; Felger 10, p. 89.

Description.-Above a metallic bronze, becoming steely-blue on the neck and head; all the feathers edged with white or tawny-white, producing a streaked appearance; head strongly crested; wing more greenish; tail very strongly graduated; the three outer pairs of feathers steely-blue with a terminal band of white; below dull whitish, the feathers of the fore-neck and throat with dusky centres edged with tawny; iris red, bill and legs dark horny, a bare space round the eye pale fleshy, eyelids blue. Length 20.5 ; wing 7.75 ; tail 12.0 ; culmen $2 \cdot 1$; tarsus $2 \cdot 4$.

The sexes are alike, and the young bird is very similar-iridescent from the first, but with more white and less tawny.

Distribution.--South-west United States, from California and Colorado south to Mexico, east to south-west Kansas and Oklahoma.

The Road-runner is a fairly common resident in Colorado along and south of the Arkansas Valley. North of this it is rare, but has been met with on several occasions in El Paso co., by Aiken and others, while Cooke states that Carter once observed it at Littleton just south of Denver, and Felger has recently recorded it from. Denver itself; this is the most northern record. Others are : Las Animas (Goss), Fort Lyon (Coues), Gaume's Ranche (Warren and Cary), Wet Mountains at 8,000 feet (Lowe), Trinchera (Brunner) and La Plata co. (Morrison). It keeps chiefly to the lower altitudes of the cedar and piñon zone, and has not been met with above 8,000 feet (Lowe).

Habits.-This ground-loving Cuckoo, often known as the Chaparral Cock and by the Mexicans as the Paisano, is a bird of remarkable aspect, and reminds one more of a small hen Pheasant than of a Cuckoo. It is thoroughly terrestrial and a great runner, and is said to be able to outstrip a galloping horse, aided by its wings outstretched as supporters. It also flies well.

The Road-runner is rather unsocial, and only one or two are to be met with together; it prefers bushy hill-sides and scrub-oak, seldom or never entering pine woods. Its note is compared by Bendire to the cooing 
of a Dove and the cackling of a hen, and it also makes a noise by snapping its mandibles.

The food consists chiefly of large insects, such as grasshoppers and beetles, and also lizards, snakes and young birds. Stories of its killing large rattlesnakes are often told, but these appear to be exaggerated.

The nest is built in a low bush, as a rule three to eight feet above the ground; it consists of a flat, shallow and compact mass of sticks, lined generally with dry grass, sometimes with other material such as a few feathers. The number of eggs varies considerably, possibly where twelve have been found they are from two hens. They are ovate, white and unspotted, and measure 1.54 $\times 1 \cdot 18$. They are laid at considerable intervals, and incubation commences after the first few are deposited. No details in regard to the nesting of this bird within the State have yet been published.

\section{Genus COCCYZUS.}

Head not crested; bill stout at the base, compressed and gently downcurved throughout; wing pointed, about equal to the tail in length; tail of ten obtusely-ending, strongly graduated feathers; legs moderate, tarsus about equal to middle toe.

Three species are found in the United States.

\section{Key of the Species.}

A. Lower mandible chiefly yellow; outer tail-feathers strongly tipped with white.

a. Smaller; wing $5 \cdot 5$, culmen $\cdot 93$. C. americanus, p. 218 :

b. Larger; wing $5 \cdot 8$, culmen $1 \cdot 05$.

C. a. occidentalis, p. 220

B. Lower mandible black; outer tail-feathers obscurely white at the tip.

C. erythropilialmus, p. 220

Yellow-billed Cuckoo. Coccyzus americanus.

A.O.U. Checklist no 387-Colorado Records-Ridgway 79, p. 231 Drew 85, p. 17 ; Morrison 89, p. 67 ; Cooke 97, pp. 82, 207 ; Rockwell 08 , p. 164; Henderson 09, p. 231. (This list includes records for both subspecies.) 
Description.-Above greyish-brown with a slight bronzy lustre, becoming naore rufous on the wings; the inner webs of the wing-quills largely light rufous; tail graduated, the three outer-pairs of feathers black, tipped with white; the outer pair white along the outer web as well; below white; iris brown, bill with upper mandible and tip of lower, black, rest of lower and cutting-edges of both yellow, legs plumbeous. Length 10.75 ; wing 5.5 ; tail 5.5 ; culmen .93 ; tarsus $1 \cdot 1$.

Young birds have less white on the tail and the black not so pure.

Distribution.-Breeding in eastern North America, from Nova Scotia and South Dakota south to the Gulf States and West Indies; in winter, south through eastern Mexico to Costa Rica.

The Yellow-billed Cuckoo is a rare summer visitor to Colorado chiefly met with on the eastern plains, but oocasionally penetrating into the mountains up to 8,000 feet. It was noticed breeding in Middle Park by Carter ; it was taken at Fort Lyon by Thorne, and there is an example from Ramah in El Paso co., obtained June 4th, in the Aiken collection. Miss Eggleston states that it is a summer resident at Grand Junction, and that a pair nested several seasons in an orchard there (Rockwell).

Cooke referred the Yellow-billed Cuckoo of Colorado to the western subspecies $C$. a. occidentalis, but two examples in the Aiken collection, from Ramah and from Gem, Thomas co., Kans, undoubtedly belong to the smaller race. Possibly the birds from the western slope are nearer the western form.

Habits.-The Yellow-billed Cuckoo is often called the "Rain Crow," or the "Kow-Kow," the former because it is more noisy when the atmosphere is moist, the latter from its note. It is an arboreal bird, keeping itself concealed in thick trees, and is more often heard than seen. It feeds chiefly on caterpillars, and will devour even the more hairy and spiny forms rejected by other birds. In some cases the stomach-walls have been found full of these spines, without any apparent injury to the birds. They also eat other insects and fruits, and have been accused, but on doubtful evidence, of sucking other birds' eggs.

The nest in a shallow, frail structure, poorly put together, placed low down in bushes or vines. The eggs, three to five in number, are light bluish-green in colour ; they 
are unspotted and measure $1.19 \times 90$. Occasionally this Cuckoo shows a tendency to parasitism. Eggs have been known to have been dropped in the nests of other birds, most often perhaps in the nest of the Black-billed Cuckoo.

\section{California Cuckoo. Coccyzus americanus occidentalis.}

\section{A.O.U. Checklist no 387a.}

Description.-Larger than $C$. americanus, with a proportionally larger and stouter bill; wing 5.84 ; tail 6.59 ; culmen 1.05 .

Distribution.-Western North America from British Columbia south to Lower California, New Mexico, and the tablelands of Mexico proper.

Cooke refers the Yellow-billed Cuckoo of Colorado to this subspecies, but most of the Colorado examples which I have seen appear to be nearer the eastern race. In the State Historical Collection at Denver there are two specimens, obtained in Denver, which perhaps might be referred. to the larger-billed form, while others taken in Yuma are certainly smaller, and should more properly be referred to the eastern race.

\section{Black-billed Cuckoo. Coccyzus erythropthalmus.}

A.O.U. Checklist no 388-Colorado Records-Bendire 92, p. 27 ; Cooke 94, p. 183 ; 97, p. 82 ; H. G. Smith 05, p. 82.

Description.-Above greyish-brown with a slight bronzy. lustre, no rufous on the wings, tail-feathers all like the back, subterminally dusky, terminally obscurely white; below white; iris brown, bare skin round the eye red, bill black, sometimes a trace of yellow on the lower mandible; legs plumbeous. Length 11.5 ; wing 5.4 ; tail 6.15 ; oulmen .85 ; tarsus 9 . Young birds have the feathers of the upper-parts edged with whitish.

Distribution.-Breeding in eastern North Amerioa from Manitoba, Labrador and Nova Scotia, south to the Gulf States; south in winter to the West Indies, Central America and northern South America.

The Black-billed Cuckoo is even rarer in Colorado than the Yellowbilled. It is probably a summer resident, but has not yet been found nesting, and has hitherto only been met with in the north-eastern plains counties. An example now mounted in the Museum at Fort Collins was collected by Breninger on June 11th. W. G. Smith and Osburn found it rare at Loveland, but believed that it nested there, and more recently H. G. Smith obtained a single example in Jackson's cañon, near Wray, on May 2lst, 1904.

Habits.-The Black-billed Cuckoo hardly differs from the Yellow-billed Cuckoo in this respect. 


\section{Family ALCEDINID里.}

\section{Genus CERYLE.}

Bill longer than the head, straight, stout and acute; head with an occipital crest ; wings long and pointed, almost double the length of the even, twelve-feathered tail; legs short and weak, tarsus very short; toes arranged with three in front and one behind and syndactylousthat is, with the third and fourth bound up in a common sheath for about half their length.

This is a large and almost cosmopolitan genus of Kingfishers, but with only one species widely distributed in the United States.

\section{Belted Kingfisher. Ceryle alcyon.}

A.O.U. Checklist no 390-Colorado Records-Allen 72, pp. 151, 179 ; Aiken 72, p. 206 ; Henshaw 75, p. 366 ; Scott 79, p. 95 ; Allen \& Brewster 83, p. 196 ; Drew 85, p. 17 ; Morrison 86, p. 153 ; 88, p. 115 ; 89, p. 67 ; Kellogg 90, p. 87 ; Cooke 97, pp. 82, 207 ; Henderson 03, p. 235; 09, p. 231 ; Dillo 03, p. 74; Markman 07, p. 156; Gilman 07, p. 154 ; Warren 08, p. 21 ; 09, p. 14 ; Rockwell 08, p. 164.

Description.-Male-Above and a pectoral band across the chest slaty-blue with black shaft-lines; head crested, a white collar round the nape; primaries dusky, with white at the base of the inner webs ; fow white spots on the wing-coverts; tail spotted with white, and black on the inner web; below, including a spot in front of and below the eye white, except for the pectoral band; iris dark brown, bill black, legs dusky. Length 11.5 ; wing 6.25 ; tail 3.4 ; culmen 2.15; tarsus -45 .

The female has the sides and flanks and a band across the middle chestnut.

Distribution.-Breeding from Alaska and Labrador to the southern border of the United States; a resident from New England, Colorado and Washington, southwards ; in winter, south as far as the West Indies and Panama.

The Kingfisher is fairly abundant throughout Colorado wherever suitable conditions prevail. It ranges from the plains to about 9,500 feet in summer, while a few birds undoubtedly winter at lower elevations, and where there is open water during this season. The following are recorded localities : Big Thompson in Estes Park, common (Kellogg); Boulder co., wintering in the valley, breeding in the hills (Gale \& Henderson); Breckenridge, breeding (Carter), El Paso co., rather rare (Aiken), Salida, arriving April 16th (Frey), Fort Garland, August (Henshaw), Sulphur Springs and Routt co. (Warren), Grand Junction, 
a few in winter, common in summer, and Plateau Valley in summer only (Rockwell), Sweetwater Lake in winter (Cooke), La Plata co., rather rare (Morrison).

Habits.-Kingfishers are seldom found away form rivers and lakes, where fishes form the bulk of their fare; though at times they may be met with far from water, where they take to lizards, snakes and large insects. They are rather unsocial and quarrelsome birds, and two are to be seen together only in the breeding season. Each individual or pair seem to have their own range or beat along a stream, where they allow no intruder. They sit perched on a branch overhanging the water, or on a stone, often for hours, watching for a fish. When one appears they rise in the air before diving down after it. The fish is carried back to the perch and swallowed head first. Occasionally they hover over the water and dive from this position. The note is rather shrill and they have a characteristic rattle.

The nest is a tunnel in a sand-bank or soft cliff, from four to fifteen feet in length; it ends in a dome-shaped cavity; here the eggs are deposited without any true nest, though as the same site is used year after year, there is often a large accumulation of fish bones and scales. The eggs, about six in number, are white, subspheroidal and glossy, and average 1.34 $\times 1.04$. Dille gives June 5th as a date for fresh eggs.

\section{ORDER PICI.}

This order contains the Woodpeckers, a homogeneous group, easily distinguished by both internal and external characters; bill stout and strong and used like a hammer or chisel; wing of ten primaries, the outer one short but obvious; tail of twelve rectrices, but the 
outer pair rudimentary and concealed, so that there appear to be only ten; these are very stiff and strong with rigid shafts and pointed tips. Tarsi scutellate in front, reticulate behind; toes four or sometimes three, the hallux being occasionally lost, the fourth toe reversed and pointing backwards alongside the first or hallux. Tongue very long, worm-like and extensile, and actuated by a special arrangement of the hyoid muscles and bones.

\section{Family PICIDÆ.}

All the North American Woodpeckers are included in this family.

\section{KEY OF THE GENERA.}

A. Outer hind toe longer than the outer front toe.

a. Four toes.

a Plumage black and white, red on the crown only, no yellow.

Dryobates, p. 223.

b' Plumage black, white, yellow and red. Sphyrapicus, p. 228.

b. Three toes only; crown with yellow, not red. Picoides, p. 227

B. Outer hind toe about equal to the outer front toe.

a. Back red, black and white in masses. Melanerpes, p. 233.

b. Back glossy green with a grey nuchal collar. Asyndesmus, p. 235 .

c. Back cross-barred with black and white. Centurus, p. 237.

C. Outer hind toe distinctly shorter than outer front toe.

a. Head red-crested, size large, wing over 8. Phlootomus, p. 232.

b. Head not crested; belly with round, black spots.

Colaptes, p. 238.

\section{Genus DRYOBATES.}

Bill stout and straight, about equal to the head; a sharply defined ridge on the culmen and on a groove on either side of the upper mandible; wing long and pointed, the outer primary quite short; four toes, the outer posterior (fourth) longer than the outer anterior (third); plumage black and white, the wings black with white spots; red on the head in the male only.

A considerable genus with six species in the United States. 


\section{Key of THE SPECIES.}

A. Back black, with a longitudinal central white patch.

a. Outer tail-feathers plain white.

$a^{1}$ Larger ; wing about 5; wing-coverts unspotted.

D. v. monticola, p. 224.

b1 Smaller, wing about 4.8; wing-coverts profusely whitespotted.

D. villosus, p. 225.

b. Outer tail-feathers barred with black; smaller wing, about 4-0.

D. p. homorus, p. 226 :

B. Back black, cross-barred black and white.

D. s. bairdi, p. 227.

\section{Rocky Mountain Hairy Woodpecker.}

\section{Dryobates villosus monticola.}

A.O.U. Checklist no 393e-Colorado Records-Allen 72, p. 151, 163 ; Aiken 72, p. 206 (Picus villosus harrisi); Henshaw 75, p. 386 ; Scott 79, p. 95 ; Drew 81, p. 140 ; 85, p. 17 ; Allen \& Brewster 83, p. 196 ; Morrison 86, p. 36; 88, p. 107 ; 89, p. 67 ; Beckham 87, p. 121 ; Kellogg 90, p. 87 ; Bendire 92, p. 53 (D. v. hyloscopus) ; Lowe 94, p. 268 ; Anthony 96, p. 32 ; Cooke 97, pp. 82, 207 ; Henderson 03, p. 235 ; 09, p. 231 ; Gilman 07, p. 154; Rockwell 08, p. 164 ; Warren 09, p. 14 ; Hersey \& Rockwell 09, p. 118.

Description.-Male-Above black; red nape band and a white stripe down the middle of the back; wing-quills spotted with white on the outer web, but the tertiaries and coverts plain black; outer tail-feathers plain white; below, patch on the lores, a stripe behind the eye and below the eye to the nape white, not smoky; iris brown, bill dusky horn, legs dusky greyish. Longth 9.25 ; wing 5.2 ; tail 3.6 ; culmen 1.2 ; tarsus .95

The female is slightly smaller-wing $5 \cdot 0$, and has no red nuchal band. A young bird has the crown mostly red.

Distribution.-The Rocky Mountein region from Montana to northern New Mexico, east to north-east Nebraska, west to the Uintah Mountains of Utah.

In Colorado the Rocky-Mountain form of the Hairy Woodpecker is a common resident from the plains to timber line. In the winter it is chiefly met with at lower elevations in the plains and foothills, while in summer it resorts to the pine forests between 8,000 and 10,000 feet, but it is by no means strictly confined within these limits.

The following are notices of its occurrence: Estes Park (Kellogg), Boulder co., breeding in the mountains, wintering in the valley (Gale and Henderson), Mount Lincoln, near timber line (Allen), Barr Lake district (Hersey and Rockwell); El Paso co., commoner in winter 


\section{Hairy Woodpecker}

(Aiken) ; Twin Lakes, breeding (Scott) Wet Mountains to 10,000 feet (Lowe); Breckenridge, breeding (Carter), Mesa co., common (Rockwell); San Juan co., breeding up to timber line (Drew).

Habits.-In the winter Hairy Woodpeckers can often be met with among the cotton-woods and undergrowth along the streams of the foothills, but in summer they are mostly in the pine woods and aspens higher up. They are active and industrious, hammering among the tree trunks, searching for wood-borers and other insects, while in the winter they devour a few berries as well. Aiken took a nest near Fountain in El Paso co., on May 26th; it contained four eggs. Gale also found a great many nests about Gold Hill in Boulder co. They were nearly all located in aspen trees, from three to twenty feet up.

The nest-hole is excavated by the bird itself in most cases, though not infrequently a Sap-sucker's is appropriated. Tough-wooded trees are seldom chosen, and the same site is often occupied for successive years. The eggs, usually four or five in number, are white and measure $98 \times 73$. Gale found fresh eggs from May 5th to June.

\section{Hairy Woodpecker. Dryobates villosus.}

A.O.U. Checklist no 393-Colorado Records-Anthony 96, p. 32 ; H. G. Smith 08, p. 185.

Description.-Closely resembling $D$. v. monticola, but smaller ; wing about 4.8 ; tail 3.25 ; and the wing-coverts and inner secondaries profusely white-spotted.

Distribution.-Middle portion of the eastern United States from the Atlantic to eastern Colorado.

Anthony mentions a Colorado example of the typical eastern race of the Heiry Woodpecker, and Smith took a pair, June 9th, 1906, on Boye's Ranch, Dry Willow Creek, Yuma co. An example in the Aiken collection from Dellvale, Norton co., Kansas, is typical of the eastern form. 
Batchelder's Woodpecker. Dryobates pubescens homorus.

A.O.U. Checklist no 394b--Colorado Records-Aiken 72, p. 206 (Picus gairdneri); Henshaw 75, p. 388 ; Scott 79, p. 95 ; Drew 81, p. 141 ; 85, p. 17 ; Allen \& Brewster 83, p. 196 ; Beckham 85, p. 143 ; Morrison 88 , p. 107 ; 89, p. 67 ; Batchelder 89, p. 253 (D. p. oreocus) ; Kellogg 90, p. 87 ; Low 94 , p. 268 ; Cooke 97, pp. 83, 207 ; Henderson 03, p. 107 ; 09, p. 231 ; Gilman 07, p. 154; Rockwell 08, p. 164 ; Warren 09 , p. 14.

Description.-Very similar in general coloration to $D$. villosus monticola, but considerably smaller and with the lateral tail-feathers transversely spotted with black; inner secondaries and wing-coverts unspotted; white of under-surface not smoky, and under tail-coverts unmarked; iris brown, bill and legs dusky slate. Irength $6 \cdot 6$; wing $4 \cdot 0$; tail 2.5 ; culmen $\cdot 65$; tarsus $\cdot 65$.

The female has no red on the head, and is slightly smallerwing $3 \cdot 80$.

Distribution.-The Rocky Mountain region from southern British Columbia and north-east Nebraska south through Colorado to Arizona and New Mexico, perhaps to southern California.

In Colorado a less common resident than the Rocky Mountain Hairy, but still by no means rare, breeding in summer from the foothills up to timber line, and wintering more commonly on the plains along the base of the mountains and occasionally as high as 10,000 feet. I have not heard of its occurring out on the plains except that it was seen by Warren in March at Orchard, some forty miles from the foothills.

The following are notices: Estes Park (Kellogg); Boulder co. resident in valley and mountains (Gale); near Colorado Springs, January, May and October (Aiken coll.), near Fort Garland 8,000 to 10,000 feet (Henshaw), Breckenridge, breeding (Carter), Mesa co. breeding commonly above 7,000 feet, wintering up to 9,000 feet (Rockwell), La Plata co., common resident (Morrison).

Habits.-A restless and energetic little Woodpecker, constantly tapping the tree trunks in search of insects. It has hardly any distinctive traits of character from the Hairy.

It is a late breeder; Gale found fresh eggs from June 5th to 25th. These are deposited in a hole excavated in an aspen or pine, or sometimes in an old dead stub, and are three or four in number. They are white in colour, and measure $\cdot 74 \times \cdot 60$. 


\section{Texan Woodpecker}

\section{Texan Woodpecker. Dryobates scalaris bairdi.}

A.O.U. Checklist no 396-Colorado Records-Cooke 97, pp. 83, 162 ; Warren 06, p. 21.

Description.-Male-Above regularly barred with black and white; crown black, specked with white and overlaid by crimson; tail-covert and four central tail-feathérs black, outer ones barred black and white, below, including a stripe through the eye and the frontal bristles smoky grey, whiter posteriorly; the flanks and abdomen spotted with black. Length 6.0 ; wing 4.1 ; tail 2.5 ; culmen .85 ; tarsus $\cdot 7$.

The female has no orimson on the head, which is plain black.

Distribution.-From western Texas, southern Colorado and south-east California south to northern Mexico.

The Texan Woodpecker was first noticed in Colorado by Lowe, who informed Cooke that it was a not uncommon resident in Pueblo and Huerfano cos., and that he believed that they nested in the St. Charles eañon near Beulah. Warren obtained a pair near Springfield in Baca co., and recently Aiken has received examples from Mr. Wright, taken in the Fountain Valley some twenty miles north of Pueblo. It is no doubt a resident throughout the south-eastern part of the State at low or moderate elevations.

\section{Genus PICOIDES.}

With three toes only, the inner posterior or hallux being absent; plumage black and white, rather similar to that of Dryobates, but the head-patch of the male yellow, not red.

A circumpolar genus confined to the northern parts of the old and New Worlds; two species and one additional subspecies in the United States.

\section{Alpine Three-toed Woodpecker.}

\section{Piciodes americanus dorsalis.}

A.O.U. Checklist no 401b-Colorado Records-Allen 72, pp. 163, 180 ; Henshaw 75, p. 391 ; Scott 79, p. 95 ; Drew 81 , p. 141; 85, p. 17 ; Stone 84 , p. 9 ; Morrison 88 , p. 107 ; 89, p. 67 ; Kellogg 90 , p. 87 ; Bendire 92, p. 80 ; Lowe 94, p. 268 ; Cooke 97, pp. 83, 207 ; Bangs 00, p. 135 ; Henderson 03, p. 107 ; 09, p. 231.

Description.-Male-Above black, a white stripe down the middle of the back not interrupted by conspicuous barring; primaries and secondaries with white spots, but none on the coverts; central tailfeathers black; lateral ones black and white; crown-patch goldenyellow ; rest of the head black, with a few white spots and conspicuous postocular and malar white stripes; below white, a fow black spots 
on the sides and flanks ; iris dark cherry-red, bill dusky plumbeous, legs plumbeous. Length 8.25 ; wing 5.0 ; tail 3.25 ; culmen 1.15; tarsus $\cdot 90$.

The fomale has no yellow, the crown is shining black, slightly speckled with white.

Distribution.-The Rocky Mountain region from Montane, where it intergrades with $P$. americanus, south to the Santa Fé mountains of New Mexico.

The Three-toed Woodpecker is a not uncommon resident in the mountainous portions of Colorado. It very seldom comes down below 7,000 feot, and is chiefly a bird of the yellow-pine and spruce zones, from about 8,000 to 11,500 feet both in winter and summer. It has been, noticed throughout the mountains from Estes Park (Kellogg) to the Wet Mountains (Lowe) and La Plata co. (Morrison). Warren obtained a specimen on the Divide between the Sapinero and Currecanti creeks in Gunnison co. at 9,350 feet in October, which I have examined; he also took a nest containing two almost fledged young on July 27th, 1911, at Buffelo Pass, altitude 10,300 feet; and there is a pair taken by $W$. Ferril in the State collection at Denver, the male at Palmer Lake, 7,200 feet, the female at Cumbres in Conejos co., at 10,000 feet.

Habits.-Mrs. Stone found a nest with five young birds near Hancock, at about 10,000 feet, on July 10th, but gives no details. Breninger informed Bendire that he found a nest early in May at the low level of 6,500 feet, west of Fort Collins. The site was located in a burnt spruce-stump and contained five eggs. It is most unusual to find either spruces or three-toed Woodpeckers at so low an elevation, and I cannot help thinking that there must be some mistake about this observation. No one else has written on the nidification of this species in Colorado, and it is remarkable that Gale does not mention the bird at all in his notebooks.

\section{Genus SPHYRAPICUS.}

Bill less stout than in Dryobates, hardly as long as the head, the lateral ridges extending only about half way along its length; outer primary very small ; tail feathers produced and attenuated; toes four, the outer posterior (fourth) longer than the outer anterior (third); plumage with a good deal of yellow and red. 
In this genus the tongue is hardly extensile, and the tip is obtuse and brushy; this is correlated with the habit of feeding on the inner bark and sap of trees.

A genus confined to America, with three species in the United States.

The Yellow-bellied Sapsucker (Sphyrapicus varius) of eastern North America wes included in the Colorado list by Ridgway (73, p. 185) and Cooke $(97$, p. 83), on the authority of Aiken presumably. Mr. Aiken informs me he never took this bird in Colorado and that he does not believe that it comes so far east, and that the record rests on a misapprehension ; it is, however, included in the key, as follows :-

A. Back black, spotted with white and pale yellowish.

u. Nape yellowish; throat red, bounded laterally by black.

S. varius.

b. Nape crimson like the crown, separated from it by a narrow black band as a rule; red throat hardly showing black a.t sides.

S. v. nuchalis, p. 229 .

B. Back glossy-black, unmarked.

S. thyroideus, ơ p. 231.

C. Back cross-banded with black and white. S. thyroideus, $q$ p. 231.

\section{Red-naped Sapsucker. Sphyrapicus varius nuchalis.}

A.O.U. Checklist no 402a-Colorado Records-Allen 72, pp. 158, 180 ; Henshaw 75, p. 392 ; Scott 79, p. 95 ; Tresz 81, p. 186; Drew 81, p. 141 ; 85, p. 17 ; Allen \& Brewster 83, p. 196 ; Bendire 88, p. 227 ; 92,p. 88 ; Morrison 86, p. 153 ; 88,p. 108 ; 89,p. 68 ; Kellogg 90,p. 87 ; Goss 91, p. 331 ; Lowe 94, p. 268 ; McGregor 97, p. 38 ; Cooke 97, pp. 83, 207 ; Keyser 02, p. 211 ; Henderson 03, p. 235 ; 09, p. 231 ; Gilman 07, p. 154 ; Warren 08, p. 21 ; 09, p. 15 ; Rockwell 08, p. 164 ; Hersey \& Rockwell, 09, p. 118.

Description.-Male-Crown and a transverse nuchal band crimson, separated by a narrow occipital band of black; upper-parts black, largely variegated with white and with a faint wash of yellowish in the centre; wings with the quills spotted with white, and a patch of white on the coverts; tail also with white; below, chin and throatpatch crimson, followed by a crescent-shaped patch of black; a line from the bill below the eye and rest of the under-parts pale yellow with dusky sagittate markings on the sides; iris brown, bill slatybrown, feet dusky. Length 7.5 ; wing 4.9 ; tail 3.0 ; culmen .8 ; tarsus $\cdot 8$.

The female is like the male, but has the chin white, though the throat remains crimson. A young male killed July 31st, has the crown black with a very faint wash of crimson, and a red throat and black chest with a mottling of dusky and yellowish.

Distribution.-Frcm eastern British Columbia and Alberta, south through Colorado to north-western Mexico, west to the Cascades, 
east casually to western Kansas, breeding chiefly from Colorado northwards.

In Colorado the Red-naped Sapsucker is common summer bird in the mountains, breeding in the aspens chiefly from 8,000 to 10,000 feet. It occasionally extends up as high as 12,000 feet, at which elevation it was observed by Rothrock in South Park (Henshaw). It appears to be only found on the plajns on migration, arriving from the south towards the end of April (April 25th, Gale), and departing again in September.

The following are some breeding notices: Estes Park (Bendire), Boulder co. (Gale), Breckenridge (Carter), Twin Lakes (Scott), Fort Garland (Goss), Mesa co., 8,000 to 9,000 feet (Rockwell), and La Plata co. (Morrison). It was noticed on migration at Barr (Hersey \& Rockwell), in El Paso co., in April and May, by Allen and Brewster, and there is an example from the same county taken in September in the Aiken collection.

Habits.-The Sapsuckers get their name from their habit of boring tiny gimlet-holes through the bark of trees, in order to allow the sap to run; this not only attracts insects but is itself greedily drunk. Sometimes trees are entirely girdled by rows of small holes, and considerable injury is caused, especially to fruit trees.

This bird is seldom found among the pines; it keeps to the deciduous trees, especially to the groves of "quaking aspens" (Populus tremuloides) which clothe patches of the mountain sides.

Gale investigated and took a very large number of nests and eggs in the hills of Boulder co. In almost every case the nest-hole was bored in a live aspen tree. These, though apparently sound, are nearly always decayed in the centre. The bird has to chisel through the tough outer zone of two or three inches, after which its task is an easy one. The carity is usually gourdshaped and is completed in six to ten days, chiefly by the female bird. It is situated from five to thirty feet up from the ground, at elevations of from 7,000 to 10,000 feet. Four or five pure white ovate eggs, 
measuring about $\cdot 90 \times \cdot 67$, are laid on the wood chips at the bottom of the hole, between June 1st and 15th. If the nest is disturbed or robbed, a second set will be found in another site near by, about ten or fifteen days later. Gale only found one or two nests in dead stumps, but Morrison states that near Fort Lewis cotton-wood stumps along the river were much preferred.

\section{Williamson's Sapsucker. Sphyrapicus thyroideus.}

A.O.U. Checklist no, 404-Colorado Records-Allen 72, p. 158 (S. williamsoni); Trippe 74, p. 289 ; Henshaw 74, p. 242 ; 75, p. 394 ; Scott 79, p. 95 ; Tresz 81, p. 186 ; Allen \& Brewster 83, p. 196; Drew 85, p. 17 ; Bendire 88, p. 235 ; 92, p. 97 ; Morrison 89, p. 68 ; Kellogg 90, p. 87 ; Lowe 94, p. 268 ; McGregor 97, p. 38 ; Cooke 97, pp. 84, 207 ; Keyser 02, pp. 76-79; Henderson 03, p. 107 ; 09, p. 231 ; Rockwell 08, p. 164.

Description.-Malo-Above black, more glossy on the crown and middle of the back, more dusky on the wings and tail; a postocular stripe and another from the base of the bill below the eye, a few spots on the wing-quills, large patch on the coverts, and the upper tailcoverts all white; below, a narrow patch on the throat red, sides of the throat and breast black, centre of the belly yellow, flanks and under tail-coverts mottled black and white; iris reddish-brown, bill slaty, legs greyish-green. Length 8.0 ; wing 5.5 ; tail 3.3 ; oulmen .9 ; tarsus $\cdot 8$.

The female is very different. Above regulerly barred with black and white to brownish-white, the crown-hair brown, and the upper tail-coverts white; below also barred, but the belly yellow as in the male, and a shield-shaped area on the chest black ; sometimes a little red on the throat. The young male is like the adult male, but has a white throat-patch and no red; the young female is like the adult female, but has the crown and breast barred like the rest of the body.

Distribution.-Breeding in the Rocky Mountains region from southern British Columbia to southern California and New Mexico, chiefly in the mountains; wintering in western Texas and Mexico as far as Jalisco.

In Colorado this Sapsucker is a far from uncommon summer resident, breeding in the mountains at from about 7,000 to 10,000 feet. At lower levels it is only a migrant. Breeding records are: Estes Park 7,000 to 8,000 feet, W. G. Smith (Bendire), Boulder co, 8,000 to 10,000 feet (Gale), Idaho Springs (Trippe), Pikes Peak at 8,400 feet (Keyser), Breckenridge (Carter), Twin Lakes (Scott), and Fort Garland at 10,000 feet (Henshaw). On migration it was noticed by Allen and Brewster 
in El Paso co., April 5th and 15th, and there is an example taken September 10th in the same county in the Aiken collection. On the western slope it occurs at Grand Junction in spring.

Habits.-The remarkable dissimilarity of the two sexes in this Woodpecker, caused them to be at first regarded as two different species. The male was known as S. williamsoni, the female as S. thyroideus. Henshaw (74) first found the two supposed species breeding together at Fort Garland, and solved the difficulty which had always been felt in regard to them. In most respects Williamson's Sapsucker resembles the Red-naped, but is apt to be somewhat shyer and more wary. It feeds on insects and their larvæ, but whether it bores for sap like the other form, appears to be rather uncertain. I have found no undoubted evidence on the subject. It has rather a shrill cry, "Huit, huit." Gale says : "This species affects generally old pine or spruce trees, and stumps that are rotten and easily worked, frequenting the same tree for several years, but making a fresh hole each year. It occasionally chooses aspens, but if it excavates for itself it ohooses a rotten tree. Sometimes it uses an old hole of a Red-naped Sapsucker."

The male does most of the work, both of excavation and incubation; when the female is on the nest, he sits on a branch near by and warns her of danger by a special tapping. The eggs, five or six in number, are laid from about May 30th to June 15th. They are white and often somewhat pyriform in shape, which is unusual in this family. They average $95 \times \cdot 68$.

\section{Genus PHLGOTOMUS.}

Of large size-wings 8 to 10 ; bill stout, longer than the head, with well marked culminal and lateral ridges; head conspicuously crested; toes four, the outer posterior (fourth) shorter than the outer anterior (third); plumage chiefly black with a red crest.

Only two closely allied subspecies found in the United States. 


\section{Northern Pileated Woodpecker.}

\section{Phlootomus pileatus abieticola.}

A.O.U. Checklist no 405a-Colorado Records-Drew 81, p. 140; Morrison 89, p. 68; Cooke 97, pp. 84, 207.

Description.-Male-Ábove and below dark brown, almost black; crown, occipital crest and malar stripe crimson; a stripe below the eye, chin and a patch on the wings white. Wing 9.0 ; tail 6.25 ; culmen 2.05. The female has the crown and malar stripes brown, but retains the erimson crest.

Distribution.-The wooded regions of North Americe from the southern Alleghanies north nearly to Hudson Bay, and west to Vancouver Island, but exterminated in most of the settled regions.

The occurrence of this handsome bird in Colorado rests on most slender evictence. Drew was told of the existence of a large crested Woodpecker in San Juan co., and H. G. Hoskins informed Cooke that he had seen what he took to be this bird on one occasion when pessing the Tuttle Ranch in Kit Karson co., close to the Kansas line.

\section{Genus MELANERPES.}

Bill moderate, about as long as the head, culmen slightly curved, the culminal and lateral ridges evident, but not strongly marked; nostrils hardly concealed by the bristles; head not crested ; toes four, the anterior and posterior outer toes about equal; plumage black, white and red in masses.

Two species in the United States. The Californian Woodpecker is found in Arizona and New Mexico, but does not reach our limits.

\section{Red-headed Woodpecker. Melanerpes erythrocephalus.}

A.O.U. Checklist no 406-Colorado Records-Allen 72, pp. 151, 158, 180 ; Aiken 72, p. 207 ; Trippe 74, p. 290 ; Henshaw 75, p. 398 ; Tresz 81, p. 186 ; Allen \& Brewster 83, p. 196 ; Beckham 85, p. 143 ; Drew 85, p. 17 ; McGregor 88, p. 44 ; 97, p. 38 ; Morrison 89, p. 145; Kellogg 90, p. 87; Bendire 92, p. 107 ; Cooke 97, pp. 84, 207 ; Henderson, 03, p. 235 ; 09, p. 231 ; Dille 03, p. 74 ; Warren 06, p. 21 ; 08,p. 21 ; Markman 07, p. 156.

Description.-Male-Head, all round, including the fore-breast crimson, bordered with black on the breast; back, wings (except the secondaries) and tail glossy blue-black, the latter with lateral feathers edged with white; secondaries, upper tail-coverts and under-parts white; iris brown, bill and feet dusky brown. Length 8.5 ; wing 5.75 ; tail 3.2 ; culmen $1 \cdot 1$; tarsus 9 .

The female is like the male, but slightly smaller-wing 5.4 
A young bird-a female killed in September-is quite different, the red parts are mottled grey and dusky, the back black, edged with greyish, the white secondaries variegated with black and the underparts grey, streaked with dusky.

Distribution.-Eastern North America from Ontario to the Gulf States, west to the Rooky Mountains from Colorado to British Columbia, migratory in the northern, a resident in the southern parts of its range, casual to Utah and Arizona.

The Red-head is a common summer bird in eastern Colorado, more abundant in the plains than in the mountains, though said to nest by Drew as high as 10,000 feet. The only breeding record in the mountains I have met with is that of Gale, which probably does not exceed 8,000 feet; and it is stated to be rare at Estes Park (Kellogg) and in South Park (Allen). It arrives late from the south-Springfield, May 15th (Warren), Pueblo, May 15th (Beckham) and El Paso co., May 12th (Aiken coll.), and Henderson reports it as late as October 23rd at Boulder. Apart from Breckenridge, which is practically on the continental Divide, the only record for the western slope is that of Warren (08), who saw a male near Steamboat Springs on June 10th. Breeding records are: Boulder co. (Gale), Crow Creek, Weld co. (McGregor).

Habits.-This is a handsome and attractive bird, but is rather disreputable in its habits. There can be no question that it sucks the eggs and kills the young birds of other species. Mr. W. G. Smith writes to Bendire: "I consider it a veritable butcher among our Nuthatches and Chickadees, driving every one away from its nestingsite; and woe to the bird that this villain can reach. It destroys both eggs and young, dragging the latter out of their nests and frequently leaving the dead at the entrance of their holes."

The Red-head is chiefly met with along the borders of woods and in the cotton-wood groves along the streams. It catches insects on the wing, darting at them from a fence or telegraph post, where they often perch. They do not work for the wood-borers as other Woodpeckers, but obtain larvæ and other insects from tree bark, and in the autumn feed largely on acorns, nuts and berries, sometimes laying up a store like the Californian 
Woodpecker. The flight is undulating and characteristic and the cry a loud "Tchur, tchur."

The nest-site is sometimes a natural hole, sometimes excavated by the birds in a semi-rotten tree, either a pine, willow or cotton-wood; the entrance is narrow, only about an inch and three-quarters in diameter, and the eggs are laid upon the wood chips. These are five to seven in number, short, ovate and glossy-white, and average $\cdot 99 \times 76$. Gale considered it one of the latest breeders, and found fresh eggs from June 10th to July 1st; and there is a set of seven eggs, taken June 16th near Greeley by I. C. Hall, and presented to the Colorado College Museum.

McGregor obtained a curious clutch of ten eggs, varying from normal size to the size of a song-sparrow's, in Weld co., on Crow Creek. The smallest egg was quite fresh but the normal ones heavily incubated.

\section{Genus ASYNDESMUS.}

Resembling Melanerpes in general structure, but the wing somewhat longer, and folding almost to the tip of the tail, and the feathers of the under-parts of peculiar struoture; the barbs stiff, bristle-like and loose ; plumage glossy metallic-green above with a grey nuchal collar.

Only one species; confined to western North America.

\section{Lewis' Woodpecker. Asyndesmus lewisi.}

A.O.U. Checklist no 408-Colorado Records-Allen 72, pp. 151, 180 (Melanerpes torquatus); Aiken 72, p. 207 ; Trippe 74, p. 292 ; Henshaw 75, p. 397 ; Allen \& Brewster 83, p. 196 ; Beckham 85, p. 143 ; Drew 85, p. 17 ; Morrison 86, p. 153 ; 88, p. 108 ; 89, p. 145 ; Bendire 92, p. 117 ; Lowe 94, p. 268 ; Cooke 97, pp, 84, 162, 208 ; Brewster 98, p. 188 ; Keyser 02, pp. 160-2 ; Dille 03, p. 74 ; Henderson 03, p. 235 ; 09, p. 231 ; Gilman 07, p. 154 ; Warren 08, p. 21 ; 09, p. 15 ; Rockwell $08, p .164$.

Description.-Male-Above, including the wings and tail iridescent bronzy-greenish-black, a narrow nuchal collar of grey continuous with the breast, which is the same colour; sides of the face, frontal region and chin crimson, followed by a patch of black on the throat; lower- 
breast and belly pink, slightly pencilled with grey; under tail-coverts bronzy like the beck ; iris brown, bill blackish, legs dusky slate. Length 9.5 ; wing 6.6 ; tail 3.9 ; culmon 1.05 ; tarsus 1.0 .

The fomale is like the male, perhaps a little smaller. The young bird is at first without lustre or crimson, the collar is absent, and the lower-parts are dull brown; the iridescence and crimson are gradually acquired.

Distribution.-Western North America from southern British Columbia and Alberta to western Texas and southern Californis; east to the Black Hills of South Dakota.

Lewis' Woodpecker is a common summer bird in Colorado, breoding chiefly along the eastern foothills and somewhat less commonly in the mountains up to about 9,000 feet. Above this level it occurs up to 10,000 feet in the Wet Mountains (Lowe) and near Fort Garland (Brunner), and even to 12,000 feet in La Plata co. (Morrison), but has not been found nesting. Cooke classes it as a resident, but it is certainly not a common bird in winter; Aiken tells me he has never met with it in this season. It does occasionally remain, however, as there is an example in the Colorado College Museum, killed January 13th, 1907, near Sedalia, by G. Flower. Breeding records are: Loveland (W. G. Smith apud Bendire), Boulder co. (Gale), near Colorado Springs and Buena Vista (Keyser), Wet Mountains to 8,000 feet (Lowe), Rouse Junction (Christie apud Cooke), Mesa co. up to 6,500 foet (Rockwell), La Plata co. to 9,000 feet (Morrison).

Most of the birds arrive from the south about the middle of May; El Paso co., May 6th (Aiken), Pueblo, May 13th (Beckham).

Habits. - At first sight this bird is more like a Grackle than a Woodpecker, owing to its iridescent colouring; and its ways rather confirm this. It is somewhat silent and very shy. It frequently perches on boughs like other birds, and it seldom "drums" or searches trunks of trees for insects.

It catches its prey, which consists chiefly of grasshoppers and other large insects, on the wing, and often sits on a bare bough high up to get a good view around. Besides insects, it feeds on berries and seeds; it has been accused of causing considerable damage in cherry orchards. In the late fall it was observed by S. French, storing up acorns for future use in holes in cottonwood and other trees; some of these were small 
and only held five or six acorns, each tightly wedged in, while others, three inches across and extending downwards for six or eight inches, held many more. It was evident that the birds brought the acorns to the holes and shelled them there, as the ground beneath was littered with empty shells. These observations were made at Happy Cañon, about twenty miles southeast of Denver, in November, and were published by Brewster (98).

The eggs of this Woodpecker are deposited in natural cavities or old Flicker-holes, generally in old pines or spruces, or in cotton-woods on the plains. Gale states that they seldom if ever excavate a new hole for themselves. The eggs, usually seven, are very ovate, white and not very glossy, and measure $1.03 \times 80$. Both sexes share in incubation, and fresh eggs may be met with between May 15th and June 15th.

\section{Genus CENTURUS.}

Closely resembling Melanerpes in structure, but with a different style of coloration; the back and wings closely cross-barred with bleck and white.

Three species in the United States.

\section{Red-bellied Woodpecker. Centurus carolinus.}

A.O.U. Checklist no 409-Colorado Records-Ridgway 73, p. 185; Morrison 89, p. 145 ; Cooke 97, pp. 84, 208.

Description.-Male-Crown and nape bright scarlet: upper-parts cross-barred with black and white; primaries and tail-feathers black with white markings, chiefly spots and edginga; below and sides of the face grey, with a faint wash of yellow, reddening on the abdomen; iris red, bill black, legs dusky slate. Length 8.4 ; wing 5.1 ; tail 3.25 ; culmen 1.1 ; tarsus .85 .

The female has the crown grey, the frontal plumes dull red and the nape acarlet. Young birds are very like the adults, but the red on the head is rather indistinct and the belly buffy.

Distribution.-Eastern North America from Ontario and Massachusetts to Florida and Texas, west to Kansas and Nebraska. 
The Red-bellied Woodpecker is a straggler to eastern Colorado only. It was seen by Z. X. Snyder near Greeley in 1895, and Aiken procured a single male close to Limon on May 23rd, 1899. This specimen is now in the Colorado College Museum.

\section{Genus COLAPTES.}

Bill rather weak for the family ; culmen slightly curved and strongly ridged, but the lateral ridges absent and the nostrils exposed; toes four, the outer posterior distinetly shorter than the outer anterior, the inner posterior (hallux) very short; plumage variegated, but the under-parts always with round black spots on a pale ground.

An American genus with three species in the United States as well as several geographical subspecies and hybrids.

\section{KEY OF THE SPEcIES.}

A. Lining of the wings and tail yellow. $\quad$ C. a. luteus, p. 238 .

B. Lining of the wings and tail red. C. collaris, p. 239.

\section{Northern Flicker. Colaptes auratus luteus.}

A.O.U. Checklist no 412a-Colorado Rocords-Thorne 87, p. 264 ; Morrison 89, p. 145; Allen 92, pp. 21-44; Osburn 93, p. 212 ; Cooke 97, pp. 85, 162, 208 ; Burns 00, pp. 1-82 ; Felger 05, p. 421 ; Markman 07, p. 156.

Description.-Male-Crown, back and sides of the neck ashy-grey, with a transverse scarlet nuchal band; back and exposed parts of wings olive, transversely banded with black; rump white, upper tailcoverts black and white; primaries and tail-quills black with yellow shafts (except the two median tajl-feathers) and yellow linings below; sides of the face, throat and fore-neck vinaceous, with a black moustach $\theta$ patch and a black creseent on the breast; posteriorly pale vinaceous to dirty white, spotted with black ; iris brown, bill and feet dark-slaty. Length 12.0 ; wing 6.0 ; tail 4.25 ; culmen 1.4 ; tarsus 1.1 .

The female resembles the male, but has no black moustache patch.

Distribution.-Eastern and northern North America from Alaska, Yukon and Labrador south, chiefly east of the Rocky Mountains, to Kansas and North Carolina.

In Colorado pure-bred examples of the Yellow Flicker are seldom met with, though the intermediates or hybrids are common enough.

Osburn obtained a typical Yellow Flicker at Loveland, September 24th, 1889, and Thorne another at Fort Lyon in December, 1883. An example was recently collected by Felger at Hall Valley in Park co. at an elevation of 10,000 feot, October 24th, 1904, showing that it sometimes extends into the mountains. Markman found a nest on the Big 
Thompson, which he believed, from an examination of the young birds, belonged to the Yellow Flicker. If this be correct it is the first breeding record for the State.

\section{Red-shafted Flicker. Colaptes cafer collaris.}

A.O.U. Checklist no 413-Colorado Records-Allen 72, pp. 151, 158, 163, 180 (Colaptes mexicanus); Aiken 72, p. 207 ; Trippe 74, p. 295; Henshaw 75, p. 401 ; Scott 79, p. 95 ; Drew 81, p. 141; 85, p. 17 ; Tresz 81, p. 187 ; Allen \& Brewster 83, p. 196 ; Beckham 85, p. 143, 87, p. 124 ; Morrison 88, p. 115 ; 89, p. 145; Kellogg 90, p. 88 ; Goss 91, p. 341 ; Lowe 94, p. 268 ; Cooke 97, pp. 85, 162, 208 ; Dille 03, p. 74 ; Henderson 03, p. 235 ; 09, p. 231 ; Warren 06, p. 21 ; 08, p. 21 ; 09, p. 15 ; Gilman 07, p. 154; Markman 07, p. 156; Richards 08, p. 38 ; Rockwoll 08, p. 164.

Description.-Male-Resembling C. a. luteus in most respects-in its banded back, white rump and black wings and tail ; differing as follows : fore-part of crown vinaceous shading into grey on the nape, sides of the face and breast ; no red nape band ; moustache spot scarlet, not black ; shafts and linings of the wing and tail-quills orange-red to vermilion; ground-colour of the upper and lower sides rather more pinkish in shade; iris dark brown, bill dusky slate, feet dusky horn. Length 12.5 ; wing 6.5 ; tail 4.75 ; culmen 1.65 ; tarsus 1.15 .

The female is like the male, but has no red moustache patch ; wing 6.25. A young male, killed July 23rd, has the whole head and nape cinnamon or vinaceous and the red moustache already distinct, and is otherwise much like the adult (see Plate 7).

Distribution.-From south-eastern British Columbia to western Texas and perhaps northern Mexico, west to the Pacific in California, to the Cascades from Oregon northwards.

The Red-shafted Flicker is a very common resident throughout the whole of Colorado, breeding from the plains to about 10,000 feet, and often wandering higher up to 12,000 feet-Boreas Pass at 12,000 feet and at 11,700 near Crested Butte (Warren). It winters in considerable numbers in the foothills along the creeks, though a certain number undoubtedly move further south. Warren met with it even as high as Mosea at 7,560 feet on January 17 th, and it is quite a common winter bird about Colorado Springs.

The following are some notices: Boulder co., resident, breeding 5,500 to 9,000 (Gale); Idaho Springs, April to October only (Trippe); Twin Lakes, breeding (Scott); Pikes Peak to timber line in summer (Aiken); Ramah, nesting (Aiken); Wet Mountains, nesting to 10,000 feet (Lowe); Mesa co., common, resident, breeding at all altitudes, wintering along streams at lower levels (Rockwell); Montrose co., resident, more common in summer (Warren 09); San Juan co., summer only (Drew). 
Habits.-The Flicker is one of the most familiar birds in Colorado. It is commonly seen in the suburban portions of the towns, often, unlike other Woodpeckers, perched crossways, and flying from tree to tree with its characteristic undulating line, which displays its white rump and a flash of red from under the wings. They are equally at home in open country far from trees, in the cotton-woods along the streams, or in the pine timber of the mountains. The cry is a clear ringing "Piute," and a harsh and rather shrill chuckle is very characteristic.

The bill of the Flicker is not so strong as that of other Woodpeckers, and they do not " drum " on the tree-trunks nearly so often. They get their food on the ground to a great extent, often digging in pastures for worms and grubs and feeding largely on ants. They occasionally catch insects on the wing, and are fond of berries and small fruits as well as insects.

The Flicker is no great excavator ; it uses by preference natural cavities or else chooses decayed trees for its nest-site ; it will make use of almost any tree available, and sometimes selects telegraph posts or buildings, or even a hayrick; where there are no trees it occasionally makes a burrow in a bank. Gale sometimes witnessed a battle royal between the Flicker and the Screech $O w l$, for the possession of a desirable site; and old Flickerholes are used by many other birds. The eggs, usually seven in number, are laid at the bottom of the cavity, on the wood chips; occasionally many more eggs have been found, but in these cases they have probably been deposited by more than one female. The eggs are pure white and average $1 \cdot 12 \times 85$. Gale found fresh eggs from May 5th to June 5th at 5,500 feet, and after June 5th at 9,000 feet. On one occasion he found two nests 


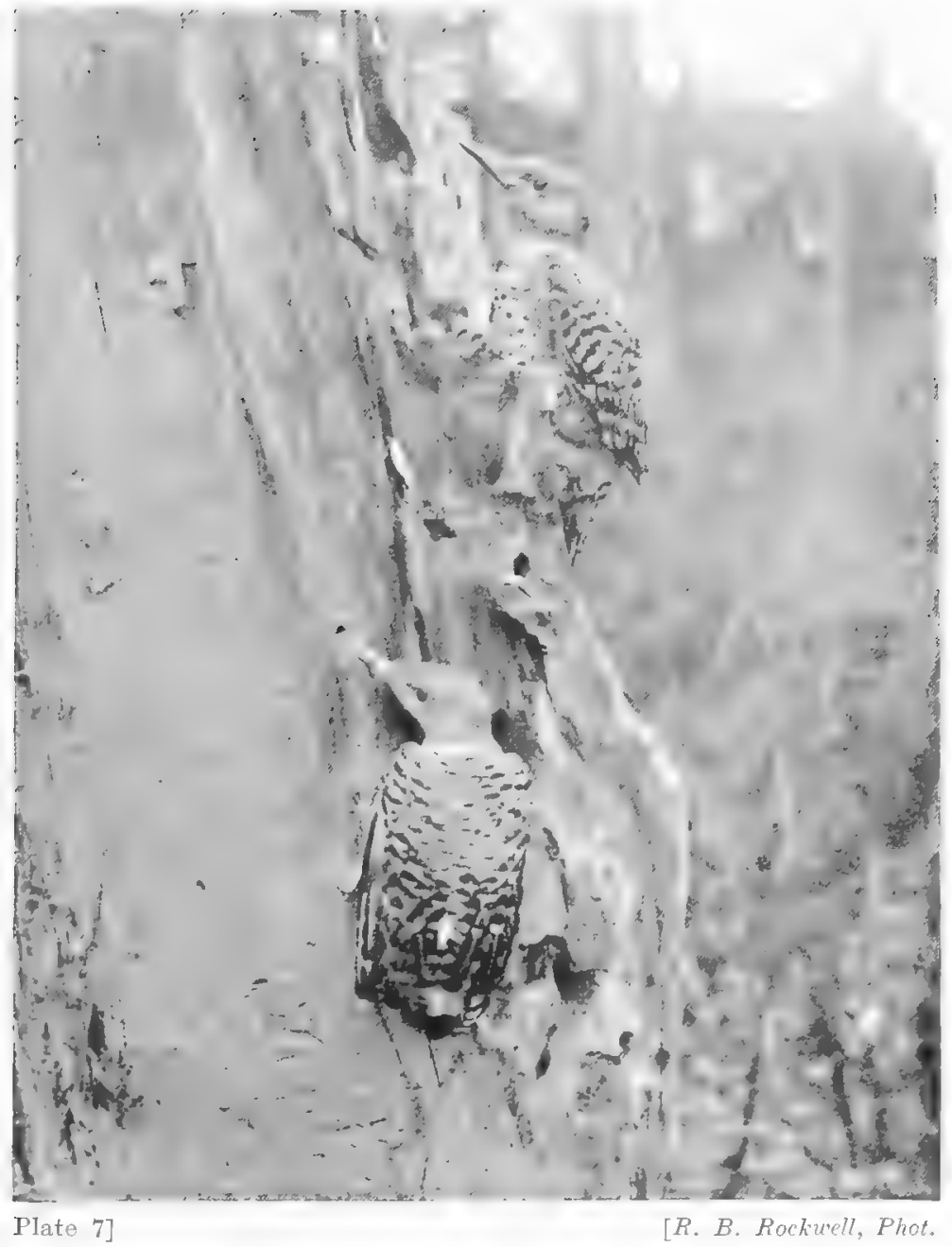

IOUNG RED-SHAFTED FLICKERS ON A COTTON-WOOD AT LITTLETON, NEAR DENVER, JUNE 6TH, 1908. 

with eight and nine fresh eggs on April 30th. Dille gives May 29th near Denver, while Scott at Twin Lakes notes June lst as average dates.

Intermediate forms.-Where the range of the Yellowshafted Flicker meets that of the Red-shafted formfrom western Texas north along the eastern bases of the Rocky Mountains to Montana and Alberta, and especially in Wyoming and Montana-most of the Flickers are intermediate in character between these two quite distinct species. Every gradation between the two bas been observed. Baird (58, p. 122) first drew attention to this remarkable state of affairs, which he characterised as "unparalleled in the annals of ornithology." $\mathrm{He}$ believed that it was due to interbreeding of the two original forms, continued into successive generations. Although this view has not been wholly accepted by Coues (74, p. 292) and Allen (92), both of whom have discussed the matter at considerable length, it appears to be the only conclusion possible to account for the facts. A series of experiments in interbreeding these two birds in captivity on Mendelian lines, would probably throw light on the matter.

In the eastern plains and foothills of Colorado the intermediate forms are not at all uncommon, and there are a considerable number from the neighbourtood of Colorado Springs showing every step between the two pure-bred forms in the Aiken collection. Nearly all these were taken in April on the spring migration, and as a rule they go further north to breed.

\section{ORDER MACROCHIRES.}

This order. contains the Goatsuckers, Swifts and Hummers, three groups of birds of very different external appearance, but undoubtedly allied to one another in 
structure. The following are the external characters, which, however, are sufficiently vague: Bill either very short and depressed with a very wide and deeply cleft gape, or very long and slender, far exceeding the head, but never with a cere; wings very long with ten primaries and tail with ten rectrices; feet always small and weak.

KEy of the FaMities.

A. Bill short, broad and depressed, but gape very large.

a. Plumage lax and soft; claw of middle toe pectinated.

Caprimulgidæe, p. 242.

b. Plumage firm and hard ; claw of middle toe not pectinated.

Cypselida, p. 248.

B. Bill very long and slender, gape not deeply cleft; plumage more or less metallic.

Trochilidæ, p. 251.

\section{Family CAPRIMULGID平.}

Head broad and flat, bill very small, depressed, triangular in shape from above, but the gape extending back to below the eye, and with usually a great development of the rictal bristles; wing moderate, the secondaries never so short and reduced as in the Swifts and Hummers; legs short and weak, the claw of the middle toe pectinated along its inner margin.

This family contains the birds known as Goatsuckers or Nightjars in the Old World, Whip-poor-wills in the New; they are further distinguished by their soft, lax plumage, mottled with black, tawny and white, and by their nocturnal or crepuscular habits.

\section{Key of the Genera.}

A. Rictal bristles very long and conspicuous.
a. Tarsus bare; nostrils tubular.
Phalanoptilus, p. 243.

b. Tarsus feathered; nostrils not tubular. Antrostomus, p. 243.

B. Rictal bristles very small and hardly noticeable; tarsus half feathered.

Chordeiles, p. 245. 


\section{Genus ANTROSTOMUS.}

Nostril oval, surrounded by a raised rim which, however, is not produced into a distinct tube; rictal bristles very long and conspicuous; tail slightly rounded, shorter than the wing; tarsus not so long as the middle toe, and feathered in front nearly to the base of the toes; plumage soft and mottled, tawny and black.

Two species in the United States.

\section{Whip-poor-will. Antrostomus vociferus.}

A.O.U. Checklist no 417-Colorado Record-Burnett 04, p. 278.

Description.-Male-Above finely mottled and marbled with duskv, tawny and grey, a few black marks on the crown and back; primaries dusky with tawny spots almost forming bars; three outer tail-feathers dusky with the terminal third white; below mottled like the back, becoming paler and more mixed with white posteriorly; a white throat bar; iris and bill black, legs dusky. Length 10.2 ; wings 6.4 ; tail 5.15 ; culmen .44 ; tarsus .6 .

The female is smaller-wing 6.2 ; the throat bar is tawny, and the white of the tail is much reduced and ochraceous; the general tone is lighter and more oohrey.

Distribution.-Eastern North America from Manitoba and New Brunswick south through eastern Nebraska and Kansas to Teaas; in winter, south to the West Indies and Guatemala.

A straggler to Colorado : only once recorded. A single example, greatly emaciated but in good plumage, was found dead in an orohard. near Fort Collins by Mrs. R. J. Tenny, about September 14th, 1903. It was determined at Washington to be this species, and is now preserved in the Museum of the Agricultural College at Fort Collins.

\section{Genus PHALANOPTILUS.}

Nostrils tubular and cylindrical, opening rather forwards; rictal bristles well developed; tail rather short and slightly rounded; tarsus bare except just at the joint, longer than the middle toe without elaw.

One species only in the United States, with two additional subspecific geographical races.

A. Darker and more richly coloured.

P. nuttalli, p. 243.

B. Paler and more silvery.

P. n. nitidus, p. 245 .

\section{Poor-will. Phalonoptilus nuttalli.}

A.O.U. Checklist no 418-Colorado Records-Allen 72, pp. 151, 179; Aiken 72, p. 206 ; Henshaw 75, p. 369 ; Allen \& Brewster 83, p. 195 ; Drew 85, p. 17 ; Beckham 85, p. 143 ; Morrison 89, p. 145 ; Kellogg 
90, p. 88 ; Bendire 92, p. 153 ; Lowe 94, p. 268 ; Cooke 97, pp. 85, 208 ; Henderson 03, p. 235 ; 09, p. 232 ; Gilman 07, p. 154 ; Warren 08, p. 21; 09, p. 15 ; Rockwell 08, p. 165 ; Hersey \& Rockwell 09, p. 118.

Description.-Male-Above silvery-grey, finely mottled and marked with velvety-black bars and angular spots; primaries and outer secondaries tawny, barred with dusky, mottled like the back at the tips ; tail with four central feathers like the back, outer one chiefly dusky with white terminal patches, about .75 inch long; below a white throat-patch, breast almost black with a few whitish spots, abdomen pele buffy irregularly barred with brown; under tail-coverts plain buffy; iris dark brown, bill and legs dusky, the latter purplish. Length 7.0 ; wing 5.5 ; tail 3.0 ; culmen .32 ; tarsus .65 .

The female is very like the male, but the white terminal bands of the tail are narrower, about .5 inch, and tinged with tawny.

Distribution.-The dryer parts of western North America, breeding from south-east British Columbia and North Dakota south to the Mexican border, east to Kansas and Oklahoma, west to the Cascades and Sierra Nevada; in winter through eastern Mexico to Guatemala.

The Poor-will is a fairly common summer bird in Colorado. It reaches El Paso co. early in May, Austins Bluffs, May 3rd (Allen \& Brewster), and has been found nesting both in the plains and in the parks to about 8,000 feet, while Lowe both saw and heard it as high as 10,000 feet in the Wet Mountains.

The following are notices: Estes Park, nesting (W. G. Smith apud Bendire), Boulder co., nesting in the hills (Gale), Barr Lake district, rare (Horsey \& Rockwell), Denver, May 15th, and Fort Garland, August (Henshaw), Middle Park, breeding (Carter), Craig, June (Warren, 09), Mesa co., 6,500 to 8,000 feet in Plateau Valley (Rockwell), Montrose co., breeding (Warren 09).

Habits.-Unlike the other members of the Goatsucker family, the Poor-will is not confined to wooded districts; it is quite as much at home on the open prairie and on the desolate sage-brush plains. It is thoroughly crepuscular, coming out at dusk and noiselessly pursuing night-flying moths and beetles; it also gathers a good deal of its prey on the ground. Like the Owls it ejects the hard and indigestible parts of its food in the form of pellets. During the day it remains quiet on the ground, sheltered from view by a bush or a bunch of grass. It has a melancholy wailing song, "Poor-will,". heard at 
dusk or sometimes before dawn, and it is more often recognized by its voice than by its appearance. It often alights on the bare ground, and when it does so it is most difficult to detect it.

The eggs, two in number, are laid on the bare ground, sometimes in the open, sometimes sheltered by a tuft of grass or a bush. They are oval or blunt oval, creamywhite, with a faint pink suffusion which does not disappear. They measure $\cdot 99 \times \cdot 75$.

\section{Frosted Poor-will. Phalconoptilus nuttalli nitidus.}

A.O.U. Checklist no 418a-Colorado Records-Bendire 92, p. 157 ; Cooke 97, pp. 85, 162, 224.

Description.-Very similar to $P$. nuttalli, but paler and more silvery, and the derk marks of the crown and back fewer and more sharply defined; below the transverse bars of the abdomer finer, paler and less conspicuous. Dimensions about the same, perhaps averaging little smaller.

Distribution.-From Texas to Arizona, north to southern Colorado and south-west Kansas, south to northern Mexico.

Of three Poor-wills taken by Captain Thorne at Fort Lyon, Mr. Brewster considered that one should be referred to this subspecies.

Bendire and Goss believe that this subspecies is only a colour-phase of the typical Poor-will, as the ranges of the two are practically identical and they do not differ appreciably in habits, action or size.

\section{Genus CHORDEILES.}

Horny part of the bill extremely small; nostril cylindrical and rimmed but not tubular; gape with very short rictal bristles; wing long and pointed, the outer (10th) primary almost equal to the ninth; tail slightly forked, very short, about half the length of the wing; tarsus about as long as the middle toe without claw, feathered about half way down.

Two distinct species and several subspecific races of Night-Hawks are found in the United States.

\section{KEY OF THE SPECTES.}

A. Larger ; wing 7 to 8; white patches on the five outer primaries, nearer the base than tip.

C. v. henryi, p. 246 .

B. Smaller; wing 6 to 7 ; white patches on four outer primaries only, nearer the tip than the bese.

C. a. texensis, p. 247. 
Western Night-Hawk. Chordeiles virginianus henryi.

A.O.U. Checklist no 420a-Colorado Records-Baird 54, p. 13; Allon 72, pp. 151, 158, 179 ; Aiken 72, p. 206 ; Henshaw 75, p. 367 ; Seott 79, p. 95 ; Tresz 81 , p. 184 ; Drew 81 , p. 140 ; 85, p. 17 ; Allen \& Brewster 83, p. 196 ; Beckham 85, p. 143 ; Morrison 88, p. 107 ; 89 , p. 145 ; Kellogg 90 , p. 88 ; Bendire 92, p. 167 ; Lowe 94, p. 268 ; MeGregor 97, p. 38 ; Cooke 97, pp. 85, 208 ; Keyser 02, p. 262 ; Dille 03, p. 74 ; Henderson 03, p. 235 ; 09, p. 232 ; Warren 06, p. 21 ; 08 , p. 21 ; 09, p. 15 ; Gilman 07, p. 154 ; Markman 07, p. 156 ; Rockwell 08 , p. 165.

Description.-Male-Above mottled with black and tawny and a little white, the last chiefly on the wing-coverts; primaries, greater-coverts and secondaries dusky black; the five outer primaries with a conspicuous white spot about the middle of their length; tail with black bars and a white subterminal band on all except the central pair of feathers; below, a white triangular throat-patch; breast and sides of the throat and face mottled dusky and tawny; posteriorly barred with dusky and tawny-white; bands fading away on the under tail. coverts ; iris and bill blackish, legs dusky grey. Length 9.0 ; wing 7.5 ; tail 3.75 ; culmen .3 ; tarsus .5 .

A female is similar, but the throat-patch is tawny and white tail-tips are absent. A young female is paler and more silvery above, has the primaries edged with white at the tips, but the white patches much smaller below ; the throat patch is hardly defined, and there is no trace of the white on the tril.

Distribution.-Western North America from central British Columbia and Manitoba south to central Mexico, east to Illinois and Kansas, west to California; south in winter to northern South America, perhaps to Patagonia.

The Western Night-Hawk was taken as long ago at 1853 by Captain Gunnison in the Rio Grande Valley, and it is an abundant summer bird all over Colorado, breeding from the plains to about 10,000 feet, perhaps even higher. It was noticed by Keyser flying about on the top of the peak "Tillie Ann" in the Ten-mile range near Breckenridge, above timber line at about 13,000 feet.

It arrives from the south towards the end of May; it was seen by Warren at Gaume's Ranche in Baca co., on the 21st, in El Paso co. on the 23rd, and near Grand Junction by Sullivan as early as the 8th. It leaves again in September, though seen as late as October 18th at Grand Jinction by Sullivan (Rockwell). Breeding records are Boulder co., up to 9,500 feet (Gale), Breckenridge (Carter), Fairplay (Tresz), Twin Lakes (Scott) and Crested Butte (Warren).

Habits.-The Night-Hawk is hardly well named, as it is often to be seen about in the day-time, even on 
sunny days, though it is more commonly noticed at dusk. They are birds of graceful and swift flight, delighting in swift turns and zigzags when in pursuit of insects, of which they must destroy enormous numbers.

They are to be found chiefly in prairie country, and in the open bare parts of the mountains. They are social in their habits, and are often seen together in considerable numbers. They alight on horizontal branches of trees or fence-rails, and sit lengthways; but except when nesting, do not often squat on bare ground, according to Bendire.

The eggs, laid on the bare ground, are two in number, and laid on alternate days. In shape slightly ovate or oval, and in colour creamy-white or grey profusely blotched with slaty or smoky-drab or lavender, they vary very considerably. They average $1.18 \times \cdot 85$. Gale found fresh eggs from June 20th to July 10th in Boulder co., and Dille gives June 19th as an average date. Warren secured eggs near Crested Butte on July 9th. Henderson states they sometimes lay their eggs on the flat roofs of business houses in Denver.

\section{Texan Night-Hawk. Chordeiles acutipennis texensis.}

A.O.U. Checklist no 421.

Description.-Rather smaller then $C$. $v$. henryi and less tawny;, more greyish in tone; at once distinguished by the white patches on the primaries, which are confined to the outer four, and are placed distinctly nearer the tip than the base of the wing; below with a white throatpatch and abdomen barred buffy and dusky, but with no black on the chest; primaries slightly spotted with tawny below the white patches. Length 8.0 ; wing 6.6 ; tail 3.5 ; culmen .2 ; tarsus .45 .

The female has the wing-patches pale tawny, and the white tail band restricted or wenting.

Distribution.-South-west United States from western Texas to southern California, Nevada and Utah; in winter, south so far as Veragua in Columbia. 
An example of this species was recently secured by Aiken at Hoehne, near Trinidad, on June 11th, 1908. This constitutes a new record for Colorado.

\section{Family CXPSELID压.}

This family contains the Swifts-birds distinguished for their great power of rapid flight. The following are a few of the most obvious external characters, sufficient to distinguish them : Bill very small, flattened and triangular, but with the gape of the mouth very large and extending back to under the eye; no rictal bristles; wing long, thin and pointed, made up chiefly of the primaries, which are ten in number; secondaries very strort and reduced; tail-feathers ten, variable in shape and arrangement; legs and feet small and weak, adapted only for perching; toes four, variously arranged in different genera.

The salivary glands of the Swifts are very greatly developed, and their secretion, which forms a ghuey mass, is used more or less in the construction of the nest.

\section{KeY of The Genera.}

A. Tarsi feathered, plumage black and white. Aëronautes, p. 249.

B. Tarsi naked, plumage black, no white. Cypseloides, p. 248.

\section{Genus CYPSELOIDES.}

Nostrils embedded in the frontal feathers; wing with the outer primary the longest; tail forked, the feathers obtusely pointed, but the shafts not produced to form needlo-like points; tarsi naked, hallux normal, turned backwards, slightly elevated above the others; plumage black.

An exclusively American genus with five or six species, one of which is found in the western United States.

\section{Black Swift. Cypseloides niger borealis.}

A.O.U. Checkliat no 422-Colorado Records-Drew 81, p. 140 ; 82, p. 182 ; Morrison 89, p. 145 ; Bendire 92, p. 175 ; Cooke 97, p. 86. 
Description.- Sooty black above and below, with a slight greenish gloss, a little paler below than above; a velvety-black area in front of the eye; forehead hoary; bill black, feet dusky purplish. Length about 7.0 ; wing 7.0 ; tail 2.45 , forked about .5 ; tarsus .5 .

The female resembles the male, but according to Coues has the tail merely forked, not emarginate. Young birds are dull black with a good deal of white tipping and edging, especially on the rump; abdomen and under tail-coverts nearly pure white.

Distribution.-Western North America, chiefly in the mountains from British Columbia to southern California, east to Colorado and Nevuda. In winter south to Lower California and Costa Rica.

The Black Swift has only been met with in the southern part of the State where, however, judging from Drew's account, it is far from uncommon at high elevations in the San Juan co. It breeds in the cliffs from about 10,000 to 12,000 feet, and ranges to the highest summits. At Howardsville it arrives towards the end of June and stays till September. A. K. Fisher told Bendire that he had seen a number of these birds above the cliffe near Trinidad in July, 1892. These constitute the only observations in Colorado.

Habits.-This species is generally seen in flocks, flying high among the mountains, and only coming down near the ground after rain, in pursuit of the small flies (Ephemeridoe) on which they subsist. They are stated to be rather less noisy than other species, but in no other respect to be remarkable. Anthony, who noticed this bird in large numbers near Silverton, killed some females between June 25 and July 10th with ova ready to deposit, and had no doubt they nested in the cliffs near by. The nest and eggs have been taken in similar situations in California.

\section{Genus Ä̈RONAUTES.}

Nostrils oval and not concealed; wing with the outer primary a little shorter than the next; tail short, less than half the wing, slightly forked and not spiny; tarsus and toes feathered, hallux laterally directed, not reversible and jointed above the other toes; plumage black and white.

One North American species only. 


\section{White-throated Swift. Aèronautes melanoleucus.}

A.O.U. Checklist no 425-Colorado Records-Allen 72, p. 151 (Panyptila melanoleuca); Aiken 72, p. 206 ; Minot 80, p. 231 ; Stone 81, p. 67 ; Allen \& Brewster 83, p. 196 (Cypselus saxatilis); Drew 85, p. 17 ; Morrison 88, p. 107 ; 89, p. 145 ; Lowe 92, p. 101 ; 94, p. 268 ; Bendire 92, p. 185 ; Cooke 97, pp.19, 86, 208 ; Henderson 03, p. 235 ; 06 , p. 109 ; 09, p. 232 ; Gilman 07,p. 154 ; Markman 07,p. 156 ; Rockwell 08, p. 165 ; Cary 09, p. 181.

Description.-General colour black, rather glossy on the back ; lores, a narrow eyebrow, edge of the outer primary, tips of the inner secondaries, whole of the chin, sides of the face, throat and fore-breast, continued as a narrow line down the middle of the belly, and patch on the flanks, white; bill black, feet yellowish. Length 6.5 ; wing 5.8 ; tail 2.5 ; culmen $\cdot 2$; tarsus $\cdot 45$.

Distribution.-Western North America from California, Montana and South Dakota, south through western Texas and Mexico to Guatemala; s resident in southern California and Arizona; north of this a summer bird.

The White-throated Swift is far from uncommon in Colorado, where there are cliffs and inaccessible rocks suitable for nesting. It reaches El Paso co. from the south about the second week in April, though a fow were seen as early as March 24th by Allen and Brewster.

The following are known breeding places: Pawnee Buttes (Henderson), Boulder co. (Gale), Horsetooth Mountain, 7,000 feet, near Fort Collins (Cooke), Garden of the Gods, Glen Eyrie and Cheyenne Cañon, all close to Colorado Springs (Allen \& Aiken), Wet Mountains to 10,000 (Lowe), Breckenridge (Carter), Book Cliffs coal mine, near Grand Junction (Rockwell), Silverton (Anthony apud Bendire). It breeds indifferently from the plains up to 12,000 feet, and often wanders to the highest summits.

Habits.-Like other Swifts this species is a bird of rapid and powerful flight, seldom seen low down except in cloudy or damp weather. Their loud, shrill titter can often be heard about rock pinnacles and cliffs, where they are very numerous, circling round and flashing past with incredible speed. They make their nests in the cavities of the cliffs, in places that are practically inaccessible, so that although the bird is far from scarce their nests and eggs are almost unknown. It is said to be a saucer-like structure, made of shreds of bark 
and other vegetable matter and a few feathers, all glued together with hardened saliva. The eggs, four or five, are white and measure $87 \times \cdot 52$.

A female shot by Drew, June 20th, at 13,000 feet near Silverton, contained an egg ready for extrusion; while Gale, though he apparently never actually took eggs of this species, gives May 25th to June 10th as the date for fresh eggs in Boulder co.

\section{Family TROCHILIDÆ.}

The Humming-birds which make up this family hardly require a diagnosis; their tiny size and their metallic colouring at once distinguish them. The bill is very long and slender and usually straight, the nostrils are linear and protected by an overhanging scale or operculum, and often feathered and concealed; the wing is long and consists of ten elongated and often curiously attenuated primaries, and six reduced and very short secondaries; the tail consists of ten rectrices; the feet are extremely small and weak, and only adapted to perching.

The jollowing Key separates the Species fodNd in Colorado.

A. Tail not white-tipped (males).

a. Baok chiefly rufous, gorget coppery-red. S. rufus, $\delta$ p. 255.

b. Back and central tail-feathers green.

a Tail rufous at the base, gorget crimson.

S. platycercus, d.p. 253.

b1 Tail without rufous; gorget dusky purplish.

A. alexandri, ठ p. 252.

c. Back green, central tail-feathers dusky. S. calliope, $\delta$ p. 256.

B. Tail white-tipped (females).

a. No visible rufous at the base of the tail.

a Tail-feathers obtusely pointed; no rufous on the flanks.

A. alexandri, 우 p. 252.

b1 Tail-feathers spoon-shaped and rounded, flanks slightly washed with rufous.

S. calliope, + p. 256 . 
b. Tail-feathers rufous on basal half.

a 1 Outer tail-feathers about $\cdot 25$ across, very little if any rufous on the flanks.

S. platycercus, + p. 253.

$b^{1}$ Outer tail-feathers narrower, about 12 across; flanks and under tail-coverts washed with rufous. S. rufus, 우 p. 255.

\section{Genus ARCHITROCHILUS.}

Bill long, slender and black; nostrils concealed ; wing with the outer primary incurved and scimitar-shaped; tail forked in the mele, the feathers lanceolate and pointed, but not specially narrowed; in the female rounded and white-tipped; male with a metallic gorget, produced and elongated at the corners; no rufous about the plumage.

Two species in the United States; the Ruby-throat of the east does not normally come further west than eastern Nebraska and Kansas, but may possibly stray to Colorado.

\section{Black-chinned Humming-bird. Architrochilus alexandri.}

A.O.U. Checklist no 429-Colorado Records-Morrison 86, p. 153 ; 88, p. 107 ; 89, p. 146 ; Bendire 92, p. 198 ; Cooke 97, pp. 86, 208.

Description.-Male-Above golden-green; wings dusky purplish, below grey, greenish at sides; throat velvety-black becoming irideacent violet posteriorly; tail forked about $\cdot 1$; tail-feathers pointed. Length 3.25 ; wing 1.65 ; tail 1.1 ; culmen $\cdot 7$.

The female has no gorget, the throat sometimes with dusky spots; tail rounded, all but the central feathers dusky purplish with terminal bands of white; wing 1.9 .

Distribution.-Western North Americe from southern British Columbia to western Texas and Sonora, wintering to southern Mexico.

The Black-chinned Fumming-bird is confined to the south-west and western portions of Colorado. Morrison found it fairly common and breeding in La Plata co. about Fort Lewis; a fine male was taken near Glenwood Springs in 1898 by William Cross. These are the only definite records for the State.

Habits.-Morrison states he was shown a nest containing three eggs; this is unusual, as Humming-birds almost invariably lay but two eggs.

\section{Genus SELASPHORUS.}

Nostrils concealed; wing with the outer or two outer primaries strongly attenuated and bowed in the male, less so in the female; tail rounded or graduated, not forked; male with a gorget not produced 


\section{Broad-tailed Humming-bird}

into a ruff; female with white-tipped tail ; a certain amount of rufous in the plumage, especially at the base of the tail in both sexes.

Three well-known species are found in the United States; for key, see p. 251.

\section{Broad-tailed Humming-bird. Selasphorus platycercus.}

A.O.U. Checklist no 432-Colorado Records-Allen 72, pp. 151, 158, 163, 180; Aiken 72, p. 206 ; Coues \& Trippe 74, p. 272 ; Henshaw 75 , p. 377 ; Coues 78, p. 95 ; Scott 79, p. 95 ; Minot 80, p. 232 ; Tresz 81 , p. 185 (T. colubris) ; Drew 81, p. 140 ; 85, p. 17 ; Allon \& Brewster 83 , p. 196 ; Morrison 86, p. 153 ; 88, p. 107 ; 89, p. 146 ; Kellogg 90, p. 88 ; Ridgway 90, p. 350 ; Bendire 92, p. 210 ; Lowe 92, p. 101 ; 94, p. 268 ; McGregor 97, p. 38 ; Cooke 97, pp. 86, 208 ; Keyser 02, pp. 103, 230 ; Dille 03, p. 74 ; Henderson 03, p. 235 ; 09, p. 232 ; Gilman 07, p. 154; Rockwell 08, p. 165 ; Warren 07, p. 81 ; 08, p. 21 ; 09, p. 15 ; Frөy 09, p. 70.

Description.-Male.-Above, including the orown and middle tailfeathers, metallic green; wings dusky purplish, the outer primary narrowed and pointed, the apex turned slightly outwards; the next also attenuated but less so; lateral tail-feather dusky purplish with sometimes a slight edging of chestnut; tail graduated, the middlefeathers broad and obtusely pointed; gorget metallic crimson to purplish-red; below greyish-white with a little golden-green on the sides. Length 3.9 ; wing 2.0 ; tail 1.25 ; culmen $\cdot 6$.

The female is green above like the male; the outer primary is narrow, but with no special attenuation; the lateral tail-feathers are chestnut at the base, then purplish-black with white tips; there is no gorget, the throat is spotted with dark or greenish specks; there is no green below, but a wash of rufous, which is not nearly so marked, however, 8 in $S$. rufus.

Distribution.-The Rocky Mountain regions from Idaho and Wyoming south to Arizona and New Mexico, east to the foothills of Colorado, west to the Sierra Nevada; in winter south over Mexico to Guatemala.

The Broad-tailed Humming-bird is the only species commonly met with in Colorado. It arrives early in May; Aiken notes May 5th, near Fountain, Rockwell the same date for Mesa co. as the earliest. It nests everywhere, from the foothills up to 10,000 or 11,000 feet, and wanders higher, often above timber line, but it is most common between 7,000 and 9,000 feet. It departs again in September, the males leaving some little time before the females and young birds. It was seen as late as October 15th by Rockwell in Mesa co. It has not been met with on the eastern plains. Nesting records are : Estes Park (McGregor), Boulder co., foothills to 10,000 feet (Gale), Glen Eyrie, near Colorado Springs, 6,500 feet (W. L. Sclater), Twin Lakes (Scott), Wet Mountains 
to 10,000 feet (Lowe), Steamboat Springs (Warren), Breckenridge (Carter), Buzzard Creek, Mesa co., at 8,000 feet (Rockwell), San Juan co. (Drew), and the head-waters of the La Plata (Coues, 78).

Habits.-This Humming-bird is very common, and universally distributed over the mountain sides and throughout the valleys; it congregates everywhere where there are flowers, from which it not only gets the nectar, but also the insects attracted to the flowers. It is also an expert insect-catcher, perching on a dead limb and making sharp excursions after passing insects. It has a sharp, quick note, uttered when angry or alarmed. During early summer it mounts straight up into the air, poising itself there for a few moments and then descending again, and repeating this manœuvre several times. When flying a rattling, buzzing sound is produced by the vibration of the wings, quite different from the gentle hum of the eastern Ruby-throat.

The nest of the Broad-tailed Humming-bird is generally placed low down in a willow or alder bush overhanging a stream ; though sometimes it is saddled on a horizontal bough of a pine or fir; but it is seldom more than fifteen feet from the ground, generally a good deal lower. It is an exquisite little structure, built up of the cottony down of willows and cotton-woods, and has no feather lining. The outside is covered with lichen, leaves or shreds of bark, secured with spider or cocoon silk. A large nest taken by W. G. Smith at Pinewood, June 23rd, measured $2 \times 1 \frac{3}{8}$ inches outside, while the cup was $1 \times \frac{3}{4}$. The eggs are two or very rarely three in number, white in colour, and a.verage $50 \times 33$.

According to Gale fresh eggs may be found in the foothills as early as May 6th, at 8,500 feet by June 10th, and at 10,000 feet on July 10th. Some observers state that two or three broods are raised at 


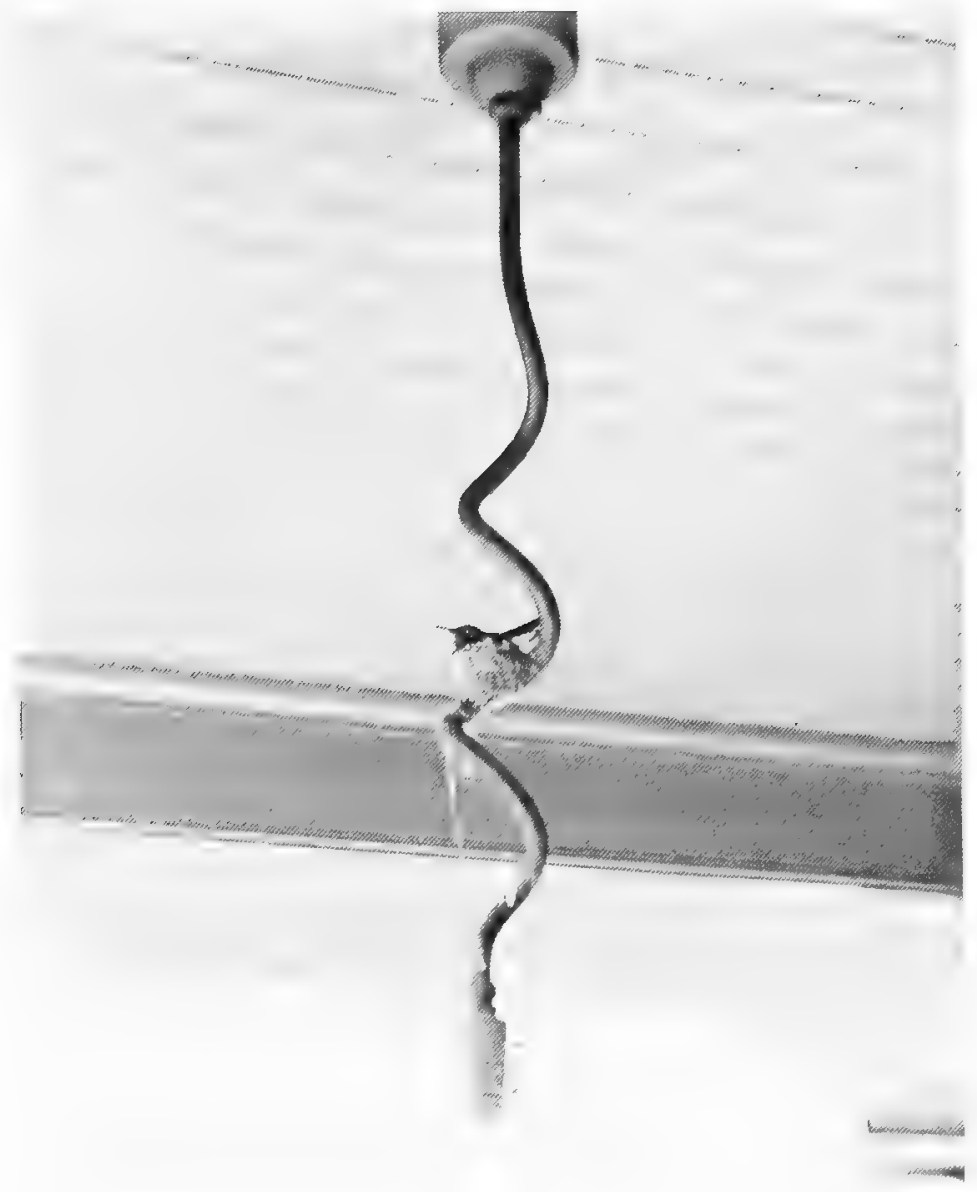

Plate 8]

[E. R. Warren, Phot.

BROAD-TAILED HUMMING-BIRD ON ITS NEST, BCILT ON AN ELECTRIC-LIGHT PENDANT ON A STOOP AT COLORADO SPRINGS. 

successively increasing elevations by the same parents, but direct proof of this seems very difficult to obtain.

A rather remarkable nesting-place for this species was noticed and photographed by Warren (Plate 8). The nest was fixed on a spiral-shaped electric-light fixture, on a porch in front of a house in Colorado Springs. Although the house was occupied and the porch was constantly being used, two young ones were successfully reared and flew away.

\section{Rufous Humming-bird. Selasphorus rufus.}

A.O.U. Checklist no 433-Colorado Records-Henshaw 75, p. 375 ; Drew 81, p. 140 ; 85, p. 17 ; Morrison 88, p. 107 ; 89, p. 146 ; Ridgway 90, p. 343 ; Cooke 97, pp. 86, 162, 208 ; Henderson 03, p. 235 ; 09, p. 232 ; Rockwell 08, p. 165.

Description.-Male-Above rufous-brown with a patch of metallic green on the crown and also sometimes on the back; wings purplishdusky, the outer primary narrowed, falcate and bent inwards; below, tail like the back, but with a little dusky purplish at the edge and tip, the central pair of feathers broad and rather narrowed and pointed at the tip, the next pair nicked near the tip of the inner web, the outer one considerably narrowed; below, the gorget coppery-red, somewhat prolonged at the corners into a ruff; breast white, posteriorly rufousbrown, rather paler than above. Length 3.4 ; wing 1.6 ; tail .9 ; culmen 65 .

The female above is chiefly metallic green overlying the rufous; the male characters of the wings and tail hardly show; the middle tail-feathers are rufous, darkening at the tip; the others cinnamon, then purplish, then white; the gorget is absent, but the throat is white, usually spotted with metallic-scarlet or greenish in some lights; the rest of the under-parts washed with rufous.

Distribution.-Western North America from southern Alaska south to the mountains of southern California, east to Wyoming, Colorado and western Texas; in winter south to Oaxaca in Mexico.

The Rufous Humming-bird is not common in Colorado except perhaps in the extreme south-west, where in La Plata and San Juan cos. it is said to breed from 6,500 to 10,500 feet by Drew and Morrison. It was first taken in the State by Aiken at Fort Garland, August 12th, 1874. It is rare along the eastern foothills; Aiken met with it at Ramah in July, 1897, and noticed one in a garden in Colorado Springs, 
August 21st, 1898. Carter took one at Breckenridge, and W. G. Smith informed Bendire it was rare in Larímer, but more common in Arapahoe county ; Cook and Henderson state that Gale obtained one at Boulder, but the species is not mentioned in his notes; Rockwell reports that it is an occasional spring migrant at Grand Junction, according to Miss Eggleston.

Habits.-Henshaw writes that the males of this species are very pugnacious, and wage unceasing warfare amongst themselves as well as with other species, especially the Broad-tailed. In other respects there does not seem anything very remarkable about the species. The nesting habits in Colorado have not been described, but elsewhere it appears to locate its nest somewhat higher than the Broad-tailed, though it is constructed in a very similar manner. The eggs are two in number, white in colour, and measure $50 \times \cdot 33$.

\section{Genus STELLULA.}

Outer primaries simple, hardly attenuated; tail of the male doublorounded, feathers rather spoon-shaped and rounded at tip, not attenuated or pointed; male with a gorget of metallic spots set on white.

One species only in the United States.

\section{Calliope Humming-bird. Stellula calliope.}

A.O.U. Checklist no 436-Colorado Record-Cooke 97, pp. 163, 208. Description.-Male-Above metallic green; wings and tail dusky, the feathers of the latter with a little concealed rufous about the bases, and with slightly paler tips; gorget with the feathers white basally, metallic purplish terminally, forming a series of metallic rays on w white ground; rest of lower-surface whitish with a little green on the sides. Length 2.9 ; wing 1.55 ; tail .8 ; culmen .55 .

The fermale has no gorget, the throat is white with a few dusky specks, and the under-parts are washed with rufous; the two middle pairs of tail-feathers are green tipped with dusky; the others dusky, tipped with white, with rufous at the extreme base-wing 1.75.

Distribution.-Mountains of western North America, breeding from British Columbia south to southern California and New Mexico; south in winter into Mexico.

The Calliope is a rare species in Colorado, and has been only twice recorded. Aiken found an adult male dead in Cheyenne Cañon, near 
Colorado Springs July 25th, 1897, and there is an example in the Carter collection taken at Breckenridge, June 30th, 1882.

\section{ORDER PASSERES.}

This group embodies the ordinary perching birds and contains over 6,000 species - as many as all the other orders put together. It is by no means an easy order to diagnose by external characters, but the following apply, at any rate, to all North American forms: Bill of variable shape and size, but never with a soft or tumid cere at the base; wing with nine or ten primaries, if the latter the outer one usually very distinctly shorter than the others ; secondaries always more than six ; tail of varying size and shape, but always of twelve rectrices; feet with four toes, the first or hallux directed backwards, not reversible, and always jointed at the same level as the others; oil-gland naked; young hatched naked and helpless.

\section{KEY OF THE FAMILIES.}

A. Tarsus rounded behind; sides and back of the tarsus covered with variously arranged scutes, with a "seam" along the inner side.

a. Ten primaries, the outer the longest; hind toe longer than its claw, which is curved.

Tyrannidæ, p. 259.

b. Only nine primaries, the outer (tenth) obsolete; hind claw straight and longer than its toe. Alaudida, p. 279.

B. Tarsus covered postero-laterally with two entire Iongitudinal plates, meeting posteriorly to form a sharp ridge.

a. Primaries apparently only nine, the outer (tenth) rudimentary or obsolete, not obvious.

$a^{1}$ Outer primaries twice as long as the inner ones; bill short; broad, flat, notehed and deeply cleft.

Hirundinidæ, p. 412.

bl Outer primaries not twice the inner ones.

$a^{2}$ Bill slender and thin at base.

$a^{3}$ Head crested, outer (tenth) primary present, but su short as readily to escape notice.

Bombycillidæ, p. 424. 
$b^{3}$ Head not crested.

$a^{*}$ Inner secondaries elongated, nearly as long as the longer primaries; hind claw straight, equal to or exceeding the hind toe. Motacillidæ, p. 472.

$b^{4}$ Inner secondaries not elongated, hind claw curved, always clearly shorter than the hind toe.

Mniotiltidæ, p. 438.

$b^{2}$ Bill short, stout, deep and conical.

$a^{8} \quad$ Bill notched at the tip and with bristles at the gape.

a Nostrils more or less concealed by bristles or overhung by a distinct scale, or the cutting-edge of the lower mandible forming a distinct angle.

Fringillidæ, p. 319.

$b^{4}$ Nostrils exposed; cutting-edge of the lower mandible always straight and without any angle.

Tangaridæe, p. 408.

$b^{3}$ Bill without notch at the tip, or bristles at the gape.

Icteridæ, p. 299.

b. Primaries obviously ten; the outer one more or less shortened. $a^{1}$ Tarsus distinctly scutellate in front.

$a^{2}$ Outer primary at least half as long as the next.

$\mathrm{a}^{3}$ Bill distinctly hooked at the tip. Laniidæ, p. 427.

$b^{3}$ Bill not distinctly hooked at the tip.

a Nasal plumes erect or inclined backwards.

$a^{5} \quad$ Rictal bristles well developed.

Mimidæ (except Oroscoptes), p. 477.

$b^{5} \quad$ No rictal bristles.

Troglodytidz, p. 485.

b Nasal bristles directed forwards and nostrils concealed.

Corvidæ, p. 282.

$\mathrm{b}^{2}$ Outer primary not half as Iong as the next, generally much shorter.

$a^{3}$ Bill slightly hooked or notched at the tip.

a Smaller; wing under 2.5.

$a^{5}$ Above greenish or greyish; tail even.

Vireonidæ, p. 431.

b $^{5} \quad$ Above bluish, tail graduated.

Sylviidæ (Polioptila), p. 509.

$b^{4}$ Larger, wing over 3.5 .

$b^{3}$ Bill not hooked or notched.

Mimidæ (Oroscoptes), p. 477.

a Tail-feathers stiff and pointed at tip.

Certhiidæ, p. 496. 
$b^{4}$ Tail-feathers normal.

$a^{5}$ Bill slender, as long as the head; tail shorter than the wing.

Sittidæ, p. 498.

$b^{5}$ Bill stout, shorter than the head; tail equal to or longer than the wing.

Paridæ, p. 503.

$b^{1}$ Tarsus booted, not divided into plates except at the extreme base.

$a^{2}$ No rictal bristles; tail abnormally short.

$\mathrm{b}^{2} \quad$ Rictal bristles present; tail normal.

Cinclidæ, p. 474.

$a^{3}$ Small; wing under 3.0 ; plumage greenish; young not spotted. Sylviidx (Regulus), p. 509.

$b^{3}$ Larger, wing over $3 \cdot 0$; young spotted.

Turdidæ, p. 514 .

\section{Family TYRANNIDÆ.}

Bill broad, depressed and flat, the tip down-turned; nostrils not operculate; wings with ten primaries, the outer one of which is always well developed and obvious ; tail of twelve rectrices usually even or nearly so; feet small and weak, tarsus excapedian, i.e. covered with variously arranged scutes, not forming a ridge at the posterior edge, but meeting on the postero-internal face in a deep groove.

Six of the twelve North American genera are found in Colorado. They can be distinguished as follows:-

A. Tips of the outer primaries attenuated; concealed crownpatch of orange.

Tyrannus, p. 260.

B. Tips of the outer primaries not attenuated; no erown-patch.

a. Tail marked with rufous; a distinct crest. Myiarchus, p. 264.

b. Tail plain coloured without rufous; no distinct crest.

$a^{1}$ Feet very small; tarsus not exceeding the culmen in length.

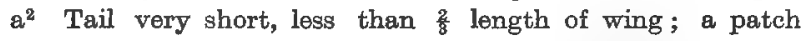
of silky feathers on either side of the rump.

Nuttallornis, p. 268.

$b^{2}$ Tail longer, about $\frac{3}{4}$ length of wing; no silky patch on rump.

Myiochanes, p. 270.

* Muscivora forficata, the Scissors-tailed Flycatcher, is included by Cooke in the Colorado avifauna on the strength of it havng been once seen by G. F. Brenninger at Table Rock, on the Arkansas.Platte divide. 
$b^{1}$ Feet of normal size; tarsus always longer than the culmen. $a^{2}$ Larger, wing three to four inches; bill narrow, its width at nostrils barely half the length of culmen.

Sayornis, p. 266.

$b^{2}$ Smaller, wing 2.25 to 3.25 ; bill broad, its width at nostrils equal to or exceeding half the length of the culmen.

Empidonax, p. 272.

\section{Genus TYRANNUS.}

Moderate-sized birds with wings from four to six inches; wings with the tips of the outer primaries more or less attenuated; tail less than three-fourths the length of the wing and never deeply forked; a concealed crown-patch of yellow or orange in the adults.

This genus ranges over the whole of temperate and tropical America. Three out of ten described species occur in Colorado as follows :-

A. Plumage black, grey and white; no yellow. T. tyrannus, p. 260.

B. Abdomen and under tail-coverts canary-yellow.

a. Outer (tenth) primary about the same length as ninth, longer than fifth; shaft and whole of outer web of outer tailfeathers markedly white below. T. verticalis, p. 262.

b. Outer (tenth) primary markedly shorter than ninth, also shorter than fifth; outer web of outer tail-feathers paler, and merely edged with white. T. vociferans, p. 263.

\section{Kingbird. Tyrannus tyrannus.}

A.O.U. Checklist no 444-Colorado Records-Allen 72, p. 150 ; Aiken 72, p. 205; Trippe 74, p. 236; Henshaw 75, p. 341 ; Allen \& Brewster 83, p. 194 ; Beckham 85, p. 142 ; Morrison 89, p. 146 ; Bendire 92, p. 236 ; Lowe 92, p. 101 ; Cooke 97, pp. 19, 87, 209 ; Keyser 02, p. 97 ; Henderson 03 , p. 235 ; 09, p. 232 ; Dille 03, p. 74 ; Warren 06, p. 21 ; 08, p. 21 ; Gilman 07, p. 154 ; Rockwell 08, p. 165 ; Cary 09, p. 182.

Description.-Dark slate above, becoming black on the head and tail; below and edges of the wings and tail white, a grey patch across the chest, a concealed patch of orange-red along the middle of the crown; tips of the two outer primaries attenuated. Length 8.0 ; wing 4.80 ; tail 3.50 ; tarsus .75 ; culmen $\cdot 62$.

The female resembles the male, but the orange patch is more restricted and the tips of the primaries less attenuated; the young bird has no crown-patch, and the edges of the wings and tail are brownish.

Distribution.-Breeding throughout temperate North America from southern British Columbia and Nova Scotia southwards, chiefly east of the Rocky Mountains to the Gulf of Mexico; wintering in Cuba, the Bahamas, Central and South America to southern Bolivia. 
In Colorado the Kingbird is a summer resident, chiefly on the plains and eastern foothills up to about 7,000 feet. It arrives at Colorado Springs about the first week in May, and is quite common on the plains ; it has been recorded from an elevation of 7,500 foet at Idaho Springs by Trippe, and Frey has taken a pair, May 15th, at Salida. It is said to breed in Middle Park, but it is not common in the mountrins. In Baca co., in the south-eastern corner of the State, Warren found it by no means common, while in Routt co. he saw it on several occasions between Steamboat Springs and Lay.

Habits. - The Kingbird is well known for its bold and fearless characteristics, and for its pugnacity towards birds larger and stronger than itself. It has been seen. by Aiken to attack even so large a bird as Swainson's Hawk, flying above it and alighting on its shoulders and pecking out its feathers.

The food of the Kingbird consists almost entirely of insects of various kinds, chiefly taken on the wing. It has been accused of killing honey-bees, and indeed is often known as the Bee-Martin or Bee-bird, but the investigations of the Agricultural Department have shown that its propensities in this respect have been greatly exaggerated, and in only a small percentage of the stomachs examined did bees occur, and these mostly drones.

The nest, generally placed in the crotch of a tree, often in an orchard or near a dwelling-house, is well built, chiefly of twigs with a lining of hair or wool, and is often occupied several successive years. The male assists in incubation and in the construction of the nest.

The eggs, three or four in number, measure $95 \times \cdot 72$, and are white to pale pink, varyingly blotched with brown or lavender. In Colorado the eggs are usually laid about the middle of June. Bendire figures an egg from a clutch taken by Dennis Gale at Gold Hill, in Boulder co., on June 25th, while Dille gives June 12th as an average date for fresh eggs. 


\section{Arkansas Kingbird. Tyrannus verticalis.}

A.O.U. Checklist no 447-Colorado Records-Sey 23, vol. ii., p. 60 ; Allen 72, p. 150 ; Aiken 72, p. 205 ; Henshaw 75, p. 342 ; Allen \& Brewster 83, p. 195 ; Beckham 85, p. 143; Morrison 86, p. 153 ; 88, p. 107 ; 89, p. 146; Kellogg 90, p. 90 ; Lowe 92, p. 101; Cooke 97, pp. 19, 87, 163, 209; Dille 03, p. 74 ; Keyser 02, p. 95 ; Henderson 03 , p. 107 ; 09, p. 232 ; Warren 06, p. 21 ; 08, p. 21 ; 09, p. 15; Gilman 07, p. 154; Markman 07, p. 156 ; Rockwell 08, p. 165.

Description.-Head, neck all round, and breast pale grey, becoming whiter on the chin; w concealed patch of orange-red on the crown; back washed with greenish; wings slaty-black, tail black, below with the outer web of the outer tail-feathers very distinctly white; abdomen and under tail-coverts canary-yellow; four outer primaries gradually attenuated at tips, outermost (tenth) longer than fifth. Length about 8.5 ; wing $5 \cdot 30$; tail 3.75 ; tarsus $\cdot 90$; culmen $\cdot 70$.

The female resembles the male, but the tips of the primaries are less attenuated and the crown-patch more restricted. The young are without the crown-patch and the yellow of the under-parts is paler.

Distribution.-Breeding throughout the United States west of about the 100th meridian from southern British Columbia to northern Mexico, wintering in Guatemala.

The Arkansas Flycatcher is a common summer resident in eastern Colorado, both in the plains and foothills. It arrives in El Paso co. about the 6th of May, and eggs may be looked for about a month later; it leaves again for the south in September. Its range extends up into the mountain parks to about 8,000 feet; it has been known to breed in Middle Park in the middle of June, and is noted as a rare summer resident in Estes Park by Kellogg. In south-east Colorado it was met with by Warren in May, while in Gunnison co. he found it breeding in June, but in La Plata co., in the south-west, Gilman states that it is a straggler, though it is common at Coventry (Warren, 09) and Grand Junction (Rockwell), and was found nesting near Craig and Buford, in Rio Blanco co., by Warren (08) (Plate 9).

Habits.-The Arkansas Kingbird frequents open country, but is seldom found far from water and the cotton-wood trees which usually line the banks of streams in Colorado. It is a loud and noisy bird, even more so than the Kingbird, and the males are very pugnacious until they have paired off for the breeding season; they do not seem so bold however in attacking other larger birds, such as hawks. The food consists almost entirely 


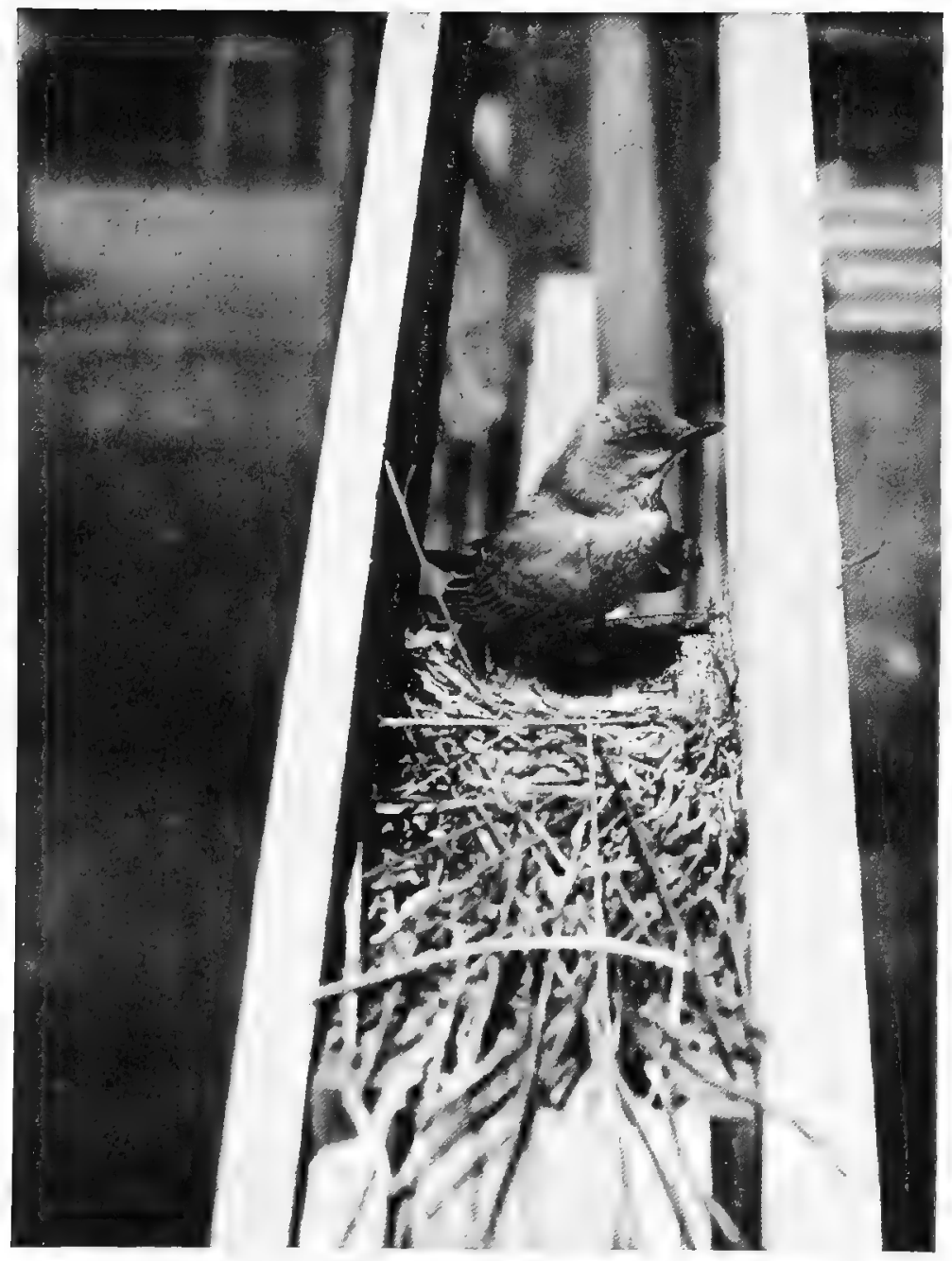

Plate 9]

[R. B. Rockwell, Phot.

ARKANSAS KINGBIRD ON NEST IN THE FRAME OF A FARALGATE, PLATEAU VALLEY, MESA CO. 

of insects caught on the wing, and while they have been accused of destroying honey-bees, it appears that only the drones attract them, and that they are in every way most useful and desirable birds and deserve rigid protection.

The nest, which is completed about the first week in June, is generally placed in a fork or on a horizontal bough of a cotton-wood tree, and is often a bulky structure. The eggs, three or four in number, closely resemble those of the Kingbird and measure about $93 \times \cdot 69$ inch.

\section{Cassin's Kingbird. Tyrannus vociferans.}

A.O.U. Checklist no 448-Colorado Records-Aiken 872, p. 205 ; Henshaw 74, p. 343 ; Allen \& Brewster 83, p. 195 ; Drew 85, p. 17 ; Beckham 87, p. 122 ; Morrison 89, p. 146 ; Kellogg 90, p. 88; Lowe 92, p. 101 ; Cooke 97. pp. 87, 209 ; Dille 03, p. 74 ; Gilman 07, p. 155 ; Rockwell 08, p. 166 ; Warren 09, p. 15; Henderson 09, p. 232.

Description.-Closely resembling $T$. verticalis in size and colour, but the breast o much darker ashy, and contrasting more strongly with the whiter chin; the outer web of the outer tail-feather below paler than the inner one, but never pure white; four outer primaries abruptly attenuated, the outermost (tenth) shorter than the fifth; middle toe shorter than the tarsus. Length about 7.9; wing 5.30; tail 3.70 ; tarsus .82 ; culmen .70 .

The female resembles the male in colour, but the tips of the primaries are hardly attenuated, and the orange-red crown spot is somewhat restricted; the young birds have no crown-patch.

Distribution.-Breeding throughout the south-western portion of the United States, from Wyoming southwards to western Texas and through New Mexico and Arizona to southern California (but not, apparently, in Utah or Nevada) ; also in northern and middle Mexico, wintering in southern Mexico and Guatemala, and also, it is said, in southern California.

In Colorado Cassin's Kingbird is a common summer resident along the eastern foothills and the adjacent plains, arriving in El Paso co. about the second week in May, a little later than the Arkansas Kingbird. It ranges up into the mountain parks to 9,000 feet, having been observed breeding at that elevation near Breckenridge by Carter, and by Kellogg in Estes Park at 8,000 feet. North of the Arkansas-Platte divide this species does not appear to be nearly so abundant, as it has only once been met with by Henderson 
in Boulder co., and is rare at Barr. It is quite a common resident in Mesa, co., arriving early in May and nesting a fortnight later. Gilman has found it breeding in La Plata co. (7,500 feet), in the extreme southwest corner of the State.

Habits.-Cassin's Kingbird is found in very similar country and has very similar habits to its cousin, but is described as being more sedate and less lively in its disposition. Its notes, too, are more harsh and less frequently uttered. It builds its nest in cotton-wood trees as well as in pines and other trees, generally fixing it well out on a horizontal limb. It is sociable and fond of human habitations, often making use of gate frames or log fences in which to locate its nest. The eggs, three or four in number, resemble closely those of the Arkansas Kingbird, but are not usually so heavily spotted.

\section{Genus MYIARCHUS.}

Dull-coloured Flycatchers, of moderate size with wings measuring from 2.75 to 4.5 ; tips of the primaries not attenuated; culmen about equal to or longer than the middle toe and claw; crown with a slight crest; tail never edged with white, but generally marked with rufous or rusty.

Of about thirty-five species and subspecies of this genus, which ranges over the whole of temperate and tropical America, one only is commonly met with in Colorado.

\section{KeY of THE Spectes.}

A. Larger ; wing about 4 ; inner webs of the rectrices cinnamon.

M. cinerascens, p. 264.

B. Smaller; wing about 3.25 ; inner webs of rectrices chiefly darkbrown.

M. 1. olivascens, p. 266 .

Ash-throated Flycatcher. Myiarchus cinerascens.

A.O.U. Checklist no 454-Colorado Records-Aiken 72, p. 205 (M. mexicanus) Ridgway 73, p 184; Drew 85, p. 17 ; Morrison 89, p. 146 ; Lowe 92, p. 101 ; Cooke 97, pp. 87, 209 ; Warren 06, p. 21 ; 08, p. 21 ; 09, p. 15 ; Gilman 07, p. 155 ; H. G. Smith 08, p. 185 ; Rockwell 08, p. 166. 
Description.-General colour above greyish-brown, less ashy on the crown, which is crested, the feathers being longer and somewhat pointed; wings darker, the secondaries edged with dull whitish, the primaries with cinnamon-rufous; breast very pale ashy-grey, abdomen and under tail-coverts very pale yellow; tail with the outer web of the outer feather almost white; the inner web cinnamon-rufous with brown tips. Length 7.50 ; wing 4.00 ; tail 3.50 ; tarsus .95 ; culmen $\cdot 70$.

The female is very similar, but is slightly smaller; the young are essentially like the adults.

Distribution.-Breeding in the western United States from southern Wyoming and Oregon southwards to northern Mexico; in winter through central and southern Mexico to Yucatan and Guatemala.

The Ash-throated Flycatcher is a rare summer resident in Colorado, and is more frequently met with in the southern portion of the State; there are several examples, taken in May and June, in Fremont co., in the Aiken collection, where it is not uncommon in the cedar and piñon country; it was once noticed by Warren in Baca co., while Gilman observed "one in spring," in La Plata co. North of the Arkansas divide it seems to be rare, but, according to Cooke, has been taken by Osburn at Golden, and by Bond at Cheyenne, just over the northern border of the State. Warren met with it at Douglas Spring in Routt co., and at Dotsero in Garfield co., while Sullivan reports it to be rather a rare summer resident at Grand Junction from May 2nd to August 22nd; he was unable to find the nest, though he had little doubt it bred in the neighbourhood (Rockwell). It arrives from the south late in May and returns in September.

Habits.-This Flycatcher is of a retiring disposition and not easily seen or flushed; it frequents dense thickets along creek bottoms; it is not very noisy, and its food consists chiefly of insects, with some berries.

I have not met with any account of its nesting habits in Colorado, but Bendire states that it frequently makes use of the nests of other birds, such as the Cactus-Wren and the smaller Woodpeckers; but that when it makes its own nest it is usually a bulky structure of rootlets, lined with hair, and that the eggs, three to six in number, are creamy to pinkish-buff, profusely covered with fine longitudinal streaks of dark purplish. 


\section{Olivaceous Flycatcher. Myiarchus lawrencei olivascens.}

A.O.U. Checklist no 455a-Colorado Records-Thorne 89, p. 276 ; Cooke 97, p. 88.

Description.-General colour above plain olive-brown; tail and wings without any distinct rusty-red edgings; below pale primrose.

Length about 6.5 ; wing 3.25 ; tail 3.0 ; tarsus .75 ; culmen .70 . The female is slightly smaller-wing $3 \cdot 00$.

Distribution.-This species ranges from southern Arizona southward through western and southern Mexico to Oaxaca.

It was once taken in Colorado by Captain Thorne at Fort Lyon in Bent co., on April 20th, 1874. It may be regarded as an accidental visitor to the State.

\section{Genus SAYORNIS.}

Medium-sized Flycatchers with a wing measurement of 3 to 4.5 ; bill somewhat narrow, a little less than half the length of the culmen. across the nostrils; culmen shorter than both the tarsus and the middle toe; wings without attenuated tips to the primaries, long and pointed, the seventh, eighth and ninth primaries the longest, the tenth (outer) intermediate between the fourth and sixth; tail plain-coloured without rufous or rusty, even or slightly emarginate; tarsus always longer than the middle toe and claw. Only three species of this genus, ranging from North America to Bolivia, are recognized. One of these is commonly met with in Colorado.

A. Larger; wing about 4.0 ; abdomen cinnamon-buff. S. saya, p. 267.

B. Smaller; wing about 3.5 ; abdomen pale primrose-yellow.

S. phœbe, p. 266.

Phœbe. Sayornis phobe.

A.O.U. Checklist no 456-Colorado Record-Thorne 89, p. 276.

Description. - Crown and sides of the head dark sooty-brown, becoming paler and olivaceous-brown on the back; wings and tail dull brown, the wings with paler greyish margins, most conspicuous on the secondaries and greater coverts; the outer web of the outer tail-feather distinctly edged with greyish-olive; below pale yellowish, the throat and chest washed over with dusky greyish and the sides of the breast. brownish-olive; iris dark brown, bill and legs black. Length 6.5; wing 3.50 ; tail 2.70 ; tarsus $\cdot 7$; culmen .52 .

The adults are alike, except that the female is slightly smaller-wing 3.25 ; young birds resemble the adults, but are rather browner above, and the wing-coverts are broadly tipped with cinnamon-buff.

Distribution.-Breeding throughout eastern North America from Maine and Great Slave Lake southwards to western Texas and the highlands of South Carolina; wintering in the states south of 37. , Cuba, eastern and central Mexico. 
This very familiar eastern bird, though common in eastern Kansas, has only once been taken in Colorado, by Captein Thorne at Fort Lyon, April 20th, 1884.

\section{Say's Phœebe. Sayornis sayus.}

A.O.U. Checklist no 457-Colorado Records-Bonaparte 25, p. 20 ; Allen 72, p. 151 ; Aiken 72, p. 205 ; Henshow 75, p. 349 ; Allen \& Brewster 83, p. 195 ; H. G. Smith 84, p. 120 ; Drew 85, p. 17 ; Morrison 87,p. 35 ; 89, p. 146 ; Lowe 92, p. 101 ; Bendire 92, p. 276 ; Cooke 97, pp. 18, 88, 209; Keyser 02, pp. 131, 270 ; Henderson 03, p. 235; 09, p. 232 ; Dille 03, p. 74 ; Warren 06, p. 21 ; 08, p. $21 ; 09$, p. 15 ; Gilman 07, p. 155; Markman 07, p. 156 ; Rockwell 08, p. 166 ; Hersey \& Rockwell 09, p. 118.

Description.-Above ashy-brown, slightly darker on the crown; tail nearly black, the outer rectrices indistinctly edged with whitish; wing pale brown, the greater-coverts and secondaries edged and tipped with paler ; below throat and breast pale ashy-brown, becoming tinged posteriorly with cinnamon, most strongly on the under tail-coverts; iris brown; bill, legs and feet black. Length 7.0 ; wing 4.25 ; tail $3 \cdot 20$; tarsus $\cdot 70$; culmen $\cdot 50$.

The sexes are alike; young birds are browner, and have the wingcoverts more distinctly marked with tips of cinnamon-buff.

Distribution.-Breeding from Alaska, Manitoba, and middle Kansas southwards and westwards to northern and perhaps central Mexico; wintering in Mexico, the coast of Texas, and perhaps southern California.

In Colorado, Say's Phœbe is w common summer resident, chiefly along the eastern foothills, but also throughout the mountain valleys up to 9,500 feet, at which elevation it was found breeding by Keyser near Malta in Lake County, and at Jefferson in South Park. It has been noted as common in May in Baca co. by Warren, in La Plata co. by Gilman, in the San Luis Valley by Henshaw, in the Boulder co. plains by Henderson, near Barr by Hersey and Rockwell, and in Larimer co. by Bendire. It is a common summer resident in Mesa co., reaching Grand Junction as early as March 4 th and Plateau Valley, at a higher elevation, about March 20th (Rockwell).

Habits.-Say's Phobe reaches El Paso co. from the south early in April, and has been noted at Pueblo on March 17th (Lowe), and fresh eggs may be found about the middle of May or beginning of June. It leaves again in September, and was seen as late as the 15th by Henderson, near Boulder. Like the eastern Phoebe, it evinces a great attachment for its old home, returning 
year after year to build in the same place, which is usually under the eaves of barns or sheds, or under bridges, but generally in the neighbourhood of a ranche. In early days, before the advent of civilization, it made use of caves and overhanging banks for its nest. This is a bulky structure plastered up with mud, and generally lined with hair or wool, with a base of various materials. The eggs are usually four or five in number, rather short ovates in shape, and generally pure white. Two broods are often raised in one season.

Say's Phœbe is a restless bird, constantly flicking its tail and raising its crest; it is always on the move, looking out for insects, which almost exclusively form its food, and which it often catches on the wing; like Owls, it rejects the hard parts of these in the form of pellets. The note is loud and somewhat plaintive.

\section{Genus NUTT ALLORNIS.}

Flycatchers of moderate size-wing about $4 \cdot 0$, with a very stout bill, the width of which at the nostrils exceeds half the length of the culmen; wings long and pointed, the outer (tenth) primary exceeding the seventh distinctly; tail short, about two-thirds of the length of the wing, plain coloured and emarginate; feet very small, tarsus shorter than the culmen and the middle toe and claw; a patch of silky white feathers on either side of the rump.

Only the one species here described is assigned to this genus.

Olive-sided Flycatcher. Nuttallornis borealis.

A.O.U. Cheoklist no 459-Colorado Records-Allen 72, p. 158; Aiken 72, p. 206 ; Henshaw 75, p. 350 ; Scott 79, p. 94 ; Minot 80 , p. 231 ; Drew 81, p. 140 ; Tresz 81, p. 183 ; Allen \& Brewster 83, p. 195 ; Drew 85 , p. 17 ; Morrison 88 , p. 107 ; 89, p. 146 ; Lowe 92, p. 101 ; 94, p. 268 ; Bendire 92, p. 282 ; Cooke 97, pp. 19, 88, 201 ; Henderson 03, p. 235 ; 09, p. 232 ; Gilman 07, p. 155; Rockwell 08, p. 167.

Description. - General colour above slaty-olive, feathers of the crown with darker centres; wings and tail dark brown, the former with the secondaries and greater coverts edged and tipped with whitish; below the chin and throat very pale yellowish; the centre of the breast, 
abdomen and under tail-coverts somewhat less pale; the sides of the neck, breast and flanks ashy-brown, indistinctly streaked with darker; a patch of pale yellowish, fluffy feathers on the flanks, generally concealed but sometimes very clearly visible on either side of the rump; iris brown, bill and legs brownish-black. Length 6.5 ; wing 4.20 ; tail 2.5 ; tarsus .55 ; culmen .85 . The sexes are alike, and the young essentially like the adults, but the pale tips of the coverts and eecondaries are brownish.

Distribution.-Breeding throughout the coniferous forest regions from Alaska and Hudson Bay southwards to Now York and Minnesota, and thence along the Alleghanies, Rockies and subsidiary ranges of the west to northern Mexico, migrating southwards to Columbia, western Ecuador and Peru.

A fairly common summer resident in the mountains of Colorado, but only a migrant in the plains and not so often met with. It is noted as a migrant in the plains of Boulder co. by Henderson, and is not very abundant in EI Paso co. on the plains, but Scott found it not uncommon near Twin Lakes at about 9,300 feet, and Minot at 10,000 feet on Pikes Peak. Gale found nests from 8,000 to 9,500 feet in the mountains of Boulder co.; Lowe records it nesting at about 9,500 feet in the Wet Mountains in Huerfano co., and Henshaw met with it from 7,000 feet to timber line near Fort Garland. In Mesa co. it is stated by Rockwell to be quite rare; he only observed it once in Plateau Valley at 6,800 feet.

It arrives from the south in May; W. G. Smith notes it once at Loveland on the 11th; Allen and Brewster first saw it on the 17th; Aiken's earliest record is the 21st. It departs south again at the end of August or beginning of September.

Habits.-The Olive-sided Flycatcher is never very abundant, possibly owing to its quarrelsome and unsociable nature. Its favourite resort is the top of a bare spruce, whence it makes constant sallies after passing insects, clicking its bill as it catches them on the wing. It has a loud whistle-like call-note, as well as a "Chip, chip, chip."

The nest is usually saddled far out on the horizontal limb of a fir, and is completed about the middle of June ; it is small and flat, and appears fragile though constructed of strong material. The eggs are generally three in number, with a white to pale pinkish ground-colour, thickly blotched and spotted with chestnut and purple. 


\section{Bendire describes a nest sent him by Denis Gale from Gold Hill, taken on July 7th, at about 9,500 feet.}

\section{Genus MYIOCHANES.}

Flycatchers of medium or small size-wing 2.5 to 4.5 , with a broad, flattened bill, the width of which across the nostrils is often $\frac{2}{3}$ the length of the culmen; wing long and pointed, the outer primary always exceeding the fifth, often the sixth; tail slightly emarginate, plain coloured, from $\frac{3}{4}$ to $\frac{7}{8}$ the length of the wing; feet very slender and small ; tarsus about the same length as the culmen and generally exceeding the middle toe and claw; no conspicuous silky tufts on either side of the rump.

A considerable genus of some seventeen species, spread over the whole of temperate and tropical America (except the West Indies); one species commonly occurs in Colorado.

KEY OF THE SPECIES.

A. Dusky olive above; lower mandible dusky brown.

C. richardsoni, p. 271.

B. Greenigh-olive above; lower mandible whitish.

C. virens, p. 270 .

Wood-Pewee. Myiochanes virens.

A.O.U. Checklist no 461-Colorado Record-Warren 06, p. 21.

Description.-Closely resembling the Western Wood-Pewee, but distinguished by the darker and more olive and less ashy shade of the back; by the less extent of the dusky grey band on the chest, which is more or less interrupted in the middle so as to form two lateral patches; and by the pale whitish colour of the lower mandible, which is pinkish in life, but usually has the extreme tip brownish. Length 5.50; wing 3.30 ; tail 2.50 ; tarsus .40 ; culmen .50 .

The sexes are alike, and the young essentially similar to the adults.

Distribution.-Breeding throughout eastern North America, from Manitoba and Prince Edward Island southwards to Texas and Florida; migrating southwards in winter through Mexico and Central America as far as Ecuador and Poru, and also to Cuba.

The Wood-Pewee is common as far as the eastern border of the great plains, westwards of which (i.e. in western Kansas) it is rare. It has only once been met with in Colorado; Warren obtained a single specimen near Springfield, in the extreme south-east corner of the State, on May 12th, 1905. 


\section{Western Wood-Pewee. Myiochanes richardsoni.}

A.O.U. Checklist no 462.-Colorado Records-Allen 72, pp. 151, 158 ; Aiken 72, p. 206 ; Trippe 74, p. 247 ; Henshaw 75, p. 353 ; Scott 79, p. 94 ; Minot 80 , p. 231 ; Drew 81 , p. 140 ; Tresz 81 , p. 183 ; Allen \& Brewster 83, p. 195 ; Drew 85, p. 17 ; Beckham 85, p. 143 ; Morrison 86 , p. 153 ; 88, p. 107 ; 89, p. 146 ; Kellogg 90 , p. 90 ; Lowe 92, p. 101 ; 94, p. 268 ; Miller 94, p. 38 ; MoGregor 97, p. 38 ; Cooke 97, pp. 19, 88, 209 ; Keyser 02, p. 32 ; Henderson 03, p. 235 ; 09, p. 232 ; Warren 06, p. 21 ; 08, p. 21 ; Gilman 07, p. 155 ; Rockwell 08, p. 167 ; Markman 08 , p. 156 .

Description.-Above very dark slaty-brown, with w very faint wash of olive, darker brown on the crown; wings and tail bleckish-brown; the greater- and middle-coverts and secondaries edged with whitish; below dusky grey over the greater part of the breast and flanks; paler, sometimes whitish, on the chin and throat; the middle of the abdomen usually washed with very pale yellow; upper mandible dark brown, lower mandible pale brown, but never so pale as in $M$. virens. Length 5.50 ; wing 3.50 ; tail 2.50 ; culmen .50 ; tarsus 47 .

The young birds are very like the adults, the sexes of which are alike, but the pale tips of the coverts and secondaries are more conspicuous and tinged with pale rufous.

Distribution.-Breeding through western North America from Alaska and Manitoba southwards to western Texas and northern Mexico, in winter south over the rest of Mexico and Central America to Ecuador and northern Bolivia.

The Western Wood-Pewee is a common summer resident throughout Colorado, breeding from the plains to at least 10,000 feet. It has been recorded as common in the following localities: Boulder co. (Minot \& Henderson), El Paso co. (Aiken), Estes Park (Kellogg), Bergin Park, 7,500 feet (Trippe), South Park (Allen); Wet Mountains, 10,000 feet (Lowe); Breckenridge, 9,700 feet (Carter); Twin Lakes, 9,300 feet (Scott); Deep Creek, Gunnison co., breeding, June 30th (Warren); San Juan co. (Drew); La Plata co. (Morrison); Mesa co., 7,000 to 10,000 feet (Rockwell), and Baca co. (Warren). It arrives in El Paso co. abr, ut the first week in May, reaching the mountains about three weeks later, and leaves again for the south in September. It has been noticed as early as April 25th at Pueblo (Lowe).

Habits.-The Western Pewee, though closely resembling its relative of the east in appearance, differs from it very considerably in habits ; it frequents more open country, and has a much harsher, more abrupt, and less-pleasing song. It is generally to be found in the lower branches 
of trees, whence it darts out after its insect prey. Some controversy seems to have arisen in regard to the situation of the nest: Aiken states, as is the case with the eastern bird, it is usually saddled on the outer fork of a horizontal bough, and in plain sight. It is somewhat deeper and more strongly constructed than that of the eastern bird, and is covered externally with leaves and bark, not, as a rule, with lichens. Fresh eggs are to be found at low elevations in the middle of June; but at Twin Lakes, Scott took a nest with three eggs on July 11th. These, generally three in number, are white to pale cream, spotted and blotched with reddish. They cannot be distinguished from those of the eastern bird.

\section{Genus EMIPIDONAX.}

Small Flycatchers-wings measuring from $2 \cdot 25$ to $3 \cdot 25$-with broad, flattened bills, the width of which across the nostrils is about equal to the culmen; wings long and pointed, the tenth (outer) primary between the fourth and sixth, the ninth to seventh the longest; tail even or slightly emarginate, shorter than the wings, generally about $\frac{4}{5}$ to $\frac{8}{9}$; legs and feet of normal size, the tarsus from $\frac{1}{5}$ to $\frac{1}{3}$ the length of the wing, always exceeding the culmen and middle toe and claw.

About thirty species and subspecies have been recognized, spread over the greater part of America, except the West Indies. Seven of these have been taken in Colorado.

The members of this genus have a very similar coloration, varying from olive to dark grey above and from pale yellow to whitish-grey below ; they are also very nearly of the same size, and are consequently difficult to discriminate; the following key, therefore, should be used with caution, and the description in all cases referred to before a satisfactory conclusion can be reached.

\section{KEY OF THE SPFCIES.}

A. Yellow wash of under-side richer, and distinctly extending over the throat; size large (wing 2.85); tail emarginate.

E. difficilis, p. 273 .

B. Yellow wash of under-side paler, not extending over the throat, which is markedly white. 
a. Tail even; size larger; wing about $2 \cdot 70$.

$a^{1}$ Above duller and more brownish; culmen longer, about $\cdot 5$; lower mandible dusky. $\quad$ E. trailli, p. 274.

bl Above brighter and more greenish; culmen shorter, about 4 lower mandible whitish. $\quad$ E. t. alnorum, p. 275.

b. Tail slightly emarginate; size much smaller; wing about 2.55 .

E. minimus, p. 275 .

C. Yellow wash of under-side overlaid by the extended area of the grey of the breast; throat more or less grey; tail emarginate.

a. Tenth (outer) primary longer than the fifth; bill small and narrow; culmen about 40 . $\quad$ E. hammondi, p. 276.

b. Tenth (outer) primary shorter than the fifth.

$a^{1}$ Smaller; wing about 2.75; bill large ; culmen .52 , lower mandible dark. $\quad$ E. wrighti, p. 277.

$b^{1}$ Larger; wing 2.85; bill smaller; culmen .50; lower mandible pale, tipped dusky. $\quad$ E. griseus, p. 278.

\section{Western Flycatcher. Empidonax difficilis.}

A.O.U. Checklist no 464-Colorado Records-Ridgway 73, p. 184 ; Trippe 74, p. 258 ; Henshaw 75, p. 359 ; Minot 80 ; p. 231 ; Drew 81 ; p. 140 ; Tresz 81 , p. 183 ; Allen \& Brewster 83, p. 195 ; Drew 85, p. 17 ; Morrison 89, p. 146 ; Kellogg 90, p. 90 ; Bendire 92, p. 298 ; Cooke 97, pp. 88, 209 ; Henderson 03, p. 107 ; 09, p. 233.

Description.-Above dull olive-brown; wings and tail dusky brown, the outer webs edged with yellowish-olive, the middle- and greatercoverts strongly tipped with greenish-brown, forming a conspicuous double wing-bend; below pele primrose, soiled with buffy-olive on the breast and neck, paling slightly on the throat, which is distinctly yellow; a pale yellow orbital ring; outer (tenth) primary distinctly shorter than the fifth; tail emarginate; iris brown, upper mandible dark brown, lower pale yellowish; legs dusky brown. Length $5 \cdot 10$ wings 2.85 ; tail 2.40 ; culmen $\cdot 45$; tarsus $\cdot 62$.

The sexes are alike; the young are browner above and the wing-band more ochraceous.

Distribution.-Breeding throughout the western half of North America, from Alaska and western Manitoba southwards to western Texas, northern Mexico and California; in winter, south to Oaxaca and Guererro in southern Mexico.

In Colorado the Western Flycatcher is a regular summer resident in the mountains and neighbouring foothills, breeding up to 10,000 feet, but not apparently in the plains. It has been recorded from Estes Park, 8,000 feet (Kellogg); Gold Hill, breeding from 8,500 feet to 10,000 
feet (Gale) ; Breckenridge, breeding at 9,700 feet (Carter); Green Mountain Falls, 7,700 feet, in EI Paso co., and Beaver Creek, Fremont co. (Aiken); San Juan co., breeding up to 10,000 feet (Drew).

It arrives late (May 24th in Fremont co., Aiken), and nests at the ond of June or beginning of July, and returns south in September.

Habits.-This Flycatcher generally affects narrow cañons, or shady glades near a mountain stream. It sometimes perches on dead tree-tops, whence it keeps watch for passing insects. It has a somewhat plaintive call of two low notes, and a clear, pleasing song as well.

A nest found by A. W. Anthony on June 25th, in the San Juan co., was placed on a ledge of rock, about ten feet above the cart road; it was a large ball of green moss, with a little cup in the centre lined with hair; the eggs, generally three in number, are creamy-white, spotted and blotched with einnamon, rufous and buffypink ; they measure about $\cdot 66 \times \cdot 52$. Out of nine nests taken by Gale, three were from mine-shafts or tunnels.

\section{Traill's Flycatcher. Empidonax trailli.}

A.O.U. Checklist no 466-Colorado Records-Aiken 72, p. 206 (E. prusillus) ; Henshaw 75, p. 356 ; Minot 80, p. 231 ; Drew 81, p. 140 ; 85 , p. 17 ; Morrison 88, p. 107 ; 89, p. 146 ; Bendire 92, p. 305 ; H. G. Smith 96, p. 76 ; Cooke 97 , pp. 88, 209 ; Henderson 03, p. 235 ; 09, p. 233 ; Warren 06, p. 21.

Description.-Above dull olive-brown, slightly darker on the crown; wings and tail dark brown, the secondaries edged with whitish-olive and the middle- and greater-coverts broadly tipped with pale buffy, forming two conspicuous wing-bands; below ashy-grey, white on the throat, duskier on the breast, becoming pale primrose on the flanks and abdomen; tenth (outer) primary longer than the fifth; tail even. Iris brown, upper mandible blackish-brown, lower pale brownishwhite, legs brownish-black. Length 5.20 ; wing 2.70 ; tail 2.40; culmen .50 ; tarsus $\cdot 60$.

The sexes are alike, and the young birds hardly differ from the adults.

Distribution.-Breeding in western North America from southern Alaska through Idaho to the Mississippi Valley and westwards; in winter, south over Mexico and Central America to Colombia.

Trail's Flycatcher is a common summer resident in Colorado from the plains to about 8,000 feet. It reaches El Paso co. about May 15th, 
and leaves again late in September. It has been recorded from Boulder co., breeding at 5,500 feet (Gale), Limon and El Paso co. (Aiken); Baca co. (Warren), Salida, May 17th (Frey), Pueblo, Fort Garland, 7,900 feet, and Pagosa Springs, 7,100 feet (Henshaw), and San Juan co. (Drew).

Habits.-This little Flycatcher is chiefly to be met with among the willows and alders which fringe so many of the streams, both on the plains and in the lower mountain valleys and parks; it is shy, quick and nervous, constantly flicking its tail and catching insects, and its call is a sharp single "Whit."

Dennis Gale found it breeding in the alder bushes, along a stream in Boulder co. at about 5,500 feet, on July 2nd; the nest contained five eggs, one of which belonged to a Cow-bird. The eggs are creamy-white, moderately spotted with vinaceous and ferruginous; they measure about $\cdot 70 \times \cdot 53$.

\section{Alder Flycatcher. Empidonax trailli alnorum.}

A.O.U. Checklist no $466 \mathrm{a}$.

Description.-Closely resembling $E$. trailli, but the general colour above, including the sides of the head, very distinctly brighter greenisholive; below, the breast clearly washed with greenish-olive, and the flanks and abdomen a brighter shade of yellow; bill distinctly smaller, about 45 instead of $\cdot 50$, and the lower mandible much paler, almost white.

Distribution.-This species replaces Traill's Flycatcher in northeastern North America, where it breeds from the Yukon to the Now England States and the Alleghanies in Maryland; it migrates south in winter to south-eastern Mexico, Central America, and Ecuador.

A Flycatcher obtained by Aiken near Limon in Lincoln co., May 27th, 1905, appears to be an undoubted example of this subspecies; it is probably a straggler from the general line of migration, and is so far the only record from. Colorado. It was identified by Ridgway.

\section{Least Flycatcher. Empidonax minimus.}

A.O.U. Checklist no 467-Colorado Records-Baird, Brewer \& Ridgway 74, vol. iii., p. 519 ; Henshaw 75, p. 358 ; Allen \& Brewster 83, p. 195 ; Drew 85, p. 17 ; Morrison 89, p. 146; Cooke 97, pp. 19, 89 ; Warren 06, p. 21. 
Description.-Closely resembling $E$. trailli, but slightly richer in colour, and the wing-bands a cleaner white. At once distinguishable, however, by its distinctly emarginate tail, and by its smaller size. The amount of yellow on the under-surface varies considerably, but the throat is always pure white; lower mandible pale dusky. Length 4.90 ; wing 2.55 ; tail 2.20 ; culmen $\cdot 40$; trrsus $\cdot 55$.

Distribution.-Breeding in eastern North America from the esstern base of the Rocky Mountains in Athabasca and western Texas to Prince Edward Island and North Carolina; southward in winter through eastern Mexico and Central America to northern Peru.

In Colorado the Least Flycatcher has only been found, as a regular, though rather rare spring migrant, on the eastern plains and foothills of the State. It has not hitherto been found nesting, though it probably does so; nor has it been met with in or west of the Rocky Mountains. It has been noticed in the following localities only: Loveland, May 12th (Cooke); Denver, May 12th to 17th (Henshaw); El Paso co., May 13th to June 6th, Elbert co., May 21st, Lincoln co., May 22nd to 27th, and Fremont co., May 11th (Aiken); Baca co., May 13th (Warren).

Habits. - This little Flycatcher is a common bird in the east, where it is often known as the "Chebec," from its call ; it prefers open, cultivated country, and can often be seen in orchards and hedgerows; it is an exceedingly restless creature, constantly flitting about and darting after insects.

\section{Hammond's Flycatcher. Empidonax hammondi.}

A.O.U. Checklist no 468-Colorado Records-Ridgway 73, p. 184 ; Trippe 74, p. 258 ; Henshaw 75, p. 362 ; Minot 80, p. 231 ; Allen \& Brewster 83, p. 195 ; Drew 85, p. 17 ; Beckham 85, p. 143 ; Morrison 89, p. 146 ; Bendire 92, p. 315 ; McGregor 97, p. 38 ; Cooke 97, pp. 89 , 209 ; Gilman 07, p. 155 ; Henderson 09, p. 233.

Description.-Closely resembling $E$. minimus, with the tail distinctly emarginate, but the bill narrower and the wing, tail and middle toe longer. Below the ashy shading on the breast is darker and more widely spread, extending over the throat, which is not distinctly white; tenth (outer) primary equal to the fifth. As in $E$. minimus, there are two distinct colour phases, some individuals being strongly washed with pele yellow below, others being without any trace of yellow; the bulk of specimens are intermediate, and the differentiation does not seem to depend on age, sex or season. Length 5.10 ; wing 2.85 ; tail 2.40 ; culmen .40 ; tarsus $\cdot 60$. 
Distribution.-Breeding in the mountains of Colorado and California, north to south-east Alaska; south in winter through Mexico to Guatemala.

Hammond's Flycatcher is a rather uncommon summer resident in the mountains of Colorado, and does not occur in the plains except on migration. It has been recorded as follows : Gold Hill, Boulder co., breeding 10,000 feet (Gale); Idaho Springs, 7,500 fe日t (Trippe), Dillon, breeding at 9,000 feet (Carter), Pikes Peek and Turkey Creek, El Paso co. and Fremont co., May 23rd (Aiken), Pueblo (Beckham), Salida, May 21st (Frey), La Plata co, breeding (Gilman).

Habits.-This is a silent and retiring bird of very different disposition from its nearest relative, the Least Flycatcher; it affects the glens and recesses of the mountains, and is to be met with in the alder bushes along alpine streams. From time to time it makes a dart at a passing insect, and quickly returns to its perch. Dennis Gale found a nest at Gold Hill, on 27th June; it was saddled on the horizontal arm of a spruce, about fourteen feet from the ground, and three feet from the trunk; the nest was solidly constructed with an outer covering of old weed-stems, bark, etc., etc., and lined within with fine bark, hair and a few feathers; the eggs, four in number, are creamy-white and generally unspotted; they measure $66 \times \cdot 51$.

\section{Wright's Flycatcher. Empidonax wrighti.}

A.O.U. Checklist no 469-Colorado Records-Allen 72, pp. 151, 158 (E. obscurus); Trippe 74, p. 258 ; Henshaw 75, p. 360 ; Scott 79, p. 95 ; Tresz 81, p. 183 ; Allen \& Brewster 83, p. 195 ; Drew 85, p. 17 ; Morrison 89, p. 147 ; Kellogg 90, p. 90 ; Bendire 92, p. 318 (E. wrighti); Lowe 94, p. 268; MeGregor 97, p. 38 ; Cooke 97 pp. 89, 209 ; Henderson 03, p. 107 ; 09, p. 233 ; Rockwell 08, p. 167.

Description.-Very similar to $E$. hammondi, but distinctly a larger bird, though the wing is proportionately shorter; bill much longer; tail and tarsus longer; the outer (tenth) primary shorter than the fifth; ashy wash on breast slightly paler and less extended; lower mandible generally dark brown, but varying; teil emarginate. Length 5.25 ; wing 2.75 ; tail 2.40 ; culmen .52 ; tarsus .69 .

Distribution.-Breeding in the Rocky Mountains from Montana and Oregon to Arizona and New Mexico; in winter to southern California and Mexico as far south as the State of Oaxaca. 
In Colorado, Wright's Flycatcher is a fairly common summer resident, especially in the mountains; it is probably only a migrant in the plains. It has been recorded from Estes Park (Kellogg) ; Boulder co., breeding at 10,000 feet (Gale); Denver, May 12th to 17th (Henshaw); Idaho Springs (Trippe); Breckenridge (Carter); Twin Lakes (Scott); South Park, breeding (Allen); Crested Butte, Gunnison co., breeding 8,800 feet (Warren); El Paso and Lincoln cos. (Aiken); Wet Mountains (Lowe); Fort Garland 7,000 feet (Henshaw), Mesa co., 7,000 to 9,000 feet, common (Rockwell), and Silverton, breeding (Anthony apud Bendire). The earliest date for arrival in El Paso co. is May 5th.

Habits.-Like the Hammond Flycatcher, this species is shy and retiring, concealing itself in the thick willow and alder bushes along the courses of mountain streams, and seldom venturing forth on to the mountain sides.

Dennis Gale found a nest containing four eggs on July 22nd, in Boulder co. It was built in thick spruce-bush, about thirty inches from the ground. Warren found three nests in the summer of 1900, near Crested Butte; they were all largely constructed of fibre from the inner bark of dead aspen trees, and were placed in bushes four to six feet above the ground.

The eggs are dull white and unspotted; they average $.68 \times .5 \%$.

\section{Gray Flycatcher. Empidonax griseus.}

A.O.U. Checklist no 469.1-Colorado Record-Ridgway 01 pt. iv., p. 571 .

Description.--Resembling $E$. wrighti, but much grejer above (with hardly any trace of olive) as well as below; wing averaging longer, tail shorter and bill narrower; lower mandible very pale (pinkish in life) with a dusky tip ; tail emarginate, tenth primary about equal to the fourth. Length 5.25 ; wing 2.85 ; tail 2.30 ; culmen .50 ; tarsus $\cdot 70$.

Distribution.-Breeding from southern California to southern New Mexico and the highlands of northern Mexico; in winter to Lower California.

This bird is only an accidental streggler in Colorado; Ridgway records an example taken at Newcastle on the Grand River on May 24th, while a Flycatcher in the Aiken collection taken by Mr. Aiken, May 3rd, 1872, near Fountain in El Paso co., appears to be undoubtedy referable to this species. 


\section{Family ALAUDID压.}

\section{Characters of the single genus.}

\section{Genus OTOCORIS.}

Bill stout, somewhat conical; nostrils circular, completely concealed by stiff feathers directed forwards; primaries nine, the tenth (outer) not obvious; tail nearly square; tarsus rounded in front and behind, and covered both anteriorly and posteriorly with scutes; claws of front toes slightly curved, that of hind toe straight and exceeding its digit in length; head not crested, but with a little erectile, elongated feather-tuft on either side.

This genus is spread over nearly all of North America and extends south to Colombia; also over Europe, Asia and northern Africa.

The Horned Larks are remarkable for the great amount of variation which they have undergone throughout their range; these variations are not very marked, and as a rule are connected by intermediate forms. Mr. Oberholser, the most recent monographer of the genus, recognizes no less than thirty-six forms, of which only six, in his opinion, are worthy of specific separation. All the American forms are included in one species, Otocoris alpestris (Linn.).

The Horned Larks of Colorado were by Henshaw (84) supposed to be referable to two subspecies-(a) a large pale form with a white throat (O. leucolama of Henshaw $=0$.arcticola of Obersholser), breeding in Alaska and wintering in the north-western United States; and (b) a smaller resident form (O. arenicola of Henshaw $=0$. leucolama of Coues and Oberholser) with a distinct yellow throat. A further examination of material however leads to the conclusion, that there is only one form commonly met with in Colorado, and this is a resident throughout the year. Oberholser is of opinion that a subspecies (O. alpestris enthymia), described by him as breeding from the British province of Saskatchewan to North Dakota, comes south in winter to northern Colorado. I have not examined examples of this form.

\section{Desert Horned Lark. Otocoris alpestris leucoloma.}

A.O.U. Checklist no $474 \mathrm{c}$-Colorado Records-Baird 1858, p. 403 (Eremophila cornuta); Allen 72, pp. 149, 156 (Eremophila alpestris); Aiken 72, p. 202 ; Trippe 74, p. 231 (E. a. chrysoloma); Henshaw 75, p. 309 ; Scott 79 , p. 92 ; Drew 81 , p. 78 ; 85 p. 16 ; Tresz 81 , p. 39 ; Allen \& Brewster 83, p. 193 : Henshaw 84, p. 254 (O. a. arenicola); W. G. Smith 84, p. 95 ; Beckham 85, p. 142 ; Morrison 89, p. 147 ; Dwight 90, p. 146 ; Kellogg 90, p. 88 ; Miller 94, p. 32 ; Lowe 95, p. 170 ; Cooke 97, pp. 89, 163, 209 ; Oberholser 02, p. 820 ; Keyser 02, pp. 84, 
268 ; Henderson 03, p. 235 ; 09, p. 233 ; Dille 03, p. 74; Warren 04, p. 6 ; 06 , p. $6 ; 08$, p. 21 ; 09, p. 15; McAttie 05, p. 1 ; Markman 07, p. 157 ; Gilmen 07, p. 155.

Description.-Male in breeding dress; above sandy-brown, streaked with darker, becoming pinkish on the occiput and hind-neck; top of the head black, prolonged back into two points slightly erectile above the ears; forehead and eyebrows white or very pale yellow; malar stripe below the eye and band across the chest black; throat very pale yellow; below white, slightly soiled, tinged with vinaceous on the sides of the breast and flanks. Length 6.0 ; wing 4.10 ; tail 2.7 ; culmen .42 ; tarsus $\cdot 75$.

In winter the males as a rule are brighter yellow on the throat and forehead, and the black is dulled by the paler tips to the feathers of those parts; by the wear of these tips the breeding plumage is acquired.

The female is smaller than the male-wing $3 \cdot 75$, and has, as a rule, little or no trace of the black head-mark, while the malar and breast stripes are much lese conspicuous; the back is brown, streaked from the vertex to the rump, and there is no pink nape area. A female killed in August, probably a young bird after the first moult, has the breast mark quite concealed by the paler tips of the feathers, while below this is a pale-buffy-brown area across the lower breast. Above, it is brown throughout, streaked with darker, and more richly coloured than the winter female. A nestling is pale buffy above, conspicuously spotted with white.

Distribution.-Breeding in the great plains and Rocky Mountain region of the western United States, from western Kansas and Nebraska north to Alberta, west to Nevada, and south to western Texas, both on the plains and in the mountains, wintering in Colorado and southwards perhaps to northern Mexico and south-eastern California.

In eastern Colorado this little bird is one of the most common resident species throughout the year. During the winter it is to be met with all over the eastern half of the State, very commonly on the open prairie, and it extends up into the lower parks (recorded by Drew in Baker's Park, San Juan co., at about 9,500 feet in winter; by Tresz a.t Fairplay in December, and by Warren, near Mosca, in January). In summer it moves up more freely into the mountains, and is found everywhere in suitable localities up to timber line (Bergin Park, above timber line, Trippe; timber line, near Crested Bute, Warren), as well as in the eastern plains. In Mese co. on the western slope, it is more common in winter than in summer, and Rockwell believes that the winter birds go north to breed.

Habits.-The Horned Lark is found on the open treeless plains and on high mesas, often far away from 


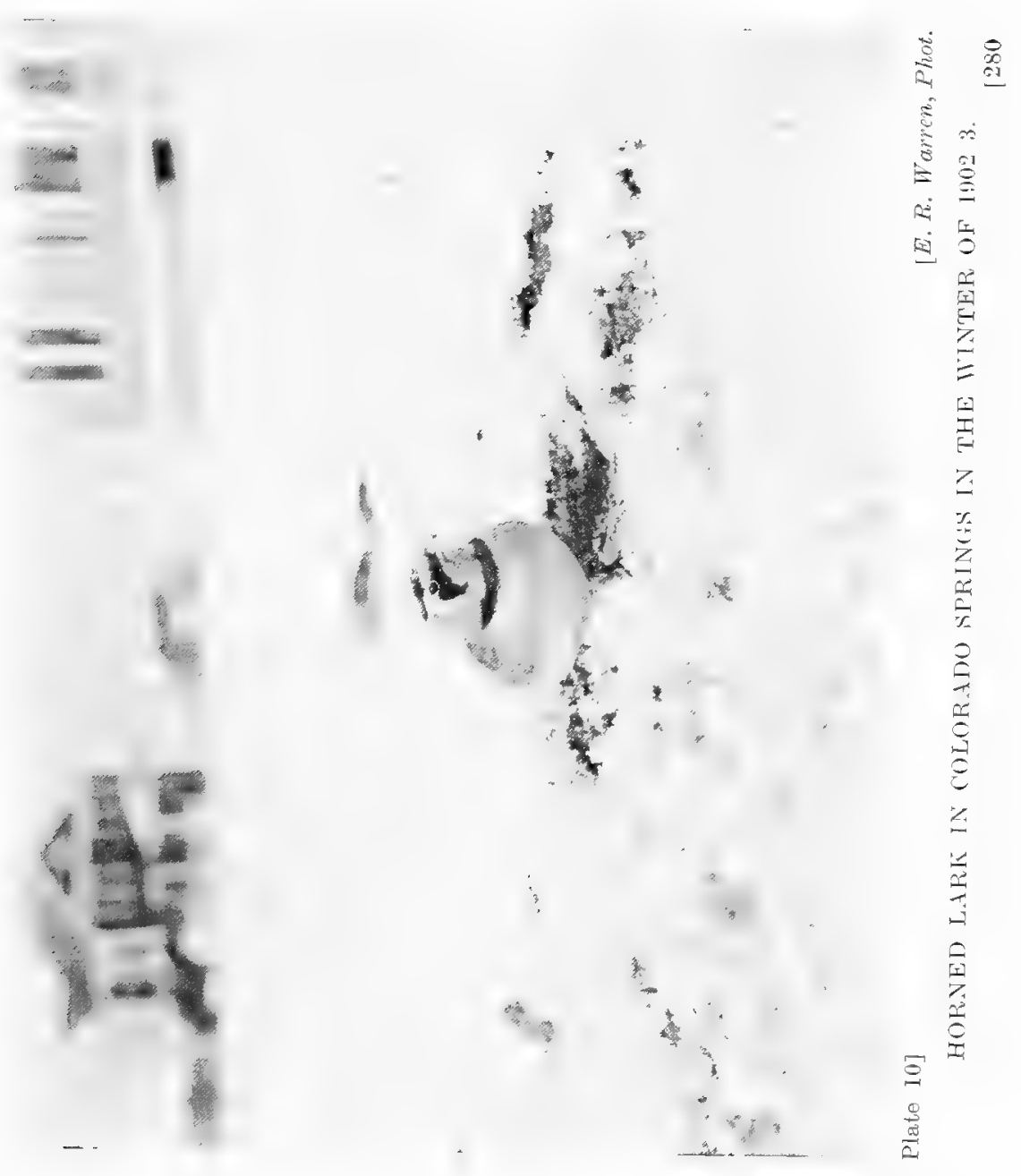



water. It is one of the most terrestrial of the smaller birds, roosting generally on the bare earth and building on the ground, and is rarely, if ever, seen perching in trees and bushes. In the winter it is generally in small parties of a dozen to twenty birds, and is fond of squatting on roads or trails. During very severe snow storms as in January and February, 1903, and February, 1899, they were driven into the towns by thousands, being unable to find their accustomed food outside, and many were doubtless saved from starvation by being fed by kind-hearted people (see Plate 10).

The food of the Horned Lark has been shown by McAttie to consist almost entirely of vegetable matterseeds of grass and weeds, and perhaps some grainduring the winter, while during the summer about twenty per cent. of animal matter, chiefly small insects, is added.

This bird is an early breeder, commencing to nest in April, and continuing until August, so that two or three broods are raised every year. The nest is placed on the bare ground, often in the open, without much protection, and is merely a little cup of grass placed in a slight depression; the eggs, three or four in number, are drab-coloured, profusely blotched with pale brown or even uniformly pale grey; they measure about $\cdot 86 \times{ }^{\cdot} 62$.

Saskatchewan" Horned Lark. Otocoris alpestris enthymia.

Oberholser 02, p. 817.

Description.-Closely resembling O. u. leucolama, but the upper-parts slightly paler and greyer, the superciliary stripe white and the throat paler yellow. Measurements identical.

Distribution.-Breeding on the plains of south-central British America, including Saskatchewan and Assinaboia; in winter south to Kansas, Colorado, and perhaps Utah to Arizona.

This form appears to be very doubtfully separable from O. a. leucolcema. Mr. Oberholser records one winter example from Loveland. If separable it probably winters throughout the plains portion of the State. 


\section{Family CORVID压.}

Generally large birds with the nostrils concealed by bristles (except Cyanocephalus); bill variable in shape, but usually as long as the head, compressed and conical and never distinctly notched; wing of ten primaries, the outer (tenth) well developed, and about half the length of the ninth ; tail of twelve rectrices ; tarsus small, scutellated in front, the hinder aspect covered with two long laminæ forming a sharp posterior edge; sexes alike; young closely resemble the adults; an autumn moult only.

\section{KeY OF THE GENERA.}

A. Tail much longer than the wings; no crest. Pica, p. 282.

B. Tail about the same length as the wing.

a. Head crested; plumage chiefly blue. Cyanocitta, p. 284.

b. No crest.

$a^{I}$ Bill about as long as the head; plumage chiefly blue.

Aphelocoma, p. 287.

$b^{1}$ Bill about half as long as the head; plumage grey.

Perisoreus, p. 289.

C. Tail very markedly shorter than the wing.

a. Nostrils concealed by long plumes covering the basal third of the bill ; plumage black.

Corvus, p. 291.

b. Nostrils concealed by short plumes, less than $\frac{1}{4}$ the length of the bill ; plumage grey, black and white. Nucifraga, p. 295.

c. Nostrils exposed; plumage blue.

Cyanocephalus, p. 297.

\section{Genus PICA.}

Bill short and strong, its basal half as well as the nostrils concealed by the nasal plumes; no crest; wing short and rounded, the outer (tenth) primary short, falcate and about half the length of the ninth; tail very long, markedly exceeding the wing in length, very strongly graduated, the outer feathers about half the length of the central pair.

This genus is distributed over the whole of the Palæarctic region, and the western half of North America.

One species, separable from the common Magpie of the Old World only by a subspecific characters, is found in Colorado.

American Magpie. Pica pica hudsonia.

A.O.U. Checklist no 475-Colorado Records-Pike 10 vol. ii., p. 460 (Coues' ed.); Say 23, vol. ii., p. 182 ; Baird 58, p. 576; Allen 72, pp. 150 
157 ; Aiken 72, p. 204 ; Trippe 74, p. 213 ; Henshaw 75, p. 334 ; Scott 79, p. 94 ; Drew 81, p. 139 ; 85, p. 16 ; Stone 81, p. 45 ; Allen \& Brewster 83, p. 193 ; Beckham 85, p. 142 ; Dille 86, p. 7 ; 88, p. 23 ; Morrison 87, p. $197 ; 88$, p, 197 ; 89, p. 147 ; Kellogg 90, p. 88 ; Bendire 92, p. 349 ; Lowe 94, p. 268 ; MoGregor 97, p. 38 ; Cooke 97, pp. 89, 210 ; Keyser 02, p. 40 ; Henderson 03, p. 235 ; 09, p. 233 ; Dille 03, p. 74 ; Markman 07, p. 157 ; Warren 07, p. 5 ; 08, p. 22 ; 09, p. 15 ; Gilman 07, p. 155 ; H. G. Smith 08, p. 186 ; Rockwell 98, p. 168.

Description.-Adult-Head, neck, chest (with concealed white bases), back, lesser wing-coverts and abdomen black, crown and back slightly glossed with metallic; scapulars and lower-breast white; wings and tail metallic, steely-blue or green, less metallic on the primaries which are extensively white on the inner web; bill, bare spot round eye and legs black; iris brown, with a greyish outer ring (blue in autumn apud Aiken). Length 18 ; wing 8 ; tail 10.5; culmen 1.2 ; tarsus 1.9 .

The young bird resembles the adult, but is generally duller and less metallic, the white throat spots are larger and more conspicuous, and the white of the scapulars and breast are tinged with sooty.

Distribution.-The American Magpie is found throughout western North America, except in the coast and interior valleys of California, extending from Aleska to western Texas and Arizona, and eastwards to the western portion of the great plains.

In Colorado the Magpie is a common resident almost everywhere, but specially along the eastern foothills and in the mountain parks, from 6,000 to 8,000 feet; above this it becomes rarer, though recorded by Scott from Twin Lakes-9,300 feet-as a rare breeder, by Lowe from 10,000 feet in the Wet Mountains, and by Carter from Breckenridge at 10,500 feet, while Aiken tells me it is a resident all the year round at about timber line on Pikes Peak; east of the foothills it is less common, though apparently extending to the extreme eastern limit of the State-Julesburg, February, and Holly, December (Smith, 08). In winter it has been found as high as 9,000 feet.

The American Magpie only differs from the European bird in its slightly larger size, and the lesser development of the setaceous shafts on its throat.

Habits.-The Magpie is one of the most conspicuous birds in Colorado; its bold ways, its slow and rather laboured flight, and its size and colouring, all rendering it most noticeable. It is generally seen in pairs or small family parties, and is almost omnivorous, feeding on seeds, insects, and carrion, while it is a very persistent robber 
of the nests of other birds, and will even carry off eggs from the poultry yard, piercing them through the shell with its beak. It is also said to pick the eyes of young lambs and the sores on the backs of horses and cattle, but this does not seem to be a very general habit. It has a loud, harsh voice, but is silent in the breeding season. If taken young from the nest it is easily domesticated, and soon learns to talk like its European cousin (Plate 11.)

Its favourite resort is in the oak and willow brushwood along the banks and the valley slopes of streams. Here its bulky nests are a very conspicuous feature; these are built towards the end of March, and are used and added to several years in succession. The nest proper is built up of small twigs, with a lining of clay and an inner lining of hair and fine rootlets; this is placed on a foundation of larger sticks, which are built up all round and above, to form a complete domed nest with an inconspicuous entrance on one side, the whole structure being often two to three feet in diameter. It is usually placed in a thick bush from ten to twenty feet from the ground, though sometimes I have seen one as high as sixty feet in a cotton-wood tree.

The eggs, seven or eight in number, are laid between April 15th and 30th in the foothills, and about a fortnight later in the mountains, and the young are hatched in about eighteen days; normally only one brood is reared. The eggs vary in shape and markings, but are usually grey, heavily blotched with pale brown, and measure $1.28 \times 0.90$. Rockwell found eggs as early as March 31st in Mesa co., at about 6,500 feet.

\section{Genus CYANOCITT A.}

Bill moderate, the basal half covered by nasal plumes which conceal the nostrils; crown very distinctly crested; wings and tail approximately of equal length; tail slightly graduated. 


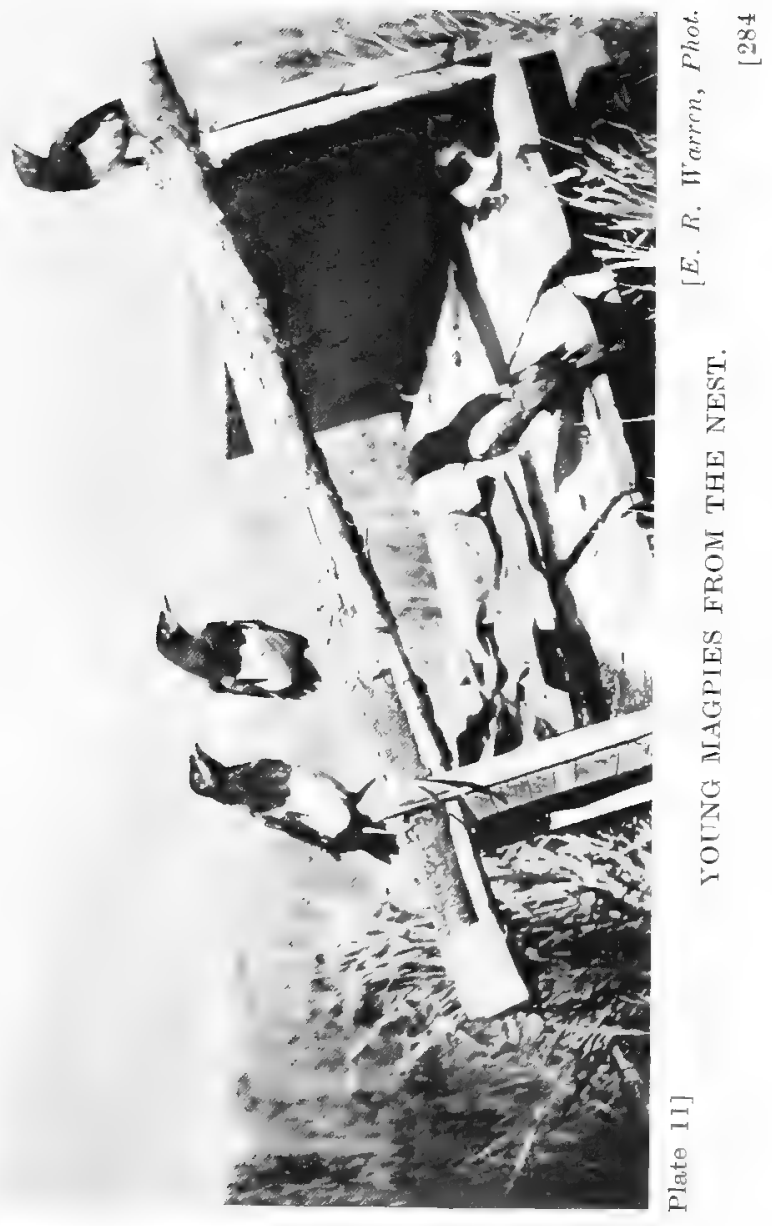



This genus, containing two species now divided into ten geographical races, is confined to North America, including the high plateau of Mexico and Guatemala. Only one species is commonly met with in Colorado, but the eastern Blue Jay occurs as a straggler.

\section{Key of the Speores.}

A. Below blue, becoming dusky on the chest.

C. stelleri diademata, p. 286.

B. Below dirty white, with a black collar across the chest.

C. cristata, p. 285 .

\section{Blue Jay. Cyanocitta cristata.}

A.O.U. Checklist no 477-Colorado Records-H. G. Smith 05, p. 81 ; 08, p. 186 ; Henderson 05, p. 82.

Description.-Adult-General colour above blue, with a purplish tinge; feathers of the crown elongated and erectile, forming a crest; patch round nostrils, above and below the eye, chin, throat and rest of under-parts greyish-white; lores, a few frontal feathers and a postocular band which extends back and joins a crescentric band across the chest black ; primary-coverts, secondaries and tail cobalt blue, narrowly barred with black and tipped with white (except the two central rectrices); primaries dark ashy on the inner, plain azure-blue on outer webs; iris brown, bill and legs black. Length about 11.0 ; wing 5.10; tail $5 \cdot 10$; culmen .90 ; tarsus $1 \cdot 3$. Young birds are very similar to the adults, but the colours are less bright and less sharply defined.

Distribution.-Eastern North America from Manitoba and Nova Scotia south through eastern Colorado and eastern Texas to the Gulf of Mexico, but not Florida. The Blue Jay has only recently been recorded from Colorado. Possibly it has only lately reached our border as Brunner ("Birds of Nebraska," p. 70) states thet in that State it is rapidly spreading westward. H. G. Smith obtained one specimen, a female, on 2lst of May, 1904, close to Wray in Yuma co,, near the Nebraska border, and saw several others, some of which were engaged in building a nest. In the following year he found them nesting in Dry Willow Creek, some little distance south-east of Wray, and in 1907 obtained a female at Holly, in the south-east corner of the State; while Miss Jennie M. Patten (Henderson 05) identified a specimen on November 18t, 04, at Yuma, some twenty-five miles further east. There is a fermale in the Aiken collection, taken by Aiken close to Limon on May 27th, 1905, and I am told that it was seen by Mr. Schulze in Colorado Springs, October 10th, 1903, so that it will probably be found more commonly in the future. 
Habits.-Smith took two sets of eggs on June 4th, 1905, at Dry Willow Creek : one nest was in a dead, black willow overhung with grape vines, and contained five slightly incubated eggs; the other about twenty-five feet up in a cotton-wood tree held four eggs, in which incubation had progressed about one fourth.

\section{Long-crested Jay. Cyanocitta stelleri diademata.}

A.O.U. Checklist no $478 \mathrm{~b}$-Colorado Records-Baird 58, p. 582 (Cyanura macrolopha); Allen 72, pp. 150, 163; Aiken 72, p. 205; Trippe 74, p. 218 ; Henshaw 75, p. 335 ; Scott 79, p. 94 ; Drew 81, p. 139 ; 85, p. 16 ; Allen \& Brewster 83, p. 193 ; Beckham 85, p. 142 ; 87 , p. 124; Morrison 86, p. 153 ; 88, p. 107 ; 89, p. 147 ; Kellogg 90 , p. 88 ; Lowe 94, p. 268; Bendire 92, p. 367 ; McGregor 97, p. 38 ; Cooke 97, pp. 90, 210 ; Keyser 02, p. 149; Henderson 03, p. 235; 09, p. 233 ; Gilman 07, p. 155; Rockwell 08, p. 168 ; Warren 08, p. 22 ; 09 , p. 15.

Description.-Adult-Crown, including the long crest-feathers and sides of the head black; forehead with a very pale blue longitudinal streak on either side; superciliary patch quite white and very conspicuous; back bluish-grey, brightening on the rump; wings and tail bright blue, the primary-coverts, secondaries and tail-feathers more strongly marked with narrow, black cross-bands; below the throat and chest are black (the chin streaked with white), becoming dull blue posteriorly on the abdomen and under tail-coverts; iris brown, bill and legs black. Length 11.5 ; wing 5.90 ; tail 5.60 ; culmen 1.20 ; tarsus $1 \cdot 70$. The female is very similar but slightly smaller-wing $\mathbf{5} \cdot 60$. A young bird has the back and the whole of the under-parts dusky grey, darker than the back of the adult; the black of the crest is less marked, and the streaks and superciliary stripe are hardly to be detected.

Distribution.-The Rocky Mountain region from Utah and Colorado southwards to Zacatecas State in central Mexico, merging in Wyoming with Cyanocitta stelleri annectens.

In Colorado the Long-crested Jay is a common resident throughout the year in the foothills and mountain districts, from Estes Park (Kellogg) to Fort Garland (Henshaw), and from Grand and Routt cos. (Warren) and Mesa co. (Rockwell) to La Plata co. (Gilman); it does not occur in the open eastern plains as a rule, though it has been observed at the Old Fort Lyon in Bent co, in December by Trippe, and also near Peyton on the Arkansas Divide, about twenty miles from the mountaing by Aiken. 
During the winter it is very common along the foothills and perhaps up to 10,000 feet; during the summer the bulk of the birds go up into the mountains, breeding chiefly between 7,000 and 9,000 feet, more rarely to timber line.

Habits.-This Jay is one of the handsomest and most conspicuous birds in Colorado : the bright sun glancing on his blue wings and tail and his constantly moving crest, together with his harsh, querulous and scolding note, easily attract attention. Seldom found far away from the pine forest, his food consists largely of seeds of conifers, though he will often be found near human habitations in order to pick up any stray scraps, especially in winter. Like most of the family, the Jay is intelligent and crafty; he has been seen storing heads of grain in trees for future use, and is known to persecute smaller birds, and to steal and suck their eggs.

The Long-crested Jay breeds rather early; eggs are generally laid in May at lower levels; Dennis Gale found four fresh eggs as early as April 23rd, at Gold Hill, near Boulder. The nest though bulky is difficult to find; it is made largely of small twigs plastered with mud, and lined with fine rootlets, and is not as a rule placed very high up, generally in a bushy pine. The eggs, three to six in number, are pale blue spotted and blotched with brown; they measure $1.22 \times \cdot 88$.

\section{Genus APHELOCOMA.}

Bill rather slender, nasal plumes not well developed, barely concealing the nostrils; no crest; wings longer or shorter than the tail (shorter in the Colorado species); tail slightly rounded; prevailing colour blue.

This genus is found through the western half of the United States southwards to Guatemala; also in Florida. Out of nine species and nineteen subspecies, only one is met with in Colorado.

Woodhouse-Jay. Aphelocoma woodhousei.

A.O.U. Checklist no 480-Colorado Records-Allen 72, p. 150; Aiken 72, p. 205 ; Henshaw 75, p. 337 ; Drew 81, p. 140; Allen \& Brewster 
83, p. 193 ; Drew 85, p. 16 ; Morrison 88, p. 107 ; 89, p. 147 ; Lowe 94, p. 268 ; Bendire 92, p. 372 ; Cooke 97, p. 90; Henderson 03, p. 107 ; 09, p. 233 ; Rockwell 07, p. 81 ; Gilman 07, p. 155; Warren 08, p. 22 ; 09, p. 15 ; Rockwell 08, p. 168 ; Cary 09, p. 182.

Description.-Adult-General colour above azure-blue, the centre of the back and scapulars ashy-grey with a slight bluish tinge; a narrow, interrupted white line above the eye and ear-coverts; below, the chin and throat ashy-white streaked with bluish, most strongly on the sides and breast; lower breast and abdomen ashy-grey, becoming tinged with blue on the under tail-coverts; iris brown, bill, legs and feet black. Length 10.25 ; wing 5.10 ; tail 5.40 ; culmen 1.0 ; tarsus 1.4 .

The female is like the male, but rather smaller-wing 5.0 ; the young bird has the crown ashy-grey and very little blue on the under-side.

Distribution.-Western United States from south-eastern Oregon and southern Idaho south to Arizona, southern New Mexico and north-west Texas, chiefly in the transition zone.

The Woodhouse Jay is a common resident throughout the western half of Colorado at moderate elevations, being seldom found above 8,000 feet. It is common along the foothills in El Paso co, and has been recorded from nearly all the eastern foothill counties-from Boulder, where, however, it is quite rare, to Las Animas; it is also stated by Rockwell to be a common resident in Mesa co. on the west side of the range, at from 6,000 to 9,000 feet. It seldoms wanders east of the foothills, though stated by Cooke to have been observed by Captain Thorne at Fort Lyon in the Arkansas River valley in winter, and Aiken has reported it near Rocky Ford in September; Cary has recently observed troops of this species in the dense growth of cedars in north-west Baca co. in late November, and believes that they winter there.

Habits.-The Woodhouse Jay is found in brushwood and scrub, clothing the sides of rocky valleys and cañons, and seldom, if ever, in the thick forest. It is somewhat terrestrial in habits, keeping on or near the ground, searching for fruits and the seeds of piñons and oaks on which it principally subsists. It is most commonly seen in winter, when it frequents cultivated lands and the neighbourhood of houses and ranches, and when its harsh, grating ory is often heard; in summer it is much more silent and retiring. Rockwell considers that 
its bad reputation as a robber of other birds' nests is undeserved, as it appears to live in perfect amity with them.

This Jay builds its nest in low scrub or piñon trees not far from water; no mud or clay is used in its construction. The nest proper is placed on a platform of crooked, dead twigs, thickly interlaced; on this is a cup of interwoven stalks and roots lined with finer material of the same kind, and sometimes with horsehair as well. The whole structure is very carefully concealed and difficult to locate. The eggs, three to five in number, are laid about the first week in May in El Paso co. They are a dirty pea-green colour, sparingly spotted with reddish-brown, and measure $1.09 \times 79$. Aiken (72) was the first to describe the nesting habits, and his remarks have recently been amply corroborated by Rockwell (07).

\section{GenUS PERISOREUS.}

Bill short and conical, about half the length of the head; nostrils concealed by the short, stiff nasal bristles; no crest; wings rather long and pointed, about the same length as the tail, which is strongly graduated, the outer tail-feathers about $\frac{s}{4}$ the length of the middle one; plumage lax, the prevailing colour grey.

A boreal genus, found in the northern pine forests of the Old and New Worlds, and south in the Rocky Mountains to the Mexican border. Three species are generally recognized; a subspecific form of one of these is found in Colorado.

White-headed Jay. Perisoreus canadensis capitalis.

A.O.U. Checklist no 484a-Colorado Records-Baird 58, p. 590; Allen 72, p. 163 ; Henshow 75, p. 339 ; Brewer 79, p. 239 ; Scott 79, p. 94 ; Drew 81 , p. 149 ; Stone 82 , p. 181 ; Drew 85, p. 16 ; Morrison 88 , p. 107 ; 89 p. 147 ; Kellogg 90 , p. 88 ; Bendire 92, p. 388 ; Lowe 94, p. 268 ; Cooke 97, pp. 90, 210 ; Henderson 03, p. 235 ; 09, p. 233 ; Gilman 07, p. 155 ; Warren 08, p. 22 ; 09, p. 15 ; Rockwell 08, p. 168.

Description.-Adult-Crown pure white, separated from a somewhat vaguely defined, dirty-white collar by a dark slaty nuchal patch; rest of the upper-surface slate-grey, the wing and tail-feathers white tipped; 
below grey with a pale brownish tinge, becoming whiter on the throat and ear-coverts; iris brown, bill and feet black. Length 11.0 ; wing 6.20 ; tail 5.80 ; tarsus 1.30 ; culmen .85 .

The female is slightly amaller-wing 6.0 ; young birds have a pale grey crown.

Distribution.-The pine forests of the Canadian zone from eastern British Columbia to Arizona and New Mexico.

In Colorado the White-headed Jay is a resident, only found at elevations of from 8,000 feet to timber line (about 11,500), about the lower limit in winter and the upper in summer. It is fairly common where it occurs. It is recorded from the following counties : Boulder (Henderson), Summit (Carter apud Brewer), Park (Allen), Lake (Scott), Huerfano (Baird \& Lowe), Garfield (Warren 08), Mesa (Rockwell), Costilla (Henshaw), San Juan (Drew) and La Plata, where it is rare (Gilman). Occasionally after heavy storms it is driven down to lower levels : it has been seen by Aiken at Colorado City, and by Henderson in Boulder town on such occasions.

Habits.-This Jay is often known as the Camp Bird or Camp Robber, from its familiarity with man and its fondness for scraps at miners' cabins. It is an arrant thief, and so tame does it sometimes become that it will take food from the hand, Warren tells me (see Plate 12). It is also known as the Whiskey Jack, a corruption of an Indian word Wiss-ka-chon, applied to the eastern and typical form of the bird.

The only recorded observations on the breeding habits of this bird are those of the late A. Carter of Breckenridge (Brewer 79). He found a nest on April 2nd near Breckenridge. It was placed forty feet from the ground on the horizontal limb of a pine tree; the nest was constructed of twigs and grass-stems, and scantily lined with down and feathers; it contained three eggs slightly incubated. These were greyish-white in colour blotched with brown, and measured about $1 \cdot 16 \times \cdot 85$. Gale found young birds in the nest twice, at 10,000 and 11,000 feet, but never took the eggs. It is a very remarkable fact that a bird of the mountains sbould breed so early, 


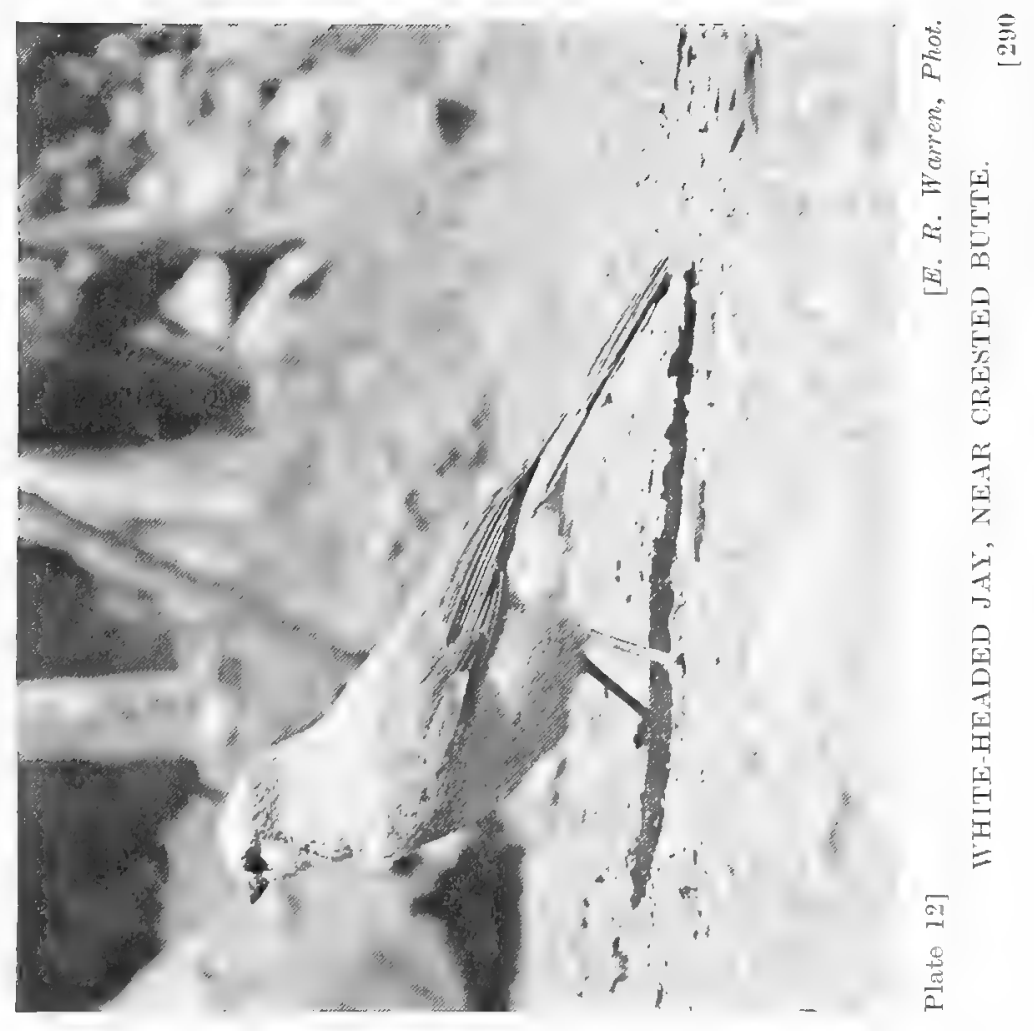



long before the snow is off the ground. But that it is so, appears to be the fact, as Warren tells me he has seen fully-fledged young ones with their parents on May 21st, in Gunnison co., while the typical form of the Canadian Jay of the eastern states is an equally early breeder.

\section{Gemus CORVUS.}

Large birds with the wings over 10 inches ; bill very stout and strong, with arched culmen; nostrils concealed by the forwardly direeted nasal plumes, which cover at least the basal third of the bill; no crest; wing long and pointed, far exceeding the tail in length; the four outermost primaries sinuated on the inner web; tail short and slightly rounded; prevailing colour of the plumage black.

This genus, conteining the Ravens, Crows and Rooks, is spread over the greater part of the world. There are five species in North America, three of which are found in Colorado; these are distinguished as follows :

A. Feathers of the throat elongate and lanceolate.

a. Largest (wing over 14); bases of the nape-feathers grey.

C. corax sinuatus, p. 291.

b. Smaller (wing 12-14); feathers of the nape, upper-back and breast with concealed white bases.

C. cryptoleucus, p. 293.

B. Feathers of the throat normal; smallest (wing generally less than 12); no white bases to the nape-feathers.

C. brachyrhynchos hesperis, p 294.

\section{Western Raven. Corvus corax sinuatus.}

A.O.U. Checklist no 486-Colorado Records-Pike 10, vol. ii., p. 459 (in Coues' ed.); Baird 54, p. 14 (Corvus carnivorus); Allon 72, pp. 150, 157 ; Scott 79, p. 94 ; Drew 81, p. 139 ; 85 p. 16 ; Morrison 88, p. 107 ; 89, p. 147 ; Kellogg 90, p. 90 ; Lowe 94, p. 268 ; Cooke 97, pp. 91, 210 ; Gilman 07, p. 155 ; Rockwell 08, p. 168 ; Warren 08, p. 22; 09, p. 15.

Description.-Adult-Plumage throughout black with a violet and blueish metallic gloss on most parts; feathers of the throat elongate, lanceolate and somewhat outstanding; bases of the nape-feathers grey, but never white. Length 21 ; wing 15.5 ; tail 9.25 ; culmen 2.55 ; tarsus 2.50 .

The measurements are those of a small female; a male is a good deal larger-length 25.5, wing 16.75, according to Ridgway.

Distribution.-The Western or Mexican Raven is found throughout the western United States, southwards over the Mexican platean to northern Honduras. It replaces the northern Raven (Corvus corax 
principalis) of the northern and eastern portions of the Continent, from which it appears to be but doubtfully separable, and the ranges of the two forms are hardly accurately discriminated.

In Colorado the Raven is a resident but a somewhat irregular wanderer ; it is most common on the western slope of the range, and is found at 10,000 to 12,000 feet in summer. It descends slightly lower in winter, and is occasionally met with on the plains.

It has been noticed at Estes Park (Kellogg); Breckenridge, breeding (Carter); Twin Lakes, not common (Scott); Pikes Peak, at timber line (Aiken); near Salida, January (Warren); Wet Mountains (Lowe); Mesa co., breeding 5,000 to 7,000 feet (Rockwell); Gunnison co. and Coventry (Warren); San Juan co., common in fall (Drew); La Plata co., common (Morrison).

Habits.-The Raven is a stately and sedate bird; it is usually shy and suspicious of man, but where not molested will mingle with the fowls and pick up scraps about ranches and isolated cabins; it is not particular in its diet, feeding on carrion, dead fish, insects, worms and slugs, while it is said to prey on young rabbits and even lambs; but definite evidence for the latter propensity does not seem to be forthcoming. It is often seen consorting with the Turkey-Vulture round carcasses, and the two are evidently on the best of terms. Its voice is a loud, harsh "Craack, craack."

It breeds in Mesa co., according to Rockwell, during April, from 5000 to 7000 feet, frequenting rocky, unsettled localities and nesting in high sandstone cliffs. It is particularly numerous in the box cañons emptying into the cañon of the Grand River. Warren (09) reports that Smith has taken several nests near Coventry, where it breeds in the sandstone ledges of the Naturita Cañon. The nest, as stated by Bendire, is nearly always placed on a ledge in a cliff with a south aspect, much more rarely in a tree; it is built up of sticks and lined with wool or hair; the eggs, five or six in number, are greenish, spotted and blotched with drab and brown, and measure $1.95 \times 1.29$. 


\section{White-necked Raven. Corvus cryptoleucus.}

A.O.U. Checklist no 487-Colorado Records-Aiken 72, p. 203; 73, p. 16 ; Trippe 74, p. 206 ; Henshaw 75, p. 326 ; Ridgway 79, p. 230 ; Drew 85, p. 16 ; Dille, 87, p. 99 (C. corax carnivorus) ; Morrison .89 , p. 147 ; Bendire 92, p. 402 ; Cooke 97, pp. 91, 163, 210; Henderson 03, p. 236 ; 09, p. 233.

Description.-Adult-Resembling C. corax sinuatus, but smaller, and with relatively longer nasal plumes, which extend quite half the length of the bill; the feathers of the nape, upper-back and breast with concealed white bases; iris brown, bill and legs black. Length 20 ; wing 14.20 ; tail 8.0 ; culmen 2.20 ; tarsus 2.35 .

The female averages slightly smaller-wing about 13.5. Young birds are less glossy, have no lanceolate feathers on the throat, and the basal half of the mandible light coloured.

Distribution.-The western plains of the United States, from southeast Wyoming and western Nebraska south to central Mexico, and westwards through Arizona to southern Celifornia.

In Colorado the White-necked Raven was excessively abundant along the eastern foothills of the Rockies from Cheyenne to Trinidad, in the early seventies of the last century. Aiken states that in the winter of 1871-2, a flock of over a thousand birds wintered close to Colorado Springs, which was founded in that year. Now they seldom if ever are seen, having been probably driven away by settlement. They do not seem to go to any great elevation in the mountains, though observed by Carter at Dillon (about 8,800 feet) in Summit co., and by W. G. Smith in the foothills near Loveland; nor are they found on the western side of the range, but they do or did extend out over the eastern plains to the Kansas border, and Mr. Ferril has recently informed me that he observed them at Kit Carson in October, 1907, in the extreme west of the State.

Habits.-The White-necked Raven seems to be a more sociable bird than the Mexican Raven, congregating in large flocks in winter; it becomes tame when not molested, though naturally suspicious and wary. The note is said to be not so loud or varied as that of the Mexican Raven. Dille (87) found two nests on the plains in Weld co. on May 24th; they were placed in willow trees, and very neatly constructed and lined with cow's hair ; the eggs, eight in number in each nest, were fresh. Aiken also found the nest of this bird in May, 1878, on 
Horse Creek, forty miles east of Colorado Springs, on the plains. The eggs, according to Bendire, are usually four to six in number, and though varying a good deal in colour and markings, are usually greenish, with characteristic longitudinal, rather fine streaks and blotches of lilac and drab. They average $1.74 \times 1 \cdot 19$ in measurement.

\section{Western Crow. Corvus brachyrhynchos hesperis.}

A.O.U. Checklist no $448 \mathrm{~b}$-Colorado Records-Ridgway 79, p. 230 (C. americarus); Stephens 78, p. 94 ; Drew 81, p. 143; 85, p. 16 ; Dille 86, p. 15 ; 03, p. 74 ; Morrison 88, p. 107 ; 89, p. 147 ; Burns 95, pp. 1-41 ; Barrows \& Schwarz 95, pp. 1-98; Cooke 97, pp. 92, 210; Gilman 07, p. 155; Markman 08, p. 157 ; Warren 09, p. 15 ; Henderson 09, p. 233.

Description.-Adult-Plumage black throughout with a gloss of metallic purple; feathers of the throat not elongate or lanceolate; iris brown, bill and legs black. Length 17.0; wing 11.70 ; tail 7.0 ; culmen 1.80 ; tarsus $2 \cdot 15$. The female is slightly smaller than the male; the young bird is duller and less glossy, and has a greyish iris.

Distribution.-The Western Crow only differs from the Crow of the east in its slightly smaller size and more slender bill. It is found throughout western North America (except the north-western coast from Puget Sound northwards) from British Columbia to south-west Texas, and is a resident except perhaps in the extreme south, where it is not known to breed.

In Colorado the Crow is almost unknown except in the north-east and south-western parts of the State, where, however, it is comparatively common and resident. It is abundant near Fort Collins (Cooke) and breeds commonly near Greeley (Dille); it has been found nesting on Clear Creek in Jefferson co., near Denver. It has been noticed on one or two occasions in Boulder co. (Henderson). Near Colorado Springs it is very rare; there are two examples in the Aiken collection, one a partial albino, from the immediate neighbourhood of the Springs, and another from the upper valley of the Monument Creek twenty miles to the north, obtained in November. Stephens secured several in South Perk in October some years ago. In La Plata co. in the extreme south-west corner of the State it has been recorded as common, especially in winter, by Drew, Morrison and Gilman, and near Coventry in spring and fall by Warren, but no nest was found. It does not seem to ascend above 8,000 feet at the most. 
Habits.-The Western Crow appears to be a less wary and suspicious bird than its eastern cousin, probably because it has had less contact with man. Its food consists chiefly of insects, slugs and grubs in the summer, but in the fall and winter grain and seeds, especially corn, are eaten in large quantities, and its benefit or harmfulness from the farmers' point of view seems to be about evenly balanced. In the east the Crow associates during the fall and winter in enormous flocks, which roost together in special woods, generally near a stream, but I have not heard of such roosts in Colorado.

The Western Crow generally builds its nest in cottonwood trees along the valleys of streams. Dille has found many nests in the neighbourhood of the South Platte, near Greeley; the date for a full set of eggs is April 27th to May 8th; the eggs are five or six in number, and are greenish in colour, with irregular spots and blotches of brown or grey; they average $1.63 \times 1.15$.

\section{Genus NUCIFRAGA.}

Birds of moderate size, wing less than 8.0 , with a rather long and elender bill; the culmen rounded not ridged; nostrils rather basally pleced, and completely concealed by short, stiff plumes; wings long and pointed, nearly reaching the tip of the tail when closed, and considerably exceeding it in length; tail slightly rounded. Plumage grey, black and white.

This genus is confined to the northern and mountainous regions of Europe, Asia and North America. Four species are generally recognized ; only one of these is found in America.

\section{Clarke's Nutcracker. Nucifraga columbiana.}

A.O.ర. Checklist no 491-Colorado Records-Aiken 72, p. 203; Trippe 74, p. 209 ; Henshaw 75, p. 328 ; Scott 79, p. 94 ; Drew 81, p. 139 ; 85 , p. 16 ; Goss 83 , p. 44 ; 89 , p. 123 ; Stone 84 , p. 20 ; Batchelder 84, p. 16 ; Morrison 88, p. 107 ; 89, p. 147 ; Bendire 89, p. 226 ; 90, p. 92 ; 95, p. 418 ; Lowe 94, p. 269 ; McGregor 97, p. 38 ; Cooke 97, pp. 92, 163, 210 ; Henderson 03, p. 236 ; 09, p. 234 ; Gilman 07, p. 155 ; Warren 08, p. 22 ; Rockwell 08, p. 168. 
Description.-Adult-Head all round, back and under-parts smokygrey, becoming a dirty yellowish-white on the nasal tufts and forehead; upper tail-coverts, two middle rectrices and the wings black, with a metallic purplish gloss; secondaries broadly tipped with white; under tail-coverts and four pairs of outer rectrices white, fifth pair bleck and white; iris brown, bill and legs black. Length 12.0; wing 7.80 ; tail 4.90 ; culmen 1.5 ; tarsus 1.3 .

The female is slightly smaller-wing about 7.30. In summer the grey is rather paler and of a browner tinge; the young birds closely resermble the summer adults, but the black of the wings and tail has less gloss.

Distribution.-A resident in the coniferous forest regions of western North America, from Alaska to Lower California and New Mexico. In Colorado the Nutcracker is found commonly through the mountainous western half of the State, at elevations of 7,000 to 12,000 feet, chiefly at 9,000 to 10,000 in summer and 7,000 to 9,000 feet in winter. It is a great wanderer, and has not infrequently been met with on the plains in winter (Burlington, January-Hoskins apud Cooke), and localities in western Kansas and Nebraska. On the other hand it wanders above timber line as high as 13,000 feet, especially in summer and early fall.

Habits.-Clarke's Nutcracker resembles in many ways the Rocky Mountain Jay in its habits, and shares with it the opprobrious name of Camp Robber. It is naturally shy and suspicious, but when not molested soon becomes tame, and frequents mountain camps and miners' cabins for scraps and offal. In the fall they are generally met with in large flocks, which pursue their way noisily and busily through a grove of piñon or yellow pines, in search of the seeds which they extract with considerable skill from the cones, often hanging down below a branch for this purpose like a Chickadee. They have a Woodpecker-like habit of sitting on a dead branch and hammering with their beaks; this is not to obtain insects, but to crack the pine nuts for their kernels; they also somewhat resemble Woodpeckers in their undulating flight.

The Nutcracker breeds early, in fact long before the snow has disappeared. Dennis Gale obtained the 
first eggs taken in Colorado, on March 5th, 1888, near Gold Hill, in Boulder co. The nest was placed about eight feet from the ground, in a thick and bushy yellow pine, at an elevation of 8,500 feet; it consisted of a platform of twigs of the juniper, on which was raised the nest proper, mostly constructed of strips of the inner bark of the juniper, skilfully woven into a deep cup, together with grass and pine needles; no wool or feathers were used. The eggs, three in number, were pale greenishblue, slightly peppered with greyish-brown. A second nest was found the following year, on April 16th. Only one brood is raised each year, and the young ones are flying in the middle of May.

\section{Genus CYANOCEPHALUS.}

Birds of moderate size-wing under 6.0-with a long, slender and somewhat compressed bill; nostrils oval and exposed, not concealed by bristles, with a slightly developed, overhanging operculum; no crest; wing long and pointed, tail rather short, about $\frac{2}{2}$ the length of wing, nearly even; plumage blue.

The Piñon Jay is the only species assigned to this somewhat aberrant genus.

\section{Pinon Jay. Cyanocephalus cyanocephalus.}

A.O.J. Checklist no 492-Colorado Records-Aiken 72, p. 204; 75 , p. 370 ; Henshaw 75 , p. 331 ; 78 , p. 112 ; Drew 81 , p. 139 ; 85, p. 16 ; Goss 83, p. 43 ; Allen \& Brewster 83, p. 193 ; Morrison 88, p. 107 ; 89, p. 147 ; Bendire 92, p. 424 ; Lowe 94, p. 269 ; Cooke 97, pp. 93, 210 ; Christy 98 , p. 57 ; Henderson 03, p. 107 ; 09, p. 234 ; Warren 06 , p. 22 ; 08 , p. 22 ; 09, p. 15 ; Gilman 07 , p. 156 ; Rockwell 08, p. 169 ; Cary 09, p. 182.

Description.-Adult-General colour above and below greyish-blue, becoming darker and richer on the crown, brighter, almost azure, on the cheeks, and streaked with greyish-white on the chin and throat; below slightly paler than the back, especially posteriorly; iris brown, bill and legs black. Length 9.75 ; wing 5.90 ; tail 3.90 ; culmen 1.30 ; tarsus $\mathbf{1} \cdot \mathbf{3 0}$.

The female is slightly smaller-wing about 5.70. Birds in the fall and winter are a good deal brighter. The young bird is dull, smokygrey above, somewhat paler below; the wings and tail greyish-blue as in the adult. 
Distribution.-Western North America from the interior of southern British Columbia southwards to Lower California and western Texas, chiefly in the upper Sonoran (piñon) zone.

The Piñon Jay, also known as Maximillian's Jay and the Blue Crow, is quite a common resident locally throughout the mountainous part of the State. It ranges chiefly from 5,000 to 9,000 feet, and is said by Drew to ascend to 13,000 feet in autumn. In winter it sometimes wanders out on to the plains as far as Western Kansas and Nebraska. It is most abundant in the southern and western parts of the State in the cedar and piñon country. It has been recorded from Boulder co. (Henderson), Summit co., in autumn (Carter), El Paso co. (Ajken), Salida, in winter (Frey), Costilla co. (Henshaw \& Goss), and north-west Baca co., in November (Cary); on the western slopes from Routt co. (Warren), Mesa co. (Rockwell), San Juan co. (Drew) and La Plata co. (Morrison).

Habits.-This is a somewhat remarkable bird, since it combines the form of a Crow and the colour of a Jay with a characteristic bill all its own. In habit it is singularly sociable, being found in large flocks throughout the greater part of the year, while even in summer it nests in small communities, Its food consists chiefly of the nuts of the piñon pine (Pinus edulis), and to a smaller extent of the yellow pine (Pinus scopulorum); while in summer it also feeds on berries and insects, and even grass-seeds.

Though not a migrant, at least in Colorado, it is a great wanderer and very erratic in its movements, and its vertical range does not seem to be very dependent on seasons. Its note is harsh and querulous.

Aiken (75) was the first to take the eggs of the Piñon Jay. He found several nests on May 13th in El Paso co., one of which contained five well incubated eggs. The nest is bulky and compact, and has a deep cup; it is built up of twigs of piñon, juniper and sage-brush, and lined with strands of bark, and is placed from five to twelve feet from the ground in a piñon tree, generally in a high and open situation, and not specially concealed. 


\section{Piñon Jay}

The eggs, four or five in number, are laid at the end of April or beginning of May; they are blueish-white in colour, moderately speckled with small spots and blotches of brown; they measure $1.19 \times 87$.

Christy gives a few further particulars; he found nests with fresh eggs between April 5th and May 20th, near Rouse Junction, in Huerfano co.; the birds there nest in colonies of from 12 to 150 pairs, at elevations of 7,500 to 8,000 feet.

\section{Family ICTERID里.}

Bill of very varying shape-crow-like to finch-likewithout rectal bristles; wing with nine primaries and nine secondaries; tail with twelve rectrices; tarsus scutellate.

This family is confined to the New World, and out of some thirty genera, representatives of eight occur in Colorado.

\section{KEY OF THE GENERA.}

A. Tail-feathers sharp pointed, only two primaries, seventh and eighth sinuated on their outer webs. Dolichonyx, p. 300.

B. Tail-feathers not distinctly sharp pointed; at least three primaries sinuated on their outer webs.

a. Tail very short, about $\frac{\text { sis }}{3}$ of wing.

a Bill elongated and slender, as long as the head; hind toe stout, longer than the lateral ones. Sturnella, p. 309.

$b^{1}$ Bill stout and conical, about $\frac{1}{8}$ the length of the head; hind toe normal.

Molothrus, p. 302.

b. Tail always more than $\frac{2}{3}$ of wing.

a Tail strongly graduated and plicate; capable of being folded vertically.

Quiscalus, p. 319.

$b^{1}$ Tail square or but slightly rounded.

$a^{2}$ Bill slender, culmen straight or slightly decurved; feet weak, tarsus about equal to the middle toe and claw.

Icterus, p. 311 .

$b^{2}$ Bill distinctly decurved, narrow and shorter than the head; tarsus longer than the middle toe and claw.

Euphagus, p. 315. 
$c^{2}$ Bill wedge-shaped, shorter than the head; culmen straight.

$a^{3}$ Ninth primary longest or equal to the longest.

Xanthocephalus, p. 304.

$b^{3}$ Ninth primary shorter than the eighth; about equal to the sixth.

Agelaius, p. 306 .

\section{Genus DOLICHONYX.}

Small birds-wing about 4-with short, conical, finch-like bills ; wing with only the eighth and seventh primaries sinuated on the outer web; tail with the feathers sharp pointed; middle toe long and claws long and pointed ; plumage of the breeding male chiefly black, of the winter male and female buff, streaked with black.

This genus contains only the single species here described.

\section{Bobolink. Dolichonyx oryzivorus.}

A.O.U. Checklist no 494 -Colorado Records-Henshaw 75, p. 311 ; Allen \& Brewster 83, p. 192 ; Morrison 89, p. 148 ; Cooke 97, pp. 93, 163,211 ; 98, p. 13 ; Beal 00, pp. 12-22; Henderson 03, p. 107 ; 04 , p. 486 ; 09 , p. 234 ; Hopkins 06 , p. 461 ; Warren 08, p. 22 ; 09 , p. 33 ; H. G. Smith 08, p. 186.

Description.-Male in breeding plumage-General colour above and below black; nape buff; scapulars, rump and upper tail-coverts white to grey; upper-back slightly streaked with buffy; wings and tail slightly margined with whitish; feathers of the flanks, thighs and under tail-coverts margined and tipped with buff; iris brown, bill black, legs dark brown. Length 6.70 ; wing 4.0 ; tait, 2.75 ; culmen .60 ; tarsus 1.0.

In summer the nape becomes white or nearly so, and the buffy tips on the flanks and abdomen wear off, leaving those parts plain black. In autumn and winter the male is a rich buff, most of the feathers with black centres; the crown with a median plain buff and two lateral black stripes, the wings and tail chiefly dusky, the sides of the breast, flanks and under tail-coverts marked with black streaks, and the bill pale brown.

The female resembles the winter male, but is a good deal smaller (wing $\mathbf{2 \cdot 5}$, tail $2 \cdot 5$ ) and less richly coloured; in summer it is a good deal paler than in early spring, and has the black streales more plainly defined. The young bird resembles the female, but the buff is a richer shade and there is a faint row of black spots across the chest.

The change of plumage in the male is acquired by a double moult, one in the early fall before the southward migration, the other in early spring before coming north, while the change from the early spring to the summer plumage is brought about by abrasion of the buffy tips to the feathers. 
Distribution.-Breeding from Pennsylvania westwards to Utah, and northwards to Quebec and British Columbia; on migration through the southern States via the West Indies and Yucstan to southern Brazil and Bolivia in winter.

In Colorado the Bobolink is quite an uncommon bird and has never yet been met with nesting. It is chiefly confined to the eastern plains, though occasionally straying into the park regions, having been noticed by Carter in Middle and South Parks in May at elevations of about 7,000 to 8,000 feet. Other records are as follows : Near Meeker, 6,000 feet in Rio Blanco co. (Hopkins), Steamboat Springs, June lst to 8 th (Warren), Loveland (Osburn and Cooke), Boulder co, several records (Henderson), El Paso co., May and September (Aiken), Limon (Aiken), Salida (Warren 09), Huerfano co., May (Henshaw).

Habits.-The Bobolink is also known as the SkunkBlackbird, Reed-bird and Rice-bird, in various parts of its range. In Colorado its best-known name, Bobolink, is very generally applied to the Lark-Bunting (Calamospiza melanocorys), and it is by no means the familiar bird it is in the east, where its habits are so well known. It is a bird of the open country, and is never found in forest, and it appears to be gradually extending its western range with the cultivation of cereal crops, on which it depends to a great extent for its food. In the south it does a very great deal of damage among the rice crops, during its northward and southward migrations, but in the breeding season and further north it subsists chiefly on insects, and those mostly injurious ones.

The Bobolink is not known to breed in Colorado, but in the east it builds its nest on the ground, often in company. The eggs, five or six in number, vary a good deal; the ground-colour is grey to light brown, spotted and blotched with deeper purplish and reddishbrown. They measure $83 \times 62$. Only one brood is raised in the year. Judge Henderson of Boulder informs me that he has reason to believe that the Bobolink breeds on the plains near Boulder, but he has not yet sufficient evidence to positively confirm his observations. 


\section{Genus MOLOT HRUS.}

Small birds-wing under 4.5-with a short, conical bill and small rounded nostrils; wing long and pointed, with the eighth to sixth primaries sinuated on the outer web; tail about $\frac{8}{3}$ the length of the wing, even or slightly forked; tarsus a little longer than the middle toe and claw; the clews short and curved; plumage chiefly glossy black and brown.

This genus contains the Cow-birds, many of which are parasitic in habit, leying their eggs in the nests of other birds. They are found throughout temperate and tropical America, and a number of species have been described; only the common North American form is found in Colorado.

\section{Cow-bird. Molothrus ater.}

A.O.U. Checklist no 495-Colorado Records-Allen 72 pp. 150,157 (Molothrus pecoris); Aiken 72, p. 202 ; Henshaw 75, p. 312 ; Tresz 81, p. 94 ; Allen \& Brewster 83, p. 192 ; Drew 85, p. 16 ; Beckham 85, p. 142 ; Morrison 89, p. 148 ; Lowe 92, p. 101 ; Bendire 92, p. 434 ; 95, pp. 587-597; Cooke 97, pp. 93, 211 ; Henderson 03, p. 236 ; 09, p. 234 ; Dille 03, p. 74 ; Warren 06, p. 22 ; Markman 07, p. 157 ; Gilman 07, p. 156 ; Rockwell 08, p. 169 ; Warren 08, p. 22 ; 09, p. 15.

Description.-Male-General colour above and below black, with metallic purplish gloss; head, neck and chest all round sepia-brown; iris brown, bill and legs black. Length 7.5 ; wing 4.5 ; tail $3 \cdot 10$ culmen $\cdot 65$; tarsus 1.0 .

The female is smaller (wing 4.1) and dusky greyish-brown in colour, rather paler below, marked with darker centres and blackish shaftstreaks especially above; the chin nearly white; bill brownish. The young birds are rather duller than the adults and more variegated, with paler margins and darker centres to the feathers.

Distribution.-Breeding throughout the United States, except Florida, and the southern portions of the Dominion to the Mexican border and the Pacific coast; south in winter to central and south-eastern Mexico

In Colorado the Cow-bird is a fairly common summer resident in the eastern foothills region and plains from Larimer co. (Markman), through El Paso co. (Aiken), to Baca co. (Warren); it passes up in the mountain parks to an elevation of about 7,000 to 8,000 feet, having been found breeding in both Middle and South Parks by Carter (Cooke); it is reported from La Plata co. in spring (Gilman) and is common in Mesa co. (Rockwell), and in Routt and Grand cos. (Warren). It arrives from the south about the end of March, and departs again about the end of September.

Habits. - The Cow-bird is gregarious, polyandrous and parasitic in its habits; after arrival from the south 
it is generally to be seen in small flocks of six to twelve individuals, in grassy meadows and corrals, in the company of the horses and cattle. From Beal's (1900) researches it does not appear to appreciate the parasites and flies found naturally about the cattle, but picks up the grasshoppers and other insects disturbed by their movements. The greater part of their food consists, however, of seeds of noxious weeds, whose destruction is a positive benefit to the farmer.

Like the European Cuckoo, the Cow-bird builds no nest and undertakes no maternal cares, but foists its eggs on other birds, usually smaller than itself. Bendire enumerates ninety species made use of in this way, the largest being the Mourning Dove and the Meadow-Lark, while the smaller Finches, Warblers and Flycatchers are the commonest victims.

It is believed that about eight eggs are laid, each in the nest of a separate victim, with an interval of a day or so between each; where more than one Cow-bird's egg is found in a nest, they have been laid by different individuals. Sometimes they go so far as to eject the eggs already in the nest, but even if this is not done the eggs of the host have little chance, as the Cow-bird's egg hatches in most cases more quickly, and being bigger gets more warmth; and, in the same way, if the eggs of both host and parasite are hatched, the Cow-bird being larger gets the lion's share of the food, so that the host's nestlings are either smothered or starved.

Bendire (95) figures an egg taken from the nest of a Mountain Song-Sparrow on July 2nd, in El Paso co., while Aiken has taken two eggs from the nest of a MeadowLark, near Ramah, in El Paso co., on June 4th ; Bendire also states that W. G. Smith found a Cow-bird's egg in a Rock-Wren's nest, under a ledge of rock fully two 
feet from the entrance, which was barely large enough for the Wren to squeeze through much less the Cow-bird. Aiken informs me he once found in Wet Mountain Valley a Yellow Warbler's nest, built in three stories, the lower one of which contained eggs of the Cow-bird; it is presumed that the successive stories were built by the Warblers to avoid hatching the Cow-bird eggs. The eggs of the Cow-bird are very strongly shelled; whitish in colour, profusely speckled with reddishbrown; they average $84 \times \cdot 65$ in measurement.

\section{Genus XANTHOCEPHALUS.}

Medium-sized birds-wing under 6-with a stout, conical bill, shorter than the head, the culmen straight, not decurved; nostril oval, overhung by a prominent operculum; wings long and pointed; the outer (ninth) primary usually the longest ; tarsus stout, nearly twice es long as the culmen; plumage black or dusky, and jellow.

The Yellow-headed Blackbird is the only species assigned to this genus.

\section{Yellow-headed Blackbird. Xanthocephalus xanthocephalus.}

A.O.ర. Checklist no 497-Colorado Records-Baird 58, p. 531 (X. icterocephalus); Aiken 72, p. 202 ; Henshaw 75, p. 315; Scott 79, p. 94 ; Minot 80, p. 230 ; Allen \& Brewster 83, p. 193 ; Drew 85, p. 16 ; Beckham 85, p. 142; Thorne 88, p. 112 ; Morrison 89, p. 148 ; Lowe 92, p. 101 ; Cooke 97, pp. 18, 93, 211 ; Keyser 02, p. 141 ; Dille 03, p. 74 ; Henderson 03, p. 236 ; 09, p. 234 ; Warren 06, p. 22 ; 08 , p. 22 ; 09, p. 15 ; Markman 07, p. 157 ; Gilman 07, p. 156 ; Rockwell 08, p. 169 ; Hersey \& Rockwell 09, p. 118.

Description.-Male in summer-Head, neck and chest bright orangeyellow; a patch round the eye and base of the bill and the whole of the rest of the plumage black; a white patch on the base of the wing involving the primary and some of the greater coverts; a rather indistinct yellow anal-patch; iris brown, bill and legs black. Length 10.5 ; wing 5.75 ; tail 4.65 ; culmen .85 ; tarsus 1.50 .

In winter the yellow of the crown and hind-neck is obscured by dusky tips to the feathers. The female is much smaller than the male (wing about 4.5); it is dark sepia-brown in colour with the superciliary stripe, chin, throat and upper-breast dull yellow, and the lower-breast streaked with white; no white wing-patch. The young male resembles the female, but is larger and somewhat darker, both as regards the brown and the jellow. 


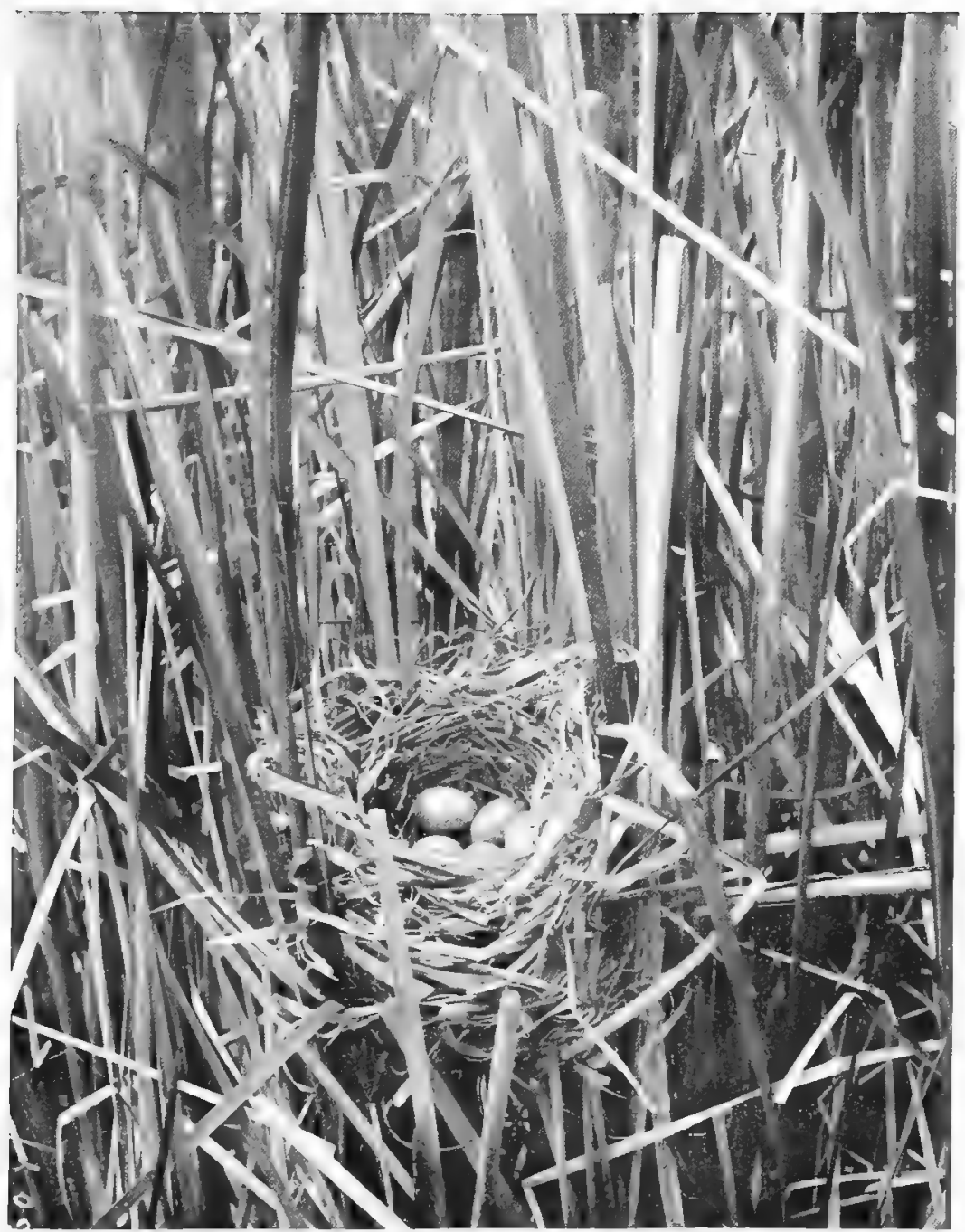

Plate 137

「R. B. Rockwell, Phot.

NEST AND EGGS OF THE YELLOW-HEADED BLACKBIRD, NEAR DENTER. 

Distribution.-Breeding throughout central and western North America from Illinois and Indiana to British Columbia, southern California and northern Mexico, wintering in the southern part of its breeding range and in central and southern Mexico.

In Colorado the Yellow-headed Blackbird is a common summer resident, breeding in suitable localities in the plains and in the mountains up to about 8,000 feet. It has been recorded from Weld co. (Markman), Boulder co. (Henderson), Barr Lakes, where it is extremely abundant (Rockwell \& Hersey), Lincoln and El Paso cos. (Aiken) and Baca co. (Warren), in the plains and foothills; from Middle and South Parks, breeding (Carter apud Cooke), Routt co. (Warren), Grand Junotion (Rockwell), Chaffee co., breeding near Buena Vista, about 8,000 feet (Keyser), Costilla co, breeding at San Louis Lake, (Henshaw \& Aiken), Twin Lakes, about 9,000 feet (Scott), Archuleta co. (Henshaw) and Montezuma co., breeding near Cortez (Gilman). It arrives about the middle of April, and departs south in September.

Habits.-The Yellow-headed Blackbird is a gregarious bird, and is found in flocks throughout the year; during the summer it resorts to sloughs and marshes, where it breeds, in company often with other species; later in the season it is generally to be found in the grainfields in large flocks, and there, when in sufficient numbers, it commits considerable havoc. It is seldom met with in arid or thickly-wooded country.

Its food consists of the seeds of grasses and weeds in addition to grain, while chiefly in the middle of the summer it devours large numbers of insects.

The nests are large and bulky, attached to several reeds or rushes about ten to thirty inches above the water, and constructed almost entirely of coarse grasses and reeds, with a lining of finer material of the same sort-no mud being made use of (Plate 13). Fresh eggs are to be found about the end of May as a rule, but there is a good deal of irregularity about the times of laying, and unfinished nests, freshly-laid eggs and nestlings are often met with in one colony at the same date. The eggs, usually about four in number, are whitish, profusely 


\section{speckled and blotched with various shades of brown; they measure $1.02 \times \cdot 71$.}

\section{Genus AGELAIUS.}

Moderate-sized birds-wing usually under 5.5-with a stout, wedgeshaped and pointed bill with a straight culmen; nostril with a small operculum; wings long and pointed, the ninth primary usually distinctly shorter than the eighth, seventh or sixth; tail at least 3 the length of the wing, more or less rounded; tarsus about as long as the middle toe and claw; sexes very distinct-males black with brightcoloured shoulders, females streaked with white and dark brown.

This genus, containing the Red-winged Blackbirds, ranges over the whole of Amer ca, North and South. About twelve species, split up into a considerable number of subspecies, are usually recognized. Two forms of the common eastern American species are found in Colorado.

Agelaius tricolor, the Tricoloured Blackbird of California, is stated by Morrison (86, p. 107 ; 88, p. 74, and 89, p. 148) to be found in La Plata co., in the extreme south-west corner of the State. No examples were procured, but a flock was seen near Fort Lewis on February 3rd. Further confirmation is necessary before this species can be placed on the Colorado list, but it has been included in the key.

A. Plumage without greenish gloss; lesser wing-coverts scarlet to orange; middle-coverts buffy to tawny.

a. Smaller; wing of the male about 4.8 ; bill more slender.

A. phœniceus, p. 306 .

b. Larger; wing of the male about 5.0 ; bill stouter, though hardly longer.

A. p. fortis, p. 308.

B. Plumage with a bluish-green gloss; lesser wing-coverts dull crimson; middle-coverts whitish to pale buff. A. tricolor.

Red-winged Blackbird. Agelaius phoniceus.

A.O.U Checklist no 498-Colorado Records-Allen 72, p. 150; Aiken 72, p. 202 ; Henshaw 75, p. 313 ; Minot 80, p. 230; Allen \& Brewster 83, p. 192 ; Nash 83, p. 225 ; Drew 85, p. 16 ; Beckham 85, p. 142 ; W. G. Smith 86, p. 13 ; Anthony 85, p. 152 ; Morrison 89, p. 148 ; Kellogg 90, p. 88 ; Cooke 97, pp. 94, 211 ; McGregor 97, p. 38 ; Dille 03, p. 74; Henderson 03, p. 107 ; 09, p. 234 ; Warren 06, p. 22 ; Gilman 07, p. 156 ; Oberholser 07, p. 332 ; Markman 07,.p. 157 ; Warren 08, p. 22 ; 09, p. 15 ; Rockwell 08, pp. 93,170 . (Some of the above records undoubtedly refer partly or wholly to other subspecies.)

Description.-Adult Male-Uniform deep black with a faint metallic gloss ; angle of the wing and lesser-coverts scarlet, middle-coverts buffy, 


\section{Red-winged Blackbird}

sometimes paling to almost white at the tips; iris brown, bill and legs black. Length 8.25 ; wing 4.8 ; tail 3.5 ; tarsus 1.05 ; culmen 80 .

In winter the buff of the middle wing-coverts is somewhat deeper in tone, and the scapulars are narrowly edged with rusty.

The female is smaller than the male (wing about 3.8), and is brown above, slightly streaked with white, especially on the head;. below white tinged with pale salmon or buff on the chin, and streaked with dusky brown. In winter the upper-parts are more conspicuously marked with white and rusty-brown.

Young birds are very similar to the summer female, but the marking above is more conspicuous, while the male is larger and soon shows traces of his red shoulders before losing his stripy coat.

The above description applies to the rather smaller race breeding in Colorado, and considered by Ridgway to be identical with the original eastern type-form of the species. Oberholser (07) considers that the Colorado breeding bird should be separated from the eastern form under the name of $A$. phoniceus fortis, while the Colorado winter birds are believed to be a different race, breeding further north and named A. phoniceus arctolegus. Until the definite decision of the A.O.U. Committee on this point has been given, I have followed Ridgway in this matter. In the meantime, Rockwell (08, p. 93) records a third subspecies, A. p. neutralis, among the visiting birds in Colorado, and according to the third edition of the Checklist the two Colorado forms are A. p. fortis breeding in the north-east of the State, and A. $p$. neutralis elsewhere.

Distribution.-Breeding throughout the eastern United States and corresponding southern portion of the Dominion of Canada from the Atlantic to the eastern slopes of the Rocky Mountains.

In Colorado the Red-winged Blackbird is a common summer resident chiefly on the eastern plains and foothills, but occurring and perhaps even breeding up to 9,000 feet occasionally; the highest definite breeding record seems to be Kellogg's (Estes Park, about 8,000 feet), while Warren noted them near Crested Butte at 9,000 feet in June and October.

This bird arrives early from the south, generally about the middle of March, but does not commence nesting operations until about a month or six weeks later; it departs again for the south in October. It is possible some individuals may winter in the State, but most of those so doing appear to be referable to the following subspecies.

From the following localities there are records : Estes Park (Kellogg), Weld co. (Markman), Boulder co. (Minot \& Henderson), Denver (Allen), South and Middle Parks (Carter), El Paso, Teller, Lincoln and Fremont cos. (Aiken), Gunnison and Prowers cos. (Warren), San Luis Lakes (Aiken), and Mesa co. (Rockwell). 
Whether the birds on the west side of the Divide should be referred to this or some other subspecies cannot at present be definitely decided.

Habits.-The Red-winged Blackbird is an exceedingly gregarious and sociable bird. It is nearly always found in large flocks except during the breeding season, and even then it nearly always breeds in companies. In the early spring the two sexes usually form separate troops. During the greater part of the year its food consists almost entirely of the seeds of various plants and weeds, but in June, while the young are being reared, large quantities of insects, chiefly beetles and grasshoppers, are eaten. In July and August it resorts to the grain-fields, and when in large numbers does a considerable amount of damage, chiefly to the oat crops.

It seldom nests far from water-generally among reeds or rushes growing in swamps or sloughs. The nest is a large one, constructed of coarse grasses woven wet, and lined with finer material of the same sort. It is generally a foot or two above the water. Four is the usual number of egge; these are pale greenish, spotted and blotched with various shades of brown and purplish. They average $98 \times \cdot 69$. Only one brood is raised in the season, and the males appear to be polygamous, a small colony often containing only one cock.

Northern Redwing. Agelaius phceniceus fortis.

A.O.U. Checklist no 498 d.

Description.-Closely resembling $A$. phoniceus, but distinctly larger and with a stouter and relatively shorter bill. Length 9.0 ; wing 5.0 ; tail 3.8 ; tarsus 1.19 ; culmen .80 .

The female is correspondingly larger than the female of the typical form; wing $4 \cdot 15$.

Distribution.-This subspecies, recently discriminated by Ridgway, breeds in the interior districts of British America, on the Mackenzie River and in Athabasea. It migrates south in winter through the westorn half of the Missigsippi Valley as far south as western Texas and Arizona. The Redwings which winter in Colorado in considerable 
numbers in suitable localities, seem to be referable to this subspecies. There are examples in the Aiken collection from El Paso (February and March) and from Pueblo (November 11th).

\section{Genus STURNELLA.}

Medium-sized birds-wing about 5.0-with a long and slender beak about as long as the head; nostrils oval, overhung by a prominent horny operculum; tail very short, about $\frac{2}{3}$ the length of wing; the tips of the feathers slightly pointed and stiffened; tarsus long and strong, nearly $\frac{1}{3}$ the length of wing, longer than the middle toe and claw; plumage mottled with brown above, chiefly yellow below; sexes alike, except that the female is markedly smaller.

The Meadow-Larks, comprising three species and several subspecies, range over temperate and tropical America southwards to the valley of the Amazon. Only one species is found in Colorado.

\section{Western Meadow-Lark. Sturnella neglecta.}

A.O.U. Checklist no 501.1-Colorado Records-Allen 72, pp. 150, 157 (S. Ludoviciana neglecta); Aiken 72, p. 203; Henshaw 75, p. 317 ; Scott 79, p. 94 ; Minot 80, p. 230 ; Tresz 81, p. 94 ; Drew 81, p. 139 ; 85 , p. 16 ; C. N. Allen 81, p. 145 ; Nash 83, p. 225 ; Allen \& Brewster 83 , p. 193 ; Becliham 85, p. 142 ; 87, p. 124 ; W. G. Smith 86, p. 13 ; Morrison 88, p. 75 ; 89, p. 148 ; Kellogg 90, p. 88 ; Lowe 92, p. 101 ; 01, p. 276 ; Miller 94, p. 32 ; Cooke 97, pp. 94, 211 ; Dille 03, p. 74 ; Henderson 03 , p. 236 ; 09, p. 234 ; Warren 06, p. 22 ; 08, p. $24 ; 09$, p. 15 ; Markman 07, p. 157 ; Gilman 07, p. 156 ; Rockwell 08, p. 170.

Description.-Male in summer-General colour above pale brown, blotched and marked with darker; a median stripe on the crown and two superciliary stripes pale, separated by broad stripes of almost black; the inner secondaries, tail-coverts and tail are marked with transverse bands of darker; below, the chin, malar region, throat, centre of the breast, edge of the wing and front portion of the superciliary stripe bright lemon-yellow ; a black crescent-band across the chest ; sides of the body, flanks and under tail-coverts whitish, spotted and streaked with black; iris brown; upper mandible black, lower greyish; legs pale pinkish-grey. Length 9.10 ; wing 5.0 ; tail 3.0 ; culmen 1.15 ; tærsus 1.45 .

The male in winter is brighter above, the darker brown being concealed at the bases of the feathers; most of the feathers of the back, too, are edged pale buffy-white. The yellow below is a brighter shade, but it and the black necklace are considerably obscured by the white tips to most of the feathers, which apparently wear off in the spring. The upper mandible is also much paler. The female in summer resembles the male, but is markedly smaller (wing 4-30); the black 
necklace is narrower and the upper mandible is brown. The young birds are light, like the adults, in winter, but there is much less yellow below, and the black necklace is very obscurely marked or absent.

The western bird differs from the eastern Meadow-Lark in its paler colour above, and in the much greater extension of the yellow of the malar region on either side of the throat.

Distribution.-Breeding throughout western North America, from British Columbia and western Manitoba southwards to Texas and California ; south to central Mexico in winter, though a few birds winter as far north as Washington and Idaho.

In Colorado the Meadow-Lark is a very abundant summer resident, especially on the eastern plains and foothills and up into the lower mountain parks to 8,000 feet. In favourable localities it goes up to timber line in summer time, and is noted as breeding at Breckenridge $(9,700$ feet) by Carter, and at Crested Butte $(9,000$ feet $)$ by Warren, while Professor Brunner informs me that he has seen it at timber line near Fort Garland.

There is no doubt that quite a few Meadow-Larks winter in Colorado. During the winter 1907-8, I observed a small flock every few days close to my house near Colorado Springs. The greater number, however, arrive from the south early in March (Pueblo, March 3rd, Lowe 01), and leave again about the middle of October.

Habits.-The Meadow-Lark is a bird of the open country, generally seen about arable and grass land. It is quite familiar and unsuspicious, and can frequently be noticed within the limits of Colorado Springs, perched on a telegraph pole for preference, and pouring forth its glorious melody. Naturally, in spring it is heard to greatest advantage, but it sings also in the autumn, and even in winter if the day is warm and bright. There is a great variety about the notes, but everyone is agreed that the song is entirely distinct from that of the eastern bird, and that it is far more melodious and sweet. C. N. Allen (81) has endeavoured to reduce the song to musical notation, and has given examples of twientyseven different melodies.

The food of the Meadow-Lark consists chiefly of insects, beetles, grasshoppers and crickets ; but it also eats quantities of weed seeds, and is a valuable ally of the farmer. 
The nest is placed on the ground and is usually well concealed by a tuft of grass; it is sometimes approached by a covered way through tangled weeds and grasses. It is constructed of dried weeds and grasses woven together, and lined with finer material of the same kind. The eggs, usually five in number, are laid in Colorado during the latter half of May : Dille (03) gives May 15th for the Denver neighbourhood. Aiken records nests in El Paso co. on May 15th and June 4th; in the latter instance the nest contained four Meadow-Lark eggs and two Cowbird eggs. At Bedrock, 5, 100 feet, in south-west Colorado, Warren found a nest as early as April 23rd. Both sexes assist in incubation. The eggs are white, sometimes with a faint pink or greenish suffusion, spotted and blotched with various shades of brown; they measure $1 \cdot 12 \times \cdot 81$.

\section{Genus ICTERUS.}

Small birds-wing under 4.5 in Colorado species-with a slender, somewhat acute bill, rather less than the length of the head; culmen straight or slightly decurved; nostrils large with a conspicuous operculum; wing moderate, the ninth (outer primary) always shorter than the eighth; generally between the fifth and sixth; tail at least $\frac{3}{4}$ the length of wing, more or less rounded; feet weak; tarsus equal to or exceeding the middle toe and claw; sexes usually distinct, plumage black and orange, or black and chestnut.

This is a large genus, containing the birds generally known in America as Orioles (not to be confused with the true Orioles of the Old World). More than fifty species and subspecies are recognized, ranging over the whole of temperate and tropical America. Only one species is at all abundant in Colorado, but two of the commoner eastern forms have occasionally been met with.

\section{Key of the Species.}

A. Chestnut below; bill distinctly decurved. I. spurius, $\delta$ p. 312.

B. Orange or yellow below; culmen nearly straight.
t. Head and neck black all round.
I. galbula, $\delta$ p. 312 .
b. Crown and throat black, sides of the head orange.

I. bullocki, of p. 313 
C. Pale yellow or grey below.

a. Smaller; wing under 3.0; bill distinctly decurved.

I. spurius, 우 et juv., p. 312.

b. Larger; wing well over 3.0 ; culmen straight.

$a^{1}$ Rump yellowish, contrasting with the brown back.

$\mathrm{b}^{1}$ Rump greyish-brown like the back.

I. galbula, + et juv., p. 312 .

I. bullocki, ot et juv., p. 313.

Orchard Oriole. Icterus spurius.

A.O.U. Checklist no 506-Colorado Records-Allen 72, pp. 150, 158 ; Drew 85, p. 16 ; Morrison 89, p. 148 ; Cooke 97, pp. 94, 164 ; H. G. Smith 08, p. 186.

Description.-Head, neck, chest, upper-back, tail and wings black, the latter with whitish edgings to the quills and greater coverts; rump, upper tail-coverts, middle and lesser wing-coverts and under-parts from the chest, rich chestnut-brown; iris brown, bill black, pale at the base of the lower mandible; legs dark horn. Length 6.10 ; wing 3.08 ; tail 2.65 ; culmen .65 ; tarsus $\cdot 75$.

The female is dull greenish above, dusky in the centre of the back and on the wings, brightest on the upper tail-coverts; below greenishyellow.

The young male resembles the female, but is brighter yellow below and has the lores and throat black.

Distribution.-Breeding throughout eastern North America from southern Ontario to Texas; in winter south to Cuba and through Mexico to Colombia.

The Orchard Oriole is not uncommon throughout Kansas ; there is an example in the Aiken collection from Gem in Thomas co., about sixty miles from the Colorado border, but it is certainly very rare within our limits. Aiken reports (Cooke, 97) that he saw three examples on Beaver Creek in Fremont co. in May, 1875. Recently H. G. Smith has found it quite common and nesting in early June at Boyes ranch on Dry Willow Creek, about twelve miles south-east of Wray.

\section{Baltimore Oriole. Icterus galbula.}

A.O.U. Checklist no 507-Colorado Records-Allen 72, p. 150; Baird, Brewer \& Ridgway 74 vol. iii., p. 518; Drew 85, p. 16 ; Morrison 89, p. 148 ; Cooke 97, pp. 95, 164; Henderson 03, p. 236 ; 05, p. 421 ; 09, p. 234 ; H. G. Smith 08, p. 187.

Description.-Head, neck, chest and upper-back wholly, wings and tail chiefly, black; rump and upper tail-coverts, lesser and middle wing-coverts and rest of the under-parts of the body rich orangeyellow; primary-coverts strongly tipped, remiges slightly edged 


\section{Bullock's Oriole}

with white; tail-feathers, except the central pair, pale yellow crossed by a basal band of black; iris brown, bill blackish, bluish at base of the lower mandible; legs dusky horn. Length 6.75 ; wing 3.75 ; tail 2.85 ; culmen .72 ; tarsus .90 .

The female has the upper-parts dull saffron-olive, brightest on the rump and upper tail-coverts, duskier in the middle of the back; the wings dusky black with the feathers edged with whitish; below safron or dull orange-yellow throughout, the throat sometimes with, sometimes without, black. The young male is like the female, or intermediate between it and the male.

Distribution.-Breeding throughout eastern North America from Manitoba and Nova Scotia to the Carolinas and Texas, wintering in eastern Mexico and Central America as far as Venezuela and Colombia.

The Baltimore Oriole is a common summer resident as far west as Kansas, but can only be considered a straggler in Colorado. Allen records it from near Denver, and Morrison states that it is common at Fort Lyon, but in both these cases it was probably mistaken for Bullock's Oriole. Mr. Aiken tells me he has never met with it in Colorado, and the records attributed to him by Baird, Brewer and Ridgway (74) and by Cooke (97) are based on a misunderstanding. Henderson (05), however, states that it has recently (May 22nd-23rd, 1905) been observed by Miss J. M. Patten at Yuma, in the north-eastern part of the State, while H. G. Smith reports that he found it fairly common and nesting in early June at Boyes Ranch near Wray, and that Bullock's Oriole was also not uncommon in the same locality.

\section{Bullock's Oriole. Icterus bullocki.}

A.O.U. Checklist no 508-Colorado Records-Ridgway 73, p. 183 ; Henshaw 75, p. 320 ; Allen \& Brewster 83, p. 193 ; Drew 85, p. 16 ; Beckham 85, p. 142 ; 87 , p. 124 ; Morrison 89, p. 148 ; Kellogg 90 , p. 90 ; Lowe 92 , p. 101 ; H. G. Smith 93, p. 244 ; Cooke 97, pp. 19, 95, 211 ; Keyser 02, p. 33 ; Dille 03, p. 74; Henderson 03, p. 236 ; 09, p. 234 ; Warren 06, p. 22 ; 08, p. 22 ; Markman 07, p. 157 ; Gilman 07, p. 156 ; Rockwell 08, p. 170.

Description.-Male in summer-Crown, back, scapulars, lores, a narrow postocular stripe, chin and narrow throat-stripe, the greater part of the tail, and wings black ; most of the wing-coverts white, forming conspicuous patch, the primaries and secondaries edged with white; rest of the body, including the forehead, superciliary region, lower-back, rump and under-parts orange-yellow, richest on the sides of the head and breast; tail with the central feathers black, the outer yellow, the others black and yellow; iris brown, bill black, legs dusky horn. Length 7.4 ; wing 4.10 ; tail 3.20 ; culmen 7 ; tarsus 9 . 
The female is dull greyish-brown above, the head and base of the tail washed with yellow; wings dusky, the middle coverts tipped with white forming a wing-band, the greater coverts and secondaries edged with white; below, the sides of the head and chest are bright yellow, paling slightly on the throat, the rest of the under-parts whitish, tinged with dusky on the flanks, and yellow on the under tailcoverts; wing $3 \cdot 80$.

A young male of the year (July 15th) is like the female; one of the second year (June 25th) is intermediate, with a black throat and patch on the crown, but mostly greenish-yellow above, and yellow, not. orange, below.

Distribution.-Breeding throughout western North America from southern British Columbia to northern Mexico, and east to the middle portions of South Dakota, Kansas and Texas ; in winter to central and southern Mexico.

Bullock's Oriole is a very common summer resident in Colorado, especially in the plains and along the eastern and western bases of the mountains. It is stated by Drew to breed up to 10,000 feet, but there seems no authority for this. It is rare at Estes Park (Kellogg), and this and Middle Park, where it was seen by Carter, seem to be the highest recorded localities. It arrives from the south at the end of April (Pueblo 27th April, Lowe) or beginning of May (May 10th earliest in El Paso co., Aiken, and for Salida, Frey), breeds in June and leaves again at the end of August or beginning of September.

The following are additional recorded localities : Boulder co. (Henderson), Weld co. (Markman), Denver (Henshaw), El Paso and Lincoln cos. (Aiken), Baca co. (Warren), Steamboat Springs (Warren), Mesa co., May 10th, August 7th (Rockwell); La Plata co. (Morrison \& Gilman).

Habits.-Bullock's Oriole is one of the most conspicuous and bright-coloured of our summer birds. They are chiefly to be met with in open, rolling or prairie country, along the streams where there are cotton-wood and other trees, and they may often be seen in the suburbs of towns where there are plenty of high trees to perch in and hang their nests from; they are not usually met with in thickly-wooded or mountainous country, or far from water. Their food consists chiefly of berries and insects, the latter being eaten in very large quantities in the breeding season; the call-note is like that of the Baltimore Oriole, but the song is not so melodious. 
Breeding commences about the beginning of June in the central part of the State; Aiken found a nest nearly complete on June 6th, in El Paso co., while Dille (03) gives June 12th as the average date for fresh eggs about Denver. The nest, a very common object in cotton-wood trees in and around Colorado Springs, is pensile, being suspended from the horizontal branch of a tree at a good height, twelve to twenty feet above the ground, and is often quite inaccessible. The nest is woven of shreds of wild flax, of the inner bark of various trees and such-like material, and is lined with horsehair, wool, vegetable down or even moss. The eggs, five or six in number, are elongate and whitish in colour, marked with fine hair-lines and streaks and blotches of brown. They measure $94 \times \cdot 63$. The female alone incubates, and only one brood is raised.

\section{Genus EUPHAGUS.}

Medium-sized birds-wing about 4.5 to 5.0 -with short bills, and with a distinctly down-curved culmen; wing long and pointed, the ninth primary always shorter than the seventh and eighth, usually between the sixth and fifth; tail long, about $\frac{3}{4}$ the length of wing, rounded, but not plicate; tarsus stout and strong, distinctly longer than the middle toe and claw. Plumage of the males glossy black, of the females dusky brown.

Only two species, ranging chiefly over the temperate regions of North America, are recognised; both occur in Colorado.

KEy OF THE SPEcies.

A. Bill slender, its depth at the nostril less than $\frac{1}{2}$ the length of the mandible; plumage faintly glossy. E. carolinus, p. 315.

B. Bill stouter, its depth at the nostril about equal to $\frac{1}{1}$ the length of the mandible; plumage more strongly glossed.

E. cyanocephalus, p. 316 .

Rusty Blackbird. Euphagus carolinus.

A.O.U. Checklist no 509-Colorado Records-H. G. Smith 86, p. 284 ; Thorne 88, p. 264 ; Morrison 89, p. 148 ; Osburn 93, p. 212 ; Cooke 97, p. 95 (Scolecophagus carolinus). 
Description.-Male in summer-Black with slight, bluish metallic gloss; under tail-coverts edged with whitish; iris pale yellow; bill and legs black. Length 8.75 ; wing 4.5 ; tail 3.50 ; culmen .75 ; tarsus 1.20 .

In winter the feathers of the head and upper-back are tipped with dark rusty-brown, those of the sides of the head, throat and breast with buffy-brown, whence the vernacular name. The female in summer is uniform dull slate, darkest and slightly glossed on the back; it is also smaller (wing 4.25); iris pale yellow. In winter the head and upper-back are overlaid with rusty-brown and the lower surface, including the superciliary stripe, with pale buffy-brown.

Distribution.-Breeding from northern New England and Michigan northwards to Labrador and Alaska, wintering in the middle and Gulf states westwards to the great plains.

The Rusty Blackbird is a rare winter visitor to Colorado, and has been met with only on three occasions, so far as I am aware. Anthony (Smith, 86) shot two near Denver on 17 th of December, 1883, Professor Osburn, one near Loveland in November, 1889, and recently Aiken obtained two from a small flock wintering in the Fountain Valley, six miles south of Colorado Springs, January 15th, 1908. The Thorne record seems to be a somewhat doubtful one.

\section{Brewer's Blackbird. Euphagus cyanocephalus.}

A.O.U. Checklist no 510-Colorado Records-Allen 72, pp. 150, 157, 163 ; Aiken 72, p. 203 ; Trippe 74, p. 202 ; Henshaw 75, p. 321 ; Scott 79, p. 94; Drew 81, p. 139 ; Tres\& 81, p. 95 ; Allen \& Brewster 83, p. 193 ; Drew 85 , p. 16 ; Beckham 85, p. 142 ; 87, p. 124 ; Morrison 88 , p. 75 ; 89 , p. 148 ; Kellogg 90, p. 88 ; Cooke 97, pp. 18, 95, 211 ; Keyser 02, pp. 98, 140, 230 ; Dille 03, p. 74 ; Henderson 03, p. 236 ; 09 , p. 235 ; Warren 06, p. 22 ; 08, p. 23 ; 09, p. 16 ; Gilman 07, p. 156 ; Maxkman 07, p. 157 ; Rockwell 08, p. 170.

Description.-Male-Black throughout, the head and neck strongly glossed with violet, the rest of the plumage less strongly with greenish; iris pale yellow, bill and legs black; bill much stouter at the base than that of $E$. carolinus. Length 9.25 ; wing 5.1 ; tail 4.0 ; culmen .85 ; tarsus $1 \cdot 25$.

A winter bird from New Mexico has the feathers of the head and back obscurely tipped with dark brown, and traces of greyish-buff tipping on the breast. A female is pale earthy-brown above and below, becoming more dusky towards the tail, which, with the upper tail-coverts, is glossed with greenish; it is smaller, wing 4.5. The young bird is very much like the female.

Distribution.-Western North America, breeding from British Columbia and Manitoba south to Lower California, Texas and northern Mexico; in winter over the whole of Mexico to northern Guatemala, as well as in many places throughout the breeding range. 
In Colorado Brewer's Blackbird is a very common summer resident throughout the plains and mountains, nesting up to about 10,000 feet; Scott found it breeding at Twin Lakes 9,300 feet; Warren near Crested Butte 9,000 feet; Carter at Breckenridge, 9,700 feet. It arrivés from the south in El Paso co. as early as April 8th, and leaves again towards the end of September, moving up into the mountains as the summer advances, and after breeding wandering up to and above timber line. It is stated by Cooke that some birds winter in the south of the State, and this is confirmed by Mr. Sullivan's observations at Grand Junction (Rockwell). It has been recorded from the following additional localities : Weld co. (Markman), Boulder co. (Henderson), Pueblo (Henshaw \& Beckham), Salida (Frey), Baca co. (Warren), in the plains and foothills; Estes Park (Kellogg), Bergin Park (Trippe), Buena Vista (Keyser), Gunnison co. (Warren), Fort Garland (Henshaw), Mesa co., common May lst to October (Rockwell), St. Juan co. (Drew), La Plata co. (Morrison).

Habits.-Brewer's Blackbird, like most of the other members of the family, is a highly social bird; it is generally in large flocks, and even in the breeding season small bunches of six to twelve birds usually nest close to one another. It is a bird of the open country, but is not such a swamp-lover as the Red-shouldered, though usually found near a stream. It is amicable and far from shy, frequenting towns and villages, and picking up grain and refuse. Its call-note is "Tchack, tchack," and it has a song as well. The food consists chiefly of grain, especially oats, which form about 60 per cent. of the food, according to Beal, while insects, more particularly grasshoppers, make up the remainder. The nest is built towards the latter half of May, and fresh eggs can be looked for about the 29th of that month near Denver (Dille 03) ; the nest is as often as not built on the ground, usually under the shelter of a bush, and often in the bank of an irrigation ditch ; sometimes it is placed in shrubs or trees as high as twelve feet from the ground. It is a bulky structure built up of sticks, weeds, reeds, and bark strips, often, though not always, cemented together with mud or manure, and lined internally 
with fine rootlets and horsehair. The eggs, five in number, are very variable in colour and markings; the ground-colour (a greyish-white) is sometimes almost entirely concealed by blotches and spots of brown, sometimes only moderately covered. They measure $1.0 \times 73$. Only one brood is as a rule raised, and the female alone incubates, though if the nest is destroyed, as is often the case when placed on an irrigation ditch, another will be built and a fresh attempt to rear a family will be made.

\section{Genus QUISCALUS.}

Rather large birds-wing from 5 to 6 -with stout, strongly decurved bills, about as long as the head and of the corvine type; wings moderate, though exceeding the tail, which is long and strongly graduated, and capable of being folded vertically so that it is then V-shaped in transverse section (i.e. plicate); plumage black with metallic gloss.

This genus, confined to eastern North America, includes three subspecies of a single, rather variable species; only one of these reaches Colorado.

Bronzed Grackle. Quiscalus quiscula aneus.

A.O.U. Checklist no 51lb-Colorado Records-Ridgway 73, p. 184 (Q. purpureus ceneus); Henshaw 75, p. 324; Drew 85, p. 16 ; Morrison 89, p. 149 ; Cooke 97, p. 95 ; Henderson 03, p. 236 ; 09, p. 235 ; Warren 06, p. 22.

Description.-Male-Black all over, the head, neck and breast glossed with greenish-purple; rest of the body with dark, bronzy metallic; wings and tail purplish and less glossy; iris pale yellow, bill and legs black. Length 11.45 ; wing 5.5 ; tail 4.75 ; culmen 1.20 ; tarsus 1.30. The female resembles the male, but is smaller - wing about $5 \cdot 0$ and is duller in colour. The young bird is sooty-brown throughout, the metallic gloss being gradually acquired.

Distribution.-Breeding throughout the middle regions of North America north to Great Slave Lake and south Labrador, east to New England and the Alleghanies, south nearly to the upper portions of the Gulf states, and west to the eastern bases of the Rocky Mountains; wintering in the southern portion of the breeding range, and even as far north as Illinois and Minnesota in sheltered spots.

In Colorado the Bronzed Grackle has only been met with in the summer months in the eastern plains and foothills, and is not very common except locally. It breeds in suitable localities, though very 
little is recorded about this. It has been noticed by Aiken in El Paso co. as early as April 19th, and he has found it breeding in the Fountain Valley below Colorado Springs, and there is no reason why it should not be found in sheltered spots throughout our winter.

The following are recorded localities: Boulder co. (Henderson), about Denver (Henshaw), Burlington, Pueblo and Fort Lyon (Cooke), El Paso co. (Aiken), Baca co. (Warren), near Fort Garland (Brunner).

Habits.-The Bronzed Grackle or Western Crow Blackbird is a gregarious bird, migrating in large flocks and often nesting in colonies. It is omnivorous in its diet, and many complaints have been made about it where it is numerous, owing to its partiality for corn, wheat and other grain, as well as for fruit; but it also destroys large numbers of noxious insects and probably does more good than harm on the whole.

In the east the Grackle usually chooses a coniferous tree for its nest, but in the west it is said to frequently resort to natural cavities or hollow stumps, or even to make use of the nest-hole of a Flicker; but I have met with no detailed account of its nesting habits in Colorado. The eggs, usually five in number, are very variable in markings; the ground-colour is pale, scrolled and blotched with shades of brown, sometimes so profusely as to hide the ground-colour; they measure $1 \cdot 14 \times \cdot 82$.

\section{Family FRINGILLID压.}

Bill very variable in shape, but usually more or less short, stout, and conical; nostrils always nearer the culmen than the cutting-edge of the bill, and close to the frontal feathers, so that they are sometimes concealed, or partially concealed, either by the frontal feathers or by a specially developed tuft of forwardly growing bristles. Wing with only nine primaries, the tenth (outermost), if present, very small and degenerate, and entirely concealed and often displaced by the growth 
of the next. Tail of twelve feathers. Tarsus scutellated in front, the sides covered with two long undivided plates forming a sharp ridge behind. One complete moult in the year in the fall after the breeding season, but frequently a partial change of colour in spring, due to the wearing away and falling off of the worn feather-tips.

This family comprises the birds generally known as Finches, Sparrows, Buntings and Grosbeaks, and is spread all over the world, except in the Australasian region. It is the largest of all North American bird families, comprising about one seventh of the bird population.

\section{Key of THE Genera.}

A. Tail distinctly shorter than the wing.

a. Tail less than 7 of the wing.

$a^{2}$ Bill very large, culmen about equal to tarsus; rami of mandible very short, only about $\frac{1}{5}$ of gonys.

Hesperiphona, p. 325.

$b^{2}$ Bill with the tips of the mandibles crossed. Loxia, p. 333 .

$c^{2}$ Bill small or moderate and normal.

$a^{3}$ Wings long and pointed; difference between the primaries and secondaries distinctly exceeding the tarsus.

a Nostrils concealed by forwardly growing bristles.

$a^{5}$ Tarsus shorter than the middle toe and olaw.

$a^{6}$ Bill shorter and less acute; plumage largely yellow, not streaky.

Astragalinus, p. 342.

$b^{6}$ Bill longer and more acute; plumage streaky above and below.

Spinus, p. 346.

$b^{5}$ Tarsus longer than the middle toe and claw.

$a^{6}$ Upper and lower mandibles about equally deep; plumage with a good deal of pink.

Leucosticte, p. 335.

$b^{6}$ Lower mandible distinctly deeper than the upper; no red in the plumage. Plectrophenax, p. 349.

b' Nostrils exposed.

$2^{5}$ Plumage without pink; claw of hind toe more or less elongated and straight. Rhynchophanes, p. 353. 


\section{Fringillidae}

$b^{5}$ Plumage always with pink in males; claw of hind toe short, curved and normal.

Carpodacus (in part), p. 328.

$b^{a} \quad$ Wing more rounded; difference between primaries and secondaries less than tarsus; inner secondaries elongated.

$a^{5} \quad$ Wings longer, clearly exceeding the tail and tarsus together.

Passerculus, p. 356.

$b^{6}$ Wings shorter, hardly equal to the tail and tarsus together.

Ammodramus, p. 359.

b. Tail longer, from .7 to .9 of the wing.

$a^{a}$ Wing pointed; difference between the primaries and secondaries exceeding the length of the tarsus.

$a^{3}$ Tail forked, even or slightly rounded, but difference

between inner and outer feathers always less than culmen.

$a^{4}$ Nostrils concealed by forwardly growing nasal bristles. $a^{5}$ La.ge; wing over 4 ; bill strongly hooked.

Pinicola, p. 327.

$b^{5}$ Smaller; wing about 3 ; bill very slender and compressed.

$b^{4} \quad$ Nostrils exposed.

Acanthis, p. 340.

$a^{j}$ Bill very large and deep; lower mandible distinctly deeper than the upper. Zamelodia, p. 398.

$b^{5}$ Bill moderate; upper and lower mandibles of approximately equal depth.

$a^{6}$ Claw of hind to elongated and straight.

Calcarius, p. 350 .

$b^{6}$ Claw of hind toe short, curved and normal.

Carpodacus (in part), p. 328.

$b^{2}$ Tail graduated, difference between inner and outer feathers equal to culmen; upper mandible distinctly deeper than the lower. Chondestes, p. 361.

$\mathrm{b}^{2} \quad$ Wing moderately pointed; difference between primaries and secondaries about equal to the tarsus.

$a^{3}$ Upper mandible deeper than the lower; nostrils more or less concealed.

Passer, p. 348.

$b^{3}$ Lower mandible distinctly deeper than the upper.

$a^{4} \quad$ Inner secondaries not elongated; tail-feathers broad and rounded.

$a^{5} \quad$ Larger ; wing over 3 ; culmen rounded, not ridged.

Guiraca, p. 401.

$b^{5} \quad$ Smaller ; wing under 3 ; culmen distinctly ridged.

Passerina (in part), p. 403. 
b Inner secondaries slightly elongated; tail-feathers narrow and pointed. Spiza, p. 405.

$c^{2}$ Wing rounded, difference between primaries and secondaries clearly less than the tarsus.

$a^{3} \quad$ Inner secondaries elongated.

$a^{4}$ Outer primary much shorter than the fifth; plumage streaky. Centronyx, p. 358.

$b^{4}$ Ninth to sixth primaries about equal and abruptly longer than the fifth; plumage black in male, streaky in female. Calamospiza, p. 406 .

$b^{3}$ Inner secondaries not elongated.

$a^{4}$ Four outer primaries about equal; upper mandible deeper than the lower; plumage streaky, outer tail-feathers chiefly white. Pocectes, p. 354.

$b^{4}$ Ninth primary longer than the sixth, seventh and eighth the longest; plumage bright coloured in male, not streaky; no white on tail.

B. Tail about equal to wing.

Passerina (in part), p. 403.

a. Tail graduated.

$a^{2}$ Tail-feathers narrow and pointed. Passerherbulus, p. 360 .

$b^{2} \quad$ Tail-feathers rounded at tips.

$a^{3}$ Outer (ninth) primary longer than third; edge of wing yellow.

Peucæa, p. 384.

$\mathbf{b}^{3}$ Outer (ninth) primary shorter than third; edge of wing not yellow.

Aimophila, p. 385.

b. Tail distinctly forked, central feathers always shorter than tho lateral.

Spizella, p. 368.

c. Tail nearly even, difference between inner and outer feathers always less than culmen.

$a^{2}$ Outer tail-feathers wholly or chiefly white; plumage unstreaked in adult.

Junco, p. 373.

$\mathrm{b}^{2} \quad$ Tail black with a white edging, and sometimes a terminal spot on the outer web of the outer pair of tail-feathers only.

Amphispiza, p. 381.

$c^{2}$ Tail without white; plumage streaky above.

$\mathrm{a}^{3}$ Outer toe small, not reaching the middle of the subterminal phalanx of the middle toe.

$a^{4}$ Tarsus at least $\frac{1}{3}$ of wing and breast distinctly streaked.

Melospiza, p. 386.

$\mathrm{b}^{4}$ Tarsus less than $\frac{1}{3}$ of wing, breast never streaked.

Zonotrichia, p. 363.

$\mathrm{b}^{3}$ Outer toe large, reaching to middle of subterminal phalanx of the middle toe; plumage streaky above nd below.

Passerella, p. 390. 


\section{Fringillidae}

C. Tail distinctly exceeding the wing.

a. Head crested; plumage red.

Cardinalis, p. 398.

b. Head not crested.

$a^{2}$ Outer (ninth) primary shorter than second; tail black, tipped with white or brown. $\quad$ Pipilo, p. 392.

$b^{2}$ Outer (ninth) primary longer than second; tail greenish.

Oreospiza, p. 396.

As the genera of this family are by no means easy to discriminate, an alternative key is given; this is adapted from that of Coues, in which colour and plumage characters are more freely used.

A. Bill with tips of mandibles crossed.

Loxia, p. 333.

B. Bill very large, culmen almost equal to tarsus, greenish in colour.

Hesperiphona, p. 325.

C. Bill large and reddish; head crested. Cardinalis, p. 398.

D. Bill with a pair of tufts of bristles at base of upper mandible partially or completely concealing nostrils.

a. Length over 8 ; plumage grey with red in male, yellow in female.

Pinicola, p. 327.

b. Length less than 8 .

$a^{2}$ Plumage black and white, washed with clear brown in winter.

Plectrophenax, p. 349 .

$b^{2}$ Plumage chocolate or dusky, with rosy edgings and washings.

Leucosticte, p. 335.

$c^{2}$ Plumage chiefly yellow, no red; wings and tail black.

$d^{2}$ Plumage streaky.

Astragalinus, p. 342 .

$a^{3} \quad$ Bill turgid; male chiefly rosy; female dusky, no yellow.

$b^{3}$ Bill acute; crown crimson.

Carpodacus, p. 328.

$c^{3}$ Bill acute, no red; yellow about wings and tail.

Spinus, p. 346.

E. Bill without tufts; nostrils generally exposed.

a. Hind claw lengthened and straightened.

$a^{2}$ Bill moderate; white on tail oblique. Calcarius, p. 350.

$b^{2}$ Bill turgid, white on tail transverse.

Rhynchophanes, p. 353.

b. Hind and fore claws lengthened, the inner reaching at least half-way to the end of middle one.

$a^{2}$ Plumage sparrow-like, spotted and streaked.

$b^{2}$ Plumage black, white and chestnut in masses.

Passerella, p. 390.

Pipilo (in part), p. 392. 
c. Claws normal, not enlarged.

$a^{2}$ Length over 7.5.

$a^{3}$ Tail longer then wing; plumage plain brown, or black, white and chestnut. Pipilo (in part), p. 392.

$b^{3}$ Tail shorter than the wing; male rose or orange on breast, female yellow on under wing-coverts.

$b^{2}$ Length less than $7 \cdot 5$.

Zamelodia, p. 398.

$a^{3}$ Colour greenish; crown chestnut. Oreospiza, p. 396.

$b^{8}$ Colour not green; not extensively streaked.

a $^{4}$ Black with white wing-patch.

Calamospiza (male), p. 406.

b4 Male blue, with chestnut wing-band, female plain brown; length over 6. Guiraca, p. 401.

c Male blue, with rufous and white, female brown; length under $6 . \quad$ Passerina, p. 403.

d" Slaty or ashy; outer tail-feathers white. Junco, p. 373.

$\theta^{4}$ Grey; throat and tail black with white edges.

Amphispiza (in part), p. 381.

c $^{3}$ Colour not greenish; extensively streaked.

$a^{4}$ Inner secondaries lengthened.

$a^{5}$ A large white or buffy-white wing-patch.

Calamospiza (female), p. 406.

$b^{5}$ Bend of wing chestnut, outer tail-feathers white.

$c^{5}$ No white or chestnut on wing.

Poceetes, p. 354.

$a^{6}$ Edge of wing faint yellow, wings longer, exceeding tail and tarsus together.

Passerculus, p. 356.

$b^{6}$ Edge of wing bright yellow; wings shorter, about equal to tail and tarsus together.

Ammodramus, p. 359.

$c^{6}$ Edge of wing white, wing short, hardly equal to tail and tarsus together. Centronyx, p. 358.

b4 Inner secondaries not lengthened; wing decidedly longer than tail.

$a^{5}$ Yellow on breast, edge of wing and eyebrow; throat-patch black. Spiza, p. 405.

$b^{\text {n }}$ No yellow; head with black, white and chestnut; tail black, tipped with white.

Chondestes, p. 361 .

$\mathbf{c}^{5}$ No yellow; white bar on wing, throat black in male.

Passer, p. 348. 


\section{Western Evening-Grosbeak}

$\mathrm{c}^{4}$ Inner secondaries not lengthened; wing about equal to or shorter than the tail.

$a^{5} \quad$ Tail graduated.

$a^{6}$ Tail-feathers very narrow and pointed.

Passerherbulus, p. 360.

$b^{6}$ Tail-feathers normal, rounded at ends.

$a^{7}$ Edge of wing yellow. Peucza, p. 384.

$b^{7}$ Edge of wing not yellow. Aimophila, p. 385.

$b^{5} \quad$ Tail forked; no yellow on wing. Spizella, p. 368.

$\mathrm{c}^{5}$ Tail even or slightly rounded.

$a^{6}$ Tail black with white edges. Amphispiza, p. 381.

$b^{6}$ Tail not black.

$a^{7}$ Streaked below.

Melospiza, p. 386.

$b^{7}$ Not streaked below. Zonotrichia, p. 363 .

\section{Genus HESPERIPHONA.}

Large Finches-wing over $4 \cdot 0-$ with w very staut and swollen bill of a greenish tinge, the culmen of which is about equal to the tarsus; rami of the lower mandible very short, only about one-fifth of the gonys; head not crested; wings long and pointed, the difference between the primaries and secondaries about twice the length of the tarsus; tail short, slightly forked, hardly more than half the length of the wing; tarsus very short. Plumage yellow or grey and black with w white patch on the wing.

This genus, containing only two species, is confined to North and Central America. One subspecies, differing from the typical eastern form only by its slightly larger bill, is found in Colorado.

\section{Western Evening-Grosbeak. \\ Hesperiphona vespertina montana.}

A.O.U. Checklist no 514a-Colorado Records-Aiken 72, p. 199 ; Drew 85, p. 15 ; Morrison 89, p. 149 ; Lowe 94, p. 269 ; Cooke 97, pp. 95, 169, 211 ; Henderson 03, p. 236 ; 09, p. 235 ; Dille 04, p. 50 ; 09, p. 87 ; Markman 07, p. 157 ; H. G. Smith 08, p. 187 ; Rockwell 08, p. 170 .

Description.-Male-A broad frontal band of yellow; occiput black, becoming olive-brown on the upper-back, sides of the head and breast, and paling into yellow on the scapulars, rump, lower-breast and abdomen; wings and upper tail-coverts and tail black, except for the inner greater coverts and inner secondaries, which are white; legfeathers black. Iris brown, bill apple-green to pale yellowish-green, legs light brown. Length 6.75 ; wing 4.30 ; tail 2.40 ; culmen .85 ; tarsus $\cdot 75$. 
The female is smoky-grey above, darkest on the head and tinged on the hind-neck with greenish-yellow; wings, tail and tail-coverts black, with white tips and patches on many of the feathers; below buffy-grey, becoming white on the throat and under tail-coverts; a dusky sub-malar streak on each side of the throat.

This subspecies differs from the eastern form in its smaller and more slender bill, its narrow frontal band and in the more buffy under-parts of the fermale.

Distribution.-Western North America from British Columbia to northern Mexico, east to the eastern bases of the Rocky Mountains.

In Colorado the Evening-Grosbeak is an irregular wanderer, appearing from time to time and then not seen perhaps for months or even years; but as it has been met with during every month in the year and is known to breed, it may be classed as w resident bird. Its range extends from the plains to 10,000 feet, at which elevation Lowe records it in the fall from the Wet Mountains. Other records are: Fort Collins, July, October (Cooke), Estes Park, breeding (Dille), Boulder co., regularly in winter since 1901 (Henderson), Weld co., June (Markman), EI Paso co., January, May, June (Aiken) ; Fremont co., April (Aiken), Beulah, May, July and August (Jones apud Cooke); Fort Lyon, May (Cooke), Routt co., breeding (H. G. Smith), Mesa co. (Rockwell), La Plata co., May (Morrison).

Habits.-This handsome bird is almost always to be met with in small flocks, and generally in the pine woods of the mountains, though it sometimes comes down to the plains, and I have even seen it in the suburbs of Colorado Springs in October, attracted by the buds of the maple trees planted in the streets, of which it appears to be excessively fond. It also feeds on the berries of the cedars and other fruits, while in summer caterpillars and insects form its chief food. Its voice is a loud, clear whistle.

Dille and his collector Andrews found a nest of this bird in Estes Park in 1903, at an elevation of about 9,000 feet. There were many of the birds at the time in the park, but the nest was not located till July 4th. It was placed about forty feet up, towards the end of a horizontal limb of a tall white pine (Pinus flexilis). The nest was a deep cup and well constructed; it consisted 


\section{Rocky Mountain Pine-Grosbeak}

entirely of rootlets woven together, and contained four eggs which were slightly incubated; the eggs were dull green spotted with brown, and closely resembled those of the Red-winged Blackbird.

Smith (08) states that H. S. Reed found a brood of four or five young birds just out of the nest on July 22nd, 1898, in California Park in the Elk Head Mountains, Routt co., so that it probably breeds not uncommonly in the mountain parks.

\section{Genus PINICOLA.}

Large Finches-wing over 4.0-with a broad, stout and short bill, the culmen strongly down-curved and hooked at the tip, and less than the length of the tarsus ; nostrils more or less concealed by forwardly growing bristles; wing long and pointed, difference between primaries and secondaries less than twice the length of the tarsus; tail moderate, slightly emarginate, about .75 length of wing; tarsus shorter than the middle toe and claw; plumage plain grey with a wash of red or yellow.

The Pine-Grosbeaks are all included under one species, spread over the northern parts of the Old and New Worlds. A number of subspecific races have been recognized by recent authors, and one of these is found at higher elevations in Colorado.

\section{Rocky Mountain Pine-Grosbeak.}

Pinicola enucleator montana.

A.O.U. Checklist no 515a-Colorado Records-Ridgway 73, p. 181 ; Trippe 74, p. 105 ; Drew 81, p. 89 ; 85, p. 15 ; Stone 82, p. 191 ; Morrison 88 , p. 73 ; 89, p. 149 ; Kellogg 90, p. 88 ; MeGregor 97, p. 38 ; Cooke 97, pp. 96, 212 ; Henderson 03, p. 236 ; 09, p. 235 ; Rockwell 08 , p. 170.

Description.-Male-General colour above and below ashy-grey becoming dusky or blackish on the wings and tail, most of the wingfeathers margined with white; the greater part of the body-feathers, especially on the head, rump and breast, overlaid with bright carminered; bill dull black to horn-brown; legs black. Length 8.25 ; wing 4.60 ; tail 3.60 ; culmen $\cdot 60$; tarsus 60 .

The female has no red, but the crown and sides of the heac are bright golden-yellow, and there is a touch of the same colour on the upper tail-coverts. Young males usually resemble the females, but there is a good deal of abnormality about the plumage of this species; adult 
males are occasionally met with having the plumage of the female, and the amount of red or yellow is subject to considerable variation.

Distribution.-The Rocky Mountain Pine-Grosbeak is confined to the Rocky Mountains from Idaho and Montana to New Mexico, and breeds throughout its range at high elevations. The species as a whole is found over the northern parts of the Old and New Worlds.

In Colorado the Pine-Grosbeak is a not uncommon resident at high elevations, chiefly between 9,500 and 12,000 feet, where it is found throughout the year, though occasionally stragglers descend to the foothills and plains, probably driven down by storms. It has been recorded as follows : Estes Park, at timber line (Kellogg and McGregor), Boulder co., 10,000 feet, July, 9,000 feet, November (Gale); slope of James Peak (Trippe), Breckenridge, breeding (Carter), Tennessee Gulch, Lake co. and Pikes Peak (Aiken), Crested Butte, October (Warren), S. Mamm Peak, 10,000 feet, Mesa co. (Rockwell), San Juan co. (Drew) and La Plata co. (Morrison); stragglers to the plains have been noticed at Fort Collins in November (Breninger), and at Fort Lyon by Captain Thorne (Cooke).

Habits.-As its name implies this bird is chiefly found in the pine woods, and except during the breeding season is generally in flocks or small parties; it feeds chiefly on the buds and seeds of the pines as well as on those of the birch and alder, and perhaps a few berries and insects, especially in the breeding season. It has a clear, sweet, flowing song, something like that of the Purple Finch. It nests in July near timber line at 11,000 feet, according to Mrs. Stone, but information in regard to its breeding habits is very scanty.

\section{Genus CARPODACUS.}

Moderate-sized birds-wings under $4 \cdot 0$, with a moderately developed, slightly swollen bill; the culmen either straight or curved, and the mandibles of approximately equal depth; nostrils hardly concealed by the forwardly growing bristles; wings long and pointed; tail rather short or moderate, from .62 to .77 of the wing, slightly emarginate to nearly square; plumage of the males with crimson, of the females stripy brown.

A large genus with a number of species distributed over the temperate regions of Europe, Asia and North Americe. Two species commonly occur in Colorado, while a third, the easterm Purple Finch, is a straggler. 


\section{Purple Finch}

\section{Kry of THe SpecLes.}

A. Crown and rump crimson (males).

a. Tail distinctly emarginate; wing washed with reddish.

$a^{1}$ Bill smaller, culmen 45 ; flanks and under tail-coverts white and unstreaked. $\quad$ C. purpureus, $\delta$ p. 329.

$b^{1}$ Bill larger, culmen .50 ; flanks and under tail-coverts smoky-white and streaked with dusky.

C. cassini, ơ p. 329

b. Tail almost square; wings without red wash.

c. m. frontalis, $\delta$ p. 331

B. Crown and rump without red.

a. Tail emarginate.

$a^{1}$ Back tawny-brown with dusky streaks.

C. purpureus, o p. 329 .

b1 Back with a strong wash of olive, streaked with dusky.

C. cassini, ㅇ p. 329 .

b. Tail square; back plain grey-brown, obsoletely streaked.

C. m. frontalis, + p. 331 .

\section{Purple Finch. Carpodacus purpureus.}

\section{A.O.U. Checklist no 517-Colorado Record-Cooke 97, p. 96.}

Description.-Male-Crown and rump crimson, the latter of a paler shade, back pinkish-brown, streaked with darker ; wing and tail dusky brown; below throat and chest crimson, like the rump; abdomen and under tail-coverts white and unstreaked, flanks with streaks of dusky; tail markedly forked. Length 5.80 ; wing 3.20 ; tail 1.90 ; culmen 45 ; tarsus $\cdot 60$.

The female has no crimson, is pale brown above, streaked with darker, and below whitish, streaked throughout, except the under tail-coverts with dark brown.

Distribution.--Eastern North America, breeding from Pennsylvania to Manitoba northwards, wintering south from eastern Texas to Florida.

The only record of the occurrence of this eastern bird in Colorado is that of Anthony, who wrote to Cooke that he had shot a female example near Denver, November 15th, 1885; it was in company with Cassin's and the House-Finch, and can only be considered straggler in the State.

\section{Cassin's Purple Finch. Carpodacus cassini.}

A.O.U. Checklist no 518-Colorado Records-Allen 72, pp. 156, 162 (C. purpureus); Aiken 72, p. 199 ; Trippe 74, p. 107 ; Henshaw 75, p. 240 ; Scott 79, p. 93 ; Minot 80 , p. 220 ; Drew 81 , p. 89 ; 85, p. 16 ; Tresz 81, p. 41; Allen \& Brewster 83, p. 160 ; Stone 84, p. 20 ; 
H. G. Smith 85, p. 90; Morrison 88, p. 73; 89, p. 149; Lowe 94, p. 269 ; MoGregor 97, p. 38 ; Cooke 97, pp. 96, 212 ; Henderson 03, p. 107 ; 09, p. 235 ; Gilman 07, 156 ; Rockwell 08, p. 170 ; Warren 09, p. 16.

Description,-Male-Crown rich rosy-red, back dull rosy-pink, the scapulars and upper-back with strongly marked darker centres to the feathers; the rump and upper tail-coverts without; wings and tail dusky, with pale pinkish edges to most of the wing-feathers; below, the sides of the head, throat and chest dull rosy-pink, paling posteriorly to dirty white; a few inconspicuous streaks of brown on the flanks; tail slightly forked; iris brown, bill dark blueish-horn, dusky flesh on the lower mandible, feet dusky brown. Length 5.75 ; wing 3.5 ; tail 2.35 ; culmen .50 ; tarsus .68 .

The female is dusky grey above with an olive wash, sometimes very pronounced, streaked heavily with dusky brown; below, whitish, streaked throughout, including the under tail-coverts, with dusky; young birds are practically indistinguishable from the females.

Distribution.-Western North America from the eastern bases of the Rocky Mountains to the Pacific; north to southern British Columbia; south to Central Mexico, near Mexico City.

In Colorado, Cassin's Purple Finch is chiefly a resident, wintering along the eastern foothills and in the lower parks up to about 7,500 feet, and ascending the mountains to breed at 7,000 to 11,000 feet elevations. A certain number of birds doubtless go further south to winter. The following are recorded summer localities: Estes Park (MeGregor), Breckenridge (Carter), Twin Lakes, June (Scott), Hancock, July (Stone), South Park, July (Allen), San Juan co. (Drew), La Plata co. (Morrison), slopes of Mount Baldy at timber line in July, Costilla co. (Brunner). Winter records are Boulder (Henderson), Bergen Park, 7,600 feet (Trippe), near Denver, February, March (Smith), El Paso co., December to April ; Pueblo, November; Cañon City, April (Aiken), Salida, January (Frey), Mesa co. (Rockwell); a straggler as far east as Fort Lyon, May 28th (Thorne apud Cooke).

Habits.-In the winter Cassin's Finch is to be found in sheltered spots along streams in the foothills in small parties, and on a fine bright day they may often be seen sitting on the bare branches of cotton-wood trees, sunning themselves and enjoying the warmth; in March or April they move up into the mountains, where their strong, sweet and clear song can be heard among the willows along the streams. They breed about the middle of June in the pine woods; Gale found many nests with eggs 
between June 15th and July 30th near Ward $(9,200$ feet), and at Duck Lake in Boulder co. In nearly every case the nest was placed on the horizontal branch of a Douglas spruce, about twenty-five feet above the ground, and was composed of twigs and strong grasses woven together and lined with cowhair. The eggs, four or five in number, are pale greenish to white, sparsely sprinkled and scratched with blackish surface-markings and lilac shell-marks. They measure $85 \times \cdot 65$.

House-Finch. Carpodacus mexicanus frontalis.

A.O.U. Checklist no 519-Colorado Records-Say 23, vol ii., p. 40 ; Aiken 72, p. 199 ; Trippe 74, p. 109 ; Henshaw 75, p. 241 ; Nash 83, p. 225 ; H. G. Smith 84 , p. 120 ; Drew 85, p. 16 ; Beckham 85, p. 16 ; 87, p. 124 ; Morrison 89, p. 149 ; H. G. Smith 93, p. 244 ; Cooke 97, p. 96 ; Keyser 02, p. 181 ; Henderson 03, p. 236; 05, p. 421 ; 09, p. 235 ; Warren 06, p. 22 ; Bergtold 07, p. 61 ; Gilman 07, p. 156 ; Markman 07, p. 157 ; Rockwell 08, p. 170.

Description.-Male-Front half of the top of the head, rump, throat and upper-breast a rich dark carmine, paling on the occiput and back to a faint wash; the back in addition strongly streaked with dusky; wings and tail, including the upper tail-coverts, dusky edged with whitish; the lower-breast and rest of the under-parts dull white, strongly streaked with dusky; tail slightly forked; iris brown, bill and legs horny-brown. Length 5.5 ; wing $3 \cdot 10$; tail 2.40 ; culmen .41 ; tarsus $\cdot 75$.

The female resembles a male without any red, the breast being rather heavily streaked with brown. The immature male, and occasionally even the adult breeding male (Henderson 05), resemble the female and show no red.

Distribution.-The western United States and northern Mexico, chiefly in the Rocky Mountain region from Oregon and southern Wyoming to northern Mexico and northern Lower California.

In Colorado the House-Finch is found most abundantly in the foothills, and at lower elevations up to 9,000 feet in the mountains; it is a resident throughout the year chiefly in the towns and villages. It is rarely met with on the plains or at great elevations. It is abundant at Boulder (Henderson), Denver (Bergtold), Colorado Springs (Aiken), Pueblo (Beckham) and Salida (Frey), and was noted by Keyser at Red Cliff $(8,600$ feet) end Glenwood, and by Rockwell at Grand Junction on the western side of the range. Warren has recorded it from Baca co., and Gilman from La Plata co. and Montezuma co. 
Habits.-The House-Finch rivals the English Sparrow in its attachment to towns and villages, moreover it seems well able to hold its own against it although inferior in size. Its bright colour and beautiful song endear it to all the inhabitants of western towns, and if encouraged it becomes tame and familiar.

Dr. Bergtold relates how it will come to his windowsill in the centre of Denver to drink water put out for it, and will even enter the room through the open window, to take advantage of the radiators. When met with in the country, it frequents open hill-sides and ravines, but shows none of the familiarity it displays in towns. The food consists chiefly of scraps in the town, but in the country it has a distinct taste for fruit. The nest (Plate 14, Fig. 1) is a compact structure of twigs and grass stems, sometimes lined with wool; it is placed in bushes or creepers growing about verandahs and porches, while in Denver the bird has been frequently observed to adapt the large arc-light globes used for lighting the streets as a safe, warm place to rear a family. It is an early breeder, eggs having been found so soon as March 15th, and as it raises two broods it is often still engaged in incubation as late as July. The male, according to Aiken, does not assist in this matter. The eggs, usually five in number, are white, with a blueish or greenish tinge, sparsely speckled, chiefly at the larger end, with black, and measure $\cdot 75 \times \cdot 54$. Gale found it nesting at Gold Hill at about 9,000 feet (Henderson).

\section{Genus LOXIA.}

Moderate-sized Finches-wing 3 to 4 -with the upper and lower mandibles falcate and crossed in adults; nostrils concealed by the nasal bristles; wing long and pointed, tail short, about .60 length of wing. Plumage of the males with reddish, of the females with yellowish-green.

This genus, containing the Crossbills, is found throughout the more 

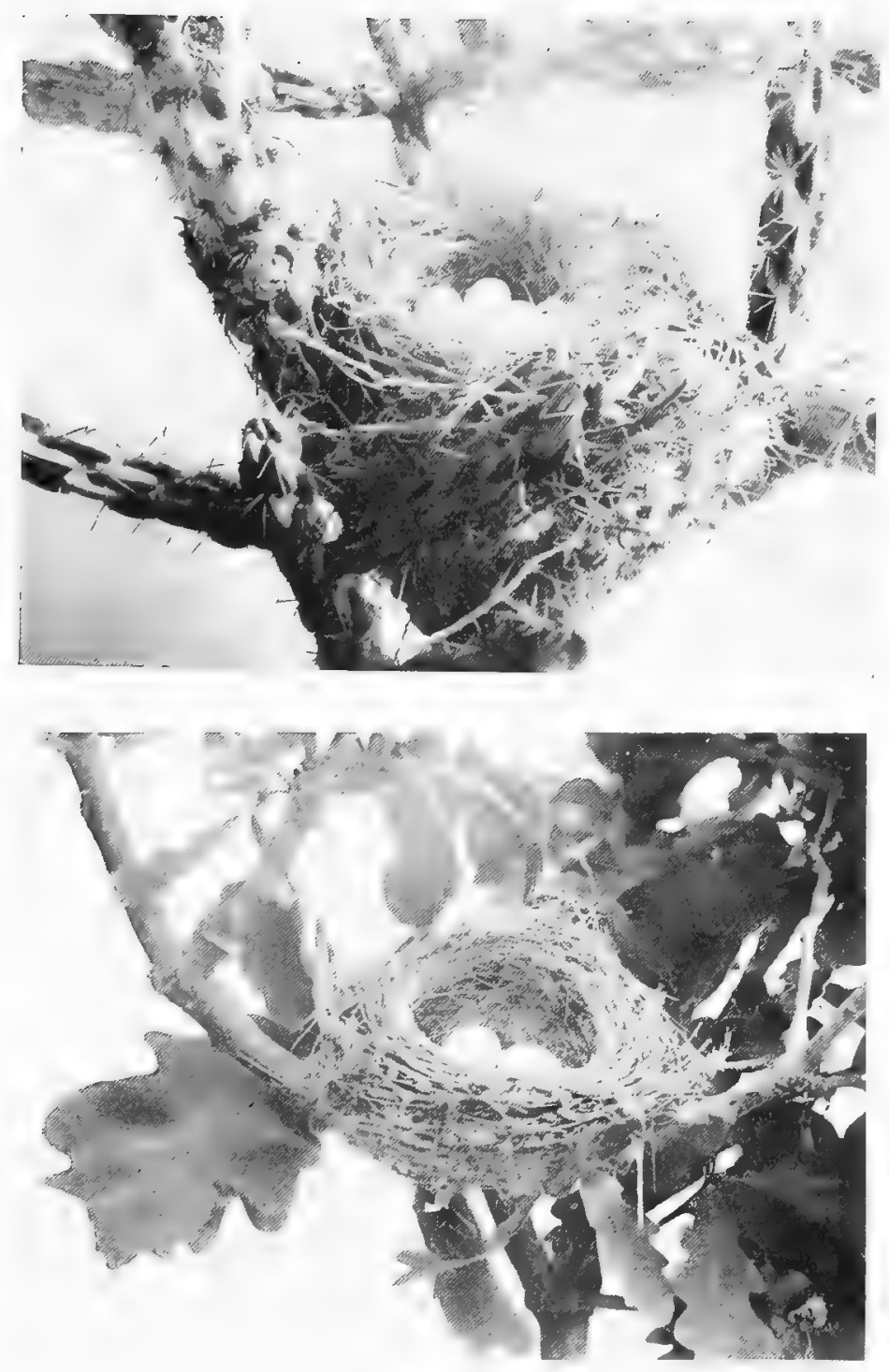

Plate 14]

「H. H'. Nush, Phot.

NEST AND EGGS OF (1) THE HOLSE-FINCH AND (2) THE ARKANSAS GOLDFINCH. 

northern portions of the Old and New Worlds, extending south along high mountain ranges, especially where there are pine forests. Three forms have been met with in Colorado.

KEX of THE Specres.

A. Wing without white bars.

a. Smaller; wing 3.5; bill shorter, culmen -70. L. c. minor, p. 333 .

b. Larger; wing $3 \cdot 8$; bill longer, culmen $\cdot 90$.

B. Wing with two white cross-bars.

L. c. stricklandi, p. 334 .

L. leucoptera, p. 334 .

American Crossbill. Loxia curvirostra minor.

A.O.U. Checklist no 521-Colorado Records (including those of $L$. c. stricklandi)-Trippe 74, p. 109 ; Henshaw 75, p. 248 ; Scott 79, p. 93 ; Minot 80, p. 229; Drew 81, p. 143 ; 85, p. 16 ; Allen \& Brewster 83, p. 160 ; Morrison 87 , p. 35 ; 88, p. 73 ; 89, p. 149 ; Kellogg 90 , p. 88 ; Breninger 94, p. 99 ; Cooke 97, pp. 97, 212 ; Henderson 03, p. 236 ; 07, p. 440 ; 09, p. 235 ; Gilman 07, p. 156.

Description.-Male-General colour dull red, brightest on the rump, becoming plain dusky on the wings and tail; 'below, the reddish becomes dusky grey on the abdomen, while the under tail-coverts are pale dusky edged with whitish; iris brown, bill horn, legs dusky brown; the intensity and amount of red vary a good deal, and some birds breed while still in immature plumage. Length 5.5; wing 3.5; tail 2.30 ; culmen $\cdot 70$; tarsus $\cdot 70$.

In the female the red is replaced by olive-yellow, which becomes quite bright yellow on the rump, but is often little more than a thin wash on the rest of the body. It is also slightly smaller (wing 3 to 4 ). Young birds are like the female, but at first have bills like other Finches; the fully crossed mandibles are attained at about six months.

Distribution.-The American Crossbill is found breeding throughout the northern parts of North America and the mountains further south, more especially among the coniferous forests, from Alaska to the Sierra Nevada, Colorado, and the Alleghanies of northern Georgia, wintering at lower elevations and further south to New Orleans, New Mexico and the coast districts of California.

In Colorado the Crossbill is a resident, and is chiefly to be seen in the pine woods along the foothills and at lower elevations up to 8,000 feet, though roving parties may be met with almost anywhere at any time of the year up to timber line and even out on the plains. Cooke saw a young bird near Lamar in July over 100 miles from the mountains.

Habits. - Except during the breeding season the Crossbill is always in flocks, wandering irregularly over 
the country, appearing suddenly at some particular spot and staying some time while food lasts, and then disappearing again for some months. They are noisy birds and keep up a continuous chatter, while during the breeding season they sing quite sweetly. The food consists chiefly of the seeds of coniferous trees, which they are able to obtain with the help of their powerful mandibles.

But few ornithologists have taken the eggs of this bird; Breninger (94) found twelve nests near Palmer Lake, between January and April. Dennis Gale (Henderson 07) found a nest in a pine tree on a sheltered hillside on the slopes of Buckhorn Mountain; it was eighteen feet above the ground, and fixed on a horizontal limb. The eggs, which were slightly incubated when taken on April 3rd, were three in number; they were pale blueish-green, spotted with rusty-lavender, and measured on an average $70 \times \cdot 44$. The nest was composed of twigs and grass stems, with a few feathers in the lining.

Mexican Crossbill. Loxia curvirostra stricklandi.

A.O.U. Checklist 521a-Colorado Records (see records of $L$. c. minor).

Description.-Very similar to $L$. c. minor, but decidedly larger and with a longer bill. Dimensions of a Colorado male: Length 6.5; wing 3.80 ; tail $2 \cdot 25$; culmen .90 ; tarsus 60 .

Distribution.-Mountains of New Mexico, Arizona and Old Mexico to Guatemala, wandering northwards at any rate to El Paso co., Colorado. A pair of Crossbills collected by Aiken, May 22nd, 1874, in El Paso co., the dimensions of which are given above, are obviously referable to this subspecies, as are those found nesting near Fort Lewis in La Plata co., on January 15th, 1887, by Morrison.

White-winged Crossbill. Loxia leucoptera.

A.O.U. Checklist no 522-Colorado Records-Drew 81, p. $89 ; 85$, p. 16; Morrison 88, p. 73 ; 89, p. 149 ; Cooke 97, p. 97 ; Knøebel 07, p. $10 \mathrm{I}$ 
Description.-Malo-General colour of the upper- and lower-parts red, usually of a pinkish tinge; scapulars, wings, tail and tail-coverts black ; the wings marked with two conspicuous bands of white across the middle and greater coverts; abdomen and flanks dull whitish; under tail-coverts black, edged with whitish. Length 6.5 ; wing $3 \cdot 30$; tail $2 \cdot 20$; culmen $\cdot 60$; tarsus $\cdot 60$.

The female is dusky, streaked above and below with a faint wash of olive-yellow; rump light yellow; the wings and tail as in the male.

Distribution. - The coniferous forests of western Europe and northern North America as far south as the Adirondacks and northern Michigan; south in winter to the middle States from the District of Colombia to Nevada.

In Colorado this bird is w rare straggler; Drew noted an example in the collection of Dr. Brown of Silverton, taken in Bakers Park, about 9,500 feet, in San Juan co., and recently Knaebel observed a pair on a ranch on a tributary of the upper Bear Creek in Clear Creek co., at about 8,400 feet, at the end of August, on several successive occasions.

Mr. Chas. S. Thompson, of Glenwood, writes me that in November, 1907, he watched for some time a female White-winged Crossbill in an orchard at Eaton. It was very tame and was busily engaged feeding on the winter buds of the apple trees at the time, and was so near that there could not possibly be any mistake in identification.

\section{Genus LEU CosTICTE.}

Moderate-sized Finches-wing 4 to $4 \cdot 5$-with a rather small conical bill, and the upper and lower mandibles of approximately equal depth; the nostrils completely concealed by nasal plumes; wings long and pointed, the primaries exceeding the secondaries by about twice the length of the tarsus; tail short, from .60 to .65 of wing, distinctly emarginated, more than half concealed by the upper tail-coverts; tarsus longer than the middle toe and claw; plumage black or brown, with a good deal of rosy-red.

The range of this genus covers the more arctic and elevated regions of central and eastern Asia and western America. Of the five distinguishable American forms, four are not infrequent in Colorado.

\section{KEY OF THE SPECIE8.}

A. Plumage distinctly dusky or blackish. $\quad$ L. atrata, p. 338.

B. Plumage distinctly a shade of brown.

a. Sides of the crown and nape ashy-grey; ear-coverts brown, sharply defined from the ashy-grey. L. tephrocotis, p. 336.

b. Ear-coverts, and throat as well, grey like the nape.

L. t. littoralis. p. 337 .

c. No grey on the head, the dusky crown merging into the general brown of the upper-parts. $\quad$ L. australis, p. 338. 


\section{Grey-crowned Rose-Finch. Leucosticte tephrocotis.}

A.O.U. Checklist no 524-Colorado Records-Allen 72, p. 162 (in part) ; Ridgway 73, p. 182 ; 75, p. 68 ; Trippe 74, p. 888 (in part); Drew 85, p. 16 ; Cooke 97, pp. 97, 164, 212 ; Henderson 03, p. 236 ; 09, p. 235.

Description.-Male in winter-Forehead and crown black, separated from the general brown colour of the body by an ashy-grey band running back from the eye and crossing the occiput; wings and tail dusky black ; feathers of the rump and upper tail-coverts, the wing-coverts, the flanks and under tail-coverts all tipped with pink; the outer primaries edged with the same; iris brown, legs black; bill yellowish with dusky tip. Length 6.30 ; wing 4.15 ; tail 2.60 ; culmen .40 ; tarsus .75 .

In summer the male has a black bill. The fermale closely resembles the male, but the black of the crown is not so distinctly demarcated posteriorly, and fades into the grey of the hind-neck; the pink wash, especially on the flanks, is less pronounced; it is also slightly smaller -wing about $4 \cdot 05$.

Distribution.-Breeding so far as is known only in the higher mountains of California, in winter and during migration eastwards to the mountains of Colorado to Nebraska, Manitoba and Saskatchewan.

In Colorado the Grey-crowned Rose-Finch is only a winter bird, and is chiefly confined to the mountains unless driven down by heavy storms, when it often resorts to ranches and to suburbs of towns along the foothills.

The following are recorded localities: Gold Hill, Boulder co., November and February (Gale), Magnolia, Boulder co., November (Sprague apud Cooke), Breckenridge (Carter), near Colorado Springs, January, February, March; Fremont co., April ; South Park, January ; between Rifle and Meeker at about 8,000 feet, October 27th (Aiken); Lake Moraine, slopes of Pikes Peak, 10,250 feet, December, and Crested Butte, 9,000 feet (Warren); Salida, December (Frey); a straggler to Fort Collins, March 31st (Cooke).

Habits.-The Grey-erowned Rose-Finch is essentially a mountain bird, inhabiting the cold and snowy solitudes about timber line during the winter season, and apparently finding a subsistence on grass and other seeds; it is usually met with in flocks. After a heavy storm in the mountains it is often driven down to lower elevations, and takes refuge in towns and villages. Mr. Aiken found an enormous number of this and other species of the same genus on such an occasion, crowded 
together in an empty lot in Cañon City, on April 20th, 1874. He secured very large numbers of specimens, and there are still in the Aiken collection forty-seven examples of this species, fifteen of $L$. $t$. littoralis, and some forty-two of $L$. australis. I have seen large flocks of this and other species of the genus on grassy slopes of the Mesa, near Colorado Springs, in the middle of December, after a bad storm in the mountains; the flocks are very large and the birds keep very close together, almost like a swarm of locusts.

Its nest and eggs have recently been discovered on Pyramid Peak, Eldorado co., California, by Milton S. Ray and others ("Condor," XII., 1910, p. 147).

\section{Hepburn's Rose-Finch. Leucosticte tephrocotis littoralis.}

A.O.U. Checklist no 524a-Colorado Records-Baird 70, p. 163 (L. compestris) ; Ridgway 75, p. 74 ; Drew 85, p. 16 ; Morrison 89, p. 149 ; Cooke 97, pp. 98, 212 ; Henderson 09, p. 235.

Description.-Closely resembling $L$. tephrocotis, but the grey of the sides of the head extending downwards over the ear-coverts and cheeks and in some cases clear across the throat. Length 6.25 ; wing $4 \cdot 10$; tail 2.60 ; culmen 40 ; tarsus 07 .

The female is slightly smaller (wing 3.9 ), and as a rule paler, the pink wash, on the flanks especially, of a paler tinge.

Distribution.-The mountains of western North America, believed to breed in the mountains of southern Alaska and perhaps southwards to Washington and Oregon; in winter along the Pacific coast and eastwards to Nevada, Uteh and Colorado.

This subspecies is only a winter bird in Colorado and is normelly only found in the mountains, unless driven down to lower levels by heavy storms; it is not so often met with as the Grey-crowned, and may be considered quite a scarce bird. Morrison states that it is more common on the western slope of the range, though $I$ do not know on what authority. There are examples in the Aiken collection taken close to Colorado Springs in March, 1874, and in January, 1879, and a number taken at Cañon City, 20th April, 1874, on the occasion alluded to, under L. tephrocotis. It has also been observed by Carter at Breckenridge and by Dennis Gale at Gold Hill, Boulder co., where is winters. Warren informs me he has taken it at Lake Moraine, on the slopes of Pikes Peak, 10,250 feet, in December, associated in flocks with the other 
species of this genus. On December 14th, 1908, Frey took a good number of Rose-Finches from a large flock near Salida. Among them there was a single example of this species.

\section{Black Rose-Finch. Leucosticte atrata.}

A.O.U. Checklist no 525-Colorado Records-Ridgway 74, p. 241 ; Drew 85, p. 16; Morrison 89, p. 36; Cooke 97, pp. 98, 164 ; Warren 08, p. 23.

Description.-Male in winter-Closely resembling $L$. tephrocotis, but the brown of the back and under-parts replaced by black ; scapulars and inter-seapulars margined with paler; bill jellowish, tipped with dusky, legs black. Length 6.10 ; wing 4.20 ; tail 2.70 ; culmen -45 ; tarsus .70 .

The male in breeding dress has a black bill and the paler margins to the feathers are less apparent. In the female the black of the back, wings and under-parts is replaced by dark sooty-brown; the pink wash is much less conspicuous and paler in shade, being absent on the wings and flanks; size smaller, wing $3 \cdot 95$.

Distribution.--Said to breed above timber line in the mountains of Idaho and Wyoming, moving southwards in winter to the mountains of Colorado and Utah.

The species was founded on four examples taken by Aiken at Cañon City in Fremont co. on the 18th and 20th April, 1874, under the circumstances already recorded. There are a number of other specimeng in the Aiken collection, obtained in the neighbourhood of Colorado Springs in January and February, 1879, and one collected by Warren at Lake Moraine (10,250 feet) on the slopes of Pikes Peak in December, while the same observer has recently detected a Black Rose-Finch in a flock of Juncos at Sulphur Springs (7,600 feet) in Middle Park, on April 6th. Frey obtained three examples in December at Salida.

\section{Brown-capped Rose-Finch. Leucosticte australis.}

A.O.U. Checklist no 526-Coloredo Records-Allen 72a, p. 350 (L. griseinucha), 72, pp. 121, 162, 177 (L. tephrocotis in part); Aiken 72, p. 199 (L. tephrocotis); Ridgway 73, p. 182 ; Trippe 74, p. 113 (in part); Henshaw 75, p. 249 ; 05, p. 315 ; Drew 81 , p. 89 ; 85, p. 16 ; Anthony 88, p. 257 ; Kellogg 90, p. 88 ; Morrison 89 , p. 36 ; Cooke 95, p. $152 ; 97$, pp. 98, 212 ; Keyser 03, pp. 59, 240; Henderson 03, p. 236; 09, p. 236 ; Gilman 07, p. 156 ; Warren 08, p. 23 ; Rookwell 08, p. 171.

Description.-Male in summer-Crown dusky black, becoming a little paler at the edges without any distinct grey bands; nasal tufts white; back, sides of the head and neck, throat and chest cinnamonbrown, darkest on the throat; wings and tail dusky black, edged rith 


\section{Brown-capped Rose-Finch}

peach-blossom pink, the wing-coverts and upper tail-coverts tipped, and the whole of the flanks and abdomen washed with the same, the colour richest on the abdomen; iris brown; bill and legs black. Longth 6.30 ; wing 4.20 ; tail 2.60 ; culmen .40 ; tarsus .70 .

The male in winter has the bill horny-yellow, tipped with black; the general colour is greyer owing chiefly to most of the feathers being tipped and edged with greyish-brown, while the pink is very much lighter in shade. The female is greyer than the male, the brown being of a duskier shade; the pink wash is much less distinct, and in some specimens almost absent. Young birds are buffy-brown, including the crown, and show no pink.

Distribution.-Breeding above timber line-11,000 feet, to summits of the higher mountain ranges of Colorado; in winter descending to below timber line, but not leaving the mountains except when driven down by storms.

The following are summer records: Longs Peak, July (Kellogg), Bald Mountain, 10,000 to 11,000 feet (Gale), Grays Peak (Keyser), mountains near Breckenridge (Carter apud Cooke), Mount Lincoln, July (Allen), Mount Harvard (Henshaw), Pikes Peak (Keyser), mountains near Crested Butte (Warren), Sangre de Cristo range above timber line, June, 1874, and Summit Peak, Conejos co., September (Aiken), San Juan co. (Drew), La Plata Mountains, 13,000 feet, June, July (Gilman).

Winter records are: Gold Hill, Boulder co., January (Anthony); near Colorado Springs, January, March (Aiken), Lake Moraine, El Paso co. (10,230 feet), December (Warren), Cañon City, April (Aiken); Salida, December 14th (Frey); Fort Lewis, La Plata co., 7,500 feet, January (Gilman), near De Beque, Mesa co., March (Rockwell).

So far as I am aware this species has never yet been recorded from outside the State of Colorado. Its reported occurrence in New Mexico is due to an error (Henshaw 05).

Habits.-This is the only species of the genus which is known to breed in Colorado, and even now eggs have never yet been taken. Mr. Richmond informs me that there is a nest in the United States National Museum supposed to have been that of a Brown-capped RoseFinch, from which the young had already flown, taken by F. M. Drew at Round Mt., San Juan co., on the 27th of August, 1883, at an elevation of 13,000 feet.

In fact, the only species of the genus of which the breeding habits are well known is $L$. griseinucha, from 


\section{Greater Redpoll. Acanthis linaria rostrata.}

A.O.U. Checklist no 528b-Colorado Records-Cooke 97, p. 165; Henderson 09, p. 236.

Description.-Closely resembling $A$. linaria, but larger (wing of male averaging 3.15), and bill stouter and longer (culmen about 40 ), but with the same changes of plumage.

Distribution.-Breeding and resident in Greenlend; southwards in winter to Massachusetts and northern Illinois. The only Colorado specimen known was obtained by Mr. W. A. Sprague on December 9th, 1895, near Magnolia in Boulder co., at about 7,500 feet.

\section{Genus ASTRAGALINUS.}

Small Finches with rather slender, acute and compressed bills, and with the nostrils conceeled by nasal plumes; wings long and pointed; tail from $\cdot 6$ to .7 of the wing, strongly emarginate; tarsus shorter than the middle toe and claw; plumage not streaky; males with yellow, no red.

This genus, consisting of three species divided into some ten subspecies, is confined to North and Central America.

\section{KEY OF THE SPECIES.}

A. Upper and under tail-coverts white or whitish.

a. Smaller ; wing of male averaging 2.75 ; yellow of male richer.

A. tristis, p. 342 .

b. Larger; wing of male averaging 3.0 ; yellow of male paler.

A. t. pallidus, p. 344 .

B. Upper tail-coverts dusky or greenish, lower yellow.

a. Crown black.

$a^{2}$ Back olive-green. A. psaltria, ơ p. 344.

$b^{2}$ Back olive-green and black intermingled.

A. p. arizonæ, ơ p. 345 .

$c^{2}$ Back black like the crown. A. p. mexicana, of p. 346 .

b. Crown green like the back. A. psaltria, of p. 344.

American Goldfinch. Astragalinus tristis.

A.0.U. Checklist no 529-Colorado Records-Allen 72, p. 149 ; Aiken 72, p. 199 ; Henshaw 75, p. 243 ; Drew 81, p. 90 ; 85, p. 16 ; Allen \& Brewster 83, p. 161 ; Beckham 85, p. 141 ; 87, p. 124 ; Morrison 88 , p. 73 ; 89 , p. 38 ; Cooke 97 , p. 98 ; Henderson 03 , p. 236 ; 09 , p. 236 ; Warren 08 , p. 23 ; 09, p. 16.

(Some of these records doubtless apply to $A . t$. pallida.)

Description.-Male in summer-General colour above and below bright lemon-yellow; crown, wings and tail black; tips of the middleand greater-coverts, edges of most of the remiges and tail-feathers, 
and the whole of the tail-coverts white; iris brown, bill orange, tipped black, legs light brown. Length 4.5 ; wing 2.75 ; tail 1.90; culmen 40 ; tarsus .50 .

The male in winter is a dull brown above, becoming dull grey on the rump; wing and tail as in the breeding male, but with white edgings and tips; below very pale brown, becoming white posteriorly, washed with yellow more or less anteriorly; bill horn-coloured.

The female is like the male in winter, but is smaller (wing 2.65); the young bird is like the female, but the white markings of the wings and tail are tinged with pale rusty.

Distribution.-Eastern North America to the base of the Rocky Mountains from southern Labrador and Manitoba to the Gulf coast.

In Colorado the prevalent form of the Goldfinch is the eastern typical subspecies; it is a resident chiefly in the plains and foothills, though its numbers are largely reinforced in summer by migrants. It breeds from the plains up to 7,000 feet, rarely up to 10,000 , and its movements are irregular.

The following are recorded localities : Boulder co., wintering in valley and nesting on Gold Hill (Gale); near Denver, El Paso co, January to May, Limon, May, and Pueblo, November (Aiken); Salide, winter and summer (Frey).

Habits.-Goldfinches are found in flocks throughout the greater part of the year, and very often associate with Pine-Linnets and other species; they wande about in rather an irregular manner and feed on small seeds, especially those of the thistle; they have a plaintive, lisping song. The nesting date varies somewhat, but fresh eggs are usually to be met with at the end of June or beginning of July. Dennis Gale found two nests on July 31st, one of which contained five young birds, while the other was only just completed, and was still empty. The former one was placed in a box alder about seven feet up, saddled on an outer branch; it was composed of wool on the outside, grass for the middle, while the lining was of cotton and thistle down. The eggs, usually four or five in number, are faintly bluish-white, and normally unmarked; they measure $.65 \times \cdot 50$. 
Western Goldfinch. Astragalus tristis pallidus.

A.O.U. Checklist no 520a-Colorado Records-Cooke 97, p. 212 ; Aiken 00, p. 298 ; Gilman 07, p. 156; Rockwell 08, p. 171.

Description.-Closely resembling $A$. tristis, but distinctly larger; the breeding males perhaps a shade paler and the winter males paler and greyer, and as compared with typical eastern specimens the white markings of the wings and tail more extended; but the typical form in Colorado is somewhat intermediate in this respect. Dimensions of a Colorado example, a male in breeding plumage : Length 4.8 ; wing 3.0 ; tail 1.90 ; culmen .42 ; tarsus .52 .

Distribution.- The Rocky Mountain region of western North America, from British Columbia and western Manitoba south to northern and eastern Mexico.

Mr. Aiken first pointed out that both the subspecies of Goldfinch occurred in Colorado, but the present subspecies seems the rarer in the eastern portion; it is represented in the Aiken collection by one Colorado example-a male in breeding plumage, taken close to Colorado Springs on 17th May, 1898. The Goldfinch of La Plata co. and south and west Colorado is probably the western form. This subspecies most probably breeds in Colorado, though so far has not been definitely recorded as doing so. It is reported from Grand Junction, November 11th (Rockwell).

\section{Arkansas Goldfinch. Astragalinus psaltria.}

A.O.U. Checklist no 530-Coloredo Records-Say 23, vol. ii., p. 40 ; Henshaw 75, p. 245 ; Drew 81, p. 90 ; 85, p. 16 ; Allen \& Brewster 83 , p. 161 ; Beckham 85, p. 141 ; 87, p. 124 ; Morrison 88, p. 73 ; 89, p. 38 ; Nash 97, p. 29 ; Cooke 97, pp. 99, 213 ; Keyser 02, p. 32 ; Henderson 03, p. 108; 09, p. 236; Gilman 07, p. 156 ; Rockwell 08, p. 171 ; Warren 09, p. 16 ; Cary 09, p. 182.

Description.-Mele-General colour above, including the ear-coverts, olive-green; top of the head, wings and tail, and upper tail-coverts black; a patch at base of primaries, the edges and the inner secondaries the tips of the middle-coverts, the inner webs, except the tips of the three outer tail-feathers, all white; below bright canary-yellow; iris brown, bill horny-brown, legs brownish. Length $4 \cdot 20$; wing 2.65 ; tail 1.70 ; culmen .40 ; tarsus .47 .

The female has the crown like the back, but generally with slight traces of dusky streaks : the wing and tail like the male, but rather duller in colour and the white somewhat restricted; below dull olive-yellow paling posteriorly; size smaller, wing $2-45$. The young bird is like the adult female, but tinged with buffy.

Distribution. - The western United States, breeding from northern Californis to the eastern base of the Rocky Mounteins in Colorado; south in winter to Lower California, Arizona and New Mexico 
In Colorado the Arkansas Goldfinch is a common summer bird. especially in the southern parts of the State; it is far less abundant north of the Arkansas-Platte Divide, but has been taken as far as Cheyenne, just over the Wyoming border. It is a late comer from the south, as a rule not appearing before June, but Aiken has taken it at Colorado Springs as early as April 20th, while in the fall it does not leave till the end of October or beginning of November, Beaver Creek Fremont co., November 11th (Aiken collection) is the latest date I have met with. It is chiefly found in the plains and foothills, but goes up into the mountains as high at least as 9,000 feet (Crested Butte, Gunnison co. Warren). Other localities are: Boulder co. (Henderson), near Denver (Morrison), Pueblo (Ailen apud Henshaw), Meeker and Steamboat Springs (Cary), Glenwood Springs, breeding (Cooke), Bedrock (Warren), Animas River, San Juan co. (Drew), Fort Lewis, breeding (Morrison).

Habits.-Like the other Goldfinches, this species is generally seen in flocks in waste places where thistles and other weeds grow ; and on the seeds of these it chiefly feeds. Little has been recorded about its nesting habits, which seem to resemble those of the other Goldfinches; Morrison found a nest in a cotton-wood sapling, at Fort Lewis, while a photograph of a nest containing two eggs, evidently built in a scrub-oak bush, near Beulah, Pueblo co., taken by H. W. Nash, is here reproduced (Plate 14, Fig. 2).

Arizona Goldfinch. Astragalinus psaltria arizonoe.

A.O.U. Checklist (2nd ed.) no 530a-Colorado Records-Morrison 89, p. 36 ; Cooke 97, pp. 99, 213.

Description.-Closely resembling A. psaltria, but the olive-green of the back intermixed with black in varying amounts; dimensions about the same; females indistinguishable from the typical form.

Distribution.-The south-western borders of the United States from western Texas to California, north to Colorado, south to north-west Mexico. In Colorado this form of the Arkansas Goldfinch is a rather rare summer bird; it has been taken as far north as Loveland and Golden by Professor Osburn in the breeding season, and there are several examples in the Aiken collection from Colorado Springs, killed in August, and from Fremont co. It was found breeding at Glenwood Springs by Wm. Cross and in La Plata co. by Morrison. 
This subspecies has been recently eliminated from the Checklist ("Auk," XX., p. 347) as " The characters ascribed to it are mainly due to age or season." It seems to me, however, that the form is undoubtedly an intermediate between $A$. psaltria and $A$. mexicanus, and, as was originally pointed out by Coues, as such it is a convenience to retain it.

\section{Mexican Goldfinch. Astragalus psaltria mexicanus.}

A.O.U. Checklist no 530b-Colorado Records-Cooke 97, p. 213 ; 99, p. 187 ; Bergtold 09, p. 79.

Description.-Closely resembling A. paaltria in size and markings, but the whole of the upper-parts, including the ear-coverts glossy black. Fernales and young birds not to be distinguished from those of A. psaltrio and A. p. arizonce.

Distribution.-Mexico and southern Texas, accidental in Colorado. In Colorado an example, taken by T. A. Allen, near Denver, was identified by J. A. Allen. Another, not quite typical, with slight traces of olive-green on the back, obtained by Aiken near Colorado Springs, 4th August, 1898, is in his collection, while Cooke believed that he aaw examples near Trinidad in June, 1898. Quite recently Bergtold noticed a typical example of this form in a vacant lot in Denver, and watched it for some time on June 30th, 1908, and Frey has taken a male at Salida, August 3rd, now in Mr. Warren's collection.

\section{Genus SPINUS.}

Small Finches-wing under 3.0-closely resembling Astragalinus, but with a slightly longer and more actutely pointed bill, with concave sides when seen from above; wing, tail and feet as in Astragalinus; plumage (in the Colorado species) streaked with yellow at the base of the tail- and wing-feathers.

The Siskins form a considerable genus, ranging over the greater part of the Old and Now Worlds; only one species is found in the United States.

\section{Pine Siskin. Spinus pinus.}

A.O.U. Checklist no 533-Colorado Records-Allen 72, pp. 149, 162 ; Aiken 72, p. 199 ; Trippe 74, p. 116 ; Henshaw 75, p. 246; Scott 79, p. 93 ; Tresz 81 , p. 40 ; Drew 81, p. 90 ; 85, p. 16 ; Allen \& Brewster 83 , p. 161 ; Beckham 85, p. 141 ; 87, p. 124 ; Morrison 90, p. 36 ; H. G. Smith 93, p. 244 ; Lowe 94, p. 269 ; Cooke 97, pp. 99, 213 ; Dille 00, p. 73 ; Keyser 02, p. 199 ; Dille 03, p. 74 ; Henderson 03, p. 105 ; 09, p. 236 ; Gilman 07, p. 156 ; Warren 08, p. 23 ; 09, p. 16 ; Rockwell 08, p. 171. 
Description.-Male-General colour greyish-brown strongly streaked with dusky, the ground-colour of the rump and the lower side much paler, becoming almost white on the abdomen; wings and tail dusky black, the bases of the remiges and rectrices and their outer edges pale lemon-yellow, the middle- and greater-coverts generally tipped with white; iris black, bill and legs dark horn. Length 4.15; wing 2.85 ; tail 1.75 ; culmen 40 ; tarsus .55 .

The female resembles the male; a young bird has a buffy wash above and below and has buffy tips to the wing-coverts.

Distribution.-Breeding in the pine forests of northern North America south to New England and Minnesota, and along the mountain ranges to North Carolina and the Mexican border; south in winter to the Gulf States and Mexico. In Colorado the Pine Siskin is a resident, breeding both in the mountains up to about timber line and also in the plains, though perhaps most abundantly in the former; in the winter it is found at lower elevations in the mountains and in the foothills, but its movements are very erratic, like those of the Crossbill.

It appears to be widely distributed throughout the State, as the following selected records show, viz.: Boulder co. (Henderson), El Paso and Lincoln cos. (Aiken), Salida, January and May (Frey), Fort Garland (Henshaw), Grand, Routt and Eagle cos. (Warren), Twin Lakes (Scott), San Juan co. (Drew).

Habits.-Like most of its near relatives, the Pine Siskin is nearly always in small parties or large flocks and generally in the pine forest, on the buds of which it chiefly subsists. They are very erratic in their movements, often appearing for a short time in large numbers, and then disappearing again completely. In the spring they relish the catkins of the cotton-wood, and buds of other deciduous trees, while in the autumn they often associate with Goldfinches, and feed on the seed of the thistle and other weeds. Frey observed large numbers of them in May, in the City Park at Salida, digging their bills into the dandelions and feeding on the unripened seed. Their flight is undulating, and they have an agreeable song in the spring.

In the plains eggs may be looked for from May 15th to June 1st, in the mountains from June 15th to July 5th. The nest is usually high up in a pine tree, though 
Aiken found one in a willow at Limon, on the plains. It is a somewhat flat structure, formed of twigs and rootlets and well lined with fine rootlets and hairs; the eggs, three or four in number, are pale bluish-green, speckled chiefly at the larger end with rusty-brown. They measure about $65 \times \mathbf{4 5}$.

Dille states that the Siskin nests in the lilac bushes in the Denver suburbs; he found three eggs laid between May 13th and 17th.

\section{Genus PASSER.}

Rather small birds with a stout and deep bill in which the lines of the culmen and the gonys are slightly convex, and the upper mandible is slightly deeper than the lower ; nostrils concealed by the nasel plumes; wing moderately pointed, the difference between the primaries and secondaries about equal to the tarsus; tail about 75 the length of wing, nearly even; plumage without red or yellow; wings white barred.

The genus is by nature confined to the Old World. Two species have been introduced and one has spread over the greater part of North America ; the other, the European Tree-Sparrow, seems to be confined to the neighbourhood of St. Louis, Mo.

\section{English Sparrow. Passer domesticus.}

Colorado Records-Lowe 95, p. 99 ; Cooke 97, pp. 99, 165, 213 ; Keyser 02, p. 127 ; Henderson 03, p. 236 ; 09, p. 236 ; Warren 06, p. 22 ; 08, p. 23 ; 09, p. 16 ; Gilman 07, p. 156 ; Markman 07, p. 157 ; Rockwell 08, p. 171.

Description.-Male-Crown dark grey bordered on either side by a triangular postocular patoh of dark chestnut; back rufous-chestnut, striped with black; rump grey; wings and tail dusky, with chestnut edgings and tips, middle-coverts tipped with white; below ashy, becoming white on the centre; a bleck patch covering the chin, throat and upper-breast; bill black, feet horn-brown. Length 5.5; wing 3.0 ; tail 2.25 ; culmen .5 ; tarsus $\cdot 70$.

The female has the crown and postocular region greyish-brown or olive, no black on the throat and is less brightly coloured; bill horny-brown. Young birds are like the fermale but soon acquire the dusky throat.

Distribution.-Furope, except Italy; introduced into America, Australia and many other parts of the world and thoroughly naturalized. Seid to have been first brought to Portland, Maine, in 1858 ; established 
in Salt Lake City in 1871, but does not appear to have been noticed in Colorado till 1895, when it was seen for the first time on February 20th, at Pueblo, by Lowe; it is said to have reached Denver in the summer of 1896, and there is an example from Colorado Springs in the Aiken collection, obtained on 18th October of that year; Henderson first noticed it at Boulder in 1898 ; on the western slope of the range it was noticed at Grand Junction in the fall of 1899 .

At the present time it is spread all over the country up to about 9,500 feet, at which elevation it has been noticed by Warren at Jefferson, but it is stated by Keyser not to be found in Leadville (10,200 feet), though $I$ have myself seen it at Cripple Creek and Victor $(9,500$ to 9,800 feet). It swarms in Colorado Springs, Denver and Durango and in all the smaller towns, and is also found about isolated ranches and places like Springfield and Coventry (Warren 06 and 09), which are far from the railway.

In Colorado Springe it lives side by side with the House-Finch which manages to hold its own, although I am told it has driven away to a great extent the Bluebirds and House-Wrens which were formerly to be seen about the town.

\section{Genus PLECTROPHENAX.}

Terrestrial Finches of moderate size-wing 4 to 5-with w small, delicate bill in which the lower mandible is rather deeper than the upper vertically; nostrils concealed by nasal bristles; wing very long and pointed, falling short of the tip of the tail by about half the length of the tarsus; tail short, about $\cdot 6$ of wing; hind claw lengthened, about equal to its digit, less curved than the others, but not straight. Plumage white and black in summer; in winter overlaid with tawny edgings which wear off in spring.

The Snowflakes or Snow-Buntings are circumpolar birds, breeding in the arctic and subarctic Regions and moving south in winter; only the best known species occur in Colorado.

\section{Snow-Bunting. Plectrophenax nivalis.}

A.O.U. Checklist no 534-Colorado Records-Ridgway 73, p. 182 ; Morrison 88, p. 74 ; 89, p. 36 ; Cooke 97, pp. 100, 165, 214 ; Henderson 03 , p. $236 ; 09$, p. 236.

Description.-Male in winter-Crown and nape, ear-coverts, and a collar across the chest pale rufous-brown, darkest on the forehead; back the same, streaked with dusky; wings dusky, middle and greatercoverts tipped, remiges edged with white, inner secondaries with rufousbrown; lateral tail-feathers chiefly white, rest dusky; below, except the collar, pure white; bill yellow. Length 6.1 ; wing 4.0 ; tail 2.5 ; culmen 40 ; tarsus 90 . 
The male in summer has the back, scapulars, greater part of the primaries, inner secondaries, alula, greater wing-coverts and the middle tail-feathers black, rest of the plumage white; the female in winter has the head and neck more or less streaked like the back, and the rusty wash not quite so strong as in the winter male; the breeding female is without the rusty-brown wash.

Distribution.-The northern parts of the Old and New Worlds, breeding in the arctic or subarctic regions from northern Labrador and Alaska, migrating south in winter, normally to the northern states, irregularly as far south as Georgia, Ohio and Colorado.

The Snow-Bunting is a rare and somewhat irregular winter visitor to Colorado. It is most often met with on the plains in the north-east corner of the State: Fort Collins, Loveland, Boulder and Denver are mentioned as localities by Cooke; there are a pair in the Aiken collection taken near Colorado Springs in the winter of 1876-7, and Morrison (88) saw a small flock of six on March 1st during a heavy snow-storm at Fort Lewis in La Plata co.; though normally only found on the plains, it was observed by Carter on one occasion between Breckenridge and Middle Park at about 8,000 feet.

Habits. - The Snow-Bunting is a common bird in the arctic regions as far north as explorations have been made; it comes south in winter in vast flocks, but hardly comes regularly so far south as Colorado, though common in Wyoming and Nebraska. Its food consists chiefly of seeds in winter, and as long as these are to be obtained the birds live happily, even when the thermometer is $30^{\circ}$ below zero.

\section{Genus CALCARIUS.}

Terrestrial Finches of medium size-wings three to four inches-with a small bill, which, however is larger than that of Plectrophenax, and has the upper mandible as deep or deeper than the lower; nostrils exposed; wings and tail as in Plectrophenax, the latter slightly longer, exceeding $\cdot 7$ in wing, doubly rounded and more than half concealed by the elongated coverts; claw of hind toe slender, elongated and nearly straight; plumage streaked ; tail-feathers with white and black, obliquely arranged.

The Longspurs are also circumpolar in distribution, breeding in the arctic regions of both hemispheres and on the great plains of North America; they migrate south in winter. One of the three American species (Calcarius pictus) is said to be common in Kansas by Goss, and 
will very probably be found in Colorado, though not yet recorded from the State. It can be distinguished by its buffy abdomen. The other two can easily be diagnosed as follows:-

\section{Key of THE SPECLES.}

A. Outer tail-feathers dusky at base on both webs.

C. 1. alascensis, p. 351 .

B. Outer tail-feathers pure white at bese.

C. ornatus, p. 352 .

\section{Alaskan Longspur. Calcarius lapponicus alascensis.}

A.O.U. Checklist no 536a-Colorado Records-Trippe 74, p. 120 ; Ridgway 79, p. 228 ; Morrison 89, p. 36 ; Cooke 97, pp. 100, 214 ; Brunner 06, p. 85.

Description.-Male in winter-General colour above pale buffy, streaked with black, darkest on the head; a collar of buffy-chestnut across the hind-neck; stripe behind the eye and the ear-coverts pale buff, both bordered below by a black patch; wings dusky, middlecoverts and secondaries bordered with rufous; tail dusky, the two outer pair of feathers chiefly white, except the base of the inner and tip of the outer web; below white with a black patch on the throat and chest, sometimes obscured by the white tips to the feathers; flanks streaked with black; bill pale horn, dusky tipped. Length 5.75 ; wing 3.63 ; tail 2.55 ; culmen .45 ; tarsus .80 ; hind too and claw .80 ; claw slender and straight.

In summer the head and chest become pure black by the wearing away of the tips of the feathers, and the chestnut collar becomes brighter and purer. The female is slightly smaller than the male-wing 3.50 ; in winter the head is not darker than the back, the chestnut nuchal collar is absent or very faintly marked, and the black area of the chest is merely streaked with a few dusky markings. The summer female is like the winter male, but the markings are more sharply defined. The Colorado birds are now referred to this subspecies, which differs from the typical form in its lighter colour and less heavily streaked back.

Distribution.-Breeding throughout Alaska and Yukon province; south in winter to Nevada, Colorado and western Kansas.

The Alaskan Longspur is a rather scarce winter visitor chiefly to the plaing of eastern Colorado, though sometimes passing up to the lower mountain parks. Trippe (74) saw a large flock in Middle Park in October and Cooke records it from Breckenridge (March 21 st, during a snowstorm, Carter) and from Wet Mountain Valley (8,000 feet, Baker), while there is a large series in the Aiken collection obtained in January, 1877, in the neighbourhood of Colorado Springs ; Warren killed four near Orchard on March 27th, 1909, where they were associated with Horned 
Larks in large flocks. Brunner found large numbers of these birds lying dead by the railroad track between Wray, Colo., and Heigler Neb., November 16th, 1901. They had been killed by flying against the telegraph wires.

Habits. - Like the preceding one, this species breeds far away in the north and comes south in large flocks in October, wandering over the desolate and treeless prairies in immense numbers, and subsisting on grass and weed seeds; they skim over the ground in a wary zigzag manner, and as soon as they alight, run swiftly hither and thither in search of their food. They often fall a prey to the Prairie-Falcon and other hawks.

\section{Chestnut-collared Longspur. Calcarius ornatus.}

A.O.U. Checklist no 538-Colorado Records-Ridgway 79, p. 228 ; Allen \& Brewster 83, p. 161 ; Drew 85, p. 16 ; Morrison 89, p. 36 ; Cooke 97, p. 100; Gilman 07, p. 156 ; Henderson 09, p. 236.

Description.-Male in summer-Crown, stripe behind the eye, spot below the ear-coverts, chest and abdomen black; lower parts often with a strong rufous wash; hind-neck deep chestnut-rufous; superciliary stripe, chin and throat white, rest of the back strealred with buffy and dusky; tail white, with increasing amounts of dusky at the tips from the outer-feathers inwards; lesser wing-coverts bleck, with white tips forming a shoulder-patch. Length 5.5 ; wing 3.40 ; tail 2.4 ; tarsus 75 ; culmen $\cdot 40$.

In winter the black and chestnut are almost completely obscured by buffy tips and edges to the feathers. The female is streaked above throughout with dusky and buffy, and is pale greyish-buff below; tail as in the male, but no black shoulder-patch to the wing. The young bird is at first like the female.

Distribution.-Breeding throughout the prairie states from Kansas north to Saskatchewan, south in winter to Mexico and Arizona.

This species appears to be a somewhat rere resident both in winter and summer in eastern Colorado, while during migration it is more plentiful. Winter records are : Fort Collins, Loveland, Boulder, Pueblo and Fort Lyon (Cooke); while in summer it has been noted near Colorado Springs (Allen \& Brewater); at Resolis in Elbert co., and Squirrel Creek in eastern El Paso co. (Aiken); and at Cortez in the south-western part of the State on April 4th by Warren (Gilman, 07). Though not actually recorded as breeding in the State, there can be little doubt that it does so. 
Habits.-Allen found the Chestnut-collared Longspur one of the most interesting and characteristic birds of the plains in central Kansas; it has a short, shrill, but very sweet song, often uttered while on the wing. The nest is a neat though slight structure, placed on the ground and composed of dry grass and rootlets. The eggs, generally five, are blotched and streaked with rusty on a white ground. Full fresh sets are to be found about June 3rd.

\section{Genus RHYNCHOPHANES.}

Terrestrial Finches of medium size, closely resembling Calcarius, but with a larger and somewhat stouter and more turgid bill and shorter tail, averaging about $\mathbf{5 7}$ of the length of the wing; hind claw nearly straight and usually less than the hind toe. Plumage streaky, tail with a transverse terminal black band ; a chestnut shoulder-patch, but no chestnut collar in the male.

This genus contrins only the single species here deseribed.

\section{McCown's Longspur. Rhynchophanes mccowni.}

A.O.U. Checklist no 539-Colorado Records-Trippe 74, p. 125 ; Allen \& Brewster 83, p. 161 ; Drew 85, p. 16 ; Morrison 89, p. 36 ; Cooke 97, p. 101 ; Warren 06, p. 22.

Description.-Male in winter-General colour above streaked dusky and pale buff, darkest on the crown where the black bases of the feathers show through; wings dusky, edged with buffy or white, the lesser and middle coverts chestnut, forming a wing-patch ; tail-feathers, except the central pair, which are dusky throughout, white; outer pair very slightly, others more markedly, tipped with dusky; below dirtywhite, the black bases of the feathers showing through more or less; iris brown, bill brown, dusky at the tip, legs horn. Length 5.55 ; wing 3.50 ; tail 2.0 ; tersus $\cdot 70$; culmen $\cdot 48$.

By abrasion of the feather tips the male in the breeding season has the crown, a rictal streak and a crescent band across the chest black, the nape, rump and edges of the wing-coverts slaty-grey, the underparts pale grey; the bill is blackish. The female is like the winter male, but the basal black does not show through, and there is no chestnut shoulder-patch; a well-marked broad superciliary and rictal stripe of pale buffy contrasts with the darker brown ear-coverts; below, buffy, whitening on the abdomen and throat. The young bird is like the female, but with the chest broadly streaked with dusky. 
Distribution.-The great plains of North America, breeding from north-west Nebraska northwards to Saskatchewan; in winter south through Texas and south-west through New Mexico and Arizona to north-west Mexico.

In Colorado McCown's Longspur is most common on migration on the eastern plains, and is also an irregular winter visitor. It has not been met with in the mountains or to the west. It has frequently been stated that it breeds in Colorado, but, so far as I know, there are no authentic records of its doing so, though there is no reason why it should not.

The records of its occurrence are few, viz.: Arkansas Valley in winter (Trippe), El Paso co., February (Aiken), May (Allen \& Brewster), near Springfield, Baca co., April until 26th (Warren 06).

Habits.-This Longspur has much the same habits as the Chestnut-collared, and is often found in association with it; in flocks of considerable size it frequents dry, high country, where the grass is short, and where it roams about in search of food; as a rule when flushed it flies only a short distance with a circling, wavy flight. The nest is placed on the ground in the open; it is loosely constructed of dry grass and lined with finer materials, often hair or feathers. The eggs, three to six in number, are dull greenish to olive-white, speckled and spotted with varying shades of reddish-brown to black.

\section{Genus POCECETES.}

Medium-sized Sparrow-like birds, with moderate bills, the upper mandible very distinctly deeper than the lower; nostrils exposed; wings fairly long and pointed, but the difference between the primaries and secondaries less than the length of the tarsus; tail slightly emarginate, with the lateral tail-feathers white, and about .75 length of wing ; tarsus stout, hind claw normal not straight, less than the length of its toe; plumage streaked above and across the breast; no yellow or red.

This genus contains one species, consisting of three recognizable races, spread over temperate North America.

The following is a key to the Colorado Grass-Sparrows contained in this and the next four genera, which are somewhat difficult of discrimination. 


\section{Western Vesper-Sparrow}

A. Larger; wing over 3; lateral tail-feathers white; no median crown-stripe.

P. g. confinis, p. 355 .

B. Smaller; wing under 3 ; lateral tail-feathers not conspicuously white.

«. Edge of the wing white.

$a^{2}$ Median crown-stripe anteriorly buffy, posteriorly white.

$b^{2}$ Median crown-stripe if defined, buffy throughout. P. lecontei, p. 361 .

$a^{3}$ Superciliary stripes bright yellow, contrasting with the dusky buffy ear-coverts. $\quad$ P. s. alaudinus, p. 357.

$b^{3}$ Superciliary region buffy, like the ear-coverts.

C. bairdi, p. 358 .

b. Edge of the wing yellow; breast buffy without stripes (in adult).

A. s. bimaculatus, p. 359 .

\section{Western Vesper-Sparrow. Pocecetes gramineus confinis.}

A.O.U. Checklist no 540a-Colorado Records-Allen 72, pp. 149, 156 , 162 ; Aiken 72, p. 199 ; Ridgway 73, p. 182; Trippe 74, p. 129 ; Henshaw 75, p. 256 ; Scott 79, p. 93 ; Drew 81, p. 90 ; 85, p. 16 ; Tresz 81, p. 42 ; Allen \& Brewster 83, p. 189 ; Beckham 85, p. 141 ; Morrison 88, p. 74 ; 89, p. 36 ; Lowe 92, p. 101 ; Cooke 97, pp. 18, 101, 214 ; Dille 03, p. 74 ; Henderson 03, p. 108 ; 09, p. 236 ; Warren 06, p. 22 ; 08, p. 23 ; 09 p. 16 ; Gilman 07, p. 156; Markman 07, p. 157 ; Rockwell 08, p. 171 .

Description.-Male-General colour above pale greyish-brown, conspicuously striped with dusky black; wings dusky, edged with pale brown, lesser wing-coverts cinnamon or rufous-brown, forming shoulder-patch; tail like the wings, but the outer pair of feathers largely white, with a narrow basal strip of dusky along the inner webs; below white narrowly streaked with dusky on the breast and flanks; traces of a white nuchal collar, especially behind the ear-coverts; iris brown, bill horny, dusky toward the culmen and tip, legs pale brown. Length 6.0 ; wing 3.40 ; tail 2.60 ; culmen .45 ; tarsus .73 .

The sexes are alike; in the autumn after the moult they are rather more richly coloured with a rufous-brown tinge, but the change is not marked. Young birds closely resemble the adults, but the markings are not so well defined and the rufous or greyish edgings to the scapulars and secondaries are broader and more conspicuous.

Distribution.-Western North America except the Pacific coast; breeding from British Columbia and Manitoba southwards to the highlands of Mexico and Arizona; south in winter to Texas, southern Mexico and southern California.

The Western Vesper-Sparrow is a very common summer bird in Colorado, and is found throughout the State from the plains up to 
timber line; it is most common on migration in the plains, and nests most abundantly between about 7,000 to 9,000 feet. Grale took it at 11,000 feet on Bald Mountain, September 15th, 1888. It reaches southern Colorado early in April and the mountain parks a little later. The following are dates: Pueblo, April 4th (Lowe), La Plata co., April 3rd (Gilman), Mesa co., mid April till October (Rockwell), El Paso co., April 9th (Aiken), Sulphur Springs, April 26th (Warren, 08), Idaho Springs, early May (Trippe). It leaves in October-the latest I have is October 6th (Sapanero Creek, Gunnison co., Warren).

Habits.-The Western Vesper-Sparrow frequents open country where there are few bushes, and is fond of cultivated fields, the valleys of the larger streams in the mountains and grassy hill-sides; it has a good variety of songs, some of them very sweet, and sings late in the evening, whence its name. The nest is placed on the ground, usually in an open field, clear of any shelter; it is constructed of dried grass-stalks rather loosely put together, and lined with a little horsehair or other finer material.

Freshly laid eggs are found as early as the beginning of May in the south, but not generally till the beginning of June in the north of the State, and perhaps later still in the mountains, but a second brood is sometimes raised. The eggs are greyish or greenish-white, blotched and spotted with reddish and purplish-brown. The brooding hen sits very close, and does not flush till nearly trodden on.

\section{Genus PASSERCULUS.}

Rather small terrestrial, Sparrow-like Finches-wing under 3.0with small, conical bills and exposed nostrils; wings short, but still exceeding the tail and tarsus combined; less pointed than in Pooecetes, the difference between the primaries and secondaries far less than the tarsus; five outer primaries (ninth to fifth) more or less equal, the fourth distinctly shorter; tail nearly square about .65 length of wing, the feathers rather narrow but not attenuated or pointed at the tip. Plumage streaky, without white on the outer tail-feathers; a yellow superciliary stripe often present. 
This genus, as here restricted, contains four species, including several subspecific forms. It ranges all over North America including Mexico, but only one form comes within our limits (see key, p. 355).

\section{Western Savannah Sparrow. Passerculus sandwichensis alaudinus.}

A.O.U. Checklist 542b-Colorado Records-Allen 72, p. 162 (P. savanna) ; Henshaw 75, p. 254 ; Tresz 81, p. 41 ; Allen \& Brewster 83, p. 161 ; Drew 85, p. 16 ; Beckham 88, p. 122 ; Morrison 89, p. 36 ; Lowe 92, p. 101 ; Cooke 97, pp. 18, 101, 165, 214 ; Keyser 02, pp. 266, 274 ; Rockwell 08, p. 172 ; Henderson 09, p. 236.

Description.-Male-Above brown, streaked with black, especially conspicuous in the centre of the back; crown with a central stripe of pale buffy, and bright yellow superciliary stripes usually present, but varying in development; tail and wings dusky, edged with paler, but no distinct white; below white, marked with conspicuous black stripes on the sides of the throat, flanks and across the breast. Length 4.75 ; wing 2.75 ; tail 1.85 ; culmen .40 ; tarsus .73 .

The sexes are alike; young birds in the autumn have the edges of the feathers above much more rufous, and the chest and sides are also washed with the same colour, and the median buffy and superciliary yellow stripes are much less conspicuous and often obsolete.

Distribution.-Western North Americe, breeding from Alaska to southern Mexico and from the Pacific nearly to the Mississippi ; wintering in the southern part of its breeding range, from Arizona and southern California southwards to Guatemala.

In Colorado this Sparrow is most abundant on migration, especially in the plains, where it is not known to breed ; it resorts, however, to the mountains, where it is a common summer resident and breeder up to timber line. It reaches the State early in April-Pueblo, April lat (Lowe), El Paso co., exceptionally as early as March 19th (Aiken)- and remains as late as October 13th, but the late lingerers are chiefiy young birds.

The following are breeding localities recorded : Breckenridge (Carter), South Park (Allen, Tresz \& Keyser), Wet Mountain Valley (Aiken), Mesa co. (Rockwell), On migration it is common at Denver (Henshaw \& Morrison), El Paso and Lincoln cos. (Aiken), Pueblo (Lowe), Salida (Frey), Fort Garland (Henshaw), Fort Lyon and Fort Lewis (Morrison).

Habits. - A terrestrial bird, frequenting both moist meadow lands as well as the arid plains. Keyser found it nesting abundantly in South Park where it is 
very common. The males sit on the fence-posts or tall weeds, and pour out their weak but rather sweet little song while the females are busy on their nests. These are placed on the ground, generally flush with the surface, and concealed in the long grass to a certain extent. The eggs, four or five in number, are blueish white, spotted and blotched-sometimes so heavily as nearly to obliterate the ground-colour-with varying shades of brown. The date for fresh eggs is June or the beginning of July. Rockwell found it nesting commonly up to about 8,000 feet in Plateau Valley in May, June and July; it raises two broods, and there the favourite nesting-site is in the alfalfa fields.

\section{Genus CENTRONYX.}

Small Sparrow-like birds generally resembling Passerculus, but with the teil longer in proportion, about $\cdot 75$ the length of the wing; tail-feathers still narrower and distinctly pointed; inner secondaries elongated; outer primary shorter than the fifth; edge of the wing white; plumage streaky above and on the breast.

This genus contains only the single species here described (see key, p. 355).

\section{Baird's Sparrow. Centronyx bairdi.}

A.O.U. Cheoklist no 545-Colorado Records-Aiken 73, p. 236 (C. ochrocephahus); Ridgway 73, p. 190 ; Baird, Brewer \& Ridgway 74, p. 510 ; Henshaw 75, p. 253 ; 86, p. 333 ; Coues 78, p. 1 ; Drew 85 , p. 16 ; Morrison 89, p. 37 ; Cooke 97, p. 101.

Description.-Male-Sides and top of the head ochraceous-yellow, the crown and nape strongly streaked with black, tending to form two lateral bands of black; upper-parts, wings and tail dusky with brown, light brown and often white edgings to the festhers; edge of the wing white; outer pair of tail-feathers nearly white; below, the throat and chest with a pale wash of buffy, strongly streaked on the breast, sides of the throat and flanks with black; tail-feathers narrow, attenuated and pointed; iris brown, bill brown, legs pale horny. Length 5.0 ; wing 2.8 ; tail $2 \cdot 15$; culmen 40 ; tarsus 75 .

The above description is from a freshly moulted male, killed October 19th. The sexes are alike, and the young essentially like the adults. 
Distribution.-The plains of western North America, breeding in Alberta, Saskatchewan and Manitoba, south to eastern Montana and Minnesota; south in winter to Texas and north-west Mexico.

A rare bird in Colorado, only occurring on migration, chiefly in the autumn, and only along the eastern bases of the mountains. There is a good series of examples in the Aiken collection, taken between 22nd August and the 13th of October, all near Colorado Springs. The only other definite record is Del Norte on the Rio Grande, August 22nd (Aiken apud Henshaw); while so far as I am aware there is only one spring record-El Paso co., May 6th, 1873, the second specimen taken by Aiken (Ridgway, 73).

Habits.-Baird's Sparrow resembles the Savannah in its habits as well as in its appearance. Coues states that it took him several days before he could distinguish them in the field. The males often, especially in the breeding season, sit on low bushes and grass stems and sing, but the females keep concealed in the grass. The flight is very erratic, short and zigzag, and rather quicker than that of the Savannah. The nest was first found by Allen, July 1st, 1873, on Big Muddy Creek in Dakota ; it was a slight structure, placed on the ground, and contained five eggs, closely resembling those of the Vesper-Sparrow.

\section{Genus AMMODRAMUS.}

Small Sparrow-like birds resembling Passerculus, but with an even, more rounded wing, which is shorter than the tail and tarsus combined; tail relatively short, under -7 length of the wing; emarginate or slightly double-rounded.

Following Ridgway this genus contains only one species, running into several subspecific forms, distributed over North America, including Mexico and the Antilles (see key, p. 355).

\section{Western Grasshopper-Sparrow.}

Ammodramus savannarum bimaculatus.

A.O.U. Checklist no 546a-Colorado Records-Ridgway 73, p. 182 (C. passerinus perpallidus) ; Drew 85, p. 16 ; Morrison 89, p. 37 ; Cooke 97, pp. 18, 101, 166 ; Henderson 09, p. 236 ; Hersey \& Rockwell 09. p. 120. 
Description.-Male in summer-General colour above dusky brown, with paler, chiefly greyish-buffy edgings to the feathers; crown very dark with a narrow median, whitish stripe; superciliary stripe to top of the eye and edge of the wing bright yellow; a dusky postocular stripe; below whitish, faintly tinged with buff on the throat and breast, not striped; iris brown, upper mandible dusky, lower mandible pale brown, legs pale horn. Length 4.5 ; wing 2.3 ; tail 1.60 ; culmen .5 ; tarsus 7 .

The sexes are alike; after the eutumn moult the colours are much brighter, there is a good deal of chestnut and less black on the upperparts, while below the buffy wash is much more clearly marked and extends on to the fianks. A young bird is like the winter male, but does not at first have the yellow on the edge of the wing and over the eye, and the chest is distinctly streaked with dusky.

Distribution.-The western United States, breeding from Minnesota and Iowe to California, south in winter to Mexico and Costa Rica.

The Grasshopper-Sparrow does not appear to be a common bird in Colorado, or else it has escaped the notice of observers through its likeness to the Savannah and Baird's Sparrows. There are four Colorado examples in the Aiken collection, all obtained in El Paso co. on the plains on July 15th and 20th, August 8th and September 24th, the latter apparently a young bird in freshly moulted plumage. At Barr, Hersey and Rockwell state that it is not uncommon and nests. Cooke says that it reaches the State in the middle of May, though in his " dates of arrival," on p. 18, he notes it from Loveland on April 21st on the authority of W. G. Smith. One taken by Bragg near Haystack Butte in the plains of Boulder co., is now in the State collection at Denver (Henderson).

Habits.-Like Baird's Sparrow this is a thoroughly terrestrial form, frequenting old fields and skulking in the rank herbage. It derives its generic name from its likeness to a diminutive Quail (Coturnix), and its vernacular name from its peculiar chirring note, like that of a grasshopper. Allen found it nesting abundantly near Fort Hays in central Kansas, and took several sets of fresh eggs, usually five in number, between June 3rd and 10th.

\section{Genus PASSERHERBULUS.}

Small Sparrow-like birds resembling Passerculus, but with the tail nearly or quite as long as the wing and much graduated; the feathers narrow and pointed; ninth primary shorter than the seventh. 
This genus contains six species of Sparrow, with several additional subspecies, all confined to the eastern and central parts of North America (see key, p. 355).

\section{Leconte's Sparrow. Passerherbulus lecontei.}

A.O.U. Checklist no 548-Colorado Record-Cooke 98, p. 13 ; 97, p. 214.

Description.-Adult Male-Crown with a median stripe-buffy anteriorly, whitish posteriorly-separating two blackigh lateral stripes; rest of the upper-parts dusky with chestnut and pale buffy edgings to the feathers; tail-feathers very narrow and acutely pointed; a buffy superciliary stripe; below pale buffy, whitening on the throat and abdomen, streaked with black on the sides of the breast and flanks; edge of the wing white; no yellow superciliary spot; bill horn-brown, darker at the tip. Length 5.0 ; wing 2.05 ; tail 2.0 ; culmen .36 ; tarsus $\cdot 70$.

The sexes are alike; the birds in summer are less bright and have a black bill.

Distribution.-Middle of North America, breeding from Saskatchewan to northern Illinois, and migrating south to South Carolina and the Gulf states. Leconte's Sparrow is only of accidental occurrence in Colorado; it was taken by Carter at Breckenridge on October 24th, 1886. This is the only record for the State, though it has been obtained still further west, at Fort Sherman in north-west Idaho, by Merrill on September 28th ("Auk," XV., p. 16).

\section{Genus CHONDESTES.}

Medium-sized sparrow-like birds-wing 3.4-with a rather stout, conical bill and long and pointed wings; the difference between the length of the primaries and secondaries exceeding the length of the tarsus; tail about .78 length of the wing, strongly graduated, the outer feathers shorter than the middle ones by about the length of the culmen. Plumage streaky on the back, head stripped with chestnut, tail black, broadly tipped with white.

Only one species, separated into two races, is recognized; it is spread over western North America and Mexico.

Western Lark-Sparrow. Chondestes grammicus strigatus.

A.O.U. Checklist no 552a-Colorado Records-Allen 72, pp. 149, 156 ; Henshaw 74, p. 259 ; Drew 81, p. 139 ; 85, p. 16 ; Tresz 81, p. 245 ; Allen \& Brewster 83, p. 191 ; Beckham 85, p. 141 ; Morrison 88, p. 74; 89, p. 37 ; Lowe 92, p. 101 ; Cooke 97, pp. 19, 102, 214 ; Henderson 03, p. 108 ; 09, p. 236 ; Warren 06, p. 22 ; 08, p. 23 ; 09 , p. 16; Gilman 07, p. 156 ; Markman 07, p. 157 ; Rockwell 08, p. 172. 
Description.-Adult Male-Sides of the crown and ear-coverts rich chestnut, becoming black anteriorly; general colour above, including the median portion of the crown, pale brown; the back streaked with black; the wings dusky, edged with paler or whitish; the central tailfeathers dusky brown, the others black with increasing amounts of white at their tips from within outwards; the outer pair wholly white on the outer web, half white on the inner; a white spot below the eye, and a smaller one behind the ear-coverts; a line across the lores in front of the chestnut ear-coverts and along the malar region black; below dirty-white with a semi-concealed black patch in the middle of the breast; iris, bill and legs brown. Length 6.25; wing 3.5 ; tail 2.75 ; culmen .45 ; tarsus .74 .

The female is smaller-wing 3.35 -otherwise like the male.

Distribution.-Western North America from Manitoba westwards and southwards, south in winter to southern and Lower California, Mexico and Guatemala.

The Western Lark-Sparrow is a common summer resident throughout the whole of Colorado, though rarer in the west and south-west districts; it breeds abundantly in the plains and less commonly in the mountain parks and up to about 10,000 feet. The highest records I have come across are Pando, Eagle co., 9,200 feet (Warren 08), and Breckenridge, 9,700 feet (Carter apud Cooke). It reaches Colorado in spring, about the end of April-Pueblo, April 23rd (Lowe), Salida, May 14th (Frey), Baca co., April 26th (Warren, 06), Limon, April 30th (Aiken coll.), Mesa co., April Ist to September 22nd, extreme dates (Rockwell).

Habits.-One of the most characteristic birds of the prairies, this species seems equally at home on the high dry plains, in the cultivated fields, and in open groves along the rivers. It has a clear, rich and varied song, probably equal to that of any of the rest of the family. The nest is usually placed on the ground in the open, but often sheltered by a tuft of grass. It is made of grass and generally lined with cow or horse hair. Fresh eggs are to be found about the end of May or the first week in June. Warren (06) found fresh eggs near Springfield on May 28th, Dennis Gale at Gold Hill on June 3rd. They are usually three in number, and are white with a blueish tinge marked with a few spots and blotches 
and a number of dark, purplish-brown, zigzag lines, principally at the hinder end. They vary very much in size, but average $80 \times 70$.

Morrison found this bird nesting in trees and bushes twenty feet up, in the Arkansas Valley near Fort Lyon, where the ground was liable to be flooded.

\section{Genus ZONOTRICHIA.}

Medium to rather large Sparrow-like birds, with small, conical bills, and with nostrils, partly at any rate, concealed by bristles; wings fairly long and pointed, but the difference between the primaries and secondaries less than the tarsus; the ninth (outer) primary about equal to the fifth or fourth, the intervening sixth to eighth being the longest; teil long, nearly or quite equal to the wing, always above .90 of the wing, slightly rounded or double rounded; plumage with streaky back, and a crown either wholly or partially black.

As restricted by Ridgway, this genus is confined to North America, including Mexico. Of the six recognized forms no less than five have beer found in Coloredo, but only two of these are at all commonly met with.

KEY OF THE SPECIES.

A. Crown black, no median stripe, throat black. Z. querula, p. 363.

B. Crown black laterally, with a median stripe, yellow anteriorly, grey posteriorly.

Z. coronata, p. 367 .

C. Crown black laterally, with a median stripe of white.

a. Supraloral region bright yellow, a well defined throat-patch of white.

Z. albicollis, p. 367 .

b. Supraloral region black, continuous with crown and extending to anterior border of the eye.

Z. leucophrys, p. 364 .

c. Supraloral region grey, continuous with the superciliary stripe.

Z. 1. gambeli, p. 366 .

D. Crown with chestnut-brown lateral stripes.
a. Lores chestnut-brown.
$Z$. leucophrys, imm., p. 364 .
b. Lores pale buffy, like the superciliary stripe.

Z. 1. gambeli, imm., p. 366 .

\section{Harris's Sparrow. Zonotrichia querula.}

A.O.U. Checklist no 553-Colorado Records-Beckham 87, p. 122 ; Morrison 89, p. 37 ; Cooke 94, p. 183 ; 97, pp. 102, 214 ; H. G. Smith 08 , p. 187. 
Description.-Male-Top of the head, face and throat black; sides of the head and ear-coverts light brown; back and rump brown, the former streaked with derker; wings and tail dusky, the middle and greater-coverts tipped with white, forming a wing-band; below white, becoming pale brown on the flanks, which are streaked more or less with chestnut and dusky; iris brown, bill coral-red, legs light brown. Length 7.25 ; wing 3.5 ; tail 3.25 ; culmen .52 ; tarsus .90 .

The female resembles the male-wing 3.25 ; a young bird has the black crown-feathers edged with grey, the throat and chest white, the latter spotted with dusky.

Distribution.-Middle North America, breeding on the shores of Hudson Bay and south across the great plains and Mississippi Valley, to winter in Texas.

A rare straggler in Colorado in winter or on migration; a male in autumn dress, mingled with a flock of Juncos, was shot near Pueblo, October 19th, 1886, by Beckham; and Cooke observed one near Holly, in the south-east corner of the State, on May 10th, migrating with White-crowned Sparrows. Smith reports a female shot by W. C. Ferril, October 9th, 1907, near Kit Carson, in Cheyenne co., associating with a flock of Tree- and Vesper-Sparrows, while there are two Colorado examples in the Colorado College Museum-one from Salida, taken December 15th, 1907, by J. W. Frey, and another from Butte, El Paso co., taken January 24 th, 1908, by C. E. Aiken.

\section{White-crowned Sparrow. Zonotrichia leucophrys.}

A.O.U. Checklist no 554-Colorado Records-Allen 72, pp. 156, 163 ; Aiken 72, p. 200 ; Trippe 74, p. 155 ; Henshaw 75, p. 260 ; Scott 79, p. 94 ; Minot 80 , p. 229 ; Drew 81 , p. 138 ; 85, p. 16 ; Tresz 81, p. 246 ; Allen \& Brewster 83, p. 191 ; Beckham 85, p. 141 ; Morrison 88, p. 74 ; 89, p. 37 ; Kellogg 90, p. 89 ; Anthony 91, p. 379 ; McGregor 97, p. 38 ; Cooke 97, pp. 18, 102, 214; Keyser 02, pp. 54, 238, 281 ; Henderson 03, p. 236; 09, p. 236; Gilman 07, p. 157 ; Warren 08, p. 23 ; Rockwell 08, p. 172.

Description.-Adult Male-Crown with a median white stripe separating two broad lateral black ones; these are produced over the lores and cut off the narrow, white superciliary stripe in front; a narrow, postocular black stripe bounds the superciliary stripe below; hindneck, breast and back, ashy-grey, striped with dark brown; rump and tail plain brown, wings dusky, edged with paler or rufous ; the middle and greater coverts white-tipped, forming a double wing-band; below the ashy becomes whitish on the chin and abdomen, with a wash of pale buffy on the flanks and under tail-coverts; iris brown, bill reddishbrown, dusky at the tip; legs horny-brown. Length 6.65 ; wing 3.30 ; tail 3.0 ; culmen .5 ; tarsus 85 . 
The female is like the male but is smaller-wing about 2.9 ; and the white crown-stripe is sometimes narrower. A young bird has the lateral stripes on the head rich chestnut, not black, and the median stripe pale brown, and the ground-colour of the back cinnamon-brown rather than grey.

Distribution.-Breeding from Vermont and Manitoba northwards to Labrador and Greenland and south along the Rocky Mountains and Sierra Nevada to New Mexico and Arizona, south in winter over the eastern and southern states to Mexico as far as Mexico City.

In Colorado the White-crowned Sparrow is very common in the plains and along the foothills, and also on the western slope during the migration periods, but is confined to the mountains, from about 8,000 feet to timber line, during the breeding season. It arrives at Colorado Springs about the last week in April, and gradually moves up into the mountains, reaching timber line about the middle of June. After nesting it descends in September and October to lower levels, and lingers till early in November. Dennis Gale saw one on December 13th in the Boulder Valley, and belioved that a fow regularly wintered there.

Breeding records are: Near Ward, Boulder co., 10,000 feet (Gale), Chicago Lakes, 11,500 feet, Clear Creek co. (Trippe), Mount Lincoln Allen), Bailey, Park co., 7,700 feet, and Pikes Peak (Keyser), Salida, arriving April 19th and breeding (Frey).

Habits.-The White-crowned Sparrow is a somewhat terrestrial bird, frequenting the scrubby banks of streams, but seldom venturing on the open hill-sides; it is most abundant in June and July in the dense thickets that mark, as a rule, the upper limits of the timber. The male sings constantly during June, July and August, usually mounting on the top of a high bush or some other wellelevated perch for this purpose, and continuing often till late at night, while the female is incubating; the nest is placed sometimes on the ground under a bush, sometimes in a low bush twelve to thirty inches up. It is made of grass stems, and lined with finer material of the same sort, sometimes with a few hairs. The date of nesting is rather variable; Dennis Gale found fresh eggs at various dates between June 22nd and July 27th. The clutch numbers four or five, and the eggs are light greenish-white, mottled and speckled with two shades 
of chocolate and reddish-brown. Gale believed that only one brood was raised, but Drew states that in San Juan co. a first brood is hatched in Baker's Park, at a comparatively low elevation, and that the parents then move up to timber line and raise a second brood. This is confirmed by Anthony.

\section{Intermediate or Gambel's Sparrow. Zonotrichia leucophrys gambeli.}

A.O.U. Checklist no 554a-Colorado Records-Allen 72, p. 157 ; Aiken 72, p. 199 ; Rídgway 73, p. 182 (Z. l. intermedia); Henshaw 75, p. 261 ; Allen \& Brewster 83, p. 101 ; Stone 84, p. 20; Drew 85, p. 16 ; Beckham 85, p. 141; 87, p. 124; Morrison 87, p. 107; 89, p. 37 ; Kellogg 90, p. 89 ; Lowe 92, p. 101 ; Cooke 97, p. 102 ; Henderson 03, p. 108 ; 09 , p. 237 ; Warren 06, p. 22 ; 09, p. 16 ; Gilman 07, p. 157 ; Rockwell 08, p. 172.

Description.-Closely resembling $Z$. leucophrys, but the white superciliary stripe extending forward to the base of the bill, and the lores grey like the chin; the black crown-bands not extending so far down between the eye and the base of the bill ; iris reddish-hazel, bill yellowish with dusky tips, legs horny-brown. Length 6.10 ; wing 3.05 ; tail 2.65 ; culmen $\cdot 47$; tarsus $\cdot 82$.

Distribution.-Gambel's Sparrow breeds in north-western North America, from Alaska southwards to Montana; migrating south in winter through the western states to the middle of Mexipo.

In Colorado this subspecies is only known as a migrant, arriving rather earlier than the White-crowned, and very quickly passing on north to its breeding grounds. It reaches Colorado Springs about the last week in March, and is common through April, while Aiken saw a flock at Limon as late as the middle of May. In the fall they arrive as early as September 8 th, but chiefly pass through in October, and a large proportion are young birds with chestnut crown-bands. Other recorded localities are : Boulder co. (HEnderson), Orchard, March 29th (Warren), Denver, May 20th (Henshaw), Pueblo, arriving March 18th (Lowe), common in October (Beckham), Baca co., April 27th to May 15th (Warren), La Plata co. (Gilman).

There is evidence that this species occasionally winters in Colorado ; Osburn states that in the winter of 1889 he found Yellow-crowned mingled with this Sparrow on the Big Thompson near Lovelend, and there is a skin in the Aiken collection taken in El Paso co. on February 27th. Rockwell also reports that Sullivan has observed a few all through the winter at Grand Junction, and that they often linger up to the middle of December. 


\section{Golden-crowned Sparrow. Zonotrichia coronata.}

A.O.U. Checklist no 557-Colorado Records-Osburn 93, p. 212 ; Cooke 97, p. 102 ; Warren 09, p. 33.

Description.-Male-Top of the crown golden-yellow, bounded in front and on either side by a pair of black bands extending to the nape; occiput, sides of the head and throat ashy-grey; upper-parts brown; the back streaked with black; tips of the middle and greater coverts white, forming two distinct wing-bands; below ashy to brownishgrey, nearly white on the abdomen. Length $7 \cdot 10$; wing 3.20 ; tail 3.0 ; culmen .50 ; tarsus .93 .

The female closely resembles the male; the young birds have the head brown flecked with dusky and a wash of golden on the crown, but hardly any indication of the black side-bands at first.

Distribution.-Breeding in Alaslia; south in winter along the Pacific coast as far as Lower California and straggling eastwards to Nevada and Colorado.

There are only two records for Colorado: Osburn observed a small flock of this species in the winter of 1889 , in thickets along the Big Thompson near Loveland, mixed with flocks of the Gambel Sparrow on February 23rd; and Frey obtained a young male at Salida on April 19th, 1908, now in the Colorado College Museum.

\section{White-throated Sparrow. Zonotrichia albicollis.}

A.O.U. Checklist no 558-Colorado Records-Beckham 87, p. 122 ; Morrison 89, p. 37 ; H. G. Smith 96, p. 76; Cooke 97, pp. 103, 166.

Description.-Male-Crown with a median white band separating two lateral black bands, these again separated from a black postocular band by a superciliary stripe, yellow anteriorly, white posteriorly; rest of the upper-parts brown, more reddish and streaked with black on the middle of the back; wing-coverts tipped white, forming a double wing-bar ; edge of the wing pale yellow; below ashy-grey, paler on the abdomen, and a well defined white patch on the throat margined laterally with a narrow black rictal streak. Length 6.5 ; wing 2.8 ; tail 2.75 ; culmen $\cdot 40$; tarsus $\cdot 88$.

The female is very similar, but rather duller and slightly smaller; the young bird has the head markings ill-defined, of dark and light brown and no yellow eye-stripe; the chin-patch is indistinct and the breast slightly streaked with dusky.

Distribution.-Eastern North America, breeding from Massachusetts and eastern Montana northwards to Hudson Bay and Labrador; south in winter to Florida and Texas.

The White-throated Sparrow is a rare straggler to Colorado during the autumn migration. It has been recorded on three occasions only: 
near Pueblo, October 24th, 1886 (Beckham), at the same place October 18th, 1893, by Nash (Cooke), and at Coal Creek, eight miles east of Denver, October 5th, 1892 (H. G. Smith).

\section{Genus SPIZELIA.}

Small Sparrow-like birds with the wing about three inches or under, with small bills and nostrils at least partially hidden by bristles; wing rather long and pointed; ninth (outer) primary usually shorter than the sixth, fifth to eighth the longest; tail long, always more than .87 of the wing, sometimes exceeding it; forked or occasionally rounded. Plumage streaked above, plain grey below in adults, no yellow on the wing or elsewhere.

Ridgway recognizes seven species and twelve subspecies in this genus, ranging over North and Central America. Five occur in Colorado.

\section{KEY OF THE SPECIES.}

A. Larger ; wing over 3.0 ; a dark spot in the middle of the breast.

S. m. ochracea, p. 368.

B. Smaller; wing under 3.0; no dark spot on the breast.

a. Crown rufous.

$a^{1}$ A black or dusky streak through the eye.

S. p. arizonæ, p. 369 .

bi No black or dusky streak through the eye.

b. Crown streaked like the back.

S. p. arenacea, p. 373 .

a1 Back more heavily streaked with black on a richer brown ground; crown with traces of rufous at the bases of the feathers.

S. p. arizonæ, juv., p. 369 .

bI Back less heavily streaked on a paler greyish-brown ground; crown without any traces of rufous.

S. breweri, p. 372.

c. Crown with a median paler-greyish stripe, bordered by two lateral, very heavily streaked stripes. S. pallida, p. 371.

Western Tree-Sparrow. Spizella monticola ochracea.

A.O.U. Checklist no 559a-Colorado Records-Aiken 72, p. 200 ; Trippe 74, p. 147 ; Henshaw 75, p. 277 ; Drew 81, p. 91 ; 85, p. 16 ; Beckham 87, p. 122 ; Morrison 88, p. 74 ; 89, p. 37 ; Cooke 97, pp. 103, 215 ; Henderson 03, p. 236 ; 09, p. 237 ; Gilman 07, p. 157 ; Rookwell 08 , p. 172.

Description.-Male-Crown and occiput, a postocular stripe and a patch on side of breast rich chestnut ; a broad, grey superciliary stripe; above pale brown, the middle of the back and scapulars with black 


\section{Western Chipping Sparrow}

centres to the feathers; the hind-neck greyish; wings and tail dusky, the middle and greater coverts tipped, the inner secondaries edged, with white, forming a double wing-band; tail-feathers edged with whitish ; below dull white with a grey tinge on the throat and a brown tinge on the flanks; a median, semi-concealed patch of dusky on the breast; iris brown, upper mandible black, lower yellow, tipped with dusky; legs dark brown. Length 5.30 ; wing 3.05 ; tail 2.70 ; culmen .40 ; tarsus .83 .

The sexes are alike; in winter the crown-patch is more or less flecked with buffy.

Distribution.-Breeding in Alaska and Yukon; south in winter through western North American to Colorado, Utah, Arizona and Texas.

The Western Tree-Sparrow is one of the commonest of the winter visitors in Colorado, and is found throughout the State from the plains to about 9,000 feet-Crested Butte, October 10th (E. R. Warren), is the highest definite record I have met with. It reaches Colorado Springs, where it is abundant, at the end of October, and leaves again in March and April; Aiken's earliest and latest dates are, October 24th and April 20th. In south-west Colorado, according to Morrison and Gilman, it is not so abundent; but it is far from rare in Mesa co. up to 7,500 feet.

Habits.-The Tree-Sparrow is found everywhere-in thickets of scrub-oak and willow along the streams, or wherever there is shelter. It sings with a somewhat low and weak voice, but very sweetly in October after its arrival; and is able to endure a very considerable amount of cold. In winter it maintains itself almost entirely on seeds, and is often found mingling with the Junco flocks.

\section{Western Chipping Sparrow. Spizella passerina arizonce.}

A.O.U. Checklist no 560a-Colorado Records-Allen 72, pp. 149, 157, 163 ; Aiken 72, p. 200 ; Henshaw 75, p. 277 ; Scott 79, p. 93 ; Minot 80, p. 230 ; Drew 81, p. 91 ; 85, p. 16 ; Tresz 81 , p. 43 ; Allen \& Brewster 83, p. 190 ; Beckham 85, p. 141 ; 87, p. 124 ; H. G. Smith 86, p. 284 ; Thome 87, p. 264 ; Morrison 88, p. 74 ; 89, p. 37 ; McGregor 97, p. 38 ; Cooke 97, pp. 19, 103, 166, 215 ; Henderson 03, pp. 108, 236 ; 09, p. 237 ; Warren 06, p. 22 ; 08, p. 23 ; 09, p. 16 ; Gilman 07, p. 157 ; Rockwell 08, p. 172.

Description.-Male-Crown chestnut, the forehead black, often with a median spot of grey; back and scapulars pale brown streaked with dusky, becoming greyish on the nape and rump; wings and tail dusky, 
the coverts edged and tipped with pale rufous, not forming a very distinct wing-band; a white superciliary band, margined below by a generally rather ill-defined postocular black streak; below pale ashy-grey, whitish on the throat and under-tail-coverts, darkest on the ear-coverts ; iris brown, bill black, legs horny-brown. Length 5.05 ; wing 2.9 ; tail 2.55 , culmen .40 ; tarsus .70 .

The female resembles the male, but often has the crown-patch streaked with dusky. In winter the bill is brown, palest on the lower mandible. Young birds have no chestnut on the erown, which is streaked like the back; the lower-parts are also streaked with dusky; in the fall the breast-streaks disappear, and the birds then closely resemble Brewer's Sparrow; but the crown now begins to show the chestnut, especially at the bases of the feathers.

Distribution.-Western North America, breeding from Alaska to the Mexican border and from western Kansas to the Pacific, south in winter to southern Mexico.

In Colorado the Western Chipping Sparrow is a common summer visitor, breeding chiefly in the foothills and mountains up to about 10,000 feet. The highest record I have met with is Ward, Boulder co., 10,000 feet (D. Gale), but it is most commonly found between 6,000 and 7,000 feet. It reaches Colorado Springs from the south early in April, and remains in flocks till the middle of May, when it moves up into the mountains; it goes south again in October. The earliest date of arrival is March 24th, latest date October 24th in El Paso co., according to Aiken. It is a common summer bird in Mesa co. (Rockwell).

I have followed Ridgway in including all the Colorado Chipping Sparrows under the western subspecies. There is a very extensive series in the Aiken collection, most of which are undoubtedly the western form, though some appear to be somewhat intermediate; but the distinctive characters of the two races-that of dimensions, the western race certainly averaging larger-are very fine drawn.

Habits.-The Chipping Sparrow frequents cultivated fields and waste-places, and is very often to be seen in gardens and parks near houses, and is a somewhat familiar and domestic bird. It gets its name from its sharp, characteristic "Chip." The nest is placed low down, seldom over twelve feet from the ground, in a thick bush; the eggs, four or five in number, are pale blue, slightly spotted with reddish and purplish-brown, and measure $70 \times{ }^{\circ} 51$; Scott found three nests at Twin Lakes $(9,500$ feet), one June 14th with four fresh eggs, 
another July 4th with four eggs slightly incubated, and July 1lth with two chicks just hatched. Dennis Gale states that at Gold Hill, Chipping Sparrows arrive about April 30th, build June 20th, and lay July 4th.

\section{Clay-coloured Sparrow. Spizella pallida.}

A.O.U. Checklist no 561-Colorado Records-Allen 72, p. 149 ; Ridgway 73, pp. 182, 191 ; Allen \& Brewster 83,p. 191 ; Drew 85, p. 16 ; Beckham 85, p. 141 ; Morrison 89, p. 38 ; Kellogg 90, p. 89 ; Cooke 97, pp. 19, 104; Warren 06, p. 22.

Description.-Male-Above pale clay-coloured brown, heavily streaked with black; the head with a more or less distinct median stripe of grey or buffy, and a superciliary stripe of the same colour; a wash of grey round the hind-neck, forming a collar ; wings and tail dusky, the former with rufous edgings and tips to most of the feathers, but no distinct wing-bands; ear-coverts brown, margined above and below with a narrow streak of dusky; a rictal streak as well on the sides of the throat; below dull whitish with a faint buffy wash on the chest and flanks; upper mandible dusky, lower much paler, legs pale horny. Length $5 \cdot 1$; wing $2 \cdot 40$; tril $2 \cdot 5$; culmen $\cdot 37$; tarsus $\cdot 65$.

The sexes are alike, in winter the black streaks, especially on the head, are narrower ; the young birds are streaked with blackish on the breast.

Distribution.-The great plains region of North America, breeding from Saskatchewan to Nebraska and north-western Illinois and in eastern Colorado; south in winter to Lower California and over the Mexican plateau to the State of Oaxaca.

In Colorado the Clay-coloured Sparrow appears to be confined to the eastern plains section of the State, where it is fairly common on migration, and breeds, according to Aiken, commonly in El Paso and Fremont cos., as well as in the San Luis Valley. It reaches Colorado Springs in May, and is again seen in September, the extreme dates for El Paso co. in the Aiken collection being May 11th and September 28th. The only notice of its occurrence in the mountains is that of Kellogg, who procured a single example in Estes Park on August 10th. Other records are : Lincoln co., May (Aiken), Pueblo (Beckham), Baca co., common after May 4th (Warren).

Habits.-The Clay-coloured Sparrow is a characteristic bird of the great plains region, and is generally found about thickets and bush along river valleys; it has much the same habits as the Chipping Sparrow, which it closely resembles, and with which it is often associated. I 
have no details as to their nesting habits in Colorado but Elliott Coues found them breeding in large numbers on the Red River in Dakota, in June. Nests were placed in willow bushes within a few inches of the ground, and the eggs, three or four in number, were light greenish, scantily but sharply speckled with various shades of brown, and measured $62 \times 50$. The note of this bird is described by Beckham as a wheezy rattle, while Coues states that: "I know of no more assiduous and persistent songster than this little bird is, although his vocal efforts are of a humble sort."

\section{Brewer's Sparrow. Spizella breweri.}

A.O.U. Checklist no 562-Colorado Records-Ridgway 73, p. 182 ; Henshaw 75, p. 279 ; Allen \& Brewster 83, p. 191 ; Drew 85, p. 16 ; Morrison 89, p. 38 ; Cooke 97, p. 104 ; Henderson 03, p. 108 ; 09, p. 237 ; Warren 06, p. 23 ; 08, p. 23; 09, p. 16 ; Markman 07, p. 157.

Description.--Very similar to $S$. pallida, but the striping of the crown and back quite uniform throughout, and of a narrower character than that of $S$. pallida; the grey nape-collar, the white supercilium and the dusky postocular stripes are hardly to be distinguished, and the general colour is duller throughout; bill brownish, liliaceous-brown in life, lower mandible paler. Length 5.10 ; wing 2.53 ; tail 2.48 ; culmen .35 ; tarsus .60 .

The sexes are alike; the young closely resemble the adults, but have the breast streaked with dusky at first.

Distribution.-Western North America, breeding from British Columbia southwards to the southern limits of the United States; in winter south through north-western Mexico to Jalisco.

In Colorado Brewer's Sparrow is a summer resident most abundent in the sage-brush country of the south and west of the State, though far from uncommon in the eastern grassy plains as well. It does not appear to range up to any great elevation as a rule, but Henderson took two and saw several others at Silver Lake in Boulder co., at 10,000, in September. Brewer's Sparrow is a late migrant, reaching central Colorado early in May (earliest date for El Paso co, April 30th) and leaving again in early October. Other recorded localities are: Weld co. (Markman), Boulder co. (Henderson), Denver (Henshaw), Lincoln co. (Aiken coll.), Fort Lyon (Thorne apud Cooke), Baca co,, after April 29th, Routt and Rio Blanco cos. (Warren 06, 08). 
Habits.-Brewer's Sparrow hardly differs from the Chipping or Clay-coloured Sparrow in habits, except that it is a more western species and affects the sage bush (Artemesia) and greasewood (Sarcobatus) country rather than the grassy plains. It has a short, weak, tinkling song, and is frequently met with in flocks with Chipping Sparrows. It undoubtedly breeds in Colorado, but I have not met with any notice or description of its doing so. Mrs. Bailey states that the nest is placed in a sage bush and is made of fine grass stems and leaves, lined with horsehair; the eggs, usually four, closely resemble those of the Clay-coloured Sparrow, but are rather more distinctly marked.

Western Field-Sparrow. Spizella pusilla arenacea.

A.O.U. Checklist no 563a-Colorado Record-Cooke 09, p. 314.

Description.-Sexes alike; crown (generally with a medien stripe of grey), ear-coverts and postocular region dull chestnut; no decided black or white about the head; back brownish-ash with black streaks and pale edgings; below white unmarked, but washed with pale greyishbrown on the sides and breast; tips of the middle and greater coverts whitish, forming two cross-bands more or less distinct; iris brown, bill cinnamon-rufous, legs pale brown. Length 5.75 ; wing 2.75 ; tail 2.70 ; culmen .35 ; tarsus .75 . Young birds have the chest and sides streaked with dusky, and the crown duller and slightly streaked as well.

Distribution.-The western portion of the Great Plains, breeding from Nebraska to eastern Montana; south in winter to southerm Texas.

This bird has only recently been detected in Colorado. Miss Jennie Patten observed one at Yuma on May 9 th to 11 th, 1908. It is probably not uncommon in the eastern portion of the State.

\section{Genus JUNCO.}

Medium-sized; semi-terrestrial Finches with wings from three to four inches, and rather small, conical and generally pale coloured bills; nostrils nearly concealed by bristles ; wing moderately long and pointed, the ninth (outer) primary shorter than the fifth, usually longer than the fourth, the eighth and seventh the longest; tail long, at least (except in $J$. hyemalis) .90 of the wing, double-rounded, the outer and centrel feathers slightly shorter than the intermediate ones. Plumage (in all Colorado forms) plain greys and browns, without streaks in the adults, and with the outer tail-feathers always white. 
A genus of considerable size, containing at least thirteen species and a number of additional subspecific and intermediate forms, ranging over North and Central America as far as Costa Rica, but breeding in the higher mountains of the boreal zone only to the southwards.

Colorado has representatives of six species as well as three intermediate forms which are possibly hybrids.

KeY of THE SPECIES (for the intergrades, see p. 380).

A. Plain grey or dusky grey on the head and back.

a. Larger-wing $3 \cdot 35$-and paler; three outer tail-feathers white, a double white wing-bar.

J. aikeni, p. 374.

b. Smaller-wing 3.15-and duskier; third pair of outer tailfeathers largely dusky ; no wing-bars. J. hyemalis, p. 375 .

B. Back some shade of brown, contrasting with the head.

a. Head, neck and chest black, contrasting with the sepia-brown back; flanks slightly vinaceous. J. shufeldti, of p. 376.

b. Head, neck and chest greyish, not contrasting very strongly with the greyish-brown back.

$a^{2}$ Smaller; wing under 3.0; flanks slightly vinaceous.

J. shufeldti, ㅇ p. 376 .

$\mathrm{b}^{2}$ Larger; wing about 3.30 ; flanks strongly vinaceouspink, extending almost all over the abdomen.

J. mearnsi, p. 377 .

c. Centre of the back cinnamon-rufous, strongly contrasting with the dark slaty head; flanks grey.

$a^{2}$ Upper mandible pale (pinkish in life); below darker grey.

J. caniceps, p. 378 .

$b^{3} \quad$ Upper mandible blackish; below paler-grey.

J. dorsalis, p. 380 .

White-winged Junco. Junco aikeni.

A.O.U. Checklist no 566-Colorado Records-Aiken 72, p. 201 ; Ridgway 73, p. 613; Trippe 74, p. 145 ; Henshaw 75, p. 266 ; Drew 81 , p. 90 ; 85 , p. 16 ; Allen \& Brewster 83, p. 190 ; Beckham 87, p. 122 ; Morrison 88, p. 74 ; 89, p. 38 ; Cooke 97, pp. 104, 166, 215; Henderson 03, p. 236; 09, p. 237 ; Rockwell 08, p. 172 ; Cary 09, p. 182 ; Hersey \& Rookwell 09, p. 120.

Description.-Male-General colour above and below anteriorly, slaty-grey ; tips of the middle and greater wing-coverts, three pairs of outer-feathers, lower-breast and abdomen white; bill flesh-coloured. Length 6.90 ; wing 3.25 ; tail 3.05 ; culmen .48 ; tarsus .75 .

The female resembles the male, but is a shade paler in colour, and the wing-bands are not nearly so well marked, though there is considerable variation in this respect in both sexes. Some specimens have a distinct buffy wash on the back; these are probably young birds. 
Distribution.-The central regions of the United States, breeding in Wyoming, north-west Nebraska and Colorado, south in winter in Colorado, and occasionally to Kansas and Oklahama.

This Junco is a common winter bird in Colorado along the eastern base of the Rockies, and ranges as high as 10,000 feet (Trippe \& Gale); it reaches EI Paso co., where it is quite common, at the end of October, and leaves again at the end of March; the earliest and latest dates in the Aiken collection for El Paso co. are October 22nd and April 7th.

Other recorded Colorado localities are: Ward, 10,000 feet, April 8th (D. Gale), Idaho Springs (Trippe), Barr Lakes, rare winter resident (Hersey \& Rockwell), Pueblo (Beckham), north-west Baca co., November (Cary), San Juan co. (Drew), La Plata co. (Morrison), Mesa co. (Rockwell). I have a note of Professor Brunner that he observed this species in the Ute Creek district of Costilla, co. at an elevation of 10,000 feet in summer, so that it will probably be classed as a resident. This observation has recently been confirmed by Cary, who reports that Mr. Blanchard, of Boulder, showed him a nest containing young birds on June 11th, near Magnolia in Boulder co., at about 7,000 feet.

Habits. -The White-winged Junco arrives in Colorado, as a rule, after the first heavy snowstorm in the autumn. Though pretty generally associated with mixed flocks of other species, it occasionally forms little exclusive parties of its own. The favourite resorts of this and other Juncos are the bushes and thickets along the banks of streams, and especially in the neighbourhood of houses and ranches, where it picks up a living about the corrals and the straw-yards during the winter. If not molested it becomes fairly tame and confiding.

\section{Slate-coloured Junco. Junco hyemalis.}

A.O.U. Checklist no 567-Colorado Records-Aiken 72, p. 201 ; Trippe 74, p. 144 ; Beckham 87, p. 122 ; Cooke 97, p. 104 ; Henderson 03, pp. 108, 110 ; 09, p. 237 ; Warren 06, p. 23 ; Gilman 07, p. 157.

Description.-Male-Closely resembling $J$. aikeni in general coloration but slightly darker slaty, without any trace of the white wingbands, and with the third pair of tail-feathers (counting from the outermost) white on the outer, dusky on the inner half, instead of nearly pure white; iris dark reddish-brown, bill pinkish with dusky tip, feet brownish. Length 6.15; wing 3.15 ; tail 2.50 ; culmen .42 ; tarsus .70 . 
The female is of a lighter shade of slate, and the second pair of tailfeathers are partially dusky, the third pair almost wholly so; it is also smaller-wing 2.90. Young birds have a distinct wash of brown on the back.

Distribution.-Breeding from Alaska to Maine and northwards also south along the Alleghany mountains; migrating south to the borders of the United States from Florida to California.

In. Colorado the Slate-coloured Junco is a rather uncommon winter visitor, almost always found associated with other species of the genus; it has been chiefly taken along the eastern base of the Rocky Mountains, and hardly ever penetrates into the mountains themselves; it was noted by Trippe up to 8,000 feet. The earliest date for El Paso co. in the Aiken collection is November 25th, but it is less abundant in the early part of the winter than on the spring migration, when it has been taken as late as April 25th. Other recorded localities are Boulder co. (Henderson), Clear Creek co. (Trippe), Pueblo (Beckham), Lamar, April 6th (Warren), Fort Lewis, January and March (Gilman).

Habits. - A well-known winter bird in the east, but not at all familiar in Colorado, where it is always met with in flocks, mixed with the other Juncos. It has a cheery little chirp in winter, and in the north in its breeding grounds a pleasant song, not so often heard.

\section{Shufeldt's Junco. Junco hyemalis shufeldti.}

A.O.U. Checklist no $567 \mathrm{~b}$-Colorado Records-Aiken 72, p. 200 (J.oregonus); Trippe 74, p. 144; Drew 81, p. 90 ; 85, p. 16 ; Beckham 85 , p. 141 ; 87, p. 125 ; Morrison 89, p. 38 ; Lowe 94, p. 269 ; Coues 97, p. 95 ; Cooke 97, pp. 105, 215 (J.h. connectens); Henderson 03, p. 236 ; 09, p. 237 ; Gilman 07, p. 157 ; Warren 08, p. 23 ; 09, p. 16 ; Rockwell 08, p. 172.

Description.-Male-Head, neck, and chest very dark slaty-black, very clearly marked off from the sepia-brown of the back, the white of the lower-breast and abdomen, and the cinnamon-pink of the sides and flanks; wings and six central tail-feathers dusky; two outermost pairs white, third pair partly white and partly black ; iris reddish-brown, bill pinkish, dusky at tip; legs light brown. Length 5.90; wing 3.15; tail 2.85 ; culmen 40 ; tarsus 80 .

The female has the black of the head replaced by a dull slate, and the crown is washed with sepia-brown so as to obliterate the distinct line of demarcation between the head and back. 
I have followed Ridgway in the nomenclature of this subspecies; the earlier name- "connectens" of Coues, often applied to it, is stated by Ridgway, after an examination of the type, to be referable to a hybrid or intermediate form between $J$. hyemalis and the present subspecies.

Distribution.-Breeding in central and southern British Columbia, Washington and perhaps Idaho and Montana; south in winter over the Rocky Mountain region to Texas and northern Mexico.

In Colorado Shufeldt's Junco is a common winter bird, from the plains to about 10,500 feet; there is an example, taken at Lake Moraine on the slopes of Pikes Peak, 10,250 feet, by Warren in December, now in the Colorado College Museum; but it is most abundant at lower elevations from 6,000 to 8,000 feet. It arrives in El Paso co. at the end of October, and leaves again about the middle of April ; the earliest and latest dates in the Aiken collection being October 25th and April 9th. Other recorded localities are: Gold Hill, Boulder co. (D. Gale), Sulphur Springs, March 30th (Warren, 08), Clear Creek co. (Trippe), Pueblo (Beckham), Salida (Frey), Wet Mountains to 9,000 feet (Lowe), Mesa co. (Rockwell), Crested Butte (Warren), San Juan co. (Drew) and Fort Lewis (Gilman).

Habits. - This and the Pink-sided Junco are perhaps the two most abundant of the Juncos near Colorado Springs. They are to be seen on the ground or in low bushes, making short flights and exhibiting their white, lateral tail-feathers, which form an unfailing mark of recognition in the field. They are most often seen in the immediate neighbourhood of houses and ranches, where they pick up a living among the litter and straw.

\section{Pink-sided Junco. Junco mearnsi.}

A.O.J. Checklist no 568 (3rd ed., $567 \mathrm{~g}$ )-Colorado Records-Aiken 72, p. 201 (J. annectens) ; Trippe 74, p. 145; Henshaw 75, p. 268 ; Drew 81, p. 90 ; 85, p. 16 ; Allen \& Brewster 83, p. 190 ; Beokham, 87, p. 123; Morrison 88, p. 74; 90, p. 38 ; Lowe 94, p. 269 ; Cooke 97, p. 105 ; Henderson 03, p. 236 ; 09, p. 237 ; Gilman 07, p. 157 ; Warren 08, p. 23 ; 09, p. 16 ; Rockwell 08, p. 172.

Description.-Male-Head, neck and breast grey, becoming dusky on the lores; back, scapulars and edges of the secondaries drab-brown; wings and central tail-feathers dusky, two outer pairs white, third outermost pair white and dusky; below the sides and flanks broadly 
pink, leaving a narrow strip of white along the centre of the abdomen; bill pinkish, tipped with dusky, legs horn-brown. Length 6.10 ; wing 3.30 ; tail 3.0 ; culmen .48 ; tarsus .70 .

The female resembles the male, but is smaller-wing 2.9 ; the young bird has the crown and hind-neck washed with drab and the chest with pinkish.

Distribution.-Breeding in Idaho and Montana and migrating southwards to Arizona, New Mexico and the neighbouring portion of Old Mexico. In Colorado the Pink-sided Juneo is an abundant winter bird, especially along the eastern base of the Rocky Mountains, where, it abounds from the end of October to the middle of April; the earliest and latest dates for El Paso co. in the Aiken collection are October 24th and April 24th, but Mr. Warren tells me he has seen and obtained specimens as early as September 22nd on the Sapinero Creek in Gunnison. co., and as late as May 5th at Sulphur Springs. Dennis Gale observed this species at Ward in Boulder co., at an elevation of 10,000 feet, in early April, so that it is by no means confined to the plains.

Other recorded localities are: Clear Creek co., up to 9,500 feet (Trippe), Orchard, March 26th to 28th (Warren), Pueblo (Beckham), Fort Lyon (Thorne apud Cooke), Wet Mountains up to 8,500 feet (Lowe), Mesa co. (Rockwell), San Juan co. (Drew), and Fort Lewis (Gilman).

Habits. - The Pink-sided is perhaps the largest constituent of the winter flocks of Juncos in El Paso co. It has no characteristics distinguishing it from the other species.

\section{Grey-headed Junco. Junco caniceps.}

A.O.U. Checklist no 569 (3rd ed., 570b)-Colorado Records-Allen 72, pp. 157, 163, 177 ; Aiken 72, p. 200 ; 75, p. 370 ; Trippe 74, p. 144 ; Henshaw 75, p. 269 ; Ridgway 77, p. II ; Brewer 78, p. 72 ; Drew 81, p. 90 ; 85 , p. 16 ; Stone 82 , p. 191 ; 84 , p. 20 ; Tresz 81 , p. 246 ; Allen \& Brewster 83, p. 190 ; Beckham 85, p. 141 ; Morrison 88, p. 74 ; 89, p. 38 ; Kellogg 90, p. 90 ; Lowe 94, p. 269 ; Cooke 97, pp. 105, 166, 215 ; MeGregor 97, p. 38 ; Keyser 02, p. 74 ; Henderson 03, p. 236 ; 09, p. 237 ; Gilman 07, p. 157 ; Warren 08, p. 23 ; 09, p. 16; Rockwell 08, p. 172 ; 10, p. 164.

Description.-Malo-General colour above and below, slaty-grey, derkest on the crown and becoming much paler, almost white, on the centre of the abdomen and under tail-coverts ; a very distinct triangular patch of rich chestnut occupies the middle of the back, but does not extend on to the wings or rump ; wings and tail dusky, the two outer 
feathers of the latter white, the third pair partly white and dusky; iris brown, bill pale pinkish in life, dusky at tip, legs horn-brown. Length 6.10 ; wing 3.35 ; tail 3.05 ; culmen .40 ; tarsus $\cdot 75$.

The female resembles the male, but is smaller-wing about 3.0 ; a young bird is dull greyish-white on the head and neck and below, while the back is a duller shade of the adult chestnut; the head, back, throat and breast are all streaked with blackish; the streaking is lost by the first winter, when it is essentially like the adult.

Distribution.-Breeding in the mountains of southern Wyoming, south through Colorado, Utah and Nevada to northern New Mexico, wintering in lower levels in the mountains and in the foothills, and south to northern Mexico.

In Colorado the Grey-headed Junco is a resident, breeding everywhere in the mountains from about 7,500 feet (Magnolia, Boulder co., Sprague apud Cooke, 97) to timber line (Trippe). It winters in sheltered spots at lower elevations in the mountains, but is chiefly met with in the plains on the spring migration; nearly all Mr. Aiken's series from near Colorado Springs were obtained in March and April.

The following are some breeding records : Columbine Lake, Grand co., 9,000 feet (Rockwell), Estes Park (McGregor), Boulder co., 9,500 to 10,000 feet (D. Gale); near Hancock (Stone); Pikes Peak and Mount Fisher, near Trinidad (Aiken), Wet Mountains (Lowe); Mesa co. (Rockwell), San Juan co. (Drew), while it has been taken by Aiken on the plains at Resolis in Elbert co. (Drew), fifty miles from the mountains, as late as May 25th, and at Fort Lyon by Captain Thorne.

Habits.-The Grey-headed Junco is not commonly seen near Colorado Springs with flocks of the other species during winter; it seems to keep by itself and to remain at somewhat higher elevations, but in March and April it becomes abundant, arriving from the south and gradually moving up into the mountains to nest. Aiken (75) was the first to describe the nest and eggs of this species, but many observers have done so since. Fresh eggs are to be met with from the end of May till late in July, and there seems to be no reasonable doubt that two or three broods are raised in the season. Gale found a great many nests near Gold Hill, and the following is taken from his notes on the subject: "Nests on the ground, and is fond of selecting sheltered places such as the side of a hill or bank; the nest is well set in 
the ground and concealed with care and cunning, only the smallest aperture being left for the entrance and exit of the bird; it is generally placed under the shelter of some shrub or among its roots, under which a slight excavation in made; it is constructed of coarse grass, lined with finer material, and sometimes hair or feathers as well." The eggs are four or five in number; they are white or faint whitish-green, finely speckled with red, which becomes thicker at the larger end, but the amount of red freckling varies a good deal even with eggs from the same clutch. They measure about $83 \times{ }^{\circ} 60$.

\section{Red-backed Junco. Junco dorsalis.}

A.O.U. Checklist no 570a-Colorado Records-Morrison 89, p. 38 ; Cooke 97, p. 106.

Description.-Very similar to $J$. caniceps, but the patch on the back is of a darker and richer shade of chestnut-brown, and the under-parts are much paler grey throughout; the bill is larger, and the upper mandible blackish instead of yellow. Length 5.80; wing 3.20; tail 3.05 ; culmen .48 ; tarsus $\cdot 80$.

Distribution.-Breeding on the high mountains of New Mexico and Arizona; southwards in winter to northern Mexico and western Texas.

Morrison found a large flock of this Junco on the banks of La Plata River in the extreme south-west corner of Colorado, in the spring of 1887. This is the only record for the State, but as it is common in Arizona and New Mexico, it is probably not infrequent in the southern part of Colorado ; its similarity to $J$. caniceps has doubtless caused it to be overlooked.

Three intermediate forms must be here mentioned, each of which seems to connect two comparatively well characterized species. They may be regarded as intergrades between what are not really true distinct species or as simple hylbrids. They have all three been described under distinct names :-

Junco connectens $=J$. hyemalis $\times J$. shufeldti.

Junco hiemalis connectens Coues, Key N. Amer. Birds, 2nd ed., p. 378 (1884). 
This form combines the dark, sooty back of $J$. hyemalis with the lowerparts of $J$. shufeldti, the flanks being slightly tinged with pink, and sometimes ashy as well. It is far from uncommon near Colorado Springs during spring, and is represented in the Aiken collection by a good series obtained in March and April.

\section{Junco montanus $=J$. shufeldti $\times J$. mearnsi. \\ Junco montanus, Ridgway, Auk, XT., p. 321 (1898).}

In this form the head and chest are dark slate instead of black as in typical $J$. shufeldti, or pale grey-slate as in J.mearnsi, while the pink on the flanks is usually more developed than in J. shufeldti and less than in $J$. mearnsi. As the breeding range of this form is more or less intermediate between that of the more northern $J$. shufeldti and the more southern $J$. mearnoi, it is perhaps most logical to consider it as an intergrade rather than as a hybrid. There is a considerable series of this form in the Aiken collection, collected chiefly in the months of March and April when it is a common constituent of Junco flocks.

\section{Junco annectens $=J$. caniceps $\times J$. mearnsi.}

Junco annectens Baird, in Cooper's Orn. Cal., p. 564 (1870).

This form combines the chestnut back-patch of $J$.caniceps with the pink flanks of $J$. mearnsi. An example was obtained by McGregor ("Auk, X.," 1893, p. 205) near Boulder, on November 25th, 1892, in a mixed flock, and was identified as $J$. ridgwayi, which was subsequently shown to be a synonym of $J$. annectens. The only example in the Aiken collection is a male from Salt Lake City, taken by Aiken, April 16th, 1894. Aiken informs me that this is the prevailing form of Junco in the Utah plains during the migration season, and that it breeds in the Uintah Mountains.

\section{Genus AMPHISPIZA.}

Medium-sized or small terrestrial, Sparrow-like birds with small, conical bills and moderately long and pointed wings; the ninth (outer) primary shorter than the fourth, longer than the third; the eighth and seventh the longest; primaries exceeding the secondaries by less than the length of the tarsus; tail slightly shorter than (about .90 of) the wing, and slightly rounded or double rounded. Plumage plain greyish-brown with or without streaks on the back; tail blackish with a white or pale-coloured edging on the outer web of the outer feathers, and sometimes a white spot as well. 
This genus, as restricted by Ridgway, contains two rather distinct species with several additional geographical races; it ranges over the arid plains of south-west United States and northern Mexico.

A. A white superciliary stripe; throat-patch black in adults.

A. b. deserticola, p. 382 .

B. Only the supraloral spot white; chin and throat chiefly white.

A. nevadensis, p. 383 .

\section{Desert-Sparrow. Amphispiza bilineata deserticola.}

A.0.U. Checklist no 573a-Colorado Records-Ridgway 73, p. 182 ; Cooke 97, pp. 106, 215 ; Warren 06, p. 23 ; 09, p. 16 ; Gilmen 07, p. 157.

Description.-Male-Above plain greyish-brown; a conspicuous white superciliary and malar stripe, the former edged with black above; lores, malar region, throat and chest black; ear-coverts and sides of the chest ashy, shading into white on the rest of the lower surface; outer pair of tail-feathers with the outer web and a terminal spot about $\cdot 25$ inch long white; iris black, bill blackish with a paler spot on the lower mandible. Length 5.25 ; wing 2.75 ; tail 2.5 ; culmen .42 tarsus $\cdot 70$.

The sexes are alike, but the female is slightly smaller. A young bird is like the adult, but has no black on the head, the throat and chest being white, finely streaked with dusky.

Distribution.-The desert country of south-west United States and northern Mexico, from western Texas to southern California, and from northern Nevada and Utah to Chihuahua.

The Desert-Sparrow is not uncommon in the southern and southwestern portions of Colorado where desert conditions prevail, and where the sage-brush is predominant. It is probably a summer resident, wintering further south. The first definite record is that of Aiken, who obtained an example in Fremont co., July 27th, 1872. It has subsequently been recorded from near Cañon City by P. L. Jones, who found s single pair nesting in 1888 (Cooke), from Gaume's Ranche in the north-western corner of Baca co., where Warren found it common and breeding from 18th to 25.th May; from La Plata River near the New Mexican boundary, and from the McElmo district of Montezuma co. (Gilman), and Bedrock, Montrose co., after April 17th (Warren, 09).

Habits. -This bird is eminently characteristic of the dry mesas and sage-brush (Artemesia) and chaparalcovered wastes of New Mexico and Arizona, though it is to be found in the rocky hills as well. It has a cheerful song, with clear tinkling notes. The nest is placed low down in a bush, generally an Artemesia, 
and is composed of stiff grasses lined with finer, and often a few hairs; the eggs, usually three in number, are faint blueish-white without spots, or rarely faintly spotted, and measure about $\cdot 73 \times \cdot 58$.

The typical form of the species ( $A$. bilineata) replacing $A$. $b$. deserticola in middle and eastern Texas, is said to reach western Kansas, but the example from Fremont co. alluded to above, undoubtedly should be referred to the last named form, distinguished by its larger size, paler colour and smaller tail-spot.

\section{Sage-Sparrow. Amphispiza nevadensis.}

A.O.U. Checklist no 574.1-Colorado Records-Ridgway 73, p. 182 ; Henshaw 75, p. 275 ; Drew 85, p. 16 ; Cooke 97, pp. 106, 166 ; Dille 04, p. 79 ; 09, p. 87 ; Henderson 03, p. 108 ; 09, p. 237 ; Gilman 07, p. 157 ; Rockwell 08, p. 173 ; Warren 09, p. 16.

Description.-Male-Above pale sandy-brown, faintly streaked with dusky, becoming slaty-grey on the head and nape, including the earcoverts; wings and tail dusky, edged with pale brown, outer tailfeathers white on the outer web, and to a lesser extent along the edge of the inner; the angle and edge of the wing pale yellow; below, including a supraloral spot, a ring round the eye, and a stripe on the sides of the neck, white; a semi-concealed spot in the middle of the breast and stripes on the sidea dusky ; iris dark brown, bill blackish, lower mandible with a blueish tinge; legs horny-brown. Length 6.10 ; wing 3.20 ; tail 2.90 ; culmen .40 ; tarsus .80 .

The female is slightly smaller-wing about 3.0 ; the young birds have the head, chest and sides streaked like the back.

Distribution.-Breeding from Oregon and Wyoming south to New Mexico; further south to the Mexican border, western Texas and southern California in winter.

In Colorado the Sage-Sparrow is fairly common in the sage-brush plains of the south and west of the State, while along the eastern bases of the Rocky Mountains it is a rare straggler, and has only been once met with by Dille, near Longmont, on March 18th, 1904. It is reported by Aiken (Henshaw, 75) from the San Luis Valley, where Brunner also states it is a characteristic bird of the sage-brush flats below 8,000 feet; Warren informs me it is fairly common about Coventry in the spring, and Rockwell gives it as a common summer resident in Mesa co. at low elevations. 
Habits.-The Sage-Sparrow shares the desolate sagebrush plains with the Desert-Sparrow, and is common enough in suitable localities; it is very shy and runs quickly, with its tail erected vertically, like that of a Wren; its only note is a chirp, according to Henshaw, but Vernon Bailey states that during the breeding season " the sage-brush fairly rings with their simple but exquisitely sweet song." There is no definite information of their breeding habits in Colorado, but elsewhere the nest is placed low down in a bush and constructed chiefly of sage-brush, bark and dry grass; the eggs, three or fotr, are greenish-white, speckled chiefly at the larger end with reddish and darker brown.

\section{Genus PEUC左A.}

Small Sparrow-like forms-wing under 3.0-with moderate conical bills; wing short and rounded, hardly extending beyond the base of the tail; the ninth (outer) primary usually between the fourth and third; tail long, about the same length as the wing, sometimes slightly longer and very distinctly graduated, the outer tail-feathers falling short of the longest by .25 to .50 inch. Plumage streaked or scaly above, plain below; edge of the wing yellow.

This genus, following Coues, includes three species ranging over the southern United States and Mexico. One species only has been found in Colorado.

\section{Cassin's Sparrow. Peuccea cassini.}

A.O.U. Checklist no 578-Colorado Records-Warren 05, p. 417 ; 06, p. 23 ; Hersey \& Rockwell 07, p. 191.

Description.-Male-Above dark chestnut-brown, the feathers edged with grey, those of the back and rump with subterminal marks of black ; wings dusky brown, most of the feathers with paler edges; shoulder and edge of the wing yellow ; middle tail-feathers greyish with a median darker stripe with serrated edges; below white, washed with pale brown across the breast and on the flanks, the latter streaked with dusky. Length $5 \cdot 10$; wing 2.55 ; tail 2.50 ; culmen $\cdot 40$; tarsus $\cdot 70$.

These measurements are taken from a moulting bird in which the old tail-feathers had not been shed; the tail should average slightly longer than the wings. The sexes are alike.

Distribution.-Breeding in the arid districts of western North America from western Kansas and southern Nevada to northern Mexico. 
This Sparrow has only recently been detected in Colorado. Warren took a single female near Springfield in Baca co. in the south-easterm part of the State, May 27th, 1905. As its breast was bare of feathers he considered it might be incubating. That it does breed in the State is confirmed by Hersey and Rockwell, who found a nest near Barr in Adams co., on July 14th, 1907, and subsequently observed several other examples of this species. It is probably not uncommon throughout the dry plains of the eastern part of the State.

Habits.-Cassin's Sparrow is typically a bird of the arid plains dotted with mesquite, grass and low bushes. It is shy and retiring, but the male, in the breeding season at least, is one of the sweetest of songsters. It sometimes sings from a perch, but more often it rises in the air some twenty feet or more, then hovers and drops back on to its perch. Hersey and Rockwell found the nest well concealed in low rabbit-brush (Gutierrezia), and only visible from straight above; it was placed in the bush but rested on the ground, and was constructed of dry grass-stems and strips of bark, and lined with finer material of the same kind. The nest was rather deeply cupped and slightly rimmed in. The eggs, four in number, were pure crystalline white and rather pointed ; they average $\cdot 78 \times 57$.

\section{Genus AIMOPHILA.}

Small, Sparrow-like birds resembling Peuccea, but with a still shorter and more rounded wing, the ninth (outer) primary being shorter than the third and the tail always longer than the wing. Edge of the wing not jellow.

An extensive genus, with which Peucaa is merged by Ridgway, ranging over south-western United States and Mexico to Costa Rica, chiefly at high elevations in the south. One species only is a straggler to Colorado.

Scott's Sparrow. Aimophila ruficeps scotti.

A.O.U. Checklist no 580a-Colorado Record-Howell 05, p. 210.

Description.-Male-Above dark chestnut-brown, more rufous on the crown, all the feathers edged with ashy-grey; the rump and sides of the head nearly pure ashy-grey; tail and wings pale dusky, edged 
with brown; below white, washed with pale buffy and ashy, except on the throat and abdomen; a white supraloral and black submalar streak ; iris brown ; upper mandible dusky, lower paler. Length 6.10 ; wing 2.60 ; tail 2.90 ; culmen .42 ; tarsus .80 .

The sexes are alike; the young birds are duller brown above, streaked with grey and ashy below, finely streaked with dusky on the breast.

Distribution.-Western Texas to Arizona, south to north-western Mexico, north to southern Colorado, in which State it has only once been met with. A. H. Howell collected an immature example on September 17th, 1903, on a piñon ridge near Trinidad in the south of the State. It was evidently migrating southwards.

\section{Genus MELOSPIZA.}

Medium-sized Sparrow-like forms with a comparatively small wing, usually under $3 \cdot 0$, and a bill of varying proportions; wing short and rounded, barely reaching the base of the tail ; the ninth (outer) primary equal to or less than the fourth; tail long, nearly equal to or exceeding the wing; slightly rounded or double rounded. Plumage conspicuously streaked above and below (except $M$. georgianc).

This genus includes three species only; one of which ( $M$. melodia) has been sub-divided into a very large number of varying local races chiefly occurring on the Pacific coast. Twenty of these are recognized by Ridgway. The range of the genus includes the whole of North and Central America as far as Panama.

A. Below white, with brown streaks on the breast and flanks.

a. Larger-wing averaging $2 \cdot 85$-but with a smaller bill proportionally.

M. m. montana, p. 386 .

b. Smaller-wing averaging $2 \cdot 60$-but with a larger bill proportionally.

M. melodia, p. 388 .

B. Below with a buffy band across the chest, and flanks streaked with black.

M. lincolni, p. 388.

C. Below chiefly ashy, not streaked.

M. georgiana, p. 390 .

\section{Mountain Song-Sparrow. Melospiza melodia montana.}

A.O.U. Checklist no 581b-Colorado Records-Allen 72, pp. 147, 157 ( $M$. melodia); Henshaw 75, p. 281 ( $M$. melodia fallax); Tresz 81, p. 42 ; Allen \& Brewster 83, p. 189 ( $M$. fasciata fallax); Drew 85, p. 16 ; Beckham 85, p. 141 ; Kellogg 90, p. 90 ; McGregor 97, p. 38 ; Cooke 97, pp. 19, 107, 216 ; Keyser 02, pp. 133, 193 ; Dille 03, p. 74 ; Henderson 03, p. 108 ; 09, p. 237 ; Gilman 07, p. 157 ; Warren 08, p. 23 ; 09 , p. 16 ; Richards 08, p. 38 ; Rockwell 08, p. 173 ; Hersey \& Rockwell 09, p. 120. 


\section{Mountain Song-Sparrow}

Description.-Male-Above brown, rich umber on the crown, which has a median stripe of ashy-grey; greyer on the back; paler umber on the wings and tail ; the crown narrowly, the back broadly streaked with dusky brown; ear-coverts and a superciliary streak grey, separated by a brown postocular line; below white, the breast, malar region and flanks marked with wedge-shaped streaks of brown; in the middle of the breast the spots forming an irregular patch ; iris brown, bill dusky, base of the lower mandible paler; legs pale brown. Length 5.90; wing 2.85 ; tail 2.80 ; culmen .50 ; tarsus .85 .

The sexes are alike, the female averaging slightly smaller; young birds are very much like the adults but with greyish-white under-parts ; autumn birds are browner and the markings more diffused.

Distribution.-The Rocky Mountains region of the United States, breeding from Oregon and Montana southwards to Colorado, further south in winter to northern Mexico.

In Colorado the Song-Sparrow is a fairly common resident, breeding chiefly in the mountains at moderate elevations not exceeding 8,000 feet, while a fair number find winter-quarters in the foothills and at lower levels in sheltered spots. Richards saw a flock of about a hundred at Littleton near Denver on Christmas Day, and there are examples from El Paso co. in the Aiken collection taken every month from November to May. The migrants from the south arrive towards the end of March, and fresh eggs can be found about the end of May.

Other localities are : Estes Park (Kellogg), Blue River, Summit co., breeding at 7,000 feet, July 5 th (Carter); Grand and Routt cos. (Warren), Buena Vista, 7,960 feet (Keyser), Barr Lakes, summer and winter (Hersey \& Rockwell), South Park, breeding (Allen), Gunnison co., eggs, June 20th (Warren), Pueblo (Beckham), Salida, breeding (Frey), Fort Garland (Henshaw), Mesa co., common (Rockwell), and Fort Lewis (Gilman).

Habits. - More familiar perhaps in the east than in the west, the Song-Sparrow is a tuneful bird, enlivening the shrubbery and thicket with his cheerful note. In Colorado it is chiefly found among the bushes and in the meadows along the river valleys, and is not specially common, at least near Colorado Springs. The nest may be placed on the ground under the shelter of a grass tuft or bush, or sometimes on a low branch of a tree; it is constructed of coarse grasses and lined with finer, and sometimes a fow hairs; the 
eggs, four or five in number, are greenish to greyishwhite, thickly spotted and blotched with reddishbrown, and varying considerably in marking. They average $\cdot 70 \times \cdot 57$.

Two or three broods are often raised in the year. Dille gives May 29th as an average date for fresh eggs near Denver, Gale May 30th at Gold Hill, while Carter found a nest as late as July 5th, probably the second laying.

\section{Eastern Song-Sparrow. Melospiza melodia.}

A.o.U. Checklist no 581-Colorado Record-Cooke 97, p. 106.

Description.-Very close to $M$. m. montana, but rather smaller; the wing, tail and tarsus averaging less, but the bill distinctly stouter and more swollen; coloration brighter and less grey. Dimensions of an average male: length 5.85 ; wing 2.60 ; tail 2.55 ; culmen .50; tarsus 82 .

Distribution.-Eastern North America, breeding from Manitoba to Virginia and wintering in the northern part of its breeding range and further south; west to Kansas.

Cooke identified one out of five Song-Sparrows taken at Fort Lyon by Capt. Thorne as the eastern subspecies. This is the only definite record for Colorado. On the other hand a Song-Sparrow from Argentine in eastern Kansas in the Aiken collection seems rather to belong to M. m. montana.

\section{Lincoln's Sparrow. Melospiza lincolni.}

A.0.U. Checklist no 583-Colorado Records-Allen 72, pp. 157, 163 ; Trippe 74, p. 136 ; Henshaw 75, p. 283 ; Minot 80, p. 229 ; Drew 81, p. 90 ; 85 , p. 16 ; Tresz 81 , p. 43 ; Allen \& Brewster 83 , p. 189 ; Stone 84 , p. 20 ; Beckham 85, p. 142 ; 87, p. 125 ; Breninger 87, p. 191 ; Morrison 88, p. 74 ; Goss 91, p. 473 ; Cooke 97, pp. 19, 107, 216 ; McGregor 97, p. 38 ; Henderson 03, p. 236 ; 09, p. 237 ; Gilman 07, p. 157 ; Rockwell 08, p. 173.

Description.-Male-Above brown, more olive on the back, more chestnut on the head and wings, conspicuously streaked with black; median crown and superciliary stripes and sides of the neck ashy-grey; ear-coverts browner, margined above and below by a postocular and rictal streak of black; band across the chest continued forward to the malar region and backwards to the flanks, pale buffy; rest of the under-parts white, streaked with black throughout, except the centre 
of abdomen; ninth primary always longer than the fourth; iris brown, bill blackish, a pale spot at base of lower mandible, legs pale horn. Length 5.40 ; wing 2.60 ; teil 2.25 ; culmen .45 ; tarsus .80 .

The female is a shade smaller, otherwise like the male; young birds are like the adults but more buffy and with less defined markings.

Distribution.-Breeding from arctic North America southwards along the Rocky Mountains to Colorado, in the east to New York; in winter south to the southern states and Mexico as far as Panama.

In Colorado Lincoln's Finch is a common summer resident, breeding in the mountains from 9,000 feet up to timber line, but not, so far as I am aware, much below that level or in the plains. It reaches El Paso co. in April (though Aiken has seen it early in March) and gradually moves into the mountains or further north in May. It comes down again in October, leaving for the south soon after (latest date in Aiken coll. for El Paso co., September 28th).

Recorded breeding localities are: Valley of Cache La Poudre, Larimer co. (Breninger), South Park, near Fairplay, 9,700 feet (Allen \& Tresz), Breckenridge (Carter), Lake Moraine on Pikes Peak (Aiken), San Juan co. (Drew); on migration: Denver in May (Henshaw), Fremont co. and Limon, May (Aiken), Pueblo (Beckham), Fort Garland (Henshaw), Fort Lewis (Gilman).

Habits.-Lincoln's Sparrow is a very retiring bird, seldom leaving the thickets and undergrowth along the valleys of rivers and streams, where it keeps near the ground and obtains the seeds and insects which make up its food; it is very silent except in the breeding season, when it has a low but prolonged song not in any way very remarkable. It is stated by Cooke to breed in the foothills from 7,000 feet and upwards to timber line; but I have not been able to find evidence of nesting below about 9,500 feet. Dennis Gale took numerous clutches of eggs at Ward (about 10,000 feet) in Boulder co. Full sets of fresh eggs were found by him from June 10th to the end of the month, and he believed that the later dates represented a second brood. The nests were always placed on the ground, well sunk in, and sheltered by a tuft of long grass, a bush or a tree; the spot was generally a dry one in a damp locality near a 
lake or stream, and the nest was constructed wholly of dry grass; the eggs, four or five in number, are greenishwhite heavily marked, especially at the larger end, with lavender and chestnut-brown. They average $\cdot 80 \times \cdot 58$.

\section{Swamp-Sparrow. Melospiza georgiana.}

A.O.U. Checklist no 584-Colorado Records-Thorne 87, p. 264 (in error apud Cooke, 97, p. 39) ; Cooke 97, p. 166 ; Cary 09, p. 182.

Description.-Male-Forehead black, crown chestnut with a more or less indistinct median line of grey, sometimes plain, sometimes streaked with black; supereiliary line, nape and sides of the neck ashy-grey ; rest of the upper surface brown, heavily marked with black on the middle of the back; wings broadly edged with rufous; the two middle tail-feathers with a median stripe of dusky; below greyishwhite, the breast lightly, the flanks heavily washed with tawny-brown; Length 5.00 ; wing 2.35 ; tail 2.25 ; culmen $\cdot 40$; tarsus $\cdot 80$.

The sexes are alike; young birds and perhaps some adults have the crown plain brown, streaked with black.

Distribution.-Eastern North America, breeding from Illinois and Pennsylvania north to Labrador, south in winter to the southern states. A very rare straggler to Colorado. It was seen by Aiken near Colorado Springs on one occasion only, on the 22nd August, 1897 ; it has been taken more recently by Merritt Cary, of the Biological Survey, at Medano Springs Ranche, north-east of Mosca in the San Luis Valley, October 23rd, 1907.

\section{Genus PASSERELLA.}

Medium-sized Sparrow-like birds-wing from 3 to 4 ; with rather stout, strong bills; wing moderately long and pointed, the ninth (outer) primary about equal to the fifth ; tail long, from about 80 of the wing to longer than the wing, nearly square; feet and claws large, tarsus about twice as long as the culmen; outer toe reaching the subterminal phalanx of the middle toe. Plumage reddish and slaty above, below white with conspicuous triangular spots of reddish or dusky horn.

Only one species, including several geographical races, is included in this genus; it ranges all over North America as far south as California.

Slate-coloured Fox-Sparrow. Passerella iliaca schistacea.

A.O.U. Checklist no 585c-Colorado Records-Ridgway 73, p. 183 ; Cooke 97 , pp. 107, 167, 216; 98, p. 13 ; Gilman 07, p. 157 ; Rockwell 08, p. 173. 
Description.-Male--General colour above dark grey, becoming russetbrown on the wings and tail; a greyish-white supraloral spot and a few white specks round the eye; below white, the throst, chest and flanks with fairly large spots of sepia-brown; iris brown, upper mandible horn-brown, lower bluish at tip, whitish at base, legs fleshy Length 6.90 ; wing 3.15 ; tail 2.90 ; culmen .42 ; tarsus .93 .

The sexes are alike and nearly the same size; the young are like the adults, but the upper-parts are tinged with brown.

Distribution.-Breeding from the interior of British Columbia, south to south-east California and east to western Colorado; south in winter to New Mexico and Arizona. Casual to western Kansas.

In Colorado the Slate-coloured Sparrow is of rare occurrence. It has never been obtained east of the mountains, nor is there a Colorado example in the Aiken collection. In fact the only recorded occurrences are: Florissant about 8,000 feet, June, 1889, J. L. Goodale; Grand River, near Glenwood, June, 1897, D. Bruce; and Blue River, near junction with Grand River, July, 1877, Carter-all mentioned by Cooke; while it has recently been obtained by H. G. Smith, July 3rd, 1908, at Sulphur Springs, and was seen at Fort Lewis by Gilman. As it is common in parts of Utah, it will probably be found to be a summer resident on the western slopes of Colorado.

Habits.-Bendire ("Auk," VI., p. 113) gives a good account of the habits of this Sparrow as observed by him at Camp Harney, Grant co., Oregon, where he found it a very common summer resident. He states it was there a tame and familiar bird, keeping about the gardens and yards of the post and often consorting with the fowls. It was terrestrial in habits, spending most of the day scratching amongst manure heaps or fallen leaves in search of worms, larvæ and seeds. Nesting takes place at the end of May or beginning of June. The nest is a bulky structure, the outer coats of which consist of coarse grass, bark strips and fibre woven together in a damp or wet condition, and forming a compact, solid mass when dry. The lining is of fine grass or sometimes horsehair. It is usually placed in a willow or other bush, about three feet above the ground. The eggs, three or four in number, are pale greenish, fairly evenly 


\section{marked throughout with spots and blotches of various shades of brown and lavender, and measure $88 \times \cdot 63$.}

\section{Genus PIPIIO.}

Large terrestrial or semi-terrestrial Finches, exceeding seven inches in length, with moderate conical bills and very short and rounded wings; ninth (outer) primary very short, usually shorter than the second, seventh to fifth the longest; tail long, clearly exceeding the wing and more or less graduated; feet stout and strong. Plumage either pied, black and white and rufous, or plain brownish; only the young streaked.

This is a large genus, containing, according to Ridgway, twelve species, separated into some twenty-six subspecies, and distributed over North and Central America as far as Guatemala.

A. Throat and chest black or dusky-brown; outer tail-feathers tipped with white.

a. Tail longer, averaging 4.0 ; white spot on the outer tailfeather about 1.1 in length. $\quad$ P. m. montanus, p. 392.

b. Tail shorter, averaging 3.80 ; white spot on the outer tailfeather about 1.35 in length. P. m. arcticus, p. 394.

B. Throat and chest without black, like rest of under-parts ; tailfeathers without white.

a. Crown rufous; lores not dusky. $\quad$ P. mesoleucus, p. 394.

b. Crown brown like the back; lores and chin dusky.

P. aberti, p. 395 .

Mountain or Spurred Towhee. Pipito maculatus montanus.

A.O.U. Checklist no 588a-Colorado Records-Allen 72, p. 150 (P. erythrophthalmus oregonus) ; Ridgway 73, p. 192 ; Trippe 74, p. 176 (P. mac. arcticus); Henshaw 75, p. 303; Drew 81, p. 139 ; 85, p. 16 ; Allen \& Brewster 83, p. 191 ; Beckham 85, p. 142;87, p. 125 ; Morrison 88, p. 74; Lowe 92, p. 101 ; Cooke 97, pp. 18, 108, 216 ; Keyser 02, p. 36 ; Dille 03, p. 74 ; Henderson 03, p. 236 ; 09, p. 238 ; Warren 06, p. 23 ; 08, p. 23 ; 09, p. 16 ; Gilman 07, p. 157 ; Markham 07, p. 157 ; Rockwell 08, p. 173.

Description.-Male-General colour above, including the head, neck and breast, black, shading to dusky-grey on the rump; edges of some of the primaries and secondaries, tips of the middle and greater coverts, edges of the scapulars and some of the feathers of the back, terminal portions of the three outer pairs of tail-feathers and outer web, as well as in the outer pair, all white; below, centre of the lower-breast and abdomen white, sides and flanks tawny-rufous, becoming paler on the under tail-coverts; iris red, bill black, feet horn-brown. Length 8.0 ; wing 3.50 ; tail 4.0 ; culmen .55 ; tarsus 1.00 ; hind claw averages 50 ; and white on lateral tail-feather 1.1 


\section{Mountain or Spurred Towhee}

The female resembles the male but is slightly smaller-wing about 3.20, and has the black duller and of a more sooty shade. Young birds are tinged with rufous on the back, and are streaked below with dusky.

Distribution.-Breeding from British Columbia and central California eastwards to Wyoming, Colorado and western Texas, south in winter to northern Mexico.

The Mountain Towhee is a very common summer bird throughout Colorado in the plains, and at the lower elevations up to about 7,500 feet, occasionally reaching as high as 10,000 feet. It usually arrives about the end of March or beginning of April in the neighbourhood of Colorado Springs, and at correspondingly earlier and later dates to the south and north. It again leaves for the south in September. Aiken's latest date is September 26th.

The following are recorded localities : Weld co. (Markham), Boulder co. (Henderson), Idaho Springs, occasionally to 9,000 feet (Trippe), Lincoln co. (Aiken), Pueblo (Lowe), Baca, Routt, Montrose and Garfield cos. (Warren), La Plata (Morrison), San Juan co. (Drew), Mesa co. (Rockwell).

Habits. - The Mountain, or as formerly called, the Spurred Towhee, is rather a skulking bird, keeping near or on the ground in thick bush and scrub-oak, where it scratches away the fallen leaves for its food. It is often betrayed by its loud, harsh eall-note, which closely resembles that of a Catbird, and is quite different from that of the Chewink ( $P$. erythrophthalmus) of the east, though most observers say that its song is almost the same.

The nest is placed on the ground or in a low bush, often in scrub-oak or wild-rose bushes; it is built up of bark strips, leaves and grass. Fresh eggs are to be found in the neighbourhood of Denver (Dille 03) about June 12th, while Dennis Gale gives May 25th to June 10th for Gold Hill. The eggs, four or five in number, are pale greenish or blueish, finely speckled with brown and lavender, chiefly at the larger end. They measure $.95 \times \cdot 68$. 
Arctic Towhee. Pipilo maculatus arcticus.

A.0.ण. Checklist no 588-Colorado Records-Cooke 97, p. 107: Gilman 07, p. 157 ; Rockwell 08, p. 173 ; Henderson 09, p. 237 (some. of the records of $P$. m. montanus may refer to this subspecies).

Description,-Closely resembling $P . m$. montanus and distinguished. only by the relative characters of a shorter tail, tarsus, and hind claw, a smaller bill and a greater extension of the white patches on the tail. Wing 3.25 ; tail 3.80 ; eulmen .50 ; tarsus 1.0 ; hind claw .4 ; white on the lateral tail-feather 1.35.

Colorado specimens of this and the previous subspecies are most of them intermediate, which is not surprising, as this region lies more or less between the centres of the breeding areas of the two races, but on the whole those examples I have examined seem nearer to $P . m$. montanus.

Distribution.-Breeding in the plains and eastern foothills of the Rocky Mountains from Montana and perhaps Wyoming, northwards to the Saskatchewan, south in winter as far as Utah and Texas.

In Colorado a few Towhees winter in the foothills; these and other birds passing south in the fall and returning north in the spring are probably referable to this subspecies, but the difficulty of separating the two forms renders it impossible to give a satisfactory account of their respective ranges.

\section{Cañon Towhee. Pipilo fuscus mesoleucus.}

A.O.U. Checklist no 591-Colorado Records-Aiken 72, p. 202 ; Beckham 87, p. 123 ; Lowe 94, p. 269 ; Cooke 97, p. 108 ; Smith 08, p. 188 ; Cary 09, p. 182 ; Henderson 09, p. 238.

Description.-Male-General colour above pale greyish-brown, becoming dusky on the tail; crown chestnut-rufous; below grey, washed with buffy, becoming almost white on the middle of the abdomen, and tawny on the lower flanks and under tail-coverts; chest slightly mottled with black; a narrow terminal tawny band on the tail-feathers below; iris light brown, bill dusky brown, legs light brown. Length 7.80 ; wing 3.75 ; tail 4.0 ; culmen .54 ; tarsus 1.0 .

The sexes are alike.

Distribution.-A resident from the Arkansas Valley of Colorado, southwards through Arizona, New Mexico and western Texas to. northern Mexico.

In Colorado the Cañon Towhee is a common resident in the south of the State as far as the Arkansas Valley; there is an example from. Red Cañon, near Colorado City, in the Aiken collection, and it has recently been seen by the writer on Camp Creek, close by Colorado. City, constantly throughout the winter, while Smith has lately recorded 
an example from near Boulder, shot March 15th, 1895, by H. S. Reed. This is the most northern record. Others are Trinidad and Cañon City (Aiken), Pueblo (Beckham), Wet Mountains up to 10,000 feet (Lowe), Apishapa (Aiken collection), Las Animas, Bent co. (Smith), Gaume's Ranche and Caddoa in November (Cary).

Habits.-The Cañon Towhee is a terrestrial bird, delighting in dry, bare, rocky banks and arroyas; it is shy and difficult to observe. A pair noticed by the writer kept constantly near a barn-yard close to Colorado City all through the winter, and were frequently seen, but always made off at once into some thick oak-scrub close by. The nest has not been taken in Colorado, so far as I know, but Bendire ("Auk," VII., p. 22) gives a good account of their breeding habits in southern Arizona, where they are plentiful. The nest was placed not more than eight feet from the ground, usually in mesquite bush; it was constructed of plant and grass stems and lined with fine material, or horsehair if available; it was usually deep. Two or even three broods are raised in the year.

The eggs, usually three in number, are pearl-grey to bluish-white, spotted or blotched with a deep brown, almost black, the spots being generally connected with fine lines and scrolls. They measure $92 \times{ }^{\circ} 69$.

\section{Abert's Towhee. Pipilo aberti.}

A.O.U. Checklist no 592-Colorado Records-Henshaw 75, p. 306 Cooke 97, p. 108 ; Gilman 07, p. 157.

Description.-Male-General colour above greyish-brown, rather more dusky on the wings and tail ; lores and chin dusky-black; below cinnamon-grey, becoming more cinnamon and less grey posteriorly, especially on the under tail-coverts; a few dusky streaks on the throat. Bill greyish-brown, legs brown. Length 8.60 ; wing 3.60 ; tail 4.60 ; culmen .60 ; tarsus $1 \cdot 1$.

The sexes are alike; the young birds are paler and duller in colour, especially below, and have the breast indistinctly streaked with greyish or dusky. 
Distribution.-The desert regions of south-western United States, from south-east California to north-east New Mexico.

The occurrence of Abert's Towhee in Colorado rests on rather slender evidence. Henshaw found a nest containing two eggs which he believed belonged to this species at San Luis Lakes, north-west of Fort Garland, in 1873, but he did not obtain the bird itself. More recently Gilman saw, but did not procure, what he believed to be this species between Cortez and Navajo Springs, in the extreme south-western corner of the State.

\section{Genus OREOSPIZA.}

Medium-sized Finches-wing under 3.5-with moderate bills and exposed nostrils; wing short and rounded, though longer than in Pipilo; outer primary about equal to fourth ; seventh and sixth longest ; tail long, exceeding the wing, graduated, the outer feather falling short of the longest by about the length of the culmen; tarsus stout and strong, a little less than one-third of the wing. Plumage chiefly greenish, edge of wing yellow, crown rufous.

This genus contains only one western species, which has not yet been separated into recognized local races.

\section{Green-tailed Towhee. Oreospiza chlorura.}

A.O.U. Checklist no 592.1-Colorado Records-Allen 72, pp. 150, 157 ; Aiken 72, p. 202 ; Trippe 74, p. 176 ; Henshaw 75, p. 307 ; Scott 79, p. 94 ; Minot 80 , p. 230 ; Drew 81, p. 139 ; 85, p. 16 ; Allen \& Brewster 83, p. 192 ; Beckham 85, p. 142 ; Morrison 86, p. 153 ; 88 , p. 74 ; Breninger 88, p. 90 ; Kellogg 90, p. 89 ; Lowe 92, p. 101 ; 94, p. 269; McGregor 97, p. 38 ; Cooke 97, pp. 19, 108, 216 ; Keyser 02, pp. 37, 292 ; Henderson 03, p. 236 ; 09, p. 238 ; Warron 06, p. 23 ; 08, p. 24; 09, p. 16 ; Gilman 07, p. 157 ; Rockwell 08, p. 173.

Description.-Male-Crown and occiput chestnut, rest of the uppersurface, including the forehead, deep ashy-grey, washed slightly with yellowish-olive; the wings and tail strongly washed with olive-green, becoming bright yellow on the edge of the wing; a white supraloral spot and malar streak, bordered below by a black line; chin and throat white, contresting with the grey of under-parts, which pele to nearly white in the centre of the abdomen, and are washed with buffy on the flanks and under tail-coverts; iris reddish, bill black, paler on the lower mandible, legs horn-brown. Length 6.75 ; wing 3.20 ; tail 3.50 ; culmen .48 ; tarsus .90 .

The female resembles the male but is smaller-wing about 3.0 . The young bird is at first without the chestnut crown-patch and is more olivaceous and slightly streaked with dusky on the back, and has the flanks more strongly tinged with buffy. 
Distribution.-Breeding throughout the mountainous parts of western United States, from Montana to New Mexico and California; south in winter to middle Mexico and Lower California.

The Green-tailed Towhee is an abundant summer bird throughout the western mountainous half of Colorado, but is found but seldom east of the foothills on the plains, except in Bace co., where Warren (06) met with it commonly a.t Monon, on the Kansas border, in May. It reaches Colorado Springs about the end of April, though Aiken has taken one as early as March 19th, and leaves again at the end of September, spending the intervening time in the mountains, chiefly at elevations of 7,500 to 9,000 feet; the highest record I have met with is Gale's, who found several nests near Ward, in Boulder co., at 10,000 feet.

Other records are as follows: Estes Park (Kellogg), Clear Creek co. (Trippe), Denver (Henshaw), Resolis, Elbert co. (Aiken), Pueblo (Beckham), Fort Lyon (Thorne apud Cooke), Wet Mountains (Lowe), Moser Pass, breeding (Aiken), Breckenridge, breeding, 9,500 feet (Keyser), Routt co., Garfield co., and Crested Butte (Warren), San Juan co. (Drew) and La Plata co. (Gilman), Mesa co. (Rockwell).

Habits. -This Towhee is a sprightly and active bird, and though far from uncommon, is not so often seen owing to its retiring and shy nature; it is chiefly met with in moist thickets along the mountain streams; it has a pleasing song, but the call note closely resembles the scold of a Catbird. The nest is placed on the ground or in low bushes from twelve to twenty-four inches above the ground, and is constructed of coarse, wiry grass and other plant stems, and lined with finer material of the same nature, with the occasional addition of a few horsehairs; Galo describes the eggs as clear white with a speckling of warm brown, and states that the full clutches of four or five may be looked for between June 15th and 25th at 7,000 feet, and between June 30th and July 10th at 10,000 feet in Boulder co. Warren found this bird very common in the neighbourhood of Crested Butte, in Gunnison co., and examined a nest built in a low sage brush; it contained three young birds about ten days old, on July 10th; the nest was 


\section{three or four inches above the ground, and was almost completely hidden from sight.}

\section{Genus CARDINALIS.}

Rather large Finches with conspicuous crests; bill very large, stout and conical, much deeper than broad; depth about equal to culmen; wing rather short and rounded; tail longer than the wing and slightly rounded; tarsus moderate about 44 of wing; plumage wholly red in males, partly so in females, with a black face-patch.

The Cardinals are found throughout the southern United States and southwards to British Honduras; and again in northern South America. Only one species has been met with in Colorado.

\section{Cardinal. Cardinalis cardinalis.}

A.O.U. Checklist no 593-Colorado Records-Baird, Brewer \& Ridgway 74, p. 516 (in error); Cooke 97, pp. 108, 167.

Description.-Male-General colour above dull crimson, washed with grey, brightest on the head and crest; forehead, lores, chin and throat black; below bright crimson-red, becoming duller on the under tail-coverts and tail ; iris brown, bill bright orange-red, feet hornybrown. Length 8.40 ; wing 3.75 ; tail 4.00 ; culmen .65 ; tarsus .93 .

The female is dull olive-grey above; part of the crest, the wings and tail dull crimson; below a buffy-grey, fading to nearly white posteriorly; w young male is very like the adult female, but lacks the facial shield and has the bill dusky horn.

Distribution.-The eastern United States from about New York to the Gulf and westwards to eastern Kansas, breeding throughout its range.

The Cardinal can only be considered an accidental visitor to Colorado. Only two records are given by Cooke. One was taken near Denver December 5th, 1883, according to A. W. Anthony, another was seen by $H$. W. Nash near Pueblo, November 28th, 1895. The bird is rather a favourite cage-bird, and in both these instances may quite possibly have escaped from captivity.

Aiken tells me that Baird, Brewer and Ridgway's record is based on a mistake; he himself has never seen it in El Paso co.; but he has been recently informed of its occurrence during the winter of 1908-9 on Wright's Ranch in the Monument Valley a few miles north of Pueblo.

\section{Genus ZAMELODIA.}

Large Finches with very stout, swollen and deep bills, the lower mandible distinctly deeper than the upper; culmen rounded and nostrils exposed; wing long and pointed, the ninth (outer) primary 
always exceeding the fifth, sometimes the sixth; difference between the primaries and secondaries more than the length of the tarsus; tail comparatively short, between .7 and .8 in the wing; even or slightly rounded. Plumage with the under wing-coverts yellow or pink, and the wings and tail marked with white.

Two species only of this genus are generally recognized; it ranges over temperate North America, southwards in winter to northern South America.

A. Under wing-coverts red.

Z. ludoviciana, శ̊ p. 399.

B. Under wing-coverts yellow.
a. Chest tinged with rosy.
Z. ludoviciana, 우 p. 399 .
b. Chest cinnamon.
Z. melanocephala, of \& 우 p. 399.

\section{Rose-breasted Grosbeak. Zamelodia ludoviciana.}

A.O.U. Checklist no 595-Colorado Records-Cooke 97, p. 167 ; Burnett 02, p. 94 ; Henderson 09, p. 238.

Description.-Male-General colour above, including the sides of the head and throat black; rump, a patch at the bese of the primaries, tips of some of the coverts and tertiaries, subterminal patches on the inner webs of the three outer pairs of tail-feathers, all white; chest, axillaries and under wing-coverts rose-pink, rest of the lower-surface white; iris brown, bill light brown, dusky terminally, legs greyishhorn. Length 6.75 ; wing 4.0 ; tail 2.90 ; culmen .70 ; tarsus .80 .

The male in winter has the head and back brown, streaked with black, the under-parts pale brown, somewhat streaked with dusky. The female has the axillaries and under wing-coverts yellow, instead of rose-pink, and the wings and tail brown instead of black.

Distribution.-Breeding in esstern North America from Manitoba to Nova Scotia southwards to North Carolina in the mountains, south in winter to Ecuador and Colombia through Cuba, Jamaica and Mexico.

The status of this bird as a Colorado species rests on two occurrences. In the summer of 1894 a pair nested near the house of Mrs. J. W. Bacon at Longmont, in Boulder co.; the young were hatched and one was secured; Burnett saw a pair on June 1st, 1902, near Loveland, and secured the male. Goss states that it is not a common bird except on migration in eastern Kansas, and that he has not met with it west of Junction City in the middle of the State.

\section{Black-headed Grosbeak. Zamelodia melanocephala.}

A.O.U. Checklist no 596-Colorado Records-Allen 72, p. 149 ; Trippe 74, p. 167 ; Henshaw 75, p. 296 ; Minot 80, p. 230 ; Stone 81 , p. 45 ; Allen \& Brewster 83, p. 191 ; Beckham 83, p. 63 ; 85, p. 142 ; Drew 85, p. 16 ; Lowe 94, p. 269 ; Cook $\Theta 97$, pp. 19, 108, 216 ; Dille 
03, p. 74 ; Gilman 07, p. 157 ; Warren 08, p. 24 ; 09, p. 16 ; Rockwell 08, p. 173 ; Henderson 09, p. 238.

Description.-Adult Male-Top and sides of the head black; back black streaked with tawny ochre, wings and tail black, the former with white tips to the median and greater coverts and inner secondaries, and a white band across the bases of the primaries, the latter with large white subterminal spots on the inner webs of two or three of the outer tail-feathers; rump, collar round the hind neck and under-parts cinnamon or tawny, becoming white on the anal region; patch on the abdomen, under wing-coverts and axillaries lemon-yellow; iris dark brown, bill dull slate, paler on the lower mandible, legs bluish-grey. Length 7.20 ; wing 4.0 ; tail 3.20 ; culmen .70 ; tarsus .90 .

The female is dusky above, mottled with pale cinnamon streaks about the middle of the crown and on the hind-neck; the white markings on the wings much restricted, those on the tail absent; a white super. cilium; below much paler cinnamon than in the male, the sides and flanks with fine streaks of dusky, the centre of the abdomen and axillaries lemon-yellow. A young male is somewhat intermediate between the male and female; it has a buffy median stripe on the head and a marked supercilium.

Distribution.-Western North America, breeding from British Columbia to the southern Mexican plateau; migrant in the northern part of its range, resident throughout the year in the south.

In Colorado the Black-headed Grosbeak is a common summer resident, arriving late, about the middle of May, and departing about the beginning of September. Aiken's earliest date for El Paso co. is May 11th. It breeds throughout the plains and the mountains up to about 8,500 feet, at which elevation it was found nesting on the Blue River in Middle Park by Carter (Cooke 97); Lowe states that he has found it as high as 10,000 feet in the Wet Mountains, but this is not confirmed by other observers. Other records are: Boulder co. (Minot), near Denver (Allen), Bergin Park (Trippe), Pueblo (Beckham), Salida, arriving May 9th and breeding (Frey), Fort Garland (Henshaw), Routt and Gunnison cos. (Warren), La Plata co. (Gilman), Mesa co. (Rockwell).

Habits. - A handsome and conspicuous bird, this Grosbeak is generally to be found among deciduous trees and bushes along the courses of streams, where it feeds on buds and soft vegetable matter. It is said to have a predilection for garden peas and to be unpopular in consequence. The male has a superb song, generally given from the top branch of a tree, while Coues likened its call to that of a Gambel Partridge. 


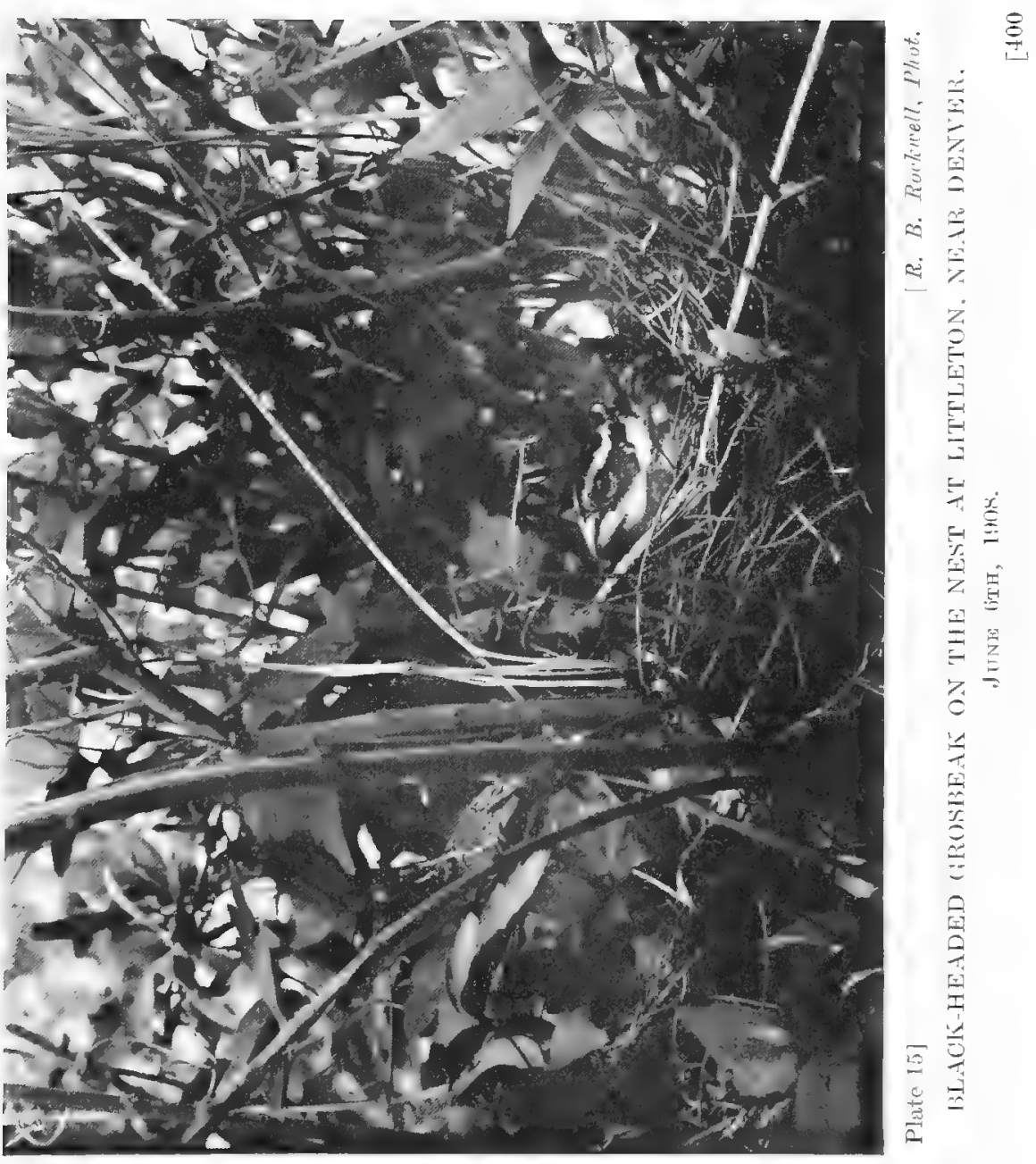



Dennis Gale's notes contain the following account of the breeding habits: "The nest is low down in bushes or small trees, usually in deep shade, constructed chiefly of stems of wild vines, and rather shallow and slight in the middle, so that eggs can be seen from below. The eggs are generally four in number, and vary a good deal in shape, size and markings; the ground-colour is some shade of pale green, speckled with umber or reddish-brown, chiefly at the larger end. Full clutches of fresh eggs are to be met with at the beginning of June, but a second brood is often raised later in the season. Both sexes assist in incubation, and the Cowbird not infrequently imposes on them." (Plate 15.) The eggs measure $1.05 \times 7$.

\section{Genus GUIRACA.}

Finches of medium size-wing 3 to 3.5 , with a large conical and somewhat compressed bill, the culmen rounded, not ridged; the lower mandible decidedly deeper than the upper; nostril exposed; wing fairly long and pointed, the difference between the primaries and secondaries about equal to the tarsus, the ninth primary longer than the fifth; tail of moderate length-over .8 in the wing-nearly even. Sexes distinct, male blue, female brown.

This genus includes only one species ranging over the southern United States and Mexico and south in winter to Cuba and Nicaragua. In Colorado only the larger western form occurs.

\section{Western Blue Grosbeak. Guiraca carulea lazula.}

A.O.U. Checklist no 597a-Colorado Records-Ridgway 73, p. 183 ; Baird, Brewer \& Ridgway 74, p. 516 ; Henshaw 75, p. 298 ; Drew 85, p. 16 ; Beckham 85, p. 142 ; Cooke 97, pp. 109, 167, 216 ; Dille 02, p. 94 ; 09, p. 87 ; Felger 02, p. 294 ; Henderson 03, p. 108 ; 09, p. 238 ; H. G. Smith 05, p. 82 ; 08, p. 188.

Description.-Male-General colour a rich ultramarine blue, back slightly shaded with dusky; a narrow black edging round the base of the beak; wings and tail dusky, with blueish edgings, middle wingcoverts rich chestnut, greater coverts tipped with paler chestnut; under tail-coverts and tips of the outer tail-feathers narrowly tipped 
with white; iris brown, upper mandible dusky, lower greyish-blue, feet dark horn. Length 6.80 ; wing 3.50 ; tail 2.95 ; culmen .67; tarsus $\cdot 80$.

The female is tawny-brown above, with a slight wash of blue on the rump, below paler brown or buffy, darkest on the breast-wing 3.35; a very young female is more dusky and shows narrow dark streaks below, while immature males show intermediate stages between adult females and males, gradually assuming the latter's plumage.

Distribution.-Breeding from California and Nebraska southwards to the tableland of Mexico; in winter the lower parts of Mexico and Central America to southern Costa Rica.

The Western Blue Grosbeak is a somewhat uncommon and locally distributed summer resident in Colorado, found most commonly in the south-eastern part of the State, though it has been taken as far north as Altona in Boulder co. (Felger \& Dille) and Wray in Yuma co., where it is not uncommon and breeds (Smith). It does not enter the mountains or indeed extend to a higher level than about 6,000 feet, nor has it been recorded at all from the west side of the continental Divide. It arrives rather late about the end of May, and leaves again in early September. Additional localities are: Morrison in Jefferson co. (Smith apud Cooke); El Paso and Lincoln cos. (Aiken); Pueblo co. (Beckham), and Fort Lyon (Thorne apud Cooke).

Habits. - Western Blue Grosbeaks are generally found. along the banks of streams where there are some trees and bushes. They are always rather local. They feed chiefly on seeds and buds, crushing the larger grains with their stout bills. The males sing quite sweetly in the breeding season, but are not specially highly rated in this respect.

P. L. Jones found four nests near Beulah in Pueblo co. in the summer of 1897 , but gives no details. Goss describes a nest taken near Wallace in Kansas, on June 16 th, as being built about seven feet from the ground in a willow tree; it was composed of the inner bark of a dead cotton-wood, mixed with leaves and bits of paper and lined with fine rootlets; it contained three eggs, blueish-white in colour, and unmarked; they measured $.85 \times \cdot 66$. 


\section{Indigo Bunting}

\section{Genus PASSERINA.}

Small Finches-wing under 3.0-with rather small acute and pointed bills, with the lower mandible deeper than the upper and the culmen ridged; nostrils exposed; wings moderately long and pointed, the ninth primary nearly the longest (in $P$. amcena), or rounded with the seventh and eighth the longest (in $P$. cyanea) ; tail moderate, exceeding .75 in the wing, more or less even; sexes unlike, males brilliantly coloured with blue and other bright colours, females mostly plain brown.

This genus, containing, according to Ridgway, six species, ranges over the temperate and tropical portions of North America as far south as Panama.
A. Blue above and below.
C. cyanea, $\delta$ p. 403.
B. Blue above, abdomen white, a red band on chest.

C. amcna, ơ p. 404.

C. Brown above.

a. Rump brown like the back, but slightly washed with greenish.

b. Rump dull slaty-blue.

C. cyanea, + p. 403 .

C. amcria, 우 p. 404.

\section{Indigo Bunting. Passerina cyanea.}

A.O.U. Checklist no 598-Colorado Records-Ridgway 73, p. 176 ; Cooke 97, pp. 109, 216 ; Burnett 00, p. 90 ; Felger 02, p. 294 ; H. G. Smith 08, p. 188.

Description.-Male-General colour azure blue, rather more ultramarine blue on the head; wings and tail dusky, edged with blue, the coverts and tertials almost black in the centre; iris brown, upper mandible black, lower greyish-blue with w narrow line of black from angle to tip, legs dusky. Length 4.75 ; wing 2.55 ; tail 1.90 ; culmen .40 ; tarsus $\cdot 62$.

The female is dark tawny-brown above with a trace of greenish wash on the rump; below dull white washed with buffy on the chest and more strongly on the sides and flanks, where there are traces of dusky streaks -wing 2.50. The young male is at first like the female and does not acquire the full adult blue livery for two or even three years.

Distribution.-Breeding throughout eastern North America, from Minnesota and Ontario southwards; south in winter to Bahamas and Cuba, and through eastern Mexico to Veragua in Colombie.

In Colorado the Indigo Bunting is hardly more than straggler; the following are the recorded instances of its occurrence: El Paso co. May 18th, 1872 (Aiken), Fort Collins, several seen one secured, May, 1900, by W. Link (Cooke); Clear Creek near Denver observed May 7th, 1901 (Felger); Hugo, Lincoln co., June 9th (H. G. Smith). 


\section{Lazuli Bunting. Passerina amøna.}

A.O.U. Checklist no 599-Colorado Records-Say 23, vol. ii.p: 47; Allen 72, p. 150 ; Aiken 72, p. 201 ; Trippe 74, p. 171 ; Henshaw 75, p. 300 ; Minot 80, p. 230; Allen \& Brewster 83, p. 191 ; Drew 85, p. 16; Beckham 85, p. 142 ; Lowe 92, p. 101 ; Cooke 97, pp. 19, 109, 217 ; Keyser 02, p. 154; Henderson 03, p. 236; 09, p. 238; Gilman 07, p. 157; Markman 07, p. 157; Warren 08, p. 24; 09, p. 16; Rockwell 08, p. 173.

Description.-Male-General colour above turquoise blue, washed with dusky in the middle of the back; wings and tail dusky, the middle wing-coverts broadly, the greater coverts narrowly tipped with white, forming a double wing-bar; lores black; sides of the head and throat like the back; chest taway, paling on the flanks and becoming quite white on the abdomen and under tail-coverts; iris brown, upper mandible black, lower greyish-blue with o dusky median streak; legs dusky. Length 4.90 ; wing 2.75 ; tail 2.12 ; culmen .40 ; tarsus .65 .

The female is earthy-brown above, with a slight wash of blueish on the rump; the coverts are tipped with pale buffy and the under-parts are dirty-white, with a buffy tinge across the chest. Young birds are rather more tawny above and have the blueish tinge on the rump. Young males in the second year have the blue of the back clouded over with cinnamon-brown.

Distribution.-Western North America, breeding from British Columbia and South Dakota to New Mexico, south in winter to lower California and the Valley of Mexico.

In Colorado this Bunting is a common summer bird on the plains and lower foothills up to about 7,000 feet, occasionally ascending to 9,100 feet, at which elevation it was taken by Prof. C. P. Gillette, July 7 th, 1896, on Little Beaver Creek in Larimer co. It arrives early in May-Aiken's earliest date is the 9th-and breeds towards the end of June. Other recorded localities are: near Greeley (Markman), Boulder co. (Henderson), Bergin Park (Trippe), Lincoln and El Paso cos. (Aiken), Pueblo (Henshaw), and on the west side of the Divide, Middle Park (Carter apud Cooke), Glenwood, Meeker and Gunnison cos. (Warren), Mesa co. (Rockwell), Fort Lewis (Gilman).

Habits. - The Lazuli replaces the Indigo bird in the west, and has very similar ways ; it frequents open country, where there are low bushes and has a weak and not very melodious or well sustained song, difficult to distinguish from that of the Summer or Mountain Warbler. It nests in a low bush, such as a wild-rose or cherry, and lays three or four blueish-white eggs, generally unspeckled, 
which measure about $78 \times 59$. Aiken found a nest on a hill-side near Colorado Springs in a rose bush, containing three eggs and one of a Cowbird, on June 19th, while Dennis Gale gives June 25th to July 5th as the average time for finding freshly laid eggs.

\section{Genus SPIZA.}

Medium-sized Finches-wing under 3.5-with a large bill somewhat compressed and acute; the culmen more than half the length of the tarsus and the lower mandible deeper than the upper; nostrils exposed; wing long and moderately pointed, the outer primary (ninth) longer than the sixth, often longest of all; inner secondaries slightly lengthened; tail rather short, about .75 of wing, more than half concealed by the upper tail-coverts, feathers narrow and pointed, especially when unworn; tarsus about as long or a little longer than the middle toe and claw. Plumage streaky brown above with yellow on head and throat.

Only the one species, here described, is generally known. A second supposed species is represented by one example in the U.S. National Museum.

\section{Dickcissel. Spiza americana.}

A.O.U. Checklist no 604-Colorado Records-Allen 72, p. 149 ; Ridgway 73, p. 183 ; Cooke 97, pp. 109, 167, 217 ; Henderson 03, p. 108 ; 09 , p. 238 ; Smith 08, p. 188.

Description.-Male-Top and sides of the head grey, generally washed with olive-yellow anteriorly; a yellow superciliary stripe; rest of the upper-surface brown, the middle of the back streaked with black, the lesser and middle coverts chestnut; below dull white; a triangular black patch on the throat of varying development; middle of the breast yellow ; malar stripe and edge of the wing yellow; iris brown, upper and tip of lower mandible blackish, lower and sides of upper blueish, feet brown. Length 6.50 ; wing 3.25 ; tail 2.50 ; culmen .60 ; tarsus .88 .

The female is markedly smaller-wing about 2.90 , tail 2.0 -and cluller than the male; the chestnut wing-patch and black throat-patch are absent and the yellow on the head and breast much restricted. Young birds have a more buffy tinge and traces of black stripes on the flanks.

Distribution.-Eastern North America, breeding from South Dakota and Massachusetts south to the Gulf; south in winter through Mexico and Central America to Colombia and Trinidad. Now almost extinct as a breeding bird east of the Alleghanies. 
The Dickcissel is a rare bird in Colorado, and has only been found on the eastern plains and foothills of the mountains. Though noted by Allen as " common near Colorado City" in 1871, it has only been met a few times since. There is one example in the Aiken collection taken near Colorado Springs August 29th, 1897 ; Capt. Thorne saw six near Fort Lyon June 22nd, 1884 ; P. L. Jones found it nesting in 1890 near Cañon City, and a few pairs spend the summer near Fort Collins (Cooke); recently Smith found it to be not uncommon near Wray in June, and has little doubt that they nest in the neighbourhood of the town, and also on Boye's Ranche, some twelve miles to the south.

Habits. - The Dickcissel is a well-known bird in the middle west, making its summer-home on the open fields and prairies. The males are very conspicuous in the breeding season, perching on tall weeds or fence posts, and continually giving vent to their somewhat inharmonious attempts at song. They are strong on the wing, but seldom fly high, except on migration. Their food is chiefly seeds with some berries, and insects especially when rearing their young.

The nest is placed upon the ground or in a low bush ; the eggs, four or five in number, are uniform light blue, and measure $82 \times \cdot 63$.

\section{Genus CALAMOSPIZA.}

Terrestrial Finches of medium size-wing under 3.75-with a stout, somewhat swollen bill; the upper and lower mandibles about equal in depth; the culmen more than half the length of the tarsus ; nostrils exposed; wing long, the four outer primaries about equal and abruptly longer than the fifth; inner secondaries elongated so that the difference between primaries and secondaries is less than the tarsus; tail about .78 of the wing ; tarsus stout about one-third of tail. Sexes distinct in summer, alike in winter; males black with white wing-patch, females and winter males streaked.

Only one species is included in this genus.

\section{Lark-Bunting. Calamospiza melanocorys.}

A.O.U. Checklist no 605-Colorado Records-Baird 58, p. 493 (C. bicolor); Allen 72, pp. 149, 157 ; Henshaw 75, p. 294 ; Allen \& Brewster 83, p. 191 ; Drew 85, p. 16 ; Dille 86, p. 29 ; 03, p. 74 ; Lowe 
92, p. 101 ; Cooke 97, pp. 19, 109, 217 ; Keyser 02, p. 285 ; Henderson 03 , p. 236; 09, p. 238 ; Warren 06, p. 23 ; 08, p. 24 ; 09, p. 16 ; Gilman 07, p. 157 ; Markman 07, p. 157 ; Cary 09, p. 183.

Description.-Male-General colour black above and below, middle and greater coverts white forming a conspicuous wing-patch; narrow white borders and tips to many of the wing and tail-feathers and coverts, these often wearing off later in the summer; iris brown, bill dusky blue, legs dark horn. Length 5.25 ; wing 3.50 ; tail 2.75 ; culmen .55 ; tarsus $\cdot 90$.

The female is buffy-brown above streaked with dusky, and white below streaked with blackish; the wing-patch as in the male but rather smaller and tinged with buffy. The male in winter is like the female, but the bases of the feathers, especially of the under-parts, are black, and tend to show through; the chin also is black. The young bird is also like the female but is more buffy.

Distribution.-The great plains of middle North America between the Missouri and the Rocky Mountains, breeding from Assinaboia to Kansas, south in winter through Texas to southern California and the Mexican plateau as far as Guanajuato.

In Colorado the Lark-Bunting is one of the commonest summer birds on the dry eastern prairie portion of the State. It enters the foothills and mountain parks, but is not often seen at elevations above 8,000 feet, though found breeding by Carter (Cooke 97) near Dillon at 8,800 feet. On the western side of the range it was met with by Warren at several localities in Routt co. near Yampa and Steamboat Springs, and Gilman observed it near Cortez in the extreme south-west corner of the State. Other localities are: near Greeley (Markman), Boulder co. (Henderson), Denver (Henshaw), South Park (Allen), El Paso and Lincoln cos. (Aiken), Pueblo (Lowe), Salida (Frey), near Saguache (Cary), and Monon, Baca co. (Warren).

The Lark-Bunting arrives early in May (April 30th at Monon, May 9th at Pueblo), the males first, the females about a week later; they leave again at the end of August. Cary saw a belated fall-migrant as late as November 7th near Saguache in San Luis Valley.

Habits.-This bird, often miscalled the Bobolink in Colorado, is one of the most characteristic features of prairie bird-life. It is usually met with in flocks of twenty to forty birds in early May, and again after the breeding season is over, when the post-nuptial moult has taken place and the sexes are alike. It is a bird of powerful flight, delighting to struggle against the strongest gales 
when most birds take shelter. During the breeding the males sing very continuously, sometimes perched on tall weed stalks, but more often on the wing. They rise obliquely in the air at an angle of about $50^{\circ}$, to a height of fifteen or twenty feet, then descend obliquely again, alighting fifteen or twenty feet from where they started, singing continuously.

The Lark-Bunting breeds early in June, and fresh eggs are to be met with about June 5th near Denver (Dille). There is a clutch of fresh eggs in the Colorado College Museum, taken by I. C. Hall as late as July 5th near Greeley'; perhaps this is a second brood. The nest in this case was placed in a slight hollow in the ground, in a freshly cut alfalfa field, and was made up of alfalfa stems and leaves. The eggs, five in number, are pale greenish-blue and unspotted; they measure about $90 \times 65$.

\section{Family TANGARIDA.}

Bill conirostral, resembling that of the Fringillido, but without any angulation at the base of the commissure or cutting edge, though often dentirostral, i.e. with an indication of a tooth-like projection about half way along the cutting edge; primaries nine in number; habit frugivorous and insectivorous but never graminivorous,

It is difficult, if not impossible, to draw an absolute distinction between this family and the Fringillidoe though the conformation of the bill is generally available. The Tanagers are mostly birds of brilliant colouring and are confined to America, where they are chiefly met with in the tropical regions. Only one genus is represented in Colorado. 


\section{Western or Louisiana Tanager}

\section{Genus PIRANGA.}

Medium sized Tanagers with the cutting edge of the upper mandible generally prolonged into a median tooth ; nostrils basal, not concealed; wing long and pointed, the outer three or four primaries about equal and longest; tail shorter than the wing and slightly forked; tarsus short and weak; sexes unlike; males with at least the head red.

The range of this genus includes the greater part of the temperate and tropical regions of America. One species only is commonly found in Colorado, two others are accidental or casual visitors.

A. Plumage with red at least on the heads (males).

a. Only the head and neck red, wings black with yellow wingbars.

P. ludoviciana, ơ p. 409.

b. Wings and tail black, rest of plumage red.

P. erythromelas, $\delta$ p. 410.

c. Whole plumage dull red, wings dusky, largely edged with red.

P. cooperi, of p. 411 :

B. Plumage chiefly olive-green, no red.

a. Wing with two conspicuous white or yellow cross-bands.

P. ludoviciana, ㅇ p. 409 .

b. No wing-bands.

$a^{2}$ Under wing-coverts white with a darker dusky border.

P. erythromelas, 우 p. 410 .

b $^{2}$ Under wing-coverts yellow, without dusky border.

P. cooperi, ㅇ p. 411 .

\section{Western or Louisiana Tanager. Piranga ludoviciana.}

A.O.U. Checklist no 607-Colorado Records-Allen 72, p. 149 ; Aiken 72, p. 199 ; Trippe 74, p. 232 ; Henshaw 75, p. 235 ; Scott 79, p. 92 ; Minot 80 , p. 228 ; Drew 81 , p. 88 ; 85, p. 15 ; Allen \& Brewster 83 , p. 159 ; Beckham 85, p. 141 ; Morrison 88, p. 73 ; Kellogg 90, p. 89 ; Lowe 92, p. 101 ; 94, p. 269 ; McGregor 97, p. 38 ; Cooke 97, pp. 19, $110,167,217$; Keyser 02, pp. 39, 279 ; Henderson 03, p. 236 ; 09, p. 238 ; Gilman 07, p. 158 ; Warren 08, p. 24 ; 09, p. 17 ; Rockwell 08, p. 174.

Description.-Male-Head and neck all round and upper-breast crimson-red, becoming more orange in shade posteriorly; centre of back, wings and tail black, lesser wing-coverts, tips of the greater coverts, rump, upper tail-coverts and rest of the under-parts canaryyellow, tips to the inner secondaries and tail-feathers whitish; iris brown, bill horn, waxy-yellow towards the base, legs blueish-grey. Length 6.75 ; wing 3.8 ; tail 2.75 ; culmen .60 ; tarsus .75 .

The female has the crown and rump dull olive-green, the centre of the back grey and the wings and tail dusky; the coverts and inner secondaries edged and tipped with yellowish or whitish, forming a 
double wing-band; below dull yellowish, becoming brighter on the centre of the breast and the under tail-coverts; size about the same as the male. A young female is still duller in colour. A young male has no crimson on the head, and resembles the female but is rather brighter in tone.

Distribution.-Breeding in western North America from the eastern base of the Rocky Mountains to the Pacific, and from British Columbia. southwards; in winter south over the greater part of Mexico to the highlands of Guatemala.

This Tanager is a common summer bird in Colorado, breeding chiefly in the mountains from about 6,500 to 10,000 feet. It arrives about the middle of May at Colorado Springs. Aiken's earliest date is May 11th. About a fortnight later it moves up into the mountains, coming down to the plains again early in September and leaving soon after, though taken by Aiken as late as October 14th at Pueblo (Henshaw). It is well distributed over the whole of the State except in the plains region east of the mountains. The following are some additional recorded localities: Estes Park (Kellogg), Idaho Springs (Trippe), Wet Mountains (Lowe), Fort Garland (Henshaw), Routt and Gunnison cos. (Warren), Glenwood Springs (Keyser), Mesa co. (Rockwell), La Plata co. (Morrison).

Habits.-The Western Tanager keeps chiefly to high trees, the cotton-woods along the valleys at low elevations, the pine trees in the mountains; Trippe describes them as rambling leisurely along through the pine woods and singing from the tree tops. They feed chiefly on insects, which they catch on the wing like a flycatcher, and also. search for among the branches of the trees.

The nest is generally built on the horizontal limb of a spruce or other conifer, upwards of twenty feet from the ground; Dennis Gale found fresh eggs about June 15th at 8,000 feet to 9,000 feet in Boulder co. The eggs, three to four in number, are pale blueish-green, lightly spotted with browns and purples.

\section{Scarlet Tanager. Piranga erythromelas.}

A.O.U. Checklist no 608-Colorado Records-Cooke 97, pp. 168, 217 ; H. G. Smith 02, p. 290 ; 08, p. 189 ; Rockwell 08, p. 174. 
Description.--Male-General colour throughout scarlet; wings and tail black, under wing-coverts white; iris brown, bill greyish-blue basally, dull greenish terminally, legs palo lavender-grey. Length 6.25 ; wing 3.90 ; tail 2.90 ; culmen .60 ; tarsus .72 .

In the winter the red is replaced by greenish. The female is olivegreen above, the wings and tail dusky with greenish edging to the feathers but no wing-bars; below dull greenish-yellow, purer yellow on the under tail-coverts; under wing-coverts white with w dusky border. The young male is intermediate between the female and adult male.

Distribution.-Breeding in eastern North America from Manitoba and Nova Scotia southwards to eastern Kansas and North Carolina in the mountains; south in winter to the West Indies and through Mexico to Bolivia and central Peru.

The Scarlet Tanager may be regarded as an occasional visitor to Colorado; it has been met with some half-dozen times. Berthoud took one near Golden in 1867, and saw another in the Del Norte Valley in September, 1883. Cooke saw two mounted males taken near Newcastle in the spring of 1892. Aiken reports the occurrence of one near Limon in May, 1899. There are two adult males in the collection of the State Museum of Denver (Smith 02 and 08) ; one of these was taken at Palmer Lake in El Paso co. on May 17th, 1902, by W. C. Ferril, the other near Pueblo on May 20th, 1904, by B. G. Voight. Rockwell states that Sullivan saw one on June 4th, 1904, near Grand Junction.

\section{Western Summer Tanager. Piranga rubra cooperi.}

A.O.U. Checklist no 610a-Colorado Record-Henshaw 75, p. 239. Description.-Mals-Throughout a rather dull crimson-red, brightest on the head, rump and under-parts; wings dusky brown but edged with red so that the dusky is concealed in the closed wing ; iris brown, bill light brown, paler along the cutting edge; legs horny. Length 7.2 ; wing 4.0 ; tail 3.0 ; culmen $\cdot 75$; tarsus $\cdot 78$.

In the female the red is replaced by yellowish-olive, rather more greyish in shade in the middle of the back, and more yellowish below; under wing-coverts yellow without dusky border. The dimensions about the same.

Distribution.-South-west United States from central Texas to California; south through Western Mexico to Colima.

This Tanager is of accidental occurrence in Colorado. It has been only once obtained-by Henshaw on May 10th, 1873, near Denver.

It is rather remarkable that it has not since been met with, as it is common in New Mexico and Arizona. The nearest point to Colorado 
from which it seems to have been recorded is between Albuquerque and Mesilla on the Rio Grande in New Mexico (Brewster, "Bull. Orn. Club," VII., p. 147).

\section{Family HIRUNDINID平.}

Bill short, flat, very broad at the base, triangular in shape when viewed from above; edges of the mandibles smooth, upper slightly notched. Gape very wide, rictal bristles weak. Wings long and sharp-pointed, of nine primaries only, the two outer (8th and 9th) the longest and subequal to one another; tail of twelve feathers, usually more or less forked; feet short, small and weak, ill adapted for progression on the ground. Only one moult in the year, in spring. Sexes usually alike and the young closely resembling the adults.

The Swallows form a well-marked and sharply isolated family with no very close allies. Over a hundred species are recognised, and they are distributed all over the globe, except in the Arctic and Antarctic regions.

KEY OF THE Genera.

A. Nostrils rounded, opening superiorly, without operculum or overhanging scale.

a. Larger-wing over 5; tail distinctly forked. Progne, p. 413.

b. Smaller-wing under 5; tail square Petrochelidon, p. 415.

c. Smallest—wing under 4.5 ; tail square ; outer primary roughed with hooks

Stelgidopteryx, p. 422 .

B. Nostrils elongate or oval, opening laterally below an operculum or overhanging scale.

a. Lower part of the tarsus with a tuft of feathers.

b. No tuft of feathers on the lower part of the tarsus.

Riparia, p. 421.

$a^{2}$ Tail very strongly forked for at least $\frac{1}{3}$ of its length; the outer feather attenuated; a white spot on the inner web of each tail-feather.

Hirundo, p. 416.

$b^{2}$. Tail less strongly forked; the outer feathers not attenuated; no white spots on the tail.

$a^{3}$ Tail longer, about $\frac{1}{2}$ wing, forked for about $\frac{1}{4} \mathrm{its}$ length.

Iridoprocne, p. 418.

$b^{8}$ Tail shorter, about $\frac{2}{5}$ wing, forked for about $\frac{1}{5}$ its length.

Tachycineta, p. 420 . 


\section{Alternative Plumage Kex to the Colorado speches.}

A. Larger-wing over 5 .

a. Glossy blue-black above and below. P. subis, $d$ p. 413.

b. Glossy blue-black above, grey below. P. subis, 9 p. 413.

A. Smaller-wing under 5 .

a. Rump rufous, contrasting with the glossy blue-black back.

b. Rump purplish, contrasting with green back.

P. lunifrons, p. 415 .

T. t. lepida, p. 420 .

c. Rump the same colour as the back.

$a^{2}$ Forehead and throat rufous. H. erythrogastra, p. 417.

$b^{2}$ Forehead and throat without rufous.

$a^{3} \quad$ Glossy blueish above.

I. bicolor, p. 418 .

$b^{3}$ Mouse-brown above, without gloss.

a 4 Throat white, contrasting with the brown chestband.

R. riparia, p. 422 .

$b^{4}$ Throat and chest smoky-brown.

S. serripennis, p. 423 .

\section{Genus PROGNE.}

Large Swallows-wing over 5.0-with a stout strong bill and curved culmen with deflected tip; nostrils opening superiorly, large, rounded and without scale or operculum; tail moderately forked, the lateral rectrices tapering and obtusely pointed ; tarsus shorter than the middle toe and claw ; sexes quite distinct; eggs white.

The Purple Martins, of which six species are recognized by Ridgway, range over the whole of temperate and tropical America.

\section{Purple Martin. Progne subis.}

A.O.U. Checklist no 611-Colorado Records-Ridgway 73, p. 181 ; Drew 81, p. 15 ; Morrison 86, p. 153 ; 88, p. 73 ; Cooke 97, pp. 18, 110, 217 ; Warren 06, p. 23 ; 08, p. 24 ; Rockwell 08, p. 174 ; Cary 09, p. 183.

Description.-Male-General colour above and below metallic steelyblue-black; wings and tail dull black, a concealed white patch on both sides beneath the wing; iris brown, bill black, legs dark brown to blackish. Length 7.25 ; wing 5.75 ; tail 3.00 ; culmen .50 ; tarsus $\cdot 52$.

The female resembles the male above but is much duller in shade, and the forehead shows good deal of greyish; the hind-neck has a collar of grey more or less distinct; below pearly-grey, duskier on the breast and tanks, paler on the abdomen and under tail-coverts, most of the feathers with dusky shaft streaks; wing 5.55, tail 2.75. Young birds closely resemble the adult female but are usually less glossy. 
Distribution.-Breeding throughout temperate North America, except the Pacific coast region, from Nova Scotia, Manitoba and Montana southwards to Florida and the Mexican plateau, south in winter to Venezuela and Brazil.

The Purple Martin is a rare bird in Colorado and quite local in its distribution. It seldom occurs along the eastern slopes of the mountains and is not represented in the Aiken collection by Colorado examples. It was, however, found breeding by Aiken at the head waters of the Apishapa Creek in June, 1872, and also at Brewster and Colby in western Kansas. On the western slope of the mountains it is more common, it was seen by Warren (08) at Mud Springs, 8,800 feet in Rio Blanco co., and also near Newcastle, while Cooke states that it is common at Grand Junction and breeds in the river banks near by.*

Morrison reports that it is common at Fort Lewis in La Plata co. and arrives there late. Warren (06) was told that it had formerly been noticed at Monon in Baca co., but that it had not bred there. Cary has recently met with it on the White River plateau, 25 miles south-east of Meeker at about 8,500 feet in August, and on the Uncompaghre Butte in Mesa co. at 9,000 feet in July. No arrival dates for Colorado appear to be recorded, but Goss states that they reach Kansas at the end of March or beginning of April, and leave before the middle of September.

Habits. - The Purple Martin is a much-welcomed and familiar harbinger of spring in the east, where birdhouses are put out for them in the hope that they may be tempted to remain and breed. But in the wilder regions they resort to the holes of Woodpeckers, or to natural cavities in the trees, to nest and rear their young. Morrison states that at Fort Lewis they nested in hollow trees, or in the latticed ventilators of the barracks. They are noisy birds, keeping up a constant chattering, especially early in the morning, and their attempt at song, though not very musical, is quite pleasing. Like other Swallows their food is taken on the wing exolusively, and consists of insects, especially the larger kinds of beetles.

* This statement rests on the evidence of Miss Myra Eggleston and is controverted by Sullivan (Rockwell 08). 
The nest is composed of various materials loosely thrown together, such as dry grasses, straw, leaves, etc., etc., and is warmly lined with feathers. The eggs, four to six in number, are creamy-white, and measure $.97 \times \cdot 70$.

\section{Genus PETROCHELIDON.}

Swallows of moderate size-wing under 5.0-with small and triangular-shaped bills, with the culmen straight to near the tip, which is abruptly decurved; nostrils large, rounded and superior, without operculum; tail short, less than half the wing and even; rectrices not tapering, but broad and rounded at the tips; tarsus shorter than the middle toe and claw; the middle and outer toes adherent basally. Sexes alike; eggs spotted.

This genus, contrining the Cliff-Swallows, ranges over temperate and tropical America, South Africa, India and the Indo-Malayan and Australien regions. Only one species is found in North America.

\section{Cliff-Swallow. Petrochelidon lunifrons.}

A.O.U. Checklist no 612-Colorado Records-Say 23, vol. ii, p. 47; Allen 72, pp. 148, 156, 162 ; Aiken 72, p. 198 ; Henshaw 75, p. 215 ; Scott 79, p. 93 ; Tresz 81, p. 288 ; Allen \& Brewster 83, p. 260 ; Anthony 85, p. 152 ; Drew 85 , p. 15 ; Morrison 88, p. 73 ; Kellogg 90, p. 89 ; Lowe 92, p. 101 ; MeGregor 97, p. 38 ; Cooke 97, pp. 18, 110, 217 ; Keyser 02, pp. 118, 263 ; Dille 03, p. 74; Henderson 03 , p. 236 ; 09, p. 238 ; Warren 06, p. 23 ; 08, p. $24 ; 09$, p. 17 ; Gilman 07, p. 194 ; Markman 07, p. 157 ; Rockwell 08, p. 175.

Description.-Adult-Crown glossy blue-black, abruptly defined from the frontal patch, which varies from dull white to drab-browa; back also glossy blue-black, but slightly streaked with grey and separated from the crown by a double collar of rich chestnut followed by grey, the former continuous with the ear-coverts; cheeks and throat also a rich chestnut; wings, tail and upper tail-coverts dusky black, rump light cinnamon-rufous; below paling from the chestnut throat to greyish-brown on the breast, and white on the abdomen and flanks; some of the under tail-coverts brown margined with white; a glossy blue-black patch on the lower throat; iris brown, bill black, legs dusky. Length 5.5; wing 4.5 ; tail 2.20 ; culmen .30 ; tarsus .45 .

The sexes are alike; young birds are duller than the adults, and have no glossy blue-black; the forehead is often chestnut, and the sides of the head and throat dusky brown. 
Distribution.--Breeding in favourable situations throughout the greater part of North America as far north as the Yukon Valley, and south through north-west Mexico to Mazatlan; south in winter as far as Fonduras and perhaps to South America.

The Cliff-Swallow is a common summer bird in Colorado, breeding locally from the plains to about 10,000 feet (colony at Fairplay in South Park, 9,800 feet, Allen 72). They reach Colorado from the south about. the beginning of May-Cañon City April 27th, Aiken (Henshaw 75), Pueblo May 8th (Lowe), but do not breed before June, and leave again early in September. They have been recorded from all over the State, from Weld co. (Markman), Limon (Aiken), and Baca co. (Warren 06) on the eastern plains ; from Estes Park (Kellogg), Twin Lakes (Scott), and Fort Garland (Henshaw), on the eastern slope; and from Routt co. (Warren 08), Red-cliff (Keyser), and La Plata co. (Gilman) on the western slope of the Divide.

Habits. - The Cliff-Swallow breeds in colonies, either on vertical or overhanging cliffs along rivers or, perhaps more frequently since the advent of man, on the walls or under the eaves of barns or outhouses. The nest is built up of pellets of mud partially no doubt moistened and softened by the saliva of the bird, and is usually in the shape of a squat bottle, with the opening in front, at other times like a retort, with an opening at the top of the nest, and a passage leading and opening downwards ; the nest so formed is lined with feathers, straw, paper, leaves, or other soft material ; four or five eggs are laid about June 5th in the plains, about a fortnight or three weeks later in the mountains. A set of three eggs, taken by I. C. Hall on June 15th, near Greeley, are rather long-ovals in shape; they are white, moderately spotted with two shades of brown, and average $\cdot 87 \times \cdot 55$. Like other Swallows, these birds feed entirely on the wing, chiefly on smaller insects, and are seldom seen on the ground, as their legs are very small and weak.

\section{Genus HIRUNDO.}

Moderate-sized Swallows-wing less than 5.0-with bill like that of Petrochelidon but slightly longer; nostrils narrow, elongated, opening 


\section{Barn-Swallow}

laterally, overhung by a distinct operculum or scale; tail long, more than half the wing, very strongly forked, the outer feathers attenuated and about twice the length of the middle ones, all with a white spot on the inner web. Sexes alike; eggs spotted.

This genus, containing the typical Swallows, is a large one, and ranges all over the world. Only one species is ordinarily met with in North Americe, and this is so similar to the common Chimney-Swallow of Europe, that many naturalists do not consider it worthy of more than subspecifie separation.

\section{Barn-Swallow. Hirundo erythrogastra.}

A.O.U. Checklist no 613-Colorado Records-Allen 72, pp. 148, 156, 162 (H. horreorum) ; Aiken 72, p. 198 ; Henshaw 75, p. 216 ; Scott 79 , p. 93 ; Tresz 81 , p. 287 ; Allen \& Brewster 83, p. 160 ; Beckham 85, p. 141 ; Drew 85 , p. 15 ; Lowe 92 , p. 101 ; H. G. Smith 93 , p. 244 ; Cooke 97, pp. 18, 111, 217 ; Dille 03, p. 74; Henderson 03, p. 236 ; 09, p. 238 ; Warren 06, p. 23 ; 08, p. 24 ; 09, p. 17 ; Gilman 07, p. 158 ; Markman 07, p. 157 ; Rockwell 08, p. 175; Hersey \& Rockwell 09, p. 121 .

Description.-Male-General colour above dark steely-blue, less glossy and more dusky on the wings and teil ; a white spot on the middle of the inner web of all the tail-feathers, except the central pair ; forehead, malar region, chin and throat dark cinnamon-rufous, rest of the under-parts pale cinnamon-rufous, sometimes almost white, sometimes nearly as dark as the throat; a steely dark blue patch on either side of the breast, occasionally narrowly connected to form a complete band; iris brown, bill black, legs dusky horn. Length 6.1; wing 4.60 ; teil 3.20 ; culmen .30 ; tarsus .40 .

The female is very similar, sometimes a little paler and smaller; a young bird is much duller with sooty-black crown and light cinnamon-brown forehead and throat.

Distribution.--Breeding throughout the greater part of North America from Alaska and Labrador, south through western Mexico to Guadalajara; in winter from south Florida, the West Indies and southern Mexico to the Argentine.

In Colorado the Barn-Swallow is less common than the other Swallows but is still far from rare; it is found all ver the State in suitable localities from the plains to about 10,000 feet. The highest breeding record I have met with is Breckenridge, where it was observed by Carter (Cooke 97), while Allen (72) noticed it flying about at the tops of the mountains near Montgomery in South Park at 12,000 feet. It arrives about the end of April (April 20th at Gold Hill, Gale).

The following are additional recorded locelities: Weld co. (Markman), Barr Lakes, common (Hersey \& Rockwell), Limon (Aiken), 
Pueblo (Beckham), Springfield, Baca co. (Warren), Twin Lakes breeding (Scott), Fort Garland (Henshaw), Routt co. (Warren 08), Mesa co. (Rockwell), Fort Lewis and Cortez (Gilman).

Habits. - The habits of the Barn-Swallow have been modified by civilized man. Formerly no doubt they bred in caves and crannies in cliff faces, as indeed is described by Dawson ("Auk" XIV., p. 95), who found this species in its natural condition on the shores of Lake Chelan in Washington. Now they make use of buildings or bridges, to which they affix their nests; these are usually in the shape of a half-cup, and are built up of mud pellets, often held together with small sticks or straws, with an inside lining of feathers and hair. The eggs, usually four in number, are laid in June, and a second brood is raised later on in the middle of July or early in August. This Swallow is very constant to its chosen nesting-place; Smith (93) related that a pair which he believed to be the same birds returned to his barn in Denver for fifteen successive years, and raised, when not disturbed, two broods each year. A clutch of four eggs taken by I. C. Hall on June 1st, near Greeley, are white, spotted fairly evenly but not very profusely with reddish-brown, and average $8 \times \cdot 55$.

\section{Genus IRIDOPROCNE.}

Swallows of moderate size, wing under 5.0-with rather slender bills and narrow, elongated nostrils overhung by an operculum; tail rather short, less than half the wing and forked for about a quarter of its length; lateral toes long, the claws reaching quite to the base of the middle claw. Sexes alike; eggs white.

This genus, ranging over the continental portions of temperate and tropical America, comprises five species, only one of which occurs in the United States.

\section{Tree-Swallow. Iridoprocne bicolor.}

A.O.U. Checklist no 614 -Colorado Records-Allen 72, pp. 156, 162 ; Henshaw 75, p. 217 ; Scott 79, p. 93 ; Drew 81, pp. 88, 115 ; 85, 


\section{Tree-Swallow}

p. 15 ; Tresz 81, p. 287 ; Allen \& Brewster 83, p. 160 ; Morrison 88, p. 73 ; Cooke 97, pp. 19, 111, 217 ; Rockwell 08, p. 175 ; Henderson 09, p. 238 .

Description.-Male-Above, including the sides of the head and neck, metallic steely-blue; wings and tail dusky black without much gloss, below pure white; iris brown, bill black, legs horny. Length 5.25 ; wing 4.65 ; tail 2.15 ; culmen .25 ; tarsus .45 .

The female resembles the male, but is usually rather duller in colour and slightly smaller-wing about 4.5. A young bird is uniform dark mouse-grey above and beneath white, shaded across the chest with pale greyish-brown.

Distribution.-Breeding throughout North America from Alaska and Labrador, south to California and Virginia; in winter from South Carolina and the Gulf states to the Bahamas and through Mexico to the Guatemala highlands.

The Tree-Swallow is a rather uncommon summer resident in Colorado, breeding from the plains to about 10,000 feet in the mountains, chiefly in the latter. Dennis Gale found a good many nests about Ward at 10,000 feet in Boulder co., and Aiken noticed it breeding at Mosca Pass at about the same elevation. It arrives in April, breeds in June and departs in September.

The following are recorded localities: Boulder co. (Gale), South Park (Allen), El Paso co. (Allen \& Brewster), Fremont co. (Aiken), Twin Lakes (Scott), Crested Butte (Warren), Grand Junction, rare (Rockwell), San Juan (Drew), and Fort Lewis (Morrison).

Habits. -The Tree-Swallow is not quite so swift and agile on the wing as some of the other Swallows, and it is also rather quarrelsome, frequently contending with the Violet-green and ousting it away from its nestingplaces. It builds its nest in hollow trees, very frequently making use of the nesting-site of the Woodpecker, and often driving its rightful owner out. Dennis Gale found a good many nests on Jim Creek and near Ward in Boulder co.; most of these were in Sapsuckers' holes in aspens; in one case another Woodpecker, the Rocky Mountain (Dryobates v. monticola) had already laid its eggs when the Swallows appropriated the hole and built a nest above the Woodpecker's eggs. The nest is formed of a foundation of grass stems with a lining of feathers. 


\section{Fresh eggs are to be met with between June lst and 15 th ; a full clutch is usually six ; the eggs are pure white and unspotted.}

\section{Genus TACHYCINETA.}

Closely allied to Iridoprocne, but distinguished by its shorter and less forked tail, about $\frac{2}{5}$ the length of the wing and forked for about $\frac{7}{6}$ of its length, and by its shorter lateral toes, the claws of which fall short of the bese of the middle claw.

This genus contains one species forming three geographical races, and ranges over western North America as far south as Costa Rica.

\section{Violet-green Swallow. Tachycineta thalassina lepida.}

A.O.U. Checklist no 615-Colorado Records-Allen 72, p. 149 ; Trippe 74, p. 88 ; Henshaw 75, p. 217 ; Scott 79, p. 93 ; Minot 80, p. 228 ; Stone 81 , p. 67 ; Drew 81 , p. 88 ; 85, p. 15 ; Allen \& Brewster 83 , p. 160 ; Beckham 85, p. 141 ; Morrison 88, p. 73 ; Kellogg 90, p. 89 ; Lowe 92, p. 101 ; 94, p. 269 ; Cooke 97, pp. 19, 111, 217 ; McGregor 97, p. 39 ; Keyser 02, p. 207 ; Henderson 03, p. 108 ; 09, p. 238; Gilman 07, p. 194 ; Markman 07, p. 158 ; Warren 08, p. 24 ; 09, p. 17 ; Rockwell 08, pp. $175,195$.

Description.-Male-Above green, the head of a more mossy tinge, the back more bronzy, the two shades separated by narrow purplish collar, more or less conspicuous ; rump and upper tail-coverts mixed metallic purplish and blue, with a conspicuous white patch on either side at the base; wings and tail dusky with a slight metallic gloss; below, including the ear-coverts and a patch above the eye white; iris brown, bill black, legs brownish. Length 4.75 ; wing 4.70 ; tail 1.90 ; culmen .20 ; tarsus .38 .

The female is duller than the male throughout; the crown is a dull brown, very slightly glossed with greenish, the ear-coverts and supraorbital patch are mottled grey, and the size is smaller-wing about 4.15. A young bird is plain dusky above, the metallic gloss gradually appearing, first on the middle of the back.

Distribution.-Western North America, breeding from Alaska to western Texas and New Mexico; south in winter through Mexico to the highlands of Costa Rica.

In Colorado the Violet-green Swallow is a common summer bird, though somewhat locally distributed, from the eastern foothills westwards. Arriving during the first half of May from the south, they mostly go up into the mountains to breed, and are chiefly met with from 8,000 to 10,000 feet. They are specially common in the " parks." They come down again in late August and leave for the south in September. 
The following are some of the recorded localities: Boulder (Henderson), Denver (Henshaw), El Paso co. (Allen), Pueblo (Aiken) along the foothills; Estes Park (Kellogg), Idaho Springs (Trippe), Twin Lakes (Scott), Wet Mountains (Lowe), on the eastern slope of the mountains, Grand Lake in Middle Park, and Crested Butte (Warren), Mesa co., abundant, breeding above 6,000 feet (Rockwell), San Juan co. (Drew), and La Plata co. (Morrison) on the western slope.

Habits.-This is by far the most brilliantly coloured of our Swallows, and is of a somewhat gregarious nature, as is generally the case with these birds. Morrison states that he has often seen large numbers during a storm, huddled together on a dead limb near their homes, waiting for the weather to moderate, when they once more take to the wing to feed. They are also rather pugnacious birds, fighting with one another for the possession of a suitable nesting-hole. In the natural state they appear to nest indifferently in holes in trees, or in crevices in rocks and sand-banks, but they are commencing to make use of crevices and crannies in barns and outbuildings of ranches like the other birds of this family.

Dennis Gale states that at Gold Hill they are late breeders. He found fresh eggs from June 20th to July 10th ; in most cases the nest-holes of Woodpeckers were made use of ; the nests were made of grass, generally retaining some of its green colour, and lined with feathers ; the eggs, five or six in number, are pure white.

\section{Genus RIPARIA.}

Rather small Swallows-wing under 4.5-with small slender bills and elongated oval nostrils overhung by an operculum; tail about half the length of its wing, moderately forked; tarsus with a tuft of small feathers on its posterior edge near the joint of the hind toe; claws rather long and slender, that of the hallux exceeding its digit. Sexes alike; eggs white.

A widely spread genus, found over the greater part of the world, but with only one American species. 


\section{Bank-Swallow. Riparia riparia.}

A.O.U. Checklist no 616-Colorado Records-Aiken 72, p. 198 ; Cooke 97, pp. 19, 111 ; Rockwell 08, p. 175; Henderson 09, p. 238.

Description.-Male-Above dusky brown, becoming dusky black on the wings and tail, but without gloss; below white, except for a broad band of greyish-brown across the chest, extending back along the flanks on either side; a tuft of feathers on the tarsus, pale buffy; iris brown, bill black, legs dark horn. Length 4.90; wing 4-15; tail 2.10 ; culmen .25 ; tarsus .40 .

The sexes are alike. The young birds have the feathers of the back and upper tail-coverts, also the inner secondaries and wing-coverts, tipped with buffy-white and the chin tinged with buff.

Distribution.-The Bank-Swallow, or Sand-Martin as it is called in England, has a range perhaps more extensive than that of any other Passerine bird. It breeds throughout Europe, northern Asia and North America, in the latter continent from the Arctic regions to Georgia and northern Mexico; it goes south in winter to southerm Asia and Africa, and in America to the West Indies and through Central America to Peru and Brazil. The Bank-Swallow is quite a rare bird in Colorado, or else it has generally escaped the notice of observers. Aiken (72) records it as first noticed on April 26th in the Fountain Valley, and there is one example in the Aiken collection from Fremont co., dated May 16th. Dennis Gale notes its arrival in the Boulder Valley April 20th, but Henderson considers this record doubtful ; Rockwell reports that Sullivan found it reasonably plentiful near Grand Junction, arriving May 1st and departing September lst. This is the extent of the information available.

Habits. -The Bank-Swallow breeds in large colonies, making horizontal holes or burrows in sand-banks, generally along streams, but often too in railway cuttings ; the eggs, four to six in number, are white with a rosy tinge when unblown, and measure on an average $69 \times$ -49. Sullivan dug out of a bank on the Gunnison River, July 2nd, 1904, six young ones ready to fly.

\section{Genus STELGIDOPTERYX.}

Rather small Swallows-wing under 4.5-with slender bills and rounded, superiorly directed nostrils without an opereulum; outer primary with the tips of the barbs of the outer web produced and recurved, so as to form a series of clinging hooks along the outer edge of the wing; this structure is only fully developed in the male, in the 


\section{Rough-winged Swallow}

fernale the barbs are stiffened and produced, but not hooked; tail short, about half the length of the wing, very nearly square; tarsus without a tuft of feathers, claws short, that of the hallux less than its digit. Sexes alike; eggs white.

This genus, containing several species, is confined to the temperate and tropical regions of continental America. Only one species is met with in the United States.

\section{Rough-winged Swallow. Stelgidopteryx serripennis.}

A.O.U. Checklist no 617-Colorado Records-Allen 72, p. 149; Henshaw 75, p. 219; Allen \& Brewster 83, p. 160 ; Drew 85, p. 15 ; Beckham 85, p. 141 ; Morrison 88, p. 73 ; Cooke 97, pp. 19, 111 ; Dille 03, p. 74 ; Gilman 07, p. 158.

Description.-Male-Above pale mouse-brown nearly uniform except on the wings and tail, which are a shade darker; below a paler shade of mouse-brown shading into white on the lower-breast, abdomen and under tail-coverts; outer primary with the barbs of the outer web produced and hooked; iris brown; bill black; legs horny-brown. Length 4.75 ; wing 4.25 ; tail 2.10 ; culmen .25 ; tarsus .40 .

The female resembles the male but is slightly smaller, and the barbs of the outer web of the outer primary slightly produced and stiffened but not hooked-wing about 4.0. The young bird is slightly washed with fawn above and has fawn-coloured tips and edgings to most of the coverts and secondaries; the throat and chest are also slightly tinged with the same colour.

Distribution.-Breeding in temperate North America from British Columbia and Massachusetts south to central Mexico; south in winter to Costa Rica and occasionally on the coast of South Carolina.

In Colorado the Rough-winged Swallow is a fairly common summer bird along the eastern base of the Rocky Mountains, from Cheyenne over the Wyoming border to Trinidad, where it was found breeding by Aiken, but it does not go up into the mountains. It has also been met with in the south-western portion of the State at Fort Lewis by Gilman, and is stated by Morrison on the authority of Anthony to occur on the Animas River near Silverton; if so it reaches an elevation of 9,000 feet, a good deal higher than was previously supposed. It arrives in Colorado about the first week in May.

Habits. - The Rough-winged Swallow resembles the Bank-Swallow in habits and actions; its swift and low flight and twittering notes being very similar. They are not, however, so gregarious in their habits, and nest in smaller numbers or even singly. The nest-holes are 
almost invariably along the vertical banks of streams, and are by no means so uniform or carefully constructed as those of the Bank-Swallow; in fact Kingfishers' and other holes are often made use of, and cavities and crevices in the masonry abutments of bridges. The nest cavity is loosely lined with grass and feathers. The eggs, usually four or five, are pure white, and measure about $.70 \times .50$.

\section{Family BOMBYCILIIDE.}

Bill rather short, broad and flat, slightly hooked and notched at the tip; head conspicuously crested; nasal fossæ and nostrils almost concealed by the mass of forwardly-growing, dense, soft loral feathers; rictal bristles obsolete; wing of ten primaries, the outer (tenth) very minute, less than half the length of the primary coverts; wing long and pointed, the eighth and ninth the longest of the primaries; tail much shorter than the wing and slightly rounded; plumage soft and silky, with curious red, horny appendages attached to the inner - secondaries, and occasionally to other long feathers as well; sexes alike; young streaky.

Following Ridgway, this family includes only the Waxwings of the genus Bombycilla, formerly known as Ampelis, which appear to be sufficiently distinct from the other genera containing the Silky Flycatchers, Phainopeplas, and Palm-Chats usually associated with them.

\section{Genus BOMBYCILA.}

The characters of the genus are given with those of the family. Its range includes the temperate and subarctic portions of both the Old and New Worlds.

A. Larger-wing over 4 ; under tail-coverts chestnut; wing-feathers yellow or white tipped.

B. garrula, p. 425 .

B. Smaller-wing under 4 ; under tail-coverts white; wing-feathers without white or yellow tips.

B. cedrorum, p. 426 . 


\section{Bohemian Waxwing. Bombycilla garrula.}

A.O.U. Checklist no 618-Colorado Records-Aiken 72, p. 198 (Ampelis garmla) ; Trippe 74, p. 92 ; Drew 81, p. 89 ; 85, p. 15 ; H. G. Smith 84, p. 120 ; Morrison 88, p. 73; Cooke 97, pp. 111, 217; Henderson 03 , p. 236 ; 09, p. 238 ; Rockwell 08, p. 175.

Description.-Sexes alike. General colour above and below grey or drab-brown, becoming tinged with rufous towards the head ; forehead and under tail-coverts rufous-chestnut; a line running through the eye and along the base of the upper mandible and a patch on the chin and throat black; wings dusky grey, the primary coverts tipped on both webs with white, the primaries with the tips of the outer webs white or yellow, the secondaries also tipped with white and the shafts of several of the feathers prolonged into sealing-wax red, flattened, pear-shaped appendages; tail dusky grey with a terminal band of yellow; iris brown, bill black, blueish-grey at base, legs black. Length 6.75 ; wing 4.55 ; tail 2.65 ; culmen .45 ; tarsus .70 .

In some birds the red appendages to the secondaries are absent, and the yellow spots on the primaries are all white. This does not appear to be connected with age or sex or season.

Distribution.-Breeding in the coniferous forests of the northern parts of the Old and New Worlds; in America from Alaska to Hudson Bay, southwards in winter very irregularly as far as Pennsylvania and northern California.

In Colorado the Wraxwing is a not uncommon winter bird, more abundant in the mountains, where it has been found as high as 10,000 feet by Dennis Gale near Ward in Boulder co. ; occasionally it is seen in the foothills, but it is notoriously erratic in its movements and may occur at any place. It reaches Colorado in November or December and remains often till the end of March. It was seen by Dennis Gale as late as April 6th.

The following are recorded localities: Boulder, a few in winter (Henderson), Denver (Smith), Idaho Springs (Trippe), Breckenridge (Carter apud Cooke), El Paso co. (Aiken), Mesa co. not uncommon in winter (Rockwell), San Juan co. (Drew), La Plata co. (Morrison).

Habits. - The Bohemian Waxwing is usually seen in flocks, sometimes of very large size; it is very erratic in its wanderings, and though common one winter in one particular locality, may not be seen again in the same place for many years. It feeds chiefly on wild berries, and the presence of these in sufficient quantities may perhaps account for its wandering habits, but it 
also devours insects, catching flies on the wing like a Flycatcher. Its call is a lisping whistle. It occasionally visits the towns, and I have seen it in a suburban garden plot in Colorado Springs in October. It is not likely to be found breeding in Colorado, but its nest is a bulky structure about six to twenty feet from the ground in a tree, and its eggs, three to four in number, are blueishwhite or greyish, spotted with lilac and dark brown.

\section{Cedar-Waxwing. Bombycilla cedrorum.}

A.O.U. Checklist no 619-Colorado Records-Aiken 72, p. 198 ; Scott 79, p. 93 ; Cooke 97, p. 111 ; Warren 09, p. 17 ; Henderson 09, p. 239.

Description.-Sexes alike. General colour above brown, becoming more grey on the rump, and more cinnamon on the head and breast; a narrow black band running through the eye along the base of the upper mandible; chin dull black, paling on the throat to brown; wings dusky grey unmarked except for the red sealing-wax coloured appendages to the shafts of the secondaries ; tail also dusky grey tipped with yellow; below, flanks and abdomen pale yellowish, under tailcoverts white; iris brown, bill black, greyish towards the base; legs black. Length 5.5 ; wing 3.60 ; tail 2.10 ; culmen .40 ; tarsus $\cdot 60$.

Some examples lack the red appendages to the secondaries, while some possess them on the tail-feathers as well, and have the yellow tail-tips narrower and paler, but this does not depend on sex or age. Young birds of the year are olive-drab above and mottled white and olive-drab below; the black frontal band and the yellow tail-tip are present, but there are no red appendages to the secondaries as a rule.

Distribution.-Breeding throughout temperate North America from British Columbia and Prince Edward Island south to Arizona and Virginia; wintering over the whole of the United States, and also south to Mexico, Costa Rica, Cuba and Jamaica.

In Colorado tho Cedar-bird is far from common, though apparently a resident; it keeps chiefly to higher elevations in summer and descends to the foothills during the winter; Aiken observed it several times in early winter in El Paso co, and on one occasion saw a single bird on May 23rd, near Limon out on the plains; Scott found it breeding twenty miles east (? west) of Fairplay in South Park on June 9th at 9,000 feet, and also observed it at Twin Lakes; Warren reports that 
C. H. Smith of Coventry, in the winter of 1907-8, saw a flock from which he shot one. Henderson reports one taken by Bragg at Boulder July 4th, 1904, now in the State Collection at Denver. These con stitute the only records which $I$ have been able to find.

Habits. - The Cedar-Waxwing frequents woods, orchards and groves, going in flocks, all the year round except in the breeding season, and like the Bohemian Waxwing is a great wanderer. The notes are soft and subdued and hardly noticeable. The food consists chiefly of berries, especially those of the cedar, as well as insects. They are generally regarded with alarm by the fruit-grower in consequence of their ravages on orchards, but they also destroy immense numbers of injurious insects and are probably more beneficial than harmful. The nest is a deep bulky structure of twigs and grasses lined with leaves or fine rootlets, and placed in thick bush or low tree; the eggs, usually four in number, are blueish to purplish-grey, spotted with brown or black; they measure $\cdot 82 \times \cdot 60$.

The use and meaning of the characteristic red appendages are quite unknown; they vary considerably in development and may be found even in young birds, though as a rule best developed in adult males.

\section{Family LANIID里.}

A large and cosmopolitan family chiefly developed in the Old World, and only represented in the Western Hemisphere by two species of the genus Lanius; the characters of which may therefore be used to diagnose the American members of the family.

\section{Genus LANIUS.}

Bill robust, compressed, strongly hooked and toothed; nostrils basal, nearly round, partly at any rate concealéd by bristles; rictal bristles numerous; wing rather short and rounded, of ten primaries, the outer (tenth) about half the length of the ninth, the sixth, seventh, 
and eighth the longest; tail of twelve rectrices, about equal to the wing, and graduated; tarsus rather short, but longer than the middle toe and claw, markedly scutellate. Sexes alike; young more or less barred and vermiculated.

This is an extensive genus ranging all over Europe, Asia, Africa and North America.

A. Larger-wing over 4.25 ; no frontal band of black.

L. borealis, p. 428 .

B. Smaller-wing under 4.0; a narrow frontal band connects the two side-patches of black.

L. 1. excubitorides, p. 429 :

\section{Northern Shrike. Lanius borealis.}

A.O.U. Checklist no 621-Colorado Records-Aiken 72, p. 198 ; Trippe 74, p. 102 ; Drew 81, p. 89 ; Allen \& Brewster 83, p. 160 ; Morrison 86, p. 153 ; 88, p. 73 ; H. G. Smith 88, p. 163 ; Cooke 97, pp. 112, 217 ; Henderson 03, p. 236 ; 09, p. 239 ; Rockwell 08, p. 175 ; Warren 09, p. 17 ; Cary 09, p. 183.

Description.-Male-Above blueish-grey, whitening on the rump, scapulars and superciliary region; a black patch from the base of the bill through the eye to the ear-coverts; wings and tail black, the primaries with a white bar across them, and the secondaries tipped with white, the tail-feathers with concealed white bases and an increasing amount of white on the terminal portion from the centre outwards; below white with more or less distinct vermiculations of dusky on the breast; iris brown, bill black in summer, dusky horn in winter, legs black. Length 10.25 ; wing 4.5 ; tail 4.25 ; culmen .65 ; tarsus .95 .

The female closely resembles the male, but is slightly duller in colour; the white on the wing and tail is more restricted and the vermiculations on the chest more distinct; the dimensions a shade smaller. The young birds are distinctly brownish in shade above, with vermiculations on the rump, and more marked vermiculations on the lowersurface.

Distribution.-Breeding from Alaska to Labrador, but not south of the Canadian boundary. In winter south over to the United States as far as Virginia, New Mexico and central California.

In Colorado the Northern Shrike is a fairly common winter bird, arriving from the north in October, when it is often found at considerable elevations-up to 12,500 feet according to Drew-and wintering in the plains, foothills and mountain parks up to about 9,500 feet. It goes north again at the end of March or beginning of April-latest date April 9th (Aiken). 
The following localities are recorded : Boulder co, rather uncommon (Henderson), Idaho Springs (Trippe), Denver (Smith), El Paso co. (Aiken), Las Animas co., November (Cary), Mesa Co., not common (Rockwell), Crested Butte (Warren), San Juan co. (Drew), La Plata co. (Morrison).

Habits. - The Northern Shrike has a deserved reputation for cruelty and rapacity; it is a solitary bird and frequents open country and cultivated land, where it takes up a conspicuous perch and watches for an opportunity of securing its prey. In the autumn this consists largely of grasshoppers, beetles and other fairly large insects, but later on when these have disappeared it pounces on mice and small birds, especially the Juncos and Horned Larks, and Sparrows about the towns. It flies direct from its perch, strikes and carries back its victim in its claws to its perch again to devour at leisure. It does not appear to impale its victims on the thoms and barbed wire to any extent as other Shrikes do. Its ordinary note is harsh, but it has a sweet and pleasant song according to Smith, especially agreeable in winter, when the woods are bare and there is little else to hear.

\section{White-rumped Shrike. \\ Lanius ludovicianus excubitorides.}

A.O.U. Checklist no 622a-Colorado Records-Baird 64, p. 445 ; Allen 72, p. 149 ; Aiken 72, p. 198 ; Henshaw 75, p. 233 ; Drew 81, p. 89 ; 85, p. 15 ; Allen \& Brewster 83, p. 160 ; Beckham 87, p. 123 ; Morrison 88,p. 73; Smith 88, p. 163; S. "Bob White" 94, p. 138; Cooke 97, pp. 18, 112, 217 ; Keyser 02, p. 98 ; Dille 03, p. 74 ; Henderson 03, p. 108 ; 09, p. 239 ; Warren 06, p. 23 ; 08, p. 24 ; Gilman 07, p. 194 ; Markman 07, p. 158 ; Rockwell 08, p. 175.

Description.-Adult Male-General colour above blueish-slaty-grey, becoming broadly white on the scapulars and rump, but hardly showing any white on the frontal and superciliary region; a broad black patch from the base of the bill through the eye to the ear-coverts, this extends to the nasal tufts and the base of the culmen; wings and tail black, the former with a white band across the base of the primaries; the tips of 
the secondaries white; the tail with increasing amounts of white from the central feathers outwards ; the outermost pair wholly white, except for a small spot on the shaft towards its base; below white without freckling or vermiculation; iris brown, bill black in summer, duskyhorn in winter, legs black. Length 8.25 ; wing 3.90 ; tail 3.90 ; culmen .55 ; tarsus 1.0 .

The sexes are alike; young birds have the upper-parts finely vermiculated with dusky and the lower parts also finely barred with dusky on a brownish ground.

Distribution.-Breeding in western North America from Saskatchewan to south-eastern California, northern Mexico and western Texas. In winter over the southern part of its breeding range, and further south to the Isthmus of Tehuantepec.

The White-rumped Shrike is a common summer bird in Colorado, chiefly met with on the plains and at lower elevations and becoming rare in the mountains. The highest recorded localities seem to be those of Warren (08), who met with it between Sulphur Springs and Grand Lake in Middle Park on May 1lth, and who tells me he occasionally met with it at Crested Butte at 9,000 feet, but always in the fall. It arrives from the south early in April (April 5th Aiken for El Paso co., April 9th-14th W. G. Smith for Loveland), and may winter occasionally in the southern part of the State. The following are further recorded localities: Boulder co. (Henderson), Denver (Henshaw), Limon, Pueblo and Del Norte (Aiken), Baca co. (Warren), Mesa co., wintering near Grand Junction (Rockwell), San Juan co. (Drew), La Plata co. (Morrison).

Habits - The White-rumped Shrike preys chiefly on grasshoppers and other large insects, of which it must consume enormous quantities, less commonly on smaller birds and mice. It impales its prey on thorns, and frequently makes use of the barbs of barbed wire fencing for this purpose, though the reason for this practice seems uncertain. It catches its prey darting down on it from a fixed post, or sometimes hovering above it like a Hawk. It has a variety of call-notes and a not unpleasing song. It breeds in May, and fresh eggs are to be found at any time during the latter half of the month, or even the beginning of June. It seems probable that in the plains at least two broods are raised. Dennis Gale's notes give ample details on the nidification of 
this species. He found the nests usually placed in low bushy thick-twigged willows at from seven to twenty feet from the ground. The nest is a bulky, rather untidy structure of grass and other vegetable stems, lined with finer material, including wool and hair. The eggs, seven or eight in number, are whitish-yellow, uniformly freckled with yellowish-brown, and measure about $.97 \times .72$.

\section{Family VIREONID里.}

Bill variable in size, but rather Shrike-like, strongly hooked and notched; nostril oval or rounded, overhung by an operculum; frontal and rictal bristles present; wing with ten primaries, but the outer or tenth sometimes so small and rudimentary as to be entirely concealed, sometimes about half the length of the ninth; tarsus longer than the middle to $\theta$ and claw, scutellate in front ; toes adherent at the base, the basal joint of the middle toe rather shortened and soldered to the basal joints of the lateral toes; plumage with plain green and grey prevailing; never spotted or barred even in the young.

This is a purely New World family, containing the Vireos or Greenlets; about seventy species are known; those of North America were formerly all referred to the type genus, but it is perhaps a matter of convenience to divide them as is here done.

\section{Key of the Colorado Species.}

A. Tenth primary entirely concealed, apparently absent; no wing-bars.

V. olivacea, p. 432 .

B. Tenth primary narrowed, pointed and short, less than $\frac{1}{3}$ length of the ninth.

a. No wing-bars.

V. g. swainsoni, p. 433 .

b. Two distinct pale wing-bars.

$a^{2}$ Olive-green above and on the flanks and edges of the wing.

L. s. cassini, p. 435 .

$b^{2}$ Grey above, edges of wing whitish. L. s. plumbeus, p. 435 . 
C. Tenth primary longer, from $\frac{x}{3}$ to $\frac{1}{2}$ of the ninth.

a. Larger-wing over 2.5 ; upper-parts grey, no olive.

b. Smaller-wing under 2.5 ; upper-parts olive-green.

V. vicinior, p. 438.

V. belli, p. 437 .

\section{Genus VIREOSYLVA.}

Medium-sized or small Vireos, with a bill somewhat variable in length, but generally rather slender, narrow and compressed; its depth at the base not more than half the distance from the nostril to the tip; culmen straight with abruptly down-curved tip; wing long and pointed, the tenth (outer) primary either rudimentary and wholly concealed, or if present, narrow and pointed and less than $\frac{1}{s}$ the length of the ninth; ninth primary longer than the fourth; tail shorter than the wing, nearly even; wings without bars.

This genus containing a considerable number of species, ranges over the whole of temperate and tropical America. (For key, see p. 431).

\section{Red-eyed Vireo. Vireosylva olivacea.}

A.O.U. Checklist no 624 -Colorado Records-? Allen 72, p. 176 ; Thorne 87, p. 264 ; Cooke 97, pp. 19, 112, 168, 218 ; Henderson 05, p. 421 ; 07, p. 239 ; H. G. Smith 08, p. 189.

Description.-Male-Crown slaty-grey, faintly margined with a narrow line of dusky ; rest of upper-parts dull olive-green; wings and tail dusky, edged with olive-green; a white superciliary line extending over the ear-coverts, and a dusky loral stripe in front of the eye; below white tinged on the flanks and under tail-coverts with jellowish-olive; under wing-coverts pale yellow; tenth (outer) primary obsolete; iris brownish-red, bill dusky grey, lower mandible rather paler, legs dusky. Length 5.5 ; wing 3.10 ; tail 2.10 ; culmen .50 ; tarsus .63 .

The sexes are alike. A young bird is brown above and has the postocular streak rather indistinct.

Distribution.-Breeding throughout temperate North America, except in arid districts, from British Columbia and Nova Scotia to western Texas and Florida; in winter south to the Bahamas and through Mexico to Brazil and Bolivia.

The Red-eyed Vireo is a somewhat rare summer bird in the plains country of eastern Colorado and does not extend into the foothills or mountains. It arrives late in May and departs again in September. The following are the recorded occurrences: Fort Lyon May 29th, three times (Thorne); Loveland, once seen May 12th by Prof. W. Osburn, and Denver, one seen May 22nd, 1892, by H. G. Smith (Cooke) ; Limon, 
pair collected 22nd to 24th May, 1899 (Aiken); Yuma, seen by Miss Patten, May 27th, 1905 (Henderson); Boulder, one male taken May 30th, 1904, by L. C. Bragg, and Wray, one male taken May 26th, 1906 , W. C. Ferril (H. G. Smith.) Allen (72) states, "mountains of Colorado up to 11,000 feet," but this seems based on an error, as it has not since been met with away from the eastern plains.

Habits. - These birds are found mostly along timbered streams, and are often met with near dwelling-houses in groves and among shade trees; they have an animated song, consisting, according to Goss, of a few clear warbling notes repeated in a loud, animated and almost continuous strain while seated on the topmost branches of a tree. Their food consists chiefly of insects, which they hunt for among the leaves and branches and also catch on the wing, but small berries are also relished. Their nests are suspended from the forks of the trees; they are made of fibres, vine stalks, old leaves and spider threads, woven in and fastened together with saliva and lined with fine stems and rootlets. They are hung by material of the same kind fastened to the rim. The eggs, three to five in number, are pure white, thinly and irregularly speckled with reddish-brown, and measure about $\cdot 82 \times \cdot 56$.

\section{Western Warbling Vireo.}

Vireosylva gilva swainsoni.

A.O.U. Checklist no 627a-Colorado Records-Allen 72, pp. 149 , 156, 176 ; Aiken 72, p. 198 ; Henshaw 75, p. 221 ; Scott 79, p. 93 ; Minot 80, p. 229 ; Drew 81, p. 89 ; 85, p. 15 ; Tresz 81, p. 288 ; Allen \& Brewster 83, p. 160 ; Beckham 85, p. 141 ; Morrison 88, p. 73 ; Kellogg 90 , p. 89 ; McGregor 97, p. 39 ; Cooke 97, pp. 19, 112, 218 ; Keyser 02, pp. 198, 230 ; Henderson 03, p. 237 ; 09, p. 239 ; Warren 06, p. 23 ; Gilman 07, p. 194 ; Rockwell 08, p. 176.

Description.-Male-General colour dark slaty-grey, darkest on the head, washed with olive-green on the back and edges of the wings; the inner webs of the wing and tail-feathers edged with white; a white superciliary line from the base of the bill to above the ear-coverts, and an indistinct line of dusky below; under-parts whitish, faintly washed with olive-yellow, especially on the flanks; tenth (outer) 
primary obvious, longer than the coverts; iris brown, bill pale horn, legs dusky. Length 4.90 ; wing 2.90 ; tail 2.2 ; culmen .40 ; tarsus $\mathbf{7 5}$.

The sexes are alike; the young bird has the top of the head buffy, and buffy tips to some of the coverts.

Distribution.-Breeding in western North America from British Columbia and Athabasea south along the eastern border of the Rocky Mountains to New Mexico and Lower California; further south in winter to Vera Cruz and Oaxaca in Mexico.

In Colorado this species is the commonest of the Vireos, arriving from the south about the middle of May in El Paso co., and spreading up into the mountains, where it breeds up to about 10,000 feet. The earliest date for El Paso co. is May 15th among the Aiken collection, but Warren gives May 3rd for Baca co., and Henshaw the same date for Fort Garland. Other recorded localities are Loveland, May 12th, W. G. Smith (Cooke), Boulder co. (Minot), Limon (Aiken), and Pueblo (Beckham), in the plains and foothills; in the mountains, Estes Park (Kellogg), Graymont, 10,000 feet (Keyser), Breckenridge (Carter apud Cooke), Twin Lakes (Scott), South Park (Allen), Mesa co., common, breeding at 7,500 feet (Rockwell), San Juan co. (Drew) and La Plata co. (Gilman).

Habits. - The Warbling Vireo frequents deciduous trees, especially cotton-woods and aspens, and also groves and orchards about the dwelling-places of man. They are celebrated for the sweetness of their song, their notes being soft, low and musical; according to Keyser they sing even while sitting on the nest. They are of great service to man as insect destroyers, devouring large numbers of scale and other insects injurious to fruit and shade trees.

The nest, like that of the Red-eyed, is suspended to the slender forks of twigs either of a cotton-wood or at great elevations of a quaking aspen; it is somewhat smoother and more compact in its make-up. The eggs, four to five in number, are white, sparingly spotted about the larger end with reddish to dark brown and lilac. They measure about $75 \times{ }^{\cdot 55}$. Fresh eggs may be looked for about July 1st. 


\section{Genus LANIVIREO.}

Medium-sized Vireos resembling Vireosylva, but with a relatively shorter and stouter bill, the depth of which at the base is far more than half the distance from the nostrils to the tip; wings as in Vireosylva, but with two conspicuous wing-bars.

This genus, containing three species, ranges over temperate North America, south to Colombia (for key, see p.431).

Cassin's Vireo. Lanivireo solitarius cassini.

A.O.U. Checklist no $629 a$-Colorado Records-Ridgway 79, p. 228 ; H. G. Smith 96, p.76 ; 08, p.189; Cooke 97, pp.112, 168 ; Cary 09, p.183.

Description.-Male-Top and sides of the head dark ashy-grey, passing into olive-green on the back and rump; at white ring round the eye, continued forward over the lores ; wings and tail dusky, edged with olive-yellow; the innermost secondaries with almost white, and the middle and greater coverts with pale jellow tips, forming a double wing-bar; below white, becoming pale olive-yellow on the flanks; inner webs of wing-and tail-feathers edged with white; iris brown, bill greyish with a darker tip, legs dusky. Length 4.90 ; wing 2.90 ; tail 2.15 ; culmen .42 ; tarsus .70 .

The sexes are practically alike; the young birds have the orbital ring and the under-parts tinged with brownish-buff.

Distribution.-Breeding in western North America from British Columbia to southern California, eastwards on migration through Arizona and New Mexico, and south through Mexico to Oaxaca.

Cassin's Vireo is of accidental occurrence in Colorado. It was represented in the Maxwell collection (Ridgway), and has since been obtained on three occasions near Denver by H. G. Smith-a male on the Platte River, September 16th, 1884, another example at Cresswell in Jefferson co. on September 9th, 1887, and a female on Coal Creek on May 13th, 1888 ; it was also taken by W. F. Doertenbach near Pueblo September 6th, 1897 (Cooke), and Cary has recently obtained an example on September 4th on the Escalante hills in westernRoutt co.

Plumbeous Vireo. Lanivireo solitarius plumbeus.

A.O.U. Checklist no $629 \mathrm{~b}$-Colorado Records-Allen 72, pp. 149, 156 ; Aiken 72, p. 198 ; Trippe 74, p. 100 ; Henshaw 75, p. 224 ; Minot 80 , p. 229 ; Tresz 81 , p. 289 ; Allen \& Brewster 83, p. 160 ; Drew 85, p. 15 ; Beckham 85, p. 141 ; Kellogg 90, p. 90 ; Lowe 94, p. 269 ; Cooke 97, pp. 19, 112, 218 ; Henderson 03, p. 236 ; 09, p. 239.

Description.-Male-General colour above slaty-grey, with a very faint tinge of olive on the rump; orbital ring and supra-loral stripe white, slightly separated by a black spot in front of the eye; wings and tail dusky black edged with white, especially the outer tail-feathers 
and the inner secondaries; middle and greater coverts tipped with white, forming a double wing-bar; below white, slightly washed on the sides and flanks with pale slaty-grey and a tinge of olive; iris brown, bill blackish, paler at the base of the lower mandible, legs dusky. Length $5 \cdot 30$; wing 3.15 ; tail 2.25 ; culnen .45 ; tarsus .75 .

The sexes are alike; young birds are very similar to the adults, but have the back more brownish.

Distribution.-Breeding in the Rocky Mountains region from southern Wyoming through Mexico to the State of Vera Cruz; further south in winter to Oaxaca.

The Plumbeous Vireo is a fairly common summer bird in Colorado, passing along the eastern bases of the mountains during migration, and breeding chiefly in the mountains up to about 10,000 feet. It arrives from the south early in May-El Paso co. May 3rd, Allen \& Brewster-passes up into the mountains about the end of the month, and breeds in June. The highest breeding locality seems to be Breckenridge, 9,700 feet (Carter apud Cooke). Other localities are: Loveland (Cooke), Estes Park (Kellogg), Boulder co. (Minot), Idaho Springs (Trippe), South Park (Allen), Pueblo (Beckham), and Wet Mountains (Lowe). It does not seem to be recorded from the western slopes or from the eastern plains hitherto.

Habits. - This Vireo does not seem to be very different in its habits from the others, except that it appears to have a more decided liking for pine woods, in the recesses of which it is often to be found. The nest was first taken by Aiken in May, 1872, on Turkey Creek in El Passo co., and is described by Henshaw as composed of soft cottony substances bound with strips of bark and other fibrous material, and lined with fine grasses; the eggs, four or five in number, are white, spotted chiefly at the larger end with reddish-brown. Fresh clutches may be looked for from June 10th to June 25th according to Gale's notes. Minot does not consider its song so sweet as that of its eastern ally, the Solitary Vireo.

\section{Genus VIREO.}

Small Vireos with the tenth (outer) primary well developed, always more than one-third, often half, the length of the ninth, the latter shorter than the fourth. 
This genus, containing a considerable number of species, ranges over North America as far south as Costa Rica and throughout the Greater Antilles (for key, see p. 431).

\section{Bell's Vireo. Vireo belli.}

A.O.U. Checklist no 633-Colorado Records-Thorne 87, p. 264 (error apud Cooke) ; Cooke 97, p. 218 ; H. G. Smith 03, p. 438; 05, p. 82 ; 08, p. 189.

Description.-Male-Above dull greyish-brown, slightly tinged with olive, more so on the rump and upper tail-coverts; orbital ring and supra-loral streak obscurely white; wings and tail dull dusky with paler edgings, and an obscure double wing-band formed by the pale tips of the middle and greater coverts; below white, tinged on the sides, flanks, under tail-coverts, axillaries and under wing-coverts with sulphuryellow; iris brown, bill pale horn, lower mandible paler, legs dusky horn. Length 4.15 ; wing 2.20 ; tail 1.80 ; culmen .38 ; tarsus .75 .

The sexes are alike; the young birds closely resemble the adults, but the wing-bands are more distinct and the inner secondaries are edged with yellowish-white.

Distribution.--Breeding in the prairie regions from North Dakota and Indiana southwards to north-east Mexico; in winter further south through Mexico to Oaxaca. Bell's Vireo, long suspected to be a regular summer visitor to Colorado, has only recently, through the observations of H. G. Snith, been proved to be so. He has taken it in considerable numbers at Julesburg, Wray and Holly, all localities on the easterm border of the State, between the 18th of May and 3lst of August, while his first example was obtained on Clear Creek near Denver on June 6th, 1903. It may be considered a regular summer bird in the eastern half of the State.

Habits.-Goss writes: "These active birds inhabit dense patches of bushes and briers on the prairies; hedgefences are also a favourite resort. Their call and alarm notes are rather harsh, and their song does not rank very high. Their deep, cup-shaped nests are suspended from slender forks of twigs or vines and are composed. of lint-like strippings from plants, neatly interwoven with bits of old leaves, and lined with fine weed stems, and in some cases hairs. The eggs, usually four in number, are pure white, thinly speckled at the larger end with dark reddish-brown, and measure $69 \times 50$. .' 


\section{Grey Vireo. Vireo vicinior.}

A.O.U. Checklist no 634-Colorado Record-H. G. Smith 08, p. 189. Description.-Male-Above slaty-grey, with a hardly perceptible wash of olive on the rump; a white orbital ring and dirty-white lores ; wings and tail dusky, edged with whitish ; greater coverts tipped with whitish, but hardly forming a distinct wing-band; below dull white tinged with grey on the throat and breast and more or less with olive on the flanks; iris brown, bill dusky, markedly pale along the cuttingedges, legs dusky. Length 4.90 ; wing 2.60 ; tail 2.30 ; culmen .40 ; tarsus .72 .

The sexes are alike, and the young are very similar to the adults.

Distribution.-From southern California and western Texas southwards into north-west Mexico and Lower California.

The inclusion of the Grey Vireo in the Colorado fauna is also due to the indefatigable collecting of Mr. H. G. Smith, who obtained two pairs of this species at Lamar on the Arkansas River in Prowers co., between May 16th and 20th, 1907, thus extending the range of the species considerably northwards; the nearest recorded locality in New Mexico is Las Vegas.

\section{Family MNIOTILTIDE.}

This family contains the Warblers or, more properly speaking, the American Warblers, as the birds known by that name in Europe belong to quite another family.

The American Warblers are all small birds; except Icteria and Seiurus, they hardly average over five inches in length. It is not possible to characterize them exactly and definitely, as they present a number of minor modifications of form in the direction of other families, but they have the following external characteristics in common: Bill small, generally acute, the breadth and depth about equal; no lobe or tooth along the cuttingedge, never strongly hooked at the tip and never very much flattened; gape comparatively short and usually with a few rictal bristles; wings with nine primaries, the inner secondaries or tertials never greatly elongated; tarsus scutellate; rectrices twelve.

The members of this family are confined to America, and have their centre of abundance perhaps in the eastern 
parts of the United States. Colorado has 29 species out of about 155 distributed in summer from Alaska to the Argentine.

The following is a plumage key to the Colorado species, as the genera are not easily discriminated. The key will not invariably hold good for the females and juveniles, for which the main text should be always consulted.

\section{Plumage Key of the Colorado Warblers.}

A. Tail particoloured, dusky or slaty marked with white.

a. With a bright yellow patch on the wing. V. chrysoptera, p. 443.

b. Without a conspicuous yellow patch on the wing.

$a^{1}$ Below white, with or without black markings or streaks, but no yellow.

$a^{2}$ Head and back streaked with black and white.

$b^{2}$ Head black, not streaked.

M. varia, p. 441.

$a^{3}$ Back slaty; a yellow spot in front of the eye.

$b^{3}$ Back olive-grey; no yellow spot. D. striata, p. 455. $c^{2}$ Crown and back greyish-blue.
$a^{3} \quad$ Throat black.
D. crerulescens, p. 451 .

$b^{3} \quad$ Throat white.

D. cerulea, p. 455.

$d^{2}$ Crown and back yellowish-green ; sides of the face yellow.

b1 Below with some yellow.

D. virens, $p, 459$.

$a^{2}$ Crown and back slaty-blue, and an olive patch in the middle of the back.

C. a. usneæ, p. 447.

$b^{2}$ Crown and head all round bright orange-yellow.

P. citrea, p. 442.

$c^{2}$ Crown with a yellow patch surrounded by black or dusky.
$a^{3}$ Throat yellow.
D. auduboni, p. 453.

$b^{3}$ Throat white.

D. coronata, p. 451.

$\mathrm{d}^{2}$ Crown grey, rump yellow. $\quad$ D. magnolia, p. 454.

$e^{2}$ Crown grey, streaked with black, rump like the back, not yellow.

D. graciz, p. 456 .

$f^{2}$ Crown bleck, with a yellow superciliary line on either side; rump like the back. D. townsendi, p. 459.

$\mathrm{g}^{2}$ Crown chestnut.

D. palmarum, p. 460 .

$\mathrm{h}^{2}$ Crown and back olive-green. D. cærulescens $q, \mathrm{p} .451$. 
B. Tail dusky and bright yellow; rest of the plumage yellow.

D. æastiva, p. 449.

C. Tail with salmon-red or pale yellow at the base; rest of plumage black or brown with salmon. S. ruticilla, p. 470.

D. Tail dusky or olive, not marked or spotted.

a. Large-wing at least 3.0 ; breast bright yellow.

I. $\nabla$. longicauda, p. 467.

b. Smaller-wing 2.75 to 3.0 ; breast white, spotted with black. a Crown with an orange patch bordered by black stripes.

S. aurocapillus, p. 461 .

$b^{1}$ Crown like the back, brown. $\quad$ S. n. notabilis, p. 462.

c. Smallest-wing under 2.75 ; breast never white, spotted with black.

al Bill acute and pointed, rictal bristles hardly evident.

$a^{2}$ Crown slaty-blue, becoming olive-green on the back.

$a^{3}$ Sides of the head and breast like the crown-slaty; posteriorly yellow below.

$a^{4}$ A complete white ring round the eye. O. agilis, p. 462.

$b^{4}$ A white spot only above and below the eye.

O. tolmiei, p. 463 .

$b^{3} \quad$ Below whitish, no slaty or yellow. V. peregrina, p. 446.

$\mathrm{b}^{2}$ Crown and back olive-green; forehead and sides of the head black' G. t. occidentalis, p. 465.

$c^{2}$ Above grey, a concealed crown-patch of chestnut.

V. virginiz, p. 443 .

$\mathrm{d}^{2}$ Above dull olive-green with a concealed crown-patch of orange.

V. celata, p. 444.

$b^{1}$ Bill broad, flat and triangular, rictal bristles long and conspicuous.

$a^{2}$. Breast yellow, spotted with black.

W. canadensis, p. 470 .

$b^{2}$ Breast yellow but unspotted.

$a^{3}$ Larger-wing 4.25 ; forehead bright yellow.

W. p. pileolata, p. 468 .

$b^{3}$ Smaller-wing 4.15 ; forehead pale yellow.

W. pusilla, p. 469 .

\section{Genus M N IOT ILTA.}

Bill rather long, about equal to the head, laterally compressed, with curved culmen and rather short rictal bristles; wing long and pointed, the three outer primaries about equal to one another; tail even, distinctly shorter than the wing; hind toe and claw very long; plumage black and white.

Only one species. 


\section{Black and White Warbler}

\section{Black and White Warbler. Mniotilta varia.}

A.O.U. Checklist no 636-Colorado Records-Minot 80, p. 226 ; Morrison 88, p. 72 ; Cooke 97, p. 113 ; 04, p. 18 ; Henderson 03, p. 237 ; 09, p. 239 ; Chapman 07, p. 38 ; Smith 08, p. 190.

Description.-Male-Crown and sides of the head black, with a central and two lateral white streaks through and above the eye; back striped black and white; upper tail-coverts black with white edges; wings and tail black with white or grey margins to most of the feathers; wing with double wing-bar formed by the white tips of the median and greater coverts, tail with the two outer feathers with a terminal white spot on the inner web; below, the throat black, centre of abdomen white, rest of the under-parts black and white striped; iris and bill black, legs dusky horn. Length 4.5 ; wing 2.75 ; tail 2.10 ; culmen .40 ; tarsus $\cdot 60$.

The female is duller in colour than the male; the ear-coverts are buffy, not black, bordered above by a narrow streak of black, the throat is white, and the streaks of the under-parts less distinct and the white ground-colour tinged with buffy. The young bird resembles the female, but the colouring is even less distinct and the white more buffy.

Distribution.-Breeding in eastern North America from the Mackenzie Valley and Newfoundland to Virginia and Texas, wintering along the Gulf coasts, in the West Indies and through Mexico to Ecuador and Venezuela.

The Black and White Warbler is a rare straggler into Colorado; it has been observed but not obtained on four occasions only-at Boulder on June 1st, 1880, by Minot; at Fort Lewis by Morrison; at Table Rock near Palmer Lake by Brenninger (Cooke), and at Holly in Prowers co. on May 23rd, 1907, by H. G. Smith.

Habits.-The Black and White Warbler is distinguished by its Creeper-like habits; it runs actively up tree trunks and along the branches of the deciduous trees among which it is chiefly met with, with all the agility of a Creeper or Nuthatch. It is not known to breed in Colorado, but in the east the nest is usually placed on the ground, under the shelter of a tree trunk, rock or fallen log; the eggs, four or five in number, are creamy-white, heavily spotted with various shades of brown and lavender, and measure $66 \times 53$. 


\section{Genus PROTONOTARIA.}

Bill large and stout, rather wedge-shaped, culmen slightly decurved; rictal bristles very short, hardly visible; wing rather pointed, the three outer primaries subequal, and much longer than the short, square tail; hind toe short but stout; plumage yellow and slaty-blue.

Only one species.

\section{Prothonotary Warbler. Protonotaria citrea.}

A.O.U. Checklist no 637-Colorado Record-Felger 07, p. 342.

Description.-Male-Head and neck all round bright yellow; centre of the back yellowish-olive; wings, rump and tail dark slaty-grey; wing and tail-feathers, except the central pair, white on the inner web, the tail-feathers tipped with darkex; below bright yellow, becoming white on the under tail-coverts; iris brown, bill black, legs dusky. Length 4.90 ; wing 2.80 ; tail 1.75 ; culmen .50 ; tarsus .70 .

The male in winter has a paler bill. The female is slightly smallerwing 2.75-and duller in colour.

Distribution.-Breeding in the low-lying districts of the eastern United States from Minnesota, and Virginia southwards to the Gulf states; south in winter via Yucatan to Nicaragua and Venezuela.

A rare straggler in Colorado-Felger has examined and identified three examples shot by B. G. Voigt, one between Palmer Lake and Monument, the others on the Arkansas River near Pueblo. These examples had the pale bills characteristic of the fall and winter plumage, and were probably taken in the fall, but the date appears to be uncertain. They constitute the only records.

Habits. - The Prothonotary Warbler is always associated with heavily timbered country, and slow, sluggish streams or swamps; an abundance of willows also seems to be very essential. The nest is usually placed in a hole in a tree trunk, often the deserted one of a Downy Woodpecker or Chickadee, and as a rule not very high from the ground, and near water; the nest is made up of straws, strips of bark and moss, feathers or hair being rarely used; the eggs, usually six in number, are rich creamy-white to buffy, very heavily blotched and spotted with various shades of brown, and measure $\cdot 70 \times \cdot 57$. 


\section{Golden-winged Warbler}

\section{Genus VERMIVORA.}

Bill short, slender and acute, with nearly straight eulmen; rictal bristles not evident; wings moderate but longer than the tail, which is even, and with rather narrow, rounded feathers, not marked with white (in the Colorado species) ; tarsus longer than middle toe and claw.

About ten species ; the breeding range is confined to North America (for key, see p. 439).

\section{Golden-winged Warbler. Vermivora chrysoptera.}

A.O.U. Checklist no 642-Colorado Record-Cooke 09, p. 314.

Description.-Male-General colour grey with a slight tinge of olivegreen; cheeks and throat black; a large and conspicuous patch of yellow on the wings; below white; iris brown; bill black ; legs dark brown. Length 4.3 ; wing 2.45 ; tail 1.90 ; culmen .35 ; tarsus .65 .

The female has the cheeks and throat grey, not black.

Distribution.-Breeding from Wisconsin and New Hampshire, south to northern Illinois and Georgia in the mountains; south in winter across the southern Mississippi Valley to Guaternala and Colombia.

The Golden-winged Warbler has once been noticed in Colorado, by Miss Patten at Yuma, on May 25th, 1906.

\section{Virginia's Warbler. Vermivora virginice.}

A.O.U. Checklist no 644-Colorado Records-Aiken 72, p. 196 ; Henshaw 75, p. 189 ; Minot 80, p. 226 ; Allen \& Brewster 83, p. 155 ; Drew 85, p. 15 ; Cooke 97, pp. 113, 218 ; 04, p. 37 ; Henderson 03, p. 237 ; 09, p. 239 ; Warren 06, p. 23 ; Chapman 07, p. 98 ; Rockwell 08, p. 176.

Description.-Male-General colour above dark slaty-grey; crown with partly concealed patch of dark chestnut; a conspicuous white orbital ring; rump and upper tail-coverts, a patch on the breast paling off towards the throat, and under tail-coverts bright yellow; wings and tail dusky, unmarked; below pale grey except for the yellow; iris brown, bill horn, paler on the lower mandible, legs dusky horn. Length 4.30 ; wing 2.5 ; tail 1.75 ; culmen .40 ; tarsus .72 .

In fall and winter the plumage has a much browner tinge, the yellow breast-patch is less conspicuous and the crown-patch completely concealed by the long grey tips of the feathers. The female resembles the male, but is duller in colour generally, especially as regards the chestnut of the crown and the yellow patches, all of which are more restricted. The young bird has the wing-coverts tipped buffy, forming two obscure wing-bars, and at first hardly any traces of chestnut or yellow.

Distribution.-Breeding in the Rocky Mountains region from Colorado and Nevada south to New Mexico and Arizona; in winter through Mexico as far south as Guerrero.

In Colorado Virginia's Warbler is of common occurrence along the eastern foothills of the mountains up to an elevation of about 7,500 
feet, where it breeds; it has also been met with on the plains, but probably only on migration. It arrives from the south early in MayEl Paso co. May 2nd (Aiken), Monon, Baca co., May 3rd (Warren)and leaves again late in September. At Grand Junction on the western slope Miss Eggleston states that it is a regular migrant (Rockwell).

The following are recorded localities: Estes Park, breeding (W. G. Smith apud Chapman), Boulder co. (Minot), Middle and South Parks (Carter), Beulah, Pueblo co. (Chapman), Fort Garland and Pagosa Springs (Henshaw), all in the foothills and mountains; Limon (Aiken) and Monon (Warren), in the plains.

Habits. -Aiken was the first to find this Warbler in Colorado, and to him belongs the credit of first describing the nesting habits of the species. He gives the following account (Henshaw 75): "During its migrations, this interesting little bird will be found among the cotton-woods and willows bordering the streams, and often also among the pines, but in summer it frequents only the low scrub-oak brush on the hill-sides. It exhibits at all times a good deal of shyness, hiding instantly at the approach of an intruder or keeping at a respectful distance while uttering its sharp alarm-note. The male is very musical during the nesting season, uttering his sweet little ditty continually as he skips through the bushes in search of his morning repast. No bird with which I am acquainted conceals its nest more effectually than this Warbler. This is placed at the base of a tussock of grass, among the oak bushos, being sunk in a hollow scratched in the earth so that the rim of the nest is on a level with the surface. About the first of June, five white eggs, delicately speckled with reddish-brown, are laid."

H. G. Smith found a nest on June 20th in Estes Park; it was under a rock ledge, sunk in the ground and well hidden; the eggs, four in number, were white, speckled chiefly in a wreath round the larger end, with reddish and purplish-brown, and measured $66 \times 49$. 


\section{Orange-crowned Warbler}

\section{Orange-crowned Warbler. Vermivora celata.}

A.O.U. Checklist no 646-Colorado Records-Aiken 72, p. 196; Henshaw 75, p. 191 ; Minot 79, p. 226 ; Allen \& Brewster 83, p. 156 ; Drew 85, p. 15 ; Beckham 87, p. 123 ; Lowe 92, p. 101 ; 94, p. 269 ; H. G. Smith 96, p. 76 (H. c. lutescens); Cooke 97, pp. 19, 113; 04, p. 40 ; Henderson 03 , p. 237 ; 09, p. 239 ; Oberholser 05, p. 243 (H. c. orestera) ; Warren 06, p. 23 ; Chapman 07, p. 89.

Description.-General colour above greyish-olive, brighter and purer on the rump and upper tail-coverts; crown with an orange-chestnut patch, hidden more or less by the olive-green tips to the feathers; an orbital ring of pale yellow; wings and tail dusky, unmarked; below pale greenish-yellow, with dusky or greyish wash, clearest on the under tail-coverts; iris brown; bill horny-brown, under mandible paler ; legs brownish-horny. Length 4.60 ; wing 2.40 ; tail 2.0 ; culmen .40 ; tarsus .70 .

The female is indistinguishable from the male, though generally rather duller and very slightly smaller. Young birds have no crownpatch; the wing-coverts are pale tipped, and the general coloration is duller and more buffy.

The Orange-crowned Warblers of esstern Colorado which have been examined appear to be on the whole nearest to the typical eastern form and quite separable from Californian birds (H. c. lutescens), though a specimen in the Aiken collection from Mosca Pass, taken on June 28th, is rather brighter and perhaps somewhat intermediate. Oberholser (05) has recently distinguished a Rocky Mountain race (V. c. orestera) intermediate in colour between the brighter California and duller Middle States races. Should this new race be "passed " by the A.O.U. Committee, the Colorado bird will certainly be referred to it.

Distribution.-Breeding from Alaska and Manitoba south along the Rocky Mountains to New Mexico and Arizona. In winter south to Vera Cruz in central Mexico, and east over the Mississippi Valley and Gulf states to South Carolina. The form "orestera" is stated by Oberholser to breed from British Columbia, through the Rocky Mountains to southern California and New Mexico, and to go south in winter to lower Califormia and southern Mexico.

In Colorado the Orange-crown is far from uncommon during migration, arriving from the south the first week in May (Fort Lyon May 9th, Thome; El Paso co. May 2nd, Aiken; Loveland May 2nd, W. G. Smith), and passing south again late in September. It is stated to breed in the mountains from 6,000 to 9,000 feet, but I have not been able to find any direct evidence of its doing so. It is chiefly met with on the eastern plains and foothills, as the following additional records show: Boulder May 2lst (Henderson), Denver (Henshaw), Limon, Lincoln co. (Aiken), Pueblo (Lowe), Salida May lst (Frey), 
Baca co. (Warren), Fort Garland and Pagosa Springs (Aiken), Wet Mountains to 8,000 feet (Lowe 94), and finally Mosea Pass, 10,00011,000 feet, Huerfano co. (Aiken).

Habits.-Very little has been written on the habits of the Orange-crown either in Colorado or elsewhere; Henshaw states that it frequents the tops of low trees and bushes, whence it makes Flycatcher-like darts at passing insects, and that it has a short and simple song.

Its nest has not been described, but that of its elose ally, the Lutescent Warbler, is placed on the ground, generally on dry hill-sides covered with brush, and is loosely made of dry leaves and grasses, lined with fine grass. The eggs closely resemble those of the Lutescent Warbler, being white or creamy-white, finely speckled, chiefly at the larger end, with reddish or chestnut-brown. They measure $64 \times \cdot 46$.

\section{Tennessee Warbler. Vermivora peregrina.}

A.O.U. Checklist no 647-Colorado Records-Ridgway 73, pp. 176, 180 ; Minot 80 , p. 226 ; Drew 85, p. 15 ; Cooke 97, pp. 113, 168, 218, 224 ; 04, p. 42 ; Henderson 03, p. 237 ; 09, p. 239 ; Chapman 07, p. 83 ; F. G. Smith 05, p. 82 ; 08, p. 190.

Description.-Male-Head and neck ashy-brown, rest of the uppersurface olive-green, brightest on the rump; wings and tail dusky, the primaries edged with greyish, the secondaries, coverts and tailfeathers with olive-greenish; the tail white on the inner web; superciliary streak white, bordered below by a dusky line running through the eye; below dull white, shaded with grey on the flanks; iris brown, bill blackish-brown, paler on the lower mandible; legs horny-brown. Length 4.20 ; wing 2.5 ; tail 1.75 ; culmen .43 ; tarsus .65 .

The female closely resembles the male, but sometimes the ashy-grey of the head is slightly tinged with olive. Young birds have the head and neck green like the back, and the superciliary streak and underparts, except the under tail-coverts, strongly washed with yellowisholive.

Distribution.-Breeding from Alaska and Labrador to British Columbia and New England; south in the fall through the Middle States and Mexico to Central America, Colombia and Venezuela in winter. 
In Colorado the Tennessee Warbler is fairly common on migration in the eastern plains part of the State, but seldom comes near the mountains; it is only recently that it has been commonly reported. It passes north through the State in the second half of May, and returns south late in September.

Aiken first recorded it from Colorado; young male taken in El Paso co. September 28th, 1872, is still in the Aiken collection; it has subsequently been met with by Minot at Boulder, May 31st ; at Loveland by Messrs. Osburn and W. G. Smith near the foothills; and out in the plains at Limon-five examples 19th-23rd May by Aiken, and at Julesburg, Wray, Kit Carson, Manzanola and Holly by Messrs. Smith and Ferril between May 21 st and 27 th, along the eastern border of the State (W. G. Smith 05, 08.)

Habits. - Little has been written on the habits of this bird; it often assoriates with other Warblers, generally perehing high up in trees and making darts at passing insects; Minot found it an active little creature but heard no song, only a slender "Tsip, tsip." Aiken considers that it may breed in Colorado, as he observed a bird in July in Colorado Springs which he believed to be this species, but no other evidence is forthcoming, and indeed little is known about its nesting habits at all. In British Columbia it has been found nesting on the ground; the nest was well arched over with dried grass, and was made of leaves and moss and lined with fine grass. The eggs are creamy-white, fine speckled, and also marked with larger spots of reddish-brown. They measure about $60 \times \cdot 47$.

\section{Genus COMPSOT HIYPIS.}

Bill short and acute and the culmen slightly curved; rictal bristles distinct but not very evident; wing with the four outer primaries subequal; outer and middle toe united at the base for most of the basal joint.

Three species from northern and tropical America.

Northern Parula Warbler. Compsothlypis americana usnece.

A.O.U. Checklist no 648a-Colorado Records-Aiken 72, p. 196 ; Cooke 97, pp. 114, 218 ; 04, p. 45 ; Chapman 07, p. 104 ; H. G. Smith 08 , p. 190 . 
Description.-Male-General colour above, including the sides of the head, slaty-blue with patch of rich olive-yellow in the middle of the back; middle and greater coverts tipped with white, forming two conspicuous wing-patches; tail with the three outer pairs of rectrices spotted, the next two merely edged on the inner web with white; lores black, a small white spot above and below the eye; throat and chest bright yellow, separated usually by a dusky patch; rest of the under-parts white, bluish-grey on the sides and flanks; iris brown, upper mandible black, lower yellow in life; legs brownish. Length 4.12 ; wing 2.25 ; tail 1.70 ; culmen .40 ; tarsus .65 .

The female resembles the male, but is duller throughout, and usually without the dusky chest-patch; young birds have the upper-parts washed over with olive-green; the white around the eye more extended, and the yellow of the throat paler and no dusky patch.

The birds of the Mississippi Valley appear to average slightly smaller than those breeding in the north eastern states. They have been distinguished as a subspecies (C. a. ramalince) by Ridgway (02, p. 486), but the form has not yet been recognized by the A.O.U. Committee. Colorado examples must be referred to it, if so recognized.

Distribution.-Breeding from Minnesota to Nova Scotia southwards in the mountains to Virginia; south in winter through the middle states to southern Mexico and Nicaragua.

The Parula is a rare straggler in Colorado. It was first taken by Aiken in El Paso co. on May 11th, 1872, and has since been definitely recorded twice only-from Clear Creek near Denver-a single female in May, 1904, and from Kit Carson in Cheyenne co. on May 27th, when Mr. Ferril killed one female from a flock (Smith). I have recently seen a male taken by Mr. Hersey at Barr, May 20th, 1909, now in the Natural History Museum at Denver.

Habits.-During the migration period the Parula is generally distributed, though preferring deciduous to coniferous trees. In the breeding season it is only to be found where the usnea moss grows freely. This is a lichen, growing on trees in swampy places and forming great, freely hanging masses dependent from the branches. In this the Parula makes its nest, generally with a small side-entrance. The eggs, usually four, are white to creamy-white, with coarse, ill-defined markings of reddishbrown, chestnut and grey. They vary very much in size and shape, but average $67 \times \cdot 48$. The Parula is not known to nest in Colorado. 


\section{Yellow Warbler}

\section{Genus DENDROICA.}

Bill variable but generally rather conical, the basal width and depth about equal ; culmen slightly decurved; rictal bristles quite obvious; wing with the four outer primaries about equal; tail shorter than the wing, about even or slightly rounded; plumage in most cases with white wing-bars and white patches on the tail.

This is the largest genus of the family ; it contains about thirty-four species, twenty-three of which have been found in the United States, the others inhabiting Mexico, Central America and specially the West Indies. For key, see p. 439.

\section{Yellow Warbler. Dendroica oestiva.}

A.O.U. Checklist no 652-Colorado Records-Allen 72, pp. 148, 175 ; Trippe 74, p. 232 ; Henshaw 75, p. 192 ; Minot 80, p. 226 ; Allen \& Brewster 83, p. 158; Drew 85, p. 15 ; Beckham 85, p. 141 ; Brenninger 88, p. 64 ; Lowe 92, p. 101 ; H. G. Smith 93, p. 244 ; Cooke 97, pp. 19, 114, 218 ; 04, p. 52 ; Dille 03, p. 74 ; Henderson 03, p. 237 ; 09, p. 239 ; Warren 06, p. 23 ; 08, p. 24 ; 09, p. 17 ; Chapman 07, p. 113 ; Gilman 07, p. 194 ; Markman 07, p. 158 ; Rockwell 08, p. 176.

Description.-Male-Above yellow with an olive wash on the back, clearer and richer on the head and rump; wings and tail dusky, mostiy edged and tipped with yellow; below rich yellow with chestnut streaks on the chest and flanks; iris brown, bill dusky horn, legs light horny. Length 4.50 ; wing 2.55 ; tail 2.0 ; culmen .42 ; tarsus .70 .

The female resembles the male, but is rather duller in colour throughout; the head is like the back and the chestnut streaks are usually absent, or if present quite indistinct. Size smaller-wing 2.30. Young birds are very similar to the females.

Colorado birds are, some of them, intermediate between the typical eastern form and the more yellowish form, with narrower and less marked chestnut streaks below (D. a. sonorana), which occurs in New Mexico and Arizona, but on the whole it is perhaps safest to refer them to the typical race. The Yellow Warblers of the west have been also distinguished from those of the east under the name of $D$. ce. morcomi or $D$. ce. brewsteri, but for this there hardly seems to be any justification.

Distribution.-Breeding throughout the greater part of Canada and the United States, except Florida, Georgia and the south-western states from Texas to Arizona, south in winter across the Gulf of Mexico to south Mexico, central and South America as far as Peru and the Amazon Valley

In Colorado the Yellow Warbler is perhaps the commonest of its family in summer. It arrives from the south the first woek in May, Pueblo May 4th (Beckham), El Paso co. same date (Aiken), and leaves 
again for the south in September. It nests chiefly in the plains but also in the mountains, perhaps up to 9,700 feet (Breckenridge, Carter). It is common throughout the State from Routt co. (Warren 08) to La Plata co. (Gilman), and from Weld co. (Markman) to Baca co. (Warren 06), and Costilla co. (Henshaw). In Mesa co., where it is the commonest Warbler, it breeds up to 7,000 feet.

Habits. -The Yellow Warbler is perhaps the best known of all the family owing to its conspicuous coloration and familiar habits. It is fond of frequenting parks and gardens, and is very common about the suburban parts of towns, where it frequently builds its nest. Its more natural surroundings in Colorado are willow and cotton-wood trees and bushes along streams, but it does not care for thick forest or pine woods.

Like other Warblers, its food consists entirely of insects, and it is always busy searohing for these among the leaves and smaller branches of the trees. The song is rather simple, fut sweet and lively and highly characteristic, and is indulged in even in the middle of the day.

The nest, according to Gale, is placed in a croteh of a small tree, or more often in a low bush, usually a willow or cotton-wood; in the latter case it is pensile, being fastened to the surrounding twigs at the rim. It is woven of wild hemp or vine stems and grasses, and lined with the cotton from the cotton-wood trees, and is a light, compact and well-built structure.

Fresh eggs are to be met with about June 12th (Dille); the clutch is usually four, sometimes five, and the eggs are greyish to greenish-white, marked with spots, splashes and blotches of various shades of lilac and brown. They average $68 \times{ }^{5} 50$. This Warbler is one of the most frequent victims of the parasitic Cow-bird, and appears to realize the fact, as it is one of the few birds which constantly build a second and sometimes a third story 


\section{to the nest, so as to cover up and prevent the incubation of the intruding egg.}

\section{Black-throated Blue Warbler. Dendroica carulescens.}

A.O.U. Checklist no 654-Coloraeln Records-Cooke 94, p. 183 (error); 97, p. 114 ; 04, p. 57 ; H. G. Smith 96, p. 76 ; 08, p. 190 ; Chapman 07, p. 133.

Description.-Male-Above slaty-blue, the middle of the back sometimes a little speckled with black; wings black, extensively edged with blue, a conspicuous white patch towards the base of the primaries, except the outermost; the primaries also extensively white on the inner web; tail dusky, edged with blue, the outermost feathers with a large subterminal patch on the inner web; below, throat, sides of the head and flanks black; rest of the under-parts white; iris brown, bill black, legs dusky horn. Length 4.50 ; wing 2.60 ; tail 1.90 ; culmen .40 ; tarsus .65 .

The autumn and winter male is very similar, but has a brown bill and $a$ buffy tinge on the white of the flanks. The young male has a slight greenish wash over the blue of the upper-parts and a slight white freckling on the black of the throat and flanks. The female is olive-green above, rather more bluish on the crown and tail ; an incomplete whitish ring round the eye and a white patch at the base of the primaries; below pale yellow. Size about the same as the male.

Distribution.-Eastern North America, breeding from Hudson Bay and Newfoundland south to the mountains of Pennsylvania; on migration south, chiefly east of the Mississippi to southern Florida and the Antilles.

The Black-throated Blue Warbler is a rare straggler as far west as Colorado. It has only been twice met with, on both occasions by H. G. Smith. He obtained a female on the Platte River near Denver, May 24th, 1888, and very plainly observed, but did not obtain, a male at Wray on September 18th, 1903.

\section{Myrtle-Warbler. Dendroica coronata.}

A.O.U. Checklist no 655-Colorado Records-Aiken 72, p. 196 ; Ridgway 73, p. 176 ; Trippe 74, p. 232 ; Henshaw 75, p. 193 ; Allen \& Brewster 83, p. 158 ; Cooke 97 , pp. 19,114 ; 04, p. 61 ; Henderson 03, p. 108 ; 09, p. 239 ; Chapman 07, p. 141 ; H. G. Smith 08, p. 190.

Description.-Male-Above slaty-blue, streaked with black; patch on the crown, rump, and a patch on either side of the breast, bright yellow, the rump-patch palest; wings and tail dusky, with greyish edgings, the coverts broadly tipped and edged with white, forming a double wing-bar; the three outer pair of tail-feathers with a large subterminal white spot on the inner web ; sides of the head black, with 
a little white around the eye; below white, with irregular patches of black on the chest and streaks of the same colour on the flanks; iris brown, bill black, legs dark brown. Length 5.25 ; wing 3.10 ; tail 2.55 ; culmen .40 ; tarsus .75 .

The male in autumn and winter is very different; the general colour above is dingy brown with indistinct streaks of black, the crown-patch concealed by the brownish tips of the feathers; but the rump is bright yellow; below and the sides of the head dingy white, and the yellow breast-patches are hardly noticeable. The female in spring is like the male but is smaller-wing 2.80 -and duller in colour, the back is strongly washed with brown and the crown-patch is smaller; the sides of the head dusky brown, not black, and the black of the lower-parts is more streaky and less patchy. Young birds are like the female, but duller and less marked.

Distribution.-Breeding far north from Alaska and Labrador south to the northern border of the states from Minnesota to Massachusetts, wintering in the middle tier of the states from Kansas and Massachusetts south to eastern Mexico, Panama, the Bahamas and the Greater Antilles.

The Myrtle-Warbler is a rather uncommon spring migrant in the eastern part of Colorado up to the foothills of the mountains, arriving about the last week in April-El Paso co. April 28th (Allen \& Brewster), Loveland April 24th-25th (W. G. Smith)-and passing onward about the end of May. It has not been found breeding in the State, nor has it been recorded during the fall migration, but recently H. G. Smith (08) has found it wintering at Holly in the Arkansas Valley. As it is well known to winter in south-eastern Kansas, this is not surprising.

The following are additional recorded localities: Boulder co. on migration (Henderson), Idaho Springs up to 9,000 feet (Trippe), Denver (Henshaw), Limon (Aiken), Salida May 9th (Frey), and Fort Lyon (Thorne apud Cooke).

Habits. - The Myrtle-Warbler is generally seen about low trees, moving briskly along and picking up small insects, though in winter it is said to feed largely on berries, especially those of the myrtle, from which it gets its name. It has a characteristic "Tchip" or "Tchep," while Henshaw state; that its song is a low and sweet warble resembling that of the Audubon.

Beyond our limits it nests in small coniferous trees, while the eggs, usually four in number, resemble those of other Warblers. 


\section{Audubon's Warbler. Dendroica auduboni.}

A.O.U. Checklist no 656-Colorado Records-Allen 72, pp. 148, 155, 162 ; Aiken 72, p. 197 ; Trippe 74, p. 232 ; Henshaw 75, p. 196 ; Brewer 77, p. 394 ; Scott 79, p. 92 ; Minot 80, p. 227 ; Tresz 81, p. 285 ; Drew 81, p. 88 ; Allen \& Brewster 83, p. 158 ; Beckham 85, p. 141 ; 87 , p. 125 ; Stone 84, p. 20 ; W. G. Smith 88, p. 114 ; Morrison 88, p. 72 ; Kellogg 90, p. 89 ; Lowe 92, p. 101 ; 94, p. 269 ; McGregor 97, p. 39 ; Cooke 97, pp. 18, 115, 219 ; Dille 03, p. 74 ; Henderson 03, p. 237 ; 09, p. 239 ; Cooke 04, pp. 18, 64 ; Warren 06 , p. 24 ; 08, p. $24 ; 09$, p. 17 ; Chapman 07, p. 147 ; Rockwell 08, p. 176.

Description.-Male-Closely resembling the Myrtle-Warbler in most respects, but with the throat yellow, not white, with a larger subterminal spot on four of the outer tail-feathers; the sides of the face more blueish and less black, and with a less conspicuous white eyebrow; iris brown, bill black, legs dark brown. Length 5.0 ; wing 3.1 ; tail 2.25 ; culmen .40 ; tarsus .75 .

The males in autumn, the females and young birds resemble similar stages in the Myrtle, but the throat is always at least tinged with yellow, except in the birds of the year. These are always distinguishable by the larger amount of white to the tail-feathers.

Distribution.-Audubon's Warbler replaces the Myrtle in the western part of America, breeding at high altitudes in the Rockies from British Columbia and Alberta south to southern California and northern New Mexico ; it winters in California and western Mexico south to Guatemala.

Audubon's Warbler is one of the commonest spring migrants in Colorado, arriving from the south at the end of April-April 16th in El Paso co. (Aiken), Loveland, April 19th-24th (W. G. Smith)-and slowly moving up in the mountains where it nests in June or July; it gradually descends again in August and September, and leaves the State in October-Pueblo, October 24th (Beckham), is the latest date recorded.

On the western slope in Mesa co. it is very common, breeding in heavy coniferous timber from 8,000 to 10,000 feet. It arrives in Mayearliest date May 7 th-and begins to go south late in August.

It has been recorded breeding in Estes Park 8,000 feet (W. G. Smith), Idaho Springs (Trippe), Georgetown (Keyser), near Breckenridge (Carter apud Brewer), Twin Lakes (Scott), Pikes Peak and Divide (Aiken), and San Juan co. (Drew), and on migration in Baca co., May 2nd-15th, and Bedrock, Montrose co., April 20th (Warren), and along the foothills of the range everywhere.

\section{Habits.-Audubon's Warbler is generally found in the cotton-woods and thickets along the river valleys}


in the plains, on its arrival from the south; it soon, however, passes on up into the mountains, and in the breeding season is chiefly met with among the pines and spruces, from 7,500 to 11,000 feet.

The nest and eggs were first taken by Carter and described by Brewer. The nest is generally placed in a low pine about eight to ten feet up, but so etimes (W. G. Smith) in "birch" timber near water. It is made of strips of bark or sage-brush, and lined with horsehair, and usually a few feathers. The eggs, nearly alway's four, are to be found about June 15th at 9,500 feet, and a fortnight later at 11,000 feet. They are white, generally with a blueish tinge, varyingly spotted and blotched with brown and lavender, and usually more profusely at the larger end. They average about $.70 \times .56$.

The song of the Warbler is a weak little trill, and the call-note a "Tchip," resembling that of the MyrtleWarbler.

\section{Magnolia-Warbler. Dendroica magnolia.}

A.O.U. Checklist no 657-Colorado Records-Henshaw 75, p. 196 D. maculosa) ; Cooke 97, pp. 115, 168 ; 04, p. 65 ; Chapman 07, p. 121 ; Warten 08, p. 24 ; H. G. Smith 08, p. 190.

Description.-Male-Crown and nape blueish-grey; a stripe through the eye, back, wings and tail black; eyebrow and a patch on the wingcoverts white; rump and under-parts yellow, with a black band across the upper-breast and streaks on the lower-breast and flanks; all the tail-feathers, except the two centre ones, with a transverse white band on the inner web; under tail-coverts also white; iris brown, bill black, legs dusky brown. Length 5.25 ; wing 2.4 ; tail 2.0 ; culmen .35 ; tarsus .70 .

The fernale is duller in colour than the male; the crown is dull grey, the sides of the face and back also dull grey, the centre of the back tinged with olive, spotted with black; the jellow of the rump duller, and the white wing-patch much less marked ; below without the chestband, and streaks far less conspicuous. The male in the fall and the young birds are very similar to the female. 
Distribution.-The breeding range of the Magnolia Warbler is limited to the Canadian zone, from Great Slave Lake and Newfoundland south to northern New York and along the Alleghanies to Maryland. In winter it resorts to southern Mexico and Central America as far as Panama. In Colorado it is merely a straggler and has only been taken during the spring migration. The following are the records: Near Denver with a flock of Audubons, on May 17th, 1873, by Henshaw; near Denver again, by H. G. Smith, May 17th, 1888 ; near Fort Lyon, Bent co., by Captain Thorne, on May 17th, 1884 (Cooke); near Springfield, Baca co., May 5th, 1905, by Warren; and near Holly, Prowers co., May 22nd, 1907, by H. G. Smith.

\section{Cerulean Warbler. Dendroica cerulea.}

A.O.U. Checklist no 658-Colorado Records-Henshaw 75, p. 196 ; Cooke 97 , p. 115 ; 04, p. 69 ; Chapman 07, p. 170.

Description.-Male in breeding plumage-Above bright blue, with u few black streaks; wings dusky, with a double white wing-bar ; tail black, with white subterminal patches on the inner webs; below white with a narrow chest-band and streaks along the sides of blueish-black; iris brown, bill dusky, legs dusky brown. Length 4.25 ; wing 2.50 tail 1.75 ; culmen $\cdot 3$; tarsus $\cdot 6$.

The female is duller than the male and slightly tinged with olive above and below; it has no breast-band or streaks below. The fall plumage is practically identical with that of the spring.

Distribution.-Breeding in the south-eastern United States from eastern Nebraska and Kansas eastwards, and from southern Ontario southwards, migrating south across the Gulf of Mexico to north-west South America, from Panama to Peru, where it winters.

The only Colorado record for this Warbler is that of Henshaw, who observed one individual among a flock of Audubons migrating near Denver, May 17th, 1873. It can only be regarded as a straggler.

\section{Blackpoll-Warbler. Dendroica striata.}

A.O.U. Checklist no 661-Colorado Records-Henshaw 75, p. 198 ; Minot 80, p. 227 ; Allen \& Brewster 83, p. 158 ; Cooke 97, pp. 19, 115 ; 04, p. 76 ; Chapman 07, p. 196 ; Henderson 09, p. 239 ; Hersey \& Rockwell 09, p. 121.

Description.-Male in breeding plumage-Crown black, back grey streaked with black; wings and tail dusky, the middle and greater coverts tipped with white, forming a double wing-band; centre of the back and wings with a faint wash of olive; outer tail-feathers with subterminal white spots; cheeks to below the eye and under-parts white, streaked heavily on either side of the throat and less so along the flanks with black; iris brown, bill horny-brown, darker on the 
upper mandible, legs pale jellow-brown. Length 5.25 ; wing 2.80 ; tail 2.0 ; culmen .40 ; tarsus .70 .

In autumn the male is very different, the black cap is entirely absent, and the upper-parts are olive-green, slightly streaked with black in the middle of the back, the tips of the coverts tinged with olive; below paler olive-green, becoming white on the under tail-coverts.

The female is somewhat like the fall male, but is more distinetly streaked on the crown and back, while below it is paler, often white on the centre of the abdomen, and streaked laterally with dusky.

Distribution.-Breeding far north from Alaska and Labrador to Michigan and northern New England, in winter southwards through the West Indies to northern South America as far as northern Brazil and Ecuador.

The Blackpoll cannot be considered anything but a straggler on migration in Colorado. A number were seen and one female obtained near Denver, May 17th, 1873, by Henshaw; Henderson saw one at Boulder on May 7 th, 1905, at very close range; and Hersey obtained one May 6th, 1908, at Barr ; Allen \& Brewster saw two and obtained one near Colorado Springs on May 8th and 9th, 1882; and Cooke notes it in his migration tables at Fort Lyon, May 8th, and Loveland May 12th; there is no example in the Aiken collection.

Minot states “ local summer resident at Seven Lakes," on the southern slopes of Pikes Peak. This breeding record has never been confirmed and is a long distance from Mackinac Isle, Michigan or Manitoba, the nearest recorded portions of the breeding range, and even Manitoba seems doubtful. It will be perhaps safest to neglect the Minot record until further verified, and consider the Blackpoll a rare straggler on migration, and not breeding resident.

\section{Grace's Warbler. Dendroica gracioe.}

A.O.U. Checklist no 664-Colorado Records-Drew 81, p. 142 ; Morrison 88, p. 72 ; Osburn 93, p. 212 ; Cooke 97, p. 115 ; 04, p. 86 ; Chapman 07, p. 185 ; Cary 09, p. 183.

Description.-Adult Male-Above slaty-grey with a few black stripes on the crown and the middle of the back; wings and tail dusky, the former with white tips to the coverts, forming a double wing-bar; the latter largely white on the inner webs of the outer feathers; a stripe from the base of the bill to above the eye and the throat and chest bright yellow; ear-coverts grey, with a white patch above them, rest of the under-parts white, streaked with black on either side; iris brown ; bill blackish, legs dusky brown. Length 4.50 ; wing 2.80 ; tail 2.20 ; culmen .4 ; tarsus .7 .

The female resembles the male, but is duller in colour, the grey of the back tinged with brown, and the black streaks on the back and 
flanks less distinct. Young birds of both sexes are tinged with brown on the back, and also on the flanks, and have the black streaks very indistinct.

Distribution.-Grace's Warbler, originally discovered by Coues in Arizona and named by him after his sister, breeds throughout northern Mexico and the mountaing of New Mexico, Arizona and south-west Colorado, and winters in western Mexico (Jalisco).

In Colorado it was first met with by Drew in San Juan co., and subsequently by Morrison in La Plata co. ; the latter observer describes it as an uncommon bird, but found it breeding at an elevation of 8,500 feet. Cary states that it is tolerably common in the Yellow Pine forests near Pagosa Springs. $\mathrm{H}_{\theta}$ obtained a specimen May 28th. The only other record from the State is that of Osburn, who observed a small flock on migration near Loveland in the extreme north, and obtained a single specimen on April 25th, 1889.

Habits. -Drew describes Grace's Warbler as a "dainty little inhabitant of the pines up to 7,500 feet," and in the White Mountains of Arizona, where it is one of the commonest summer Warblers, it was noted by Henshaw as frequenting the tops of the coniferous trees, running swiftly over the smaller branches at the extremity of the limbs, and pursuing its prey on the wing. It was occasionally, too, seen among the oaks.

Morrison found a nest in May, 1887, about four feet from the ground, in a juniper bush; it was placed in a forked limb and was lined with dried grass, cowhair, and a fow feathers; it contained four eggs, white with reddish spots very sparingly distributed near and on the larger end. A second nest was found a few days later. The eggs measure about $69 \times \cdot 50$.

Black-throated Grey Warbler. Dendroica nigrescens.

A.O.U. Checklist no 665-Colorado Records-Aiken 72, p. 197 ; Trippe 74, p. 232 ; Henshaw 75, p. 198 ; Morrison 88, p. 72 ; Cooke 97, pp. 19, 116, 168 ; 04, p. 87 ; Chapman 07, p. 151 ; Rockwell 08, p. 176 ; Warren 09, p. 17 ; Cary 09, p. 183.

Description.-Male in spring-Crown and head all round black, except for a white band from above the eye to the nape, and another from the base of the bill along the sides of the throat; a small yellow spot in front of the eye; back grey with a few black streaks; wings 
and tail dusky, the coverts tipped with white, forming a double wingbar; the outer three pairs of tail-feathers largely white; under-parts: white, sharply defined from the black throat; sides streaked with black; iris brown, bill black, legs dusky. Length 4.30 ; wing 2.45 ; tail 1.90 ; culmen $\cdot 4$; tarsus $\cdot 7$.

The female resembles the male, but usually has less black on the head, and a wash of brown on the back; the throat and breast are mottled black and white. Young birds and adults in the fall have less black on the head and cheeks, and have the throat mottled black and white.

Distribution.-A western Warbler, breeding from British Columbia to Lower California, and eastwards to Colorado and New Mexico, migrating south in winter as far as Oaxaca, and Vera Cruz in Mexico.

In Colorado the Black-throated Grey Warbler is a rare bird ; arriving from the south in May, and ranging up to 9,500 feet at Silverton in San Juan co. It has been reportéd from Idaho Springs, May 23rd, by Trippe, and from Loveland on May 9 th by W. G. Smith, while Aiken records it from El Paso and Fremont cos., where he tells me that he believes that it breeds among the piñon hills north and east of Cañon City, but neither he nor any other observer has taken the nest in the State. Cary reports that he saw or took this bird at Douglas. Springs in September, in Sinbad Valley in July, at Coventry, and at Mesa Verde, 7,000 feet, all localities in the west of the State.

Habits.-Aiken gives the following account: "Rather a rare migrant in Colorado; a few probably remaining to breed. I have never seen it anywhere but on the mesas and foothills that are covered with low, scraggy piñon pines. The male as he searches for insects on leaf or limb repeats at intervals a singular but withal a very pretty song, with something of a metallic ring in it. Shy and retiring in its habits, and frequenting piñon groves so dense that one can scarcely see a dozen yards ahead, it is easily overlooked and requires considerable perseverance to secure." In Arizona it is reported to nest in dense scrub-oak as well as high up in pine trees. The nest resembles that of the Yellow Warbler, and usually contains four eggs-white, delicately marked with specks of red-brown and purplish, and measuring about $69 \times 50$. 


\section{Townsend's Warbler}

\section{Black-throated Green Warbler. Dendroica virens.}

\section{A.0.U. Checklist no 667 .}

Description.-Male in spring-Above yellowish olive-green, a little streaked with black on the back; sides of the head and neck, including the malar region and a superciliary stripe, lemon-yellow, turning to olive-green on the postocular region and ear-coverts; chin, throat and chest black; rest of the under-parts white or yellowish-white, streaked with black on the flanks; wings and tail dusky, the former with a white double bar, the latter with white on the inner webs of the outer rectrices; iris brown, bill blackish, legs and feet horny. Length 4.5 ; wing 2.5 ; tail 1.9 ; culmen .4 ; tarsus .7 .

The female has the chin and throat whitish or pale yellow, but is otherwise much like the male.

Distribution.-Breeding from Nova Scotia and the southern shores of Hudson Bay, south along the mountains as far as South Carolina. In the winter south to the West Indies, and eastern Mexico as far south as Panama.

Mr. L. J. Hersey obtained a single example of the Black-throated Green Warbler at Barr, near Denver, May 20th, 1909. The specimen is now in the Natural History Museum at Denver. This is the only record of the species in the State.

\section{Townsend's Warbler. Dendroica townsendi.}

A.O.U. Checklist no 668-Colorado Records-Henshaw 75, p. 200 ; Drew 85, p. 16 ; Morrison 88, p. 72 ; Lowe 94, p. 269 ; Cooke 97, p. 116 ; 04, p. 90 ; Chapman 07, p. 154 ; Cary 09, p. 183.

Description.-Male in spring-Crown and throat black; another klack patch on the side of the head from the base of the bill to the ear-coverts, separated above and below by a yellow streak, and containing a yellow spot below the eye; back yellowish-green spotted with black, wings and tail dusky black, the coverts tipped with white, forming a double wing-band; the three outer pairs of tail-feathers largely white on the inner web; central part of the breast yellow, posterior part and under tail-coverts white, with well marked black strealks on either side; iris brown, bill blackish, legs dark horn. Length 4.75 ; wing 2.70 ; tail 2.0 ; culmen .40 ; tarsus .65 .

The female is not very unlike the male, but the crown is olive-green spotted with black, and there is little black spotting on the back; there is less white on the tail; and the chin and throat are yellow throughout, showing black bases to the feathers. The male in autumn has the black of the crown and throat obscured by olive-green tips to the feathers, and the young bird is very similar. 
Distribution.-Breeding from Alaska to Oregon, and perhaps south to the mountains of Lower California, and east to western Colorado; in winter south to western and central Mexico as far as Guatemala.

Townsend's Warbler is apparently a rare bird in Colorado, and there is no definite record of its breeding within the State. It was taken by Aiken, according to Henshaw, at Conejos, August 26th, and at the mouth of the Navajo Creek in Archuelta co., September 11 th, in the south of the State; Lowe says that it is abundant in the Wet Mountains in the fall at elevations of 7,400 to 10,000 feet; while Cooke states that one example was seen by Captain Thorne at Fort Lyon on May 26th, 1883, and Chapman notes its arrival at Loveland on May 11th, 1889. The only authority for its breeding is that of Drew, who gives no further details. Cary reports that he shot a male August 24th, 1906, on the Snake River, twenty miles west of Bagg's Crossing, while on its southward migration in company with other Warblers.

Habits. -This Warbler frequents the highest trees, and is very active in its movements after insects, so that it is difficult to obtain. According to Henshaw, it affects the firs and spruces and shuns the true pines. Its note is "described as a simple "Tsip."

The only well-authenticated eggs known appear to be a set taken at Vancouver by Walter Raine, and described by J. L. Childs in Chapman's Warblers.

\section{Palm Warbler. Dendroica palmarum.}

A.O.U. Checklist no 672-Colorado Records-Cooke 97, p. 168; 04, p. 93 ; Chapman 07, p. 213.

Description.-Male-Above dusky brown; the crown chestnut, bordered by a yellow superciliary stripe; upper tail-ooverts yellowish; wing without conspicuous bars; the two outer tail-feathers white at the tip of the inner web. Under-parts yellow, becoming almost grey on the abdomen, obscurely streaked with brownish; iris brown, bill blackish-brown; legs dusky-brown. Length 4.60 ; wing 2.50 ; tail 1.85 ; culmen .40 ; tarsus .65 .

The sexes are alike, but in winter the crown is like the back, greyishbrown with faint streaks of black ; the superciliary line and under-parts are dull white, with very slight traces of yellow, except on the under tail-coverts.

Distribution.-The Palm Warbler breeds in the interior of British North America west of Hudson Bay, and migrates south along the 
Mississippi Valley to southern Florida, the West Indies and Yucatan, where it winters.

It is a straggler to Colorado, only once recorded. H. G. Smith observed but did not secure an example near Denver, June 20th, 1891.

\section{Genus SEIURUS.}

Warblers of large size-wing over 2.75 ; close to Dendroica in structure but very different in plumage ; this is thrush-like, with spotted underparts on a white ground.

Three species, all found within the United States.

For key, see p. 439.

\section{Oven-Bird. Seiurus aurocapillus.}

A.O.U. Checklist no 674-Colorado Records-Minot 80, p. 227 ; Cooke 97, pp. 116, 219 ; 04, p. 99 ; Chapman 07, p. 219.

Description.-Adult Male-Centre of the crown orange, bordered on either side by two black stripes from the bill to the nape ; general colour above olive-green, without marks on the wings or tail; below white, the breast and flanks heavily streaked with black, and a narrow black line along either side of the throat; iris brown, upper mandible dark brown, lower paler, legs pale flesh. Length 5.25 ; wing 3.0 ; tail 2.20 ; culmen .45 ; tarsus $\cdot 80$.

The sexes closely resemble one another, but the orange crown is generally a little paler and tipped with brown in the female. In the fall the plumage colours are somewhat richer, and so too in the case of the young bird.

Distribution.-The Oven-Bird breeds from Alaska and Newfoundland, south to Kansas and the mountains of South Carolina, and winters in southern Florida, the West Indies and western Mexico, south to Columbia.

It is a rare bird in Colorado, though it was first noticed by Dr. C. Wernigk near Denver so long ago as June, 1862. The only other definite record is that of Aiken, who obtained single female, now in the Colorado College Museum at Ramah, in El Paso co., June 5th, 1898 ; the ovaries were enlarged, and it appeared likely to be about to breed, so that the bird may be regarded as a scarce resident. Minot believed that he heard the notes of the Oven-Birds at Boulder and Nederland, near by, in May, 1880.

Habits. - The Oven-Bird is a distinctly terrestrial form, seeking its food on the ground among decaying leaves, and making its remarkable covered nest, from which it gets its name, on the ground, generally under the shelter of a bush. 
Grinnell's Water-Thrush. Seiurus noveboracensis notabilis.

A.O.U. Checklist no $675 a-C o l o r a d o$ Records-Henshaw 75, p. 204 ; Minot 80, p. 227 ; Cooke 97, pp. 116, 169 ; 04, p. 105 ; Henderson 03, p. 237 ; 09, p. 239 ; Chapman 07, p. 234.

Description.-Adult-Above throughout brown, with a slight tinge of olive; a conspicuous line above the eye white with a tinge of buffy; under-parts white with a faint wash of yellowish, heavily streaked throughout with black; iris brown, bill dusky, leg pale brown. Length (of a female) 5.20 ; wing 2.80 ; tail 2.20 ; culmen .50 ; tarsus .75 .

The sexes are alike, and the seasonal variation is very slight. This, the western subspecies, is distinguished from the typical form by its longer bill, browner upper- and whiter under-parts.

Distribution.-Breeding in western North Amerioa from Alaska to Minnesota and Nebraska; on migration southwards, through the south-eastern Atlantic states to the West Indies, Mexico, Central and South America.

Grinnell's Water-Thrush is only a straggler on migration in Colorado. It was noticed at Denver May 12th, 1873, by Henshaw ; at Fort Lyon, May 6th, 1886, by Thorne; at Boulder by Minot and at Loveland by Cooke, while Aiken observed it near Cañon City in May, 1873, and obtained a specimen, now in the Colorado College Museum, near Limon May 23rd, 1900; he also informs me he saw six examples at Butte on May 3rd, 1908. There is another example in the State collection at Denver, obtained May 14th, 1904, at Boulder by Bragg (Henderson).

Habits. -Like the Oven-Bird, this species is for the most part a ground-bird and a walker, haunting swamps and deep woodland bogs, and giving vent to a sudden and loud vivid song. It is generally regarded as the most notable musician among the Warblers.

\section{Genus OPORORNIS.}

Bill as in Dendroica with the rictal bristles weak, sometimes obsolete; wings comparatively long and pointed, about $3 \frac{1}{2}$ times the length of the tarsus; plumage green, yellow and slate, without spots or bars on the wings and tail.

Four species, all breeding in the United States.

For key, see p. 439.

\section{Connecticut Warbler. Oponornis agilis.}

A.O.U. Checklist no 678-Coloradó Records-Aiken 00, p. 298 ; Cooke 97, p. 219 ; 04, p. 110 ; Chapman 07, p. 241. 
Description.-Male in spring-Above olive-green; the crown, sides of the head, throat and breast slaty-grey, paler on the throat; a white ring round the eye; rest of the under-parts jellow, tinged with olive along the flanks; iris brown, bill dusky-brown, lower mandible paler, legs pale flesh. Length 4.75 ; wing 2.70 ; tail 1.50 ; culmen .45 ; tarsus $\cdot 75$.

The female has the crown brownish-olive-green and the cheeks, throat and breast brownish-olive; young birds closely resemble the female.

Distribution.-Breeding in Manitoba and perhaps in Minnesota, Wisconsin and Michigan; migrating south along the Atlantic coests, through the Bahamas to northern South America, returning in spring along the Mississippi Valley.

In Colorado the Connecticut Warbler is a straggler on migration. It has only been once recorded. Aiken obtained a single male on May 24th, 1899, in a clump of willows bordering a water-hole near Limon in Lincoln co. This extends its range many hundred miles west, as it does not appear to have been taken previously at any distance west of the Mississippi River.

Habits.-So retiring and elusive is this Warbler that it is likely to escape the observation of one unacquainted with it. It haunts the thick undergrowth of swamps, and is only with the greatest difficulty flushed from its hiding-place. The only authentic nest of this species was found by Ernest Seton in Manitoba, June 2lst, 1883. It was placed on the ground and contained four white, slightly brown-spotted eggs.

\section{MacGillivray's Warbler. Oporornis tolmiei.}

A.O.U. Checklist no 680 -Colorado Records-Aiken 72, p. 197 (Geothlypis macgillivrayi); Trippe 74, p. 232 ; Henshaw 75, p. 205 ; Minot 80, p. 227 ; Drew 81, p. 88 ; 85, p. 15 ; Allen \& Brewster 83, p. 159 ; Beckham 85, p. 141 ; Morrison 88, p. 72 ; Lowe 94, p. 269 ; McGregor 97, p. 38 ; Cooke 97, pp. 19, 117, 219 ; 04, p. 114 ; Keyser 02, p. 205 ; Henderson 03, p. 237 ; 09, p. 240 ; Warren 06, p. 24 ; Gilman 07, p. 194 ; Chapman 07, p. 249 ; Rockwell 08, p. 177.

Description.-Male in spring-Head all round slaty-blue; a white mark above and below the eye, and the lores black; back, wings and tail olive-green; throat and upper-breast streaked with slaty-blue and slaty-black; rest of the under-parts yellow, greenish on the flanks; iris brown, upper mandible dusky brown, lower pale brown, legs light brown. Length 4.30 ; wing 2.50 ; tail 2.25 ; culmen .4 ; tarsus .85 . 
The female resembles the male, but the crown is less distinctly - slaty, and washed with olive; the throat and breast are pale slatygrey; the lores are not black, and the white eye-spots are smaller. An autumn male has the crown slightly tipped with brownish. A young bird has the crown olive-brown, not slate.

Distribution.-Breeding in western America from British Columbia to Arizona and Now Mexico, wintering from Lower California to Colombia.

This is one of the commonest summer Warblers throughout Colorado, extending for a considerable distance out into the plains and to the western slope of the mountains, and breeding from the foothills up to 11,000 feet. It reaches $\mathrm{E} 1$ Paso co. about the middle of May, and the higher elevations of the mountains towards the end of the month. It departs again in September. Henderson took one at 10,500 feet early in that month in Boulder co.

It has been recorded as breeding in Estes Park (Chapman), near Gold Hill, Boulder co., 11,000 feet (Gale), Idaho Springs (Trippe), Middle Park (Carter), Manitou (Minot), San Juan co. (Drew), and La Plata co. (Morrison), and on migration at Loveland (Cooke), Denver (Henshaw), near Colorado Springs and at Limon (Aiken), Pueblo (Beckham), Fort Lyon (Thorne apud Cooke), Springfield, Baca co. (Warren), and Grand Junction by Miss Eggleston (Rockwell).

Habits.-MacGillivray's Warbler is a shy and retiring bird, and would generally be overlooked were it not for its song; it is commonest in thickets and bushes, along the banks of streams, but is also found among. the scrub of the steep hill-sides. It spends a good deal of its time on the ground searching for insect under dry logs and among dead leaves, while its song "Cheechee-chee-chee," is short and sweet, and not easily distinguished from that of the Pileolated Warbler.

The nest is generally placed low down in bushes at six inches to two feet above the ground, but Minot found one on June 21st near Manitou in scrub-oak, about five feet up. It was a bulky structure built of shreds of stalks and grass and lined with hair. The eggs, four in number, were white, finely marked with lilac and various browns, generally forming a wreath; they average $\cdot 71 \times 52$. 
Other dates are Estes Park, June 15th (Chapman), and Decker's Ranch, near Crested Butte, 9,000 feet, July (Warren).

\section{Genus GEOTHIYPIS.}

Bill short; rictal bristles obsolete; wing short and rounded, about 23 the length of the tarsus; the outer primary (ninth) shorter than the sixth; tail nearly as long as the wing, distinctly rounded; plumage olive and yellow, with a black mask in the male.

An extensive genus of about twelve species, ranging south to the Argentime. Only one species in the United States.

\section{Western Yellow-throat. Geothlypis trichas occidentalis.}

A.O.U. Checklist no 681a-Colorado Records-Aiken 72, p. 197 ; Henshaw 75, p. 204 ; Allen \& Brewster 83, p. 158 ; Drew 85, p. 15 ; Beckham 85, p. I41 ; Cooke 97, pp. 19, 117, 219, 220; 04, p. 119 ; Aiken 00, p. 298 ; Henderson 03, p. 108 ; 09, p. 240 ; Markman 07, p. 158 ; Chapman 07, p. 259 ; Rockwell 08, p. 177 ; Cary 09, p. 183 ; Hersey \& Rockwell 09, p. 121.

Description.-Adult male in spring-A black mask over the front of the crown and extending back through the eye to the ear-coverts, bordered posteriorly with white; above olive-green, rather more dusky on the wings and tail; under-parts bright orange-yellow, fading into buffy-brown on the centre of the abdomen and the flanks; iris brown, bill blackish, legs light brown. Length 4.5 ; wing 2.25 ; tail 2.10 ; culmen .45 ; tarsus .75 .

The female has no black mask, but the front of the crown is slightly tinged with cinnamon. The under-parts are always much paler and less brilliant than in the male; sometimes the yellow is confined to the under tail-coverts. The autumn plumage is very similar to the spring, but the bill is always paler and less dusky. Young birds have no black mask, and closely resemble the females.

This subspecies is distinguished from the eastern form (G.t. trichas) by its brighter yellow under-parts, whiter and less greyish frontal band, and its longer tail. The Yellow-throat taken near Colorado Springs May 31st, 1898, by Aiken, and referred by Cooke (p. 219) to the eastern form, appears to me on the whole nearer the western variety, and I think it best to include all Colorado birds under the western name.

Distribution.-Breeding in western North America from the Canadian border to northern Mexico, and from Kansas to California, wintering in southern California and western Mexico to Tepec.

In Colorado the Western Yellow-throat is a fairly common summer bird in the plains and along the foothills of the eastern half of the State, 
but is not usually found above 6,000 feet, nor is it so common on the western slopes. It arxives from the south about the first week in May, and has been recorded from Loveland May 9th (Cooke), Boulder (Henderson), Barr, breeding abundantly (Hersey \& Rockwell), Denver May 7th (Henshaw), El Paso co. May 3rd, and Limon May 23rd (Aiken), Pueblo (Beckham), Salida, arriving April 29th and breeding (Frey), Fort Lyon May 13th (Cooke), and in western Colorado at Grand Junction, where it arrives early in May, and stays throughout the summer (Rockwell). That it occasionally enters the mountains is shown by two records given by Cooke-Sweetwater Lake in Garfield co., 8,000 feet, May 5th, 1898 (L. B. Gilmore), and breeding near Dillon, Summit co., 8,860 feet (E. Carter), while Cary recently observed it near Sulphur Springs at about 8,000 feet.

Habits. - This is an active and restless little bird, commonly found about the low weedy thickets and the thick undergrowth bordering streams or sloughs. It is constantly on the move, climbing weed stallss and searching among the leaves on the ground for small insects, and often uttering a rather harsh scolding note. It has a protty littlo characteristic song, easily identified though difficult to syllable_- "whichitee-whichitee-whichitee" seeus the nearest.

No Colorado observer appears to have described the nest, but Goss gives the following account: "Their nests are usually placed on the ground, sometimes in bushes, two or three feet up. They are composed of loosely bound grass and leaves outside, lined with fine stems and rootlets within. The eggs, usually four, vary a good deal, but are generally white, spotted and blotched with umber and other browns, chiefly at the larger end, and measure $74 \times 54 . "$

\section{Genus ICTERIA.}

The largest of the Warblers, with a wing of 3.0 or more; bill short, stout, laterally compressed and highly arched; culmen strongly ridged and curved; tail rounded, as long as or exceeding the wing.

One species only. 


\section{Long-tailed Chat. Icteria virens longicauda.}

A.O.U. Checklist no $683 \mathrm{a}-$ Colorado Records-Allen 72, p. 148 ; Aiken 72, p. 197; Henshaw 75, p. 207 ; Allen \& Brewster 83, p. 159; Drew 85 , p. 15 ; Beckham 85, p. 141 ; Miller 94 , p. 42 ; Cooke 97, p. 117 ; 04, p. 122 ; Dille 03, p. 74 ; Henderson 03, p. 237 ; 09, p. 240 ; Chapman 07, p. 268 ; Markman 07, p. 158 ; Gilman 07, p. 194; Warren 08, p. 24 ; Rockwell 08, p. 177.

Description.-Adult male-Above olive-green with a greyish tinge; superciliary line, a mark under the eye, and a malar stripe white; lores black; throat and breast, edge of wing and under wing-coverts bright yellow; abdomen white, flanks buffy; iris brown, bill black, legs dusky blueish-grey in life. Length 7.0 ; wing 3.20 ; tail 3.40 ; culmen $\cdot 55$; tarsus $\cdot 98$.

The sexes can hardly be distinguished, though the female is generally duller in colour, and the lower mandible a pale horn. The male in autumn and the young bird are very similar.

The eastern bird is distinguished by its shorter wing and tail, the latter being as a rule shorter than the wing as well, and by the restriction of the white malar stripe, which hardly reaches to below the eye. A female taken by Aiken May 21st, 1899, near Limon, in Lincoln co., now in the Colorado College Museum, is somewhat intermediate in character.

Distribution. - In summer from British Columbia to the neighbourhood of Mexico City, and from western Kansas to the Pacific; in winter in western Mexico, perhaps as far south as Costa Rica.

In Colorado the Long-tailed Chat is a common summer resident in the plains and foothills, and also on the western slopes of the Rockies, but it never breeds above 6,500 feet, and does not seem to go any higher at other times. It reaches El Paso co. about the middle of May, and has been noticed by Aiken as early as the 5th of that month. It has been recorded from Boulder co. (Henderson), Denver (Allen), El Paso co. (Aiken), and Pueblo (Beckham) on the east of the range; and from Lily in Routt co. (Warren), and Grand Junetion (Rockwell), where it breeds, on the west.

Habits.-Though often found in gardens and thick shrubbery near houses, the Long-tailed Chat shuns observation, and remains concealed in the thickest and densest growth. It is also very suspicious. It is said that no one has yet photographed this or the Yellowbreasted Chat on its nest. As a singer, the Chat is unique among the Warblers; its notes are a singular 
medley of calls and whistles, and are very often heard at night, especially if it is moonlight.

The nest is placed among small saplings or briers at from two to three feet above the ground; it is constructed of leaves and grasses, and has as a rule no special lining. The eggs, usually four, are clear white with spots and specks, or sometimes large blotches of various shades of brown, and measure about $86 \times 66$. Fresh eggs should be met with about the second week in June near Denver, according to Dille.

\section{Genus WIISONIA.}

Small fly-catching Warblers with a very short, broad and flattened bill, distinctly wider than deep at the nostrils; rictal bristles conspicuous; wing with the ninth (outer) primary longer than the fifth, the sixth to eighth the longest; tail shorter than the wing and somewhat rounded ; plumage chiefly yellow and green, no red.

Three species, all breeding in the United States.

For key, see p. 439 .

\section{Pileolated Warbler. Wilsonia pusilla pileolata.}

A.O.J. Checklist no 685a-Colorado Records-Allen 72, pp. 156, 162 ; Aiken 72, p. 197 ; Trippe 74, p. 232 ; Henshaw 75, p. 207; Minot 80, p. 228 ; Tresz 81 , p. 286 ; Allen \& Brewster 83, p. 159 ; Stone 84, p. 20 ; Drew 85 , p. 15 ; Beckham 87, p. 123 ; Morrison 88, p. 72 ; Lowe 94, p. 269 ; McGregor 97, p. 39 ; Cooke 97, pp. 19, 117, 228 ; 04, p. 128 ; Keyser 02, pp. 63, 238 ; Henderson 03, p. 108 ; 09, p. 240 ; Warren 06, p. 24 ; Gilman 07, p. 194 ; Chapman 07, p. 278 ; Rockwell 08, p. 177.

Description.-Male-Crown glossy black, forehead, eyebrow and cheeks very bright yellow; above olive-green, dusky on the wings and tail; below bright yellow throughout; iris brown, bill duskybrown, paler on the lower mandible, feet light brown. Length 4.5; wing 2.25 ; tail 2.0 ; culmen $\cdot 30$; tarsus $\cdot 75$.

The female resembles the male, but is usually duller in colour, and the black crown-patch is less glossy and smaller. The male in the autumn is very similar, and the young bird has even less trace of the black cap.

Distribution.-The species is found breeding throughout western North America from Alaska to western Texas, but only at considerable elevations towards the south. It winters throughout the greater part of Mexico, and es far south as Panama. 
In Colorado the Pileolated Warbler is a common summer bird throughout. Arriving from the south about the first week in May, it quickly moves up from the plains and foothills to the higher elevations, and nests from 7,000 to 12,000 feet, but chiefly at about 10,000 feet.

Spring migration records are as follows: Monon, Baca co., May 3rd (Warren), Fort Lyon, May 5th (Cooke), El Paso co., May 14th, and Limon, May 21st (Aiken), Denver May 14th (Henshaw), and Loveland, May 11th-13th (Cooke). Fall records are: El Paso co., September 27th (Aiken), Pueblo, October 5th (Beckham), and Sapanero, Gunnison co., September 26th (Warren M.S.). Breeding records are: above timber line near Idaho Springs, July (Trippe); Hancock, Chaffee co., 10,000 feet (Mrs. Stone), Seven Lakes, on the slopes of Pikes Peak; about 11,000 feet, June 22nd (Minot); Fort Lewis, La Plata co., 7,500 feet (Morrison).

Habits. - A sprightly and active little bird, this Warbler is generally to be found about willow swamps at high elevations; it flits from bush to bush, and seldom perches on trees. Its song is not remarkable, and is syllabled by Minot "chee-chee," seven times repeated. The nest is usually placed on the ground under the shelter of a willow or other bush, though Morrison states that he found it building in the cotton-woods and willows that fringe the Rio de la Plata. The nest taken by Mrs. Stone on July 16th contained two young birds; it was placed on the ground under a willow, and was a flimsy affair made of bark strips, rootlets and dried grasses, and lined with a few horsehairs. The eggs, four or five, are white or sometimes creamy, spotted and speckled with browns and greys, sometimes regularly throughout, sometimes in a wreath at the larger end. They average $\cdot 63 \times \cdot 49$. Gale gives June 12th to 25th for fresh eggs at Duck Lake, near Gold Hill, at 9,000 feet.

\section{Wilson's Warbler. Wilsonia pusilla.}

A.O.U. Checklist no 686-Colorado Records-Ridgway 01, pt. ii., p. 710 ; Chapman 07, p. 274.

Description.-Closely resembling the Pileolated, but averaging a little smaller (wing 2.15 as against 2.25 ), and coloration paler and 
duller, especially the forehead, which is pale yellow instead of a bright, almost orange-jellow.

Distribution.-Breeding chiefly in Canada from Hudson Bay to Newfoumdland, and wintering in Central America from Guatemala to Costa Rica.

The discrimination of the eastern and western forms of this Warbler in the Colorado records is a little uncertain, but there can be little doubt that the eastern form occasionally occurs as a straggler on migration in Colorado. There are no undoubted Colorado examples of this form in the Aiken collection, but Ridgway mentions a specimen from Fort Garland, taken in May, doubtless by Henshaw, and now in the United States National Museum. Most of the other records seem to refer to the Pileolated Warblers.

\section{Canadian Warbler. Wilsonia canadensis.}

A.O.U. Checklist no 686 -Colorado Records-Aiken 00, p. 298 ; Cooke 97, p. 220 ; Chapman 07, p. 280.

Description.-Male-Above slaty-grey, the crown slightly spotted with black, the forehead, lores and w patch under the eye usually black; a line from the bill to above the eye and the under-parts yellow; a series of black spots across the breast; under tail-coverts nearly white; iris brown, bill dusky-brown, paler on the lower mandible; legs pale horn. Length 4.75 ; wing 2.45 ; tail 2.15 ; culmen $\cdot 4$; tarsus $\cdot 75$.

The female is very similar, but duller throughout, and the black of the crown, forehead and lores is less distinct, and the breast spots dusky and not well defined. There is very little seasonal change, and the young bird is like the female, with still less sign of black.

Distribution.-Breeding from Athabasca and Newfoundland south to Minnesota and Connecticut, and further south along the Alleghany Mountains, wintering chiefly in Ecuador and Peru.

In Colorado the Canadian Warbler is a straggler on migration. It has been taken once only- by Aiken near Limon in Lincoln co., May 23rd, 1899. The single specimen, a male, is now in the Colorado College Museum.

\section{Genus SETOPHAGA.}

Closely allied to Wilsonia in structure, but the bill rather flatter and wider, and the rictal bristles generally more developed; plumage of the males with red or salmon on the wings and tail.

Two species in the United States.

American Redstart. Setophaga ruticilla.

A.O.U. Checklist no 687-Colorado Records-Allen 72, p. 148; Aiken 72, p. 197 ; Trippe 74, p. 232 ; Minot 80, p. 228 ; Allen \& Brewster 
83, p. 159 ; Drew 85, p. 15 ; Beckham 85, p. 141 ; Cooke 97, pp. 19, 118, 220 ; 04, p. 132 ; Keyser 02, p. 184 ; Henderson 03, p. 237 ; 09, p. 240 ; Warren 06, p. 24 ; Chapman 07, p. 237 ; Cary 09, p. 183 ; Hersey \& Rockwell 09, p. 121.

Description.-Male-General colour above, including the head all round, and upper-breast black ; wings with a cross-band of salmon; tail with the four outer pairs of feathers salmon, with black tips, the central pair black, the other pair with salmon on the outer web only; under-parts white, tinged with salmon, and with brilliant patch of salmon on either side of the breast; iris brown, bill black, paler in the fall, legs dark brown. Length 4.8 ; wing 2.5 ; tail 2.25 ; culnen .30 ; tarsus $\cdot 65$.

The female has the crown and sides of the head grey, and the back olive-green; the wings and tail slightly washed with the same colour; the salmon of wings, tail and breast of the male replaced by yellow; the under-parts from the chin to the under tail-coverts white. Young males in the fall closely resemble the females, and in the following spring show a few black feathers about the chest and head, but do not acquire the full male dress until the second year.

Distribution.--Breeding from Alaska and Newfoundland to Utah, Kansas and North Carolina, wintering in the West Indies and South America as far as Ecuador and British Guiana.

In Colorado the Redstart can hardly be described as common, though not infrequently met with along the eastern foothills, especially on the spring migration, and in the mountains up to about 8,000 feet, where it is stated to breed. It is absent, or at any rate quite rare, in the western part of the State. The following are migration records : Fort Lyon, May 14th (Cooke), Pueblo, May 27th (Beckham), El Paso co., May 18th (Allen \& Brewster), Barr Lake, May 10th (Hersey \& Rockwell), Boulder, May 31st (Minot), Loveland, May 9th (Cooke), Trippe states that it breeds near Idaho Springs, and Carter (Cooke) in Middle Park, but no details are given. More recently Cary observed a few migrating individuals on the Lower Snake River, twenty miles west of Baggs Crossing, in August.

Habits.-The Redstart frequents parks, groves and deep woods; it lives largely about tree tops, and flits restlessly about with outspread tail and open wings, making a display of its bright-coloured plumage, darting quickly after a passing insect, and snapping its bill at every capture.

The nest, according to Goss, is situated in small trees, as a rule from three to even thirty feet above the ground; 
it is often placed in and woven round three or more upright twigs, and is made up of stems, rootlets and plant strippings, worked in with a soft cotton-like substance, and lined inside with hairs, fine stems and sometimes a few feathers. The eggs, usually four, are white or creamy, speckled and blotched with several shades of brown and lilac of varying extent and distribution. They average $\cdot 63 \times \cdot 48$.

\section{Family MOTACILLID压.}

Bill shorter than the head, slender, straight and acute, notched at the tip ; nostrils not concealed; gape without conspicuous bristles; primaries nine; the ninth (outer) and eighth about equal, the seventh to sixth the longest; inner secondaries greatly lengthened, almost as long as the primaries; feet slender, tarsus scutellate; hind too with a long and almost straight claw.

\section{Genus ANTHUS.}

Characters as given above under the family.

Two species only are found in the United States.

\section{American Pipit. Anthus rubescens.}

A.O.U. Checklist no 697-Colorado Records-(Anthus ludovicianus and A. pensilvanicus)-Allen 72, p. 161 ; Aiken 72, p. 196 ; Trippo 74 , p. 231 ; Scott 79, p. 92 ; Minot 80, p. 226 ; Drew 81 , p. 88 ; 85, p. 15; Allen' \& Brewster 83, p. 155 ; McGregor 97, p. 39 ; Cooke 97, pp. 18, 118 ; Keyser 02, pp. 50, 239 ; Henderson 03, p. 237 ; 09, p. 240 ; Gilman 07, p. 194 ; Warren 08, p. 24 ; Rockwell 08, p. 177.

Description.-Adult in spring-Above greyish-olive with obscure dusky centres to some of the feathers, especially of the middle of the back; wings and tail with paler edgings to the feathers, but no very distinct wing-bands; two outer pairs of tail-feathers with white on the outer web; stripe above the eye and under-parts pale buffy-white; the chest and flanks usually, though by no means invariably, streaked with black; iris brown, bill dusky, paler on the lower mandible; legs brownish-black. Length of a female 5.20; wing 3.20 ; tail 2.25; culmen .43 ; tarsus .80 . 
The sexes are alike; young birds are more distinctly spotted on the back and streaked below.

Distribution.-Breeding from eastern Siberia, Alaska and Newfoundland to Quebec Province, and southwards at high elevations along the Sierra Novada and Rocky Mountains; in winter southwards over the greater part of the United States and Mexico to Guatemala. In Colorado the American Pipit is exceedingly common during migration throughout the State, and breeds at high elevations in the mountains, chiefly between 11,000 and 13,000 feet, and above timber line, though occasionally, according to Gale, as low as 9,000 feet. It arrives on the plains and foothills towards the end of April, and moving up into the mountains, reaches timber line in June, where fresh eggs may be met with from June 25 th to July 10 th ; it lingers on at high elevations until September or even October, and does not leave the State until November.

The following are spring migration records: El Paso co., last week of April (Allen \& Brewster), Limon, May lst (Aiken), Boulder co., plains, April 20th (Gale), Fort Lewis, La Plata co., April 30th (Morrison), Mesa co., "early spring" (Rockwell). Breeding records are: Estes Park at timber line (McGregor), Boulder co,, from timber line to 9,000 feet (Gale), along timber line near Idaho Springs (Trippe), Seven Lakes, 10,600 feet on Pikes Peak (Minot), above timber line on Mount Lincoln, Park co. (Allen), timber line at Mount Emmons, Gunnison co. (Warren MSS.), above timber line, San Juan co. (Drew).

Habits.-The American Pipit, or Titlark as it was formerly called, arrives from the south in large flocks, which do not break up until they reach their breeding grounds. In the mountain parks they frequent the open hill-sides, and show a strong partiality to the ploughed fields of the mountain ranches. Later on in June they reach the summit of the range and commence nesting as soon as the snow has sufficiently melted to allow the grass to spring up. They are somewhat shy at this time, hardly permitting an approach of fifty or sixty yards. The male has a song during the breeding season not heard at other times. "Rising in the air at an angle of forty-five degrees, with a fluttering uncertain flight, they commence singing when they are up a little way, and continue till they have reached a height of a hundred 
yards or so ; then descending, fluttering their wings as before, they light on a stone or sod, not far from where they started" (Trippe).

The nest is placed on the ground, usually under the shelter of a stone or bunch of grass; it is constructed entirely of dried grasses, outside coarser, inside finer, and the walls are thick and warm. The eggs, five or six in number, are dark brownish-purple, almost hidden by spots and splashes of purplish-black, and though varying somewhat, are very dark in colour. They average $\cdot 78 \times \cdot 57$.

\section{Family CINCLID E.}

Bill shorter than the head, rather slender and compressed; nostril partly concealed; no rictal bristles; wing of ten primaries, the tenth (outer) very short; wing short, rounded and concave; tail of twelve short rounded feathers almost hidden by the coverts; tarsus normal ; claws curved.

A small family distinguished chiefly by the adaptation of its members to aquatic life.

\section{Genus CINCLUS.}

Characters of the family; one species only in the United States.

American Dipper. Cinclus mexicanus unicolor.

A.O.U. Checklist no 701-Colorado Records-Allen 72, pp. 148, 161 ; Aiken 72, p. 194 ; Trippe 74, p. 229 ; Henshaw 75, p. 159 ; Scott 79 , p. 91 ; Minot 80 , p. 224 ; Drew 81 , p. 86 ; 85, p. 15 ; Stone 82 , p. 181 ; Allen \& Brewster 83, p. 154 ; Beckham 85, p. 140 ; Pearce 86, p. 8; Morrison 86 , p. 27 ; 88 , p. 71 ; W. G. Smith 88, p. 149 ; Bendire 89, p. 75 ; Kellogg 90 , p. 89 ; Lowe 94 , p. 269 ; Chamberlain 94, p. 163 ; Miller 94, p. 70 ; Taylor 96, p. 6 ; McGregor 96, p. 39 ; Cooke 97, pp. 118, 169, 221 ; Keyser 02, pp. 163-174; Dille 03, p. 74 ; Henderson 03 , p. 237 ; 09, p. 240 ; Gilman 07, p. 194 ; Henderson 08, p. 1 ; Warren 08, p. 24 ; Rockwell 08, p. 177. 
Description.-Adult-General colour throughout pale slaty-grey, faintly tinged with brown on the head and neck, which, according to Drew, is slightly bronzed and metallic in spring; below slightly paler than above; iris brown, bill black, legs horny brown. Length 6.75; wing 3.75 ; tail 2.0 ; culmen .70 ; tarsus 1.20 .

The sexes are alike; in autumn the feathers of the under-parts and most of the wings are very narrowly margined with white, and the bill is pale horny brown. Young birds are still more noticeably mottled with white below; the throat mainly, sometimes entirely white.

Distribution.-The Rocky Mountains in their widest sense, from Alaska to western Texas and southern California, including the Black Hills of Dakota. A resident throughout its range.

In Colorado the Dipper is generally to be found throughout the mountainous western half of the State wherever suitable conditions exist. It ranges from the foothills at about 5,000 feet to timber line, 11,500 feet, and though generally found at slightly lower elevations in winter, this is by no means invariably the case. It has been observed by Gilmore (Cooke) at the head waters of Clear Creek, 10,500 feet, on December 15th, and about timber line at Berthoud Pass, 11,500 feet, on October 3rd. On the other hand, in summer it has been found nesting at various elevations from 5,000 to 11,000 feet, so that it can hardly be said to be a regular vertical migrant.

It has been recorded from most of the mountainous parts of the state from Estes Park (Pearce \& Kellogg) to the Wet Mountains (Lowe), and on the western slopes from Glenwood Springs (Cooke) and Mesa co. (Rockwell) to La Plata co. (Gilman).

Habits. - The remarkable aquatic habits of the Dipper render it quite unique among the Passerine birds. This and its curious nesting ways have caused a number of observers to pay special attention to it, as is shown by the long list of Colorado records. The notes of Dennis Gale, which, through the kindness of the authorities of the University of Colorado at Boulder, I have been able to make use of, are full of observations on the Dipper, and the following account is largely based on these.

The Dipper, sometimes called the Water-Ouzel, and locally in Colorado often known as the Water-Turkey, is found only along the rushing mountain streams, which it seldom leaves, and which it follows up, skimming 
close to the surface with a rapid chattering note. Occasionally it alights on a rock or stone in mid-stream, and commences a series of little curtseyings or bobs, at the same time flicking its tail and alternately compressing its body and spreading its wings. It is this habit which has got it its name of Dipper. Presently it plunges into the icy water and dives with the help of its wings, or even walks along the pebbly bottom quite submerged, in search of the small water insects which it feeds on. In winter it will freely go below the ice, reappearing at some air-hole a few yards off, without hesitation. At this season it is often found at mountain lakes, especially if there is open water, owing to warm springs. It is a somewhat unsocial bird, and a single pair usually monopolize a stream or section of a stream to the exclusion of others. The song is clear and sweet, somewhat Wren-like in tone; according to Drew it is to be heard all the year round, both in winter and summer.

The nest (Plate 16) is placed on a rocky ledge overlooking the stream, on an island rock, behind a waterfall, or sometimes under a bridge, but nearly always within reach of the spray of the water, so that it is always moist and damp. It differs somewhat in shape in order to suit the cavity where it is situated, but is nearly always oven-shaped, a little longer than broad, with a front entrance. It is constructed chiefly of moss, with some decayed leaves and other rubbish, strongly put together in a wet state. Inside is the nest proper, saucershaped, about $1 \frac{1}{2}$ inches deep and $3 \frac{1}{2}$ wide. It is composed of a peculiar non-absorbent wiry grass, lined with a few willow leaves flat and intact, and all perfectly dry. The nest harmonizes with its surroundings, and is made use of after repairs year after year, probably by the same pair of birds. The hen undertakes most 


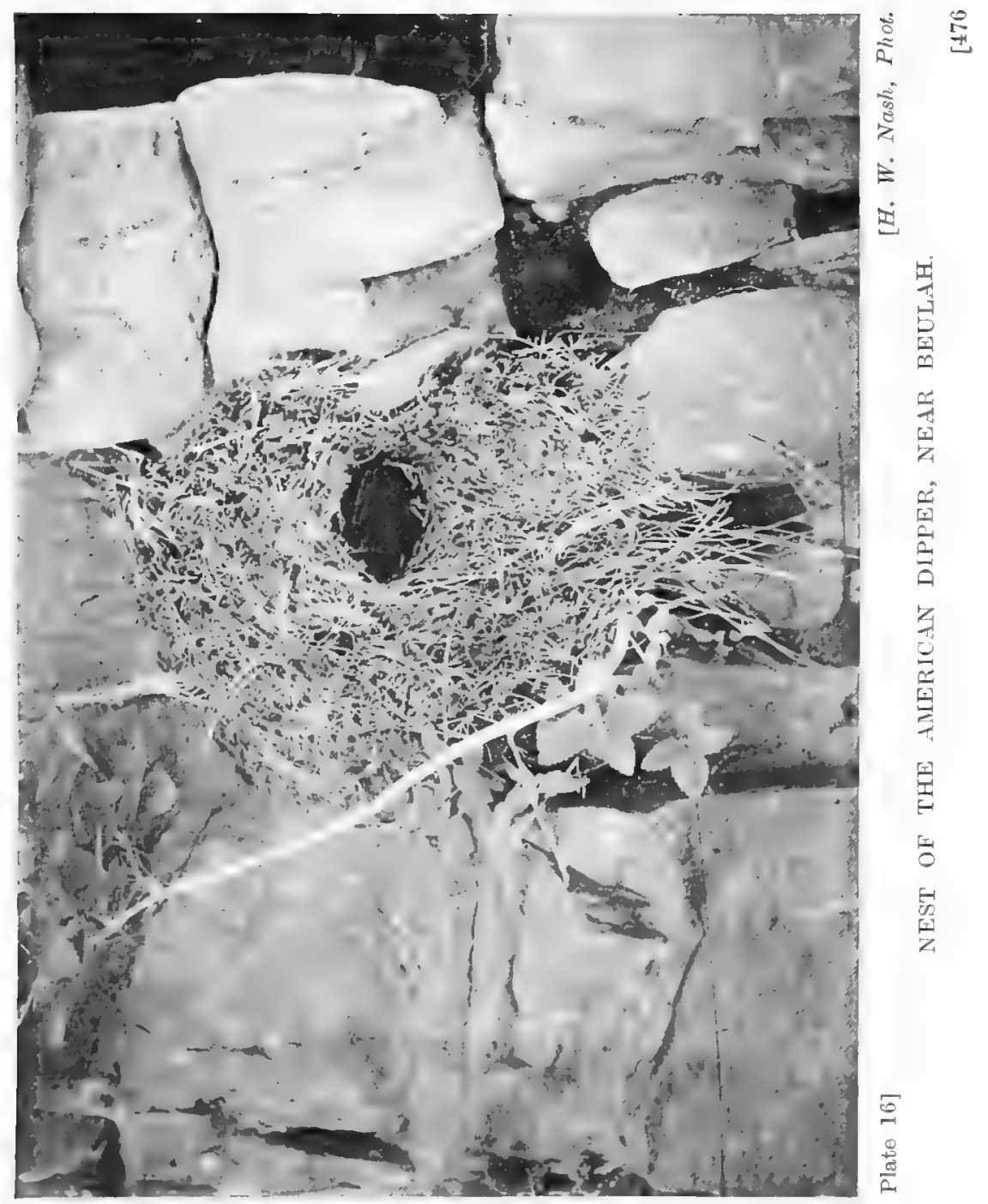



if not all the work of building. The eggs, four or five in number, are pure white, and rather pointed at one end. The time of nesting of the Dipper is rather irregular. Gale found fresh eggs from early in May until the middle of June; Drew found one nest with four hatched young, and another nest yet unfinished on the same date-June 19th in San Juan co.-while Dille gives the first week in June as a good average date for fresh eggs.

\section{Family MIMID压.}

Rather large birds with considerable external resemblance to the Thrushes, with a bill of variable size and shape, but always with conspicuous rictal bristles; wing short and rounded, shorter than or only just exceeding the tail; outer primary never very small, usually about half the length of the next; tarsus stout and adapted to walking.

This family, containing the Mocking-birds, Thrashers and their allies, is confined to America.

\section{Key OF THE GENera.}

A. Tail slightly shorter than the wing and nearly even; breast spotted.

Oroscoptes, p. 477.

B. Tail always longer than the wing and distinctly graduated.

a. Culmen shorter than the middle toe without claw.

$a^{1}$ With a good deal of white on the wings and tail.

b1 Without any white on the wings and tail.

Mimus, p. 479 .

Dumetella, p. 481 .

b. Culmen always exceeding the middle toe and without claw.

Toxostoma, p. 482 .

\section{Genus OROSCOPTES.}

Bill moderate, not hooked or curved except at the tip, shorter than the head; rictal bristles well developed; wing and tail approximately equal, the latter even or very slightly graduated; outer primary hardly half the length of the next; plumage thrush-like, dull brown with spotted under-parts.

One species only. 


\section{Sage-Thrasher. Oroscoptes montanus.}

A.O.U. Checklist no 702-Colorado Records-Allen 72, p. 147 ; Trippe 74, p. 228 ; Henshaw 75, p. 149 ; Scott 79, p. 91 ; Drew 81, p. 86, 85, p. 15; Allen \& Brewster 83, p. 153 ; Beckham 85, p. 140 ; Morrison 88, p. 71 ; MeGregor 97, p. 39 ; Cooke 97, pp. 18, 119, 221 ; Henderson 03 , p. 108 ; 09, p. 240 ; Warren 06, p. 24 ; 08, p. 25 ; 09, p. 17 ; Gilman 07, pp. 42,194 ; Rockwell 08, p. 177.

Description.-Adult-Above pale earthy-brown, with indistinct darker mesial streaks on the head; wings and tail duskier-brown, the former with pale whity edgings to the feathers, those of the coverts forming indistinct wing-bands ; three pairs of outer tail-feathers tipped with white; below white, tinged with buffy on the sides and posteriorly; a blackish malar streak and a series of triangular black spots on the breast and flanks; iris lemon-yellow, bill dusky, paler towards the base of the lower mendible; legs horny, olivaceous in the flesh. Length 7.75 ; wing 3.80 ; tail 3.50 ; culmen .75 ; tarsus 1.15 .

The sexes are alike, and the young birds are very similar, but a little browner and less grey, and with the strealss on the under-side less sharply defined.

Distribution.-Breeding throughout the drier portions of western North America from eastern British Columbia to western Texas, and from north Dakota to the interior of southern California; in winter south to northern Mexico and lower California.

The Sage-Thrasher is a not uncommon summer resident throughout Colorado, from the plains to about 9,000 feet, wherever arid conditions and the accompanying sage-brush are to be met with. It is chiefly found at moderate elevations, but has been noticed breeding at Dillon, about 9,000 feet, in Summit co, by Carter. It arrives from the south about the middle of April (10th to I5th in El Paso co., Allen \& Brewster) and leaves again in October. Other breeding records are: Fort Garland (Henshaw), Snake River in Routt co. (Warren), and between Cortez and Navajo Springs (Gilman). It is more abundant in the south and west, but is reported as far north as Boulder (Henderson).

Habits. -This bird is nearly always associated with the dreary, arid sage-bush plains, where, sitting on the top of some low bush, with its beautiful low warbling song, it makes a pleasant contrast to the surrounding desolate waste.

The nest is a bulky, inartistic structure of coarse twigs, lined with grasses and tine rootlets, and is placed sometimes in a low sage bush, sometimes in a larger thorny 
bush ; Henshaw states that in the case of a nest examined by him there was a kind of platform erected above the nest, apparently as a screen from the sun. The eggs, usually five, are greenish-blue, heavily spotted with brown and lilac. Warren found a nest with five fresh eggs on June 22nd, near the lower bridge over the Snake River, in Routt co., and Gilman (07, p. 142) several with six and seven eggs at Navajo Springs, near the New Mexico border line, on May 3lst and the following days.

\section{Genus MIMUS.}

Bill moderate, shorter than the head; culmen slightly curved; rictal bristles well developed; tail slightly longer than the wing, graduated, the outer feathers considerably shorter than the next pair; tarsus very distinctly scutellated; plumage dull brown with white on the wings and tail.

A considerable American genus with only one species in the United States, separated into an eastern and westerm race, hardly to be distinguished from each other.

Western Mocking-bird. Mimus polyglottos leucopterus.

A.O.U. Checklist no 703a-Colorado Records-Say 1823, Vol. ii., p. 182 ; Ridgway 73, p. 179 ; Henshaw 75, p. 151 ; Allen \& Brewster 83 , p. 153 ; Drew 85, p. 15 ; Beckham 85, p. 140 ; Morrison 88, p. 71 ; Lowe 92, p. 101 ; Cooke 97, pp. 19, 119, 221 ; 98, p. 13 ; Keyser 02, p. 98 ; Dille 03 , p. 74 ; Warren 06, p. 24 ; 08, p. 25 ; 09, p. 17 ; Gilman 07, p. 194 ; Markman 07, p. 158 ; Rockwell 08, p. 177 ; Henderson 09 , p. 240.

Description.-Adult male-Above dull slaty-brown, becoming dusky black on the wings and tail, the former with white on the bases of the primaries, on the greater part of the primary-coverts and the tips of some of the outer coverts; the tail with the outer pair of feathers almost entirely white, the second and third pairs with oblique white tips chiefly on the inner web; below and an indistinct superciliary stripe dirty white, rather smoky on the chest and flanks, more buffy on the breast; iris greyish-yellow, bill black, paler towards the base of the lower mandible; legs dusky. Length 8.5 ; wing 4.25 ; tail 4.5; culmen $\cdot 7$; tarsus $\mathbf{1} \cdot \mathbf{1 5}$.

The female closely resembles the male, but is a trifle smaller. A young bird is a good deal paler above, and has the light edgings on the wings more developed, and the under-parts spotted with dusky. 
The western form of the Mocking-bird differs from the eastern bird only in its slightly larger average size and relatively shorter tail.

Distribution.-South-western United States and Mexico from Texas to California, and Wyoming to Vera Cruz, breeding throughout the greater part of its range, though not wintering in the northern portion.

In Colorado the Mocking-bird is a fairly common summer resident, especially in the southern part of the State, both in the plains and at low elevations. It seldom goes above 7,000 feet. It arrives from the south about the last week in April, and nests about a month or six weeks later, departing south again in September. It is not known to winter in the State. The following are migration records: Fort Lyon, April 17th (Cooke), Pueblo, April 25th (Lowe), Salida, May 4th (Frey), Baca co., May lst (Warren), El Paso co., May 2nd (Aiken collection). The breeding records are: Fort Collins (Cooke), Evans, Weld co. (Eggs in Colo. Coll. Mus.), Boulder co. (Gale), Platte River, near Denver (Say), Ramah and Pueblo (Aiken), La Plata co. (Morrison), Grand Junction (Rockwell). It has been exceptionally met with as high as Breckenridge, 9,700 feet, by Carter.

Habits. - The Mocking-bird is justly celebrated for its vocal powers and its ability to imitate the notes of other birds; in this respect the western form shows no falling off, though perhaps less known, because less common. It is also noted for its attachment to its home, returning year after year to the same spot and often making use of the same nest after effecting repairs. In summer it chiefly feeds on insects and worms, and obtains these on or near the ground, but later on it prefers soft fruits and berries, grapes and raspberries being the favourites. The nest is frequently placed in a cactus bush where these are to be found, but willows and other low trees and bushes are also used.

Dennis Gale describes the nest as being formed of dry twigs of greasewood, fixed upon or between the twigs of a horizontal bough, and rather loosely put together, so that it falls apart when removed. The lining is of fine roots and horsehair; he states that the bulk of the nests he has examined are old ones, in which 
the lining only was renewed each year. The eggs, four or five in number, are light greenish or blueish, spotted with several shades of yellow-brown. They measure $.98 \times 74$, and are to be found about the beginning of June (Gale and Dille).

Miss Myra Eggleston reports (Rockwell) that at Grand Junction they raise two broods each season. A clutch of two eggs taken on June 10th from a nest made of Lorsehair and old rags, built in the school-house yard at Evans, Weld co., is preserved in the Colorado College Museum. They were taken and presented by Ivan Hall.

\section{Genus DUMETELLA.}

Very closely allied to Mimus, but the tarsal scutellation often very indistinct, and the plumage without white on the wings and tail.

One North American species.

\section{Cat-bird. Dumetella carolinensis.}

A.O.U. Checklist no 704-Colorado Records-Allen 72, p. 147 ; Trippe 74, p. 228 ; Henshaw 75, p. 152 ; Allen \& Brewster 83, p. 153 ; Drew 85, p. 15 ; Beckham 85, p. 140 ; Morrison 88, p. 71 ; Cooke 97, pp. 19, 119, 221 ; Dille 03, p. 74; Henderson 03, p. 237 ; 09, p. 240 ; Warren 06, p. 24 ; 08, p. 25 ; Gilman 07, p. 194 ; Markman 07, p. 158 ; Rockwell 08, p. 177 ; Hersey \& Rockwell 09, p. 121.

Description.-Male-General colour above and below slaty-grey, darker above, lighter below; erown, nape and tail sooty-black, the wings the same but edged with slaty; under tail-coverts rich chestnut; iris brown, bill black, legs dark horny. Length 8.40 ; wing 3.60 ; tail 4.0 ; culmen .65 ; tarsus 1.05 .

The fermale is very similar, but the crown is generally a little less sooty, the chestnut of the under tail-coverts less conspicuous, and it is slightly smaller-wing $\mathbf{3 . 5 5}$. In a young bird the colours are again less defined, the under-parts obsoletely spotted with darker and the under tail-coverts paler or even fawn colour.

Distribution.-Breeding from British Columbia and Oregon to Texas, and from Nova Scotia to northern Florida, wintering in the southern States, West Indies and eastern Mexico to Panama.

In Colorado the Cat-bird is a fairly common summer resident in the plains and foothills of the eastern half of the State, but is a good deal less plentiful on the western slope; it breeds in the mountains up to 
about 8,000 feet, but not so commonly. It reaches Colorado from the south about the second week in May. The following are migration records: Baca co., May 12 th (Warren), Fort Lyon, May 8th-14th (Cooke), Salida, May 14th (Frey), El Paso co., May 10th (Allen \& Brewster), Denver, May 12th (Henshaw), Loveland, May 11th (Cooke). Breeding records are: Boulder co. (Gale), Barr Lake (Hersey \& Rockwell), Middle Park (Carter apud Cooke), Fort Garland, 7,900 feet (Henshaw), Fort Lewis (Morrison \& Gilman).

Habits.-The Cat-bird is apparently somewhat more shy and silent in the west than it is in the east; it haunts thick shrubberies, and is not often seen, nor is its cat-like mew so often heard. It feeds chiefly on insects, and though fond of fruit, the damage it does in this respect is largely outweighed by its insecticidal propensities.

The nest is generally placed in willows or other low bushes along the borders of a creek; it is built of coarse stems, decayed leaves and strips of inner bark and grasses, with a lining of fine roots, and the whole made up in a wet state, according to Gale's notes. The eggs, usually four in number, are blueish-green, and measure about $\cdot 94 \times 67$. Dille gives June 12 th as an average date for fresh eggs; Gale, in Boulder co., found nests with unincubated eggs through the whole of June and up to July 3rd.

\section{Genus TOXOSTOMA.}

Bill either longer than the head and curved throughout or shorter than the head and straight, but the culmen at least equal to or longer than the middle toe without claw; wings quite short and rounded, markedly shorter than the tail, which is distinctly graduated; feot stout, tarsus strongly graduated.

A very considerable American genus, with about eight species in the United States, chiefly in the drier south-western districts.

KEY OF THE SPECIES.

A. Above rich rufous; below heavily spotted with dusky.

T. rufum, p. 483 .

B. Above greyish-brown; below very faintly marked with dusky.

T. bendirei, p. 484 . 


\section{Brown Thrasher. Toxostoma rufum.}

A.O.U. Checklist no 705-Colorado Records-Allen 72, pp. 147, 174; Henshaw 75, p. 154; Allen \& Brewster 83, p. 153; Drew 85, p. 15; Beckham 85, p. 140 ; Cooke 97, pp. 19, 120; Henderson 03, p. 108 ; 09, p. 240; Markham 07, p. 158 ; Gilman 07, p. 195.

Description.-Male-Above rufous, a little browner on the head; wing-coverts tipped with white, forming a double wing-band; underparts white, with a slight wash of pale buffy on the breast and flanks, these parts conspicuously marked with oval spots of brown; iris bright yellow, bill dusky, paler on the base of the lower mandible; legs light brown. Length 10.25 ; wing 4.10 ; tail 4.80 ; culmen .90 ; tarsus $1 \cdot 30$.

The sexes are alike, but the females average slightly smaller; the young bird is essentially like the adult, but has indistinct dusky spots on the back and the spots on the under-parts black, but less clearly defined.

Distribution.-Breeding in eastern North America from Main $\theta$ and Saskatchewan to eastern Texas and north Florida, and west to the base of the Rocky Mountains; wintering in the south-eastern states from North Carolina to south Texas.

In Colorado the Brown Thrasher is a fairly common summer resident in the eastern plains and foothills, but hardly enters the mountains or reaches a higher elevation than 7,000 feet. It arrives from the south about the second week in May, and nests in June. It has once been recorded from the western side of the range by Gilman, who states that he was told by Mr. Peterson that a pair nested in a gooseberry bush near his house at Fort Lewis, in La Plata co., in 1904. It does not appear to have been recorded from New Mexico, Arizona or Utah, though found in Wyoming and Montana. The following are migration records: Fort Lyon, May 4th-10th (Cooke), Colorado Springs, May 11th (Aiken coll.), Denver, May 12th (Henshaw), Boulder co., May 12 th (Gale), Loveland, May 10th (Cooke).

Habits.-This bird, delighting chiefly in thick undergrowth and tangled thickets, rather shuns the eye of man; yet in the spring the male mounts to a conspicuous perch and pours forth a loud and rather brilliant song. It gets its name of "Thrasher" from its habits of beating or thrashing the insects it catches until dead and deprived of wings and legs. 
Gale found several nests in Boulder co., generally in low cotton trees along the creeks. He gives the following description: "Nest about eight feet from the ground and very large, constructed outside of very coarse branches and twigs, middle structure of rather finer material and a few dead leaves, lining of fine roots. The nest was placed among thick twigs and close to the stem of an aspen tree. The eggs, four in number, were greenishwhite, speckled thickly and uniformly with small brownish-reddish markings; they were rather small for the size of the bird." This nest, in which the eggs were quite fresh, was taken on June $25 \mathrm{th}$, a rather later date than the average. The eggs measure $1.08 \times 80$.

\section{Bendire's Thrasher. Toxostoma bendirei.}

A.O.U. Checklist no 708-Colorado Records-Allen \& Brewster 83, pp. 57, 153; Cooke 97, pp. 120, 169 ; Cooke 97a, p. 7.

Description.-Adult-Above pale greyish-brown, wing with indistinct bars; tail darker, and the outer feathers tipped with white; below brownish-white, indistinetly spotted with brown; flanks brownish; iris yellow, bill dusky, paler at the base of the lower mandible, legs brownish, dull blueish in life. Length 9.5 ; wing 4.20 ; tail 4.30 ; culmen .90 ; tarsus 1.30 .

The sexes are alike; the young bird has a tawny-buff wash on wings, and the under-parts are paler and have narrower streaks.

Distribution.-The desert districts of Arizona, south-east California and Sonora, extending north to southern Colorado; in winter to southern Sonora and Sinaloa in Mexico.

Bendire's Thrasher was first recorded from Colorado by Allen \& Brewster, who obtained a single female example at Austins Bluffs, near Colorado Springs, on May 8th, 1882, after heavy storms, which had driven many birds towards the foothills for shelter. The occurrence was doubtless accidental. It has since been found by $N$. R. Christie (Cooke) at Rouse Junction, in Huerfano co., at 6,000 feet, where it breeds. Christie took four nests with eggs or young ones between June 6 th and 13 th, 1896, while in the following year he observed a pair of birds, but found no nest.

Bendire's Thrasher must be regarded as a rare resident in the southern part of the State. 


\section{Family TROGLODYTID瓜.}

The Wrens are all small birds, seldom exceeding six inches in length, with generally rather long, slender bills, without rictal bristles, and exposed nostrils; wing rather short and rounded, of ten primaries, the tenth (outer) about half the length of the ninth; tail moderate, of twelve feathers; tarsus scutellate, often behind as well as in front.

\section{Key of the Genera.}

A. Tail equal to or longer than the wing; only the middle tailfeathers barred, the others chiefly dusky. Thryomanes, p. 490.

B. Tail shorter than the wing.

a. Outer toe distinctly longer than the inmer one.

$a^{1}$ Culmen shorter than the tarsus. Salpinctes, p. 485.

$b^{1}$ Culmen longer than the tarsus. Catherpes, p. 487.

b. Outer toe not distinctly longer than the inner one.

$a^{1}$ Back plain or faintly transversely barred.

$a^{2} \quad$ Tail at least $\frac{3}{4}$ of wing. Troglodytes, p. 491 .

$b^{2}$ Tail less than $\frac{3}{4}$ of wing. Nannus, p. 493.

$b^{1}$ Back streaked with white and black.

$a^{2}$ Bill shorter, culmen less than middle toe and claw.

Cistothorus, p. 494.

$\mathrm{b}^{2}$ Bill longer, culmen exceeding middle toe and claw.

Telmatodytes, p. 495 .

\section{Genus SAIPIN CTES.}

Bill about as long as the head, slender, slightly decurved and acute, the culmen shorter than the tarsus; no rictal bristles; nostril large, rather conspicuous with an overhanging scale; wing rounded but longer than the tail, which is even and has twelve feathers with rounded ends; tarsus scutellate anteriorly and posteriorly; outer toe slightly longer than the inner one.

One species only in the United States.

\section{Rock-Wren. Salpinctes obsoletus.}

A.O.U. Checklist no 715-Colorado Records-Say 23, Vol. ii., p. 4 ; Allen 72, pp. 148, 161 ; Trippe 74, p. 230 ; Henshaw 75, p. 179 ; Minot 80 , p. 225 ; Drew 81 , p. 88 ; Allen \& Brewster 83 , p. 154 ; Drew 85, p. 15 ; W. G. Smith 86, p. 17 ; Beckham 87, p. 123 ; Morrison 88, p. 72 ; Kellogg 90, p. 89 ; Nixon 90, p. 21 ; Lowe 92, p. 101 ; 94, p. 269 ; 01 , 
p. 276 ; McGregor 97, p. 39 ; Cooke 97, pp. 19, 120, 221 ; Keyser 02, p. 296 ; Henderson 03, p. 237 ; 09, p. 240 ; Warren 06, p. 24; 08, p. 25; 09, p. 17 ; Gilman 07, p. 195 ; Markman 07, p. 168 ; Rockwell 08, p. 178.

Description. -Adult-Above pale brownish-grey, washed with rufous on the rump, delicately speckled throughout with darker; tail-feathers, except the central pair, with a subterminal band of black and a terminal one of pale buffy; below dull white tinged with buff on the flanks, the chest and lower throat finely streaked with dusky and the under tail-coverts spotted with the same; iris brown, bill horny, the lower mandible paler, legs blackish. Length of a male 5.4; wing 2.8; tail 2.1 ; culmen .75 ; tarsus .80 .

The sexes are alike; young birds are vermiculated rather than speckled above, and are immaculate below.

Distribution.-Western North America from British Columbia to central Texas, south to central Mexico, west to the Pacific, breeding throughout its range and wintering in the southern portion of it.

In Colorado the Rock-Wren is plentiful, though never very common, throughout the State from the plains to timber line, and from the Kansas to the Utah border. It arrives from the south about the middle of April, breeds from the plains to 12,000 feet, though chiefly between 6,000 and 9,000 feet, and departs again in October. There can be little doubt that a few individuals winter in the State, as it has been observed by Lowe (01) on January 12th, at the foot of the Wet Mountains, about eighteen miles south-west of Pueblo.

The following are some spring records: Springfield, Baca co., April 10th (Warren), Fort Lyon, April 20th (Cooke), Pueblo, April 7th (Lowe), El Paso co., April 27th (Allen \& Brewster), Boulder co. (Henderson), Loveland, April 29th (Coole), Mesa co., May lst (Rockwell), Coventry and Bedrock, common (Warren).

Habits. - The favourite resort of this bird is among the heaps of fallen and loose rock lying about on the mountain sides, and also about rocky cañons and bluffs ; here it skulks about, running swiftly over the bare stones more like a rat than a bird. It is a fine songster, its notes being clear and bright, though perhaps not so varied as those of the House-Wren. When singing, the male nearly always perches on some conspicuous position, the summit of a rock, or even occasionally the ridge of a miner's cabin; here he stands very erect, with head thrown up and swelling throat, and pours forth his lay; 
at intervals he frequently bobs and bows like the Dipper. Towards the end of summer, owing to the constant running over the sharp rocks, the plumage becomes a good deal worn.

The nest is placed on the ground, generally among a heap of stones, or under a projecting bank; Gale found one in the crevice of a rotten tree trunk, while Smith describes a nest, which he discovered in a hole in a bank, as having a little platform constructed in front of it, levelled off and paved with flat stones.

Nests found by Gale in Boulder co. were constructed of grass and plant stems, with a little wool added; the lining was of fine roots and hair; the eggs, six or sometimes seven in number, are white, finely spotted with chestnut brown, chiefly at the larger end; they average $\cdot 72 \times \cdot 57$.

Nixon (90) describes a nest from Rio Grande co., containing six eggs, taken on May 29th, while Gale gives from May 25th to June 10th as the average nesting dates. One set of six fresh eggs found on June 24th was probably a second laying.

\section{Genus CATHERPES.}

Resembling in most respects Schlpinctes, but the bill, which is very slender and nearly straight, longer, the culmen exceeding the tarsus; plumage with white specks above and deep rusty posteriorly below.

Only one species in the United States.

Cañon-Wren. Catherpes mexicanus conspersus.

A.O.U. Cheoklist no 717a-Colorado Records-Allen 72, p. 148 ; Ailzen 72, p. 196 ; Minot 80, pp. 181, 225 ; Allen \& Brewster 83, p. 155 ; Drew 85, p. 15 ; Miller 94, pp. 74, 85 ; Lowe 94, p. 269 ; Cooke 97, p. 120 , Henderson 03, p. 237 ; 09, p. 240 ; Warren 07, p. 111 ; Markman 07; p. 158 ; Gilman 07, p. 195 ; Bumett 08, p. 87 ; Test 08, p. 226 ; Rockwell 08, p. 178 ; Dille 09, p. 88 ; Cary 09, p. 184 ; Betts 10, p. 218.

Description.-Adult-Above umber-brown, becoming grejer on the head and more rufous posteriorly, speckled throughout with dusky and white; tail chestnut with transverse narrow black bars; throat and 
breast pure white, becoming rusty rufous on the abdomen; iris brown, bill pale horny, legs dark brown. Length 5.0 ; wing $2 \cdot 3$; tail 2.10 ; culmen $\cdot 80$; tarsus $\cdot 70$.

The sexes are alike; young birds have fewer white spots on the. upper-parts, but are more coarsely vermiculated with dusky.

Distribution.-The arid districts of western United States from Colorado to Nevada and south-eastern California; the Wyoming record appears to be based on a confusion between the two portions of the paper by Holden and Aiken, in the 15th vol. of the Proceedings of the Boston Society of Natural History, in which Holden's notes refer to Wyoming and Aiken's to Colorado.

In Colorado the Cañon-Wren is a resident throughout the year and a somewhat uncommon bird, though probably often overlooked. It is most common along the eastern foothills, hardly extending upwards beyond an elevation of 8,000 feet; it has been taken out on the arid plains near Cheyenne Wells, only eighteen miles from the Kansas border, in November, by Warren (07), but this appears to be exceptional. It is not uncommon near Colorado Springs, having been first recorded from this neighbourhood by Allen, who found it frequenting the rocks in the Garden of the Gods, where it is still to be seen and heard, while Minot found a nest near Manitou close by, and Miss Miller watched it in south Cheyenne Cañon. Other records are: Trilby, near Fort Collins, June (Markman), Longmont, October 20th (Burnett), Boulder, October to January (Betts), Golden, February 22nd and October 10th (Test), Wet Mountains, up to 8,000 feet (Lowe), Irwin's Ranch, Las Animas co., May lst (Warren), Gaume's Ranch, November (Cary,) and on the western slopes-twenty miles east of Rangeley, September (Cary), Glenwood Springs in winter (Cooke), Grand Junction, March 3rd (Smith apud Rockwell), and Fort Lewis, La Plata co. (Gilman).

Habits.-The favourite haunt of the Cañon-Wren is among the crevices in perpendicular masses of rock and cliffs; here it may be more frequently heard than seen, since its notes are exceedingly characteristic and once listened to can never be forgotten. Beginning with a high note, which is often twice repeated, it descends in chromatic scale for seven or eight notes, each distinctly marked and clearly and somewhat shrilly given out in a series of detached whistles. It is very quick in its movements and seldom still, flying up and down the perpendicular faces of the great rocks and creeping about among the crevices, and even clinging to the over- 
hanging roofs of small caves. The song is heard not only in the breeding season but in the middle of winter on a fine day, especially among the rocks of the Garden of the Gods, where it is nearly always to be met with.

Further south, in Texas and Mexico, the Cañon-Wren is a more familiar bird, often settling about houses and singing from the chimney tops, but except in the case of an individual seen by Burnett " in a yard stacked with cement building blocks" in Longmont, it appears to avoid the haunts of man in Colorado.

The only definite nesting record in Colorado is that of Minot. He found a nest near Manitou on June 8th, 1880. It was placed in a niche in the roof of a cave about ten feet above the ground, and so narrow was the entrance that he was unable to put his hand in; it was necessary finally to obtain the help of a mason to knock the slab away. The nest itself was made of twigs, very roughly and loosely put together with a lining of a thick felt of down and feathers, held together with a few plant stalks. The eggs, five in number, were white, with a rosy tinge before being blown, delicately speckled, chiefly towards the larger end, with reddish-brown. They measured $75 \times 55$.

Dille has recently given a rather different account, at least as far as the date is concerned; he located a nest in a sheltered crevice on a sixty-foot cliff in the foothills of Boulder co. By means of a rope an investigation was made on April 4th, when the nest was found to be completed, and to contain three eggs; but it was not further disturbed. Brunning mentioned to Dille three other nesting sites of the Cañon-Wren in the immediate neighbourhood, and stated that the bird arrived only about the end of November, and left again in spring, I presume after nesting was finished. 


\section{Genus THRYOMANES.}

Bill slender and rather compressed; tail very slightly exceeding the wing in length; outer and inner toe about equal; plumage plain brown, the tail chiefly dusky.

Four species in North America, including Mexico.

\section{Baird's Wren. Thryomanes bewicki bairdi.}

A.O.U. Checklist no $719 \mathrm{~b}$-Colorado Records-Beckham 85, p. 140 ; (T. b. leucogaster); Thorne 87, p. 265 ; Cooke 97, pp. 120, 169, 221 ; Gilman 07, p. 195 ; H. G. Smith 08, p. 190 ; Rockwell 08, p. 178 ; Warren 09, p. 17 ; Dille 09, p. 88 ; Cary 09, pp. 184, 311.

Description.-Adult-Above plain brown with a greyish tinge, and a few concealed white spots on the rump; middle tail-feathers dusky. grey, finely cross-barred with blackish; lateral feathers dusky, with white on the outer edges and tips; a conspicuous white superciliary streak; below dirty white, the under tail-coverts narrowly barred with black; iris brown, bill horny, peler on the lower mandible; legs hornybrown. Length 4.75 ; wing 2.10 ; tail 2.20 ; culmen .55 ; tarsus 65 .

The sexes are alike, and the young birds hardly differ from the adults.

Distribution.-The drier parts of south-western United States from Colorado and Nevada south through Mexico to the State of Oaxaca, probably a resident throughout its range.

Baird's Wren is a rare bird in Colorado ; it has only been taken some half-dozen times, and must be regarded as a scarce resident. It has been most often met with in the southern half of the State, and was observed by Christie breeding near Rouse Junction, in Huerfano co., at the beginning of June (Cooke). Other records are; Colorado Springs, May, 1879 (Aiken coll.), Pueblo (Beckham), Fort Lyon, April 27th (Thorne), Loveland (Cooke), Holly, Prowers co., May 22nd (F. G. Smith), Irwin's Ranch, Las Animas co., April 26th (Warren), near Lily and Rangeley, September (Cary), Grand Junetion, November 2nd (Rockwell), and Fort Lewis, fow noticed (Gilman).

Habits.-Baird's Wren is most numerous in cedar and piñon country in cañons and dry aroyas. It has a melodious song, sweeter and perhaps more musical than that of the House-Wren. No one has described the breeding habits in Colorado, but Coues found a nest placed in the cavity of a rotten horizontal bough of a cedar, about eight feet from the ground; it was built up of small cedar twigs and finely frayed bark of the same 
tree, and lined with a matted mass of rabbit fur, stuck full of feathers, chiefly of the Carolina Dove. The eggs were not found, but probably resemble those of Bewick's Wren; these are seven to nine in number, white, speckled with various shades of brown, chiefly at the larger end, and measure $66 \times 50$.

Ridgway has included most of the Colorado references to Bewick's Wren under the Texan subspecies (T. b. cryptus), but the examples which I have examined from Colorado Springs and from Holly certainly appear to belong to the greyer race, T.b. eremophilus of Ridgway's "Birds of Middle North America," T. b. bairdi of the last Checklist.

\section{Genus TROGLODYTES.}

Very small-wing under 2.5 ; tail shorter than the wing, but always more than three-quarters of its length; outer and inner toes about equal to one another; plumage, including tail, finely barred with dusky.

A genus with numerous species found throughout temperate and tropical America; one species only in the United States forming two local races.

\section{Western House-Wren. Troglodytes aëdon parkmani.}

A.O.U. Checklist no 721 -Colorado Records-Baird 58, p. 367 ; Allen 72, pp. 148, 155, 174 ; Aiken 72, p. 196 ; Trippe 74, p. 231 ; Henshaw 75, p. 184 ; Tresz 81, p. 285 ; Allen \& Brewster 83, p. 155 ; Drew 85, p. 15 ; Beckham 85, p. 141 ; Morrison 86, p. 153 ; Kellogg 90, p. 89 ; H. G. Smith 93, p. 244 ; Miller 94, p. 24 ; Lowe 94, p. 269 ; McGregor 97, p. 39 ; Cooke 97, pp. 19, 120, 121 ; Dille 03, p. 74 ; Henderson 03 , p. 237 ; 09, p. 240 ; Warren 06, p. 24 ; 08, p. 25 ; 09, p. 17 ; Markman 07, p. 158 ; Rockwell 08, p. 178.

Description.-Adult-Above cinnamon-brown, brighter posteriorly; the back, wings, scapulars and tail narrowly cross-barred with dusky; eyebrow paler, but rather indistinct ; below very pale brown, the sides, flanks and under tail-coverts more or less distinctly barred with blackish; iris brown, bill brown, paler on the lower mandible; legs brown. Length 4.5 ; wing 2.20 ; tail 1.90 ; culmen .45 ; tarsus $\cdot 60$.

The sexes are alike; a young bird with the tail not full-grown is rather darker than the adult, and has less dusky barring on the back, while below it is a good deal more mottled with dusky. 
Distribution.-Western North America, breeding from British Columbia and Alberta south, probably to northern Mexico, and from the Pacific to the Mississippi Valley. In winter throughout the greater part of Mexico.

In Colorado the Western House-Wren is quite a common summer resident, reaching the State early in May from the south and departing again in October. It breeds both in the plains and mountains, but most commonly in the latter, up to about 10,000 feet, and is occasionally met with up to timber line. It has been recorded from all over the State, from Estes Park (Kellogg) and Weld co. (Markman) to Baca co. (Warren) on the east, and from Routt co. (Warren) and Mesa co. (Rockwell) to La Plata co. (Morrison) on the west. The highest definite breeding record seems to be Breckenridge, where it was met with by Carter.

Habits.-This quaint little bird is found about cliffs and rocky hill-sides as well as in the thickets along the streams, and is also, as its name implies, frequently in the neighbourhood of dwellings. It has a great variety of song with a number of clear, ringing and ebullient notes; this is generally poured forth from a perch with considerable vigour, the head being thrown back and the wings trembling. In search of the insects which constitute its food, it is very industrious, creeping about and looking over dead leaves, with tail erect and with a quick, nervous manner.

The nest is to be found almost anywhere where a suitable cavity, chink or cranny can be found-under logs, in old Woodpeckers' holes, between the logs of miners' cabins, among the timber of old mining shafts, in deserted cabins; these are all sites made use of. Warren (09) relates how a pair tried to nest in his wagonbox, but when turned out of that, took possession of an empty fruit can nailed up against a cotton-wood tree close by.

On the whole, perhaps a decayed and hollow branch or stub is most frequently used. The greater part of the cavity is filled up with small twigs and other rubbish, 
only a small space back from the opening being left for the nest proper. This is made up of grasses, with a few feathers and hair or wool for lining. The full complement of eggs seems to be seven; these are white, rather thickly spotted with reddish-brown and purplish, and measure about $64 \times 49$.

Fresh eggs are to be met with, according to Gale, about the first two weeks in June, while Trippe believed that two or even three broods were raised in one season, and that the last was not hatched till late in July.

\section{Genus NANNUS.}

Closely resembling Troglodytes, but with a much shorter tail, which is less than three-quarters the length of the wing and beyond which the feet extend considerably.

Several species in the colder parts of the Old and New Worlds. One species only in the United States.

\section{Winter-Wren. Nannus hiemalis.}

A.O.U. Checklist no 722-Colorado Records-Ridgway 73, p. 180 ; H. G. Smith 96, p. 76 ; Cooke, 97 pp. 121, 222.

Description.-Adult-Above brown with rufescent tinge, stronger posteriorly ; back, wings and tail slightly barred with dusky and often with whitish as well; the outer webs of the primaries with more distinct light and dark bars; a light stripe above the eye; below pale brown, becoming darker posteriorly, owing to the mottling and barring of dark and light browns; iris brown, bill dusky, paler on the lower mandible; legs light brown. Length 3.55 ; wing 1.80 ; tail 1.25 ; culmen .38 ; tarsus $\cdot 70$.

The sexes are alike; young birds are essentially like the adults, but the barring of the upper-surface is less distinct or absent, and the eye-stripe is less noticeable.

Distribution.-Eastern North America, breeding from Manitoba and Ontario south along the Alleghanies to North Carolina, wintering in the southern part of its breeding range, and south to Florida and the Gulf of Mexico.

In Colorado the Winter-Wren is a rare bird, and has only been met with a very few times. It was first noticed by Ridgway, but on what authority I do not know. Cooke gives three records-thirty miles west of Fort Collins, in the mountains, at 8,000 feet, July 7 th, 1896, C. P. Gillette; Estes Park, about 7,000 feet, the same year, Cooke; 
Denver, July 8th, 1896, W. H. Bergtold; while H. G. Smith obtained a single female caught by a cat in his house at Denver, October $13 \mathrm{th}$, 1891. Warren informs me that he saw a specimen in the Sapinero Valley, Gunnison eo., on September 26th, 1906, at about 8,500 feet. It may therefore be considered a resident.

I have not seen a Colorado example of the Winter-Wren, but have followed Prof. Cooke in assigning the Colorado records to the eastern rather than the western form of the bird; H. G. Smith's example was also assigned by Oberholser, of the Biological Survey, to the eastern subspecies.

Habits. - The Winter-Wren is a somewhat shy and retiring bird, keeping near the ground, generally in thick undergrowth or among fallen timber, where it creeps about investigating cracks and crannies for its insect food. On this account it is probably often overlooked, and may be of commoner occurrence than it is generally thought to be. The nest is usually placed in a crevice in a fallen log or in a stump; it is large and solidly made, and lined with fur and feathers. The eggs, five to seven in number, are white, sparingly spotted with reddishbrown, and measure $65 \% \cdot 48$. It has not yet been found breeding in the State.

\section{Genus CISTOTHORUS.}

Bill very short and slender, less than half the length of the head; tail shorter than the wing, graduated; plumage with the back and crown streaked longitudinally with black and white, eggs white.

A considerable American genus, with only one species in the United States.

Short-billed Marsh-Wren. Cistothorus stellaris.

A.O.U. Checklist no 724-Colorado Record-Cary 09, p. 184.

Description.-Adult-Above streaked with dusky and light brown in varying amounts, with, in addition, narrow white streaks on the acapulars and back; tail barred with light and dark brown; below white, tinged with pale rufous on the chest, flanks and under tailcoverts; bill dusky, with quite pale horny lower mandible, legs brownish, pinkish in the flesh. Length 3.75 ; wing 1.75 ; tail 1.40 ; culmen $\cdot 40$; tarsus $\cdot 65$.

The sexes are alike; in autumn the plumage is somewhat more richly coloured. 
Distribution.-Breeding from Manitoba and Maine southwards to Georgia and westwards to Utah; wintering in the Gulf states.

This bird has been found breeding at Provo, on Utah Lake, and one example has been taken at Cheyenne, in Wyoming, but the only undoubted record of the species within the State is that of Merritt Cary, who shot one in a rank growth of marsh-grass on the Medano Springs Ranch, in the San Luis Valley, October 23rd, 1907, and saw another individual next day.

\section{Genus TELMATODYTES.}

Closely resembling Cistothorus, but the bill longer, more than half the length of the head, and the crown plain without streaks; eggis dark brown.

One species only, confined to temperate North America, but divided into a number of local races.

Western Marsh-Wren. Telmatodytes palustris plesius.

A.0.U. Checklist no 725c-Colorado Records-Aiken 72, p. 196 ; Henshaw 75, p. 185 ; Drew 81, p. 88 ; 85, p. 15 ; Allen \& Brewster 83, p. 155 ; Morrison 88 , p. 72 ; Osburn 93, p. 212 ; Cooke 97, pp. 19, 121, 222 ; Richards 08 , p. 38.

Description.-Adult-Crown dusky black, becoming brown in the centre line to a varying extent; centre of the back black, streaked with white ; rest of the upper-surface rufous-brown, dusky on the wings and tail, the upper tail-coverts more or less distinctly barred with dusky ; the tail-feathers barred dusky and rufous, especially the median pair ; a well-marked white superciliary stripe; below dull white, passing into pale cinnamon-brown on the flanks; lunder tail-coverts more or less distinctly barred; iris brown, bill dusky-brown, paler on the lower mandible; legs brownish. Length of a female 4.25 ; wing 2.10 ; tail 1.75 ; culmen .50 ; tarsus .72 .

The sexes are alike, the coloration is a little richer in autumn and the young are like the adults, but the pattern of colour is less distinct and the superciliary stripe is almost obsolete.

Distribution.-This subspecies is found in the Rocky Mountain district, extending from British Columbia to New Mexico, and west to eastern slopes of the Cascades; it winters in many places within its breeding range, as well as in the northern states of Mexico.

In Colorado the Western Marsh-Wren is not uncommon where there are suitable spots, such as marshy lakes. It is undoubtedly a resident throughout the year in many places. L. J. Hersey tells me he has repeatedly observed it at Barr Lake, near Denver, in the months of December, January and February, while Richards (08) saw two at Littleton, also near Denver, on Christmas Day, 1907, and Cooke states that it has been seen in Routt co. in January by A. A. Bennett. Other 
recorded localities are: Loveland, March, 1889 (Osburn), Colorado Springs, November 3rd, 1877 (Aiken coll.), Cañon City, April 27th (Aiken), San Luis Lakes, breeding, May 28th-June 4th (Henshaw), San Juan co. (Drew), and La Plata co. (Morrison). It is said by Carter to breed in South Park, and probably does not range above 8,000 feet.

Habits. - The Marsh-Wren is an inhabitant of swamps in which there is a thick growth of reeds, rushes and cattails; they are generally found in considerable numbers together, and sing lustily, though their voices are not particularly musical. Their flight is short and not strong, but they are full of energy, climbing up and down the reeds in every conceivable position with their heads cocked up, searching for insects.

The nest is a large globular structure, about five inches in diameter, constructed chiefly of grass, woven round upright growing reeds or cat-tails ; it has a side entrance, and is lined with feathers or other soft substances. A clutch of five eggs taken by I. C. Hall on June Ist, on Storm's Lake, near Greeley, and presented to the Colorado College Museum, are pale brown, marked with darker brown, one of them being much paler than the others. They average $65 \times 50$.

According to Henshaw, the time of nesting is rather irregular, but he found fresh eggs at San Luis Lakes about the middle of June.

\section{Family CERTHIIDE.}

A small family of birds known as Creepers, at once distinguished by their rigid and sharp-pointed tailfeathers, resembling those of a Woodpecker. Other characters are-bill long, slender, sharp-pointed and decurved, about as long as the head; nostrils exposed; no rictal bristles; wing with ten primaries, the outer one less than half the next; tail rounded, about equal to the wing. 


\section{Genus CERTHIA.}

Characters of the family; only one species in the United States, separated into several geographical races.

\section{Rocky-Mountain Creeper. Certhia familiaris montana.}

A.O.U. Checklist no 726-Colorado Records-Ridgway 73, p. 180 ; Trippe 74, p. 230 ; Henshaw 75, p. 177 ; Drew 81, p. 88 ; 85, p. 15 ; Allen \& Brewster 83, p. 154 ; Beckham 87, p. 123 ; Morrison 88, p. 72 ; Kellogg 90, p. 89 ; Lowe 94, p. 270 ; Cooke 97, pp. 121, 222 ; Henderson 03, p. 108 ; 09, p. 241 ; Gilman 07, p. 195 ; Rockwell 08, p. 178.

Description.-Adult-General colour above dusky brown, streaked with white; rump and upper tail-coverts rufous, with slaty bases and white spots to the feathers; wings dusky with white spots on the coverts and remiges; a more or less clearly defined white eyebrow; below almost pure white, very faintly tinged with buffy posteriorly; iris brown, bill dusky brown, paler at the base of the lower mandible, legs brownish. Length 4.90 ; wing 2.5 ; tail 2.6 ; culmen .52 ; tarsus .59 .

The sexes are alike and the young closely resemble the adults.

Distribution.-The Rocky Mountain region from Alaska to Now Mexico and Arizona; on migration to south-eastern California and perhaps to northern Mezico, but generally a resident throughout the year. In Colorado the Creeper is found all the year round, chiefly between 7,000 and 9,000 feet in winter, and from 9,000 feet to timber line in summer, but it may be met with almost anywhere from the foothills to timber line at almost any season. The following are breeding records: Estes Park at timber line (Kellogg), Boulder co., 9,000 to 11,000 feet (Gale), Idaho Springs, at timber line (Trippe), near Fort Garland (Henshaw), San Juan co. (Drew), and La Plata co. (Morrison); it has been taken in El Paso co. in February, May and December (Aiken coll.), and in Boulder co. in winter (Henderson), and is considered only as an occasional visitor, chiefly in winter, at Grand Junction (Rockwell).

Habits.-This bird derives its name from its habit of creeping about the trunks and larger branches of trees, and in this its stiff tail and sharp claws greatly assist it; so closely does it harmonize with the rough bark over which it glides that it is often extremely difficult to detect it; it has a thin, sharp, long drawn-out ery which generally betrays its presence. It feeds on small insects, their eggs and larvæ, for which it searches diligently under the interstices of the bark. 
The nest is placed in a hole or crevice, generally between the bark and the trunk of a rotten pine or fir. Gale found a nest in such a situation about eight feet from the ground, on June 1lth, containing five eggs slightly incubated. He states further that in Boulder co. fresh eggs can usually be found from June 10th to 25 th at 9,000 feet, and from June 30th to July 10 th at 11,000 feet.

The eggs are white, speckled with reddish-brown, and measure $59 \times \cdot 46$.

\section{Family SITTID在.}

This family contains the Nuthatches, distinguished by the following external characters: Bill rather long, straight, slender and acute, about as long as the head; nostrils rounded and concealed by bristles; wing long and pointed with ten primaries, the outer one of which is very short or even spurious, and always less than half the next; tail always considerably shorter than the wing. Tongue horny, acute and barbed.

\section{Genus SITTA.}

Characters of the family. Four species in the United States with several additional geographical races.

\section{Key OF THE Spectes.}

A. Crown black in males, dusky grey in females.

a. Larger-wing over 3.0 ; below white. S. c. nelsoni, p. 498. b. Smaller-wing under $3 \cdot 0$; below reddish-buff.

B. Crown greyish-olive.

S. canadensis, p. 500 .

Rocky-Mountain Nuthatch. Sitta carolinensis nelsoni.

A.O.U. Checklist no 727c-Colorado Records-Allen 72, pp. 148, 161 ; Aiken 72, p. 195 ; Trippe 74, p. 230 ; Henshaw 75, p. 173 ; Scott 79 , p. 92 ; Allen \& Brewster 83, p. 154 ; Drew 85, p. 15 ; Morrison 86, p. 35 ; 88, p. 72 ; Kellogg 90, p. 89 ; Lowe 94, p. 270 ; McGregor 97, p. 39 ; Cooke 97, pp. 121, 122, 222 ; Henderson 03, pp. 237, 108; 09, p. 241 ; Gilman 07, p. 195 ; Warren 08, p. 25 ; 09, p. 17 ; Richards 08 , p. 194 ; Rockwell 08, p. 178. 
Description.-Mále-Crown and nape shiny black; general colour above, including the central tail-feathers, greyish-blue; greater coverts tipped with white; on the longest tertial the central black area of the feather is acutely pointed, not rounded; tail-feathers, except the central pair, black, with increasing amounts of white towards the outer ones ; below, including the sides of the head and superciliary region, white; flanks slightly washed with grey; lower abdomen and under tailcoverts blotched with chestnut; iris brown, bill blackish, paler on the culmen at the base and on the lower mandible, legs dusky. Length 5.30 ; wing 3.50 ; tail 1.80 ; culmen .75 ; tarsus .68 .

The female has the crown more greyish, though still glossy, and the young birds are very similar to the adults.

Distribution.-Western North America from British Columbia and Manitoba, south along the eastern border of the great plains to western Texas and northern Mexico, west to the eastern slopes of the Cascades and Sierra Nevada. Generally a resident.

In Colorado the Rocky-Mountain Nuthatch is a common resident throughout the year, being found chiefly along the foothills and in the piñon and cedar zone in winter, and at higher elevations, nearly up to timber line, in summer, but it has been found breeding as low as 5,300 feet at Littleton near Denver (Richards 08).

Other breeding records are: Estes Park (McGregor), Gold Hill, Boulder co., about 9,500 feet (Gale), above Idaho Springs, from 8,000 feet to timber line (Trippe), Twin Lakes (Scott), West Monument Creek, El Paso co. (Allen \& Brewster), La Plata co., up to 11,000 feet (Morrison).

Habits. - This Nuthatch is a tree-trunk bird, resembling the Creeper; its usual position is clinging like a Woodpecker to the trunk of some rough-barked tree or running up and down looking for insects which constitute the bulk of its food. Its long hind toes and hooked claws enable it to cling to the undersides of horizontal branches and to creep down as well as up the vertical trunks. They have an unmistakable nasal ringing call "Chank, chank," by which their whereabouts can be easily detected.

The Rocky-Mountain Nuthatch nests in holes, generally in fir trees, sometimes in cotton-woods. These are more usually excavated by the bird itself, but an 
old Woodpecker's hole is sometimes taken up; Gale believed that the same hole is often utilized year after year. The nest proper is placed at the bottom of the excavation, which is about six or eight inches deep. It is made up of a felted mass of fur and feathers. The eggs, usually five in number, are white, spotted chiefly at the larger end with brown. This bird nests early; Gale gives May 10th to 30th for freshly-laid eggs, whilo the nest described by Richards (08) already seemed to contain young birds as early as May 15th, but this, of course, was at an exceptionally low elevation.

\section{Red-breasted Nuthatch. Sitta canadensis.}

A.O.U. Checklist no 728-Colorado Records-Henshaw 75, p. 174 ; Drew 85, p. 15 ; Lowe 94, p. 270 ; Cooke 97, pp. 122, 222 ; Henderson 03, p. $108 ; 09$, p. 241.

Description.-Male-Whole of the crown and a broad stripe from the lores through the eye to the side of the neck black, with a faint gloss; a white superciliary line extending above the lores; rest of the upper-surface, including the two middle tail-feathers, blueish-grey; the wing quills ashy; the outer tail-feathers black, tipped with grey, the three outermost with a subterminal band of white; throat and sides of the neck below the black band white, rest of the under-parts buffy, varying somewhat in intensity; iris brown, bill black, paler at the bese of the lower mandible, legs hormy. Length 4.10 ; wing 2.70 ; tail 1.50 ; culmen .52 ; tarsus $\cdot 60$.

The female has the black of the head less glossy and more slaty; young birds are very similar to the adults.

Distribution.-From southern Alaska and Labrador, south to the northern tier of states and further south along the Rockies and Alleghanies to California, Colorado and N. Carolina; further south to the Gulf states, Arizona and New Mexico in winter.

In Colorado the Red-breasted Nuthatch is by no means common, as can be seen by the scanty notices. It is a resident throughout the year in the mountains, breeding from 8,000 to 10,000 feet so far as records show; in the plains it has been taken by Aiken at Resolis, in Elbert co., May 26th, and at Limon, Lincoln co., May 19th, when it was probably migrating north.

The other records are as follows: Boulder co, breeding (Gale), foothills in El Paso co., about 7,000 feet, November (Colo. Coll. Mus.), 
Breckenridge (Cooke), Sapinero Creek, Gunnison co., October (Warren), Wet Mountains up to 10,000 feet (Lowe), Fort Garland, breeding (Honshaw).

Habits. - This little Nuthatch is more sociable than the previous species, and is often seen in small flocks, especially in winter. Henshaw describes it as being very brisk and busy, the male hunting with great energy for insects for the incubating female, though both sexes assist in this duty. Henshaw found a single nest among the pine woods near Fort Garland early in June. This was placed in a hole in a rotten pine stub about five inches deep, the nest itself being lined with pine bark; Gale found a nest about fifteen feet up in an old aspen tree, on June 4th ; it was made of wood fibre and strips of aspen bark, and differed from that of the Rocky-Mountain Nuthatch in having no fur or feathers. The eggs, four or five, are white, slightly rosy-tinted when unblown, thinly spotted with reddish dots confluent at the larger end; they measure $60 \times \cdot 50$.

\section{Pigmy Nuthatch. Sitta pygmcea.}

A.O.U. Checklist no 730-Colorado Records-Aiken 72, p. 195 ; Henshaw 74, p. 175 ; Trippe 75, p. 230 ; Scott 79, p. 92 ; Drew 85, p. 15 ; Morrison 86, p. 28 ; 88, p. 72 ; Norris 88, p. 173 ; Kellogg 90, p. 89 ; Lowe 94, p. 270 ; MoGregor 97, p. 39 ; Cooke 97, pp. 122, 222 ; Henderson 03, p. 237 ; 09, p. 241 ; Gilman 07, p. 195 ; Warren 08, p. 25 ; 09, p. 17 ; Cary 09, p. 184.

Description.-Adult-Crown and hind neck greyish-olive, rest of the upper surface blueish-grey, becoming dusky on the wings; a more or less concealed whitish spot at the junction of nape and back; central tail-feathers like the back, with white at the base of the inner web, black at the base of the outer; rest of the tail-feathers black, the outer two pairs crossed by an oblique band of white; below pale buffy, becoming nearly white on the throat and blueish on the flanks; iris dark brown, bill black, grey on the base of the lower mandible; legs dusky-horn. Length of a female 4.10; wing 2.50 ; tail 1.30 ; culmen .50 ; tarsus $\cdot 55$.

The sexes are alike; the young birds have the crown the same colour as the back and the flanks, and under-parts very pale buffy. 
Distribution.-The mountains of western North America from British Columbia to the State of Vera Cruz in Mexico, east to Wyoming and Colorado.

The Pigmy Nuthatch is a common resident in the mountainous portion of Colorado, being found along the foothills up to about 8,000 feet in winter, and from 7,000 to 10,000 in summer; it is as a rule, though by no means strictly, confined to these limits.

It has been recorded from Estes Park (Norris) to Fort Garland (Henshaw) on the eastern slopes, and from Douglas Spring, in Routt co., to Fort Lewis, in La Plata co., on the west; it is seldom found away from pine timber, and is not therefore to be met with on the plains.

Habits. - The Pigmy Nuthatch is a gregarious bird, associating in quite large flocks in winter with Chickadees and Woodpeckers, and even in summer being often mixed up in flocks with Warblers and Bluebirds, and squabbling with the latter and the Chickadees over nest-holes. It is practically confined to coniferous forest, and is seldom seen beyond its limits. It is excessively active and persevering in its search for insects, creeping rapidly over the limbs of trees and examining every crevice, and often striking with its bill like a Woodpecker with very considerable force. It is a noisy bird, and its loud querulous "Weet, weet" can be easily distinguished among the softer notes of the other species. It is said by Trippe to capture flying insects on the wing.

The nest is placed in a hole in a rotten pine tree, and is almost invariably excavated by the bird itself, often a zone of quite tough wood having to be cut through for this purpose ; the aperture is generally small, and the cavity from about three to four inches in depth. Upon a few chips at the bottom of the cavity is placed the nest, made up of the softest materials, chiefly soft velvety plant leaf, held together with cobweb, hair, feathers and fibres. Though perhaps often using the same site, it forms a new nest each season; the eggs, generally 
seven in number, are pure white with light reddishbrown speckling, chiefly at the larger end, and average $\cdot 62 \times \cdot 47$ (Norris). According to Gale, who took a very large number of nests in the hills of Boulder co., and from whose notes this account has been chiefly taken, fresh eggs are to be met with from the end of May to the middle of June.

\section{Family PARID压.}

Small birds-wing under 3, with a short, stout, compressed conical bill, shorter than the head, not notched, and with the culmen rounded or flattened; nostril entirely concealed by dense tufts of feathers; wing with ten primaries, the outer about half the length of the next, somewhat rounded, shorter than or only just exceeding the tail; tarsus scutellate; tail-feathers never stiff or acuminate.

\section{KEY OF THE GENERA.}

A. Head crested; plumage plain; wing slightly exceeding the tail.

B. Head not crested.

Bæolophus, p. 503.

a. Crown and throat always black; wing and tail about equal.

Penthestes, p. 504.

b. No black on crown or throat; tail distinctly exceeding the wing and markedly graduated. Psaltriparus, p. 508.

\section{Genus BEOLOPHUS.}

Head crested; build very stout and conical; wings rather long but rounded; tail slightly shorter than the wing, slightly rounded; plum,age plain grey without black.

The genus contains four species, confined to the warmer parts of North America.

Grey Titmouse. Bocolophus inornatus griseus.

A.O.U. Checklist no 733a-Colorado Records-Aiken 72, p. 195 ; Ridgway 73, pp. 179, 189 ; Drew 81, p. 87 ; 85, p. 15 ; Morrison 88, p. 71 ; Lowe 94, p. 270 ; Cooke 97, pp. 122, 169 ; Gilmen 07, p. 195 ; Warren 08, p. 25; 09, p. 17 ; Rockwell 08, p. 178 ; Cary 09, p. 184. 
Description.-Adult-Ashy-grey throughout, duskier on the wings and tail ; a good deal paler on the under-parts ; head strongly crested; iris brown, bill dusky-brown, legs dusky. Length 5.0; wing 2.75 ; tail 2.25 ; culmen .40 ; tarsus .72 .

The sexes are alike; the young birds closely resemble the adulta, but the crest is not quite so long, and the upper-parts are a shade more olivaceous.

Distribution. - The drier south-western districts of the United States, from Colorado and Nevada to western Texas and south-east California. In Colorado the Grey Titmouse is a rather uncommon resident throughout the year, more or less confined to the upper Sonoran zone of piñons and cedars, between 5,000 and 8,000 feet. On the east of the range it has been observed in Fremont and El Paso cos. by Aiken, and i3 represented in his collection by examples taken in April and October. West of the range there are many more records, viz., Douglas Spring, Routt co., June (Warren), Grand Junction, November (Roclswell), Coventry, April (Warren), San Juan co., September (Drew), Fort Lewis (Morrison). It doubtless breeds, but no details have jet been given.

Habits.-Henshaw tells us that the Grey Titmouse is generally found in the groves of piñon and scrub cedars in the northern part of its range, but in the south, in Arizona, it often frequents oak scrub; it is never found in pine-woods. It spends much of its time on the ground looking for insects, and has a harsh, scolding note, with, in summer, a short, disconnected, though somewhat pleasing song. It is gregarious in winter, but after January, according to Aiken, is found singly. Its nesting habits; so far as I am aware, have never been described, but it almost certainly builds, in holes in trees or stumps, a nest of felted material and feathers, and lays six to eight white eggs like its Pacific coast congener, the Plain Titmouse (B. inornatus).

\section{Genus PENTHESTES.}

Head not crested; bill more slender and less stout; wings and tail approximately equal; crown and throat always black.

About twelve species from the northern parts of the Old and New Worlds. 


\section{KEY OF THE SPeCIES.}

A. With no white superciliary streak. P. a. septentrionalis, p. 505.

B. With a white superciliary streak.

7

P. gambeli, p. 506 .

\section{Long-tailed Chickadee.}

\section{Penthestes atricapillus septentrionalis.}

A.O.U. Checklist no 735a-Colorado Records-Allen 72, pp. 155, 174 ; Aiken 72, p. 195 ; Trippe 74, p. 230 ; Henshaw 75, p. 170 ; Minot 80 , p. 225 ; Tresz 81 , p. 285 ; Drew 81 , p. 87 ; 85, p. 15 ; Allen \& Brewster 83, p. 154 ; Beckham 87, p. 123 ; Morrison 86, p. 153; 88, p. 72 ; Kellogg 90, p. 89 ; Lowe 94, p. 270 ; MeGregor 97, p. 37 ; Cooke 97, pp. 122, 222 ; Henderson 03, p. 237 ; 09, p. 241 ; Gilman 07, p. 195 ; Rockwell 08, p. 179 ; Richards 08, p. 194 ; Hersey \& Rockwell 09, p. 121.

Description.-Adult-Crown and nape glossy black; back slatygrey, becoming tinged with pale buffy on the rump and tail-coverts; wings and tail dusky-slate, most of the feathers edged with white; a white patch on the sides of the head extending forwards to the bill; below, chin and throat black, rest of the under-parts dull white, slightly washed with pale buffy on the flanks; iris brown, bill black, legs dusky. Length $5 \cdot 0$; wing 2.75 ; tail 2.74 ; culmen $\cdot 30$; tarsus $\cdot 70$.

The sexes are alike; in the autumn the colour is a little brighter, especially the buffy wash on the lower back and flanks; the young are very similar to the adults.

Distribution.-Central parts of western North America, from Alaska and Mackenzie to New Mexico, east to Kansas, west to Utah. In Colorado the Long-tailed Chickadee is a fairly common resident throughout the year, chiefly in the foothills and at elevations up to 9,000 feet, though occasionally wandering higher; in winter they are mostly below 8,000 feet, while in summer they breed from 5,500 to 9,000 feet.

The following localities show the breeding range in the State: Littleton near Denver, 5,500 feet (Richards), near Trinidad, 6,000 feet (Cooke), up to 9,000 feet in Boulder co. (Gale); additional records are : Estes Park, summer (Kellogg), Fort Garland, October (Henshaw), Mesa co. in winter (Rockwell), Barr Lakes in winter (Hersey \& Rockwell), San Juan co., breeding (Drew), and Fort Lewis, breeding (Gilman).

Habits. - The Chickadee is a social creature, going about in small parties, especially in winter, among the cotton-woods along the stream-beds, and very actively searching the bark and winter buds for insects, their eggs and larva, which form the bulk of its food all the year round; they are undoubtedly of the greatest value 
to the agriculturist in destroying an infinite number of insect pests, while the damage they do is infinitesimal. They creep and crawl in all sorts of attitudes, often hanging suspended from a branch or running along, head down and tail up. The note of the bird is recalled in its common name, and in this respect the eastern and western forms hardly differ at all.

The nest is placed in an old aspen stub or in a rotten pine tree, the hole being usually hollowed out by the bird itself; the nest, placed at the bottom of the hole, is made of bark strips or moss, and lined with fur, hair or feathers; the eggs, four to eight, are dull white, rather evenly speckled with reddish-brown, and measure $62 \times \cdot 48$. Gale found fresh eggs in Boulder co. between May 20th and June 15th.

\section{Mountain-Chickadee. Penthestes gambeli.}

A.O.U. Checklist no 738-Colorado Records-Allen 72, pp. 161, 174 ; Aiken 72, p. 195 ; Trippe 74, p. 230 ; Henshaw 75, p. 169 ; Scott 79 , p. 92 ; Drew 81 , p. 87 ; 85 , p. 15 ; Coues 83 , p. 240 ; Allen \& Brewster 83 , p. 154 ; Beckham 85 , p. 140 ; 87, p. 125 ; W. G. Smith 86 , p. 25 ; Morrison 88, p. 72 ; Kellogg 90, p. 89 ; Lowe 94, p. 270 ; Cooke 97, pp. 123, 222 ; Henderson 03, p. 257 ; 09, p. 241 ; Gilman 07, p. 195 ; Warren 08, p. 26 ; 09, p. 17 ; Rockwell 08, p. 179.

Description.-Adult_Closely resembling the Long-tailed Chickadee, with black crown and throat and olive-grey back, but distinguished at once by a conspicuous superciliary stripe running from the forehead over and behind the eye; whole of the back olive-grey with but little trace of the buffy on the rump; wings and tail with slightly paler edgings, but without white on the coverts; below white, becoming olive on the flanks and abdomen; iris dark brown, bill black, feet dusky, blueish-grey in the flesh. Length 5.30 ; wing 2.80 ; tail 2.50 ; culmen $\cdot 38$; tarsus $\cdot 65$.

The sexes are alike; the young closely resemble the adults, but the black of the crown and throat is duller and less glossy, and the white supercilium is less distinet and sometimes rather broken up.

Distribution.-The mountains of western North America, from British Columbia to California and western Texas. In Colorado the Mountain-Chickadee is a common resident throughout the year at the 
higher elevations of the mountains, occasionally associating with the Long-tailed Chickadee, but as a rule keeping higher up among the pines and spruces, where it breeds, chiefly between 8,000 feet and timber line. In winter it is often found at lower elevations among the piñons and cedars of the foothills, even as low as Grand Junction (4,500 feet), where it has been noticed from October to April (Rockwell), and Pueblo at 4,600 feet (Beckham). It has been recorded from Estes Park (Kellogg) and Sulphur Springs (Warren) in the north to Fort Lewis (Gilman) in the south, and appears to be a common bird throughout the mountainous part of the State.

Habits.-This Chickadee does not appear to differ very materially from its long-tailed congener. It is generally noticed in small bands or parties actively engaged in its search for insects, their larvæ and eggs, about the rough bark and the buds of trees in the winter.

Gale took a large number of nests near Gold Hill in Boulder co., between 8,200 and 10,000 feet; these were generally in aspen trees or stubs, sometimes in pines. They were either excavated by the birds themselves or, as often as not, an old Woodpecker's or other hole was taken possession of. The nest itself is composed of a felted mass of rabbits' fur or hairs, with occasionally a little moss as well. The eggs, usually seven, but varying in number, are sometimes pure white without spots, as was first pointed out by W. G. Smith to Elliot Coues (83), and sometimes faintly speckled with reddish, the proportion of spotted to plain eggs being about equal. The birds are courageous in defence of their nest-holes, and often contend with House-Wrens and Bluebirds for the possession of a desirable habitation. Before the young are hatched the nest is very difficult to locate, but afterwards the constant requirements of the large number of young soon betray the spot. Gale noted that fresh eggs were to be found between May 20 th and June 15th. 


\section{Genus PSALTRIPARUS.}

Very small Titmice-wing under 2.0; the head without crest, short and rounded wings and long and graduated tails, clearly exceeding the wing in length; plumage dull and grey without black on the head or throat.

Four species are known from the western United States and temperate parts of Mexico.

\section{Plumbeous Bush-Tit. Psaltriparus plumbeus.}

A.O.U. Checklist no 744-Colorado Records-Aiken 72, p. 195 ; Drew 85, p. 15 ; Lowe 94, p. 270 ; Cooke 97, pp. 123, 222 ; Gilman 07, p. 195 ; Rockwell 08, p. 179 ; Cary 09, p. 184 ; Warren 09, p. 17.

Description.-Adult-General colour above blueish-grey, slightly washed with olive on the back, darker and duskier on the wings and tail ; sides of the head from the lores to the ear-coverts pale greyishbrown; below dirty white; iris pale yellow (according to Aiken, brown in the male, Jellow in the female), bill and legs black. Length 4.30; wing 2.05 ; tail 2.30 ; culmen $\cdot 24$; tarsus $\cdot 65$.

The sexes are alike, and the young hardly distinguishable from the adults.

Distribution.-The drier districts of the western United States from eastern Oregon south to western Texas and south-eastern California, and perhaps into northern Mexico.

This Bush-Tit is a rather uncommon resident in Colorado and is restricted chiefly to the southern and western portions of the State. It comes as far north as Fremont and El Paso cos. on the eastern slopes of the mountains. It is practically restricted to the piñons and cedars of the upper Sonoran zone, and does not range above 7,800 foet as a rule.

The following are the recorded localities : El Paso co. and Fremont co., winter and summer (Aiken coll.), Salida, December (Frey), Wet Mountains up to 7,800 feet (Lowe), Coventry, breeding (Warren), Grand Junction, November, A. H. Howell (Rockwell); Glenwood Springs, breeding (Cooke), near Douglas Spring (Cary).

Habits. - This Bush-Tit frequents the shrubs and bushes on steep hill-sides, and the piñon and cedar country; in winter it is to be met with in fairly large flocks; it is one of the most industrious and active of the family, searching with sharp prying eyes for insects and their larvæ, and keeping up an incessant querulous chirping. 
Aiken found a nest in the foothills north-east of Cañon City, containing five eggs, May 9 th, $1876 ;$ D. P. Ingraham took three sets of eggs near Beulah, at the foot of the Wet Mountains, in the summer of 1897, and W. Cross a nest with six eggs at Glenwood Springs, but no further details are given by Cooke.

Nests taken by Lieut. Benson, U.S.A., in southern Arizona (Bendire, "P.U.S.N. Mus.," XI., p. 557) were gourd-like in shape, woven into and supported by twigs of scrub oak; they were made of sage-bush leaves, spider web, moss and lichen, and thickly lined with soft small feathers; the entrance was on the side near the top. The eggs were pure white in colour, and ovate in shape; they were four to six in number, and measured $.53 \times \cdot 40$.

\section{Family SYLVIID死.}

This family contains the true Warblers chiefly met with in the Old World. They are very closely allied to the Thrushes, from which they can best be distinguished by the fact that the young are unspotted, and that most of them undergo a double moult in spring and autumn.

The United States genera can be easily distinguished by their small size-wing under 3-their slender bill more or less notched at the tip, their wing with ten primaries, the outer of which is barely or considerably less than balf the next, and by their plain blueish or olivegreenish plumage.

KEy OF THE GENERA.

A. Tarsus booted; crown with a yellow or reddish patch.

- Regulus, p. 510.

B. Tarsus scutellate; no crown-patch; plumage chiefly slaty.

Polioptila, p. 513. 


\section{Genus REGULUS.}

Small birds-wing under 3.0 - with a very slender, straight bill, shorter than the head; nostrils slightly overhung but not concealed by small feathers ; wings rather long and pointed, exceeding the tail ; outer primary very short, always less than half the next; tail slightly forked, the feathers pointed; tarsus slender and booted, i.e. covered in front with one long scute; plumage olive-green with a patch of red or yellow on the erown.

About ten species from the northern parts of the Old and New Worlds.

\section{KEY OF THE SPECLES.}

A. Crown with orange or yellow bordered by black.

B. Crown with a red spot but no black.

R. s. olivaceus, p. 510 .

C. Crown plain, like the back.

R. calendula, $\delta$ p. 511.

R. calendula, + p. 511 .

\section{Western Golden-crowned Kinglet. Regulus satrapa olivaceus.}

A.O.U. Checklist no 748a-Colorado Records-Aiken 72, p. 195 ; Drew 81, pp. 87, 244 ; 85, p. I5 ; Allen \& Brewster 83, p. 154 ; Morrison 88, p. 71 ; Cooke 97, p. 123 ; Henderson 09, p. 241 ; Betts 10, p. 219.

Description.-Male-Centre of the crown bright orange red, narrowly edged with yellow; around this a V-shaped patch of black, while a narrow frontal and superciliary band of white bounds the black; rest of the upper-parts olive, greyer anteriorly, greener posteriorly; wings and tail dusky, edged with olive-yellow, and the middle and greater coverts tipped with whitish; under-parts white, washed with dusky olive; iris brown, bill black, legs dusky brown. Length 3.75; wing 2.20 ; tail 1.5 ; culmen .25 ; tarsus .70 .

The female is like the male, but has the orange part of the crown replaced by yellow; young birds have the crown brownish-grey with the black V-mark rather indistinet.

Distribution.-Western North America, breeding from Alaska to Mount Whitney in California, and to Colorado, wintering south to Guatemala.

The Golden-crowned appears to be quite a rare resident in the mountains of Colorado, while it is perhaps a little more common as as migrant on the plains in spring; only very few observers have noted it.

Aiken and Allen and Brewster record it from El Paso co., probably on migration, at the end of April and beginning of May. Drew obtained an adult male on July lst, at 11,500 feet, and a young bird just fledged 
at 11,000 on July 25 th in San Juan co., and concluded that it must breed at about this elevation, while Aiken recently obtained a female, now in the Colorado College Museum, at Clyde, in Teller co., 9,400 feet, on January 12th, proving that a few birds at least winter in the State. One taken by Gale in August in Boulder co. is now in Mr. Felger's collection, another was recently shot in the same district by Betts on February 6th, out of a flock of eight. Finally, Morrison states that he observed it three times in La Plata co.

Habits. - The Golden-crowned Kinglet resembles its cousin the Ruby-crowned in its habits, but has rather a different call-note-a fine high " $\mathrm{Ti}$, ti," only audible to practised ears. The nest, generally pensile, composed of green mosses, lined with fine bark strips, rootlets and feathers, is placed in coniferous trees from six to sixty feet up. The eggs, nine or ten, are creamy-white, blotched and speckled with pale wood-brown, and rarely faint lavender; they measure $55 \times 54$ (Brewster, “Auk," V., p. 337).

\section{Ruby-crowned Kinglet. Regulus calendula.}

A.O.U. Checklist no 749-Colorado Records-Allen 72, pp. 161, 174 ; Aiken 72, p. 195 ; Batty 73, p. 35 ; Trippe 74, p. 229 ; Henshaw 75 , p. 164 ; Ingersoll 76 , p. 77 ; Scott 79 , p. 91 ; Minot 80, p. 225 ; Drew 81, pp. 87, 85, p. 15 ; Stone 83, p. 83 ; Allen \& Brewster 83, p. 154 ; Beckham 87, p. 123 ; Morrison 88, p. 71 ; McGregor 97, p. 39 ; Cook $\theta$ 97, pp. 123, 222 ; Keyser 02, p. 65 ; Henderson 03, p. 108 ; 09, p. 241 ; Gilman 07, p. 195 ; Warren 08, p. 26 ; Rockwell 08, p. 179.

Description.-Male-Above olive-greyish anteriorly, more greenish posteriorly; wedge-shaped patch of scarlet from the middle of the crown to the nape, sometimes more or less concealed; wings and tail dusky, edged with olive-yellow and with dull white tips to the wingcoverts, forming a double wing-band; a whity ring round the eye; below dull olive-grey, darkest on the breast and flanks; iris and bill dark brown, legs dusky-brown. Length 3.75 ; wing 2.50 ; tail 1.75 ; culmen $\cdot 30$; tarsus $\cdot 71$.

The female resembles the male, but lacks the red crown-patch; in the fall the plumage is a somewhat brighter shade of olive; young birds resemble the female, but the wing-bands are tinged with buffy.

Distribution.-Breeding in the northern parts of North America from Alaska and Labrador to Michigan and Quebec, and further south 
along the western mountains to northern California, Arizona and N, Mexico; in winter south through the United States and Mexi to Guatemala.

The Ruby-crowned Kinglet is a common bird throughout Colorac in the plains a migrant, in the mountains a surnmer resident. arrives from the south about the middle of April and passes on nor or up into the mountains before the middle of May, descends age in September, and leaves the State in October. Its breeding ran extends vertically from about 7,000 feet-Middle Park (Carter ap Cooke) to timber line. The following are breeding records: Buffe Peaks, Park co. (Batty), Twin Lakes, 9,200 feet (Scott), Boswt 11,000 feet (E. Lewis apred Cooke), and Hancock, 11,000 feet (Ston all in Chaffee co.; Gold Hill and Ward in Boulder co. (Gale); near Fe Garland, 10,000 feet (Henshaw), San Juan co., 7,000 to 10,500 ft (Drew). During the spring migration its range extends out on $t$ plains as far as Limon, in Lincoln co., where it has been taken, Ap 30th and May 19th, by Aiken.

Habits.-The Ruby-crowned is a very sociable bir especially in the fall, when it may generally be seen small parties with Bluebirds, Titmice and Warbles pursuing its way through the woods and very active engaged in securing small insects from the branch and trunks of trees, and also catching them occasional in flight. It has a very sweet and modulated son remarkably loud and strong for so small a bird.

The first nest and eggs known were secured by Bat in the Buffalo Peaks, in Park co., on June 21st, 187 This nest was in a spruce tree, about fifteen feet up, al contained five young and one egg. It has subsequent been taken by a good many other collectors, includi Gale, who found a number in the mountains abo Boulder. They were almost always placed in a spru tree, from eight to fifty feet above the ground, sometim almost pensile and woven to the smaller twigs, sometim simply saddled on a horizontal bough. The nest its! is a large and loosely woven structure of fine moss, sc stringy fibres and spider web, lined with hair or feathe: 
The eggs, generally eight in number, are creamy-white when fresh, pure white when blown, with a very fine peppering of reddish-brown at the larger end; sometimes this is so indistinct that the egg appears to be plain white; they measure $55 \times \cdot 45$ (Scott). Gale found fresh eggs from June 1st to 30th, and believed that a second brood was often raised in July.

\section{Genus POLIOPTILA.}

Small slender birds-wing under $2 \cdot 5$, with a straight bill rather shorter than the head, broad and depressed at the base and a slightly hooked tip; nostrils exposed; wings rounded, outer primary about half the next; tail exceeding the wing and distinctly graduated, the feathers slightly club-shaped; tarsus scutellate; plumage chiefly ashy with black and white, no bright colours.

A genus of about twenty species and subspecies, confined to the warm temperate and tropical regions of America.

\section{Western Gnatcatcher. Polioptila ccerulea obscura.}

A.0.U. Checklist no 751a-Colorado Records-Ridgway, 73, p. 179 ; Drew 85, p. 15 ; Lowe 92, p. 101 ; Cooke 97, pp. 124, 169 ; Henderson 05, p. 421 ; 09, p. 241 ; H. G. Smith 08, p. 190 ; Rockwell 08, p. 179 ; Cary 09, p. 184.

Description.-Male-Above greyish-blue with a black V-shaped band across the forehead to the eye; wings dusky with whitish edgings, especially on the inner secondaries; tail and upper tail-coverts black, the outer pair of tail-feathers largely white, but the black base extending beyond the tail-coverts ; the second pair with the terminal third, the third pair only tipped with white; a white orbital ring; below white, washed with blueish-grey; iris brown, bill black, legs dusky. Length 4.55 ; wing 2.05 ; tail 2.20 ; culmen .40 ; tarsus .70 .

The female is slightly duller in colour above and lacks the black frontal band; young birds are very like the female, but rather more brownish above.

Distribution.-The drier portions of south-western North America from the interior of northern California and Colorado to Colima in Mexico.

In Colorado the Gnatcatcher is a rare summer resident in the plains and at low elevations up to about 7,000 feet. It arrives early in May, and has been noticed at Pueblo on May 6th (Lowe), in Fremont co., May 12th, and at Limon, May 23rd (Aiken coll.), and at Boulder, May 
12th (Henderson), while on the western slope it was taken by W. Ferril at Grand Junction, May 17th (Smith). The only definite bref ing record is that of Nash, who found a nest containing two you and a Cow-bird, near Pueblo, June 22nd (Cooke). Cary found it fai common in the McElmo cañon in June, and along the Dolores Rir in July.

Habits. -The Gnatcatchers are active and highl strung little birds, always on the move, cocking up thi tails and twisting their heads about; they have thr home chiefly among shrubby bushes on the hill-sides among mesquite or other cover on the plains; they for on small insects, which they catch on the wing, dartis from a fixed perch like a Flycatcher.

The nest is cup-shaped, made of shreds of bark, linı with finer shreds and feathers, and is generally plac in a bush a few feet from the ground. The eggs a marked with reddish-brown and purplish, most heavi round the larger end.

\section{Family TURDIDÆ.}

This family comprises the Thrushes, a large fami of birds, especially distinguished by the spotted pluma; of the young birds. Other special features are-b slender, more or less straight, nostril never conceal by bristles; wing with ten primaries, the outer of spurious or quite short; tail always shorter than t] wing, generally considerably so; tarsus booted, $\mathrm{i}$. covered in front with one long shield.

\section{KEY OF THE Genera.*}

A. Tail long, nearly equal to the wing and double rounded; pluma grey with a double wing-bar.

Myadestes, p. 5:

B. Tail always distinctly shorter than the wing.

w. Plumage chiefly blue.

Sialia, p. 5:

b. No blue in plumage.

"Betts" ("Auk," 1910, p. 218) has recently recorded the Varied Thrush (Ixot noevius) from Colorado. He states that he saw but did not obtain a single exam on December 5th, 1909, at Gregory Cañon, near Boulder. 


\section{Townsend's Solitaire}

$a^{1}$ Under-parts plain reddish, only the throat streaked.

$b^{1}$ Under-parts white or buffy-white.

Planesticus, p. 523.

$a^{2}$ Base of the tail white contresting with terminal portion.

Saxicola, p. 525.

$b^{2}$ Base of the tail never white, under-parts spotted.

Hylocichla, p. 517.

\section{Genus MYADESTES.}

Bill short, widened, flattened and depressed at the base; wings long and pointed, the outer primary short, less than half the length of the next; tail long though not exceeding the wing, doubly rounded, the outer and central feathers shorter than the intermediate ones; feet rather weak; tarsus booted with w single long scute before and behind; plumage of adult chiefly plain grey, of young spotted.

A purely American genus with only one species in the United States.

\section{Townsend's Solitaire. Myadestes townsendi.}

A.0.U. Checklist no 754-Colorado Records-Allen 72, p. 161; Aiken 72, p. 198 ; Trippe 74, p. 95 ; Henshaw 75, p. 231 ; Lamb 77, p. 77 ; Scott 79, p. 93 ; Drew 81 , p. 15 ; Stone 82 , p. 191 ; 84, p. 20 ; Allen \& Brewster 83, p. 160 ; Coues 83, p. 239 ; Beckham 85, p. 140 ; 87 , p. 125 ; W. G. Smith 86, p. 25 ; Morrison 88, p. 71 ; Kellogg 90, p. 89 ; Lowe 94, p. 270 ; MeGregor 97, p. 39 ; Cooke 97, pp. 19, 124, 169, 223 ; Keyser 02, p. 298 ; Henderson 03, p. 237 ; 09, p. 241 ; Warren 06, p. 24; 08, p. 26 ; Gilman 07, p. 195 ; Rockwell 08, p. 179 ; Cary 09, p. 185.

Description.-Male-Above slaty-grey, becoming duskier on the wings and tail ; basal portion of the inner primaries and of the secondaries ochraceous-buff, concealed when the wing is closed, but forming a conspicuous band when the wing is spread; outer pair of tail-feathers white on the terminal half of the outer web, and tipped on the inner web with the same; second pair with a smaller white tip ; below slatygrey, but paler than the upper-parts ; iris dark brown, bill and legs bleck. Length 7.85 ; wing 4.60 ; tail 4.0 ; culmen .50 ; tarsus 80 .

The female resembles the male, but is slightly smaller-wing $\mathbf{4 . 4 5}$; young birds have the upper-parts, except the wings and tail-feathers, conspicuously spotted with buff, and most of the feathers edged with black; below pale buff, the feathers margined with dusky.

Distribution.-Western North America, breeding from Alaska south to the mountains of Zacatecas in Mexico, and from the coast ranges of the Pacific to North Dakota and western Texas; wintering from Oregon southward. 
In Colorado Townsend's Solitaire is a resident throughout the year, breeding in the mountains from about 7,000 feet to timber line, and wintering occasionally up to 9,000 feet, as well as in the piñon and cedar belts of the foothills. It sometimes wanders out into the plains, and has been recorded by Thorne from Fort Lyon in April, and by Warren .(06) from Baca co. in the same month, while Allen \& Brewster saw a large number close to Colorado Springs as late as April 29th, driven down from the mountains by a severe storm.

The following are the breeding records: Estes Park, 8,500 feet (Cooke), near Arkins, at about 6,200 feet (Cary), near Gold Hill, Boulder co., 7,000 to 10,000 feet (Gale), Buffalo Creek, Jefferson co., 6,000 feet (Smith), above Breckenridge, 10,000 feet (Lamb), Hencock and Alpine Tunnel, Chaffee co., 11,000 to 11,500 feet (Stone), Howardsville, San Juan co., 10,500 feet, Trippe (Drew).

Habits.-Townsend's Solitaire is rather a shy and retiring bird. It is not uncommon in winter in the piñon and cedar zone of the foothills, where it feeds on the cedar berries, and also on whatever insects it can procure ; these it catches like a Flycatcher, darting from a fixed perch, or searching for them among dead leaves on the ground. It is rather solitary, though occasionally seen in small bunches of four or five in the fall, probably family parties. All observers wax enthusiastic over its song-“" a silvery cascade of melody," Trippe calls it; curiously enough, it is heard chiefly in the fall and winter, not only on bright sunny days, but even in the worst weather. It has a loud and clear call-note as well.

The credit of the first discovery of its nest is due to Wilbur F. Lamb, who in July, 1876, found one in the bank of a miner's ditch among overhanging roots, at an elevation of 10,000 feet above Breckenridge in Summit co. Since then it has been described by several observers. The nest is always placed on the ground in a erevice in a bank or railway cutting (Stone), or very frequently in a miner's shaft (Gale), but always where it is screened from the direct rays of the sun by an overhanging rock or other shelter. The nest itself is loosely 
and rather carelessly and untidily constructed of sticks on the outside and coarse grasses within, and has no further lining. It is somewhat shallow and flat. The eggs, nearly always four in number, are greyish-white, splashed to a varying extent with rusty-brown and pale lilac. They measure about $95 \times 68$. Gale found fresh eggs between May 20th and June 25th, and this agrees with the observations of other naturalists.

\section{Genus HYLOCICHLA.}

Bill moderate, rather weak ; wings long and pointed, outer primary very short and spurious; tail always very clearly shorter than the wing, about even; tarsus rather long and slender, always exceeding the middle toe and claw; plumage plain brown above, spotted or streaked below on a white or yellowish-white ground; never any blue.

A considerable North American genus, closely allied to the true Thrushes (Turdus) of the Old World. Five species and a good many additional subspecies occur in the United States. H. guttata pallasi may possibly occur in Colorado, so it is here included in the key.

\section{KEY OF THE SPECIES.}

A. Spots on the lower surface very distinct and extending on to the Hlanks.

H. mustelina, p. 517.

B. Spots on the lower surface less distinct and not extending on to the flanks.

a. Upper-parts the same colour throughout.

a 1 A distinct buffy ring round the eye. H. u. swainsoni, p. 519.

$b^{1}$ No buffy ring round the eye. H. f. salicicola, p. 518 .

b. Rump and tail with a distinct rufous shade contrasting with the olive back

al Larger-wing over $\mathbf{3 \cdot 5 5}$.

$2^{2}$ More richly coloured, especially the rufous of the tail.

H. g. pallasi.

b2 Duller and less richly coloured. H. g. auduboni, p. 521. b $^{1}$ Smaller-wing under 3.50. H. guttata, p. 521 .

\section{Wood-Thrush. Hylocichla mustelina.}

A.O.U. Checklist no 755-Colorado Record-Fenderson 05, p. 42.

Description.-Adult-Above head and back cinnamon-brown, fading to olive-brown on the rump, tail and wings; a white orbital ring; below white, marked on the breast and flanks with large well-defined 
dusky-black spots ; iris dark brown, bill dusky-horn, paler on the base of the lower mandible, legs pale yellowish-brown. Length 7.25; wing 4.25 ; tail 3.0 ; culmen $\cdot 60$; tarsus 1.12 .

Young birds have the crown streaked with buff, the wing-coverts tipped with rusty-yellow, and the breast washed with brownish.

Distribution. - Eastern North America, breeding from New Hampshire and eastern Nebraska to northern Florida and eastern Texas, in winter through Mexico and Central America to Costa Rica and to the West Indies. The only record of the occurrence of the Wood-Thrush in Colorado is that of Miss J. M. Patten, who identified a specimen on May 27th, 1905, near Yuma, on the north-eastern corner of the State (Henderson).

Willow-Thrush. Hylocichla fuscescens saticicola.

A.O.U. Checklist no 576a-Colorado Records-Allen 72, pp. 155, 173 ; Trippe 74, p. 228 ; Henshaw 75, p. 148 ; Ridgway 82, p. 374 ; Drew 85, p. 15 ; Thorne 87, p. 265 ; Cooke 97, pp. 124, 223 ; Henderson 09 , p. 241.

Description.-Adult-Above dark olive-brown, slightly more dusky on the wings and tail ; eye without a white orbitel ring; below, chest and throat pale buffy streaked with dusky brown, rest of the underparts, including the chin, white; the flanks washed with slaty; iris dark brown, bill blackish, pale yellowish at the base of the lower mandible; legs pale yellowish, flesh-coloured in life. Length 6.70; wing 3.85 ; tail 2.85 ; culmen .50 ; tarsus 1.05 .

Young birds have the feathers of the upper-parts mesially streaked with yellowish-buff, and the wing-coverts spotted with brownish-buff.

Distribution.-The interior districts of western North America, breeding from British Columbia and Manitoba south to Nevada and Colorado, in winter through Mexico to central Brazil; casually east to Illinois and Mississippi.

The Willow-Thrush is a scarce migrant and summer resident in Colorado, or else it has been overlooked; it has only been noticed on the plains and along the foothills of the eastern base of the mountains, and does not reach an elevation of much more than 8,000 feet. It was found nesting by Henshaw at Fort Garland at about 8,000 feot, and it was with one of these specimens that the subspecies was first discriminated by Ridgway; it was subsequently met with by Gale in the Boulder hills, while the other records, chiefly migratory, are: Denver, May 17th (Henshaw), north fork of South Platte, between Denver and South Park (Allen), at 8,000 feet near Idaho Springs (Trippe), and various localities in the plains of El Paso, Elbert and Lincoln cos., from May 15th to June 6th (Aiken coll.). 
Habits.-Henshaw found the Willow-Thrush plentiful near Fort Garland, among the deep swampy thickets along the streams, where he often heard the "weird music of its beautiful song." He also took two nests of this species, both built on the ground and modelled in and above those obviously used in the previous season. He described the eggs as blue, and slightly darker than those of Audubon's Thrush. Gale only took one nest of this species; it was placed about three feet above the ground, in a low evergreen bush in a shady and wooded cañon near Gold Hill. The nest was made up of plant stems, mosses and grasses, and lined with fine rootlets, but with no mud or clay. The eggs, four in number, were light blue, and averaged $90 \times 70$. This nest was taken June 13th, but there appears to be some little doubt about the identification.

\section{Olive-backed Thrush. Hylocichla ustulata swainsoni.}

A.0.U. Checklist no $758 \mathrm{a}$-Oolorado Records-Trippe 74, p. 228 ; Henshaw 75, p. 147 ; Minot 80, p. 224 ; Allen \& Brewster 83, p. 153 ; Drew 85, p. 15 ; Beckham 85, p. 140 ; 87, p. 127 ; Morrison 88, p. 70 ; Cooke 97, pp. 19, 124, 223 ; Burnett 01, p. 114 (H. u. alma) ; Henderson 03, p. 237 ; 09, p. 241 ; Warren 06, p. 24 ; Rockwell 08, p. 179.

Description.-Adult-Above dark brownish-olive; a conspicuous pale buffy orbital ring; sides of the face, chin, throat and chest very pale buffy, streaked with dusky, except on the centre of the throat; rest of the under-parts white, tinged with slaty-grey on the flanks, and with a few more or less indistinct rounded spots of the same colour on the lower breast; iris dark brown, bill blackish, pale brown-horn at the base of the lower mandible, legs pale horny. Length 6.40 ; wing 3.90 ; teil 2.80 ; culmen .5 ; tarsus 1.0 .

The sexes are alike; the young birds are streaked and spotted with pale tawny above, while below the markings are more or less transverse in direction.

Distribution.-Breeding throughout the greater part of northern North Americe, except the Pacific coast belt, from Alaska and Hudson Bay south at higher elevations, to Californie, Colorado and Virginia, southwards on migration through Mexico and Central America to Peru, Bolivia, Brazil and the Argentine. 
In Colorado the Olive-backed Thrush is a common spring and fall migrant, both in the plains and mounteins; it arrives from the south early in May, the males appearing at least a week or a fortnight before the females; most of the birds pass on further north, but a small proportion stay with us to breed in the mountains, at from about 8,000 to 10,000 feet.

Gale is the only observer who has actually taken the nest of this species in Colorado, but Minot observed the bird between 9,500 and 10,500 feet on Pikes Peak, in June, where it was doubtless breeding; on spring migration it is common on the plains from Colorado Springs to Limon, and a large series in the Aiken collection show very clearly the earlier arrival of the males, the dates of these running from May 5 th to May 27th, while the females date from May 23rd to June 6th. Other migration records are: Springfield, Baca co., May 16th, males; May 29th, females (Warren); Fort Lyon, May 6th (Cooke); Pueblo, May 13th-20th (Beckham); Salida, May 10th (Frey); Denver, May 10th to 17 th (Henshaw).

The only record of its occurrence on the western slope of the Continental Divide is that of Rockwell, who found a deserted nest with two eggs, on August 1st, 1905, in Mesa co., at an altitude of about 6,500 feet.

Habits.-The Olive-backed Thrush is in no way remarkable in this respect; it is chiefly met with in shrubbery and in cotton-wood groves along the valleys of streams, and obtains its food on the ground, scratching among dead leaves. During migration it is silent and retiring, but when nesting it has a loud, ringing and characteristic song, generally heard in the twilight.

Gale found the nest of this bird on several occasions; it was placed in a willow bush close to, and almost overhanging a creek, and was securely and compactly built, chiefly of grasses with fibre and leaves, and lined with finer materials of the same kind; it was attached by the side or rim to several twigs, so that it was semi-pensile and not saddled on the limb. The eggs, generally four in number, were blueish-green, speckled with soft rufous or $\tan$, and measured $90 \times 64$. Unincubated eggs were met with between June 20th and July 7th. 


\section{Alaska Hermit or Kadiak Dwarf Thrush.}

\section{Hylocichla guttata.}

A.O.U. Checklist no 759 -Colorado Records-Sprague 96, p. 85 (Turdus aonalaschkæ); H. G. Smith 96, p. 76 ; Cooke 97, pp. 125, 170, 223 ; Henderson 03, p. 237 ; Warren 06, p. 24.

Description. - Adult-Above plain greyish-brown, becoming einnamonbrown on the upper tail-coverts and tail; a white orbital ring; sides of the face and ear-coverts greyish-brown, not buffy; below white, chest very slightly tinged with buffy, with conspienous triangular spots of dusky; flanks slightly washed with pale greyish-brown; iris brown, bill black, pale horn at the base of the lower mandible, legs light horn. Length 6.0 ; wing 3.50 ; tail 2.60 ; culmen .5 ; tarsus 1.05 .

The female is slightly smaller-wing $\mathbf{3 \cdot 2 5}$. Young birds are streaked and spotted with buffy above, the chest is more strongly tinged with buffy, and the lower-breast and flanks more or less barred with dusky.

Distribution.-Breeding in the coast districts of Alaska, and migrating south in winter to Lower California, Chihuahua and western Texas.

One of the migration routes of this Hermit-Thrush runs along the foothills and neighbouring plains of eastern Colorado, where the bird is quite common in the spring and autumn. It was first recognized as a Colorado bird by Sprague, who obtained an example at Magnolia, in Boulder co., 7,500 feet, October 6th, 1895. Other records are: Baca co., May lst to 12th (Warren), El Paso and Lincoln cos., April 24th to May 24th (Aiken coll.), Denver, May 13th, September 26th and October 5th (H. G. Smith), Fort Collins, October 1st (Cooke). Frey found large numbers of these birds along the river bottom at Salida on May 3rd, 1908, and for ten days or so afterwards. They appeared after a very heavy storm.

\section{Rocky-Mountain Hermit-Thrush.}

\section{Hylocichla guttata auduboni.}

A.O.U. Checklist no 759a-Colorado Records-Allen 72, pp. 147, 155, 161, 173 (T. pallasi) ; Trippe 74, p. 228 ; Henshaw 75, p. 144 ; Scott 79, p. 91 ; Minot 80 , p. 224 ; Tresz 81 , p. 283 ; Drew 81, p. 86 ; 85, p. 15 ; Allen \& Brewster 83, p. 152 ; Stone 84, p. 20 ; Beckham 87, p. 124 ; Morrison 88, p. 70 ; Thorne 88, p. 265 ; Kellogg 90, p. 89 ; Lowe 92, p. 101 ; 94, p. 270 ; McGregor 97, p. 39 ; Cooke 97, pp. 19, 125, 223 ; Keyser 02, pp. 68, 235 ; Henderson 03, p. 237 ; 07, p. 31 ; 09, p. 242 ; Gilman 07, p. 195 ; Rockwell 08, p. 179.

Description.--Hardly to be distinguished from $H$. guttata, except by its larger size; upper-parts a trifle greyer and cinnamon of tail a shade duller. Length 6.50 ; wing 3.87 ; tail 2.90 ; culmen .52 ; tarsus 1.12 . 
Distribution.--Breeding in the Rocky Mountains from eastern Briti Columbia to Lower California and New Mexico, south in winter throus Mexico to Guatemala ; a few wintering in western Texas.

The Rocky-Mountain Thrush is certainly the most abundant memb of its genus in Colorado. It is a summer resident, breeding througho the mountains, from about 8,000 feet to 11,000 feet and nearly up timber line; it occurs on migration out on the plains, as far as Lim, (Aiken coll., May 21st), and Fort Lyon (May 6th to 9th, Thorne), ar has been met with breeding as low as 6,500 feet on Groove Cree Mesa co., by Rockwell.

Other breeding records are: Boulder co, 5,800 to 10,000 feet (Gale above Idaho Springs, 11,000 feet to 13,000 feet (Trippe), Breckenridg Carter (Cooke), slopes of Grays and Pikes Peaks (Keyser), Hancoe 11,000 feet (Stone), slopes of Mount Baldy, near Fort Garland ( $\mathrm{He}$ shaw), San Juan co. (Drew), La Plata co., at 10,000 feet (Gilman)

On migration it arrives early in May-Pueblo, May 6th (Low and departs in October-Pueblo, October 5th, 6th and 13th (Beckharr

Habits. -The favourite haunts of the Rocky-Mounta: Thrush are deep and sheltered cañons and dark spru forest, where the sun hardly shines; here it is to be foun sometimes alone, sometimes several together, enlivenir the gloomy solitudes with its exquisite notes both durix the middle of the day and also evening and mornin It is very shy and retiring, and even when located $k$ its note is most difficult to catch a glimpse of.

Gale's notes contain the record of a large number nests found by him at various elevations, from abo: 6,000 to 11,000 feet; they were placed almost exclusive on spruce trees from about three to ten feet from $t]$ ground, generally in a spot near a mountain stream close to a spring.

Nests were constructed of various materials, such rotten wood, mosses, grasses and plant stems, and lin with rootlets, horsehair or fine grasses. All the materials have been found in the nests, though by 1 means in every nest. The construction varied considf ably, but no clay or mud is used. The nests were ve 
quickly completed; one begun on June 6th was finished on the 13th, and the first clutch of eggs laid by the 18th. The eggs, nearly always four in number, are bright greenish-blue, and unspotted, and average about $90 \times \cdot 67$. This bird generally returns to the same spot every year, sometimes repairing an old nest, sometimes building a fresh one close by. Gale also found a very large number of deserted nests, sometimes with a full complement of eggs. He believed that some of these were due to the mischievous proclivities of Jays, but he also suggested that, as the bird is a rather late migrant and the females arrive first, it was perhaps possible that they at once set to work to build nests and lay sterile eggs, and that after the arrival of the males fresh nests were made and the sterile eggs deserted. Gale found fresh eggs between June 10th and July 10th, and his observations agree very well with those of other naturalists.

\section{Genus PLANESTICUS.}

Rather large Thrushes resembling Hylocichla, but with a longer tail, which is always more than three times the length of the tarsus, and with the lower parts not spotted though the throat is streaked.

A large genus of nearly cosmopolitan distribution, with one species in the United States separated into an eastern and western subspecific form. The eastern race has a distinct white tip to the outer tailfeather, absent in the western race. The Colorado Robins are many of them somewhat intermediate in character, but on the whole seem closer to the western subspecies.

\section{Western Robin. Planesticus migratorius propinquus.}

A.O.U. Checklist no 761a-Colorado Records-Say 23, Vol., ii., p. 17 ; Allen 72, pp. 147, 155, 161, 173 ; Aiken 72, p. 193 ; Trippe 74, p. 228 ; Henshaw 75, p. 143; Scott 79, p. 91 ; Tresz 81, p. 282 ; Drew 81 ,p. 85; 85, p. 15; Allen \& Brewster 83, p. 152 ; Beckham 85, p. 140 ; 87 , p. 125 ; Morrison 86, p. 153 ; 88, p. 70 ; Kellogg 90, p. 90 ; Lowe 94, p. 270 ; McGregor 97, p. 39 ; Cooke 97, pp. 18, 126, 223 ; Keyser 02 , p. 31 ; Dille 03 , p. 74 ; Henderson 03 , p. 237 ; 09, p. 242 ; Warren 06 , p. 24 ; 08, p. 26 ; 09, p. 17 ; Gilman 07, p. 195 ; Markman 07, p. 158 ; Rockwell 08, p. 180 ; Bergtold 09, p. 196. 
Description.-Male-Crown and sides of the head black, with little white round the eye and a spot of white on the lores; rest the upper-parts slaty-olive, becoming black on the tail; outer ta feather without or with only a narrow margin of white at the ti no regular terminal spot; chin and throat white, the latter streaked wi black; rest of the under-parts cinnamon-rufous, the centre of $t$ abdomen, anal region and under tail-coverts white and grey ; iris da brown, bill yellow, dusky at the tip, legs dark horny. Length 9 . wing 5.5 ; tail 4.10 ; culmen .78 ; tarsus 1.20 .

The female resembles the male, but the black feathers of the cror are edged with greyish and it is smaller-wing about 5.25. Oth spring females, possibly birds of the previous year, have the head t same colour as the upper-parts, the tail dusky not black, the cinnamo rufous of the under-parts much paler and edged with white, and t bill much more dusky. In the fall a male has the upper-parts wash with yellowish-olive, concealing the black crown; the cinnamon the lower surface is edged with white. Young birds are dusky abor with most of the feathers tipped with black, and often a subtermin tip of white, giving a spotted appearance; below whitish, becomi buffy on the flanks and middle of the breast, which are profusely spott with black.

Distribution.-Western North America, breeding from the coe district of Alaska, south along the Rocky Mountains to the plater of Mexico, and westwards to the Pacific.

The Western Robin is one of the commonest birds in Colorad Chiefly a summer resident, it arrives from the south about the midc of March, and is to be found breeding from May to July everywhe from the plains up through the mountains to timber line. The grest number of the birds disappear southwards in November, but a if winter in sheltered places. Hersey tells me there is always a sm flock at Barr Lake, near Denver, through the winter; Frey took o near Salida on January 9th, while one or two can always be fow in Colorado Springs. They have been seen as early as February 15 at Loveland (Cooke), and in the south of the State Gilman states th he has seen one on January 30 th close to Fort Lewis, and others Montezuma co. in the same month.

Habits. - The Western Robin is a familiar bird, four in the vicinity of man, and seen in the suburbs of 0 . towns in considerable numbers, as well as in orchar and gardens in the country. It devours large quantiti of earth-worms, which it tugs out of their holes, as w as other destructive insects and their larvæ. In t] 
autumn and winter it subsists to a great extent on berries, and Trippe states it is to be found in very large numbers among the Blueberry patches on the mountain sides, in September. Its note is cheerful and musical, but not especially remarkable.

The nest is built of twigs, stiff plant stems and grasses outside; this is cemented and lined with wet mud, and when dry an inner lining of fine grasses is added, the whole forming a compact and strong structure. It is placed in a bush or small tree, generally on a crotch, and nearly always low down. The eggs, usually four in number, are plain, unspotted, and greenish-blue in colour, and measure about $1 \cdot 1 \times \cdot 80$.

Two or even three broods are raised in the year, the time for finding fresh eggs extending from May 15th to July 5th according to Gale's observations. He further believed that a fresh nest for the second laying was built at a higher elevation in the mountains by the hen before the first brood was fledged, and that the cock bird remained behind at the lower level to look after the first brood until they were able to leave the nest and fend for themselves.

Dr. Bergtold has recently given a very interesting account of a series of albino robins observed by him and others in the City Park in Denver during four successive years, from which it appears that the albinistic characters may in this case have been hereditary.

\section{Genus SAXICOLA.}

Bill shorter then the head, straight and depressed at the base; wings long and pointed; outer primary very short, not a quarter the length of the next; tail much shorter than the wing, about square; plumage without spots or streaks in the adult and with the basal portion of the tail and coverts white.

An extensive Old World genus, one species of which is a straggler in the United States. 


\section{Wheatear. Saxicola ananthe.}

A.O.U. Checklist no 765-Colorado Records-Minot 80, p. 224; Cooke 97, p. 125 ; Henderson 09, p. 242.

Description.-Male-Above plain ashy, black on the wings and terminal third of the tail; basal two-thirds of tail, except the middle feathers, white; forehead, a superciliary line and upper tail-coverts white; below pinky-buff, becoming white posteriorly; iris brown, bill and legs black. Length 6.0 ; wing 3.75 ; tail 1.75 ; culmen .55 ; tarsus 1.05.

The female is duller in colour than the male, and the black is replaced by dusky. In the winter the upper-parts are brown, the wings have lighter edgings, the under-parts are rusty-buff, and the head has no distinet streaks.

Distribution.-Breeding in northern Europe and Asia and across Bering Strait to Alaska; wintering in East Africa and India.

The Wheatear was met with by Minot at Boulder on May 14th, 1880. Minot does not specifically say that he obtained the bird, he merely writes " One specimen at Boulder," and it is possible he may have been mistaken, as it has not been taken in western America before or since. Ridgway doubtfully assigns this record to the Greenland Wheatear ( $S$. ce. leucorhoa) which breeds in Labrador, and has recently been taken in eastern Canada and New York State.

\section{Genus SIALIA.}

Bill straight and rather stout; wings very long and pointed, over five times the length of the tarsus, the outer primary short and not extending beyond the primary coverts; tail much shorter then the wing, emarginate; plumage always with a good deal of blue, not spotted except in the young bird.

A genus of three species, confined to America; three species in the United States.

\section{Key of the Spectes.}

A. Head bright blue.

a. Blue above and below, no chestnut. S. currucoides, fo p. 529.

b. Blue above, throat and chest chestnut. S. sialis, of p. 527.

c. Blue above and on the throat, chestnut across the back and breast.

S. m. bairdi, ¿ p. 527 .

B. Head brownish to dull grey-blue.
a. Throat cinnamon like the chest.
S. sialis, + p. 527
b. Throat grey, only the chest cinnemon.
S. m. bairdi, 우 p. 527 .
c. No cinnamon, below pale grey and white.

S. currucoides, $q$ p. 529 


\section{Eastern Bluebird. Sialia sialis.}

A.O.U. Checklist no 766-Colorado Records-Aiken 72, p. 194 ; Tresz 81, p. 284 ; Nash 83, p. 46 ; Beckham 85, p. 140 ; Thorne 86, p. 489 ; Cooke 97, pp. 126, 170, 223 ; H. G. Smith 96, p. 76; 08, p. 191 ; Dille 00, p. 88 ; Henderson 03, p. $237 ; 09$, p. 242.

Description. - Male-Above bright ultramarine-blue, becoming dusky on the inner webs of the wing-feathers; sides of the head dull blue; below rufus-brown, white from the centre of the abdomen to the under tail-coverts; iris dark brown, bill and legs black. Length 6.25; wing 3.80 ; tail 2.50 ; culmen .48 ; tarsus .75 .

The female is blueish-grey above, brightening to blue on the rump and tail; longer wing-feathers edged with grey or white, as is also the outer web of the outer primary. In the fall the bright blue of the male is obscured by a brownish wash. A young bird is dusky above, spotted and streaked with white or pale buffy; only the wings and tail show some blue, below dull white, the edges of the feathers marked with brown, producing a squamated appearance.

Distribution.-Breeding from Montana, Manitoba and Nova Scotia, south to Florida and Texas; wintering in the southern half of its breeding range.

The Eestern Bluebird is by no means an uncommon summer resident on the eastern plains of Colorado, and has even been found nesting in the foothills of Boulder co. by Gale (Cooke). It was first definitely recorded from the State by Holden, who took a specimen near Fountain, El Paso co. (Aiken). It has since been noticed at Julesburg, Wray, Kit Carson, Holly and Prowers, along the eastern borders of the State by Smith (08) and Ferrill, and at Limon by Aiken, while Dille found it nesting at Denver, and Thorne at Fort Lyon. It arrives in April-Pueblo, April 6th, Nash; and has been seen as late as September 6th at Denver, by H. G. Smith (96).

Habits. - A nest found by Dille was bujlt in a nestbox which had been used by the Arctic Bluebird previously the same season. A clutch of five eggs was taken on June 21st; Gale's nest contained four fresh eggs on June 18th, and was found on a ranch near Gold Hill, in Boulder co.

\section{Chestnut-backed Bluebird. Sialia mexicana bairdi.}

A.O.U. Checklist no 767a-Colorado Records-Allen 72, p. 148 ; Aiken 72, p. 194 ; Trippe 74, p. 229 ; Tresz 81, p. 284 ; Allen \& Brewster 83 , p. 153 ; Drew 85, p. 15 ; Beckham 85, p. 140 ; 87, p. 125 ; Morrison 
88 , p. 71 ; Lowe 92 , p. 101 ; 94, p. 270 ; Cooke 97 , pp. 18, 126, 223 ; Gilman 07, p. 195 ; Cary 09, p. 185 ; Warren 09, p. 17 ; Henderson 09 , p. 242.

Description.-Male-Above bright ultramarine-blue, becoming dusky on the inner edges and tips of the wing-feathers; a square patch of dark chestnut occupies the back and scapular region; below, the sides and a band across the chest chestnut, separating the blue of the throat from that of the rest of the under-parts, which fades to a grey on the abdomen and under tail-coverts; iris dark brown, bill and legs black. Length 6.0 ; wing 4.30 ; teil 2.75 ; culmen 45 ; tarsus .80 .

The female is much duller in colour; the head is greyish-blue; the rump, tail and wings a little brighter blueish, but far inferior to the male, while the chestnut of the back is replaced by dull brown; below the chestnut is much paler and the blue replaced by blue-grey; outer primary edged with white. In the fall the blue and chestnut are slightly obscured by brownish tips to the feathers both above and below. A young bird of the year is dusky-grey above, spotted with white, and becoming rather bluer on the tail and wings ; below greyish, the feathers of the breast edged with dusky-brown, giving a squamated appearance.

Distribution.-Breeding in the Rocky Mountain region from Colorado, south to Chihuahua and Durango in Mexico, wintering in New Mexico, western Texas, Sonora and southern California.

This Bluebird is not very common in Colorado, and appears to be confined to the south of the State and to the eastern foothills and neighbouring plains. It has been met with as far north as Loveland, on April lst (Cooke). It arrives about the end of March and breeds in the foothills up to about 7,500 feet, and departs in October. The following are breeding records: Boulder hills (Gale), Arkansas Divide, near Peyton, El Paso co., 7,500 feet (Aiken), West Monument Creek, El Paso co. (Allen \& Brewster), Wet Mountains to 9,500 feet (Lowe), near Fort Lewis (Morrison \& Gilman). It was not observed by Aiken at Limon, or by Thorne at Fort Lyon. Cary has recently reported seeing it near Uncompaghre Butte at about 9,000 feet, in July. This is the first record from Mesa co.

Habits. - The Chestnut-backed Bluebird does not differ from the other Bluebirds in its habits. It prefers open ground and is frequently to be seen in small parties near ranches, perched on fences or telegraph wires, whence it darts off to pick up insects from the ground. 
The nest is placed in old Woodpeckers' and other holes, or sometimes between a slab of bark and the trunk of a dead pine tree, or in nesting-boxes if provided, and the eggs, four or five in number, are pale blueish. Fresh eggs are to be met with about the end of May or beginning of June.

\section{Mountain-Bluebird. Sialia currucoides.}

A.0.U. Checklist no 768-Colorado Records-Baird 54, p. 13 (S. arctica); Allen 72, pp. 148 155, 161 ; Aiken 72, p. 194 ; Trippe 74, p. 229 ; Henshaw 75 , p. 162 ; Scott 79 , p. 91 ; Minot 80 , p. 225 ; Tresz 81 , p. 284 ; Drew 81 , p. 86 ; 85, p. 15 ; Allen \& Brewster 83, p. 153 ; Beckham 85,p. 140 ; 87, p. 125 ; Morrison 86 , p. 153 ; 88, p. 71 ; Kellogg 90, p. 90 ; Dille 94, p. 36 ; 03, p. 74 ; Lowe 94, p. 270; 01, p. 276 ; McGregor 97, p. 39 ; Cooke 97, pp. 18, 126, 223 ; Keyser 02, p. 98 ; Henderson 03 , p. 237 ; 09, p. 242 ; Gilman 07, p. 195 ; Warren 08, p. 26 ; 09, p. 17 ; Rockwell 08, p. 180 ; Cary 09, p. 185.

Description.-Male-Above bright blue of a turquoise shade, lighter than that of the other two species, becoming dusky on the tips and inner webs of the longer wing-feathers; below blue, paler and less bright than above, paling to white on the abdomen and under tailcoverts; iris dark brown, bill and legs black. Length 6.25 ; wing 4.5 ; tail 2.75 ; culmen .45 ; tarsus .78 .

The female is much duller than the male; upper-parts greyishblue, becoming rather a brighter blue on the rump, wings and tail; no white on the outer web of the outer primary; a white orbital ring; below brownish-grey, a little buffy on the throat, paling on the abdomen and under tail-coverts to dull white; a little smaller than the malewing 4.35 . In winter the male is duller in colour, the blue being obscured by the brownish tips to the feathers above and below; early arrivals in El Paso co. in March show this plumage. Young birds are ashy-brown above, the interscapular area spotted with white; rump and upper tail-coverts light ashy; below dull white; the feathers of the throat and breast broadly edged with brown, giving a strongly squamated appearance to that part.

Distribution.-Breeding in western North America, chiefly in the mountains from Yukon to Chihuahua in northern Mexico, east to south Dakota and Texas, west to California; wintering in the southern portion of the breeding range and at lower elevations.

This is far the most abundant of the Bluebirds in Colorado; it arrives from the south normally in the middle of March, and is found nesting everywhere from the plains to timber line. A warm spell 
in winter will bring up a wave of migrants even in December or January, but as a rule they are driven back by storms to the south again. Lowe (01) believed that they wintered in the State near Pueblo, and Cary found it common at Springfield and Gaume's Ranch in late November, and was told that it wintered there. It has been noticed breoding on the slopes of Mount Lincoln at timber line, at about 13,000 feet, by Allen, at various elevations from 8,000 to 10,000 feet near Gold Hill, in Boulder co. (Gale), and in the suburbs of Denver (Dille \& Minot) and Colorado Springs; while on" the western slope, in Mesa co., it is stated by Rockwell to be a common summer resident, breeding from 5,000 to 7,000 feet in the cedars. At Fort Lewis, in the extreme south-west, it was found by Gilman to be very abundant, nesting in boxes and about houses of that place. In most parts of Colorado it departs for the south in flocks at the end of November, or even the beginning of December.

Habits. - The Mountain-Bluebird comes north in flocks of considerable size, so that it can be easily recognized when migrating. It is found chiefly in open country, and likes to perch on rail fences alongside fields and pastures. It feeds on insects and wild berries in the season. Its note is rather mournful and plaintive, more so than that of the eastern bird.

It builds its nest naturally in old Woodpeckers' holes or the stubs of dead trees, sometimes, according to Gale, excavating a cavity for itself. The height of the nesthole varies from about four to twenty feet, but is usually about twelve. The nest is constructed of dried grass, and is a bulky affair; it is sometimes lined with a few feathers, but is more often without a special lining.

The eggs, usually six in number, are pale greenishblue, and measure about $85 \times 65$. Dennis Gale found fresh eggs chiefly between May 25th and June 25th, but on one occasion he took a nest with five fresh eggs on April 28th, while a pair observed by Dille (94) had laid a full complement of seven in a nesting-box by May 5th in Denver. 
After the breeding season small family parties wander up the mountains to well above timber line; probably they find insects more abundant there late in the season.

This Bluebird, like its eastern cousin, easily learns to make use of nesting-boxes placed on trees and houses for it, and will also build under a cornice or in any suitable crevice about human habitations or barns. 


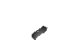

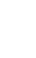

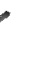

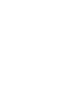

(1) 


\section{BIBLIOGRAPHY.}

This is a list of all the Titles up to December, 1910, containing anything of importance for the study of Colorado Ornithology. They are referred to throughout the text under the name of the author, with the abbreviated date only.

72 AtKen, C. E., and Holden, C. H., Jr. Notes on the Birds of Wyoming and Colorado Territories. Proc. Boston Soc. Nat. Hist., $\mathrm{xV}$., 1872, pp. 193-210. This paper is edited by Brewer, and only the notes signed "C. E. A.," contributed by Aiken, refer to Colorado. Mr Aiken spent the winter 1871-72 at Fountain, near Colorado Springs, and these observations were made at that time; some fifty-nine new birds are accredited to the State.

73 ATKEN, C. E. A glimpse at Colorado and its Birds. Amer. Nat., vin., 1873, p. 13.

73 AпKEN, C. E. A New Species of Sparrow. Amer. Nat., VII., 1873, pp. 236-7. Centronyx ochrocephalus (= C. bairdi) described.

75 ATKEr, C. E. The Nidification of the Blue Crow and the Greyheaded Snowbird. Amer. Sports., v., 1875, p. 370.

00 AIkEN, C. E. Seven New Birds for Colorado. Auk, XVIr., 1900, p. 298. i.e., Gavia arctica, Ardea egretta, Syrnium nebulosum, Astragalinus tristis pallidus, Geothlypis agitis, Geothlypis trichas and Wilsonia canadensis.

81 Aluze, C. N. Songs of the Western Meadow-Lark. Bull. Nutt. Orn. Club., vi., 1881, p. 145-150.

72 Alles, J. A. Notes of an Ornithological Reconnaissance of portions of Kansas, Colorado, Wyoming and Utah. Bull. Mus. Comp. Zool., III., 1872, pp. 113-183. This is an importent paper for the history of Colorado ornithology. Mr. Allen was the first trained ornithologist to visit the State. He was in Colorado in July and August, 1871, chiefly near Colorado Springs, in South Park and on Mount Lincoln. Some eighty-four species were observed by him for the first time in the State. 
72a Atren, J. A. Ornithological Notes from the West.--I. Notes on the Birds of Colorado. Amer. Nat., VI., 1872, pp. 342-351.

92 Arcer, J. A. The North American Species of the Genus Oolaptes, considered with Special Reference to the Relationships of $C$. auratus and $C$. cafer. Bull. Amer. Mus. N. H., IV., No. 1, pp. 21-44, 1892. An account of the supposed hybrids between the Yellow- and the Red-shafted Flickers.

83 Atren, J. A., and Brewster, W. List of Birds Observed in the Vicinity of Colorado Springs, Colorado, during March, April and May, 1882. Bull. Nutt. Orn. Club, v世I., 1883, pp. 151161 and 189-198. Bendire's Thrasher and the Florida Gallinule first recorded in Colorado.

85 ANthony, A. W. Albinos (Petrochelidon lunifrons and Agelains phoeniceus). Orn. and Ool., X., 1885, p. 152.

87 Anthonx, A. W. Winter Plumage of Leucosticte australis. Auk, IV., 1887, pp. 257-8.

91 ANThory, A. W. Secondary Migration of Birds. Zoe., I., 1891, pp. 379-81. Note on the White-crowned Sparrow raising two broods at different altitudes near Silverton.

95 Anтrony, A. W. The Scaled Partridge in Colorado. Auk, хп., 1895, p. 388.

96 Anthony, A. W. A New Subspecies of the Genus Dryobates. Auk, xIII., 1896, p. 31. D. villosus montanus from the Rocky Mountains described. Name afterwards changed to "monticola" in Auk, xv., p. 54.

54 BATRD, S. F. Report on the Birds in Beckwith and Gunnison's Report-in Vol. x. Reports of Explorations and Surveys for a Railroad Route from the Mississippi River to the Pacific Ocean ; pp. 11-16 and seven plates. Washington, 1854, 4to.

58 BAIRD, S. F. Birds-in Vol. IX. Reports of Explorations and Surveys for a Railroad Route from the Mississippi River to the Pacific Ocean. Washington, 1858, 4to.

64 Batrd, S. F. Review of American Birds in the Museum of the Smithsonian Institution. Smiths. Miscell. Coll., XI., pp. 1-478, $1864-72$.

70 BArRD, S. F. Land Birds of California, being Vol. I. (Ornthology) of the Geological Survey of California. Contains on p. 163 a reference to Leucosticte campestris (= littoralis), described from an example from Denver taken by Dr. C. Wernigk, Jan. 1862.

74 BaIRD, S. F., BreWER, T. M., and RIDGWAY, R. A History of North American Birds. Land Birds: Vols. I-III., Boston. 1874, 8vo.

00 Bangs, O. A. Review of the Three-toed Woodpeckers of North Americs. Auk, xvII., 1900, pp. 126-142. 
95 Barrows, W. B., and Schwarz, E. A. The Common Crow of the United States. Bull. No. 6, U.S. Dept. Agric. div. Orn. and Mammal. pp. 1-98, Washington, 1895, 8vo.

84 Batchitider, C. F. Description of the First Plumage of Clarke's Crow. Auk, I., 1884, pp. 16-17.

89 Batcherder, C. F. An Undescribed Subspecies of Dryobates pubescens. Auk, vr., 1889, p. 253. D. p. orececus described from Rocky Mountains $=D$. p. homorus.

73 Batty, J. H. The U. S. Geological Survey : Forest and Stream, I. 1873 , p. 35 . Note on first discovery of the nest and eggs of the Ruby-erowned Kinglet.

74 Batry, J. H. The White-tailed Ptarmigan. Lagopus leucurus. Forest and Stream, I., 1874, p. 390.

00 Beale, F. E. L. Food of the Bobolink, Blackbird and Grackles. Bull. No. 13, Biol. Surv. U.S. Dept. Agric. Washington, 1900, 8vo.

83 Becknam, C. W. The Black-headed Grosbeak. Orn. and Ool., virr., 1883, p. 63 . Note on male incubating.

85 Beckeram, C. W. Notes on some of the Birds of Pueblo, Colorado. Auk, II., 1885, p. 139.

87 Becknam, C. W. Additional Notes on the Birds of Pueblo County, Colorado. Auk, IV., 1887, p. 120.

88 Bendre, C. E. Notes on the habits, nests and eggs of the genus Sphyrapicus Baird. Auk, v., 1888, pp. 225-240.

89 BendIRE, C. E. A Peculiar Nest of Cinclus mexicanus. Auk, VI., 1889 , p. 75.

89 BrindiRe, C. E. Picicorvus columbianus (Wils.) Clarke's Nutcracker, its nest and eggs, ete. Auk, VI., 1889, pp. 226-236. Account based chielly on Gale's notes from Boulder County.

89 Bendrat, C. E. Description of the Nest and Eggs of Megascops asio maxwellice, the Rocky Mountain Screech Owl. Auk, VI., 1889, pp. 298-302.

90 Bendire, C. E. Megascops asio maxwellice. Auk, vir., 1890, p. 91. Note on results of an examination of the pellets of this Owl.

92 Brndire, C. Life Histories of North American Birds. Special Bull. U.S. Nat. Mus., Part I, 1892 ; Part 2, 1895. Washington, 4 to.

95 Bendrat, C. The Cowbirds. Rep. U.S. Nat. Mus. for 1893, pp. 587-624.

04 Bergtold, W. H. White-winged Scoter in Colorado. Auk, xxu., 1904, p. 78.

07 Bergtold, W. H. The House Finch from an Office Window. Bird Lore, Ix., 1907, pp. 61-64, with two photographs. 
09 Bergtold, W. H. Mexican Goldfinch in Colorado. Auk, XXVI., 1909 , p. 79.

09 Bergtold, W. H. Albino Robins. Auk, XXvi., 1909, pp. 196-8. Account of an unbroken series observed in or near the City Park, Denver, during four succeeding seasons.

10 Bergmold, W. H. Barn Owl in Colorado. Auk, xxvm., 1910, p. 207.

77 Berthoud, E. L. Melopelia leucoptera in Colorado. Bull. Nat. Orn. Club. II., 1877, p. 83.

10 Bets, N. DE W. Notes from Boulder County, Colorado. Auk, xXVII., 1910, pp. 218-219.

25 Bonaparte, C. L. American Ornithology. 4 vols., Philadelphia, 1825, 4to: Original description of Sayornis saya from what is now the State of Colorado.

87 Brenninger, G. F. Lincoln's Sparrow and its Nesting. Orn. and Ool., XII., 1887, p. 191.

88 Brenntnger, G. F. Nesting of the Western Yellow-Warbler and the Green-tailed Towhee. Orn. and Ool, xm, 1888, pp. 64,90 .

94 Brenninger, G. F. American and Mexican Crossbills. Nidol, I., 1894, pp 99-101, with photograph.

74 Brewer, T. M. Note on the Nesting and Eggs of Lagopus leucurus. Proc. Bost. Soc. Nat. Hist., XVI., 1874, p. 348 . Nest and eggs procured by Trippe.

77 BREWer, T. M. Letter on the Eggs and Nest of Dendroica auduboni. Ibis, 4th ser., 1877, p. 394. First description of the eggs of $D$. auduboni, taken by Edwin Carter, near Breckenridge, in Summit co.

78 Brewer, T. M. Notes on Junco caniceps and the closely allied Forms. Bull. Nutt. Orn. Club, W., 1878, pp. 72-75. Nest and eggs taken by J. H. Batty.

79 Brewer, T. M. The Rocky Mountain Golden-eye (Bucephala islandica). Bull. Nutt. Orn. Club, IV., 1879, pp. 148-152. Nest and eggs first taken by Edwin Carter in Colorado.

79 Brewer, T. M. The Rocky Mountain Whiskey-Jack. Bull. Nutt. Orn. Club, IV., 1879, pp. 239-240. Description of nest and eggs found by Edwin Carter near Brekenridge.

83 Brewster, W. Recent Occurrence of the Flammulated Owl in Colorado. Bull. Nutt. Orn. Club, VIII., 1883, p. 123. Lotter from Aiken in regard to occurrence near Colorado Springs.

87 Brewster, W. Three New Forms of North American Birds. Auk, IV., 1887, pp. 145-149. Symphemia semipalmata inornata, the Western Willet characterized; type from Larimer co., Colorado. 
91 Brewster, W. Descriptions of Seven supposed New North American Birds. Auk, virr., 1891, pp. 139-149. Megascops asio aikeni, described from Colorado.

98 BREWSTER, W. Lewis's Woodpecker Storing Acorns. Auk, xष., 1898, p. 188. Observed by S. French in November, near Denver.

(06) Bronner, L., Wolcots, R. H., and Swenk, M. H. A Preliminary Review of the Birda of Nebraska, pp. 1-116, Omaha, n.d., 8vo. Contains some references to Colorado.

96 Burnetr, W. L. Nest of the Dusky Grouse. Nidol, III., 1896, p. 64.

00 Burnett, W. L. The Indigo Bunting in Larimer co. Condor, II., 1900, p. 90. Flock of eight of ten seen in spring of 1900 .

01 Burnetr, W. L. Alma's Thrush in Colorado. Condor, III., 1901 , p. 114.

02 BuRnetr, W. L. Rose-breasted Grosbeak in Colorado. Condor, IV., 1902, p. 94.

03 BuRnetr, W. L. Rocky Mountain Screech Owl in Larimer co., Colorado. Condor, v., 1903, p. 156.

04 Burnets, W. L. Whip-poor-will (Antrostomus vociferus), a New Bird for Colorado. Auk, XXI., 1904, pp. 278-9.

08 Burnett, W. L. Another Cañon-Wren Record for Colorado. Auk, xxv., 1908, p. 87. One observed in Longmont, Boulder co., in a yard, October 20 th, 1907.

95 Burns, F. L. The American Crow (Corvus americanus), with special reference to its nest and eggs. Bull. No. 5, Wilson Ornith. Chapter of the Agassiz Assoc., pp. 1-141. Oberlin, Ohio, 1895.

00 Burns, F. L. A Monograph of the Flioker (Colaptes auratus). Wilson Bulletin, No. 31, pp. I-82, 1900.

$09 \mathrm{CARY}$, M. New Records and Important Range Extensions of Colorado Birds. Auk, xxv1., 1909, pp. 180-185 and 312. Contains the first record of the occurrence of the Short-billed MarshWren.

94 Chamberlan, C. The Water-Ouzel at Home. Nidol., 1., 1894, pp. 163-4. Notes made near Golden.

07 Chapman, F. M. The Warblers of North America. New York, 1907, 8vo.

98 Christy, N. R. The Piñon-Jay. Osprey, III., 1898, p. 57.

94 Cооке, W. W. Ten New Birds from Colorado. Auk, XI., 1894, pp. 182-183. Oidemia deglandi, Ardetta exilis, Calidris arenaria, first recorded for Colorado.

95 Cookr, W. W. The Summer Range of Colorado Birds. Auk, XII., 1895, pp. 150-155. 
97 Coore, W. W. The Birds of Colorado. Bull. No. 37, State AgriculturaI College, Fort Collins, 1897, pp. 1-144. Further Notes, Bull. No. 44, 1898, pp. 145-176. Second Appendix, Bull. No. 56,1900 , pp. 177-240. The most complete list of the Birds of Colorado, with bibliogxaphy and distribution." Supplement published in the Auk, 1909, pp. 400, should also be consulted.

97a Coовe, W. W. Bendire's Thrasher in Colorado. Osprey, II., 1897, p. 7.

97b Coоке, W. W. The Scarlet Ibis in Colorado. Auk, xIv., 1897, p. 316. A second record, made through misapprehension, subsequently corrected.

97c Cooke, W. W. A New Bird for Colorado. Oregon Naturalist, IV., 1897-8, p. 65. Stellula calliope at Colorado Springs.

98 Cooks, W. W. A New Bird for Colorado (Ammodramus lecontei). Osprey, Irr., 1898, p. 13. Also notes on Slate-coloured Sparrow, Mocking-bird and Bobolink.

98 Cooks, W. W. The Scarlet Ibis-A Correction-Auk, xv., 1898, p. 183. The record really referred to the White-faced Glossy Ibis.

99 Cooke, W. W. More New Birds for Colorado. Auk, xvI., 1899, p. 187, i.e. Astragalinus p. mexicanus, Branta v. minima and Junco montanus.

04 Cooke, W. W. Distribution and Migration of North American Warblers. Bull. No. 18, Biol. Survey, U.S. Dept. Agriculture. Washington, 1904. 8vo.

06 Cooke, W. W. Distribution and Migration of North American Ducks, Geese and Swans. Bull. No. 26, Biol. Survey, U.S. Dept. Agriculture. Washington, 1906. 8vo.

09 Cooke, W. W. Some New Birds for Colorado. Auk, xxvi., 1909 , p. 314, i.e. Sterna hirundo, Butorides virescens, Spizella pusilla arenacea and Helminthophila chrysoptera.

09 Cooke, W. W.' The Birds of Colorado-Third Supplement. Auk, xxvI., 1909, pp. 400-422. A supplement to the former work, "Cooke 97," bringing the literature and records up to date.

73 Couts, E. Range of the Geococoyx californianus. Amer. Nat., vIr., 1873, p. 751. Occurrence at Fort Lyon noted.

74 Cours, E. Birds of the North-west. Miscell. Publ, No. 3, U.S. Geological Survey of the Territories. F. V. Hayden, U.S. Geologist in charge. Washington, 1874, 4to. Contains valuable original notes by Trippe, q.v. on birds observed near Idaho Springs.

76 Coues, E. On the Breeding Habits, Nest and Eggs of the Whitetailed Ptarmigan: (L. leucurus). Bull. U.S. Geol. Surv. Terr., 2nd ser. Vol. I., No. 5, p. 263, 1876. 
77 Couts, E. Eastward Range of the Ferruginous Buzzard. Bull. Nutt. Orn. Club, Ix., 1877, p. 26. Note on the distribution of the Lanner or Prairie-Faleon in Colorado as well.

77 Cotes, E. Western range of Conurus carolinensis. Bull. Nutt. Orn. Club, II., 1876, p. 50. Reported to have been seen by E. L. Berthoud near Denver in the early sixties.

7 Cougs, E. Note on the Cinnamon-Teal. Bull. Nutt. Orn. Club, n., 1877, p. 51. Breeding with Geese, Wigeon and Shovellers in North Park.

78 Coues, E. Note on Pcasserculus bairdi and P. princeps. Bull. Nutt. Orn. Club, Wr., 1878, p. 1, with plate of $P$. bairdi.

78 Couss, E. Nest and Eggs of Selasphorus platycercus. Bull. Nutt. Orn. Club, II., 1878, p. 95. As observed by E. A. Barber in South-west Colorado.

83 Couss, E. Nest and Eggs of Myadestes townsendi. Bull. Nutt. Orn. Club, vm., 1883, p. 239. Description of a nest taken by W. G. Smith on Buffalo Creek, Jefferson co.

83 Coues, E. Nest and Eggs of Parus montanus. Bull. Nutt. Orn. Club, vIII., 1883, p. 240. Nest and eggs sent to Coues by W. G. Smith from Colorado.

97 Couss, E. Rectifications of Synonymy in the Genus Junco. Auk, xIV., 1897, pp. 94-5.

99 Dawbon, W. Some Western Horizons, No. II. Wilson, Bull., vI., 1899, pp. 49-50. List of Birds at Julesburg; the Piping Plover is first recorded from the State; this is probably the western form, Bgialitis meloda circumcincla.

79 Deare, P. Capture of a Third Specimen of the Flammulated Owl (Scops flammeola) in the United States, and first discovery of its Nest. Bull. Nutt. Orn. Club, Tv., 1879, p. 188. Taken by Aiken in Fremont co.

95 Deane, R. The old Squaw (Clangula hyemalis) in Colorado. Auk, xrr., 1895, p. 292. The first record for Colorado.

85 Drule, F. M. Nesting of Archibuteo fermgineus. Young Oologist, 1885 , pp. $44-5$.

86 Diute, F. M. Colorado Birds, etc., etc. Sunny South, Ool., I., 1886, pp. 7, 15, 29 ; i.e. Black-billed Magpie, Crow, Long-eared Owl, Lark-Bunting and Mountain Plover. Notes on habits.

87 Dille, F. M. A Week's Trip after Hawks' Eggs in Colorado. Orn. and Ool., XII., 1887, pp. 97-100. Description of nest and egge of White-necked Raven, as well as several species of Hawks.

88 Drle, F. M. Nesting of the Black-billed Magpie. Orn. and Ool., xirl., 1888, pp. 23-24.

94 Drues, F. M. Home-life of the Mountain Bluebird. Nidol., II., 1894, p. 36. 
00 Druwe, F. M. Nesting of the Pine-Siskin at Denver, Colorado. Condor, II., 1900, p. 73.

00 DrLLe, F. M. Nesting of the Eastern Bluebird at Denver, Colorado. Condor, II., 1900, p. 88.

02 Druse, F. M. Western Blue Grosbeak in Northern Colorado. Condor IV., 1902, p. 94.

03 Diule, F. M. Nesting Dates for Birds in the Denver District, Colorado. Condor, $\nabla .$, 1903, pp. 73-74.

04 DILle, F. M. Eggs of Flammulated Screech Owl and Western Evening Grosbeak, taken in Estes Park, Colorado. Condor, VI., 1904, p. 50.

04 Drute, F. M. A Sage-Sparrow in Boulder co, Colorado. Condor, VI., 1904, p. 79 .

09 DrILE, F. M. Notes of Occurrences and Nesting of certain Species additional to the "Birds of Colorado." Auk, XXVI., 1909, pp. 86-88.

81 Drew, F. M. Field Notes on the Birds of San Juan co., Colorado. Bull. Nutt. Orn. Club, vi., 1881, pp. 85-91, 138-143. An important paper; 104 species mentioned, five for the first time within the limits of the State; other notes on the same subject on pp. 115, 244, 249.

81 Dnew, F. M. Lobipes hyperboreus at 9,500 feet. Bull. Nutt. Orn. Club, VI., 1881, p. 249. Northern Phalarope at Howardsville, San Juan co.

82 DREw, F. M. Notes on the Plumage of Nephoecetes niger borealis. Bull. Nutt. Orn. Club, VII., 1882, p. 182. Black Swift observed. near Howardsville.

84 Drew, F. M. Notes on Lagopus leucurus. Auk, 1., 1884, pp. 392-3.

85 Drew, F. M. On the Vertical Range of Birds in Colorado. Auk, II., 1885, p. 11. A very important article on the birds of Colorado, containing a complete list up to date, and the vertical range of each bird as far as it was known.

90 Dwighт, J., Jr. The Horned Larks of North America. Auk, VII., 1890, pp. 138-158, and one map.

01 Feuger, A. H. The Mexican Cormorant in Colorado. Auk, XVIII., 1901, p. 189.

02 Felaer, A. H. Colorado Bird Notes. Auk, XIX., 1902, p. 294.

03 Felger, A. H. The Wood-Ibis again in Colorado. Auk, xx., 1903, p. 65 .

05 Felger, A. H. Two Records for Colorado. Auk, xxII., 1905, p. 421. Yellow Flicker in Mountains; Canvas-back breeding.

07 Felaer, A. H. Ross's Snow-Goose in Colorado. Auk, xxrv., 1907, pp. 211-212. 
07 Frlakr, A. H. The Prothonotary Warbler in Colorado. Auk, XXIV., 1907, p. 342 ; also Condor, IX., 1907, p. 110.

09 Felare, A. H. Colorado Notes. Auk, xxvi., 1909, pp. 85-6. On Cyanocitta cristato, Alchmophorus occidentalis and Porzana carolina.

09 Felger, A. H. Wild Turkey. Auk, Xxvi., 1909, p. 191. A flock near Denver in 1868.

09 Frlger, A. H. Annotated List of the Water-Birds of Weld, Morgan and Adams counties, Colorado, south to the first sectional line below the fortieth parallel. Auk, xxvr., 1909, pp. 272-291.

10 Ferger, A. H. Colorado Notes (Geococcyx californianus and Calamospiza melanocorys). Auk, XxvII., 1910, p. 89.

10 Frlakr, A. H. Status of the Black Duck (Anas rubripes) in Colorado. Auk, xxVII., 1910, pp. 451-452.

10 Fruger, A. H. Birds and Mammals of North-western Colorado. Univ. Colo. Studies, Boulder, vII., pp. 132-142.

93 Frshar, A. K. The Hawks and Owls of the United States in their relation to Agriculture, pp. 1-210, pls. 1-26. Bull. No. 3, Div. Orn. and Mamm., U. S. Dept. Agric. Washington, 1893, 8vo.

01 Fisher, A. K. Two Vanishing Game Birds-the Woodcock and the Wood Duck. Year-Book U.S. Dept. Agric., 1901, pp. 447458 , pls. 63,64 .

09 Frey, J. W. Random Notes from Chaffee co., Colorado. Condor, XI., 1909 , p. 70.

45 Frémont, J. C. Report of the Exploring Expedition to the Rocky Mountains in the year 1842, etc., etc. Washington, 1845. 8 vo. The only allusion to birds in the Colorado portion of the travels is on p. 284, where the Sage Hen or "Coq de prairie" is mentioned as occurring in Middle Park on the Blue River.

07 Griman, M. F. Magpies on the La Plata. Condor, IX., 1907, pp. 9-12. Notes on nesting habits in south-west Colorado.

07 Grimas, M. F. Migration and Nesting of the Sage-Thrasher. Condor, Ix., 1907, pp. 42-44. Observations in Montezuma co.

07 Grmman, M. F. Some Birds of south-west Colorado. Condor, IX., 1907, pp. 152-158, 194-5. A list of birds observed chiefly near Fort Lewis, La Plata co., in the extreme south-west corner of the State.

98 Grmore, L. D. Western Goshawk in Colorado. Osprey, III., 1898, p. 38.

83 Goss, B. F. Notes on the Breeding Habits of Maximilian's Jay (Gymnocitta cyanocephala) and Clarke's Crow (Picivorus columbianus). Bull. Nutt. Orn. Club, vir., 1883, pp. 43-45.

84 Goss, N. S. Notes on the Breeding Habits of the Americen Eared Grebe (Dytes nigricollis californicus). Auk, I., 1884, p. 18. 
86 Goss, N. S. Additions to the Catalogue of Kansas Birds. Auk, III., 1886, pp. 112-115. Contains a note on the Road-runner in Colorado.

89 Goss, N. S. Additions to the Catalogue of the Birds of Kansas, with notes in regard to their habits. Auk, vI., 1889, pp. 122124. Contains a note on the nesting of Clarke's Nutcracker in Colorado.

91 Goss, N. S. History of the Birds of Kanses, pp. 1-692. Topeka, 1891, 8vo. Contains a good many allusions to birds met with in Colorado.

91 Hashrodok, E. M. The Carolina Paroquet (Conurus carolinensis). Auk, VIr., 1891, pp. 369-379, with map. Account of present and past distribution.

93 Hasbrouck, E. M. The Geographical Distribution of the Genus Megascops in North America. Auk, x., 1893, pp. 250-264.

02 Henderson, J. Boulder, Colorado: Birds Increasing. Wilson Bull., XIV., No. 39, 1902, p. 74.

03 Henderson, J. Preliminary List of Birds of Boulder co., Colorado. Univ. Colo. Studies, I., 1903, p. 233. Additional List, ibid., Ir., 1904, p. 107.

04 Hinderson, J. The Bobolink in Colorado. Auk, xxI., 1904, p. 486.

04 Henderson, J. Bobolink Increasing at Boulder, Colorado. Wilson Bull., xvi., No. 48, 1904, p. 92.

05 Henderson, J. The Blue Jay at Yuma, Colorado. Auk, xxm., 1905, p. 82.

05 Hendergon, J. Colorado Notes. Auk, XXI., 1905, p. 421. Notes on Wood-Thrush, Cardinal, Red-eyed Vireo, Baltimore Oriole, Gnatcatcher, etc., etc.

06 Henderson, J. With the Birds in North-eastern Colorado. Wilson Bull., xvmI., 1906, p. 105.

07 Henderson, J. An early Colorado Naturalist-Dennis Gale. Univ. of Colo. Studies, v., 1907, p. 25. With portrait, account of his ornithological work and a few of his notes on the nesting of Colorado birds.

07 Henderson, J. Destruction of Herons by a Hailstorm. Condor, Ix., 1907, p. 162.

07 Henderson, J. Colorado Notes. Condor, IX., 1907, p. 198. Occurrence of Xema sabinei, EEdemia deglandi, Aix sponsa and Syrnium varium.

07 Henderson, J. Nesting of Crossbills in Colorado. Auk, xxrv, 1907, pp. 440-2. Extracts from Dennis Gale's Note Books. 


\section{Bibliography}

08 HENDErson, J. The American Dipper in Colorado. Bird-Lore, x., 1908, p. 1. Account of nesting habits, chiefly from Dennis Gale's MSS. Notes, with two photographs.

09 Henderson, J. An Annotated List of the Birds of Boulder co., Colorado, Univ. Colo. Studies., vI., 1909, pp. 219-242. This is an additional and amended list to the former oneHenderson, 03.

74 Hrishaw, H. W. On a Humming-bird new to our Fauno, with certain other ornithological facts. Amer. Nat, vIII., 1874, pp. 124-243. Note on Williamson's Sapsucker (Sphyrapicus thyroideus) and the Eared Grebe (Podiceps a. californicus).

75 Henshaw, H. W. Report upon Ornithological Specimens collected in the years 1871, 1872 and 1873, in Geographical and Geological Explorations and Surveys west of the one-hundredth meridian. First Lieutenant Geo. M. Wheeler, Corps of Engineers, in charge. Washington, 1874. Pp. 133-507, pls. i-xv. Many observations on Colorado birds by Henshaw and Aiken.

78 Henseaw, H. W. Nest and Eggs of the Blue Crow (Gymnokitta cyanocephala). Bull. Nutt. Orn. Club, II., 1878, pp. 112-115.

84 Hewshaw, H. W. The Shore Larks of the United States and adjacent Territory. Auk, I., 1884, pp. 254-268.

85 Henshaw, H. W. List of Birds observed in summer and fall on the Upper Pecos River, New Mexico. Auk, II, 1885, pp. $326-333$, III., 1886, pp. 73-80. Contains a note on the occurrence of Centronyx bairdi (p. 333) and Glaucidium gnoma (p. 79) in Colorado.

05 Henshaw, H. W. Note on Lagopus leucurus and Leucosticte australis. Auk, xXII., 1905, pp. 315-6.

76 Herrser, J. C. The Little White Egret in Colorado. Amer. Nat., x., 1876, p. 430.

07 Herser, L. J., and RockwrLl, R. B. A New Breeding Bird for Colorado : the Cassin Sparrow Nesting near Denver. Condor, IX., 1907, pp. 191-4, with two photographs.

09 Hersey, L. J., and RockWELL, R. B. An Annotated List of the Birds of Barr Lake District, Adams co., Colorado. Condor, xI., 1909, pp. 109-122.

06 HopkINs, F. H. The Bobolink in Colorado (Rio Blanco co.) Auk, xxuII., 1906, p. 461.

05 Howerl, A. H. Scott's Sparrow in Colorado. Auk, xxIr., 1905, p. 210. First record for the State. 
76 Inaersol, E. Our Present Knowledge of the Nidification of the American Kinglets. Bull. Nutt. Orn. Club, I., 1876, pp. 77-79. Note on a nest of the Ruby-crowned found by Batty in Buffalo Mountains, Colorado.

80 INGErsoli, E. The Flammulated Owl (Scops flammeola) in Colorado. Bull. Nutt. Orn. Club, v., p. 121-2.

97 Ingraham, D. P. Additional Records of the Flammulated Owl (Megascops flammeola) in Colorado. Auk, xrv., 1897, pp. 403-4.

98 Jones, P. L. Flammulated Owls. Osprey, III, 1898, p. 46. Note on nesting habits near Beulah, Pueblo co.

05 JUDD, S. D. The Bob-White and other Quails of the United States in their Economic Relations, pp. 1-66, 2 pls. Bull. No. 21, Bureau Biol. Surv. U.S. Dept. Agric. Washington, 1905, 8vo.

05 JUDD, S. D. The Grouse and Wild Turkeys of the United States, and their economic value. Bull. No. 24, Bureau Biol. Surv. U.S. Dept. Agric. Washington, 1905, 8vo.

90 Kerlogg, V. L. Summer Birds of Estes Park, Colorado. Trans. Kans. Acad. Sci., XII., 1889-90, pp. 86-90.

02 Keyger, L. S. Birds of the Rockies. Chiçago, 1902. 8vo. A popular work, containing accounts of tous through Colorado, illustrated with a number of coloured plates.

07 Kraeber, E. A New Colorado Record for the White-winged Crossbill (Loxia leucoptera). Auk, XxIV., 1907, p. 101.

77 LAMB, W. F. Nest and Eggs of Townsend's Flycatcher. Bull. Nutt. Orn. Club, II., 1877, p. 77. First description of nest and eggs of this bird from Summit co., Colorado, taken in July, 1876.

92 Lowe, W. P. Some Spring Arrivals at Pueblo co, Colorado. Orn. and Ool., XvII., 1892, p. 101.

94 Lowe, W. P. A List of the Birds of the Wet Mountains, Huerfano co., Colorado. Auk, xr., 1894, p. 266.

94a Lowe, W. P. The Scarlet Ibis (Guara mubra) in Colorado. Auk, XI., 1894, p. 324.

95 Lowe, W. P. An Addition to the Birds of Colorado. Auk, XII., 1895, p. 298. The Scaled Partridge (Callipepla squamata).

95 Lowe, W. P. Arrival of the English Sparrow at Pueblo, Colorado. Nidol., II., 1895, p. 99.

95 Lowe, W. P. Low Nesting Sites of Bubo. Nidol., II., 1895, p. 168. Bubo virginianus subarcticus (= pallescens) nesting near Pueblo.

95 Lowe, W. P. An Albino Pallid Horned Lark. Nidol, II., 1895, p. 170.

97 Lowe, W. P. A Young Ferruginous Rough-leg. Nidol., Iv., 1897, pp. 69, 70. With a photograph from life by $H$. W. Nash. 
01 Lowe, W. P. Bird Notes from Pueblo co., Colorado. Auk, xVIII., 1901, p. 276. Notes on several species wintering in Pueblo co.

07 Markmav, H. Birds in the Scientific Expedition to North-eastern Colorado. Univ. of Colo. Studies, IV., 1907, p. 154. List of Birds taken chiefly in Weld co., in summer of 1906.

05 McAtee, W. L. The Horned Larks and their Relation to Agriculture. Bull. No. 23, Biol. Surv. U.S. Dept. Agric. Washington, 1905. 8vo.

08 MoAtee, W. L. Food Habits of the Grosbeaks. Bull. No. 32, Biol. Survey U.S. Dept. Agric. Washington, 1908. 8vo.

88 MCGregor, R. C. A Large Set of Eggs of the Red-headed Woodpecker. Ool., v., 1888, p. 44. Set of ten eggs taken by the writer on Crow Creek, Weld co., Colorado, in May, 1887.

93 MCGREGoR, R. C. Junco ridgwayi in Colorado. Auk, x., 1893, pp. 205-6.

97 MoGregon, R. C. Birds of Estes Park. Nidol., IV., 1897, pp. 38, 39.

94 Mrucke, O. T. A Bird-lover in the West. Boston and New York, 1894, 16mo. A popular work containing observations on the habits of several birds, made near Colorado Springs.

80 Mñot, H. D. Notes on Colorado Birds. Bull. Nutt. Orn. Club, จ., 1880, pp. 181-2 and 223-232. Notes of birds observed near Boulder, Nederland, and at Seven Lakes, near Manitou, in the summer of 1880 . Saxicola Enanthe and Mniotitta varia taken near Boulder.

86 Morrison, C. F. Field Notes on some Birds of Colorado. Orn. and Ool., XI., 1886, pp. 153, 164 ; XII., 1887, pp. 27, 35, 58, 106. Notes chiefly made near Fort Lewis, in South-west Colorado.

87 Morrison, C. F. The Pinnated Grouse in Colorado. Orn. and Ool., XII., 1887, p. 58. Refers to Sharp-tailed Grouse (see Ridgway, 87.)

88 Morrison, C. F. A List of some Birds of La Plata co., Colorado, with Annotations. Orn. and Ool., xIII., 1888, pp. 70, 107, $115,139$.

89 Morrison, C. F. A List of the Birds of Colorado. Orn. and Ool. xسI., 1888, pp. 145, 165, 181 ; xIV., 1889, pp. 6, 65, 145 ; $\mathrm{XV} ., 1889$, p. 36 . The most extensive list of Colorado birds made up to date. Owing to destruction of some of the MSS the list was never completed.

83 NAsh, H. W. Colorado Bird Arrivals. Forest and Stream, xx., 1883, p. 225. Arrival dates of Eastern and Arctic Bluebirds, Kildeer Plover, Sandhill-Crane, etc., etc. 
96 NasH, H. W. American Rough-legged Hawk, with photograph. Nidol., IV., 1896, p. 15.

97 NASE, H. W. Nest and Eggs of the Arkansas Goldfinch. Nidol., IV., 1897, p. 29, with photograph.

90 NIxon, J. P. A series of Eggs of the Rock-Wren. Orn. and Ool., X.V., 1890, p. 21.

88 NorRts, J. P. A Series of Eggs of Sitta pygmaea. Orn. and Ool, xIII., 1888, p. 173.

02 Obzrholsen, H. C. A Review of the Larks of the Genus Otocoris. Proc. U.S. Nat. Mus., XxIV., 1902, pp. $801-884$, pls. $43-45$, and 4 maps.

04 OrerHolser, H. C. A Revision of the American Great Horned Owls. Prọc. U.S. Nat. Mus., XxvII., 1904, pp. 177-192. The Colorado subspecies referred to Asio magellanicus occidentalis.

05 OBERHOLSER H. C. The Forms of Vermivora celata. Auk, xxir., 1905 , p. 242. Description of Vermivora (= Helminthophila) celata orestera, the Rocky Mountain Region form of the Orangecrowned Warbler.

06 OBERHOLSER, H. C. The North. American Eagles and their Economic Relations. Bull. No. 27, Biol. Surv. U.S. Dept. Agric. pp. 1-31. Washington, 1906.

07 Orerholser, H. C. A New Agelains from Canada. Auk, xxIV., 1907, pp. 332-336. Agelains p. arctolegus and A. p. fortis occur in Colorado.

90 Osburs, W. Nesting of the Grebes (Podilymbus podiceps). Orn. and Ool., xv., 1890, p. 68.

93 OsbuRn, W. Birds of Rare Occurrence in Northern Colorado. Science, XXIr., 1893, p. 212. Zonotrichia coronata first recorded.

01 Osgood, W. H. New subspecies of North American Birds. Auk, xVII., 1901, pp. 179-185. The White-tailed Ptarmigan of Colorado, separated as a distinct subspecies (Lagopus leucurus altipetens).

86 Pearow, G. D. Water Ousel or American Dipper. Sunny South, Ool., I., 1886, p. 8.

10 PזKE, Z. M. An Account of Expeditions to the Sources of the Mississippi, and through the Western Parts of Louisiana to the Sources of the Arkansaw, Kans, La Platte and Pierre Juan Rivers, performed by order of the Government of the United States during the years 1805,1806 , and 1807, etc., etc. Philedelphia, 1810 , 8vo. The portion relating to Colorado contains allusions to the Pheasant (i.e. Dusky Grouse), Turkey, Raven, Magpie, and Carolina Parrot. Coues' edition, published in New York, in 3 vols., in 1895, is quoted in the records for these species. 
08 Richards, G. Chrigtmas Bird-census at Littleton, Colorado. Bird-lore, x., 1908, p. 38. Nineteen species recorded on Christmas Day.

08 Richards, G. An Unusual Nesting Locality for the Rocky Mountain Nuthatch. Condor, ×., 1908, p. 194.

09 Richards, G. Cliff Climbing for Prairie-Faleon's Eggs. Condor, xI., 1909, pp. 164-166.

73 Ridgway, R. On Some New Forms of North American Birds. Amer. Nat., vII., 1873, pp. 603, 615. Catherpes mexicanus conspersus and Junco hyemalis aikeni, described from Colorado.

73 Rlogwax, R. The Birds of Colorado. Bull. Essex Inst., v., 1873 , p. 174. First list of Colorado birds published.

74 Ridgway, R. Description of a New Bird (Leucosticte atrata) from Colorado. Amer. Sportsman, IV., 1874, p. 241.

75 Ridoway, R. A Monograph of the Genus Leucosticte. Bull. U.S. Geol. and Geogr. Surv. Terr., 2nd ser., No. 2, 1875, pp. 51-82.

79 Ridgway, R. Appendix to "On the Plains and Among the Peaks; or, How Mrs. Maxwell made her Natural History Collection," by Mary Dart, 2nd edition. Philadelphia, 1879. List of Mrs. Maxwell's collection of birds. This was also published in Field and Forest, II., 1876-7, pp. 195, 208.

80 RIDGWay, R. Scops flammeola in Colorado. Bull. Nutt. Orn. Club, v., 1880, p. 185. Correction of an error of Deane and Ingersoll in regard to the Colorado record.

82 RImqway, R. Descriptions of two new Thrushes from the United States. P.U.S. Nat. Mus., Iv., 1882, pp. 374-379. Description of Hylocichla fuscescens salicicola from Fort Garland, Colo.

84 RIDGway, R. On the Possible Specific Identity of Buteo coopert Cass. with B. harlani (Aud.). Auk, I., 1884, p. 253.

85 RIDGway, R. On Buteo harlani (Aud.) and B. cooperi Cass. Auk, II., 1885, p. 165. Note on a specimen from El Paso co., in the Aiken Collection.

87 Ridgway, R. A Correction. Orn. and Ool., xIr., 1887, p. 192. Morrison's account on p. 58 of same vol. refers to Sharp-tailed, not to the Pinnated Grouse or Prairie-Hen.

90 Rmoway, R. The Humming-birds. Report U.S. Nat. Mus. for 1890, pp. 253-283, pls. 1-46, published 1891 .

01 RIDqway, R. The Birds of North and Middle America. (Bull. U.S. Nat. Mus., No. 50). Parts 1, 1901 ; 2, 1902 ; 3, 1904 ; 4, 1907 (incomplete).

07 Rockwell, R. B. The Woodhouse-Jay in Western Colorado. Condor, IX., 1907, pp. 81-84. With photograph of nest and eggs. 
07 Rockwell, R. B. Some Colorado Notes on the Rocky Mountain Screech Owl. Condor, IX., 1907, pp. 140-145. With five photographs of nest and young birds.

08 Rockwlel, R. B. Nesting of the Western Horned Owl in Colorado. Condor, x., 1908, pp. 14-17. With two photographs of nest and eggs.

08 Rockwell, R. B. The Red-winged Blackbirds of Colorado. Condor, X., 1908, p. 93. Identification of a third subspecies, A. $p$. neutralis, among the wintering Red-winged Blackbirds of Colorado.

08 Rockwell, R. B. An Annotated List of the Birds of Mesa co, Colorado. Condor, x., 1908, p. 152.

08 Rockwelr, R. B. A striking Example of Protective Coloration. Condor, X., 1908, p. 207. Photograph of a Rocky Mountain Sereech Owl on the nest.

10 Rockwel, R. B. Some Colorado Night Heron Notes. Condor, xIr., 1910, pp. 113-121, six photographs.

10 Rockwell, R. B. Nesting of the Grey-headed Junco. Condor, xII , 1910, pp. 164-I65, one photograph.

s6 R. V. R. S. Winter Snipe in Colorado. Forest and Stream, XXVT., 1886, p. 5 ; also Auk, IV., p. 337.

10 Rockwell, R. B. Nesting Notes on the Americen Eared Grebe and Pied-billed Grebe. Condor, хп., 1910, pp. 188-193, five photographs.

23 SAY, T. Account of an Expedition from Pittsburg to the Rocky Mounteins, Performed in the Years 1819 and 1820. Two vols. 8vo., Philadelphia, 1823. About eight new species are described from what is now Colorado; several other species are incidentally mentioned.

94 "S. Вов-Wнгте" Feathered Butchers. Nidol., I., 1894, p. 138. Note on Northern and White-rumped Shrikes.

08 Sclater, W. L. Winter Birds of Colorado. Ibis, 1908, pp. 443-450.

79 ScorT, W. E. D. Notes on Birds Observed at Twin Lakes, Lake co., Colorado. Bull. Nutt. Orn. Club, IV., 1879, p. 90.

84 Бмітн, H. G. The Shore-Lark. Orn. and Ool., IX., 1884, p. 94.

84 Sмттн, H. G. Notes from Denver, Colorado. Orn. and Ool., IX., 1884, p. 120. Notes on House-Finch, Bohemian Waxwing and Say's Phœbo.

85 Sмiтн, H. G. Cassin's Purple Finch. Orn. and Ool., x., 1885, p. 90. Wintering near Denver.

86 Sмттн, H. G. Some Additions to the Avifauna of Colorado. Auk, IIr., 1886, p. 284 : i.e. Rusty Grackle, Cormorant and Herring-Gull. 
88 Sмптн, H. G. Food of the Great Northern Shrike. Orn. and Ool., xul., 1884, p. 163.

93 Sмrтн, H. G. City Birds of Denver, Colorado. Science, xxrI., 1893, p. 244.

93 Sмгтн, H. G. Another Megascops flammeolus for Colorado. Auk, X., 1893, p. 364 .

96 Sмптн, H. G. Some Birds New to Colorado. Nidol. III., 1895-6, pp. 48,65, 76. Notes on thirty-five species; Sterna paradisea, Oidemia perspicillata, Guara alba, Arenaria interpres, and Aluco pratincola new to Colorado.

02 SмrтH, H. G. Another Scarlet Tanager for Colorado. Auk, XIX., 1902, p. 290.

03 Smiт, H. G. Bell's Vireo (Vireo belli) in Colorado. Auk, xx., 1903, p. 438. First record for Colorado.

05 Surth, H. G. The Blue Jay and other Eastern Birds at Wray, Yuma co., Colorado. Auk, xxm., 1905, p. 81. Also Blackbilled Cuckoo, Western Blue Grosbeak, Bell's Vireo and Tennessee Warbler.

08 Sмптн, H. G. Random Notes on the Distribution of some Colorado Birds, with additions to the State Avifauna. Auk, xxv., 1908, pp. 184-191.

10 Sмгтн, H. G. Two Avian Stragglers within the State of Colorado: i.e. Pelecanus occidentalis, Bubo virginianus lagophonus. Condor, xir., 1910, p. 133.

86 Sмгтн, W. G. Colorado Bird Notes. Random Notes, Irr., 1886, pp. 13, 17, 25, and 66. Notes on Meadow-Larks and Blackbirds wintering in Larimer co.; nesting of the Rock-Wren, Townsend Flycatcher and Mountain-Tit, and of trip to Estes Park.

87 Sмптн, W. G. Hybrid Ducks. Orn. and Ool., хп., 1889, p. 169. Gadwall $\times$ Baldpate and Cinnamon $\times$ Bluewing Teal taken.

88 SмrтH, W. G. Nesting of Audubon's Warbler, of the Ruddy Duck, of the Water-Ouzel, of the Mountain-Plover. Orn. and Ool., xuI., 1888, pp. 114, 132, 149 and 187.

89 SmrтH, W. G. Nesting of the Cinnamon Teal. Orn. and Ool., XIV., 1889, p. 77.

89 Sмпtе, W. G. Nesting of the Pied-billed Grebe. Orn. and Ool., XIV., 1889, p. 138 .

89 Sмпrн, W. G. Sabine's Gull at Loveland. Orn. and Ool., XIV., 1889 , p. 176

90 Smit, W. G. Nesting of the Eared Grebe. Orn. and Ool., xष., 1890 , p. 141.

91 Smrte, W. G. Nesting of the Flammulated Screech Owl. Orn. and Ool., xVI., 1891, p. 27. 
96 Spragde, W. A. The Dwarf Thrugh in Colorado. Auk, xm., 1896, p. 85. First record of occurrence of Hylocichla aonalaschkce (= guttata) in the State.

78 Stwrens, F. Notes on Few Birds Observed in New Mexico and Arizona in 1876. Bull. Nutt. Orn. Club, III., 1878, pp. 92-94. Contains a note on occurrence of Western Crow in South Park.

81 Stone, Mrs. D. D. Notes from Denver, Colorado. Orn. and Ool., vI., 1881, pp. 45, 67.

82 Stone, Mrs. D. D. Water Ousel and Canada Jay. Orn. and Ool., VII., 1882, p. 180 : i.e. Cinclus mexicanus and Cractes canadensis capitalis.

82 Stone, Mrs. D. D. Notes from Colorado. Orn. and Ool., VI., 1882, p. 191. Notes on various birds seen at Hancock, Colorado, including nesting habits of Oregon Snowbird (Junco caniceps) and Mountain Mocker (Myadestes townsendi).

83 Stone, Mrs. D. D. The Ruby-crowned Kinglet. Orn. and Ool., vIII., 1883, p. 83.

84 Stons, Mrs. D. D. Colorado Notes. Orn. and Ool., IX., 1884, pp. 9, 20. Notes on Occurrence and Nesting of Alpine Three-toed Woodpecker, Townsend's Solitaire, Intermediate Crowned Sparrow, Wilson's Warbler, Audubon's Warbler, Clarke's Nutcracker, Lincoln's Sparrow, Audubon's Hermit-Thrush and Cassin's Purple Finch, at Hancock, 9,700 feet, Chaffee co.

96 TAYLOR, H. R. Intelligence of Ouzels. Nidol., IV., 1896, p. 6. With photographs of a nest placed in the same spot in two successive years by $H$. W. Nash, of Pueblo.

08 Test, C. D. The Cañon Wren in Colorado. Auk, xxv., 1908, p. 226. Examples obtained near Golden, February 22nd and October 10th.

83 Thorne, P. M. Winter Snipe in Colorado. Forest and Stream, Xx., 1883, p. 46.

86 Thоnne, P. M. The Eastern Bluebird at Fort Lyon, Colorado. Auk, ШI., 1886, p. 489.

87 Thorne, P. M. Additions to Drew's List of Colorado Birds. Auk, IV., 1887, p. 264.

88 Thorns, P. M. Abnormal Plumage of Xanthocephalus xantho-

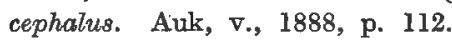

89 Thorne, T. W. (i.e. P.M.). The Olivaceous Flycatcher and Phobe in Colorado. Auk, vт., 1889, p. 276. First and only records for Colorado.

81 Tresz, F. Die Vögel des South Park in Colorado. Monatschr. Deutsch. Ver. Schutz. Vogelw., vi., p. 280, vII., pp. 39, 93, $182,243,1881-2$. 
74 Truppe, in Elliott Coues' Birds of the North-west (see Coues, 74). 00 Warren, E. R. Photographing Ptarmigan. Bird-Lore, II., pp. 169-174, with 6 photographs.

04 Warren, E. R. A Sandhill Crane's Nest. Condor, vi., 1904, p. 39, with photograph.

04 Warken, E. R. Horned Larks in Colorado Springs, Colorado. Bird-Lore, VI., 1904, p. 6, with 4 photographs.

05 Warren, E. R. Cassin's Sparrow in Colorado. Auk, xxm., 1905 , p. 417.

06 Warren, E. R. A Collecting Trip to South-eastern Colorado. Condor, VIII., 1906, pp. 18-24, and 130. List of birds collected, including Contopus virens, new to the State.

07 Warren, E. R. Photographing Magpies. Condor, Ix., 1907, pp. 5-9. Reproduction of photographs of nests and young birds.

07 Warren, E. R. An Interesting Occurrence of the Canyon-Wren. Condor, IX., 1907, p. 111. Example taken near Cheyenne Wells, Cheyenne co., Colorado, on November 23rd, 1906.

07 Warren, E. R. A Humming-bird that Wanted Light. BirdLore, Ix., 1907, p. 81. Note on a Broad-tailed Humming-bird nesting on an electric light standard on a porch in Colorado Springs.

08 W ARREN, E. R. North-western Colorado Bird Notes. Condor, x., 1908, pp. 18-26. Notes on birds observed on a journey through North-west Colorado, chiefly in Larimer and Routt cos., with a map of the route and two photographs of the nest of a House-Wren.

09 Warren, E. R. Notes on the Birds of South-western Montrose co., Colorado. Condor, XI., 1909, pp. 11-17 (correction in Condor, XII., p. 79).

09 WARREN, E. R. Concerning Thryomanes bewicki cryptus in Colorado. Auk, XXVI., 1909, p. 311.

09b Warren, E. R. Some Interesting Colorado Records. Condor, xI., 1909, p. 33 : i.e. Nyctanassa violacea, Dolichonyx oryzivorus and Zonotrichia coronata, at Salida.

10 Warren, E. R. Some Central Colorado Bird Notes. Condor, XII., 1910, pp. 23-39. Notes on birds met with during a collecting trip, chiefly in the San Luis Valley, with map of route and photograph of a Long-eared Owl.

10 Warken, E. R. Bird Notes from Salida, Chaffee co., Colorado. Compiled from memoranda of John W. Frey. Auk, xxvII., 1910 , pp. 142-151.

87 Woорвтry, A. H. Ring-billed Gull at San Luis Lakes. Orn. and Ool., xIr., 1887, p. 116. 



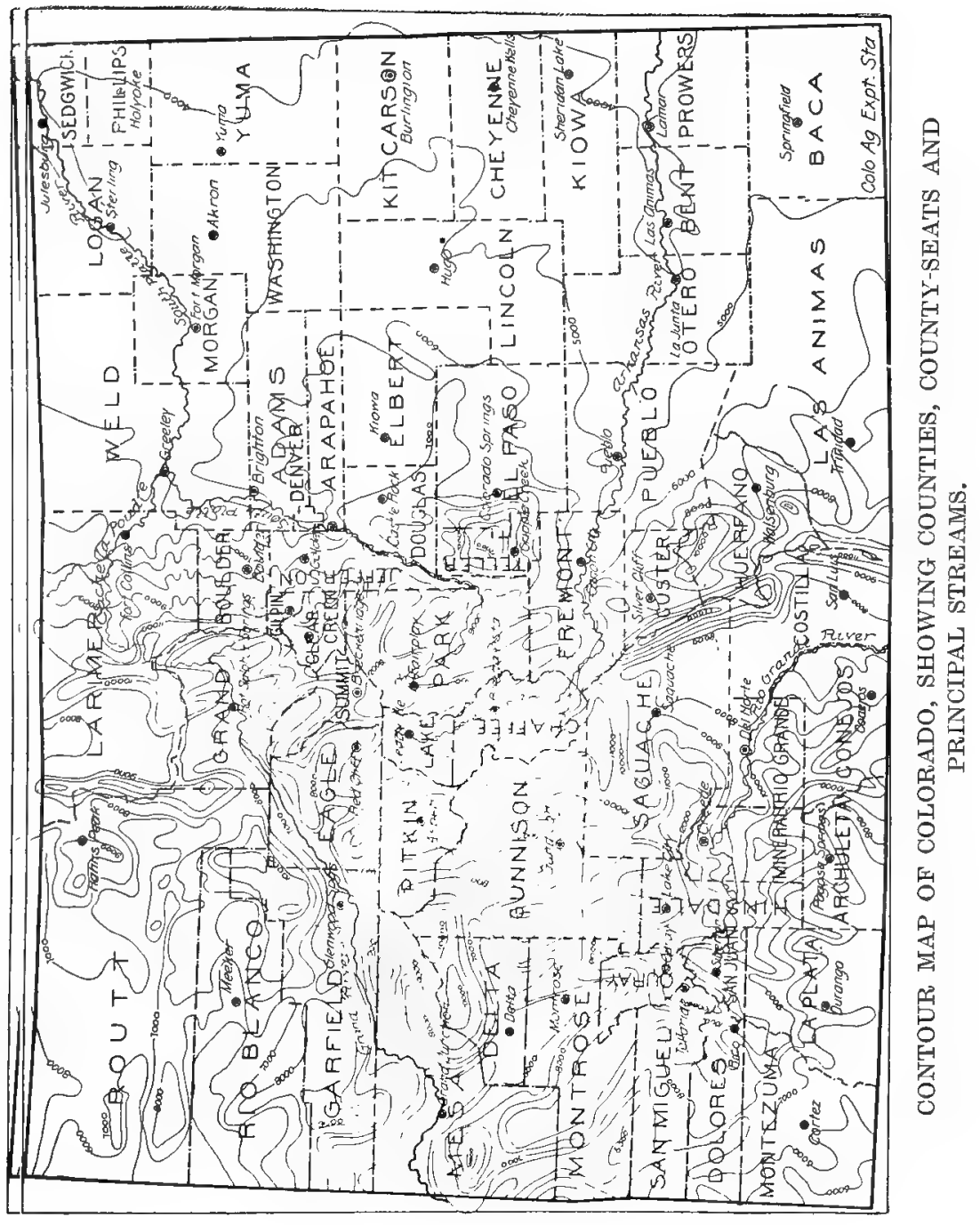





\section{GAZETTEER.}

The following is a list of the various localities mentioned in the "Birds of Colorado." Many of these are not to be found in the ordinary maps. In every case the approximate height above sealevel is given and the county in which the locality is situated. Most of the places will be found mentioned in "The Gazetteer of Colorado" by Henry Gannett, published as Bulletin No. 291 of the United States Geological Survey, in 1906.

ALPINE LAKE, Summit co. : near Breckenridge.

Alpine TunNel : between Chaffee and Gunnison cos., on the Colorado and Southern R., alt. 11,600 feet.

Artoona, Boulder co. : about ten miles north of Boulder.

Animas, river in La Plata co. : a tributary of the San Juan River.

Antmas PARK : in the upper valley of the Animas River.

Apishapa, Las Animas co. : on the Apishapa River, about 6,140 feet. Arkansas : river rising in Lake co. and flowing through Chaffee and

Fremont cos. to the eastern plains, and then to the Mississippi through Kansas.

Arking, Larimer co. : west of Loveland, alt. 5,200 feet.

AURorA LAKF, Adams co. : near Denver.

Austins Blufrs: three miles north-east of Colorado Springs, El Paso co., alt. 6,700 feet.

BarleY, Park co. : 7,700 feet, on the Colorado and Southern R.

BAKER's PARK, San Juan co. : on the head-waters of the Aninas River, about 9,500 feet.

BaLd MountaIn, Boulder co. : in the front range, alt. about 11,490 feet. Batdy Mountate, Sangre de Cristo range, Costilla co. : alt. 14,176 feet. Barr AND Barr LAKr, Adams co.: eighteen miles north-east of Denver, alt. ebout 5,100 feet.

Bear LAKE, Routt co. : near Steamboat Springs.

BeAsley Lake, Boulder co. : near Boulder.

Beraver Crem, Fremont co. : a northern tributary of the Arkangas, alt. 5,000 6,000 feet.

Bedrock, Montrose co. : on the Dolores River, alt. 5,100 feet. 
Belort, Kit Carson co. : near the Kansas line.

Bergin PaRk, Jefferson co. : south-west of Golden, alt. about 7,600 feet.

Berkeley Lake, in Denver co. : near Denver.

Berthoud, Larimer co. : near Loveland, alt. 4,950 feet.

Berthoud Pass, Clear Creek and Grand cos. : alt. 11,349 feet.

BEULAH, Pueblo co. : about twenty-five miles south-west of Pueblo, alt. about 7,000 feet.

BIG SANDY : creek rising at Ramah, El Paso co., and flowing into the Arkansas near Lamar.

Big Thompson : creek in Larimer co., flowing from Estes Park; a tributary of the Platte.

BlUE RIVer, Summit and Grand cos. : tributary of the Grend.

Book Curfys, in Garfield and Rio Blanco cos.: north of the Grand River Valley, alt. 8,000 to 8,500 feet.

Boreas Pass, between Summit and Park cos.: near Breckenridge, alt. 11,500 feet.

Bosweli, Chaffee co.

BouldER, county seat of Boulder co. : alt. 5,350 feet.

BOYDS LAKE, Larimer co. : near Loveland.

Boyes RaNCH, Yuma co. : on Dry Willow Creek, near Wray.

Breckenridge, Summit co. : on the Blue River, alt. 9,530 feet.

BUCKHoRN MoUNTAIN : between Boulder and Larimer cos.

Bunna Vista, Chaffee co.: on the Arkansas River, alt. 7,950 feet.

Buffalo Creie, Jefferson co, : a right-hand branch of the north fork of the South Platte.

BUfFalo Pass : between North Park and Steamboat Springs, Larimer and Routt cos.

Bufralo Peak : in the Park range, between Park and Lake cos., alt. 13,328 feet.

Buford, Rio Blanco co. : on the upper waters of the White River, alt. about 7,000 feet.

Buritngton, Kit Carson co. : near the Kansas border, alt. 4,160 feet. Butres, El Paso co. : on the Fountain, alt. 5,320 feet.

BUz ARD CRezk, in Mesa co. : a right-hand branch of Plateau River.

Cache LA Poudre, creok in Larimer and Weld cos. : a tributary of the South Platte near Greeley.

Cadpoa, Bent co. : on the Arkansas, between Las Animas and Lamar, alt. 3,760 feet.

Calman, El Paso co. : on the Chicago and Rock Island R., alt. 6,500 feet.

Californla Gulch, Lake co. : close to Leadville, alt. 10-11,000 feet. CaLkins Lake, Weld co.: near Longmont, alt. approximately 5,000 feet. 
Camet CRenk, El Paso co. : left-hand branch of Monument at Colorado. City.

CAÑon CTTY, Fremont co.: on the Arkansas River, alt, 5,340 feet.

Cheymene CaÑon, El Paso co. : close to Colorado Springs, alt. 6,0009,000 feet.

Cheyenne Mountain, El Paso co.: close to Colorado Springs, alt. 9,400 feet.

Cheyenne Wells, Cheyenne co. : eighteen miles from the Kansas border, alt. 4,280 feet.

Chicago Lakes, Clear Creek co. : six miles south-east of Georgetown, alt. 11,500 feet.

Crear Crefer : a tributary of the South Platte at Denver, rising from 5,000 to 12,000 feet.

Coal Cremk, Denver co. : eight miles east of Denver, alt. 5,500 feet.

Cocketopa Pass, Saguache co.. between the Gunnison watershed. and the San Luis Valley, alt. 10,032 feet.

Colorado City, El Paso co. : practically part of Colorado Springs, alt. 6,070 feet.

Colorado Springs, county seat of El Paso co. : alt. 5,870 feet.

Conejos, in Conejos co. : alt. 7,800 feet.

Cormez, county seat of Montezuma co. : in the south-west corner of the State, alt. 6,500 feet.

Coventry, Montrose co. : on the Naturita Creek, alt. about 9,000 feet.

Craig, Routt co. : on the Beaver River, alt. 6,050 feet.

Crested Butte, Gunnison co.: on the Slaty River, a tributary of the Gunnison, alt. 8,860 feet.

Creswell, Jefferson co. : above Golden.

Cripple Creek, Teller co. : alt. 9,600-9,800 feet.

Crow Creer, Weld co. : a left-hand branch of South Platte.

CUв CREeK, Jefferson co. : a right-hand branch of Bear Creek.

Cumbres, Conejos co. : a station on the Denver and Rio Grande R., alt. 10,000 feet.

Corecantr, Gunnison co. : a station on the Denver and Rio Grande R., on the Gunnison River, alt. 7,060 feet.

DE Beque, Mesa co. : alt. 4,930 feet.

DeCKrer's LaKe, Gunnison co. : near Crested Butte.

DreP CRFEK, Gunnison co.

Drer CREeK, Jefferson co. : a left-hand branch of South Platte, near Littleton.

Der NorTe, county seat of Rio Grande co. : on the RioGrande River, alt. 7,870 feet.

Denver, county seat of Denver co.. on the South Platte, alt. 5,200 feet.

Drllon, Summit co. : on the Blue River, alt. 8,860 feet. 
Drvide, Teller co. : on the Colorado Midland R., alt. 9,180 feet.

Dorores : river in the south-west of the State, flowing north-west into the Grand.

Dome Rock, Jefferson co. : in the Platte Cañon, alt. 6,200 feet.

Dotserso, Eagle co. : at junction of Grand and Eagle Rivers, alt. 6,150 feet.

Dougtas SpRing, Routt co.. north of the Escalante Hills, near the Utah border, alt. 6,700 feet.

DRY WILLOW CREER, Yuma co. : near the Nebraska border.

DUck LAKE, Boulder co. : near Gold Hill.

Durango, county seat of La Plata co. : on the Animas River, alt. 6,500 feet.

EatoN, Weld co. : near Greeley, alt. 4,830 feet.

EDWARDS, Eagle co. : on the Eagle River, alt. about 7,500 feet.

Emmons MounTan, in the Elk range, Gunnison co. : alt. 12,414 feet.

Escalante Hriss, Routt co. - near the Green River, in the northwest corner of the State.

Estes PaRK, Larimer co.: drained by the Big Thompson, alt. 7,5008,500 feet.

Evans Modntain, Clear Creek co. : west of Denver, alt. 14,321 feet.

FaIRPLay, county seat of Park co. : in South Park, on the head-waters of the South Platte, alt. 9,896, feet.

FaLCon, El Paso co. : twelve miles west of Colorado Springs, on the Rock Island R., alt. 6,830 feet.

Florissant, Teller co. : on the Colorado Midland R., alt. 8,170 feet.

Font Colunvs, Larimer co.: on the Cache La Poudre, tributary of the South Platte, alt. 5,000 feet.

Fort Gardand, Costilla co. . formerly Fort Massachusetts, alt. 7,900 feet.

Fort Lewis, La Plata co. : alt. 8,870 feet.

Fort Logan, Arapahoe co.: seven miles south of Denver.

Fort Lupton, Weld co. : on the Platte, alt. about 5,000 feet.

Forr Lyon, Bent co. : on the Arkansas, alt. about 3,900 feet.

Forr Morgan, Morgan co. : on the Burlington R., alt. 4,340 feet.

Fountand, El Paso co. : on the Fountain River, below Colorado Springs, alt. 5,600 feet.

Fraser Cregr, Grand co.: in Middle Park.

Garden of the Gods : close to Colorado City in El Paso oo., alt. 6,300 feet.

Gadme's Ranch, Baca co.: in the extreme north-west corner of the county.

Georata Pass, between Park and Summit cos.: alt. 11,476 feet.

Georgetown, Clear Creek co. : alt. 8,500 feet.

GLEN EYRIE, El Paso co. : about three miles north of Colorado City. 
GuENwood, county seat of Garfield co.: on the Grand River, alt. 5,750 feet.

GordEN, county seat of Jefferson co. : on Clear Creek, alt. 5,700 feet.

GoLD Hru, Boulder co.: alt. 8,297 feet.

Grand Jonction, county seat of Mesa co. . on the Grand River, alt. 4,570 feet.

Grand Lakn, Grand co. : in Middle Park, alt. 8,153 feet.

Grand Mresa, in the western part of Mesa co. : between the valleys of the Gunnison and Grand Rivers, rising to 10,500 feet.

GraND RIVER : chief river of western Colorado, rising in Middle Park, and flowing west to form, with the Green, the Colorado River of Utah and Arizona.

Grape Crewk, Custer and Fremont cos.: draining Wet Mountain Valley.

Graymont, Clear Creek co. : alt. 9,780 feet.

Gray's PEAK : on the water-parting of Clear Creek and Summit cos. : alt. 14,341 feet.

Greeley, county seat of Weld co. : on the Cache La Poudre, alt. 4,650 feet.

Grien Mountant Falls, El Paso co.: on the Fountain Creek, above Manitou, alt. 7,720 feet.

Gonnison River, Gunnison, Montrose and Mesa cos.: a left-hand tributary of the Grand River.

Hadi Valuey, Park co.

Harcock, Chaffee co.: twenty miles south-west of Buena Vista, alt. 11,000 feet.

Harpard Mountant, Chaffee co. : in the Saguache range, alt. 14,375 feet.

HАystack BUTTE, Boulder co. : alt. 5,596 feet.

Hothre, Las Animas co. : near Trinidad, alt. 5,710 feet.

Houly, Prowers co.: on the Arkansas, close to the Kansas border, alt. 3,387 feet.

HoLYOKE, Philips co. : in the north-east corner of the State, alt. 3,737 feet.

Hooren, Costilla co. : in the San Luis Valley, alt. 7,560 feet.

Horse Cresk : about forty miles east of Colorado Springs, in Lincoln. co. : flowing south to the Arkansas, alt. about 6,000 feet.

Horsetooth Mountatn, Larimer co. : seven miles south-west of Fort Collins, alt. 7,160 feet.

HoтchкISs, Delta co.: on the north fork of the Gunnison, alt. 5,359 feet.

Howardstille, San Juan co.: on the Silverton and Northern R., alt. 9,970 feet.

HowBerT, Park co.: on the South Platte, alt. 8,600 feet. 
Hugo, county seat of Lincoln co. : on the Union Pacific R., Kansas branch, alt. 5,060 feet.

IdAHo Springs, Clear Creek co. . alt. 7,550 feet.

IrWIN's RANCH, Las Animas co. : about thirty-five miles south of Las Animas town, in the piñon and cedar country.

JAMres PeAK : at the junction of Gilpin, Clear Creek and Grand cos., alt. 13,283 feet.

.JEFFtrson, Park co. : in South Park, alt. 9,500 feet.

Julesburg, Sedgwick co. : in the extreme north-east corner of the State, on the South Platte, alt. 3,460 feet.

Kennicott Club Lake, Boulder co. ; near Longmont.

Kit Carson, Cheyenne co. : on the Union Pacific R., Kansas branch, alt. 4,280 feet.

Kremming, Grand co.: near the junction of the Blue and Grand Rivers, in Middle Park, alt. 7,150 feet.

LA JUNTA, Otero co. : on the Arkansas River, alt. 4,050 feet.

Lamar, Prowers co. : on the Arkansas River, alt. 3,610 feet.

I Aasalle, Weld co.: on the South Platte, near Greeley, alt. 4,670 feet.

Las ANtmas, coun'y seat of Bent co. : on the Arkansas, alt. 3,800 feet.

LA VETA, Huerfano co. : alt. 7,012 feet.

LAY, Routt co. : on Lay Creek, tributary of the Yampa, alt. 6,200 feet.

LEADVILLE, county seat of Lake co.; alt. 10,200 feet.

LrIx, Routt co. : near the junction of the Snake and Bear Rivers, alt. about 7,500 feet.

Lmon, Lincoln co. : about sixty miles east of Colorado Springs, alt. 5,350 feet.

Lincoln Mountann : in the Park range, between Park and Lake cos., alt. 14,297 feet.

Litthe Beaver Creek, Larimer co.: a branoh of the south fork of the Cache La Poudre River.

ItTtue Thompson Creme, Weld and Boulder cos. : a right-hand branch of the Big Thompson, tributary of the South Platte.

Litrleton, Arapahoe co.: on the South Platte, twelve miles south of Denver, alt. 5,350 feet.

Longmont, Boulder co.: alt. 4,950 feet.

Long's PEAK, in the Front range at the junotion of Boulder, Larimer and Grand cos. : alt. 14,271 feet.

Loverand, Larimer co.: on the Big Thompson, alt. 5,000 feet.

Lyons, Boulder co. : on the St. Vrain, fifteen miles north of Boulder, alt. 5,350 feet.

Magnolia, Adams co. : about seven miles east of Denver, alt. 5,330 feet. Magnolia, Boulder co. : about five miles west of Boulder, alt. about 7,500 feet.

Matta, Lake co. : near Leadville, alt. 9,570 feet. 


\section{Gazetteer}

Mancos, Montezuma co.: on the Mancos River, alt. 7,000 feet.

Mantrot, El Paso co. : six miles west of Colorado Springs, alt. 6,300 feet.

Manitod Park, Teller co.: on Trout Creek, alt. about 7,700 feet.

Manzanola, Otero co. : on the Arkansas River, alt. 4,250 feet.

Marston Lake : near Denver.

Masters, Weld co. : on the South Platte, alt. 4,450 feot.

MoElmo, Montezuma co. . on the McElmo Creek, near the Utah boundary.

Medano Springs Ranch, Saguache co.: fifteen miles nirth-cast of Mosca, alt. about 7,500 feet.

Merkfre, Rio Blenco co. : on the White River, alt. 6,180 feet.

Mesa Verde, Montezuma co. : alt. about 7,000 feet.

MrdDle Park, Grand co. : drained by the Grand River.

Monow, Baca co.: on Bear Creek, near the Kansas boundary, alt. 3,650 feet.

Montgomery, Park co. : on the head-waters of the Platte at the northeast slope of Mount Lincoln, alt. about 12,000 feet.

Monument, creek in El Paso co. : tributary of the Fountain at Colorado Springs.

Moranne Lake, in El Paso co. : on the slopes of Pikes Peak, alt. 10,268 feet.

Mosca, Costilla co. : in the San Luis Valley, alt. 7,560 feet.

Mosca Pass : across the Sangre de Cristo range from Huerfano to Costilla co., alt. 9,713 feet.

Mud Springs, Rio Blanco co. : alt. 8,800 feet.

Naturita Cañon, Montrose co.: between Coventry and Naturita, alt. 6,000-7,000 feet.

NaVAJo CreeK, Archuelta co. . a left-hand branch of the San Juan River.

Navajo Springs, La Plata co. : in the southern Ute reservation, near the New Mexico boundary, alt. about 5,500 feet.

Nedertand, Boulder co. . about fifteen miles west of Boulder, alt. 8,260 feet.

Newcastre, Garfield co. : on the Grand River, alt. 5,550 feet.

New Windsor, Weld co. : near Greeley, alt. 4,800 feet.

Niwot, Boulder co. . about eight miles north-esst of Boulder, alt. 5,100 feet.

Nortr PaRk, Larimer co. : draining north into Wyoming by the North Platte, alt. 8,000 to 9,000 feet.

Norwood, San Miguel co. : near Coventry.

Orchard, Morgan co. : on the South Platte, alt. 4,400 feet.

Pagosa Springs, Archuelta co. : on the San Juan River, alt. 7,100 feet. 
Palmer Lake, EI Paso co. : on the Arkansas-Platte Divide, alt. 7,230 feet.

Pando, Eagle co.: on the head-waters of the Eagle River, alt. 9,200 feet.

PAWNEE BUTTES, Weld co.: near the Nebraska-Wyoming-Colorado border.

Pennsylfania Lake, Boulder co. : alt. 8,500 feet.

Peyton, El Paso co. : about twenty-five miles north-east of Colorado Springs, alt. 6,790 feet.

Ptrdra Lake, Archuelta co.. south of Pagosa Springs.

Ptikes Peak, El Paso co. : in the front range, alt. 14,108 feet.

Prine River, La Plata co.: flowing south across the State border to the San Juan River.

Pinewood, Larimer co. . twelve miles west of Loveland.

Plateau Valuey, Mesa co. : drained by the Plateau Creek, flowing into the Grand River, alt. 5,000 to 7,000 feet.

Ptatime Cañon, Douglas co.: on the South Platte.

Plum Creer, Douglas co. : a right-hand branch of the South Platte.

Prospect Lake, El Paso co. : east side of Colorado Springs.

Prowers, Bent co.: on the Arkansas River, 3,670 feet.

Pueblo, Pueblo co. : on the Arkansas, alt. 4,670 feet.

Raman, El Paso co.: on the Rock Island R., alt. 6,090 feet.

RaNarlex, north-west Rio Blanco co. : on the White River.

RED CLIFF, county seat of Eagle co. : on the Eagle River, alt. 8,600 feet.

Resolis, Elbert co.: on the Rock Island R., alt. 5,570 feet.

RIFLE, Garfield co. : on the Grand River, twenty miles below Glenwood, alt. 5,300 feet.

Rio Branco : tributary of the San Juan River in Archuelta co.

ROOKYFORD, Otero co. : in the Arkansas Valley, alt. 4,170 feet.

Round Mountan, $\mathbf{n}$ the San Juan Mountains, San Juan co. : alt. 13,422 feet.

Rouse Junction, Huerfano co. : alt. 6,140 feet.

RUSH Crmsk, Lincoln, Cheyenne and Kiowa cos. : a right-hand branch of the Big Sandy.

SAGUACHE, county seat of Saguache co. : in the upper San Luis Valley, alt. 7,740 feet.

St. Chartes Cañon, Pueblo co. : on the St. Charles River, a righthand branch of the Arkansas.

ST. Vrang, Weld co. : a left-hand branch of the South Platte.

Salida, Chaffee co. : on the Arkansas, alt. 7,040 feet.

SANGRi DE Cristo: range separating Fremont, Custer and Huerfano cos. from the San Luis Valley.

San Juan Mountanns, Hinsdale co. : between the head-waters of the Rio Grande and Piedra Rivers. 
SAN LUIS LAREs, without outlet in Costilla co. : alt. 7,592 feet.

San LoIs Varlex, or Park, Saguache and Costilla co. : drained by the San Luis Creek, alt. 7,000-8,000 feet.

San Miguel Rrver and Cațon, San Miguel co. . a right-hand branch of the Dolores.

Sapanero, Gunnison co. : on the Gunnison River, alt. 7,245 feet.

Sapanero Creek, Gunnison co.: tributary of the Gunnison, alt. at junction 7,240 feet.

Stren Lakes, El Paso co. : on the slopes of Pikes Peak, alt. 10,600 feet.

SILVER Lake, Boulder co.

Sulvertor, county seat of San Juan co. : on the Las Animas River, alt. 9,280 feet.

StNBad VATIEY - south-west corner of Mesa co, draining into the Rio Dolores.

Sloans Lake, Denver co. : close to Denver.

Smrth's Lake, Denver co. . fourteen miles north of Denver.

SNake RIVER, Routt co. : tributary of the Bear.

South Mamm Paak, between Garfield and Mesa cos., on Battlement Mesa, alt. 10,973 feet.

SotTh PARK, Park co. . drained by South Platte, alt. 8,000-10,000 feet.

Specimen Mountan : at the head-waters of the Great Thompson, on the Divide between Larimer and Grand cos.

Springfield, county seat of Baca co. : alt. 4,400 feet.

Squirrer Cresk, El Paso co. . on the plains about twenty-five miles east of Colorado Springs.

Sugarloat HiLL, Boulder co. : alt. 8,920 feet.

Sulphur Springs, county seat of Grand co. : alt. 7,665 feet.

Strmitr Peak, between Conejos and Archuelta cos. : noted as Mt. Blaine in Hayden's Survey Report, alt. 13,323 feet.

STEamboat Springs, Routt co. : near the eastern border, alt. 6,780 feet. SweETwater LAKE, Garfield co.: on Sweetwater Creek, alt. about 8,000 feet.

Tennessee Gulch, Lake co. : near Leadville, leading to Tennesseo Pass, alt. 10,240 feet.

Tricy Ann Prak, Summit co. : in the Ten-mile Range, near Breckenridge.

ThомasviLte, Pitkin co. : on the Colorado Midland R., alt. 7,968 feet.

Trmanath, Larimer co. : between Greeley and Fort Collins, alt. 4,880 feet.

Trmby, Larimer co. : near Fort Collins, alt. 5,015 feet.

TrINChera : river in Costilla co., and a station on the D. and R.G. R., alt. 8,100 feet. 
Trinidad, county seat of Las Animas co. : on the Las Animas River, alt. 6,000 feet.

TURKeY CREEK : northern tributary of the Arkansas River, El Paso co. and Pueblo co.

TuTrLe, Kit Carson co. : about twenty miles north-west of Burlington, alt. approximately 4,500 feet.

TwIN Lakms, Lake co. : alt. 9,367 feet.

Uncompahgre Butie, Mesa co. : on the Uncompahgre Plateau.

UPPER BeAR CREEK, Clear Creek co. : a tributary of Turkey Creek.

UTE CREER, Costilla co. . a tributary of the Trinchera Creek.

UTE PAss, Teller co. : west of Manitou up the Colorado Midland R., alt. 9,100 feet.

Vatagoe Lakit, Weld co. : near Greeley.

Vrctor, Teller co. . adjoining Cripple Creek, alt. 9,720 feet.

WAGON WHeEl GAP, Mineral co. : on the upper Rio Grande, alt. 8,440 feet.

WARD, Boulder co. : alt. 9,230 feet.

Wetr Mountanns: between Custer and Pueblo cos.

Wet Mountate Valley, Custer co. . drained by Grape Creok into the Arkansas.

White River P.O., Rio Blanco co. : on the White River, below Meeker.

Windsor : see Now Windsor.

Wrllow Creter, Weld co.

WooDs LAKE, Pitkin co. : near Thomasville.

WraY, county seat of Yuma co. : alt. 3,530 feet, on the Burlington $R$., near the Nebraska line.

YAMPA, Routt co. : alt. about 7,000 feet.

YUMA, Yuma co. : on the Burlington R., alt, 4,140 feet. 


\section{N D E X.}

aberti, Pipilo, 395

Abert's Towhee, 395

abieticola, Phloeotomus pileatus, 233

acadica, Cryptoglaux, 202

Acanthis, 340

Accipiter, 168

Accipitres, 161

accipitrinus, Asio, 199

Actitis, 126

acuta, Dafila, 47

adamsi, Gavia, 11

AEgialitis, 134

Achmophorus, 4

æneus, Quiscalus quiscala, 318

Ä̈ronautes, 249

æstiva, Dendroica, 449

affinis, Marila, 54

Agelaius, 306

agilis, Oporornis, 462

aikeni, Junco, 374

aikeni, Otus asio, 205

Aiken's Screech Owl, 205

Aimophila, 385

Aix, 48

Ajaja, 74

ajaja, Ajaja, 74

alascensis, Calcarius lapponicus, 351

Alaska Hermit-Thrush, 521

Alaskan Longspur, 351

Alaudidæ, 279

aleudinus,Passerculussandwichensis 357

alba, Guara, 75

albeola, Charitonetta, 58

albicollis, Zonotrichia, 367

Alcedinidx, 221

alcyon, Ceryle, 221

Alder Flycatcher, 275

alexandri, Architrochilus, 252

alnorum, Empidonax trailli, 275

Alpine Three-toed Woodpecker, 227

Aluco, 196

Aluconidæ, 195

American Avocet, 104

American Barn-Owl, 196

American Bittern, 79

American Coot, 98

American Crossbill, 333
American Dipper, 474

American Eared Grebe, 6

American Egret, 84

American Eider, 61

American Golden-eye, 56

American Golden Plover, 131

American Goldfinch, 342

American Goshawk, 171

American Long-eared Ow1, 197

American Magpie, 282

American Merganser, 32

American Osprey, 193

American Pipit, 472

American Redstart, 470

American Rough-legged Hawk, 17 ;

American Scoter, 62

American Sparrow-Hawk, 190

American White Pelican, 28

American White-fronted Goose, 68

American Woodcock, 108

americana, Clangula clangula, 56

americana, Fulica, 98

americana, Grus, 91

americana, Mareca, 40

americana, Marila, 51

americana, Mycteria, 78

americana, Oidemia, 62

americana, Recurvirostra, 104

americana, Spiza, 405

americanus, Coccyzus, 218

americanus, Mergus, 32

americanus, Numenius, 128

americanus, Tympanuchus, 150

Ammodramus, 359

amoena, Passerina, 404

Amphispiza, 381

Anas, 36

Anatinæ, 35

anatum, Falco peregrinus, 187

annectens, Junco, 377, 381

Anser, 68

Anseres, 30

Anserinæ, 65

Anthus, 472

Antrostomus, 243

aonalaschkae, Turdus, 521

Aphelocoma, 287

Aphrizidæ, 136

Aquila, 181 
Archibuteo, 178

Architrochilus, 252

Aretic Tern, 24

Arctic Towhee, 394

arctica, Gavia, 11

arctica, Sialia, 529

arcticus, Pipilo maculatus, 394

Ardea, 82

Ardeidæx, 79

arenacea, Spizella pusilla, 373

Arenaria, 136

arenaria, Calidris, 118

arenicola, Otocoris alpestris, 279

argentatus, Larus, 16

Arizona Goldfinch, 345

arizonæ, Astragalinus psaltria, 345

arizonæ, Spizella passerina, 369

Arkansas Goldfinch, 344

Arkansas Kingbird, 262

Ash-throated Flycatcher, 264

asiatica, Melopelia, 161

Asio, 197

Astragalinus, 342

Astur, 171

Asyndesmus, 235

ater, Molothrus, 302

atrata, Leucosticte, 338

atricapillus, Astur, 171

atricilla, Larus, 18

auduboni, Dendroica, 453

auduboni, Hylocichla guttata, 521

Audubon's Warbler, 453

auritus, Colymbus, 6

auritus, Phalacrocorax, 27

aurocapillus, Seiurus, 461

australis, Leucosticte, 338

utumnalis, Plegadis, 76

Avocet, American, 104

Bæolophus, 503

bairdi, Centronyx, 358

bairdi, Dryobates scalaris, 227

bairdi, Pisobia, 115

bairdi, Sialia mexicana, 527

bairdi, Thryomanes bewicki, 490

Baird's Sandpiper, 115

Baird's Sparrow, 358

Baird's Wren, 490

Bald Eagle, 183

Baldpate, 40

Baltimore Oriole, 312

Band-tailed Pigeon, 157

Bank-Swallow, 422

Barn-Owl, American, 196

Barn-Swallow, 417

Barred Owl, 200

Barrow's Golden-өye, 57
Bartramia, 125

Bartramian Sandpiper, 125

Batchelder's Woodpecker, 226

belli, Vireo, 437

Bell's Vireo, 437

Belted Kingfisher, 221

bendirei, Toxostoma, 484

Bendire's Thrasher, 484

bicolor, Iridiprocne, 418

bimaculatus, Ammodramus savannarum, 359

Bittern, American, 79

Bittern, Least, 81

Black and White Warbler, 441

Black Rail, 96

Black Rose-Finch, 338

Black Swift, 248

Black Tern, 25

Black-bellied Plover, 130

Black-billed Cuckoo, 220

Blackbird, Brewer's, 316

Blackbird, Red-winged, 306

Blackbird, Rusty, 315

Blackbird, Yellow-headed, 304

Black-chinned Humming-bird, 252

Black-crowned, Night-Heron, 87

Black-headed Grosbealk, 399

Black-necked Stilt, 106

Blackpoll Warbler, 455

Black-throated Blue Warbler, 451

Black-throated Green Warbler, 459

Black-throated Grey Warbler, 457

Black-throated Loon, 11

Blue Jay, 285

Bluebird, Chestnut-backed, 527

Bluebird, Eastern, 527

Bluebird, Mountain, 529

Blue-winged Teal, 43

Bobolink, 300

Bob-white, 139

Bohemian Waxwing, 425

Bombycilla, 424

Bonbycillidæ, 424

Bonaparte's Gull, 20

Bonasa, 147

borealis, Cypseloides niger, 248

borealis, Lanius, 428

borealis, Nuttallornis, 268

boschas, Anas, 36

Botaurus, 79

brachyotus, Otus, 199

Brant, 71

Branta, 68

breweri, Spizella, 372

Brewer's Blackbird, 316

Brewer's Sparrow, 372

Broad-tailed Humming-bird, 253 
Bronzed Grackle, 318

Brown Pelican, 30

Brown Thrasher, 483

Brown-capped Rose-Finch, 338

Bubo, 208

buccinator, Olor, 72

Buffle-head, 58

bullocki, Icterus, 313

Bullock's Oriole, 313

Bunting, Indigo, 403

Bunting, Lazuli, 404

Bunting, Snow-, 349

Burrowing Owl, 211

Bush-Tit, Plumbeous, 508

Buteo, 173

Butorides, 86

Cackling Goose, 70

cærulescens, Dendroice, 451

Calamospiza, 406

Calcarius, 350

calendula, Regulus, 511

Calidris, 118

California Cuckoo, 220

California Gull, 17

California Quail, 143

californianus, Geococcyx, 217

californicus, Colymbus nigricollis, 6 californicus, Larus, 17

californicus, Lophortyx, 143

Calliope Humming-bird, 256

calliope, Stellula, 256

Callipepla, 141

calurus, Buteo borealis, 174

campestris, Leucosticte, 337

campestris, Pediocotes phasianellus, 152

Canada Goose, 69

canadensis, Branta, 69

canadensis, Grus, 91

canadensis, Sitta, 500

canadensis, Wilsonia, 470

Canadian Warbler, 470

candidissima, Egretta, 85

caniceps, Junco, 378

Cañon Towhee, 394

Cañon-Wren, 487

Canvas-back, 52

capitalis, Perisoreus canadensis, 289

Caprimulgidæ, 242.

Cardinal, 398

Cardinalis, 398

cardinalis, Cardinalis, 398

carnivorus, Corvus, 291

Carolina Paroquet, 215

carolina, Porzana, 95

carolinensis, Conuropsis, 215 carolinensis, Dumetella, 481

carolinensis, Nettion, 41

carolinensis, Pandion haliaëtus, 193

carolinensis, Zenaidura macrura, 159

carolinus, Centurus, 237

carolinus, Euphagus, 315

Carpodacus, 328

cassini, Carpodacus, 329

cassini, Lanivireo solitarius, 435

cassini, Peucra, 384

Cassin's Kingbird, 263

Cassin's Purple Finch, 329

Cassin's Sparrow, 384

Cassin's Vireo, 435

Cat-bird, 481

Cathartes, 163

Cathartidæ, 162

Catherpes, 487

Catoptrophorus, 123

Cedar-Waxwing, 426

cedrorum, Bombycilla, 426

celata, Vermivora, 445

Centrocercus, 153

Centronyx, 358

Centurus, 237

Certhia, 497

Certhiadæ, 496

cerulea, Dendroica, 455

Cerulean Warbler, 455

Ceryle, 221

Charadriidæ, 130

Charadrius, 131

Charitonetta, 58

Chat, Long-tailed, 467

Chaulelasmaus, 38

Chen, 66

Chestnut-backed Bluebird, 527

Chestnut-collared Longspur, 352

Chickadee, Long-tailed, 505

Chickadee, Mountain, 506

chlorura, Oreospiza, 396

Chondestes, 361

Chordeiles, 245

chrysä̈tos, Aquila, 181

chrysolæma, Eremophila, 279

chrysoptera, Vermivora, 443

Ciconiidæ, 78

Cinclidæ, 474

Cinclus, 474

cinerascens, Myiarchus, 264

cinnamomeus, Helodromes solitarius, 122

Cinnamon Teal, 44

Circus, 166

Cistothorus, 494

citrea, Protonotaria, 442

Clangula, 56 
clangula americana, Clangula, 56

Clarke's Nutcracker, 295

Clay-coloured Sparrow, 371

Cliff-Swallow, 415

clypeata, Spatula, 46

Coccyges, 216

Coccyzus, 218

Colaptes, 238

Colinus, 138

collaris, Colaptes cafer, 239

collaris, Marila, 55

Columba, 157

Columbæ, 156

columbarius, Falco, 188

Columbian Sharp-tailed Grouse, 151

columbiana, Nucifraga, 295

columbianus, Olor, 72

columbianus, Pedioccetes

phasianellus, 151

Colymbidæ, 3

Colymbus, 5

Common Tern, 24

Compsothlypis, 447

confinis, Poccetes gramineus, 355

connectens, Junco, 380

Connecticut Warbler, 462

conspersus, Catherpes mexicanus, 487

Conuropsis, 215

cooperi, Accipiter, 170

cooperi, Piranga rubra, 411

Cooper's Hawk, 170

Coot, American, 98

Cormorant Double-crested, 27

Cormorant, Mexican, 28

cornuta, Eremophila, 279

coronata, Dendroica, 451

coronata, Zonotrichia, 367

Corvidæ, 282

Corvus, 291

Cow-bird, 302

Crane, Little Brown, 91

Crane, Sandhill, 92

Crane, Whooping, 91

Creciscus, 96

Creeper, Rocky-Mountain, 497

cristata, Cyanocitta, 285

Crossbill, American, 333

Crossbill, Mexican, 334

Crossbill, White-winged, 334

Crow Western, 294

Cryptoglaux, 202

cryptoleucus, Corvus, 293

Cuckoo, Black-billed, 220

Cuckoo, California, 220

Cuckoo, Yellow-billed, 218

Cuoulidæ, 216 cucullatios, Lophodytes, 34

Curlew, Hudsonian, 129

Curlew, Long-billed, 128

currucoides, Sialia, 529

cyanea, Passerina, 403

Cyanocephalus, 297

cyanocephalus, Cyanocephalus, 297

cyanocephalus, Euphagus, 316

Cyanocitta, 284

eyanoptera, Querquedula, 44

Cygninæ, 71

Cypselidæ, 248

Cypseloides, 248

Dafila, 47

deglandi, Oidemia, 62

delawarensis, Larus, 17

delicata, Gallinago, 109

Dendragapus, 145

Dendroica, 449

Desert Horned Lark, 279

Desert-Sparrow, 382

Desert Sparrow-Hawk, 192

deserticola, Amphispiza, bilineata, 382

diademata, Cyanocitta stelleri, 286

Dichromanassa, 86

Diokcissel, 405

difficilis, Empidonax, 273

dilophus, Phalacrocorax, 27

Dipper, American, 474

discors, Querquedula, 43

Dive-dapper, 9

Dolichonyx, 300

domesticus, Passer, 348

dominieus, Charadrius, 131

dorsalis, Junco, 380

dorsalis, Picoides americanus, 227

Double-crested Cormorant, 27

Dove, Mourning, 159

Dove, White-winged, 161

Dowitcher, Long-billed, 111

dresseri, Somateria, 61

Dryobates, 223

Duck, Harlequin, 60

Duck, Lesser Scaup, 54

Duck, Mottled, 38

Duck, Ring-necked, 55

Duck, Ruddy, 64

Duck, Scaup 54

Duck-Hawk, 187

Dumetella, 481

Dusky Grouse, 145

Eagle, Bald, 183

Eagle, Golden, 181

Eared Grebe, American, 6 
Eastern Bluebird, 527

Eastern Song-Sparrow, 388

Egret, American, 84

Egret, Reddish, 86

Egret, Snowy, 85

Egretta, 84

egretta, Herodias, 84

Eider, American, 61

Elanoides, 165

Empidonax, 272

English Sparrow, 348

enthymia, Otocoris alpestris, 281

Ereunetes, 117

Erismatura, 64

erythrocephalus, Melanerpes, 233

erythrogastra, Hirundo, 417

erythromelas, Piranga, 410

erythrophthaimus, Coccyzus, 220

erythrorhynchos, Pelecanus, 28

Euphagus, 315

excubitorides, Lanius Iudovicianus, 429

exilis, Ixobrychus, 81

Falco, 184

Falcon, Prairie, 185

Falconidæ, 164

fasciata, Columba, 157

fedoa, Limosa, 119

ferrugineus, Archibuteo, 179

Ferruginous Rough-leg, 179

Field-Sparrow, Western, 373

Finch, Cassin's Purple, 329

Finch, House-, 331

Finch, Purple, 329

flammeolus, Otus, 207

flammeus, Asio, 199

Flammulated Screech Owl, 207

flavipes, Totanus, 121

Flicker, Northern, 238

Flicker, Red-shafted, 239

Florida Gallinule, 97

Flycatcher, Alder, 275

Flycatcher, Ash-throated, 264

Flycatcher, Gray, 278

Flycatcher, Hammond's, 276

Flycatcher, Least, 275

Flycatcher, Olivaceous, 266

Flycatcher, Olive-sided, 268

Flycatcher, Traill's, 274

Flycatcher, Western, 273

Flycatcher, Wright's, 277

forficatus, Elanoides, 165

forsteri, Sterna, 22

Forster's Tern, 22

fortis, Agelaius phooniceus, 308

Fox-Sparrow, Slate-coloured, 390 franklini, Larus, 19

Franklin's Gull, 19

Fringillidø, 319

frontalis, Carpodacus mexicanus 331

Frosted Poor-Will, 245

Fulica, 97

fulvigula maculosa, Anas, 38

Fuligulinæ, 49

fuscicollis, Pisobia, 114

fuscus, Nisus, 168

Gadwall, 38

gairdneri, Picus, 226

galbula, Icterus, 312

galeata, Gallinula, 97

Gallinæ, 137

Gallinago, 109

Gallinula, 97

Gallinule, Florida, 97

gambeli, Anser albifrons, 68

gambeli, Lophortyx, 144

gambeli, Penthestes, 506

gambeli, Zonotrichia leucophrys, 366

Gambel's Quail, I44

Gambel's Sparrow, 366

garrula, Bombycilla, 425

Gavia, 10

Gaviidæ, 10

Geococcyx, 216

georgiana, Melospiz\&, 390

Geothlypis, 465

Glaucidium, 213

glaucogastra, Branta bernicla, 71

Glossy Ibis, 76

Gnatcatcher, Western, 513

gnoma, Glaucidium, 213

Godwit, Marbled, 119

Golden Eagle, 181

Golden-eye, American, 56

Golden-eye, Barrow's, 57

Golden-crowned Sparrow, 367

Golden-winged Warbler, 443

Goldfinch, American, 342

Goldfinch, Arizona, 345

Goldfinch, Arkansas, 344

Goldfinch, Mexican, $\mathbf{3 4 6}$

Goldfinch, Western, 344

Goose, American White-fronted, 68

Goose, Cackling, 70

Goose, Canada, 69

Goose, Hutchins's, 70

Goose, Ross's, 67

Goshawk, American, 171

Goshawk, Western, 173

Grace's Warbler, 456

gracix, Dendroica, 456 
Grackle, Bronzed, 318

Grasshopper-Sparrow, Western, 359

Great Blue Heron, 82

Greater Redpoll, 342

Greater Snow-Goose, 67

Greater Yellow-legs, 120

Grebe, American Eared, 6

Grebe, Holboell's, 5

Grebe, Horned, 6

Grebe, Pied-billed, 8

Grebe, Western, 4

Green Heron, 87

Green-tailed Towhee, 396

Green-winged Teal, 41

Grey Flycatcher, 278

Grey Ruffled Grouse, 147

Grey Titmouse, 503

Grey Vireo, 438

Grey-erowned Rose-Finch, 336

Grey-headed Junco, 378

Grinnell's Water-Thrush, 462

griseinucha, Leucosticte, 338

griseus, Bæolophus inornatus, 503

griseus, Empidonax, 278

Grosbeak, Black-headed, 399

Grosbeak, Rocky Mountain Pine, 327

Grosbeak, Rose-breasted, 399

Grosbeak, Western Blue, 401

Grosbeak, Western Evening, 325

Grouse, Columbia Sharp-tailed, 151

Grouse, Dusky, 145

Grouse, Grey Ruffled, 147

Grouse, Prairie Sharp-tailed, 152

Gruidæ, 90

Grus, 90

Guara, 75

guarauna, Plegadis, 77

Guiraca, 401

Gull, Bonaparte's, 20

Gull, California, 17

Gull, Franklin's, 19

Gull, Herring-, 16

Gull, Laughing, 18

Gull, Ring-billed, 17

Gull, Sabine's, 21

Gull, Western, 16

guttata, Hylocichla, 521

Hairy Woodpecker, 225

Haliæëtus, 183

hammondi, Empidonax, 276

Hammond's Flycatcher, 276

Harelda, 59

harlani, Buteo borealis, 176

Harlan's Hawk, 176

Harlequin Duck, 60 harrisi, Picus villosus, 224

Harris's Sparrow, 363

Hawk, American Rough-legged, 178

Hawk, Cooper's, 170

Hawk, Harlan's, 176

Hawk, Krider's, 175

Hawk, Marsh-, 166

Hawk, Pigeon-, 188

Hawk, Sharp-shinned, 168

Hawk, Swainson's, 176

Hell-diver, 9

Helodromas, 122

henryi, Chordeiles virginianus, 246

Hepburn's Rose-Finch, 337

Herodias, 84

herodias, Ardea, 82

Herodiones, 73

Heron, Black-crowned Night-, 87

Heron, Great Blue, 82

Heron, Green, 87

Heron, Yellow-crowned Night-, 89

Herring-Gull, 16

Hesperiphona, 325

hesperis, Corvus brachyrhynchos, 294

hiemalis, Nannus, 493

Himantopus, 106

himantopus, Micropalama, 112

Hirundinidæ, 412

Hirundo, 416

hirundo, Sterna, 24

Histrionicus, 60

histrionicus, Histrionicus, 60

Holboell's Grebe, 5

holbolli, Colymbus, 5

homorus, Dryobates pubescens, 226

Hooded Merganser, 34

Horned Grebe, 6

horreorum, Hirundo, 417

House-Finch, 331

hudsonia, Pica pica, 282

Hudsonian Curlew, 129

hudsonicus, Numenius, 129

hudsonius, Circus, 166

Humming-bird, Black-chinned, 252

Humming-bird, Broad-tailed, 252

Humming-bird, Calliope, 256

Humming-bird, Rufous, 255

Hutchins's Goose, 70

hutchinsi, Branta canadensis, 70

hyemalis, Harelda, 59

Hydrochelidon, 24

hyemalis, Junco, 375

hyperboreus, Chen, 66

Hylocichla, 517

hypogæa, Speotyto cunicularia, 211 
Ibididx, 75

Ibis, Glossy, 76

Ibis, Searlet, 76

Ibis, White, 75

Ibis, White-faced Glossy, 77

Ibis, Wood, 78

Icteria, 466

Icteridæ, 299

icterocephalus, Xanthocephalus, 304

Icterus, 311

Ictinia, $\mathbf{1 6 5}$

immer, Gavia, 10

Indigo Bunting, 403

inornatus, Catoptrophorus semipalmatus, 124

Intermediate Sparrow, 366

Iridoprocne, 418

islandica Clangula, 57

Ixobrychus, 81

jamaicensis, Creciscus, 96

jamaicensis, Exismatura, 64

Jay, Blue, 285

Jay, Long-crested, 286

Jay, Piñon, 297

Jay, White-headed, 289

Jay, Woodhouse, 287

Junco, 373

Junco, Grey-headed, 378

Junco, Pink-sided, 377

Junco, Red-backed, 380

Junco, Shufeldt's, 376

Junco, Slate-coloured, 375

Junco, White-winged, 374

Kadiak Dwarf Thrush, 521

Killdeer, 132

Kingbird, 260

Kingbird, Arkansas, 262

Kingbird, Cassin's, 263

Kingfisher, Belted, 221

Kinglet, Ruby-crowned, 511

Kinglet, Western Golden-crowned 510

Kite, Mississippi, 166

Kite, Swallow-tailed, 165

Kittiwake, 14

krideri, Buteo borealis, 175

Krider's Hawk, 175

Lagopus, 148

Laniidæ, 427

Lanius, 427

Lanivireo, 435

Laridæ, 14

Lark, Desert Horned, 279
Lark, Saskatchewan Horned, 281

Lark-Bunting, 406

Lark-Sparrow, Western, 361

Larus, 15

Leughing Gull, 18

lazula, Guiraca cærulea, 401

Lazuli Bunting, 404

Least Bittern, 81

Least Flycatcher, 275

Least Sandpiper, 115

lecontei, Passerherbulus, 361

Leconte"s Sparrow, 361

lentiginosus, Botaurus, 79

lepida, Tachycineta thalassina, 420

Lesser Scaup Duck, 54

leucocephalus, Haliæëtus, 183

leucogaster, Thryomanes bewicki, 490

leucolæma, Otocoris alpestris, 279

leucophæa, Calidris, 118

leucophrys, Zonotrichia, 364

leucoptera, Loxia, 334

leucoptera, Melopelia, 161

leucopterus, Mimus polyglottos, 479

Leucosticte, 335

leucurus, Lagopus, 148

Lewis' Woodpecker, 235

lewisi, Asyndesmus, 235

Limicolæ, 99

Limosa, 119

linaria, Acanthis, 340

lincolni, Melospiza, 388

Lincoln's Sparrow, 388

Little Brown Crane, 91

littoralis, Leucosticte tephrocotis, 337

lobatus, Lobipes, 102

Lobipes, 101

loculator, Tantalus, 78

Longspur, Alaskan, 351

Longspur, Chestnut-collared, 352

Longspur, McCown's, 353

Long-billed Curlew, 128

Long-billed Dowitcher, 111

Long-crested Jay, 286

Long-tailed Chat, 467

Long-tailed Chickadee, 505

longicauda, Bartramia, 125

longicauda, Icteria virens, 467

Longipennes, 12

Loon, 10

Loon, Black-throated, 11

Loon, Yellow-billed, 11

Lophodytes, 34

Lophortyx, 142

Louisiana Tanager, 409

Loxir, 332 
ludoviciana, Piranga, 409

ludoviciana, Zamelodia, 399

ludovicianus, Anthus, 472

lunifrons, Petrochelidon, 415

lutescens, Vermivora celata, 445

luteus, Colaptes auratus, 238

MacGillivray's Warbler, 463

Macrochires, 241

macrolopha, Cyanura, 286

Macrorhamphus, 111

macularia, Actitis, 126

maculata, Pisobia, 113

maculosa, Anas fulvigula, 38

maculosa, Dendroica, 454

magnolia, Dendroica, 454

Magnolia Warbler, 454

Magpie, American, 282

Mallard, 36

Marbled Godwit, 119

Mareca, 40

Marila, 50

marila, Marila, 54

Marsh-Hawk, 166

Martin, Purple, 413

mauri, Ereunetes, 118

maxwelliæ, Otus asio, 204

mecowni, Rhynchophanes, 353

MeCown's Longspur, 353

Meadow-Lark, Western, 309

mearnsi, Junco, 377

Melanerpes, 233

melanocephala, Zamelodia, 399

melanocorys, Calamospiza, 406

melanoleucus, Aëronautes, 250

melanoleucus, Totanus, 120

Meleagris, 155

Meliagrididæ, 155

melodia, Melospiza, 388

Melopelia, 160

Melospiza, 386

Merganser, American, 32

Merganser, Hooded, 34

Merganser, Red-breasted, 33

Merginæx, 31

Mergus, 32

merriami, Meleagris gallopavo, 155

Merriam's Turkey, 155

mesoleucus, Pipilo fuscus, 394

Mexican Cormorant, 28

Mexican Crossbill, 334

Mexican Goldfinch, 346

mexicana, Grus, 92

mexicanus, Astragalinus psaltria, 346

mexicanus, Colaptes, 239

mexicanus, Falco, 185 mexicanus, Himantopus, 106

mexicanus, Phalecrocorax vigua, 28

Micropalama, 112

Mimidæ, 477

Mimus, 479

minima, Branta canadensis, 70

minimus, Empidonax, 275

minor, Loxia curvirostra, 333

minor, Philohela, 108

minutilla, Pisobia, 115

Mississippi Kite, 166

mississippiensis, Ietinia, 166

Mniotilta, 440

Mniotiltidæ, 438

Mocking-bird, Western, 479

Molothrus, 302

montana, Certhia familiaris, 497

montana, Hesperiphona vespertina, 325

montana, Pinicola enucleator, 327

montana, Melospiza melodia, 386

montana, Podasocys, 135

montanus, Junco, 381

montanus, Oroscoptes, 478

montanus, Pipilo maculatus, 392

monticola, Dryobates villosus, 224

morinella, Arenaria interpres, 137

Motacillidx, 472

Mottled Duck, 38

Mountain Bluebird, 529

Mountain Chickadee, 506

Mountain Plover, 135

Mountain Song-Sparrow, 386

Mountain Towhee, 392

Mourning Dove, 159

mustelina, Hylocichla, 517

Myadestes, 515

Mycteria, 78

Myiachus 264

Myiochanes, 270

Myrtle Warbler, 451

nævius, Nycticorax nycticorax, 87

Nannus, 493

nebulosum, Syrnium, 200

neglecta, Sturnella, 309

nelsoni, Sitta carolinensis, 498

Nettion, 41

nevadensis, Amphispiza, 383

Night-Hawk, Texan, 247

Night-Hawk, Western, 246

nigra surinamensis, Hydrochelidon, 25

nigrescens, Dendroica, 457

nigricollis californicus, Colymbus, 6

nitidus, Phalænoptilus nuttalli, 245

nivalis, Chen hypoboreus, 67 
nivalis, Plectrophenax, 349

Northern Flicker, 238

Northern Parula Warbler, 447

Northern Phalarope, 102

Northern Pileated Woodpecker, 233

Northern Redwing, 308

Northern Shrike, 428

notabilis, Seiurus noveboracensis, 462

nuchalis, Sphyrapicus varius, 229

Nucifraga, 295

Numenius, 128

Nutcracker, Clarke's, 295

Nuthatch, Red-breasted, 500

Nuthatch, Pigmy, 501

Nuthatch, Rocky-Mountain, 498

nuttalli, Phalænoptilus, 243

Nuttallomis, 268

Nyctanassa, 88

Nyctea, 210

nyctea, Nyctea, 210

Nycticorax, 87

obscura, Polioptila, 513

obscurus, Dendragapus, 145

obscurus, Empidonax, 277

obsoletus, Salpinctes, 485

occidentalis, Achmophorus, 4

occidentalis, Asio magellanicus, 208

occidentalis, Coccyzus americanus, 220

occidentalis, Geothlypis trichas, 465

occidentalis, Larus, 16

occidentalis, Pelecanus, 30

occidentalis, Strix, 201

ochracea, Spizella monticola, 368

Odontophoridæ, 138

conanthe, Saxicola, 526

Oidemia, 62

Old Squaw, 59

olivacea, Vireosylva, 432

olivascens, Myiarchus lawrencei, 266

Olivaceous Flycatcher, 266

olivaceus, Regulus satrapa, 510

Olive-backed Thrush, 519

Olive-sided Flycatcher, 268

Olor, 71

Oporormis, 462

Orange-crowned Warbler, 445

Orchard Oriole, 312

oregonus, Junco, 376

Oreospiza, 396

orestera, Vermivora celata, 445

Oriole, Baltimore, 312

Oriole, Bullock's, 313

Oriole, Orchard, 312 ornatus, Calcarius, 352

Oroscoptes, 477

oryzivorus, Dolichonyx, 300

Osprey, American, 193

Otocoris, 279

Otus, 204

Oven Bird, 461

Owl, Aiken's Sereech, 205

Owl, American Long-eared, 197

Owl, Barred, 200

Owl, Burrowing, 211

Owl, Flammulated Screech, 207

Owl, Pigmy, 213

Owl, Richardson's, 202

Owl, Rocky Mountain Screech, 204

Owl, Saw-whet, 202

Owl, Short-eared, 199

Owl, Snowy, 210

Owl, Spotted, 201

Owl, Western Horned, 208

Oxyechus, 132

pallasii, Turdus, 521

pallescens, Bubo virginianus, 208

pallida, Spizella, 371

pallidus, Astragalinus tristis, 344

Palm Warbler, 460

palmarum, Dendroica, 460

Paludicolæ, 89

Pandion, 192

Pandionidæ, 192

paradisæa, Sterna, 24

Parasitic Jaeger, 13

parasiticus, Stercorarius, 13

Paridæe, 503

parkmani, Troglodytes aëdon, 491

Parroquet, Carolina, 215

Passer, 348

Passerculus, 356

Passerella, 390

Passeres, 257

Passerherbulus, 360

Passerina, 403

pecoris, Molothrus, 302

Pectoral Sandpiper, 113

Pediocætes, 151

Pelecanidæ, 28

Pelecanus, 28

Pelican, American White, 28

Pelican, Brown, 30

Pelidna, 116

pensilvanicus, Anthus, 472

Penthestes, 504

peregrina, Vermivora, 446

Perisoreus, 289

perspicillata, Oidemia, 63

Petrochelidon, 415 
Peucæa, 384

Phalacrocoracidæ, 26

Phalacrocorax, 26

phalæna, Falco sparverius, 192

Phalænoptilus, 243

Phalarope, Northern, 102

Phalaropo, Wilson's, 103

Phaleropodidx, 101

philadelphia, Larus, 20

Philohela, 107

Phlœotomus, 232

Phobe, 266

phoebe, Sayornis, 266

Phoebe, Say's, 267

phoniceus, Agelaius, 306

Pica, 282

Pici, 222

Picidæ, 223

Picoides, 227

Pied-billed Grebe, 8

Pigeon, Band-tailed, 157

Pigeon-Hawk, 188

Pigeon-Hawk, Richardson's, 189

Pigmy Nuthatch, 501

pileolata, Wilsonia pusilla, 468

Pileolated Warbler, 468

Pine-Siskin, 346

Pinicola, 327

Pińk-sided Junco, 377

Piñon Jay, 297

Pintail, 47

pinus, Spinus, 346

Pipilo, 392

Pipit, American, 472

Piranga, 409

Pisobia, 113

Planesticus, 523

Plataleidæ, 74

platycercus, Selasphorus, 253

platyrhynchos, Anas, 36

Plectrophenax, 349

Plegadis, 76

plesius, Telmatodytes palustris, 495

Plover, American Golden, 131

PIover, Black-bellied, 130

PIover, Mountain, 135

Plover, Semipalmated, 134

Plover, Upland, 125

Plumbeous Bush-Tit, 508

Plumbeous Vireo, 435

plumbeus, Lanivireo solitarius, 435

plumbeus, Psaltriparus, 508

Podasocys, 135

podiceps, Podilymbus, 8

Podilymbus, 8

Polioptila, 513

ployagrus, Falco lanarius, 185
Poccetes, 354

Poor-will, 243

Poor-will, Frosted, 245

Porzana, 95

Prairie Chicken, 150

Prairie Sharp-tailed Grouse, 152

Prairie-Falcon, 185

pratincola, Aluco, 196

Progne, 413

propinquus, Planesticus migratorius, 523

Prothonotary Warbler, 442

Protonotaria, 442

psaltria, Astragalinus, 344

Psaltriparus, 508

Psittaci, 215

Psittacidæ, 215

Ptarmigan, White-tailed, 148

Purple Finch, 329

Purple Martin, 413

purpurous, Carpodacus, 329

pusilla, Wilsonia, 469

pusillus, Empidonax, 274

pusillus, Ereunetes, 117

pygmæa, Sitta, 501

Pygmy Owl, 213

Pygopodes, 3

Quail, California, 143

Quail, Gambel's, 144

Quail, Scaled, 141

Querquedula, 43

querula, Zonotrichia, 363

Quiscalus, 318

Rail, Black, 96

Rail, Virginia, 93

Rallidæ, 93

Rallus, 93

Raven, Western, 291

Raven, White-necked, 293

Recurvirostra, 104

Recurvirostridæ, 104

Red-backed Junco, 380

Red-backed Sandpiper, 116

Red-bellied Woodpecker, 237

Red-breasted Merganser, 33

Red-breasted Nuthatch, 500

Red-eyed Vireo, 432

Red-headed Woodpecker, 233

Red-naped Sapsucker, 229

Red-shafted Flicker, 239

Red-tail, Western, 174

Red-winged Blackbird, 306

Reddish Egret, 86

Redhead, 51

Redpoll, 340 
Redpoll, Greater, 342

Redstart, American, 470

Redwing, Northern, 308

Regulus, 510

Rhynchophanes, 353

richardsoni, Cryptoglaux funerea, 202

richardsoni, Falco columbarius, 189

richardsoni, Myiochanes, 271

Richardson's Owl, 202

Richardson's Pigeon-Hawk, 189

Richardson's Skua, 14

Ring-billed Gull, 17

Ring-necked Duck, 55

Riparia, 421

riparia, Riparia, 422

Rissa, 14

Road-runner, 217

Robin, Western, 523

Rock-Wren, 485

Rocky Mountain Creeper, 497

Rocky Mountain Hairy Woodpecker, 224

Rocky Mountain Hermit-Thrush, 521

Rocky Mountain Nuthatch, 498

Rocky Mountain Pine-Grosbeak, 327

Rocky Mountain Screech-Owl, 204

Rose-breasted Grosbeak, 399

Rose-Finch, Black, 338

Rose-Finch, Brown-capped, 338

Rose-Finch, Grey-crowned, 336

Rose-Finch, Hepburn's, 337

Roseate Spoonbill, 74

rossi, Chen, 67

Ross's Goose, 67

rostrata, Acanthis linaria, 342

Rough-leg, Ferruginous, 179

Rough-winged Swallow, 423

rubescens, Anthus, 472

rubra, Guara, 76

Ruby-crowned Kinglet, 511

Ruddy Duck, 64

Ruddy Turnstone, 137

rufescens, Dichromanassa, 86

Rufous Humming-bird, 255

rubrum, Toxostoma, 483

rufus, Selasphorus, 255

Rusty Blackbird, 315

ruticilla, Setophaga, 470

sabini, Xema, 21

Sabine's Gull, 21

Sage-Hen, 153

Sage-Sparrow, 383

Sage-Thrasher, 478

sakhalina, Pelidna alpina, 116 salicicola, Hylocichla fuscescens, 518

Salpinctes, 485

saneti-johannis, Archibuteo lagopus, 178

Sanderling, 118

Sandhill Crane, 92

Sandpiper, Bartramian, 125

Sandpiper, Baird's, 115

Sandpiper, Least, 115

Sandpiper, Pectoral, 113

Sandpiper, Red-backed, 116

Sandpiper, Semipalmated, 117

Sandpiper, Spotted, 126

Sandpiper, Stilt-, 112

Sandpiper, Western, 118

Sandpiper, Western Solitary, 122

Sandpiper, White-rumped, 114

Sapsucker, Red-naped, 229

Sapsucker, Williamson's, 231

Saskatchewan Horned Lark, 281

Saw-whet Owl, 202

Saxicola, 525

Sayornis, 266

Say's Phcebe, 267

sayus, Sayornis, 267

Scaled Quail, 141

Scarlet Ibis, 76

Scarlet Tanager, 410

Scaup-Duck, 54

Scaup-Duck, Lesser, 54

schistacea, Passerella iliaca, 390

scolopaceus, Macrorhamphus

griseus, 111

Scolopacidæ, 107

Scoter, American, 62

Scoter, Surf, 63

Scoter, White-winged, 62

scotti, Aimophila ruficeps, 385

Scott's Sparrow, 385

Seiurus, 461

Selasphorus, 252

semipalmata, Egialitis, 134

Semipalmated Plover, 134

Semipalmated Sandpiper, 117

septentrionalis, Cathartes aurea, 163

septentrionalis, Penthestes atricapillus, 505

serrator, Mergus, 33

serripennis, Stelgidopteryx, 423

Setophaga, 470

Sharp-shinned Hawk, 168

Short-billed Marsh-Wren, 494

Short-eared Owl, 199

Shoveller, 46

Shrike, Northern, 428

Shrike, White-rumped, 429

shufeldti, Junco hyemalis, 376 
Shufeldt's Junco, 376

Sialia, 526

sialis, Sialia, 527

sinuatus, Corvus corax, 291

Siskin, Pine, 346

Sitta, 498

Sittidæ, 498

Skua, Richardson's, 14

Slate-coloured Fox-Sparrow, 390

Slate-coloured Junco, 375

Snipe, Wilson's, 109

Snow-Bunting, 349

Snow-Goose, 66

Snow-Goose, Greater 67

Snowy Egret, 85

Snowy Owl, 210

Solitaire, Townsend's, 515

Somateria, 61

Song-Sparrow, Eastern, 388

Song-Sparrow, Mountain, 386

Sora, 95

Sparrow, Baird's, 358

'Sparrow, Brewer's, 372

Sparrow, Cassin's, 384

Sparrow, Clay-coloured, 371

Sparrow, Desert, 382

Sparrow, English, 348

Sparrow, Golden-crowned, 367

Sparrow, Harris's, 363

Sparrow, Intermediate or Gambel's, 366

Sparrow, Leconte's, 361

Sparrow, Lincoln's, 388

Sparrow, Sage , 383

Sparrow, Scott's, 385

Sparrow, Swamp, 390

Sparrow, Western Chipping, 369

Sparrow, Western Savannah, 357

Sparrow, White-crowned, 364

Sparrow, White-throated, 367

Sparrow-Hawk, American, 190

Sparrow-Hawk, Desert, 192

sparverius, Faldo, 190

Spatula, 45

Speotyto, 211

Sphyrapicus, 228

Spinus, 346

Spiza, 405

Spizella, 368

sponsa, Aix, 48

Spoonbill, Roseate, 74

Spotted Owl, 201

Spotted Sandpiper, 126

spurius, Icterus, 312

Spurred Towhee, 392

squamata, Callipepla, 141

Squatarola, 130 squatarola, Squatarola, 130

Steganopodes, 26

Steganopus, 102

Stelgidopteryx, 422

stellaris, Cistothorus, 494

Stellula, 256

Stercorariidæ, 13

Stercorarius, 13

Sterna, 22

Stilt, Black-necked, 106

Stilt Sandpiper, 112

streperus, Chaulelasmus, 38

striata, Dendroica, 455

striatulus, Astur atricapillus, 173

stricklandi, Loxia curvirostra, 334

strigatus, Chondestes grammicus, 361

Striges, 194

Strigidæ, 197

Strix, 200

Sturnella, 309

subis, Progne, 413

Surf Scoter, 63

surinamensis, Hydrochelidon nigra, 25

swainsoni, Buteo, 176

swainsoni, Hylocichla ustulata, 519

swainsoni, Vireosylva gilva, 433

Swainson's Hawk, 176

Swallow, Bank-, 422

Swallow, Barn-, 417

Swallow, Cliff-, 415

Swallow, Rough-winged, 423

Swallow, Treo-, 418

Swallow, Violet-green, 420

Swallow-tailed Kite, 165

Swamp-Sparrow, 390

Swan, Trumpeter, 72

Swan, Whistling, 72

Swift, Black, 248

Swift, White-throated, 250

Sylviidæ, 509

Tachyoineta, 420

Tanager, Louisiana, 409

Tanager, Sc'arlet, 410

Tanager, Western, 409

Tanager, Western Summer, 411

Tangaridæ, 408

Teal, Blue-winged, 43

Teal, Cinnamon, 44

Teal, Green-winged, 41

Telmatodytes, 495

Tennessee Warbler, 446

tephrocotis, Leucosticte, 336

Tern, Arctic, 24

Tern, Black, 25 
Tern, Common, 24

Tern, Forster's, 22

Tetraonidæ, 144

Texan Night-Hawk, 247

Texan Woodpecker, 227

texensis,Chordeiles acutipennis, 247

Thrasher, Bendire's, 484

Thrasher, Brown, 483

Thrasher, Sage-, 478

Thrush, Aleska Hermit, 521

Thrush, Kadiak Dwarf, 521

Thrush, Olive-backed, 519

Thrush, Rocky Mountain Hermit-, 521

Thrush, Willow-, 518

Thrush, Wood-, 517

Thryomanes, 490

thyroideus, Sphyrapicus, 231

Titmouse, Grey, 503

tolmiei, Oporornis, 463

torquatus, Melanerpes, 235

Totanus, 120

Towhee, Abert's, 395

Towhee, Arctic, 394

Towhee, Cañon, 394

Towhee, Green-tailed, 396

Towhee, Mountain or Spurred, 392

townsendi, Dendroica, 459

townsendi, Myadestes, 515

Townsend's Solitaire, 515

Townsend's Warbler, 459

Toxostoma, 482

trailli, Empidonax, 274

Traill's Flycatcher, 274

Tree-Sparrow, Western, 368

Tree-Swallow, 418

tricolor, Steganopus, 103

tridactyla, Rissa, 14

tristis, Astragalinus, 342

Trochilidæ, 251

Troglodytes, 491

Troglodytidæ, 485

Trumpeter Swan, 72

Turdidæ, 514

Turkey, Merriam's, 155

Turkey-Vulture, 163

Turnstone, Ruddy, 137

Tympanuchus, 150

Tyrannidæ, 259

Tyrannus, 260

tyrannus, Tyrannus, 260

urnbelloides, Bonasa umbellus, 147 unicolor, Cinclus mexicanus, 474 Upland Plover, 125

urophasianus, Centrocercus, 153

usner, Compsothlypis americana, vallisneria, Marila, 52

varia, Mniotilta, 441

varia, Strix, 200

velox, Accipiter, 168

Vermivora, 443

verticalis, Tyrannus, 262

Vesper-Sparrow, Western, 355

vicinior, Vireo, 438

vigua mexicanus, Phalacrocorax, 28

villosus, Dryobates, 225

violacea, Nyctanassa, 89

Violet-green Swallow, 420

virens, Dendroica, 459

virens, Myiochanes, 270

Vireo, 436

Vireo, Bell's, 437

Vireo, Cassin's, 435

Vireo, Grey, 438

Vireo, Plumbeous, 435

Vireo, Red-eyed, 432

Vireo, Western Warbling, 433

Vireonidæ, 431

Vireosylva, 432

virescens, Butorides, 87

Virginia Rail, 93

virginiæ, Vermivora, 443

virginianus, Colinus, 139

virginianus, Rallus, 93

Virginia's Warbler, 443

virginicus, Charadrius pluvialis, 131

vociferans, Tyrannus, 263

vociferus, Antrostomus, 243

vociferus, Oxyechus, 132

Warbler, Audubon's, 453

Warbler, Black and White, 441

Warbler, Black-poll, 455

Warbler, Black-throated Blue, 451

Warbler, Black-throated Green, 459

Warbler, Black-throated Grej, 457

Warbler, Canadian, 470

Warbler, Cerulean, 455

Warbler, Connecticut, 462

Warbler, Golden-winged, 443

Warbler, Grace's, 456

Warbler, MacGillivray's, 463

Warbler, Magnolia, 454

Warbler, Myrtle, 451

Warbler, Northern Parula, 447

Warbler, Orange-crowned, 445

Warbler, Piloolated, 468

Warbler, Pelm, 460

Warbler, Prothonotary, 442

Warbler, Tennessee, 446

Warbler, Townsend's, 459

Warbler, Virginia's, 443

Warbler, Wilson's, 469 
Warbler, Yellow, 449

Water-Ouzel, 475

Water-Thrush, Grinnell's, 462

Water-witch, 9

Waxwing, Bohemian, 425

Waxwing, Cedar, 426

Western Blue Grosbeak, 401

Western Chipping Sparrow, 369

Western Crow, 294

Western Evening Grosbeak, 325

Western Field-Sparrow, 373

Western Flycatcher, 273

Western Gnatcatcher, 513

Western Golden-crowned Kinglet, 510

Western Goldfinch, 344

Western Goshawk, 173

Western Grasshopper Sparrow, 359

Western Grebe, 4

Western Gull, 16

Western Horned Owl, 208

Western House-Wren, 491

Western Lark-Sparrow, 361

Western Marsh-Wren, 495

Western Meadow-Lark, 309

Western Mocking-Bird, 479

Western Night-Hiwk, 246

Western Raven, 291

Western Red-tail, 174

Western Robin, 523

Western Sandpiper, 118

Western Savannah Sparrow, 357

Western Solitary Sandpiper, 122

Western Summer Tanager, 411

Western Tanager, 409

Western Tree-Sparrow, 368

Western Vesper-Sparrow, 355

Western Warbling Vireo, 433

Western Willet, 124

Western Wood-Pewee, 271

Western Yellow-throat, 465

Wheatear, 526

Whip-poor-will, 243

White Ibis, 75

White Pelican, American, 28

White-crowned Sparrow, 364

White-faced GIossy Ibis, 77

White-headed Jay, 289

White-necked Raven, 293

White-rumped Sandpiper, 114

White-rumped Shrike, 429

White-tailed Ptarmigan, 148

White-throated Sparrow, 367

White-throated Swift, 250

White-winged Crossbill, 334

White-winged Dove, 161

White-winged Junco, 374
White-winged Scoter, 62

Whistling Swan, 72

Whooping Crane, 91

Willet, Western, 124

williamsoni, Sphyrapicus, 231

Williamson's Sapsucker, 231

Willow-Thrush, 518

wilsoni, Gallinago, 109

Wilsonia, 468

wilsonianus, Asio, 197

Wilson's Phalarope, 103

Wilson's Snipe, 109

Wilson's Warbler, 469

Winter Wren, 493

Wood-Duck, 48

Wood-Ibis, 78

Wood-Pewee, 270

Wood-Pewee, Western, 271

Wood-Thrush, 517

Woodcock, American, 108

Woodhouse Jay, 287

woodhousei, Aphelocoma, 287

Woodpecker, Alpine Three-toed, 227

Woodpecker, Batchelder's, 226

Woodpecker, Hairy, 225

Woodpecker, Lewis', 235

Woodpecker, Northern Pileated, 233

Woodpecker, Red-bellied, 237

Woodpecker, Red-headed, 233

Woodpecker, Rocky Mountain

Hairy, 224

Woodpecker, Texan, 227

Wren, Baird's, 490

Wren, Cañon, 487

Wren, Rock, 485

Wren, Short-billed Marsh-, 494

Wren, Western House-, 491

Wren, Western Marsh-, 495

Wren, Winter, 493

wrighti, Empidonax, 277

Wright s Flycatcher, 277

Xanthocephalus, 304

xanthocephalus, Xanthocephalus 304

Xema, 21

Yellow Warbler, 449

Yellow-billed Cuckoo, 218

Yellow-billed Loon, 11

Yellow-crowned Night-Heron, 89

Yellow-headed Blackbird, 304

Yellow-legs, 121

Yellow-logs, Greater, 120

Yellow-throat, Western, 465

Zamelodia, 398

Zenaidura, 158

Zonotrichia, 363 



